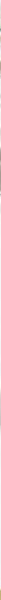

RAMÓN MÁIZ

COMPILADOR

\title{
Cultura, sentido e política \\ O(s) sentido(s) da(s) cultura(s) II
}

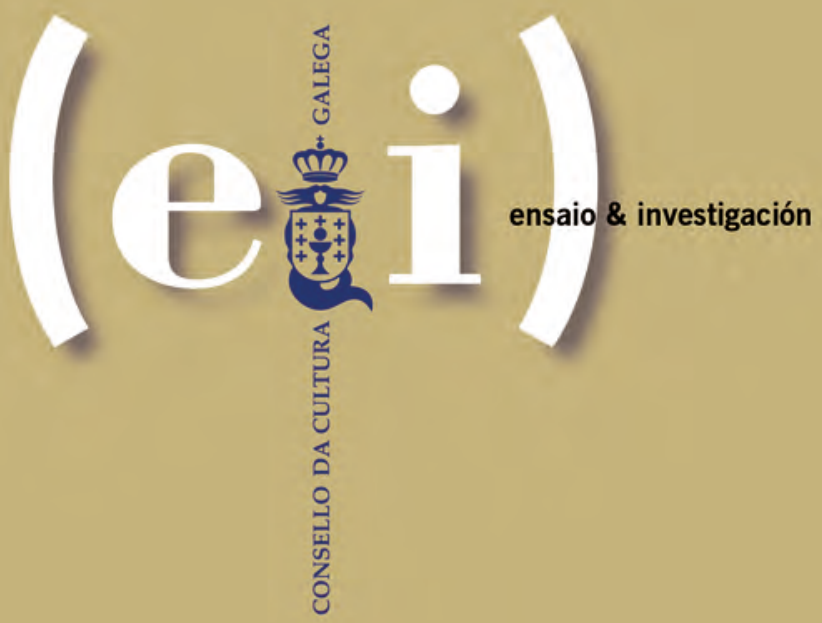




Cultura, sentido e política

$\mathrm{O}(\mathrm{s})$ sentido(s) da(s) cultura(s) II 


\section{Edita}

(c) CONSELLO DA CULTURA GALEGA, 2019

Pazo de Raxoi - $2^{\circ}$ andar - Praza do Obradoiro

$15705 \cdot$ Santiago de Compostela

T $981957202 \cdot$ F 981957205

corre0@consellodacultura.gal

www.consellodacultura.gal

\section{Proxecto gráfico}

Imago Mundi Deseño

\section{Imaxe da cuberta}

Manuel Quintana Martelo. Fragmento de Memoria 2009

\section{Maquetación}

Mabreb Aquayo, CB

Depósito Legal: C 2428-2019

ISBN 978-84-17802-11-0 


\section{RAMÓN MÁIZ}

COMPILADOR

Cultura, sentido e política
$O(s)$ sentido(s) da(s) cultura(s) II 

A Fermín Bouza Álvarez (1946-2016), in memoriam

Encadearemos adeuses de escuma para tódalas praias perdidas Xuntaremos cuadernos en branco da novela errante do vento.

E cazarémo-la vela sobre o torso rebelde das tormentas para trincar a escota dunha ilusión.

Manuel Antonio 
Presentación 
o ano 2012 saíu do prelo o libro colectivo $O(s)$ sentido(s) da(s)
cultura(s), convertido agora en primeiro dunha obra en dous
volumes, ambos compilados por Ramón Máiz, pois felizmente
logramos cumprir co desexo institucional, expresado no limiar
polo presidente Ramón Villares, de que nuns poucos anos se puidese ofrecer noutro fardelo un novo conxunto de textos e debates igualmente interesantes con que contribuírmos a repensar e a construír a cultura galega do século XXI, en permanente diálogo coas grandes correntes do pensamento actual. O primeiro volume recollía 28 textos elaborados para ser presentados e debatidos en sesións periódicas que se desenvolveron no Consello da Cultura Galega ata 2010; o segundo volume reúne 24 contribucións producidas, no mesmo ciclo e contexto, durante os anos 2010-2017. É de xustiza deixar pública constancia da paternidade intelectual do profesor Ramón Máiz, na altura membro do Pleno e coordinador da Sección de Filosofía e Pensamento, e reiterar a gratitude institucional pola dedicación, empeño e excelencia con que levou adiante o programa durante un período tan dilatado.

Partiamos xa de inicio de que o concepto de cultura non é nin estático nin atemporal, pois está en constante mutación diacrónica e diatópica, transformándose ao fío da globalización e das mobilizacións arredor do pluralismo cultural, abalando entre o individualismo e o comunitarismo. Neste marco, diante da complexidade consabida como resultado de reflexións previas propias e alleas e, sobre todo, das novas formas de entender o termo cultura, o Consello da Cultura Galega botou a andar en 2007 o ciclo $O(s)$ sentido(s) da(s) cultura(s). É difícil non reparar na oscilación intencionada entre singular e plural, tanto en sentido/ sentidos coma en culturalculturas. Respondía o ciclo á vontade de ofrecermos un espazo de reflexión sobre o propio concepto, entendido en diálogo constante coas tendencias que marcan os camińos do pensamento na sociedade actual. Foi a porta de acceso a un debate aberto e colectivo, fecundo e necesario, sobre as 
diferentes correntes de pensamento que atenden á significación e ás varias formas de representación da cultura. O volume, por forza, só contén os textos redactados polos diferentes autores e autoras; mais no repositorio do Consello da Cultura Galega están accesibles en aberto non só as gravacións das conferencias senón tamén os debates a que deron lugar, en interacción co público, entre o que se conta un selecto grupo de convidados e convidadas que tiñan acceso previo aos textos e opinión meditada.

Este novo volume recolle un debate coral, co contributo de vinte e cinco intelectuais, tan variados coma representativos, que pońen o foco sobre o concepto plural de cultura para nos mostraren con olladas diversas as moitas maneiras de entendela, e as súas implicacións. Reflexionouse sobre Europa en clave de fortaleza coa análise das diferentes formas de valados, fronteiras, exilios e demais movementos migratorios; expuxéronse as múltiples formas de discriminación (sexo, raza, xénero, orientación, capacidades...), articuladas nunha realidade complexa na que cómpre analizar non só os oprimidos senón tamén a súa relación cos grupos opresores; seguindo o ditado da actualidade, prestouse atención aos populismos, as súas formas e as súas estratexias; houbo ocasión para falar dos espazos de diálogo entre a historia, a literatura e a biografía, para repensar o rol dos museos da memoria na construción das identidades culturais, ou para mostrar a necesidade de mudar os valores cara a unha cultura da sustentabilidade... A galería de textos ábrese co capítulo de Ramón Máiz, "Cultura, sentido e política», que tamén dá título ao volume, para situar o marco teórico das reflexións sobre as mudanzas actuais do concepto, á luz das tendencias e avances da ciencia social contemporánea.

\section{Rosario Álvarez}

Presidenta do Consello da Cultura Galega 

Índice 


\section{PRESENTACIÓN}

17 Cultura, sentido e política Ramón Máiz

65 A interseccionalidade situada e os significados da cultura Nira Yuval-Davis

79 Ver e saber: a contradición das igualdades Geneviève Fraisse

93 Como é que non hai un dereito humano á túa cultura propia? Bartolomé Clavero

111 Ideoloxía e humor en tempos escuros: notas desde Siria Lisa Wedeen

141 Historia, literatura, biografía: os espazos dun diálogo Isabel Burdiel

163 Cara a unha cultura da sustentabilidade (valores, mudanza cultural e ecosocialismo no século da Gran Proba) Jorge Riechmann

181 O lugar das emocións na política Victoria Camps

199 A polémica entre Camus e Sartre: razóns dun desacordo Rosa María Rodríguez Magda

217 O novo sistema internacional e os retos do humanitarismo: a xestión da crise humanitaria e migratoria e das novas formas de violencia directa non política Rafael Grasa 
233 A política inmigratoria española no novo escenario: consideracións e propostas Antonio Izquierdo Escribano

273 Os refuxiados na era de Trump: un problema político, non unha crise humanitaria Javier de Lucas

289 A pertenza: símbolos e rituais da nación Montserrat Guibernau Berdún

299 Espertares nacionais, soños étnicos: os mitos europeos e o Rexurdimento Joep Leerssen

321 Lembrar o futuro. Os museos da memoria e o seu rol na construción das identidades culturais

Patrizia Violi

345 Paisaxismo e identidade na arte española contemporánea Carmen Pena López

381 De que falamos cando falamos de populismo? «Máis populista será a túa avoa!» Francisco Panizza

411 A dereita radical populista e a integración europea: análise comparativa dos vínculos entre partidos e votantes Margarita Gómez-Reino e Iván Llamazares

449 O populismo radical: entre as promesas de democratización e o autoritarismo Carlos de la Torre

465 Individualismo posesivo e Europa asocial

Luis Moreno

487 Da monarquía católica á república virtuosa. O imaxinario político na creación do mundo iberoamericano Anthony Pagden 
511 Historia cultural da ambición: políticos e tolos nos inicios do mundo contemporáneo

Javier Moscoso

527 Escavando túneles: a danza nos albores do século XXI Ana Abad Carlés

541 Ciencia e relixión: unha historia de guerra? William Shea 


\section{CULTURA, SENTIDO E POLÍTICA}

Ramón Máiz

Universidade de Santiago de Compostela

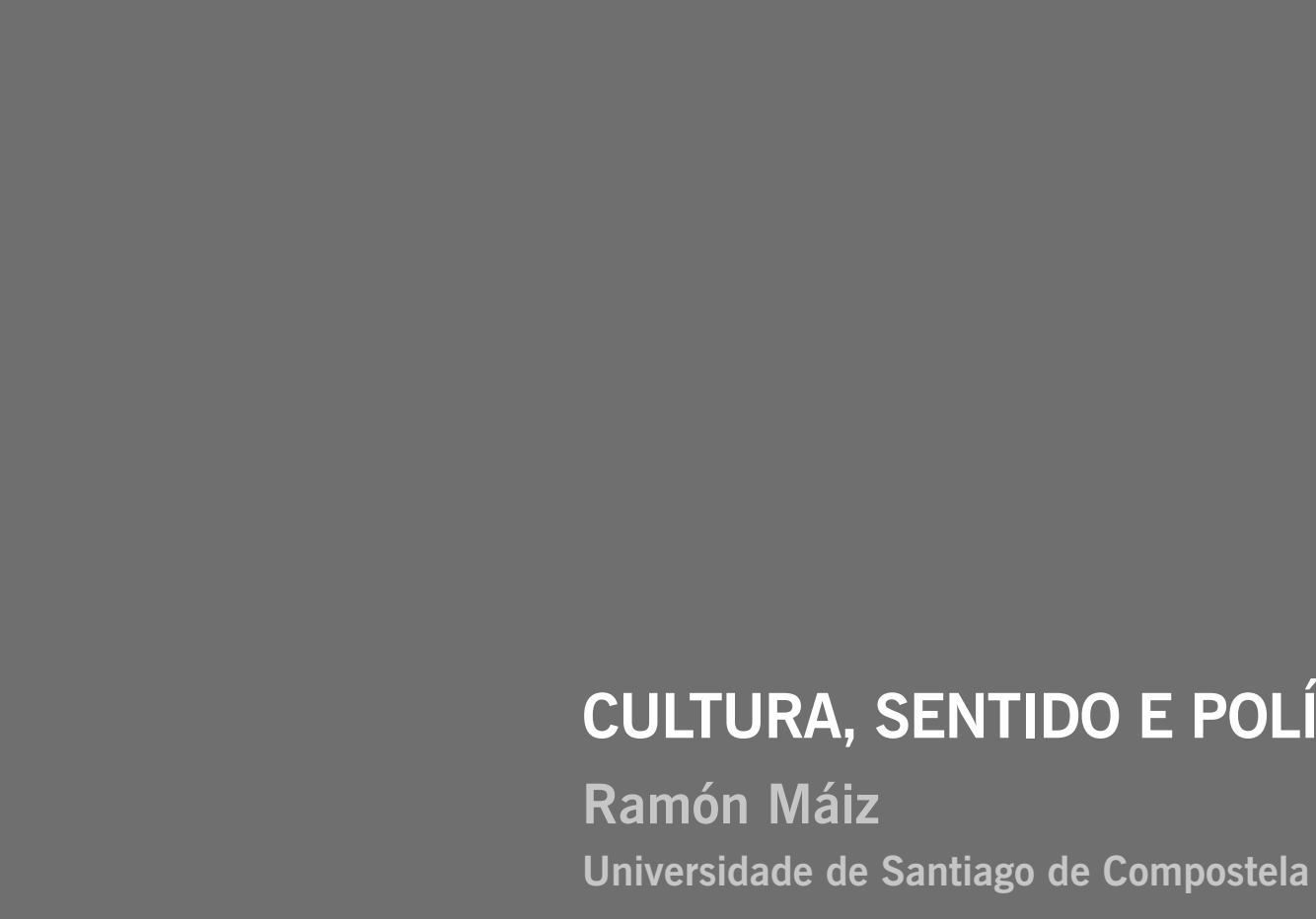



Culture is always composed of seriously contested codes and representations. James Clifford, Writing Culture

If the word "culture" is a historical and philosophical text, it is also the site of a political conflict [...]. [C]ulture arises when civilization begins to seem self-contradictory. Terry Eagleton, The Idea of Culture

O concepto dominante de cultura na ciencia política contemporánea —o concepto de «cultura política»— resultou debedor, como é ben sabido, da revolución behaviorista dos anos sesenta, e serviu durante moito tempo para designar o conxunto de actitudes e valores que producían pautas de orientación cara ao sistema político («orientations to the political system» [Almond e Verba 1963]). Diversas investigacións posteriores proseguiron con este específico obxecto de estudo (Almond e Powell 1966; Verba, Nie e Kim 1978; Inglehart 1990, 1997; Inglehart e Norris 2018), que implicaba un moi reducionista concepto de «cultura», caracterizado pola exclusiva atención a «the pattern on individual attitudes and orientations towards politics among members of a political system», isto é, á cultura considerada como mero agregado de disposicións, actitudes e valores individuais. Esta liña dominante de investigación, por unha banda, bloqueaba por definición a análise da dimensión intersubxectiva da produción de sentido político (Ross 2009) e, pola outra, ofrecía unha guía menos rigorosa para a investigación empírica da política ca outros conceptos como o de interese, que o ascenso da rational choice situaría cada vez máis no primeiro plano (Przeworsky 1985).

Por outra parte, a necesidade crecente de dar conta da dimensión colectiva de determinados fenómenos sociais e políticos, como os conflitos relixiosos, ét- 
nicos ou nacionalistas, conduciría á recepción na ciencia política dun concepto en exceso holístico de cultura, «civilización» (Huntington 1996) ou «identidade cultural» (Huntington 2004), que sublińaba os trazos primordiais compartidos (relixión, lingua), a socialización pasiva na comunidade e o inevitable conflito entre os pobos e as civilizacións. Nos anos setenta, o éxito da obra de Clifford Geertz The Interpretation of Cultures contribuíu a fornecer unha definición de cultura como "web of significance», como «a historically transmitted pattern of meaning embodied in symbols» (Geertz 1973) que, ao tempo que chamaba a atención sobre a capital dimensión simbólica dos grupos e as sociedades, insistía quizais en exceso nos aspectos comunitarios, compartidos, dela, e puña á marxe o pluralismo e o conflito internos consubstanciais a toda cultura (Wedeen 2002). As diverxencias entre ambas as correntes evidénciaa a obra de King, Keohane e Verba Designing Social Inquiry, na que, precisamente, a obra de Geertz se toma como referencia para a crítica do interpretativismo nas ciencias sociais, ao tempo que non se elabora un novo concepto de cultura política que atenda á produción política da significación alén das orientacións individuais, cunha patente obsesión unilateral polos procedementos inferenciais de investigación (King, Keohane e Verba 1994: 38-40).

Pois ben, esta tensión entre os dous extremos precitados de individualismo e comunitarismo posúe unha longa tradición tamén na teoría política. Tamén aquí atopamos quer un exceso de individualismo que desatende os aspectos da intersubxectividade e a comunicación nos fenómenos culturais, quer un exceso de holismo que reforza os lazos comunitarios, esaxera as diferenzas nós/eles e minimiza as dimensións de conflito interno, dinamismo e mudanza presentes en toda cultura. A réplica comunitarista, nas súas diferentes versións (McIntyre, Sandel ou Taylor), ao individualismo liberal de Rawls constituíu o locus classicus da necesaria atención aos shared understandings. Mais, nunha especie de movemento pendular, isto conduciu, en numerosas ocasións, a un concepto de cultura en exceso esencialista e primordialista, que resaltaba de máis a homoxeneidade dos grupos étnicos, as comunidades ou as nacións.

Nas liñas que seguen propońémonos analizar: 1) algúns dos principais argumentos e conceptos desta tensión individualismo/holismo herdados (e aínda vixentes) de dúas conxunturas críticas na historia do pensamento (a crítica romántica da Ilustración e a crítica posmoderna da idea de vangarda cultural), e 
2) a reformulación do concepto de cultura que tivo (ou está a ter) lugar, máis recentemente, na crise teórica e política do primeiro multiculturalismo e do nacionalismo cultural, e o paralelo xurdimento dunha idea de cultura como práctica semiótica, allea ao paradigma clásico, nas ciencias sociais e, en concreto, na ciencia política contemporánea.

Abofé, a teoría e as políticas do multiculturalismo e do nacionalismo cultural resultan debedoras, por unha banda, das mudanzas sociais e políticas derivadas da globalización, das reclamacións e as mobilizacións arredor do pluralismo cultural (plurinacionalismo, emigración, formas de vida alternativas) como fenómeno emerxente no mundo contemporáneo. Todo isto en desafío á homoxeneidade cultural (a tradicional ecuación Estado = nación = cultura) dos Estados nacionais, ás teses banais de «aquí fanse as cousas así» ou «somos máis e estabamos aquí antes de chegaren vostedes». Mais, por outra banda, o multiculturalismo e o nacionalismo cultural posúen a súa propia xenealoxía cultural, as súas raiceiras ideolóxicas e filosóficas, patentes na radical reformulación do concepto de cultura que postulan: a súa estrutura, historia, dimensións, relevancia etc. $\mathrm{O}$ argumento que propoñemos sostén que o concepto de cultura propio do multiculturalismo e do nacionalismo culturalista resulta debedor intelectual de, polo menos, dous movementos chave no eido das humanidades e das ciencias sociais. Estes dous desprazamentos son os seguintes: 1) a crítica romántica ao concepto universalista e "progresista» da civilización propio da Ilustración, e 2) a crítica posmoderna ás ideas de estilo e arte de vangarda propias da modernidade.

Este duplo desprazamento resulta capital, non suficiente, mais indispensable para entender o alcance, a relevancia e a textura do concepto contemporáneo de cultura que subxace aos debates referidos ás políticas do nacionalismo liberal e o multiculturalismo, o cal desborda amplamente, nas súas implicacións sociais e políticas, un suposto "xiro culturalista» e despolitizador da teoría política, os deseños institucionais e as políticas públicas. E, así mesmo, esta dupla débeda para co Romanticismo e o posmodernismo devén decisiva para explicar o tránsito teórico-práctico, profundamente autocrítico, desde unha inicial versión comunitarista e holista do multiculturalismo e o nacionalismo cara á versión construtivista e pluralista que caracteriza moitas das máis recentes formulacións de ambos os conceptos. Por último, nas ciencias sociais, un amortecido impacto teórico do posmodernismo (Wedeen 1999, 2002, 2008; Ross 2009), por unha banda, e, 
sobre todo, o desenvolvemento de programas de investigación da etnicidade e os nacionalismos, construtivistas e relacionais (Hale 2008, Chandra 2012), por outra, serán, entre outros, os factores que expliquen a aparición do concepto de cultura como conxunto plural de prácticas semióticas, converxente co desenvolvido polo nacionalismo cultural e o multiculturalismo intercultural (Laitin 2007: IX).

\section{AS RAÍCES DO DEBATE: «CULTURA» VS. «CIVILIZACIÓN» NA CRÍ- TICA ROMÁNTICA DA ILUSTRACIÓN}

O Romanticismo constituíu, como é sabido, unha crítica radical da modernidade, mais non debe esquecerse, con todo, que se tratou case sempre de «une critique moderne de la modernité» (Löwy e Sayre 1992: 35). O pensamento moderno radicalizouse na primeira Ilustración construíndo unha imaxe do mundo e da vida — da man da metáfora da luz (lumières, Aufklärung, enlightment, luces, illuminismo) — a partir dunha idea de Razón entendida especificamente como racionalidade científico-matemática. As consecuencias disto resultan ben coñecidas: separación entre suxeito (cognoscente) e obxecto (cońecido), matematización da experiencia (raciocinatio est computatio), tecnificación do método e, en fin, secularización e desencantamento do mundo (Entzäuberung en Max Weber).

Ora ben, a radicalización técnico-científica do pensamento de Bacon, Newton e Descartes comportou non só unha filosofía antropocéntrica e de dominio e explotación da natureza, considerada esta última como mero recurso instrumental, dispoñible e ilimitado, senón tamén unha idea de civilización universal, da man da ciencia e da técnica, que se impuña de modo crecente como lei inexorable do progreso á pluralidade de culturas existentes, as cales resultaban, así, entendidas como os residuos do atraso social, atávicas barreiras particularistas á converxencia final do destino común da humanidade. Narcisismo de distancia respecto á natureza (res cogitans vs. res extensa), que se reforza, alén disto, nunha idea de liberdade entendida non só como autonomía — sapere aude—, senón como distanciamento e fractura do individuo con relación á súa base comunitaria, aos seus lazos sociais, en radical desarraigamento respecto á cultura herdada e ás súas institucións, costumes e crenzas. Só desde unha filosofía materialista, 
desde unha razón calculadora e universalista ( vid. cadro 1), pode entenderse a simultánea e articulada postulación tanto de 1) un ser humano considerado como individuo asocial descontextualizado (unencumbered self), e 2) o preceptivo abandono do estado de natureza comunitario e o artificio do contrato social fundador do Estado, canto de 3) a imaxinaría mecanicista da teoría social e política moderna (non só a natureza, senón tamén a política mesma entendida «ad instar Horologii» en Leibniz, «sicut enim in Horologio automato aliave machina» en Hobbes, culminan na concepción «comme une machine ordinaire, avec ses rouages» en Sieyès).

Nada disto, porén, é pasado, mera historia do pensamento. Podemos rastrexar contemporaneamente os ecos desta filosofía ilustrada na obra fundacional de Rawls e a súa articulación analítica dos conceptos debedores do racionalismo individualista lockeano: razoabilidade/racionalidade, autonomía, consenso e prioridade do xusto sobre a idea de ben, teoría dos incentivos etc. Aquí postúlase, en efecto, un redutivo desdobramento do concepto de razón en racionalidade (a procura dos propios intereses e ideas de ben) e razoabilidade (a capacidade de chegar a acordos cooperativos para fundamentar as institucións democráticas). Por unha banda, mediante o exercicio da racionalidade individual (autonomía moral) prodúcese o pluralismo inconmensurable de ideas de ben, de doutrinas comprehensivas, de ideas de ben ou vida boa. Pola outra, mediante a razoabilidade (autonomía política) xérase, da man da hipótese neocontractualista da «posición orixinal», un consenso superposto (compatible desde diversas ideas de ben) que aluma os principios de xustiza que deben presidir as institucións políticas. Para os efectos da nosa argumentación, hai dúas teses rawlsianas que deveñen decisivas: 1) a tese da prioridade da xustiza sobre o ben (a diferenza do utilitarismo) e 2) a tese de que as ideas de ben, quer individuais, quer compartidas, non pertencen á razón pública (a diferenza do comunitarismo), senón que constitúen usos non públicos da razón que deben ficar no ámbito da máis estrita intimidade. Todo isto tradúcese en que as «devocións e os afectos» [sic], vencellados aos «vínculos e lealdades» particulares, os contextos culturais e de sentido, propios das ideas compartidas de ben, han quedar fóra do overlapping consensus que aluma os principios abstractos de Xustiza. Isto é, as paixóns e emocións conectadas ás ideas de ben, propias das comunidades e as culturas que dotan de raíces e sentido a vida dos seres humanos, incluídas "as conviccións e paixóns da maioría» [sic], 
deben ficar excluídas (nos seus propios termos: «not taken into account») do eido, racional por definición, da política.

Pois ben, a crítica romántica e posromántica ao modelo ilustrado pouco ten que ver co mero irracionalismo, coa elemental procura de «ruiner la théorie rationaliste de l'État» (Droz 1966: 44) da man dun suposto desprezo á Razón ao que «aucune des doctrines irrationalistes de son temps ne lui a donc été étrangère» (Droz 1966: 48). Nin pode ser reducida ao comunitarismo conservador dun Scruton ou un McIntyre (Taylor 1989). O obxectivo prioritario dos románticos era, sobre todo, ao fío da primeira crise da modernidade, a interrogación sobre a linearidade do Progreso e o seu custo humano, social e cultural (explotación capitalista, terror revolucionario, destrución da natureza) e a reintrodución da complexidade coa relativización, que non supresión, das dicotomías radicais da Ilustración: suxeito/obxecto, feito/valor, res cogitans/res extensa, razón/emoción, mediante a recuperación da súa, por dicilo en termos do último Kant, «descoñecida raiceira común».

Esta crítica moderna da modernidade apunta, desde a metáfora da Noite, a determinados excesos, e só a eles e non ao conxunto do paradigma, da Ilustración primeira —que ela mesma parcialmente autocorrixiría, como pode comprobarse na Crítica do xuizo de I. Kant-. En concreto (Abrams 1971, Löwy e Sayre 1992, Berlin 1999, Larmore 1996, Chai 2006): 1) o desencantamento do mundo, para lle devolver a súa dimensión perdida de misterio, de conciencia dos límites e da finitude; 2) a cuantificación do mundo e o dominio «filisteo» (Marx) dos intereses materiais, para recuperar o lugar dos valores, os principios e as virtudes cívicas; 3) a interpretación mecanicista da sociedade e a natureza, para lle opor unha visión organicista, evolucionista e adaptativa; 4) a abstracción universalista da Civilización, para recuperar o valor do heteroxéneo e plural contexto cultural e lingüístico da humanidade; 5) o hiperracionalismo frío e desapaixonado, centrado obsesivamente no interese, para reivindicar o valor ético-político e cultural dos afectos e as emocións, e 6) a perda de raíces culturais comúns da man dun individualismo exacerbado, para reclamar a esquecida eticidade (Sittlichkeit) compartida (e tamén conflitiva, non se esqueza) e as bases sociais comunitarias provedoras de sentido.

Elementos fundamentais desta perspectiva romántica foron a revalorización simultánea e intimamente imbricada de 1) a natureza fronte ao artificio, e 2) as 
culturas e linguas comunitarias, fronte ao mito universalista e homoxeneizador do Progreso. Desta sorte, o mesmo movemento intelectual que reformulaba a utopía do progreso ilimitado (memento ascendere semper), desde a lúcida conciencia da finitude e os límites (tanto da razón humana como da natureza mesma), puña de relevo, por unha banda, a inserción do ser humano na natureza e a irredutibilidade desta última a mero cálculo instrumental, exterioridade estática e simple recurso que explotar, mediante unha visión orgánica, "ambientalista» e evolucionista dela. Por outra, procedíase á recontextualización do individuo no mundo de sentido (histórico, lingüístico, cultural, institucional) da comunidade e, deste xeito, á modulación da autonomía coa dimensión da autenticidade, ao recoñecemento da débeda para coa propia tradición e o mundo de sentido comunicativo e compartido en que habitamos.

Nada disto é, tampouco, cousa do pasado, mero prurito historiográfico: a moi influente obra de Charles Taylor testemuña a recepción destes argumentos no debate contemporáneo (Taylor 1989, 1992). Se Herder reclamaba unha comprensión interna das culturas, sempre no plural, xulgándoas inconmensurables, no canto de lles aplicar os principios a priori da Razón ou os estándares universais da Civilización, é porque estes últimos non eran, ao seu xuízo, nin absolutos nin universais, senón debedores dunha Cultura, a occidental, e o seu tempo específico, a modernidade; isto é: profundamente etnocéntricos (Beiser 1987: 143). Non foi tampouco a negación da razón e a ciencia o propio da conciencia romántica, senón a construción dun retrato da razón sensible, da inseparabilidade da razón e a emoción, e dunha ciencia orgánica, evolucionista, fronte á ciencia mecanicista, como a obra de Darwin amosaría de modo xenial (Richards 2002: 514).

Menos aínda a insistencia dos primeiros románticos no valor da comunidade e da pluralidade das culturas se realizou, como se dixo ata a saciedade, ao prezo de erosionar o valor da liberdade individual e a autorrealización. Nada hai neles de irracional defensa do prexuízo e da tradición (Burke, De Maistre): o recoñecemento do valor crítico da razón non lles impide, no entanto, coma ao optimismo ilustrado, ignorar o seu lado escuro, as súas consecuencias destrutivas, o mister Hyde que axexa tras os excesos cientistas do doutor Jekyll. De aí a reformulación, que non rexeitamento, da Bildung, a depuración do elitismo de Goethe e Humboldt, para valorar a riqueza das linguas e culturas populares e nacionais, así como a defensa da accesibilidade da formación para todos os cidadáns. A vi- 
sión orgánica da sociedade e as súas metáforas vexetais dos primeiros románticos ía dirixida contra o artificialismo, elitista e autoritario, do modelo mecanicista científico-técnico da Ilustración; a saber: 1) a diferenza das máquinas, que poden ser descompostas nas súas engrenaxes e mecanismos, os individuos non se relacionan entre si só movidos por un egoísmo autointeresado e solipsista, senón que están vencellados por un mundo compartido de sentido, crenzas e emocións; 2) a diferenza das máquinas, que requiren un axente externo que forneza a enerxía precisa para o seu funcionamento, a sociedade moderna non se ve abocada a estar gobernada por unha elite incontestable e a súa alta cultura, inaccesible ás masas populares obedientes; 3) a diferenza das máquinas, que precisan a forza física para o seu mantemento, a sociedade precisa non só coerción, senón unha cultura compartida (valores, crenzas, actitudes), sen a cal as institucións non se sosteñen no tempo, e 4) en fin, a diferenza das máquinas, que son o resultado dun deseño e dunha planificación racionais, a sociedade é o produto continxente de mudanzas culturais evolutivas e adaptativas a cada contexto e tempo específi$\cos$ (Beiser 1992).

Deste xeito prodúcese unha inversión do argumento ilustrado: a idea de Ben, de «vida boa», que reside nas institucións, tradicións, vocabularios e prácticas culturais da comunidade, vólvese prioritaria á idea de xustiza e os seus principios, os cales, pola súa vez, deveñen debedores dos valores e crenzas daquela. Ora ben, e isto resulta decisivo, a tradición romántica non debe lerse de xeito unilateral -a partir dos seus epígonos e da evolución conservadora do pensamento europeo posrevolucionario - como unha proposta de sutura comunitarista ou nacionalista de homoxeneidade axiolóxica, senón, pola contra, a partir do recońecemento tráxico do pluralismo e o conflito interno de valores, crenzas e principios no seo da comunidade (Berlin 1999: 32). Os románticos expresan as dislocacións sociais e os conflitos políticos resultado da Revolución Francesa e da primeira crise da Revolución Industrial: estaban «entregados á traxedia do seu tempo» (Williams 1960: 33). Pluralismo cultural e político que atinxe tanto á diversidade externa de formas de vida no mundo, e ao igual respecto (anticolonial) entre elas, canto ao pluralismo interno de interpretacións e procesos de creación e mudanza da propia cultura herdada. Non debe esquecerse que o Romanticismo foi o pensamento da escisión, da imposibilidade da fusión na natureza (ambigüidade do sublime: atracción e á vez espanto) ou na comunidade (consenso e disentimento, 
cooperación e conflito), e de aí o absurdo de toda quimérica socialización pasiva na tradición. Pola contra, o pluralismo e o conflito, a dimensión agonista, e xa que logo propiamente política de toda comunidade, nunca suturada nin reconciliada, senón en permanente reconstrución e debate, conduce a unha idea de cultura como creación irrestrita, como imaxinación produtiva, como proceso inacabado, máis ca como obxecto dado (Larmore 1966), como apertura, continxencia e indeterminación. Conciencia tráxica que remite a dimensión cultural á estofa mesma da política, non como mera expresión adxectiva de identidades comunitarias dadas, senón como proceso plural e conflitivo de creación colectiva e individual, de construción participativa desas culturas e identidades, xamais fixadas para sempre nunha síntese nin definitiva nin esencial.

\section{ILUSTRACIÓN}

\begin{tabular}{cc}
\hline Razón & Sensibilidade \\
\hline Secularización & Misterio \\
\hline Materialismo/Intereses & Paixóns \\
\hline Artificio/Contrato & Natureza \\
\hline Máquina/Técnica & Organismo/Vida \\
\hline Ciencia & Arte \\
\hline Universalismo & Particularismo \\
\hline Civilización & Cultura \\
\hline Individuo & Comunidade \\
\hline Progreso & Finitude, límites \\
\hline Pobo & Nación \\
\hline Lei/Xustiza & Ideas de ben \\
\hline Moralidade & Eticidade \\
\hline Autonomía & Autenticidade \\
\hline Consenso & Conflito \\
\hline Cosmopolitismo & Nacionalismos \\
\hline Colonialismo & Anticolonialismo \\
\hline
\end{tabular}

$\overline{\text { Cadro 1. Os campos semántico-conceptuais da idea de cultura na Ilustración e no Roman- }}$ ticismo. Fonte: elaboración propia

\section{ROMANTICISMO}




\section{O CONCEPTO «INTERTEXTUAL» DE CULTURA VS. VANGARDA NO POSMODERNISMO}

Temos que dar un longo salto no tempo para atendermos ao segundo desenvolvemento filosófico e artístico que incidirá dun xeito decisivo na reformulación do concepto de cultura que vai operar no multiculturalismo e no nacionalismo e, en menor medida, nas ciencias sociais: o movemento posmoderno. Hai trazos constitutivos do posmodernismo que, para os efectos que aquí interesan, non poden pasar desapercibidos:

1) A tese de que desde o punto de vista económico, cultural, sociolóxico e político se produciu unha transición da modernidade a un novo estadio históricocultural ou, incluso, alén da historia mesma (un eterno presente). O desenvolvemento cualitativo das tecnoloxías, os medios de comunicación, a informatización e as mudanzas na produción (traballo inmaterial, posfordismo) (Negri e Hardt 2000, 2004, 2009) deron á luz unha sociedade «postindustrial» e á vez «postradicional» (Giddens 1991) de "capitalismo tardío» (Jameson 1991). 2) O rexeitamento do modernismo artístico e das vangardas, postulando a liberalización da estética das servidumes da coherencia, a innovación e a funcionalidade. Situando a significación, a referencia intertextual e a autorreflexividade como valores autónomos, abandonando o elitismo e recuperando o valor perdido da cultura popular. 3) A radicalización das teses do postestruturalismo como impugnación da Razón centrada no suxeito soberano, as grandes narrativas, as pretensións universais de validez, a idea de totalidade e completude e, en xeral, da hiperracionalidade ilustrada clásica (Lyotard). 4) A crítica do fundacionalismo filosófico e teórico e a aposta por unha «nova superficialidade» que se enfronta ás esaxeradas pretensións de profundidade que tiranizan o pensamento moderno; a saber: o modelo hermenéutico «interior»/«exterior», o modelo dialéctico «esencia»/«aparencia», o modelo freudiano «latente»/«manifesto», o modelo existencialista «autenticidade»/«alienación» etc. E finalmente 5) a tese da diferenza entendida como articulación de prácticas sociais, políticas e culturais, e de narrativas e interpretacións locais, que se prolonga nun gusto indisimulado polas minorías nacionais, culturais, marxinais etc. así como polos «novos» movementos sociais e as novas prácticas políticas particularistas.

A partir destas características iniciais —e alén dos seus evidentes, innegables excesos na derrogación das pretensións de verdade ou no anything goes ético- 
-político-, o posmodernismo elabora criticamente polo menos cinco grandes temas do pensamento e a cultura modernos: o Suxeito, a Historia, a Teoría, a Política e a Cultura mesma, piares básicos que serán postos en causa nos termos en que veñen formulados ou, como mínimo, segundo a fórmula de Paul Ricœur, sometidos dun xeito minucioso a unha sistemática «hermenéutica da sospeita».

Antes de máis, o problema do Suxeito, a súa unidade, a soberanía sobre o obxecto, copa gran parte da literatura posmoderna. A desaparición do autor, a crise do eu unitario e racional así como a emerxencia historicamente situada e datada do «individuo» son algúns dos elementos comprendidos na teoría da subxectividade que levarán o pensamento posmoderno cara a unha crítica da tradición humanista e o seu tema central, o «Home». O punto de vista adoptado pola radicalización da tradición postestruturalista (Foucault, Derrida, Deleuze, Lacan, Guattari...) remítenos á desintegración da visión heroica do suxeito moderno, que xa non é señor da explicación científica e deixa de ser axente efectivo da natureza. A consecuencia directa destes presupostos é a transformación da noción de identidade entendida como fixación e unidade, o advento do novo individualismo occidental (Lipovetsky 1986, Finkielkraut 1987) e os recentes dilemas do eu: o narcisismo, a pluralidade de elección, o cinismo e, sobre todo, a fragmentación das varias posicións do suxeito (Bauman 1992, 1995), a precariedade da súa condición nun mundo dislocado en que está case sempre «fóra de lugar». A obra de Foucault e Derrida, co seu fincapé na fragmentación contemporánea do sentido, na fraxilidade, a perda de fundamentos e a ambigüidade constitutiva da orde simbólica, constituíu un potente lenitivo para a metafísica da presenza e a filosofía holista e teleolóxica, quer individualista, quer comunitarista.

Así mesmo, a Historia como explicación cronolóxica, como correlato linear da supremacía do suxeito cartesiano, debilítase, disólvese a súa teleoloxía do Progreso. $\mathrm{O}$ pensamento posmoderno adopta decididamente a forma dunha «xenealoxía» e unha "arqueoloxía» (Foucault), cuxo postulado é que todos os relatos explicativos, toda forma específica de codificar a temporalidade, no fondo, encobren intereses inconscientes, conflitos de poder e outras formas de saberes. A historia sempre se escribe desde a perspectiva do presente, satisfai unha necesidade do momento. Fronte á historia ontolóxica causal ou á historia oficial, a interpretación xenealóxica esixe a relativización, en graos diversos, da idea clásica de «Verdade». En último termo, en demasiadas ocasións só existe, no sentido que 
Nietzsche atribúe á expresión, «un exército móbil de metáforas» ou "perspectivas» sobre unha realidade infinita. A arqueoloxía constitúese como técnica para descubrir o que está por debaixo do saber histórico, as configuracións nada neutrais sobre cuxo fondo se van interpretar e elaborar os obxectos de cońecemento.

No campo da Gran Teoría entran en crise os conceptos de representación (Rorty) así como os dualismos baseados na dialéctica entre esencia e aparencia (Derrida). A incredulidade respecto ás metanarrativas (Lyotard) e o abandono da distinción clara entre obxecto e suxeito (Baudrillard, Lyotard) supoñen outro distanciamento fronte ao pensamento ilustrado. Epistemoloxicamente, os autores posmodernos rexeitan o suposto moderno de que o actor ten un acceso non mediado — détaché — á realidade; en liñas xerais, seguen a Nietzsche na crítica sobre a autorreflexión, a autoidentidade ou calquera tipo de elemento racionalista que amorteza os instintos físicos vitais (Deleuze, Guattari) e a disposición a vivir e interpretar o mundo sobre a base da pluralidade.

Pola súa vez, a política como proxecto moderno de emancipación universal — «la liberté des Modernes»— é substituída pola atención a unha máis modesta micropoliti$c a$, protagonizada por diversas loitas sociais, fragmentarias e particulares, que irrompen dun xeito coordinado ou descoordinado na arena da acción política. Preséntase unha nova axenda social e política, e o anovado espectro de prácticas políticas de pequenos grupos autónomos ou novas formas emerxentes de «multitude» — desvinculadas xa dos conceptos modernos de «clase», «pobo», «masa» ou «nación» (Negri e Hardt 2000, 2004, 2009)— constitúe un fenómeno xenuinamente posmoderno aínda que, en ocasións, os propios grupos rexeiten esta presentación de inclusión nas coordenadas posmodernas.

Independentemente da posición que se sosteña respecto da súa futilidade ou relevancia, e a reserva que susciten os seus excesos relativistas, non pode ocultarse a pegada intelectual que para a reconstrución do concepto normativo moderno de Cultura —construído como Civilización universal e interpretado a partir do mito do Progreso- este movemento posmoderno deixou. Antes de máis, pola dilución e relativización (que non abolición) de fronteiras entre a Alta Cultura e a cultura popular. Así, fronte ao universalismo da civilización recuperarase o valor das culturas particulares situadas no seu tempo e o seu contexto; fronte ao vangardismo elitista, e o seu correlato da vontade de Estilo que cimenta a soberanía do Autor e a Orixinalidade, oponse unha preferencia pola mestizaxe de tendencias e motivos, a intertextualidade como plural contexto intelectual, presente ou pasado, 
de toda escritura (Kristeva), así como polas técnicas híbridas da colaxe e o pastiche (Jameson). Transunto da crítica da vangarda estética (véxase o cadro 2), aparecerá a crítica da vangarda cultural ou política, a necesidade de rearticulación do nacional-popular e a recuperación da bagaxe gramsciana da guerra de posicións e a hexemonía (Laclau). Todo isto desemboca nunha revalorización da arte pobre, dos obxectos cotiáns, das culturas e linguas minoritarias, na redefinición mesma do que debe ou pode entenderse por arte ou cultura. Máis unha vez, o abandono do exceso de universalismo e formalismo dos modernos (o «Estilo internacional» en arquitectura, por exemplo), da teleoloxía emancipadora da mensaxe profunda - que ha ser desentrañada hermeneuticamente, que ha ser descodificada semioticamentetradúcese nunha nova modestia ou, así chamada dun xeito provocador, «superficialidade». Mais isto, pola súa vez, prolóngase nunha crítica do Xuízo compartido, nunha debilitación do desprezo cara ao pasado da man do Mito do Progreso (i. e.: a idea de que este estilo ou aquela técnica están «superados»). Mais tamén nun rexeitamento da mirada despectiva de moitos dos modernos cara ás culturas populares nas súas diferentes manifestacións, baseándose nun suposto canon artístico cosmopolita de mercado. Finalmente, aplícase unha obsolescencia do «xénero» e das súas regras mediante a hibridación; o pastiche, que xa non mera parodia (Jameson 1991); a apropiación intertextual desprexuizada de materiais heteroxéneos exentos de nobreza artística, de beleza canónica.

Pluralismo radical e crítica de todo holismo homoxeneizador son temas que deixarán fonda pegada no concepto contemporáneo de cultura. A reprobación das modernas ideas de vangarda, progreso e revolución abre a porta á crítica do elitismo cultural, do Estilo con maiúscula, dos xéneros e as súas regras estritas, ás institucións que velan polo «canon occidental», ao «orientalismo». Con isto ábrese paso á irrupción da arte popular — tamén a chamada «étnica»; isto é, a dos outros — das minorías, ao informalismo e ao patchwork, ao pluralismo e a síntese de culturas e xéneros e soportes (Pollock 1996, 1999; Best e Kellner 1997; Máiz 2018a). No posmodernismo recupéranse ademais e radicalízanse temas varios do Romanticismo: o gusto pola ironía, a arte como proceso inacabado e non como obxecto finalizado, a creación compartida (fronte á soberanía do autor) co intérprete ou o lector. E, sobre todo, non debe esquecerse un aspecto fundamental que adoita pasarse por alto: «atento ás rúas e desencantado, o posmodernismo opta pola cultura como conflito real para alén de toda imaxinaria reconciliación» (Eagleton 2000: 41). 
Todos estes temas resultarán capitais para a relectura contemporánea do concepto de «cultura», como se verá nos debates que xiran arredor do multiculturalismo e o nacionalismo... e nalgunha corrente emerxente da ciencia política. Nesta discusión, en efecto, rescatando temas do Romanticismo e do posmodernismo - ao fío da crecente mobilización política de minorías étnicas, culturais, nacionais e sexuais, así como de formas de vida alternativas etc.- - o concepto de cultura xa non designará un estándar elitista e excluínte na súa autorreferencialidade. Senón un conxunto continxente e inesencial de elementos de dotación de sentido — crenzas e prácticas semióticas - que evoluciona no tempo e no espazo, a partir do pluralismo e o conflito interiores, así como de intercambios con outras culturas, mediante o cal un grupo de seres humanos regula e orienta a súa vida individual e colectiva. Velaquí a contribución incontestable do posmodernismo: as identidades contemporáneas xa non presupoñen culturas e traducións continuas, nin totalidades nas cales mergullarse acriticamente dun xeito pasivo, nin compartimentos estancos fronte a outras culturas. Hai algo máis ca decadencia e ruína nesta existencia da nosa época fragmentada e transfronteiriza, "hai algo que xorde» (Clifford 1998: 12). A cultura xa non é máis un espazo reservado ás mellores creacións de Occidente, senón que, en canto que constitúe un conxunto de marcos de significación nos cales vive a xente e forma as súas conviccións, as súas identidades e as súas solidariedades, reclama unha política que non considere a afirmación étnica, relixiosa, lingüística ou nacional como un residuo irracional, arcaico e conxénito que ten de ser suprimido e transcendido..., senón unha realidade debatida e acordada (Geertz 2000: 236). Este é, precisamente, o horizonte político que, sobre tales bases intelectuais e ante os novos desafíos e conflitos emerxentes no mundo contemporáneo, o multiculturalismo inaugurou.

MODERNISMO

\begin{tabular}{cc}
\hline Progreso & Fin da historia, distorsión temporal \\
\hline Universalismo & Particularismo \\
\hline Ascetismo & Hedonismo, narcisismo \\
\hline Sociedade industrial & Sociedade da información, cibercultura \\
\hline Gran narrativa & Deconstrución \\
\hline Orixinalidade, autenticidade & Pastiche, colaxe \\
\hline Xéneros, regras & Anticonvencionalismo, metaficción \\
\hline
\end{tabular}




\begin{tabular}{cc}
\hline Vangarda, elitismo & Arte popular \\
\hline Teleoloxía emancipatoria, mensaxe & Escepticismo, ironía, humor negro \\
\hline Experimentación & Copia, sincretismo \\
\hline Obxecto, obra & Proceso, happening, performance \\
\hline Estilo & Intertextualidade, eclecticismo \\
\hline Autor & Lector, espectador \\
\hline Estrutura & Fragmentación, dislocación \\
\hline Ruptura/Provocación & Copia, apropiación, parodia \\
\hline Profundidade & Superficialidade, simulacro, hiperrealidade \\
\hline Opacidade/Hermetismo & Falsa accesibilidade \\
\hline Formalismo & Informalismo
\end{tabular}

Cadro 2. Os campos semántico-conceptuais da idea de cultura no modernismo e no posmodernismo. Fonte: elaboración propia

\section{O CONCEPTO PLURALISTA DE CULTURA NO MULTICULTURA- LISMO RECENTE}

O concepto de «cultura» incorporado polo multiculturalismo recolle inicialmente a escisión romántica e posromántica entre Zivilisation, modo de vida universal debedor da ciencia e da técnica, e Kultur, isto é, o mundo do sentido, signos lingüísticos e símbolos dos pobos, comunidades, grupos étnicos e nacións particulares. Mais non se reduce a ela, pois, como veremos, supéraa, xa que non se limita a substituír a unha pola outra, senón a abordar normativamente a tensión creativa entre ambas. $\mathrm{O}$ multiculturalismo non nega a existencia dunha identidade humana común, senón que a constrúe, en contra do monismo, da man dun peculiar universalismo pluralista, como unha realidade complexa de, por unha banda, a natureza humana universal (capacidades, necesidades, valores) e, pola outra, trazos culturalmente específicos e particulares. Isto é, postula un thick and thin, unha dimensión tenue de valores e principios para a vida en común compartida polos seres humanos e unha dimensión densa do propio modo de vida, historia e cultura de cada comunidade que resulta decisiva para a definición dos valores e os bens (Walzer 1994, 2004). 
Mais tamén, e a diferenza do relativismo e a inconmensurabilidade radical cos que moitas veces se identifica, por mor das súas titubeantes formulacións primeiras, o multiculturalismo máis recente non comporta a aceptación acrítica de calquera interpretación particular das ideas de ben. En suma, desde o momento en que a) mantén a posibilidade duns mínimos morais universais compartidos, e b) estende, alén diso, o pluralismo e conflito cara ao interior da comunidade, o multiculturalismo máis recente distánciase do inicial comunitarismo que o caracterizaba nos seus comezos; de aí a súa tipificación, por veces, como interculturalismo.

Parte dos problemas e das insuficiencias da primeira teoría política do nacionalismo liberal e o multiculturalismo intercultural (de aquí en diante, multiculturalismo I) derívanse dunha concepción das nacións e as comunidades culturais como grupos prepolíticos, resultado obxectivo dos «feitos» sociais, demográficos e étnicos diferenciais. A filosofía política e as ciencias sociais máis recentes puxeron de relevo, con todo, que boa parte da primeira teoría política do nacionalismo e o multiculturalismo resultaba debedora de asuncións claramente insostibles (Máiz 2012): 1) cara ao interior, considerábanse as culturas e as nacións como totalidades orgánicas, integradas e homoxéneas, ignorando ou pońendo en segundo plano a diversidade interna, a pluralidade de interpretacións e proxectos concorrentes, así como o conflito entre eles; 2) cara ao exterior concibíanse as culturas e as nacións como entidades claramente individualizables e distinguibles, exacerbando a diferenza que separa o «nós» do «eles», o «propio» do «alleo», subestimando os elementos comúns; 3 ) nacións e culturas eran consideradas (e aínda o son en boa medida) como entidades definitivamente cristalizadas na historia, como conxuntos dados de antemán e esencialmente alleos a calquera eventual proceso de evolución, mudanza ou reformulación; 4) isto traduciríase, pola súa vez, en que a pertenza se equiparaba á socialización pasiva na tradición, na inmersión e aceptación acrítica das pautas e formulacións proporcionadas polos legados históricos, á marxe de calquera participación libre e creativa dos integrantes delas na súa constitución; 5) o cal se prolongaba nunha concepción museística e conservacionista da cultura das nacións e os grupos étnicos, coma se o debate, a mudanza, a mestizaxe ou a incorporación as puxesen en perigo, en risco de «contaminación», de «dexeneración», e debesen ser blindadas na súa suposta pureza prístina; 6) todo isto abocaba a unha perspectiva das identidades colectivas de grupo cultural ou nación como identidades excluíntes, separadas, incomunicadas, alumando, en rigor, unha sorte de multicomunitarismo, segundo un ideal de nacións e comunidades culturais a floreceren unhas a carón doutras, de costas, 
encerradas as primeiras no seu propio Estado nacional homoxéneo, as segundas nos seus modos de vida «auténticos» sempre ameazados; 7) finalmente, isto comportaba unha hiperculturización comunitarista e proteccionista que deixaba escasa marxe para relacionar as demandas de recoñecemento con polo menos tres dimensións básicas e estreitamente relacionadas da política democrática: a mudanza cultural e a creatividade, a igualdade de oportunidades e a deliberación política.

De maneira moi diferente, a ciencia social contemporánea, da man dunha óptica construtivista de varia índole, insistiu na natureza non de obxectos, senón de procesos complexos, continxentes das nacións e culturas, na súa apertura e indeterminación, de resultas tanto da súa natureza interna plural e conflitiva como da inevitable dimensión relacional de contactos, experiencia histórica e fluxos de comunicación con outras comunidades (Brubaker 2004; Hale 2008). Esta natureza dinámica e contestada, isto é, en rigor política das nacións e as culturas, resulta decisiva desde o punto de vista normativo que aquí interesa, pois sitúa en primeiro plano, fronte ao vocabulario do reconecemento e a autenticidade (Taylor 1992), a atención aos procesos de construción nacional, a pluralidade interna das culturas, a posibilidade de identidades superpostas, a igualdade de oportunidades na construción da propia cultura ou nación (Norman 1995, Carens 2000, Benhabib 2002). A revisión que se apunta na ciencia social e na teoría política é, xa que logo, substantiva, pois, entre outras cousas, dificilmente se pode dar conta normativa dos procesos de construción nacional e recreación cultural sen unha previa revisión da concepción de comunidades e culturas como feitos obxectivos, en boa medida dados de antemán («taken as givens» [Kymlicka 1995: 184]).

Deste xeito, pódese comprobar ata que punto no multiculturalismo posterior (multiculturalismo II ou interculturalismo) se abandonou, en conexión polo menos parcial coas achegas do Romanticismo (Taylor) e o posmodernismo, o concepto reificado e holista de cultura do comunitarismo ou do «esencialismo antiilustrado", a cultura como unha totalidade orgánica, esencialmente cristalizada na historia, coherente no seu interior e nidiamente diferenciada cara ao exterior, que aínda constitúe o albo dalgunhas críticas prominentes contemporáneas (Barry 2002).

Este concepto reformulado de cultura afástanos, xa que logo, tanto do comunitarismo como do liberalismo individualista, e iso no que respecta á relación entre individuo e contorna cultural, igual ca ao nexo entre comunidade e cultura. En principio, a argumentación multiculturalista asume que os individuos teñen un interese funda- 
mental na continuación das súas prácticas e crenzas culturais porque 1) forma parte dunha cultura subministrar o contexto desde o que realizar escollas e tomar decisións; 2) a pertenza a unha comunidade cultural constitúe parte da vida boa, da vida que paga a pena que os cidadáns vivan; 3) o apoio dunha comunidade cultural móstrase como catalizador dos bens do autorrespecto e a dignidade, e 4) a xustiza, incluída a xustiza igualitaria, non pode ser neutral culturalmente, pois posúe unha compoñente de sentido, mediado e «interpretado» polas culturas ás que se aplica.

Mais a seguir, porén, reformúlase dun xeito notorio o inicial argumento multiculturalista: unha vez que os seres humanos aspiran a se desenvolver persoalmente, a cultura debe ser fonte de autonomía, creatividade e liberdade. Esta argumentación de Taylor no seu capital The Sources of the Self(Taylor 1989) matiza dun modo importante a lectura habitual, como apoio xenérico á «supervivencia cultural» do seu texto Multiculturalism and "The Politics of Recognition" (Taylor 1992), así como o concepto mesmo de autenticidade como fidelidade pasiva e acrítica á propia cultura, pois non todo contexto cultural fundamenta a autonomía individual (Parekh 2000: 57), nin o fai no mesmo grao.

E, no que se refire á relación entre cultura e comunidade que resulta das características anteriores, é esta unha relación complexa; en concreto: as culturas non son congruentes con grupos de poboación e non é posible unha descrición indisputada da cultura dun grupo humano. O concepto de comunidade cultural ou grupo cultural é problemático e continxente: un conxunto de xente pode compartir unha cultura, unha lingua, uns mitos e símbolos; outros, para alén diso, poden compartir unha relixión; outros, unha etnicidade común. Algúns poden manter a propia cultura, mais perder os lazos coa súa comunidade de orixe (inmigrantes ou refuxiados) por razóns políticas ou económicas; ou, á inversa, pódense manter vencellos comunitarios, pero rexeitarse a cultura «propia» por mor dos termos en que vén formulada. A cultura é «un sistema de sentido e significado creado historicamente, un conxunto de crenzas e prácticas arredor das cales un grupo de seres humanos comprende, regula e estrutura a súa vida individual e colectivamente» (Parekh 2000: 218). A cultura, en suma, é o mundo de sentido que un grupo posúe - sempre dun xeito heteroxéneo e en desigual medida e aceptación crítica-, nunca o que un grupo é. Menos aínda é cultura ningunha propiedade exclusiva dun grupo étnico, nin ningún grupo étnico posúe unha cultura exenta de ambigüidade e interpretacións plurais e contestadas. 


\begin{tabular}{cc} 
MULTICULTURALISMO I & MULTICULTURALISMO II \\
\hline Holismo, homoxeneidade & Pluralismo, conflito interno \\
\hline Fronteiras impermeables (propio/alleo) & Permeabilidade, mestizaxe \\
\hline Historicismo, sutura, esencialismo & Proceso, apertura, continxencia \\
\hline Socialización, autenticidade & Creación, autonomía, crítica \\
\hline Conservación, fidelidade & Participación, mudanza \\
\hline Identidades excluíntes & Identidades superpostas \\
\hline Representación descritiva & Contestación, deliberación \\
\hline Multicomunitarismo & Interculturalismo \\
\hline Cadro 3. A evolución do concepto de cultura no multiculturalismo. Fonte: elaboración propia
\end{tabular}

Ora ben, esta radical reformulación do concepto de cultura por parte do multiculturalismo II ou interculturalismo posúe notables consecuencias normativas para a política e as políticas públicas que se levan a cabo no seu nome. A tradicional perspectiva top-down dará paso a unha nova óptica bottom-up na que os mecanismos participativos e deliberativos, as policy communities e a gobernanza horizontal substitúen a tradicional perspectiva de goberno xerárquico e verticalista. Dunhas políticas públicas para as minorías (asimilación, integración) transitarase a políticas públicas coas minorías (autonomía, deliberación, participación). Podemos sintetizar brevemente algunhas das transformacións inducidas polo novo concepto pluralista e construtivista de cultura. Antes de máis, o multiculturalismo comporta acomodación, isto é, renunciar á noción de cidadanía só no seu sentido exorbitante: o que se traduce en uniformidade, no suposto de que todos os cidadáns han ter exactamente os mesmos dereitos e deberes, pois isto non deixa lugar para a variedade de problemas e demandas específicos que xorden dos diferentes modos de vida. En suma, abandonar os argumentos de propiedade territorial que se dan como autoevidentes: «este é o noso país e así facemos as cousas aquí» ou o "somos máis e estabamos aquí antes» (Barry 2002: 232). Respecto igual, nunha sociedade multicultural, comporta respecto aos diversos trazos diferenciais e obrigas culturais específicas. Isto require, desde o punto de vista positivo, que en principio todos os grupos deban ter unha oportunidade igual de viviren o tipo de vida que a súa cultura prescribe segundo eles mesmos libremente a interpretan. E, desde o punto de vista negativo, que non deban estar sometidos, agás por 
causas maiores, a requirimentos legais que comporten violación fundamental das súas conviccións e modos de vida.

Ora ben, a consideración das culturas como plurais no seu interior, abertas cara ao exterior, contestables e dinámicas implica que a acomodación non debe asumir como dados, fixos e inmutables os trazos, prácticas e obrigas internas do grupo. Nin tampouco consideralos como espazos alleos á crítica, á negociación e aos arranxos de acomodación (Laden e Owen 2007). A perspectiva, tamén aquí, ha ser de inclusión irrestrita na esfera pública e non de xerar ámbitos exentos ao escrutinio normativo e democrático. Isto supón calibrar e sopesar os custos da mudanza dunha práctica ou costume do grupo minoritario (dependendo da súa centralidade para a propia cultura) fronte á mudanza correlativa que aquela comporta da norma derivada da cidadanía igual (dependendo da centralidade desta norma para os valores democráticos da cidadanía) (Miller 2002).

Todo o cal se traduce no abandono da preeminencia da perspectiva legalista e xurídica —isto é, a identificación dos principios relevantes e a súa aplicación a casos concretos- e na súa substitución por unha óptica abertamente política, democrática e deliberativa. Así, fronte á excesiva xudicialización do multiculturalismo inicial (no cal a maioría das disputas se resolven mediante decisión dos tribunais de xustiza), ha de postularse a súa inclusión democrática activa; isto é: construír as demandas como obxecto de disentimento, conflito e decisión, no seo dun proceso político de diálogo e debate. Pois do feito de as culturas non seren totalidades homoxéneas derívase que os principios multiculturais deben conectarse cos principios de cidadanía republicana, decisión e deliberación. Posto que só o debate democrático pode achegar o esclarecemento e a información necesarios (non só das preferencias, obrigas ou trazos do grupo, senón tamén da intensidade e centralidade destes para a súa cultura) co obxecto de aplicar o principio de igualdade de oportunidades nun contexto complexo como é o multicultural, isto devólvenos ao espazo dunha esfera pública ampliada á sociedade civil. Por iso a dimensión democrática en sentido republicano é central para as políticas interculturais porque, fronte á imposición dunha idea de igualdade universalista e sen matices ou dunha cultura nacional maioritaria, se institucionaliza un proceso de cuestionamento das regras herdadas de recoñecemento, dos propios contidos das culturas maioritarias, mais tamén das minoritarias, e de negociación mediante procedementos de proba e erro da convivencia e superposición de identidades 
(Tully 2002, Laborde 2008). O cal nos conduce, antes de máis, a un principio de deliberación «externa»; isto é, inclusión dos modos de vida na esfera pública dunha comunidade política entendida como un conxunto de maiorías, minorías e cidadáns singulares (nacionalismo liberal). Mais isto, pola súa vez, comporta dúas cousas: a) que debe asumirse que a presenza normativa do pluralismo supón a modificación parcial das institucións políticas e o ordenamento xurídico maioritarios e a posta en práctica de reasonable accommodations, e b) que, fronte ao modelo integracionista, que sostén que a maioría establece unilateralmente os criterios de inclusión, se postule un modelo autonómico, que outorgue ás minorías a capacidade de codecidir e coxestionar, conxuntamente coa maioría, os principios de xustiza que han de se aplicar nos diferentes bens que están en xogo. Isto, pola súa vez, e fronte ao mero recoñecemento, supón a reciprocidade dunha esixencia de negociabilidade de identidades e trazos culturais, discernindo aqueles que son consubstanciais ao grupo doutros máis superficiais ou que dependen dunha lectura contestada da tradición: a inclusión implica mudanzas e modificacións consensuadas tanto para as maiorías como para as minorías. Desde esta perspectiva, a necesidade de potenciar o asociacionismo das minorías vulnerables e a intermediación cultural entre os grupos pasa ao primeiro plano.

Os argumentos anteriores reenvíannos, como vemos, ao estreitamento de lazos entre política democrática e cultura, ao pluralismo e á deliberación interna ao grupo ou comunidade e á garantía, por parte dos poderes públicos, do pluralismo e da participación e o debate internos, fronte a versións tradicionalistas e, se é o caso, autoritarias. As políticas interculturais non poden recoñecer prácticas e institucións desigualitarias, vexatorias, humillantes ou opresivas, non tanto por mor de vulneraren os usos da maioría como por razóns mínimas universais que afectan á vida interior dos grupos (Parekh 2000: 272, Barry 2002: 275, Laborde 2008, Máiz 2012, 2018b). Así, do mesmo xeito que o multiculturalismo debe supor o apoderamento, mediante a inclusión na esfera pública, das minorías étnicas, culturais etc., tamén debe evitar a opresión interna ao grupo. Neste sentido resulta vital garantir o apoderamento democrático das minorías e das voces portadoras de diferentes versións no interior desas comunidades, apoiando a súa capacidade de revisión e autonomía, especialmente na xente nova e nas mulleres. Todo o cal, finalmente, nos devolve, para alén do multicomunitarismo, á dimensión universalista das irrenunciables condicións de deliberación da ética discursiva e da igualdade democrática, que comportan o cumprimento de tres condicións nor- 
mativas indispensables: a) reciprocidade igualitaria: non-discriminación dos membros das minorías fronte á maioría en virtude da súa pertenza comunitaria; b) adscrición voluntaria: fronte á adscrición étnica obrigatoria, as e os cidadáns non deben ser automaticamente asignados a un grupo cultural, relixioso ou lingüístico en virtude do seu nacemento, senón que debe permitirse a liberdade de opción dos pais, inicialmente e persoal na idade adulta, e c) posibilidade de abandono do grupo sen sancións exorbitantes así como dereito de pertenza flexible (mestizaxe, matrimonios mixtos non arranxados, liberdade de crenzas e modos de vida etc.) (Benhabib 2002: 19).

\section{A CRISE DA DICOTOMÍA «NACIONALISMO CÍVICO»/«NACIO- NALISMO ÉTNICO-CULTURAL»}

A tarefa de impor unha orde de intelixibilidade, de dotar de sentido a esquiva multiplicidade de nacionalismos, e, ao tempo, de postular unha xerarquía normativa que permita discernir entre o nacionalismo bo (o «noso», occidental, liberal, tolerante etc.) e o perigoso (o dos «outros», «oriental», autoritario, irracional etc.), a partir da súa clasificación empírica, levouse a cabo relacionalmente mediante o xogo de diferenzas entre significantes. A análise semiótica sinala que os códigos consisten en relacións convencionais e arbitrarias (no sentido de Saussure; isto é, non naturais, senón artificiais) entre significante e referente, así como que detrás de toda narrativa existe unha estrutura máis profunda que organiza o mundo discursivo en estruturas simbólicas. Os símbolos, pola súa vez, insírense en conxuntos de códigos binarios (sagrado/profano, cru/cocido, ben/mal...) e son eses conxuntos de oposicións os que en boa medida organizan os discursos.

A dicotomía de «nacionalismo cívico»/ «nacionalismo étnico-cultural» formúlase desde un lugar moi preciso, desde unha posición en absoluto neutra nin equidistante entre os seus polos, a saber: desde o nacionalismo do Estado-nación. Desde un nacionalismo de Estado implícito que dá por suposta a coincidencia entre fronteiras políticas e culturais, entre Estado e nación, e considera non problemática a cuestión do demos, de quen conforma o pobo sobre o que se alza a lexitimidade do Estado. O expediente non é sinxelo, pois tras a, eficacísima politicamente, autoevidencia de tal clasificación reside toda unha complexa operación discursiva de articulación de varios campos semántico-conceptuais. Esta 
escisión dualista entre «nacións étnicas» e "nacións cívicas», tamén formulada como «nacións culturais» e «nacións políticas», toma como base as substantivas diferenzas entre as tradicións dominantes "francesa»e «alemá» da nación, mais prolóngase, porén, e isto é o decisivo, nunha máis detallada dicotomía que transforma as diferenzas de grao en insuperables diferenzas de modelo — nacionalismo (cultura) vs. patriotismo (democracia) - e certas diferenzas de contexto en discrepancias sobre principios esenciais, alumando un bipolar e escindido mundo de nacións e nacionalismos.

E isto realízase mediante a superposición e cohonestación de dous códigos binarios complementarios. En primeiro lugar, a través da incorporación e o reforzo dunha antítese tan redutiva e falaz como consolidada ata hai ben pouco na historia do pensamento político, filosófico e estético, a saber: unha contraposición elemental e sen gradacións entre Romanticismo e Ilustración que xa criticamos e matizamos no primeiro apartado. En segundo lugar, mediante o contraste bipolar liberalismo/autoritarismo, calcado sobre o dualismo histórico-político Francia/ Alemaña, de tal sorte que a unha idealización liberal de Occidente se contrapón un arquetipo autoritario de tradición «orientalista» no sentido de Edward Said: nós/eles, civilizados/bárbaros, tolerantes/intolerantes etc. (Said 1978).

A reformulación, de común acordo, destes tres eixes bipolares (véxase o cadro 4): Francia/Alemaña, Romanticismo/Ilustración e liberalismo/autoritarismo, permite a imbricación e superposición de series binarias que arrastran, cada unha delas, conxuntos de novos pares semántico-conceptuais. Así, en primeiro lugar, o eixe Francia/Alemańa prolóngase na contraposición entre as nocións de liberdade, cidadanía, Estado e nación entre Oriente/Occidente; o ius soli, isto é, a cidadanía en virtude da soa residencia nun territorio, fronte ao ius sanguinis, a cidadanía derivada da común ascendencia étnica, quer «racial», quer cultural e lingüística; ao Estado-nación, que constrúe desde arriba a nacionalidade con criterios cívicos e inclusivos, opóńense as nacións sen Estado en demanda da súa autodeterminación a partir de determinacións étnicas excluíntes; ao progreso como horizonte de converxencia última civilizatoria, a decadencia oriental ou o seu reflexo na «decadencia de Occidente»; á civilización universal e cosmopolita, a cultura como Kultur, isto é, etnicamente delimitada, historicista e particularista. A isto superponse, en segundo lugar, como eixe adicional, unha formulación dicotómica e caricaturesca da oposición Romanticismo/Ilustración, que se artella 
sobre o dualismo emoción/razón, relixión/reencantamento do mundo, fronte a secularización e desencantamento (Entzauberung der Welt), propios da modernidade ilustrada; os conceptos de vida e organismo fronte aos de mecanismo, máquina e técnica; o retorno á natureza, formulada como natureza comunitaria, isto é, como contexto étnico-cultural da identidade, representado nas tradicións populares, fronte á artificialidade do contrato e o dereito positivo; a cultura enraizada na comunidade portadora de valores propios contra a política desasida da moral; a tradición fronte á modernidade; o destino dos pobos, o Volksgeist, o espírito único e irrepetible de cada nación, fronte á liberdade de escolla, a continxencia indeterminada produto da vontade irrestrita; a comunidade que dota de sentido compartido, solidariedade e altruísmo patriótico, de valores e dunha idea holista de ben colectivo dos cidadáns, fronte á sociedade integrada por individuos illados, descontextualizados, competitivos, únicos xuíces dos seus propios intereses egoístas; a fidelidade á tradición comunitaria propia fronte á liberdade («dos modernos»), a liberdade negativa fronte ao Estado neutral; a autenticidade e o respecto pasivo á cultura e as raíces propias fronte á autonomía, a capacidade individual de fixar os fins, de revisar os valores herdados, a disposición á crítica, a capacidade de "xuízo». Finalmente, en terceiro lugar, o par liberalismo/autoritarismo pecha a cadea binaria de equivalentes, de tal sorte que á raza ou mesmo á cultura concibida de forma esencialista e determinista como exclusión do «outro» —non só diferente, senón tamén «inferior»— se contrapón a libre vontade da cidadanía; á reacción, ao rexeitamento global da modernidade, oponse a revolución liberal, como síntese suprema de vontade e razón; á nación como unánime totalidade orgánica (das Volk), o pobo («We the People...») como conxunto de cidadáns singulares, dotados de dereitos e intereses; fronte ao chauvinismo patrioteiro, o patriotismo cívico ou constitucional, como adhesión aos principios políticos e xurídicos do Estado liberal; á cega adhesión ao «Destino» ou a «Misión» da nación, a deliberación e a discusión na esfera pública, na prensa ou no Parlamento; ao populismo oporase o civismo e un concepto de cidadanía forte; por último, ao liderado carismático, á adhesión ao líder mediante aclamación, o liderado legal racional sometido a responsiveness e accountability.

A articulación destes tres eixes configura un en extremo complexo panorama dicotómico, que tratamos de sintetizar no cadro 4 . Ora ben, como xa apuntamos, esta dicotomía non é de ningún modo neutral, non divide o mundo dos na- 
cionalismos en dous modelos dotados de semellante valor. Máis aínda, formúlase desde un punto de vista normativo que fica cego ante a eficacia naturalizadora do mito, que diría Barthes, que presenta como evidente na súa despregadura a división do mundo nacionalista en dous campos desiguais. Isto é, o estereotipo que nos ocupa formúlase sobre a base do nacionalismo cívico para exorcizar, desprazándoas enteiramente ao outro campo, todas as dimensións da «etnicidade»: mitos, símbolos, historia, cultura etc. Deste xeito, depurado de contido étnico e cultura, o nacionalismo cívico devén, mediante este dispositivo discursivo, plenamente "político»; dito doutro modo, centrado de maneira exclusiva na libre vontade da cidadanía democraticamente expresada. En suma, o nacionalismo cívico devén de feito puro "patriotismo» (ć́vico, republicano, constitucional etc.), «que non ten ren en común co nacionalismo» (Viroli 1995: 210). Desconéctanse así cidadanía e nación, a dimensión de pertenza á república con respecto á contorna histórica e cultural específica da nación. Desta sorte, a cidadanía individualízase e descontextualízase culturalmente, universalizándose. A asimilación na cultura maioritaria preséntase como un feito natural, resultado do trade-off mediante o cal se procede á constitución dun Estado de cidadáns libres e iguais ante a lei, supostamente «neutral» en cuestións culturais e lingüísticas. E, finalmente, pola súa banda, a nación desrepublicanízase, despolitízase e devén o depositario pasivo e vicario da tradición e do mito da común ascendencia.

\begin{tabular}{cc} 
NACIONALISMO ÉTNICO & NACIONALISMO CÍVICO \\
\hline- & + \\
\hline Romanticismo & Ilustración \\
\hline Emoción & Razón \\
\hline Relixión & Secularización \\
\hline Kultur & Zivilisation \\
\hline Natureza & Contrato \\
\hline Organismo & Mecanismo \\
\hline Raza & Vontade \\
\hline Cultura & Política \\
\hline Nación sen Estado & Estado-nación \\
\hline Tradición & Modernidade
\end{tabular}




\begin{tabular}{|c|c|}
\hline Destino & Continxencia \\
\hline Asignación primordial & Elección \\
\hline Decadencia & Progreso \\
\hline Reacción & Revolución \\
\hline Nación & Pobo \\
\hline Comunidade & Sociedade \\
\hline Campo & Cidade \\
\hline Fidelidade & Liberdade \\
\hline Autenticidade & Autonomía \\
\hline Fusión & Crítica \\
\hline Chauvinismo & Patriotismo \\
\hline Costume & Lei \\
\hline Orixe & Futuro \\
\hline Adhesión & Deliberación \\
\hline Liderado carismático & Liderado legal-racional \\
\hline Autoritarismo & Liberalismo \\
\hline Populismo & Civismo \\
\hline Holismo & Individualismo \\
\hline Ius sanguinis & Ius soli \\
\hline Particularismo & Universalismo \\
\hline Oriente & Occidente \\
\hline Alemańa & Francia \\
\hline
\end{tabular}

Cadro 4. Principais dimensións da dicotomía nacionalismo étnico/nacionalismo cívico. Fonte: elaboración propia.

A distinción entre nacionalismo étnico e nacionalismo cívico, porén, presenta moi serios problemas empíricos e teóricos, algúns dos cales amosaremos a seguir. Constitúe mérito indisputable de Anthony Smith realzar a indisociable relación entre as dimensións étnico-cultural e política de toda nación. En efecto, malia aceptar nalgún momento un uso matizado da distinción de "concepcións», que non de definicións, étnica e cívica da nación (Smith 1991: 91; 1996: 9), toda a súa obra supón, en boa medida, unha deconstrución sistemática de tal dualismo, ao salientar a compoñente étnica que reside na base das nacións como fenóme- 
nos políticos da modernidade. A obra de Anthony Smith (1986, 1999, 2000), alén diso, non só subliña a decisiva compoñente étnica (no sentido de ethnie, de comunidade cultural) das nacións —isto é, o conxunto de mitos, lembranzas e símbolos que os intelectuais achegan na procura de lexitimación da nación-, senón que destaca, así mesmo, o primordial carácter para a constitución moderna da nación, da índole desa herdanza do capital de mitos e narrativas herdados para a orientación política da nación. Cada proceso de construción nacional procede mediante unha articulación complexa da etnicidade achegada (redescuberta, seleccionada, inventada) polos intelectuais fundadores e as vicisitudes políticas e institucionais posteriores. De aí que resulte va toda pretensión de distinguir o cívico do cultural, pois a versión cívica atópase influenciada, en ocasións mesmo hipotecada, pola textura, a estofa, por así dicilo, dos legados étnicos, en canto produto, pola súa vez, dos intelectuais nacionalistas e prenacionalistas. De aí ese desprazamento, no decurso da obra deste autor, do nacionalismo ás nacións e das nacións ás comunidades étnicas (ethnies), e a postulación, fronte á dicotomía dos modelos étnico/cívico, de dous camiños ou rutas (que non arquetipos) alternativos cara á nacionalidade: a de incorporación burocrática desde arriba e a mobilización vernácula desde abaixo.

Vexamos, pola nosa banda, seguindo as incitacións de Smith da man do que el denomina unha «socioloxía histórica das nacións» (Smith 1998: 190), algúns dos problemas da popular dicotomía, comezando polos empíricos para abordar logo os teóricos e os normativos. Antes de máis, unha constatación imponse na máis sólida e recente (mesmo non tan recente) bibliografía sobre os nacionalismos: todos os nacionalismos cívicos occidentais posúen unha indeclinable compoñente étnica e cultural, como ilustran con claridade algúns dos casos máis exemplares que podemos revisar brevemente.

Francia, que constitúe o exemplo par excellence de nacionalismo cívico, foi fundada sobre a inicial exclusión relixiosa, constituíndo o enfrontamento histórico entre católicos e protestantes un auténtico motor do proceso de nation-building e state-building. A creación dos «franceses» posúe, como Anthony Marx mostrou, unha componente histórica fundamental: a unificación, nos albores da modernidade, dunha nación católica, simbolizada no mito de Xoana de Arco, fronte aos protestantes hugonotes, no interior, e ingleses, como inimigos externos (Marx 2003). Mesmo durante a Revolución Francesa, quintaesencia do republicanismo cívico, as 
dimensións étnicas e culturais desempeñaron un papel de certo relevo. No propio Sieyès, pouco sospeitoso de veleidades organicistas, poden rastrexarse ocasionalmente as pegadas do mito fundador da confrontación entre os plebeos galos e os aristócratas francos: «Por que non restituír aos bosques da Franconia todas esas familias que conservan a enlouquecida pretensión de seren descendentes da raza dos conquistadores? [...] Se quixésemos facer distincións de orixe, non poderiamos asegurarlles aos nosos concidadáns que o que se remonta a galos e romanos posúe polo menos tanta liñaxe coma o dos sicambros, vándalos e outros salvaxes saídos dos bosques da Xermania?». E, malia as raíces romanas predominaren dun xeito innegable como referencia histórico-discursiva do republicanismo xacobino, outra liña discorre, con todo, na sombra en que Vercingetorix, o "galo gálico», as orixes galas da Francia auténtica, desempeñan un papel non desbotable na construción da Nation Une. Será, porén, co Imperio e a Restauración, especialmente coa historiografía romántica de Thierry, cando, fronte ao patriotismo republicano e cívico de Michelet, se introduza o tema da «loita de razas» como motor da historia francesa, e a fidelidade á «raza primitiva», e o mito fundador céltico que devolve ao tronco común ario e, xa que logo, ao pé de igualdade con Alemaña, a nación francesa. Mesmo en relatos históricos tan influentes como o de Guizot reverbera o conflito mítico entre francos e galos, entre nobres e servos («a race conquise») (Poliakov 1971). O influxo do mito céltico das orixes, na versión dos Reynaud e Martin, sobre o republicanismo francés a medida que avanza o século ilustra o escenario étnico do máis «cívico» dos nacionalismos. A presenza dun «patriotismo republicano céltico» exemplifica a inseparabilidade entre a dimensión histórico-cultural e mítica e a dimensión cívica. As vicisitudes do ius soli testemuñan, así mesmo, os límites do patriotismo cívico francés: rexeitado por Napoleón e substituído polo ius sanguinis, non sería ata a Terceira República cando se readoptaría, se ben xa nun contexto de conflito con Alemaña. E, como Brubaker amosou, a súa recuperación formaría parte dun indoutrinamento — «moral and civil indoctrination» (Brubaker 1992: 45) - mediante un sistema nacional de ensino que impón unha lingua, un relato histórico e uns mitos e símbolos comúns para todos os franceses. A lenta nacionalización de Francia fronte ás nacionalidades e rexións internas, entre 1880 e 1910, como Eugen Weber mostrou na súa obra clásica, fusionou o patriotismo cívico con vertebración mediante infraestruturas viarias de unificación territorial, o sistema educativo xeneralizador da lingua, a historia nacional e os símbolos da na- 
ción así como o exército como instrumento de socialización nacionalitaria (Weber 1976: 493; 1991: 241). Finalmente, o affaire Dreyfus e o antisemitismo de Action française non farían senón actualizar o antisemitismo xa presente nunha tradición que se mantivo mesmo durante os anos da Revolución.

No caso do Reino Unido, a construción histórica do Estado e da nación como nación protestante fronte aos católicos ingleses, irlandeses ou, como inimigo externo, os franceses patentiza a exclusión orixinaria que hipoteca o carácter supostamente cívico do seu patriotismo (Marx 2003). Linda Coley amosou como no enfrontamento histórico con Francia a dimensión étnico-cultural se sitúa no núcleo mesmo da pertenza reservada aos true born Englishmen, de tal sorte que a construción da British nation se forxa en boa medida da man dun proxecto político e cultural antirrevolucionario. No imperio, a política de inmigración, unha política que permitía aos súbditos da Commonwealth chegar a ser British mais nunca English mostra de xeito patente as imbricacións cívico-étnicas. A Aliens Act de 1905, dirixida contra os xudeus da Europa do leste, e a British Nationality Act de 1981, debedora das ideas racistas de Enoch Powell e que derrogaba de feito o ius soli, amosan un retrato moito máis etnicista ca cívico da construción nacional inglesa.

Nos EuA, a exclusión fundacional das nacións indias sería o prolegómeno da xénese dunha nación arredor de criterios étnicos ben definidos, a saber: unha nación branca, protestante e de lingua inglesa, como se pode comprobar, por exemplo, na serodia incorporación dalgúns estados do sur e na manipulación das fronteiras da Florida para garantir unha maioría de poboación anglosaxoa. Por outra banda, como Élise Marienstras demostrou, paralelamente á concepción das institucións federais como substituto da comunidade nacional, existe un proxecto de nación cultural a partir da introdución de temas tales como o da «nación civilizada» fronte aos «salvaxes» (decretando ab initio a expulsión dos indios da nación americana), a mitificación da cultura anglosaxoa como a única idónea para as tarefas do novo Estado, o carácter identitario nacional da relixión e a fusión de relixión (militantemente protestante, como amosan as leis anticatólicas de varios estados) e civismo (configurando como trazo cívico a pertenza a seitas ou Igrexas protestantes) (Marienstras 1976, 1988). A. Marx demostrou, así, a centralidade da exclusión fundacional dos afroamericanos da nación: a pluralidade e o conflito das múltiples identidades brancas derivadas da inmigración europea foron suturadas e unificadas como nación branca fronte ao «outro» inte- 
rior de raza negra (Marx 1988). Fronte ao mito do melting pot, Rogers M. Smith, nunha investigación decisiva, mostrou como se introducirían progresivamente restricións raciais desde 1882, se establecerían cotas raciais en 1924 e a política de «defensa étnica», desde a década de 1830 á de 1920, sentaría as bases do criterio de exclusión e asimilación mediante a Anglo-conformity. Outras investigacións puxeron de manifesto a dimensión étnica do nacionalismo americano, a delimitación dos true Americans que, ao fío da Primeira Guerra Mundial, artellaría nun mesmo discurso compoñentes racistas, cristiano-fundamentalistas e militaristas (O’Leary 1999). Elementos étnico-culturais que adquirirían tal peso en diferentes conxunturas, nas políticas e prácticas de segregación ata a década dos sesenta do século xx que, de se aceptar retoricamente a dicotomía aquí cuestionada, para algúns especialistas sería máis exacto cualificar o nacionalismo dos EUA como nacionalismo exemplar de tipo étnico (Kaufmann 1999, 2000).

En segundo lugar, o estereotipo resulta igualmente simplificador e insostible no que atinxe á natureza exclusivamente étnica do nacionalismo «oriental». Do mesmo xeito que no tipo occidental existen anomalías xeográficas de peso — sen ir máis lonxe: o caso español-, tampouco un suposto nacionalismo oriental etnicista fai xustiza aos casos checo ou húngaro. Ou mesmo o alemán, tomado en toda a súa traxectoria. En efecto, de especial interese resulta a desvirtualización do caso alemán, pois, como xa vimos, o dualismo política/cultura superponse sobre o eixe Francia/Alemaña e refórzase sobre o de Ilustración/Romanticismo.

Segundo xa se observou no primeiro apartado, os estudos contemporáneos sobre o romanticismo filosófico e político abandonaron a caricatura que desde Heine e Ruge, elaborada sobre a innegable evolución última, conservadora ou mesmo reaccionaria, dalgúns dos románticos máis destacados, o postulaba como a negación, o totalmente outro da Ilustración. Neste senso, a obra de Beiser mostrou de xeito concluínte os vencellos co republicanismo, ata datas moi serodias, dos principais románticos alemáns, como Novalis, Schleiermacher ou Hölderlin, a súa matizada crítica á Ilustración, o seu comunitarismo democrático, o sentido moi preciso da contraposición organicismo/mecanicismo, o carácter político e non meramente estético do movemento (Beiser 1992). Michael Löwy subliñou, pola súa banda, a índole de crítica moderna, non pasadista, da modernidade nos románticos alemáns e a presenza dun romanticismo reformista ou revolucionario de Heine a Moses Hess, de Heine a Gustav Landauer (Löwy e Sayre 1992). 
Finalmente, Robert Richards, nun monumental traballo, desmontou a visión do pensamento romántico e a súa versión da Naturphilosophie como anticientífica, antiempírica e mística, e postulou a súa continuidade no pensamento de Darwin (Richards 2002).

Pola súa banda, a historiografía contemporánea someteu a crítica definitiva o arquetipo do excepcionalismo alemán —o Sonderweg-, a esaxeración de ler a historia de Alemaña desde o nazismo, reducindo a meros prolegómenos deste a complexa evolución anterior e contrapondo, fronte a unha suposta apoteose liberal das nacións occidentais, un camiño inequívoco e predestinado ao nacionalismo étnico e autoritario (Blackbourn e Eley 1984, Brubaker 1992). John Breuilly iluminou un panorama ben diferente e moito menos unívoco. Así, por exemplo, na Asemblea parlamentaria de Frankfurt de 1848 predominaba unha perspectiva liberal centrada no debate habido arredor da Constitución e os dereitos civís e políticos, ata o extremo de que a idea de nacionalidade do Estado se formulaba en termos de cidadanía, recoñecéndose a presenza de linguas minoritarias, e todo isto sen referencia a criterios étnicos. De feito, o novo Estado ao que se aspiraba non era considerado de ningún xeito como a expresión dunha identidade cultural subxacente, senón como un proxecto político (Breuilly 1993: 96). O propio Brubaker, que defende un uso matizado da distinción entre as concepcións alemá e francesa de nacionalidade, entende que o fracaso de Prusia na asimilación dos polacos se diferenza en grao, que non en calidade, do fracaso da asimilación francesa de bretóns, vascos, corsos ou alsacianos, motivada polo efecto fronteira co mundo eslavo (Brubaker 1992).

Poderiamos multiplicar os exemplos, mais só pretendemos deixar constancia de que unha leve ollada histórica mostra de xeito patente que os nacionalismos cívicos non son tan escrupulosamente "cívicos», e que os nacionalismos "étnicos» resultan en ocasións máis cívicos do que se lles supón. A bibliografía máis recente insiste en que toda nación é unha articulación complexa de elementos culturais e políticos, e moi especialmente en que esta articulación muda ao longo do tempo segundo específicas conxunturas e correlacións de forzas. Isto, no entanto, non supón, como algúns autores críticos coa dicotomía étnico/cívico sinalaron, que o proceso sexa unívoco e evolutivo desde unha inicial fase étnica a outra de madurez cívica. Na obra de Anthony Marx ou Taras Kuzio formúlase de modo diverso esta hipótese. $\mathrm{O}$ último, por exemplo, postula unha fase étnica que se mantén ata 
a década dos sesenta en Occidente (EUA) e se prolonga no leste ata os noventa, despois da caída do muro (Breton 2002, Marx 2003, Kuzio 2002). No entanto, o carácter evolutivo e relacional de cada nacionalismo en concreto, por mor de conxunturas internas e externas, da súa propia estrutura de oportunidade política e específicos formatos de mobilización e discurso (Máiz 2012), impide establecer unha síntese definitiva, unha sutura no proceso de construción nacional nun momento dado, conxelándoo nunha fase ora étnica, ora cívica. Así, os nacionalismos dos Estados nados da ruptura da ex-Iugoslavia e a ex-URss xeraron variedades ben diferentes de nacionalismos, unhas veces «nacionalizadores», outras democráticos na súa evolución (Brubaker 1996); e os nacionalismos occidentais experimentaron unha involución xenofóbica e racista, cando non estritamente fundamentalista (Silverman 1992).

Por outra banda, os estudos empíricos comparativos que ata agora se levan feito, empregando diferentes variables independentes, mostran 1) a natureza étnico-cultural e política á vez dos diferentes nacionalismos europeos (Krejčí e Velímský 1996) e 2) a forte presenza, nas nacións occidentais a mediados dos anos noventa, das concepcións fortemente culturais da nación e o apoio máis ben feble ao multiculturalismo (Shulman 2002).

Ora ben, os problemas fundamentais da dicotomía étnico/cívico non son de orde empírica, con ser estes moi importantes, senón de orde propiamente teórica. En efecto, escindindo a dimensión étnico-cultural da dimensión cívico-política e orixinando sobre cada unha delas un tipo ou modelo de nacionalismo, oclúese a posibilidade de dar conta cabal da nación — quer Estado-nación, quer «nación sen Estado»- como un proceso de articulación complexa de elementos políticos e culturais en contextos sociais específicos. Por iso non podemos aceptar, como se propuxo recentemente, salvar a dicotomía por mor do seu pretendido valor heurístico, se ben non como descrición empírica, senón como «tipo ideal» weberiano, que permitiría analizar amálgamas de compoñentes cívicas e étnicas en cada nacionalismo empírico (Zubrzycki 2002). Porque non hai, en rigor, dous tipos ideais de nación, un étnico e outro cívico, senón que o tipo ideal, se así o formulamos, do fenómeno nacionalista se configura arredor, precisamente, da articulación inextricable de elementos étnicos e cívicos, que en cada caso se concretan en sínteses político-ideolóxicas moi diferentes. Se mantemos o valor teórico da distinción, 1) bloquéase a posibilidade de dar conta da nación como 
un proceso político aberto e continxente de construción, que evoluciona de xeito desigual no tempo, a teor de circunstancias internas e externas, e polo tanto non pode ser fixado dunha vez e para sempre como cívico ou como político; 2) impide dar conta do pluralismo de formulacións, de proxectos nacionais e de loita pola hexemonía que se libra no interior de cada nación, e que supoñen outras tantas amálgamas de entre as moitas (mais non infinitas, posto que limitadas polas precondicións étnico-culturais, xeográficas e institucionais dispoñibles) posibles, e 3) se interpretan mal a mobilización, o discurso e a cultura nacionalistas como a mera expresión dunha nación dada, desconsiderando a súa natureza de factores fundamentais da construción nacional. Pois o nacionalismo non expresa ou exterioriza unha nación que se remonta á noite dos tempos, senón que contribúe decisivamente á súa recreación contemporánea, xa que selecciona, filtra e reformula os materiais dados (discursivos, estratéxicos, institucionais etc.), vencellando demandas, valores, mitos e símbolos con intereses de determinados grupos sociais.

Por iso, máis ca dous mundos á parte, as dimensións capitais da nación situaríanse ao longo dun continuum étnico-cívico. Cada nacionalismo concreto, en cada conxuntura específica, desprazaríase sobre o mencionado contínuum, nun constante proceso de rearticulación de varios dos seus elementos, con ritmos e tempos cambiantes, competindo pola hexemonía, pola dirección intelectual e moral da nación, con outras sínteses ben de elementos diferentes ou ben reelaboracións dos elementos mesmos. E sempre baixo a inercia da herdanza das formulacións pasadas, do peso (por veces coma unha lousa sobre as costas das xeracións presentes) dos mitos, narrativas e símbolos recibidos da propia tradición nacional.

Finalmente, debemos engadir algunha breve consideración de carácter normativo. Pois, formulada como se dixo, desde a posición do patriotismo cívico, a distinción étnico/cívico posúe non só os moi serios problemas empíricos e teórico-positivos xa vistos no apartado anterior, senón, así mesmo, moi notorios déficits teórico-normativos. En efecto, dando por resolta a fixación do demos mediante o recurso ao «esquecemento» da exclusión relixiosa e a violencia fundacional á que aludía Renan, e con isto a preexistencia coextensiva e autoevidente dun só pobo ou nación en cada Estado, a célebre dicotomía non é senón a outra cara da negación do carácter nacionalista ao patriotismo (cívico) de Estado. Nace así a 
ecuación oculta do Estado-nación, a saber: un Estado = unha nación = unha cultu$\mathrm{ra}=$ unha lingua $=$ unha historia. Como vimos, porén, o postulado da pretendida neutralidade estatal en materia cultural, tendo en conta que todo Estado-nación foi e é simultaneamente étnico e cívico, exclúe da avaliación normativa dous feitos fundamentais: 1) a imposición da cultura, da lingua e da narrativa histórica e mítico-simbólica da comunidade maioritaria sobre as minorías, abocadas á aculturación e á asimilación como contrapartida da adquisición da cidadanía igual, e 2) a conseguinte desigualdade estrutural, xeradora dunha cidadanía de segunda, que deste contrato de adhesión asimilacionista se deriva para os grupos e minorías nacionais internos, alí onde no canto dun demos existen unha pluralidade de demoi.

A falacia «é/debe» que se oculta no trade-off entre cidadanía libre e igual (patriotismo) e asimilación masiva na cultura e a lingua maioritarias (nacionalismo) resulta así evidente: do feito empírico da construción histórica dos estados nacionais derívase a irrelevancia ético-política da multinacionalidade. O problema é que esta falacia fundacional impide a análise e a crítica normativa destes procesos de construción nacional, isto é, a súa xustificabilidade en termos de esixencias da teoría da democracia, a saber: liberdade, igualdade, tolerancia, pluralismo, participación, deliberación, inclusión das minorías. E isto tanto nos nacionalismos de Estado como nos nacionalismos das nacións sen Estado, os cales, ao compartiren a argumentación subxacente no Estado-nación, adoptan especularmente, se ben invertida, parecida lóxica: unha historia nacional $=$ unha lingua $=$ unha cultura $=$ unha nación = un Estado independente.

Unha teoría normativa do nacionalismo democrático ha incorporar, porén, asuncións ben diferentes, que coinciden en boa medida coas xa examinadas no apartado anterior sobre o multiculturalismo: 1) o presuposto de que todo nacionalismo "cívico» ou patriotismo comporta elementos étnicos e culturais; do mesmo xeito que todo nacionalismo étnico-cultural debe responder en termos democráticos ás cuestións chaves da cidadanía: liberdade, pluralismo e inclusión; 2) que non adoitan corresponderse as fronteiras políticas e as culturais e que ningún territorio é monocultural, nin, xa que logo, titularidade ou patrimonio dunha soa cultura; 3) que a nación non é unha comunidade dada, inmutable, senón o resultado continxente dun proceso político de construción nacional e, polo tanto, constitúe un proxecto aberto; 4) que cada particular combinatoria 
de elementos políticos e étnicos proposta por cada nacionalismo é sempre o resultado dunha hexemonía entre as varias posibles e, por definición, contestable e contestada, polo que debe ser sometida a escrutinio ou avaliación normativa; 5) mais á vez resulta preciso garantir democraticamente as condicións de contexto para a deliberación, a participación e a inclusión de maiorías, minorías e individuos singulares na conversa a múltiples voces que constitúe cada nación.

Neste sentido, a evolución do debate sobre o nacionalismo democrático, o coñecido en teoría política como liberal nationalism debate, seguiu un curso moi claro: o abandono da dicotomía nacionalismo étnico-cultural/nacionalismo cívico (patriotismo). Nun primeiro momento, prodúcese unha radical depuración das compoñentes diacríticas máis organicistas do núcleo duro da etnicidade («raza», Volksgeist, relixión etc.) e promóvese unha rearticulación culturalista da idea de nación. Así, factores como a lingua, a historia, a cultura, as institucións, pasan a integrar o núcleo duro do concepto de nación, flexibilizando dun xeito importante o naturalismo e o determinismo dos factores «obxectivos» que cualifican a presenza dunha nación. Esta versión culturalista do nacionalismo permite algo fundamental, un achegamento ás demandas democráticas, á conciliación de demandas de maiorías e minorías, á posta en marcha de mecanismos de inclusión non coactivos etc. Ora ben, nun segundo momento do debate obsérvase que este xiro culturalista do concepto de nación, se ben decisivo, con respecto ao tradicional modelo organicista, posúe límites importantes: ante todo segue a ser un modelo monista, onde unha nación $=$ unha lingua $=$ unha cultura. Este monismo impide a completa politización democrática do concepto de nación, que require de modo ineludible — como xa vimos no debate do multiculturalismo- a introdución do pluralismo: non só ideolóxico, senón tamén cultural e lingüístico, no interior de cada nación. A necesidade, en definitiva, de dar un paso máis aló do nacionalismo cultural, retendo as súas achegas, para realzar unha nova síntese pluralista ou, en suma, un concepto pluralista de nación, que abandone a asunción monista — un territorio, unha nación, unha lingua — para se abrir a fórmulas de negociación, tolerancia e igual respecto entre maiorías e minorías lingüísticas, culturais e relixiosas, mediante o que deu en se chamar reasonable accommodations (Máiz 2012). 


\section{O CONCEPTO EMERXENTE DA CULTURA COMO PRÁCTICA SE- MIÓTICA NA CIENCIA POLÍTICA}

Pois ben, en importante sintonía co visto anteriormente na teoría política do multiculturalismo e o nacionalismo democrático, na ciencia política contemporánea gañou peso, paralelamente ao desenvolvemento da liña tradicional de investigación sobre a cultura política (Norris 1999, Dalton 2002, Wiarda 2002), un programa de investigación alternativo no que a cultura se estuda como un sistema de símbolos que prové de sentido político a vida colectiva dos cidadáns. En ocasións esta nova perspectiva resulta debedora explicitamente da teoría posmoderna (Wedeen 2002, Ross 2009); noutras, das achegas interpretativas da antropoloxía de Cohen ou Geertz (Laitin 1986). Mesmo no seo do paradigma tradicional, na obra de Inglehart, que —a diferenza de Almond e Verba, preocupados pola persistencia das culturas políticas no curso do tempo- se centrou desde un comezo na mudanza política e cultural, aparecerá un recońecemento explícito do carácter inherentemente normativo da democracia e dos «valores de autoexpresión» que a sustentan (Inglehart 2005).

Non debe esquecerse que para a moderna bioloxía e psicoloxía evolucionistas (e a ciencia cultural que se basea nelas) a correcta secuencia explicativa, a diferenza do behaviorismo, é como segue: empatía-instinto social-comunidade-linguaxe e culturavalores compartidos-acción individual. Como sinalaron Edward Wilson ou Mark Pagel: a cultura constitúe un mecanismo fundamental para a creación e a supervivencia dos grupos sociais (Wilson 2012: 281; Pagel 2012: 75). A cultura representa un mecanismo chave de formación grupal mediante as redes de significación, que producen meaningfulness, isto é, semiose que se constrúe en tres dimensión simultáneas: identidade, sociabilidade e sentido, xerando «strong reciprocity» que fai dos seres humanos unha excepcionalmente «cooperative species» (Bowles e Gintis 2011). Así, a identidade individual é un resultado da sociabilidade, non o seu punto de partida, e a conduta xorde da comunicación intersubxectiva no seo dun grupo cuxa idea de como se debe actuar depende de desexos compartidos e da aprobación dos outros membros. En suma: «culture sets the rules for individual action [...]. '[C]ulture makes us' rather than the other way round» (Hartley e Potts 2014: 4).

$\mathrm{Na}$ ciencia política máis recente, baixo os varios impulsos xa citados, podemos subliñar polo menos tres dimensións dun novo concepto de cultura emerxente. 
Dimensións que resultan especialmente pertinentes para dotar de base explicativa rigorosa a teoría política normativa, que ten que lidar coa dimensión cultural. a. - A cultura como conxunto de prácticas de dotación de significado. Nesta perspectiva, a cultura resulta decisiva para a análise da política porque dota de sentido as accións e as identidades dos actores organizando os seus significados e fornecendo un horizonte normativo para a súa vida, os seus intereses, as súas institucións, as súas estratexias (Sewell 1999). A análise da produción política do sentido require a investigación sistemática das conexións entre as prácticas dos actores políticos (participación, identificación, traballo etc.) e os sistemas de significación que os conforman (símbolos, mitos, linguaxe etc.). Deste xeito, a concepción da cultura como "práctica cultural», "practices embedded in traditions» (Bevir e Rhodes 2010), como práctica semiótica, posúe implicacións fundamentais (Wedeen 2002, Norton 2004, Chabal e Daloz 2006): a) investiga o que a linguaxe, os mitos e os símbolos «causan» en canto "webs of significance», isto é, como se insiren, en calidade de variables independentes, en determinadas accións e producen efectos políticos empiricamente observables; b) atende, así mesmo, á súa condición de «efectos» semióticos, en calidade de variable dependente, das estruturas de dominación, os arranxos institucionais e o conflito entre intereses estratéxicos, e d) dá conta, en fin, dun conxunto de fenómenos políticos que os programas tradicionais de investigación da «cultura política» desatendían: a explicación de por que e como os actores dotan de sentido, histórica e conflitivamente, determinadas accións ou institucións políticas. De especial interese resulta a capacidade deste enfoque para abordar os procesos de xénese de autoevidencias, naturalización e autoridade en ámbitos como relixión, identidade, lexitimidade democrática etc. Isto é, estúdase a produción da mínima intelixibilidade imprescindible para un grupo se recoñecer en determinados signos, os cales, pola súa vez, se poñen de manifesto a través de prácticas diversas de significación. Ora ben, tradicións, símbolos, imaxes, identidades e textos deveñen, nesta perspectiva, signos cuxo significado está sempre provisionalmente fixado, resulta precario e cambiante no tempo, obxecto de relacións de poder, de contestación e conflito. Así, o que a primeira vista pode parecer natural, coherente, cristalizado como unha totalidade acabada e discreta, resulta sempre produto continxente de procesos de mudanza e loitas entre interpretacións opostas. Por esta razón deben ser investigadas empiricamente en cada caso concreto (Wedeen 1999). 
b.- A cultura como recurso para a mobilización e a organización política. A cultura fornece esquemas e marcos de intelixibilidade política e por isto constitúe unha decisiva fonte de recursos organizativos e para a acción (Ross 2007, 2009). A obra seminal de Edelman Politics as Symbolic Action (Edelman 1971), de extraordinario interese neste sentido, resultou moi desatendida ata datas posteriores á eclosión dos estudos sobre os movementos sociais. En efecto, esta dimensión cultural situarase no fulcro dos novos programas de investigación xurdidos con posterioridade aos paradigmas iniciais do «proceso político» e a «mobilización de recursos» (McAdam, Tarrow e Tilly 2009) e desenvolvidos polos modelos construtivistas, a partir da obra pioneira de Alberto Melucci, ao chamaren a atención sobre a condición dos novos movementos sociais de portadores de novos códigos culturais. A partir dos anos noventa (McAdam, McCarthy e Zald 1996), a dimensión cultural, quer a través dos procesos de encadramento (framing) da mobilización, quer das tradicións culturais de mobilización, construíu unha dimensión fundamental da axenda de investigación da política de protesta. O horizonte clásico, debedor da tradición estruturalista, deu paso a unha análise atenta non só á interacción estratéxica entre os actores, senón tamén ás distintas formas de conciencia política e á cultura historicamente acumulada por movementos e organizacións (Máiz 2011). A hipótese de que o contexto histórico e cultural en que discorre a mobilización afecta dun xeito significativo aos actores, ás súas traxectorias, estratexias e concatenacións de mecanismos causais constituirá un novo punto de partida. Encadramento e interpretación representan, desde aquela, moito máis ca unha outra variable explicativa, para se integraren nun máis amplo contexto interpretativo, que abrangue desde a percepción das oportunidades políticas aos procesos de construción de identidades (McAdam, Tarrow e Tilly 2001). Así, os repertorios de acción colectiva constitúen un conxunto de costumes, hábitos e interpretacións que resultan compartidos, transmitidos e aprendidos; en suma, auténticas «creacións» (Tilly). En definitiva, as culturas e os procesos interpretativos que as integran e difunden non son considerados como meros condicionantes externos da mobilización política, senón que se analizan como factores implicados nas interaccións mesmas entre os actores en conflito.

c.- A cultura como conexión entre as identidades individuais e colectivas. A última dimensión que queremos destacar é a reformulación dos programas de investigación da elección racional para dar cabida, en complexa articulación cos seus supostos de 
individualismo metodolóxico, á dimensión cultural intersubxectiva, logo de seren consideradas estas por longo tempo «mutuamente excluíntes e antagonistas» (Bates, Figueiredo e Weingast 1998). Nesta perspectiva, a cultura considérase como máis ca un recurso facilitador da acción colectiva, para se analizar como un conxunto de crenzas, normas e visións do mundo. Así, a cultura (signos, símbolos, linguaxe) é relevante para os individuos en canto que os provén de sentido colectivo na súa vida mediante os valores profundamente arraigados no grupo cultural (Laitin 1986). A recuperación da fonda dimensión intersubxectiva da análise, perdida en moitos estudos tributarios do individualismo metodolóxico, vehicúlase a través da escolla cultural estratéxica dos autores; isto é, de decisións baseadas nos intereses propios e no curso de acción previsto por parte dos demais (Laitin 1998). Nesta perspectiva ábrese unha liña de investigación - a cultura como equilibrio dinámico- que ten como obxectivo analizar os procesos mediante os cales os membros dos grupos culturais - i. e., os que comparten un conxunto de prácticas simbólicas (relixión, lingua, arte, rituais)—, mediante unha urda de símbolos compartidos, prácticas rituais e unha densa interacción, condicionan o seu comportamento mediante crenzas culturais - i. e., de sentido común compartido- sobre o comportamento esperable por parte dos outros membros do grupo (Laitin e Weingast 2006). Toda cultura grupal, en principio, se atopa nunha condición de equilibrio, isto é, posúe unha estrutura de autorreforzo que incentiva a pertenza a ela (positiva e negativamente), excepto no caso de inconsistencia radical das crenzas coa realidade social dos actores. Así, por unha banda a coordinación estratéxica volve a cultura estable, se ben con capacidade de mudanza (equilibrio dinámico); pola outra, os símbolos compartidos constitúen o fundamento de visións do mundo comúns que provén os membros dun grupo cultural de algo moi valioso e substantivo, non meramente instrumental: un mundo de sentido compartido. E, fronte á reticencia a investigar as identidades colectivas, este programa de investigación permite considerar as nacións como poboacións dotadas dun conxunto coordinado de crenzas sobre a súa identidade cultural con pretensións ao dispor dun Estado propio (Laitin 2007). Deste xeito, a cultura devén un factor fundamental da identidade, sen resultar por iso nin ubicua nin holística, nin cristalizada nin allea ao conflito interno, e pode ser analizada empiricamente como un proceso continxente e estratéxico de construción política.

En conclusión: as achegas destes programas construtivistas e relacionais de investigación non só, como tratamos de mostrar, sintonizan coas elaboracións da teoría política máis recente sobre nacionalismo e multiculturalismo. Trátase 
de moito máis ca iso: co seu fincapé, por unha banda — fronte ás perspectivas instrumentalistas-, no capital relevo político da dimensión cultural como provedora de significado compartido para os grupos e as comunidades, e, pola outra —fronte ás perspectivas primordialistas_, no carácter continxente, construído e internamente conflitivo de toda identidade cultural, resultan de indubidable interese, de feito imprescindibles, para o debate teórico normativo sobre o multiculturalismo, o nacionalismo e a democracia. O prezo de non incorporar as súas achegas sería moi alto: limitarse a ilustrar a reflexión teórica con meros exemplos impresionistas ad hoc; prescindir dunha sólida base explicativa e comparada para os referentes empíricos da argumentación; e seguir asumindo un concepto prepolítico, esencialista e holista de cultura, nación ou grupo étnico abandonado hai tempo, por insostible, na investigación máis solvente da ciencia social contemporánea. 


\section{REFERENCIAS BIBLIOGRÁFICAS}

Almond, Gabriel A. / Sidney Verba (1963): The Civic Culture: Political Attitudes and Democracy in Five Nations, Princeton, Princeton University Press.

Almond, Gabriel A. / G. Bingham Powell Jr. (1966): Comparative Politics: A Developmental Approach, Boston, Little Brown.

Aвrams, Meyer Howard (1971): Romanticism: Tradition and Revolution, Nova York, Norton.

Barry, Brian (2002): Culture and Equality: An Egalitarian Critique of Multiculturalism, Cambridge, Polity.

Bates, Robert H. / Rui J. P. de Figueiredo / Barry R. Weingast (1998): «The Politics of Interpretation:

Rationality, Culture, and Transition", Politics and Society, 26:4, 603-642.

Bauman, Zygmunt (1992): Intimations of Postmodernity, Londres, Routledge.

Bauman, Zygmunt (1993): Postmodern Ethics, Oxford, Blackwell.

Bauman, Zygmunt (1995): Life in Fragments: Essays in Postmodern Morality, Oxford, Blackwell.

BeIner, Ronald (ed.) (1999): Theorizing Nationalism, Albany, State University of New York Press.

Beiner, Ronald / Wayne Norman (2001): Canadian Political Philosophy, Oxford, Oxford University Press.

Beiser, Frederick C. (1987): The Fate of Reason: German Philosophy from Kant to Fichte, Cambridge, Harvard University Press.

BeIser, Frederick C. (1992): Enlightenment, Revolution, and Romanticism: The Genesis of Modern German Political Thought, 1790-1800, Cambridge, Harvard University Press.

Benhabib, Seyla (2002): The Claims of Culture: Equality and Diversity in the Global Era, Princeton, Princeton University Press.

BerLin, Isaiah (1999): The Roots of Romanticism, Princeton, Princeton University Press.

Best, Steven / Douglas Kellner (1997): The Postmodern Turn, Nova York, Guilford.

Bevir, Mark / R. A. W. Rhodes (2010): The State as Cultural Practice, Oxford, Oxford University Press.

Blackbourn, David / Geoff Eley (1984): The Peculiarities of German History: Bourgeois Society and Politics in Nineteenth-Century Germany, Oxford, Oxford University Press.

Bowles, Samuel / Herbert Gintis (2011): A Cooperative Species: Human Reciprocity and Its Evolution, Princeton, Princeton University Press.

Breton, Raymond (1988): «From Ethnic to Civic Nationalism: English Canada and Quebec», Ethnic and Racial Studies, 11:1, 85-102.

Breuilly, John (1996): Nationalism and the State, Manchester, Manchester University Press.

Brubaker, Rogers (1992): Citizenship and Nationhood in France and Germany, Cambridge, MA, Harvard University Press.

Brubaker, Rogers (1996): Reframing Nationalism, Cambridge, Cambridge University Press.

Brubaker, Rogers (2004): Ethnicity without Groups, Cambridge, Harvard University Press.

Caney, Simon (2002): «Equal Treatment, Exceptions and Cultural Diversity», en Paul Kelly (ed.), Multiculturalism Reconsidered: Culture and Equality and Its Critics, Cambridge, Polity, 81-101.

Carens, Joseph H. (2000): Culture, Citizenship, and Community: A Contextual Exploration of Justice as Evenhandedness, Oxford, Oxford University Press.

Chabal, Patrick / Jean-Pascal Daloz (2006): Culture Troubles: Politics and the Interpretation of Meaning, Chicago, University of Chicago Press. 
ChaI, Leon (2006): Romantic Theory: Forms of Reflexivity in the Revolutionary Era, Baltimore, Johns Hopkins.

Chandra, Kanchan (2012): Constructivist Theories of Ethnic Politics, Oxford, Oxford University Press.

Clifford, James (1998): The Predicament of Culture: Twentieth-Century Ethnography, Literature and Art, Cambridge, Harvard University Press.

Clifford, James / George E. Marcus (1986): Writing Culture: The Poetics and Politics of Ethnography, Berkeley, University of California Press.

Dalton, Russell J. (2002): Citizen Politics, Chatham, Chatham House.

Droz, Jacques (1966): Le Romantisme allemand et l'État: résistance et collaboration dans l'Allemagne napoléonienne, París, Payot.

EAgLeton, Terry (2000): The Idea of Culture, Londres, Blackwell.

Edelman, Murray (1971): Politics as Symbolic Action: Mass Arousal and Quiescence, Nova York, Markham.

Finkielkraut, Alain (1987): La Défaite de la pensée, París, Gallimard.

Galston, William (1991): Liberal Purposes: Goods, Virtues, and Diversity in the Liberal State, Nova York, Cambridge University Press.

Geertz, Clifford (1973): The Interpretation of Cultures, Nova York, Basic Books.

Geertz, Clifford (2000): Available Light: Anthropological Reflections on Philosophical Topics, Princeton, Princeton University Press.

Giddens, Anthony (1991): Modernity and Self-identity: Self and Society in the Late Modern Age, Cambridge, Polity.

Glazer, Nathan (1983): Ethnic Dilemmas, 1964-1982, Cambridge, Harvard University Press.

Glazer, Nathan (1997): We Are All Multiculturalists Now, Cambridge, Harvard University Press.

Hale, H. E. (2008): The Foundations of Ethnic Politics, Nova York, Cambridge University Press.

Hardt, Michael / Antonio Negri (2000): Empire, Cambridge, Harvard University Press.

Hardt, Michael / Antonio Negri (2004): Multitude: War and Democracy in the Age of Empire, Londres, Penguin.

Hardt, Michael / Antonio Negri (2009): Commonwealth, Cambridge, Harvard University Press.

Hartley, John / Jason Potтs (2014): Cultural Science: A Natural History of Stories, Demes, Knowledge and Innovation, Londres, Bloomsbury.

Huntington, Samuel P. (1996): The Clash of Civilizations and the Remaking of World Order, Nova York, Simons and Schuster.

Huntington, Samuel P. (2004): Who Are We?: The Challenges to America's National Identity, Nova York, Free Press.

Inglehart, Ronald (1990): Culture Shift in Advanced Industrial Society, Princeton, Princeton University Press.

Inglehart, Ronald (1997): Modernization and Postmodernization: Cultural, Economic and Political Change in 43 Societies, Princeton, Princeton University Press.

Inglehart, Ronald / Christian Welzel (2005): Modernization, Cultural Change, and Democracy: The Human Development Sequence, Nova York, Cambridge University Press.

Inglehart, Ronald / Pippa Norris (2018): Cultural Backlash, Nova York, Cambridge University Press Jameson, Fredric (1991): Postmodernism or, The Cultural Logic of Late Capitalism, Londres, Verso.

Kaufmann, Eric (1999): «American Exceptionalism Reconsidered: Anglo-Saxon Ethnogenesis in the "Universal" Nation, 1776-1850», Journal of American Studies, 33:3, 437-458. 
Kaufmann, Eric (2000): «Ethnic or Civic Nation?: Theorizing the American Case», Canadian Review of Studies in Nationalism, XXvII:1-2, 133-155.

Kelly, Paul (ed.) (2002): Multiculturalism Reconsidered: Culture and Equality and Its Critics, Cambridge, Polity.

King, Gary / Robert O. Keohane / Sidney Verba (1994): Designing Social Inquiry: Scientific Inference in Qualitative Research, Princeton, Princeton University Press.

KrejČí, Jaroslav / Vitězslav Velímský (1996): «Ethnic and Political Nations in Europe», en John Hutchinson, Anthony D. Smith (eds.), Ethnicity, Oxford, Oxford University Press.

Kuzıo, Taras (2002): «The Myth of the Civic State», Ethnic and Racial Studies, 25:1, 20-39.

Kyмlicка, Will (1995): Multicultural Citizenship: A Liberal Theory of Minority Rights, Oxford, Oxford University Press.

Kyмlicка, Will (2001): Politics in the Vernacular: Nationalism, Multiculturalism, and Citizenship, Oxford, Oxford University Press.

Kymlicka, Will / Wayne Norman (eds.) (2000): Citizenship in Diverse Societies, Oxford, Oxford University Press. Laborde, Cécile (2008): Critical Republicanism: The Hijab Controversy and Political Philosophy, Oxford, Oxford University Press.

Laden, Anthony Simon / David Owen (eds.) (2007): Multiculturalism and Political Theory, Cambridge, Cambridge University Press.

LAFOREST, Guy (1992): De la prudence : textes politiques, Québec, Bóreal.

LAForest, Guy (1995): De l'urgence : textes politiques, Québec, Boréal.

Laitin, David D. (1986): Hegemony and Culture: Politics and Change among the Yoruba, Chicago, University of Chicago Press.

Laitin, David D. (1998) Identity in Formation: The Russian-Speaking Populations in the New Abroad, Ithaca, NY, Cornell University Press.

Laitin, David D. (2007): Nations, States and Violence, Oxford, Oxford University Press.

Laitin, David D. / Barry R. Weingast (2006): «An Equilibrium Alternative to the Study of Culture», The Good Society, 15:1, 15-21.

Larmore, Charles E. (1996): The Romantic Legacy, NovaYork, Columbia University Press.

Levy, Jacob T. (2000): The Multiculturalism of Fear, Oxford, Oxford University Press.

Lipovetsky, G. (1986): La era del vacio, Barcelona, Anagrama.

LÖWY, Michael / Robert SAYRE (1992): Révolte et mélancolie: le romantisme à contre-courant de la modernité, París, Payot.

McAdam, Doug / John D. McCarthy / Mayer N. Zald (1996): Comparative Perspectives on Social Movements: Political Opportunities, Mobilizing Structures, and Cultural Framings, Cambridge, Cambridge University Press.

McAdam, Dough / Sidney Tarrow / Charles Tilly (2001): Dynamics of Contention, Cambridge, Cambridge University Press.

Márz, Ramón (2003): «Framing the Nation: Three Rival Versions of Political Nationalist Ideology», Journal of Political Ideologies, 8:3, 251-267.

Márz, Ramón (2011): «Las dos lógicas de la explicación en la obra de Charles Tilly: Estados y repertorios de protesta», en María Jesús Funes (ed.), A propósito de Tilly, Madrid, cis, 48-77.

Márz, Ramón (2012): The Inner Frontier: The Place of Nation in the Political Theory of Democracy and Federalism, Bruxelas, Peter Lang. 
Márz, Ramón (2018a): «Una cuerda sobre el abismo. Modernismo y Postmodernismo en Metrópolis (Fritz Lang) y Blade Runner (Ridley Scott)", en M. Alcántara / S. Mariani (coords.), La politica es de cine, Madrid, Centro de Estudios Políticos y Constitucionales.

Márz, Ramón (2018b): Nacionalismo y federalismo, Madrid, Siglo XXI.

Márz, Ramón / Ferrán Requejo (2005): Democracy, Nationalism and Multiculturalism, Londres, Routledge. Marienstras, Élise (1977): Les Mythes fondateurs de la nation américaine, París, Maspero.

Marienstras, Élise (1988): Nous le peuple: les origines du nationalisme américaine, París, Gallimard.

Marx, Anthony W. (1988): Making Race and Nation: A Comparison of South Africa, the United States, and Brazil, Cambridge, Cambridge University Press.

MarX, Anthony W. (2003): Faith in Nation: Exclusionary Origins of Nationalism, Nova York, Oxford University Press.

Miller, David (1995): On Nationality, Oxford, Oxford University Press.

Miller, David (2000): Citizenship and National Identity, Cambridge, Polity.

Miller, David (2002): «Liberalism, Equal Opportunities and Cultural Commitments», en Paul Kelly (ed.), Multiculturalism Reconsidered: Culture and Equality and Its Critics, Cambridge, Polity, 45-62.

Norman, Wayne (1995): «The Ideology of Shared Values: A Myopic Vision of Unity in the Multi-nation State», en Joseph H. Carens (ed.), Is Quebec Nationalism Just?: Perspectives from Anglophone Canada, Montreal e Kingston/Londres/Buffalo, MacGill-Queen's University Press.

Norris, Pippa (ed.) (1999): Critical Citizens: Global Support for Democratic Governance, Oxford, Oxford University Press.

Norton, Anne (2004): 95 Theses on Politics, Culture, and Method, New Haven, Yale University Press.

O'Leary, Cecilia Elizabeth (1999): To Die For: The Paradox of American Patriotism, Princeton, Princeton University Press.

Pagel, Mark D. (2012): Wired for Culture: The Natural History of Human Cooperation, Londres, Penguin. PAREKH, Bhikhu (2000): Rethinking Multiculturalism: Cultural Diversity and Political Theory, Londres, MacMillan. Poliakov, Léon (1971): Le Mythe aryen, París, Calmann-Lévy.

Pollock, Griselda (1996): Generations and Geographies in the Visual Arts, Londres, Routledge.

PolLock, Griselda (1999): Differencing the Canon: Feminist Desire and the Writing of Art's Histories, Londres, Routledge.

Przeworsky, Adam (1986): «Marxism and Rational Choice», Politics and Society, 14, 379-409.

Richards, Robert J. (2002): The Romantic Conception of Life: Science and Philosophy in the Age of Goethe, Chicago, University of Chicago Press.

Rorty, Richard (1989): Contingency, Irony, and Solidarity, Cambridge, Cambridge University Press.

Ross, Marc Howard (2007): Cultural Contestation in Ethnic Conflict, Cambridge, Cambridge University Press. Ross, Marc Howard (2009): «Culture in Comparative Political Analysis», en Mark Irving Lichbach, Alan S. Zuckerman (eds.), Comparative Politics: Rationality, Culture and Structure, Nova York, Cambridge University Press.

SAID, Edward W. (1978): Orientalism, Nova York, Vintage.

Schnapper, Dominique (1994): La Communauté des citoyens, París, Gallimard.

Sewell, William H., Jr. (1999): «The Concept(s) of Culture», en Victoria E. Bonnell, Lynn Hunt, Beyond the Cultural Turn: The Poetics and Politics of Ethnography, Berkeley, University of California Press, 35-61. 
Shulman, Stephen (2002): «Challenging the Civic/Ethnic and West/East Dichotomies in the Study of Nationalism», Comparative Political Studies, 35:5, 554-585.

Silverman, Maxim (1992): Deconstructing the Nation: Immigration, Racism and Citizenship in Modern France, Londres, Routledge.

SMith, Anthony D. (1986): The Ethnic Origins of Nations, Oxford, Blackwell.

Sмiтн, Anthony D. (1991): National Identity, Londres, Penguin.

Sмith, Anthony D. (1996): "Civic and Ethnic Nationalism Revisited», The ASEN Bulletin, 12, 9-14.

SMITH, Anthony D. (1999): Myths and Memories of the Nation, Oxford, Oxford University Press.

SмIтн, Anthony D. (2000): The Nation in History: Historiographical Debates about Ethnicity and Nationalism, Cambridge, Polity.

TAYlor, Charles (1989): Sources of the Self: The Making of the Modern Identity, Cambridge, Cambridge University Press.

TAYLOR, Charles (1992): «The Politics of Recognition», en Multiculturalism and "The Politics of Recognition", ed. Amy Gutmann, Princeton, Princeton University Press.

Tully, James (1995): Strange Multiplicity: Constitutionalism in an Age of Diversity, Cambridge, Cambridge University Press.

Tully, James (2002): «The Illiberal Liberal: Brian Barry's Polemical Attack on Multiculturalism», en Paul Kelly (ed.), Multiculturalism Reconsidered: Culture and Equality and Its Critics, Cambridge, Polity, 102$-113$.

Verba, Sidney / Norman H. Nie / Jae-on Kim (1978): Participation and Political Equality: A Seven-Nation Comparison, Cambridge, Cambridge University Press.

VIroli, Maurizio (1995): For Love of Country: An Essay on Patriotism and Nationalism, Oxford, Oxford University Press.

Walzer, Michael (1996): Thick and Thin: Moral Argument at Home and Abroad, Notre Dame, University of Notre Dame Press.

Walzer, Michael (2004): Politics and Passion: Toward a More Egalitarian Liberalism, New Haven, Yale University Press.

Weber, Eugen (1976): Peasants into Frenchmen: The Modernization of Rural France, 1870-1914, Stanford, Stanford University Press.

Weber, Eugen (1991): My France: Politics, Culture, Myth, Cambridge, MA, Harvard University Press.

Wedeen, Lisa (1999): Ambiguities of Domination: Politics, Rhetoric, and Symbols in Contemporary Syria, Chicago, University of Chicago Press.

Wedeen, Lisa (2002): «Conceptualizing Culture: Possibilities for Political Science», American Political Science Review, 96:4, 713-728.

Wedeen, Lisa (2008): Peripheral Visions: Publics, Power, and Performance in Yemen, Chicago, University of Chicago Press.

Wiarda, Howard J. (2002): New Directions in Comparative Politics, Boulder, Westview Press.

Willett, Cynthia (ed.) (1998): Theorizing Multiculturalism: A Guide to the Current Debate, Oxford, Blackwell.

Williams, Raymond (1963): Culture and Society: 1780-1950, Londres, Hardmonsworth.

Wilson, Edward O. (2012): La conquista social de la Tierra, Barcelona, Random House Mondadori. 
Young, Iris Marion (2000): «Self-Determination and Global Democracy: A Critique of Liberal Nationalism», en Ian Shapiro / Stephen Macedo (eds.), Designing Democratic Institutions, Nova York, New York University Press, 147-184.

ZubrZYCKI, Geneviève (2002): «The Classical Opposition Between Civic and Ethnic Models of Nationhood: Ideology, Empirical Reality and Social Scientific Analysis», Polish Sociological Review, 3, 275-295. 
A INTERSECCIONALIDADE SITUADA E OS SIGNIFICADOS DA CULTURA

Nira Yuval-Davis

Centre for Research on Migration, Refugees

and Belonging (CMRB)

University of East London 

Neste ensaio vou presentar o marco analítico-metodolóxico da interseccionalidade situada, en tanto que lente que nos permita comprender os significados da cultura. O principal argumento deste marco radica na idea de que resulta imposible entender a cultura sen unha epistemoloxía dialóxica que abranga os ollares situados da maior cantidade posible daqueles que fan referencia a esa «cultura» e a practican.

En primeiro lugar presentarei o marco da interseccionalidade situada e, a seguir, pasarei a estudar a noción de cultura e de que maneiras a interseccionalidade situada pode arrequecer e validar a comprensión que temos dela.

\section{A INTERSECCIONALIDADE SITUADA}

Que é a interseccionalidade? Lesley McCall (2005: 1771) e outros autores argúen que a interseccionalidade é «a achega teórica máis importante que fixeron ata agora os estudos das mulleres, en conxunción con outros campos afíns» e, abofé, a pegada da análise interseccional pode detectarse con facilidade nas innovacións habidas na lexislación sobre igualdade, nos dereitos humanos e nos discursos sobre o desenvolvemento. Dada a súa historia múltiple e pluridisciplinar, a interseccionalidade non constitúe un corpo teórico unificado, senón, máis ben, un abano de ferramentas teórico-conceptuais ${ }^{1}$; porén, e en tanto que tal, aseméllase a outras destacadas perspectivas teóricas que foron elaboradas por máis dun teórico ou en máis dun contexto espazotemporal, desde o marxismo ata o neoliberalismo, pasando polo feminismo, e por non mencionar a socioloxía. O anterior non quere dicir, con todo, que non poidamos debater sobre cal debería ser o encadramento teórico axeitado que recorra á interseccionalidade para uns fins analítico-políticos concretos. Eu denomino «interseccionalidade situada» (Yuval-

\footnotetext{
${ }^{1}$ Para consultar un debate verbo da índole da interseccionalidade, véxase, por exemplo, Lutz et al. (2011) e o número especial do European Journal of Women's Studies dedicado ao tema (2006), así como Signs (2013).
} 
-Davis 2015) a miña particular versión da teoría da interseccionalidade, que difire bastante dalgunhas das outras versións que se teñen popularizado.

Malia que en orixe se concibiron como un contrapeso ás políticas da identidade que destacan (e homoxeneízan, e reifican) unhas versións unidimensionais das identidades, algúns destes enfoques interseccionais deviñeron nunha sorte de política fragmentada da identidade, cuxo foco de atención xa non reside, por exemplo, nas mulleres nin nos negros, senón nas mulleres negras. Fundamental na perspectiva que adopto ante a análise da interseccionalidade situada —que comecei a elaborar, xunto con Floya Anthias (por exemplo, 1982, 1992) nos primeiros anos do decenio de 1980, antes de o termo «interseccionalidade» ser inventado por Kimberlé Crenshaw en 1989- é a idea de que a análise interseccional tería que aplicarse a todas as persoas e non só a mulleres marxinadas e racializadas, ás cales vai ligado historicamente o xurdimento da teoría da interseccionalidade (por exemplo, Crenshaw 1989; Hill Collins 1990; véxase tamén Brah e Phoenix 2004). Nós sostemos que, se ben os intereses políticos, profesionais e disciplinares daqueles que empregan a interseccionalidade poden variar, só mediante un enfoque xenérico tal da análise da interseccionalidade se podería, en última instancia, evitar os riscos do excepcionalismo e da reificación e esencialización das fronteiras sociais. Como apuntan os estudos críticos da raza e a etnia, non son unicamente os negros os que son construídos racialmente, e as feministas recórdanlles aos homes, abofé, que eles tamén teñen sexo; e, cousa que é mesmo máis importante para o que nos interesa aquí, non son só as persoas pertencentes a minorías étnicas as que teńen «cultura e tradición».

A análise da interseccionalidade ten que ver coa distribución do poder e doutros recursos na sociedade e, xa que logo, constitúe o que en socioloxía se cońece como teoría da estratificación. A estratificación, ou, mellor dito, a estratificación social, refírese ás distintas situacións xerárquicas que ocupan os individuos e as agrupacións de persoas nas grellas de poder da sociedade. A interseccionalidade representa a abordaxe máis válida e exhaustiva do estudo da estratificación social porque non reduce a complexidade das construcións do poder a unha única división social, polo xeral a de clase, como ocorre habitualmente nas teorías da estratificación. Ao mesmo tempo, é importante subliñar que non entendo as distintas divisións sociais que constrúen as relacións de poder como sumatorias (por exemplo, en Bryan et al. [1985]), transversais (por exemplo, Crenshaw [1989]) nin entrecruzadas (por 
exemplo, Hill Collins [1990]), senón, pola contra, como elementos mutuamente constituíntes, que forman os significados concretos, matizados e contestados que teñen unhas situacións sociais dadas nuns momentos históricos específicos, no interior duns contextos sociais, económicos e políticos particulares nos cales unhas divisións sociais, como as determinadas polo sexo, a raza, a etnia, a categoría cidadá ou as capacidades, teńen un maior resalte e máis efectos en persoas concretas ou na sociedade no seu conxunto, ou en ambas, ca noutras.

No entanto, como sempre destacamos Floya Anthias e mais eu, malia que en determinadas situacións as distintas divisións sociais son constituíntes unhas doutras, resultan mutuamente irredutibles, no sentido de que cada unha posúe un discurso ontolóxico distinto sobre unhas dinámicas concretas das relacións de poder na exclusión ou na explotación, ou en ambas, para o cal se serven dun abano de tecnoloxías lexítimas e ilexítimas de inferiorización, intimidación e, por veces, violencia real para acadar ese propósito. Así, por exemplo, as relacións de clase constrúense arredor das nocións de produción e consumo; o xénero, arredor das de sexualidade e reprodución; a raza/etnia son construcións dadas por unhas fronteiras fenotípicas ou culturais determinadas; a capacidade xira arredor da noción do que é «o normal» etc. En consecuencia, as desigualdades sociais veñen sendo moito máis ca as meras «distincións» no estilo de vida que fan os enfoques culturalistas da estratificación (como no caso de Bourdieu [1984]).

A interseccionalidade pode ser descrita como unha evolución da teoría do punto de vista feminista que a firma, de maneiras algo distintas, que resulta esencial dar conta da posición social do axente social —o investigador ou o investigado-e cuestionar «o truco divino de velo todo desde ningures» (Haraway 1991: 189) por encubrir e lexitimar un posicionamento "positivista» masculinista e hexemónico. O ollar situado, o cońecemento situado e a imaxinación situada (Stoetzler e Yuval-Davis 2002) constrúen de diversas maneiras os xeitos que temos de ver o mundo. No entanto, outra irredutibilidade que existe no enfoque que adopto ante a análise da interseccionalidade (2011) reside en que eu considero crucial a diferenciación analítica entre distintas facetas da análise social: a do posicionamento persoal nas grellas socioeconómicas do poder; a das perspectivas persoais, no plano da experiencia e da identificación, da pertenza, e a dos sistemas de valores normativos da persoa. Estas varias facetas están relacionadas entre si, pero ademais non poden reducirse as unhas ás outras e deben estudarse de maneira independente, non coma 
se unhas comportasen as outras automaticamente, que é o que tenden a facer as políticas da identidade. E, mesmo así, o significado de cada unha destas distintas facetas só pode entenderse poñéndoo en relación co das demais, motivo polo cal nos fai falla unha metodoloxía investigadora en que se conxuguen o que McCall (2005) denomina enfoque intercategórico e mais o intracategórico, pois as persoas que se posicionan nas mesmas situacións sociais adoitan adoptar distintas identificacións, significados e actitudes normativas, e distintos apegos cara a elas.

Xa que logo, a análise da interseccionalidade situada, en todas as súas facetas, é moi sensible á situación xeográfica, social e temporal do individuo ou de actores sociais colectivos concretos que se estudan nesa análise, con todo o polémica, cambiante e múltiple como adoita ser tal situación. En consecuencia, na abordaxe da interseccionalidade que aquí se presenta tamén temos de destacar a importancia primordial que revisten na análise as cuestións relativas á translocalidade, é dicir, como unhas categorías dadas de división social posúen significados distintos —e, a miúdo, diferente poder relativo — nos varios espazos en que teñen lugar as relacións sociais analizadas; á transescalaridade, é dicir, como as diferentes divisións sociais adoitan ter distintos significados e poder cando as estudamos, a pequena escala, nos fogares ou nos barrios,

en cidades, Estados e rexións concretos e a nivel planetario; e á transtemporalidade, é dicir, como estes significados e este poder mudan historicamente e mesmo en distintos momentos do ciclo vital das persoas (Anthias 2012; Yuval-Davis, Wemyss e Cassidy, de próxima aparición; sobre unhas aproximacións interseccionais algo distintas, mais tamén globais, ao estudo da desigualdade, véxase Bose 2012; Walby 2007, 2009). Todos estes elementos da análise da interseccionalidade situada revisten unha importancia fundamental cando procedemos a avaliar os significados da cultura.

\section{A NOCIÓN DE «CULTURA»}

A definición e o significado do termo «cultura» teñen sido postos en dúbida, mesmo máis ca moitos outros conceptos nucleares das ciencias sociais. Raymond Williams, o «pai» dos «estudos culturais», suxire tres sentidos (1983: 90): o dun proceso xeral de desenvolvemento intelectual, espiritual e estético [cultura como «civilización»], outro relativo ás "obras e prácticas da actividade intelectual e artística» [«alta cultura»] e outro máis que é o dun "modo de vida dado, xa sexa o dunhas persoas, o dun 
período ou o dun grupo». É deste último do que, como apunta Anthony Giddens (1989: 31), tenden a se valer os sociólogos. De acordo con el, este modo de vida componse dos «valores que posúen os membros dun grupo dado, as normas que seguen e os bens materiais que crean» (Giddens, op. cit., 31).

Jonathan Friedman (1994: 67-77), que ten considerado o xurdimento do concepto de cultura na antropoloxía, describe a súa «longa e confusa historia», sobre todo no século XIX, cando «a cultura era simplemente o que resultaba distintivo nos demais»; a confusión adoita derivarse da amálgama dos tres significados anteditos do concepto, que naquela altura se diferenciaban no plano filosófico mais se fundían no antropolóxico. Tamén xerou unha íntima relación entre «raza», baixo a forma de Volkgeist, e "cultura», xa que a cultura se empregaba en tanto que "características definitorias das persoas», e non foi ata primeiros do século xx, coa obra de Franz Boas, cando a cultura se separou da súa base racial e demográfica e deu en ser estudada como abstracción autónoma, como fenómeno de pleno dereito. Con todo, non debería perderse de vista que, polo menos ata datas recentes, as culturas estudadas tenderon a ser as do «Outro»; na sociedade occidental, a cultura popular, fronte á «alta cultura», non se converteu en lexítimo obxecto de estudo ata hai relativamente pouco, do cal lle debe moito ao traballo de Stuart Hall e dos demais autores que fixeron dos estudos culturais unha disciplina académica. Máis aínda, as construcións esencializadas da «diferenza cultural» constitúen unha das principais modalidades de racismo popular contemporáneo (Modood 1994).

Durante moito tempo, o desenvolvemento do concepto de cultura veu determinado polo debate cíclico que describe Friedman entre os que sosteñen uns paradigmas universalistas da cultura e os que defenden os relativistas. Segundo a primeira perspectiva, existe unha cultura humana xenérica na cal as distintas persoas e grupos teñen un rango concreto en función do seu «estadio de desenvolvemento», que adoita describirse en termos evolutivos. Esta visión rexéitana os que avalan a perspectiva relativista, de acordo coa cal hai distintas civilizacións que teñen culturas diferentes que deben entenderse e xulgarse no seu propio contexto; así, Geertz (1966) afirma, de feito, que non hai cultura en xeral, senón só culturas concretas.

Malia a diferenza que separa estas dúas perspectivas, e malia o perpetuo debate que ten lugar entre elas, ambas comparten, como apunta Chatterjee (1986), 
unha visión esencialista da «cultura» na que esta posúe unha «materia cultural» fixa e particular composta por símbolos, comportamentos e artefactos que, dun xeito coherente e nada problemático, constitúen o que son as culturas duns colectivos nacionais e étnicos dados. En ningunha destas dúas aproximacións contan as diferenciacións internas nin as diferenzas de posicionamento.

Un xeito moito máis útil de teorizar sobre a cultura é o elaborado nos últimos anos mediante análises do discurso inspiradas tanto en Gramsci como en Foucault, nas cales as culturas se transforman e, de seren uns fenómenos homoxéneos, reificados e estáticos, comúns a todos os membros dos colectivos nacionais e étnicos, pasan a ser uns procesos sociais dinámicos que operan en terreos cuestionados onde as distintas voces se tornan máis ou menos hexemónicas nas interpretacións do mundo que ofrecen (Bhabha 1994, Friedman 1994). Aí apúntase que os discursos culturais a miúdo se asemellan máis a un campo de batalla do significado que a un punto de partida compartido; de acordo con esta perspectiva, a homoxeneidade cultural sería o resultado da homoxeneización e ficaría sempre circunscrita ao centro social, onde sería máis notable, e non ás marxes, alén de recibir a influencia da posición social dos seus portadores.

$\mathrm{O}$ anterior suscita dúbidas acerca da continuidade e a persistencia das culturas, así como sobre as relacións que se establecen entre distintas culturas. A este respecto, tanto Anthony Smith (1986) como Armstrong (1982) argumentan que os mitos e os símbolos culturais posúen unha capacidade de perdurar que se reproduce xeración tras xeración, pese ás cambiantes condicións históricas e materiais. No entanto, esta aparente perdurabilidade pode resultar moi enganosa, en primeiro lugar porque a visión que temos dela se deriva dunha perspectiva temporal moi concreta: vemos toda a materia cultural que perdurou soportando todas estas mudanzas históricas e sobreviviu. No entanto, non podemos ser de todo conscientes de canta materia cultural non sobreviviu á mudanza histórica, malia as investigacións arqueolóxicas e históricas; máis aínda, mesmo no caso da materia cultural que sobreviviu aos cambios históricos, os significados que ten poden sufrir, e de feito sofren, alteracións radicais, e a miúdo viran en meros marcadores simbólicos da identidade (Gans 1979, Armstrong 1982). De igual modo, mentres que uns representan o mundo entendido como choques entre civilizacións diferenciadas e opostas (Huntington 1998), outros son moito máis conscientes da natureza sintética de todas as culturas contemporáneas, de como 
se apropian de artefactos e significados simbólicos tirados doutras civilizacións, e da súa propia heteroxeneidade interna (Bhabha, op. cit.).

É importante recoñecer os dous elementos coexistentes e contraditorios que existen no funcionamento das culturas, que son, por unha banda, a tendencia á estabilización e á continuidade e, pola outra, a resistencia e a mudanza perpetuos. Estas dúas tendencias derívanse da íntima asociación que se dá entre as relacións de poder e a práctica cultural (Bourdieu 1984, Bottomley 1992); así, como apunta Friedman (1994: 76), as culturas non son unicamente unha colección arbitraria de valores, artefactos e condutas, senón que adquiren, en maior ou menor medida, «propiedades estabilizadoras» que son inherentes ás prácticas da súa reprodución social. Eses procesos reprodutivos non constitúen meros procedementos de clonación, senón de interacción social na cal a motivación e o desexo teñen un papel que desempeñar, e a consecuencia disto os modelos culturais retumban coa súa carga de experiencia subxectiva e se converten, pois, na maneira en que o individuo se percibe a si mesmo, as súas colectividades e o mundo.

Aínda que, analiticamente, o discurso da cultura se distingue do das relacións de poder (Assad 1993), concreta e historicamente sempre vai inserido nelas, cousa que se aplica non só con respecto ás xerarquías de poder existentes no seo das institucións culturais e nas súas relacións coas estruturas, máis xerais, de clase e poder que se dan na sociedade, senón tamén con respecto ás imaxinacións culturais e ás súas xerarquías de desexabilidade, así como ás construcións de inclusión e exclusión.

A «materia cultural», xa que logo, máis ca como corpo fixo e homoxéneo de tradicións e costumes, ha de se describir como recurso rico, normalmente cheo de contradicións internas, que é usado de forma selectiva por distintos axentes sociais, en variados proxectos sociais, no seo dunhas relacións de poder e nuns discursos políticos dados, dentro e fóra da colectividade. O sexo, a clase, a pertenza a unha colectividade, o estadio do ciclo vital, a capacidade: todos eles inflúen na posibilidade de acceder a estes recursos, na súa dispoñibilidade e na posición concreta desde a que se utilizan.

Polo tanto, a interseccionalidade situada constitúe unha ferramenta metodolóxica crucial á hora de analizar e descifrar os significados da cultura. 


\section{A INTERSECCIONALIDADE SITUADA E OS SIGNIFICADOS DA CUL- TURA}

Segundo se comentou antes, a aproximación aos significados da cultura que se adopta neste ensaio non é nin universalista nin relativista, senón que se fundamenta nunha epistemoloxía dialóxica que, como argumentan Bakhtin (2010) e Patricia Hill Collins (1990), se basea na incorporación — normalmente desigual- dos ollares situados dos diferentes axentes sociais que participan nuns encontros e prácticas sociais concretos, ou que os observan, directa ou indirectamente. Estes ollares situados constrúen significados culturais, seleccionando distintos recursos culturais sociais entre os existentes en función dos seus sistemas de valores normativos, así como das súas identificacións e apegos emocionais; con todo, a súa situación social, inserida nunhas xerarquías de poder de campo escalar variable, polo xeral debe de determinar as repercusións que teñen tales ollares na produción da "cultura» social xenérica.

Xa que logo, na aproximación metodolóxica da interseccionalidade situada ao estudo da cultura combínanse as metodoloxías intercategóricas e intracategóricas descritas por Lesley McCall (2005); a primeira atinxe ás comparacións que se fan entre os mesmos fenómenos sociais (por exemplo, a frecuencia con que persoas de distinto sexo e clase asisten a unha institución relixiosa) en distintos puntos xeográficos, mentres que a segunda se centra no significado que teñen esas prácticas nuns contextos sociohistóricos concretos. A translocalidade, a transescalaridade e a transtemporalidade da interseccionalidade situada nos permite evitar o localismo que reflicten moitos estudos sociais, así como a simple universalidade doutros que dan por supostos, sen máis, os varios significados que teñen estas prácticas sociais en diferentes situacións xeográficas, sen pescudaren neles; Mignolo (2000) denomínao pluriversalidade epistemolóxica.

No entanto, a análise da interseccionalidade situada non homoxeneíza nin reifica as fronteiras das localidades nin dos grupos, senón que toma en consideración os ollares situados de persoas concretas con respecto á súa propia situación social e ao seu benestar social. Centrármonos nestes ollares situados permítenos incorporar as perspectivas minoritarias e inconformistas dos actores sociais, no canto de darmos por suposto que todos os integrantes dunha categoría social dada, incluso da mesma posición xeográfica e social, van compartir necesaria- 
mente o mesmo significado das relacións sociais de poder ou da súa «cultura e tradición» na súa propia sociedade ou comunidade en xeral e nos seus propios posicionamentos en particular. En vez diso debemos engadirlle á epistemoloxía pluriversal outra inclusiva e dialóxica na que tome parte a maior cantidade posible de persoas que participan nun encontro social dado, e esta sería a única forma de nos aproximarmos á verdade (aínda que «a verdade» sería sempre escorregadiza; Hill Collins, op. cit.).

Polo tanto, os significados da cultura son situados, cambiantes e discutidos e posúen distintas fronteiras e distinta destacabilidade, as cales mudan o foco de atención e a súa pertinencia en diferentes perspectivas locais, temporais e escalares. Isto non quere dicir que carezan dun significado concreto; só significa que non hai xeito «obxectivo» de reivindicar ese significado. 


\section{REFERENCIAS BIBLIOGRÁFICAS}

Anthiss, Floya (2012): «Hierarchies of Social Location, Class and Intersectionality: Towards a Translocational Frame», International Sociology, 28:1, 121-138.

Anthias, Floya / Nira Yuval-Davis (1983): «Contextualizing Feminism: Gender, Ethnic and Class Divisions», Feminist Review, 15, 62-75.

Anthias, Floya / Nira Yuval-Davis (1992): Racialized Boundaries: Race, Nation, Gender, Colour and Class and the Anti-racist Struggle, Londres, Routledge.

Armstrong, John (1982): Nations Before Nationalism, Chapel Hill, University of North Carolina Press.

Assad, Talal (1993): Genealogies of Religion, Baltimore, John Hopkins University Press.

Bakhtin, Mikhail Mikhailovich (2010): The Dialogic Imagination: Four Essays, vol. 1, Austin, University of Texas Press.

Bнавна, Homi K. (1994): The Location of Culture, Londres, Routledge.

Bose, Christine E. (2012): «Intersectionality and Global Gender Inequality», Gender \& Society, 26:1, 67-72.

Bоттомley, Gillian (1992): From Another Place: Migration and the Politics of Culture, Cambridge, Cambridge University Press.

Bourdieu, Pierre (1984): Distinction: A Social Critique of the Judgement of Taste, Londres, Routledge/Kegan Paul.

Brah, Avtar / Ann Phoenix (2004): «Ain't I a Woman?: Revisiting Intersectionality», Journal of International Women's Studies, 5:3, 75-86.

Bryan, Beverley / Stella Dadzie / Suzanne Scafe (1985): The Heart of the Race: Black Women's Lives in Britain, Londres, Virago.

Chatterjee, Partha (1986): Nationalist Thought and the Colonial World: A Derivative Discourse, Londres, Zed Books.

Crenshaw, Kimberlé (1989): «Demarginalizing the Intersection of Race and Sex: A Black Feminist Critique of Antidiscrimination Doctrine, Feminist Theory and Antiracist Politics», University of Chicago Legal Forum, 1989:1, art. 8 (http://chicagounbound.uchicago.edu/uclf/vol1989/iss1/8).

EUROPEAN JOURNAL OF WOMEN'S STUDIES (2006), número especial sobre Intersectionality, 13:3.

Friedman, Jonathan (1994): Cultural Identity and Global Process, Londres, SAGE.

Gans, Herbert J. (1979): «Symbolic Ethnicity: The Future of Ethnic Groups and Cultures in America», Ethnic and Racial Studies, 2:2, 1-20.

Geertz, Clifford (1966): «Religion as a Cultural System», en Michael Banton (ed.), Anthropological Approaches to the Study of Religion, Londres, Tavistock.

Giddens, A. (1971): Capitalism and Modern Social Theory: An Analysis of the Writings of Marx, Durkheim and Max Weber, Cambridge, Cambridge University Press.

Haraway, Donna (1991): Simians, Cyborgs and Women: The Reinvention of Nature, Londres, Free Association Press.

Hill Collins, Patricia (1990): Black Feminist Thought, Nova York, Routledge.

Huntington, Samuel P. (1998): El choque de civilizaciones y la reconfiguración del orden mundial, Barcelona, Paidós.

Lutz, Helma / Maria Teresa Herrera Vivar / Linda SupIK (eds.) (2011): Framing Intersectionality: Debates on a Multi-Faceted Concept in Gender Studies, Farnham, Ashgate. 
McCall, Leslie (2005): «The Complexity of Intersectionality», Signs, 30:3, 1771-1800.

Mignolo, Walter D. (2000): Local Histories/Global Designs: Coloniality, Subaltern Knowledges, and Border Thinking, Princeton, Princeton University Press.

Modood, Tariq (1994): «Political Blackness and British Asians», Sociology, 28:4 (novembro), 859-876.

SIGNS (2013): número especial sobre Intersectionality: Theorizing Power, Empowering Theory, 38:4.

SMith, Anthony D. (1986): The Ethnic Origin of Nations, Oxford, Basil Blackwell.

Stoetzle, Marcel / Nira Yuval-Davis (2002): «Standpoint Theory, Situated Knowledge and the Situated Imagination», Feminist Theory, 3:3, 315-334.

Walby, Sylvia (2007): «Complexity Theory, Systems Theory, and Multiple Intersecting Social Inequalities», Philosophy of the Social Sciences, 37:4, 449-470.

Williams, Raymond (1983): Keywords: A Vocabulary of Culture and Society, Londres, Fontana.

Yuval-Davis, Nira (2011): The Politics of Belonging: Intersectional Contestations, Londres, SAGE.

Yuval-Davis, Nira (2015): «Situated Intersectionality and Social Inequality», Raisons Politiques, 58:2, 91-100.

Yuval-Davis, Nira / Georgie Wemyss / Kathryn Cassidy (2019): Bordering, Cambridge, Polity Press. 


\section{VER E SABER: \\ A CONTRADICIÓN DAS IGUALDADES \\ Geneviève Fraisse}

Filósofa, historiadora do pensamento feminista.

Directora de investigación en filosofía no cNRS 

O obstáculo máis forte que se lle opón ao feminismo, sexa chamado «emancipación» ou «liberación», igualdade e liberdade, consiste no recorrente anovamento do estado ahistórico das mulleres. Afirmando isto, diferénciome de todas as críticas e denuncias que fan das imaxes, discursos e prácticas da heterosocialidade e da heterosexualidade o único centro da dominación e que reclaman a «desnaturalización» das mulleres.

Por que? Porque pode disolverse a referencia lacerante á natureza das mulleres mediante a deconstrución das normas sexuais, por unha banda; tamén pode lembrarse que a vida doméstica privada é o crisol das relacións sociais, económicas e políticas, pola outra, mais iso non lles impedirá aos defensores da xerarquía dos sexos pensar a relación entre mulleres e homes a partir dun lugar sen temporalidade («en toda época...») e, xa que logo, sen historia.

Parece que os sexos non pertencen á cuestión histórica. A razón pode comprenderse doadamente: pertencer á historia é imaxinar a súa posible transformación, un mañá diferente de hoxe. Así, a miña única ambición filosófica é convencer sobre a historicidade dos sexos... E a subversión, toda subversión, é a consecuencia lóxica.

Admitindo que este obstáculo da atemporalidade sexa identificado claramente como a maior dificultade para todo o que concirne aos sexos, lembrarase que a reflexión sobre o obxecto "sexo/xénero» se construíu recentemente, na segunda metade do século $\mathrm{xx}$.

Entendámonos ben: o pensamento sobre os sexos descóbrese na longa tradición filosófica e literaria. Mais a esixencia epistemolóxica é moi recente. De aí unha pregunta que non debe descoidarse: como introducir a igualdade dos sexos na historia se a incerteza persiste no que se refire á presenza mesma desta pregunta na reflexión contemporánea, precisamente democrática? Como pensar a emancipación? Primeiro, insistindo sobre a escolla do punto de vista: pensar a emancipación ou pensar a dominación, argumentar a emancipación ou de- 
construír a dominación? A deconstrución da dominación pode facerse de varios xeitos: designando os mecanismos económicos e sociais que entran en acción, elaborando a teoría do patriarcado, apuntando cara ás normas imaxinarias, en diante chamadas a miúdo «estereotipos».

O real, o simbólico e o imaxinario son, así, como está convido, as tres vías para demostrar a potencia da dominación masculina. Demostrar o funcionamento da dominación considérase unha necesidade para permitir despois a acción, a resistencia, a subversión. Analizar e logo transformar, descubrir e logo refacer: tales serían as lóxicas dunha práctica feminista. Teoría e logo práctica, en certo modo.

\section{A INSCRICIÓN DA CONTRADICIÓN E DO CONTRATEMPO}

E, se se adopta o punto de vista da emancipación, como se pensa? Unha persoa está obrigada a volver empezar a partir da experiencia e, xa que logo, da historia da emancipación, onde a cuestión non é a deconstrución, mais a construción. Daquela, dúas pistas son esenciais: a xenealoxía do pensamento da igualdade dos sexos desde o século xvir e a Revolución Francesa, por unha banda, e a análise das contradicións inevitables (internas e externas) co conxunto de políticas e loitas, pola outra.

Estas dúas pistas reúnense mediante a adopción dunha sinxela perspectiva: a igualdade dos sexos, afirmada no espazo político en Occidente desde hai dous séculos, non agrada a todo o mundo e pode ser menosprezada por aqueles mesmos que loitan pola igualdade de todos. A igualdade dos sexos pode ser contestada, mais, como tentei dicir coa expresión «democracia exclusiva», isto faise dunha maneira desviada, implícita, hipócrita... Ningún demócrata debe pronunciarse contra a emancipación das mulleres. Falta entón eludir a contradición entre dicir a igualdade para todos e resistirse á igualdade dos sexos. Mais contradición hai, atrapada entre negación e mala fe. Así se entende decontado que a emancipación non é o outro da dominación. A dominación subsiste no interior mesmo das dinámicas de emancipación. E é precisamente isto o que constitúe a especificidade da historia das mulleres na era democrática. Volvamos a un dos seus puntos de orixe, a Revolución Francesa: a contradición é perceptible inmediatamente. Sexa que a Revolución concirna aos dous sexos e impoña a súa igualdade (de Condorcet a 
Olympe de Gouges), sexa que só fose feita para un sexo, os homes, e, por conseguinte, as mulleres deban ser rexeitadas do espazo público (véxanse os discursos de Amar explicando a necesidade de pechar os clubs de mulleres en 1793). É preciso, pois, aceptar que a contradición está no inicio do pensamento revolucionario e da era democrática que lle sucede. Mais debemos afundir o coitelo na ferida: a contradición será tanto máis forte canto máis radical sexa o pensamento revolucionario. É, de certo, a extrema esquerda revolucionaria a que mellor formaliza a necesidade de frear a emancipación das mulleres. Por exemplo, baixo a pluma dun corredactor do Manifesto dos iguais de Gracchus Babeuf, Sylvain Maréchal propón en 1801, de maneira paródica, un «Proxecto de lei sobre a prohibición de lles ensinar a ler ás mulleres». Brincadeira de patio de colexio para algúns, a lectura deste texto, extremadamente rigoroso e erudito, convence, porén, sen dificultade, do seu contido filosófico e da súa finalidade política. É unha chamada á orde, á orde xerárquica dos sexos.

O momento histórico, posrevolucionario, é propicio para ese conformismo, mais Sylvain Maréchal non tivo parada, no xornal Révolutions de París, á hora de fustrigar o desexo de emancipación das mulleres revolucionarias e, xa que logo, a esixencia da igualdade dos sexos. Ora ben, o interesante é que lle responderon dúas mulleres, autoras, moderada unha, radical a outra (Gacon-Dufour, Clément-Hémery). Así, esta apertura do espazo público, situación de debate e de controversia, é unha forma nova, coma unha escena primixenia, posta en litixio, que acompaña o debut do feminismo como xesto público e político. Así, na perspectiva democrática, a igualdade dos sexos non sempre é unha evidencia. Entón, pódese remontar a historia da "democracia exclusiva» ${ }^{1}$ e logo, á volta, seguir paso a paso os mecanismos de inclusión das mulleres na democracia e na república (desde hai xa dous séculos).

A dinámica do feminismo pode lerse historicamente, mais sen esquecer a contradición orixinaria. Socialismo, marxismo, anarquismo (e sindicalismo), ningún movemento revolucionario escapará á cuestión da sincronía, ou, máis ben, da discronía entre as emancipacións, a do pobo, a dos sexos (e das razas, e dos colonizados). Pois existe un problema de temporalidade. Se houbo, en efecto, unha «abolición» da escravitude, ruptura histórica considerable, a fin da opresión das

${ }^{1}$ Fraisse, Geneviève (1995): Muse de la raison: démocratie et exclusion des femmes en France, 1989, París, Gallimard, col. Folio. 
mulleres, como acontecemento datado, non é pensable. Exactamente, ningunha ruptura histórica é factible. Mesmo peor, a miúdo trátase a cuestión da emancipación das mulleres como desfasada no plano temporal: os liberais considéranas atrasadas e queren educalas antes de as recoñeceren como cidadás; os revolucionarios considéranas avanzadas e quérenas membros actores da Revolución antes de se ocuparen dos seus dereitos.

A desigualdade dos sexos, é ben sabido, constitúe unha «contradición secundaria», di a vulgata marxista (e non o propio Marx). Daquela, pode resumirse este problema baixo o nome de contratempo: a pregunta sobre a igualdade dos sexos nunca se formulou no momento histórico axeitado. Desta maneira, o contratempo, ese mal momento da reivindicación, é unha forma de recoñecer a contradición implícita que o feminismo envía á dominación masculina. Á falla dunha oposición á igualdade dos sexos, cuestiónase o seu fundamento estratéxico. De novo, o obstáculo é o da historicidade.

\section{OS LÍMITES DAS CATEGORÍAS, DA IMAXE, DA IDENTIDADE}

É a partir desta análise, análise que insiste na contradición e no contratempo, como pode decidirse o reto do pensamento da emancipación. Que solución teórica propor para afrontar a contradición entre as igualdades e os contratempos das estratexias? Para facer isto hai que abandonar as definicións (que son os dous sexos?) e as identidades (quen son eu?, quen somos nós?) e atopar o xeito de comprender esta situación problemática desde o prisma do xeral. Saír da particularidade da cuestión das mulleres, reflexionar sobre a universalidade posible, require desviarse de dúas esixencias habituais do feminismo, a que se centra na loita contra as imaxes, normas ou estereotipos e a que concirne á identidade do suxeito, individual ou colectivo.

Resumo así dous eixes esenciais do pensamento feminista actual, o que fai das imaxes, normas e estereotipos o lugar da dominación que debe ser destruído e o que formula a cuestión do suxeito (político) da subversión, individual ou colectiva, sexual ou social. E propoño o abandono epistemolóxico deses eixes de loita (deconstruír a diferenza dos sexos; definir o suxeito da emancipación), cuxa importancia, tanto teórica como política, por outra banda e sobre todo, non hai 
que negar. Simplemente se trata de testemuñar, testificar unha escolla teórica para unha estratexia necesaria ante a contradición e o contratempo.

\section{A crítica das normas e a súa encarnación ideolóxica e política, a loita contra os «estereotipos», ou tamén representacións, prexuízos etc.}

Todos estes termos non son equivalentes; digamos que se superpoñen e se federan. Para dicilo rapidamente, trátase da crítica das imaxes dominantes. Tras esta crítica, decláranse posibles outras referencias. A crítica das normas induce o cuestionamento dun só modelo, incluído, por unha banda, baixo a referencia da heterosexualidade e, pola outra, baixo a da estrutura dualista dos sexos. Eu resumiríaa ironicamente coa idea do «azul/rosa». Si, é preciso destruír a coacción heterosexuada, heterosocial; mais non, as imaxes non son uns «en por si». Porque, designando as imaxes estereotipadas, descualificándoas como arcaicas e escravizantes, un constitúeas como realidades «sen substrato», fóra de todo contexto, fóra de todo vencello coas persoas que levan, que transmiten esas imaxes. E se a relación entre a imaxe e os suxeitos suscitase unha dinámica contraditoria, fábrica de historia? Pero non; a norma, ou o estereotipo, son remitidos a substancias, substancias illadas, substancias en si. A crítica das normas evita formular a cuestión da historicidade, ou máis ben redúcea á herdanza cultural sen temporalidade. Mais quen son as e os que fan circular os estereotipos? As persoas, ou as institucións que forman o vencello entre o estereotipo e o seu destinatario, non están en contradición coas imaxes? O máis frecuente e que si, e así o espazo crítico xa está aí! Por que ía ser a imaxe máis forte ca os suxeitos, suxeitos portadores de imaxes, suxeitos receptores destas?

A norma e o estereotipo, devindo en substancias, en realidades en si, anulan a importancia do suxeito, suxeito crítico quizais, mais sobre todo suxeito pensante, como cada un(ha) de nós. Ao insistir de máis nas imaxes, un sacralízaas na súa esencia normativa no canto de as facer actuar, nunha temporalidade existencial ou histórica, con aqueles que as difunden ao seu pesar, ou con aqueles que as reciben con indiferenza (por exemplo).

Non é facer estereotipos das iconas, das novas iconas, elevadas así a un status simbólico? É coma se houbese unha fascinación polo que debe ser destruído: a heterosexualidade e a dualidade oposta dos dous sexos. E se a diferenza dos sexos 
fose unha categoría baleira, unha categoría, de certo, mais sen contido definido? Xénero e queer son, para alén diso e en diante, testemuñas semánticas do anterior, independentes das imaxes.

\section{A reivindicación das identidades, singular ou colectiva, a través da acción do suxeito}

Por unha banda, a identidade individual ou definición dun mesmo, procura singular dunha identidade liberada de toda restrición ligada ao sexo biolóxico e tamén ao sexo social, en xeral chamado "xénero»; nese caso a identidade persoal, centrada na cuestión da sexualidade, pode verse como un apoio con vistas a unha subversión xeral. Abandonar a asignación a unha sexualidade, supor a plasticidade das definicións sexuais e sexuadas é unha política feminista: a da definición de si, dun si liberado, como lugar de paso cara a unha subversión global (como por contaminación), desbaratando así outras desigualdades entre os sexos no espazo social.

Por outra banda, a categoría colectiva do «nós» podería designar unha categoría de loita, as mulleres, as obreiras, as inmigrantes, as traballadoras etc., e permitiría así unha base de reivindicacións claramente artelladas con outras reivindicacións ou subversións sociais, ou con ambas. Contrariamente á práctica da subversión das normas e á crítica dos estereotipos xa comentada, trátase de atopar o suxeito acaído, o que é portador da emancipación. Ese suxeito será individual ou, pola contra, colectivo. Vimos que o suxeito individual subversivo, especialmente pola reformulación libre das sexualidades, pode ser construído como o lugar da multiplicación posible dos suxeitos da emancipación. En troques, desde o punto de vista da identidade colectiva, a categoría «mulleres» considérase autónoma, illada, ou, á inversa, ponse en relación con outras categorías, nomeadamente as de cor, orixe e relixión, que poden ser pensadas en interseccionalidade, cruzamento necesario, ou en contigüidade, sumas de discriminacións reais, ou mesmo en metáforas do avasalamento en cadea ${ }^{2}$. En xeral, o «nós, as mulleres», illado doutros «nós» oprimidos ou explotados, sinala que a cuestión das mulleres, porque é transversal ás clases sociais, se distingue das outras categorías de excluídos. Simone de Beauvoir dío moi ben na introdución a $O$ segundo sexo. As mulleres viven cos homes,

2 Fraisse, Geneviève (2010): «Les amis de nos amis», en À côté du genre : sexe et philosophie de l'égalité, París, Le Bord de l'eau. 
íntima e publicamente, e son a metade dunha sociedade mesturada (Mitsein, escribe ela). Por esta razón, a da especificidade da categoría «mulleres», impúxose desde hai dous séculos unha dupla necesidade teórica e política: establecer un vencello entre varias categorías, por unha banda, ou designar a particularidade do grupo «mulleres», pola outra. En efecto, desde hai dous séculos: é preciso partir de novo de Kant, quen, na Antropoloxía, distingue tres «caracteres» (alén da "persoa» e a «especie»): pobo, sexo, raza. Estes tres caracteres son aínda os de hoxe en día. O que muda entre Kant e o pensamento contemporáneo son os falantes, é dicir, os potenciais actores que representan eses grupos. Os suxeitos da historia fixéronse cargo do seu destino categorial! Dun discurso que pretende estruturar os eixes dunha visión global das cousas pásase a unha escolla teórica e política que quere artellar entre si esas categorías. A antropoloxía fíxose historia. $\mathrm{O}$ «nós, as mulleres» só ten sentido se atravesa a raza e a clase, baixo o termo unificador de interseccionalidade. E aí, máis unha vez, a historia é esencial: a abolición da escravitude deu paso á «escravitude moderna» e non apunta só ás persoas de cor; a descolonización non impide o anovamento do imperialismo, e as mulleres, presas nas categorías precedentes, de escravas ou de colonizadas, as mulleres, todas as mulleres, atópanse na continuidade da súa historia, que non cońece ningún equivalente comparable á abolición da escravitude ou á independencia nacional. Agás se se ve a cidadanía republicana como un momento de paso radical, inclusión despois da exclusión. Non é tan sinxelo. Por conseguinte, a contradición entre a «metade» do mundo e as categorías históricas (raza + escravitude) e (pobo + clase social) está a actuar, por non dicir que está en carne viva. Como facer para saír dunha alternativa que aparece como un duplo imperativo: non esquecer ningunha muller na emancipación no referido á dominación masculina ou seguir a realidade da exclusión/explotación/ opresión que liga as discriminacións específicas de cada categoría? A risco de bloquear, nun e noutro caso, as enerxías políticas? Cal é o suxeito político bo?

\section{A MATERIALIDADE CONCEPTUAL DA IGUALDADE. NOMEAR, $E X$ - PLICAR, FORMULAR}

Decidín moi rápido, a partir dos anos 70, abandonar estas dúas pistas de construción dunha epistemoloxía política. Por que? Porque eses dous camiños semellan 
levar a dous impases: criticar as «imaxes», ou cualificar as identidades, acurralar as malas definicións, ou correr tras do suxeito axeitado, son dous procedementos que se revelan limitados ou perigosos, exactamente aporéticos. En efecto, tense unha sensación de repetición, por non dicir de cantilena: a crítica dos prexuízos do século XVII parécese furiosamente á dos estereotipos de hoxe en día, a cominación ao cruzamento das categorías recorda á denuncia do feminismo burgués de fins do XIX ou dos anos posteriores ao 68. Ora ben, pódese facer unha dupla constatación: subverter a sexualidade xamais produciu unha revolución económica, nin sequera política; e estruturar teórica ou practicamente as exclusións ou discriminacións non impide un eventual rexeitamento do feminismo por parte das explotadas ou dos revolucionarios.

Ambas as cousas quedan expostas con crueza a partir da Revolución Francesa. Estas dificultades ou contradicións que cualifican o feminismo forzan a unha "soidade voluntaria» ${ }^{3}$. Visto o préstamo semántico tomado de La Boétie, semella que o movemento das mulleres, ou MLF [Movemento de Liberación das Mulleres, polas súas siglas en francés], se entende na tensión entre acto de afirmación e medida da relación de forza coa dominación. Xa que logo, había que traballar doutro xeito. Co novo vocabulario (relacións sociais de sexo, xénero, por non falar mesmo de paridade), fican como necesidade a tentativa de crear un campo de pensamento, alén dunha intención política, e o problema da identificación teórica da cuestión «mulleres/diferenza entre os sexos». Ora ben, se a diferenza dos sexos é unha categoría baleira, pódese reflexionar noutro lugar e doutra maneira, nomeadamente cos termos clásicos (por exemplo, goberno, representación, habeas corpus... $)^{4}$, termos portadores dunha virtude explicativa. Trátase de poñer a cuestión feminista no pensamento global, mais, sobre todo, de constatar que é desde o exterior do campo teórico feminista (imaxes estereotipadas, identidade dos sexos ou categoría das mulleres) como habemos escapar da trampa da contradición e desde onde mellor se exporá o pensamento da igualdade dos sexos. Pois as palabras da tradición teñen a vantaxe de dar a amplitude filosófica necesaria, como, por exemplo, falar de mixidade (mixité) retornando ao concepto de «mestura». A mixidade é mesturar os sexos? Así, «por onde» pasar para pensar

${ }^{3}$ Fraisse, Geneviève (2012 [1978]): «La solitude volontaire (à propos d'une politique des femmes)», en $\mathrm{La}$ Fabrique du féminisme, París, Le Passager clandestin.

${ }^{4}$ Fraisse, Geneviève (2010 [2004]), «À côté du genre : un vademecum», en À côté du genre : sexe et philosophie de l'égalité, París, Le Bord de l'eau. 
a igualdade dos sexos? Nin a interrogación sobre as sexualidades nin a procura do bo suxeito político, da categoría axeitada, semellan poder escapar á repetición dos problemas e trampas que se revelan desde hai dous séculos. É, daquela, a través de configuracións singulares, nomeadamente nos momentos de mobilización feminista, como pode atoparse a palabra, por non dicir o concepto, que ha esclarecer a reflexión. Velaquí dous exemplos de proposta conceptual: o termo de «servizo» e o de "consentimento".

A finais dos anos 70 podía oírse, no movemento feminista, unha xorda tensión entre as que denunciaban a invisibilidade e a gratuidade do traballo doméstico, vida doméstica en que todas as mulleres (de todas as clases sociais) podían recoñecerse, e as que insistían na explotación das traballadoras atrapadas nunha condición de asalariadas específica para as mulleres. Mais entre a opresión das mulleres na vida privada e a explotación das obreiras non se establecía vencello ningún, e mesmo podían enfrontarse politicamente; ora ben, existía unha categoría de mulleres ás que lles concernía duplamente, a das «empregadas do fogar» (vocábulo da época), mulleres ás que se lles pagaba polo traballo doméstico no recinto da vida privada supostamente "gratuíta». É así como a palabra «servizo» pareceu axeitada para federar unha cuestión: que relación presente e futura entre privado e público, traballo doméstico e asalariado, emancipación das mulleres e servidume perpetuada?5. Entendámonos ben: non se trataba de analizar o «traballo» doméstico, senón o «servizo», a relación xerárquica entre unhas persoas, por unha banda, e o substrato doméstico, pola outra. Máis un exemplo: nos anos 90 instaláronse dous debates no espazo público, un arredor do uso do veo no recinto escolar e outro, máis clásico, sobre a prostitución como acto voluntario asumido ou como submisión socialmente imposta. Nos dous casos, a invocación do argumento do consentimento ${ }^{6}$ era ineludible, mais nun sentido limitado, é dicir, psicolóxico: que verdade, ou falsidade, do suxeito na afirmación dun «eu consinto", igual ca nun «eu quero» ou nun «estou de acordo». Aquí tamén se podían unir os dous temas, veo e prostitución, nunha soa cuestión: a do consentimento como argumento político. Non: é o consentimento un bo argumento para autenticar unha verdade individual? Senón: é o consentimento unha proposta política, é dicir, que comprometa o colectivo do presente e a sociedade de mañá? De certo,

\footnotetext{
${ }^{5}$ Fraisse, Geneviève (2009 [1979]): Service ou servitude : essai sur les femmes toutes mains, París, Le Bord de l'eau.

${ }^{6}$ Fraisse, Geneviève (2008): Du consentement, París, Seuil.
} 
«servizo» e «consentimento» reúnense como dúas cuestións debatidas no espazo político da democracia: que igualdade na xerarquía do servizo?, que igualdade nas relacións mutuas, ou asimétricas, do consentimento? Unhas palabras clásicas, que se tornaron en conceptos, alimentan así o pensamento do feminismo, o da materialidade da igualdade como reto de configuracións precisas. Pois do que se trata efectivamente é de tomar a igualdade dos sexos como testemuna, lector de cuestións igual ca necesidade política.

Xerarquía e servizo, mutualidade e consentimento; por unha banda, a cadea das mulleres que se alienan e se emancipan no servizo e polo servizo e, pola outra, asentimento voluntario ou inevitable na afirmación dun «si». Estes dous problemas, reunidos nas nocións de «servizo» e de "consentimento», abren a unha perspectiva máis vasta, a da dualidade sexual (categoría baleira, recórdolles), que cruza a representación política da igualdade. Descubrimos así dúas expresións interesantes: a da sexuación, ou, pola contra, asexuación, do político e do social, e a da simetría dos sexos como revelador político e enigma da igualdade. Tomemos, en primeiro lugar, o máis evidente, que alén diso é o máis oculto: a discusión, moral e social, arredor da prostitución divídese entre dous argumentos, o da persoa que dispón libremente do seu corpo, por unha banda, e o da explotación das persoas vulnerables, pola outra. Debate político, demostración social, a discusión repítese desde hai moito tempo e cada un mantén o seu lugar. Mais pódese formular a pregunta doutro xeito, non desde o punto de vista da dominación, senón desde o da emancipación ou, máis precisamente, da igualdade: que igualdade hai entre os sexos cando máis do $90 \%$ da oferta de prostitución son mulleres? Cando vai haber unha oferta masculina equivalente? Imaxinemos, en efecto, un mundo onde a prostitución se dividise por igual entre os dous sexos. Non poderiamos entón ter unha verdadeira discusión sobre o sentido da prostitución nunha sociedade democrática? Algúns, e algunhas, parecen dicir que a prostitución dos dous sexos é a realidade de hoxe. Todo o mundo sabe ben que non; a prostitución masculina segue a ser máis ca marxinal (para nos limitarmos á heterosexualidade). Por outra banda, no debate sobre o servizo, a discusión pode ser análoga: o care, ou coidado, o ser solícito, que substitúe o antigo servizo doméstico, prefigurando, din, un novo vencello social, talvez sexa o futuro. Si, mais quen introduce na reflexión a porcentaxe masiva de mulleres empregadas nese sector $(97 \%)$ ? Practicamente ninguén. Por que? Por varias razóns. Cons- 
tatemos, primeiramente, que é raro que se dea a ver esta asimetría; mesmo é de bo gusto ignorar ese feito, falar do servizo á persoa, do care, coma se os dous sexos estivesen implicados da mesma maneira. Como é de bo gusto clamar que a prostitución é tamén un asunto de homes. Compréndese, xaora, que así a dominación masculina sae gañando, que o encubrimento da sexuación, tanto a do servizo doméstico como a do servizo sexual, vai en beneficio da orde existente. Asexuar un problema, unha cuestión, resulta estratexicamente eficaz. Pero é máis complicado cando se comprende que esta asexuación non constitúe unicamente un enunciado da dominación. Ao descoñecemento da ausencia de simetría engádese a esixencia do neutro democrático. Non sinalar a sexuación dun problema social (por exemplo, ao transformar, á fin do século xx, as «nais solteiras» en «familias monoparentais») deriva dunha intención política virtuosa, a de terminar coa estigmatización. Non obstante, o neutro democrático non ofrece perspectiva heurística ningunha: sábese que o universal mente con frecuencia (ousar escribir durante decenios que os franceses obtiveron o sufraxio universal en 1848 cando se trataba só do sexo masculino), sábese tamén que se opón ao recoñecemento das categorías políticas dos discriminados (cfr. máis arriba).

De feito, o importante é que, ao se adoptar o punto de vista da simetría, se lle ofrece unha ferramenta máis ao pensamento da igualdade: é o mesmo para os homes e para as mulleres? Cantas mulleres ou cantos homes están concernidos pola prostitución ou polo care? Un xeito de fuxir da alternativa entre o neutro e o particular e de alimentar, así, a reflexión sobre a igualdade. Un xeito tamén de relativizar unha outra alternativa, esta vez máis actual e real: a que vincula a asexuación do social e a sexuación do político; por exemplo, co debate verbo da paridade. Enganarnos sobre a sexuación dun problema social ou sobrecargar de sexualidade o poder político son mecanismos que me levan a insistir na afirmación da diferenza dos sexos como categoría baleira.

A categoría recońece a empiricidade da duplicidade dos sexos, remite ao pensamento da sexuación do mundo, mais é unha categoría baleira e, xa que logo, carente da definición das diferenzas entre os sexos. Pois así se ve mellor a sexuación do mundo e a súa consecuencia política. É iso, esta sexuación do mundo, o que sempre se busca ocultar; e é así como o pensamento da igualdade dos sexos xorde con moita frecuencia como unha contradición, como unha idea inoportuna, sempre nun mal momento. É, efectivamente, porque a contradición entre 
as igualdades se expresa desde a Revolución Francesa, desde os balbucidos da democracia, polo que resulta tan difícil disolvela.

$\mathrm{Na}$ breve síntese que se expuxo anteriormente, tentei mostrar como salvar teoricamente a contradición nomeando os problemas coas nocións apropiadas. Velaquí por que nunca me demoro verdadeiramente na escolla de tal ou cal práctica militante ou subversiva, politicamente correcta, ou incorrecta. Velaquí por que o pragmatismo da acción feminista (todos os camińos de resistencia e de subversión son bos para os explorar) amosa, a tropezóns, a súa valía. 
COMO É QUE NON HAI UN DEREITO HUMANO A TUA CULTURA PROPIA?

Bartolomé Clavero

Universidad de Sevilla 

Despexemos antes de máis un equívoco ao que se presta a palabra «cultura». O seu sentido é polo menos duplo, un primario e outro suplementario. O primeiro fai referencia a habilidades básicas e o segundo a destrezas adquiridas. Desde a perspectiva dunha cultura neste segundo sentido, a cultura do dereito, vou ocuparme da cultura no primeiro sentido, da cultura que adquirimos con só nacermos e criármonos nun determinado medio humano, no medio particular onde nos facemos individuos e nos capacitamos como persoas. Todos os seres humanos nos socializamos nunha cultura particular, nunha de tantas culturas que existen no seo da humanidade. Aínda máis. Todos os seres humanos nos individuamos, nos facemos individuos, seres individuais, grazas a unha cultura en particular e non a algunha de alcance universal, non a algunha improbable cultura que sexa compartida por toda a humanidade. Así, grazas a unha cultura particular, é como nos capacitamos como persoas.

Todos os seres humanos o somos, chegamos a selo, pola cultura en que nacemos e con que nos criamos. Entre os mamíferos, bardante se acaso os marsupiais, os humanos somos os animais máis incapaces e máis dependentes ao nacemento. Somos tamén os que, entre todo o resto dos seres animados, nacemos cun maior potencial de capacitación e independencia, de sermos individuos con entidade propia. Non a temos de nacemento, senón que a logramos grazas á cultura particular que nos «individúa» e socializa. Grazas a ela, podemos capacitarnos e independizarnos, conseguir esta capacidade e esta independencia tanto como para nos apropiarmos doutras culturas particulares ou mesmo para optarmos entre elas, entre culturas varias, ou tamén para as acumularmos, no planeamento e desenvolvemento dos nosos proxectos de vida. Se o facemos de forma voluntaria e non por obriga de adopción e substitución, a base sempre a ofrece a cultura particular pola que nos individuamos e nos capacitamos.

Insisto en que despexemos de inicio o equívoco do duplo sentido de «cultura» polo menos nos medios dunhas linguas de matriz europea. A cultura á que aquí 
me refiro como obxecto de dereito non é unha exclusiva de ninguén, de aquelas nin de aqueles que se consideran cultas e cultos. Todas e todos nacemos, todas e todos nos individuamos, todas e todos nos socializamos, nunha cultura determinada, nunha cultura con valor para o seu medio con miras a tales efectos de individuación e socialización. Cultas e cultos somos todas e todos. Dito doutro xeito, cando se fala de cultura para tal propósito básico de individuación e socialización, non hai medios cultos e medios incultos, humanidade civilizada e humanidade incivilizada. As civilizacións mesmas son ao cabo culturas que, porque se expandiron a custa doutras, se cren superiores ou exclusivas.

Normalmente, na linguaxe xurídica predominante, adoita tomarse o concepto de cultura como obxecto de dereito no sentido menos básico, o de habilidades engadidas e destrezas suplementarias que se adquiren mediante a instrución programada e o traballo deliberado. Hai un abano que vai da artificialidade dunhas artes á utilidade dunhas ciencias que, así, adoita identificarse co obxecto propio dun dereito á cultura. Desta maneira, vén falarse do acceso a ela e aos seus beneficios. É expresión que non ten sentido cando nos referimos á cultura como a básica para a individuación e socialización dos seres humanos. Ela fai referencia a algo máis elemental e a algo, así, tamén máis xeneralizado. Non hai acceso ao beneficio da cultura en tal sentido básico, pois todos e todas, por existirmos e nos desenvolvermos, xa accedemos polo menos a unha, a que nos fixo individuos e nos capacitou como persoas.

Con este preámbulo, con este mero recordatorio de pura evidencia, poderiamos pensar que o dereito á cultura así identificada, a de valor primario, constitúe o primeiro entre todos os dereitos humanos. Cabe dicirse, abofé, que o é, en troques, o dereito á vida e a unha vida digna, conforme a dignidade que merece todo ser humano; non só, así, á existencia física, sen o cal non hai posibilidade doutro dereito ningún minimamente efectivo, senón tamén a unha vida humana digna, mais nesta dignidade xa entraría o dereito á propia cultura.

Se reducimos o dereito á vida ao seu sentido máis estrito de existencia física, non constitúe un primeiro dereito entre outros dereitos humanos, pois resulta dun principio intransitivo para a orde política e xurídica, para o dereito no seu alcance de ordenamento social. Non o predica necesariamente que se basee en dereitos, pois cabe soster que un réxime autoritario ou relixioso, sen garantía para os dereitos humanos, pode ser o máis efectivo para asegurar a vida física. Só se 
engadimos o requirimento da súa dignidade, dunha dignidade que comprende o respecto á cultura propia, teriamos unhas bases transitivas para unha orde social de dereitos humanos. Por isto digo que o primeiro entre outros dereitos humanos é o dereito á cultura particular en que nos individuamos e nos socializamos ou á que optemos libremente.

O dereito á vida impón, por si, uns deberes morais, e de certo ben fortes, de respecto ao individuo, mais non establece unhas pautas estritamente xurídicas que atinxan á orde social. Unhas normas deste xénero non se derivan do dereito estrito á vida. El non predica nada verbo de como deba organizarse a sociedade. Senta unhas regras morais verbo do ordenamento xurídico. Di que non o é, que non é dereito lexítimo, o que non parta do respecto á vida humana ou o que pońa por si mesmo en xogo medios para a destruír ou para a degradar. O dereito á cultura propia engade, en troques, algo en termos xa construtivos.

Conforme un tal dereito á cultura propia, o ordenamento xurídico debe servir antes de máis para o ser humano poder gozar pacificamente daquela en que se individúa e se socializa; para el non se ver obrigado a adoptar outra en detrimento da súa de nacemento. $\mathrm{O}$ cal de inmediato significa que o grupo humano identificado coa cultura propia debe gozar de recońecemento e de condicións para poder reproducirse baixo o signo da paz e a convivencia entre culturas; para que poida desenvolverse nun ámbito suficiente de autonomía social ou autogoberno político.

Xa se están así a definir as bases non só para unha dimensión individual do dereito, o dereito á cultura propia, senón tamén para unha dimensión colectiva, para estoutra cara necesaria do mesmo dereito, o dereito do grupo á reprodución pacífica da súa cultura, a contar cos medios, ou dígase, se se prefire, cos poderes, para a dita vida social, non só individual, en paz. Por isto resulta que o dereito á cultura representa un primeiro dereito, un primeiro de alcance constituínte para a orde social. É o que serve para identificar non só os suxeitos individuais, senón tamén uns primeiros suxeitos colectivos do ordenamento social. Digamos daquela que, se o dereito individual á cultura propia é o primeiro dereito constituínte, as culturas sociais deben contar coa posibilidade de seren "constituencias» políticas ou formaren algún tipo de corpo político por si mesmas e en relación con outras.

No entanto, resulta que esta non é a visión da orde internacional dos dereitos humanos, pois non ten o dereito á cultura propia como primeiro dereito nin no seu duplo alcance, o individual e o colectivo, nin en ningún deles por separado, 
nin como dereito básico do individuo nin como principio constituínte da comunidade. Non se entende como comprendido no dereito a unha vida digna, a unha mínima dignidade humana. Cun carácter xeral, un tal dereito bivalente á cultura propia nin sequera se concibe como tal. Mírese a despregadura normativa dos dereitos humanos desde a Declaración Universal, hai xa máis de medio século, desde 1948. Non se atopará formulado tal dereito á cultura propia como dereito humano de alcance xeral, universal, nin na Declaración que se proclama tal, universal, nin en toda a nutrida normativa que a desenvolve por impulso de Nacións Unidas.

Non figura como tal, como dereito de alcance xeral, nos corpos fundamentais desta orde internacional de dereitos humanos, no par de Pactos Internacionais de 1966, nin no de Dereitos Civís e Políticos nin no de Dereitos Económicos, Sociais e Culturais. No corpo normativo dos dereitos humanos rexístranse dereitos culturais, mais comécese por observar que o seu lugar é postremeiro. $\mathrm{Na}$ mesma Declaración Universal aparecían nun momento avanzado. A literatura xurídica adoita presentar os dereitos mesmos, os humanos ou os constitucionais que equivalen, nunha orde de xeracións conforme a cal unha primeira xeración a formarían os dereitos de carácter individual e unha segunda, os dereitos políticos e sociais de alcance colectivo, mais de titularidade aínda individual, como os de asociación, ficando para a terceira os dereitos culturais, canda outros de orixe prestacional e os de carácter estritamente colectivo, os de alcance constituínte. A composición é tópica. Tal é a orde que garda a secuencia dos Pactos Internacionais de Dereitos Civís, Políticos, Económicos, Sociais e Culturais, mesmo sen chegar aínda ao último paso, o do dereito colectivo constituínte.

O dereito á cultura concíbese como dereito de xeración última e non primeira porque se entende que fai referencia á capacitación suplementaria, non á individuación e socialización básicas nin á súa dimensión colectiva constituínte. Por isto se atopa substancialmente entre os dereitos de prestación. O problema non é entón de postergación, senón de suplantación. Non se trata do mesmo dereito situado en distinta posición. En tal concepción, os dereitos culturais de xeración postremeira cancelan o dereito primario á cultura propia. Poden facelo se os axentes políticos, relixiosos ou sociais que se fan cargo da prestación do dereito á capacitación suplementaria non pertencen á mesma cultura básica que nos habilita ou non a recońecen nin respectan. É o que adoita ocorrer cos axentes principais para a garantía dos dereitos humanos segundo a propia orde interna- 
cional, os Estados, remitentes e destinatarios a un tempo do corpo normativo de Nacións Unidas.

Se o Estado sintoniza ou mesmo se identifica cunha cultura distinta á nativa do individuo, o seu entendemento e a implantación de políticas que satisfagan dereitos culturais resultan lesivos do dereito á cultura propia. A presunta satisfacción dun dereito, daquela, realmente o conculca. Non poño, xaora, en cuestión o interese humano, dereito incluso, de acceso a outras culturas, senón o efecto que se produce cando vira en prestación de Estado ou requirimento de cidadanía en medios multiculturais, o cal é a regra e non a excepción. A construción de cidadanía mediante a comunicación de cultura é emprendida polo Estado para participar duns dereitos e os garantir para si, mentres que son experimentados por individuos e grupos doutra cultura como vulneración do dereito propio. A situación máis claramente se produce respecto a sectores indíxenas, isto é, anteriores á existencia do propio Estado no mesmo territorio. Con todo, o efecto dunhas políticas estatais de promoción de dereitos culturais resulta impeditivo e conculcatorio do dereito humano máis estrito á cultura. Impedimento prodúcese polo ofrecemento de cultura como acceso a cidadanía de Estado; conculcación, por se impor como obriga.

$\mathrm{Na}$ formulación orixinal, en 1948, do dereito internacional aos dereitos humanos había algunha que outra cousa máis en dirección tanto favorable como desfavorable para os dereitos humanos en xeral e o dereito á cultura propia en particular. Por unha banda, a menos favorable, lembremos que a posición por entón dos dereitos todos, mesmo coa Declaración Universal, non era moi relevante ou non era o relevante que será logo. O organigrama de Nacións Unidas que durou ata este último ano, o 2006, situaba o organismo que se ocupaba dos dereitos baixo doutro que se entendía de economía e sociedade. A Comisión de Dereitos Humanos era subsidiaria do Consello Económico e Social.

O organigrama respondía a formulacións de fondo comúns aos Estados capitalistas e socialistas que concorreron á fundación de Nacións Unidas. Uns como outros tińan os dereitos como o propio dun estadio ulterior á afluencia económica e á homoxeneidade social de cidadanía, para cando estivesen máis ou menos artelladas ambas, a economía e a sociedade, nun Estado. Sendo o un e o outro, o económico e o social, factores de construción da cidadanía de Estado que había de participar dos dereitos e garantilos, dificilmente podía terse en consideración un dereito que daquela, vistas así as cousas, viña interpoñerse, o dereito á cultura propia. 
Había outra parte, de signo esta menos desfavorable. Pese a todo, entre tamañas dificultades, a importancia da cultura propia non escapaba á Declaración Universal dos Dereitos Humanos. Ela responde ao paradigma das xeracións de dereitos cos dereitos culturais practicamente á cola. O dereito á cultura que rexistra como dereito humano é o que mira para o acceso a habilidades suplementarias e non á capacitación básica na propia cultura de nacemento e crianza. Por iso é polo que figura en posición postremeira. Porén, na mesma Declaración Universal a evidencia de que a cultura particular resulta clave para o individuo aparece na forma de constatación de feito para a fundamentación de deber, non de dereito: «Toda persoa ten deberes respecto á comunidade, xa que só nela pode desenvolver libre e plenamente a súa personalidade» (art. 29.1).

En todo caso, é un recoñecemento. Se entendésemos que «comunidade» era só un eufemismo por «Estado», só no cal e polo cal entón podería darse o libre e pleno desenvolvemento da personalidade do individuo, a Declaración Universal dos Dereitos Humanos resultaría totalitaria. Non esquezamos que ela se produciu nuns tempos aínda plenamente coloniais e que nela non se contén ningún recoñecemento do dereito de libre determinación dos pobos. O seu pronunciamento de que «só nela [na comunidade] pode desenvolver libre e plenamente a súa personalidade» cadaquén é un augurio do futuro, hoxe en algo presente, que agora imos ver.

Por aqueles comezos da orde internacional dos dereitos humanos, había aínda algún outro indicio de recońecemento da importancia da cultura propia, algún realmente elocuente. Practicamente coetánea da Declaración Universal dos Dereitos Humanos, precedéndoa en realidade por un día, é a Convención para a Prevención e a Sanción do Delito de Xenocidio. Para ela é xenocidio calquera "acto perpetrado coa intención de destruír, total ou parcialmente, un grupo nacional, étnico, racial ou relixioso», non só directamente mediante morte masiva, senón tamén por medios indirectos como, por exemplo, «traslado pola forza de nenos do grupo a outro grupo» (art. 2). Se a transferencia forzada de infancia ten un efecto xenocida non é porque as persoas perezan, senón porque a cultura distintiva do grupo dese xeito se extingue. É o que se persegue, pois consta a súa importancia para a propia existencia do grupo humano. Isto estaba ben claro no proxecto da Convención e aplicábase ademais sen restrición á infancia, mais diluíuse na versión final. Conspiraron para este efecto, pensando nas súas políticas de extinción de culturas indíxenas, os Estados de América, que constituían o 
grupo continental maioritario dos Estados fundadores de Nacións Unidas (vinte e dous entre cincuenta ou, en 1948, cincuenta e sete, mentres que hoxe se van achegando aos dous centenares).

Conforme a Declaración Universal dos Dereitos Humanos e ao abeiro da Convención paralela sobre o Delito de Xenocidio, antes de se iniciar a evolución que agora veremos, o que era xenocida se se aplicaba á infancia podería ser lexítimo se se facía con xente adulta. Os Estados poden e adoitan identificarse cunha cultura non compartida por toda a súa cidadanía ou, aínda menos, por toda a poboación á que atinxe, sobre todo isto, mais non exclusivamente, por tempos e en latitudes coloniais. As políticas de imposición da propia cultura podían os Estados entendelas como formas de integrar na cidadanía ou de preparar para ela, e así sempre como requisito para o exercicio e garantía dos dereitos humanos. Con todas as súas implicacións xenocidas, a construción de cidadanía pode producir os mesmos efectos extintivos de culturas ca o secuestro de infancia.

A tipificación como xenocidio do traslado forzoso de infancia constituía unha punta do iceberg na propia Convención. Era o único caso remanente dun proxecto que sumaba o xenocidio de cultura ao de poboación. Canda o «traslado por forza de nenos do grupo a outro grupo» relacionábanse como casos igualmente tipificados do delito de xenocidio o «exilio sistemático de persoas representativas da cultura dun grupo», a "prohibición do emprego da lingua nacional incluso en comunicacións privadas», a "destrución de libros» ou de «obras relixiosas» ou a "prohibición de novas publicacións» na «lingua nacional», a «destrución sistemática de monumentos históricos ou relixiosos» ou a súa «dedicación a usos que lles sexan estrańos», e a "destrución ou dispersión de documentos e obxectos de valor artístico ou relixioso ou daqueles que, en todo caso, se destinen a culto». Só se mantivo o capítulo da infancia como testemuña dunha tipificación do xenocidio en defensa non só do dereito á vida, senón tamén á cultura. Se os Estados que por entón constituían as Nacións Unidas non estaban dispostos a aceptar a dita tipificación penal do xenocidio cultural, enténdese que non incluísen entre os dereitos humanos o dereito á cultura propia.

A política daquela cualificable de xenocidio cultural cabe sen maior problema para o dereito internacional dos dereitos humanos na súa formulación de orixe, a de 1948, ou poida mesmo que sexa entendida á súa luz por parte dos Estados como a requirida e conveniente, pois así se formaría cidadanía con acceso á garantía 
dos dereitos mesmos. Deste xeito se practicou, en efecto. Redución, degradación ou extinción de culturas mediante políticas de substitución de cultura dirixidas a xente adulta ténense por formas de participación de dereitos, mentres que o propio, se se aplicaba á infancia, podía ser xenocidio. O mesmo dereito humano á cultura no sentido de acceso a habilidades suplementarias, dereito á adquisición da lingua de Estado, por exemplo, pode ser entón non medio de capacitación, senón vía de impedimento e ata negación do dereito á cultura propia, a aquela pola que o individuo adquiriu a súa capacitación básica. Imponse unha cultura de Estado sen consideración e con prexuízo para con outras culturas. Co conflito entre elas, o que se produce son situacións non de garantía reforzada, senón de vulnerabilidade extremada de dereitos, dos mesmos dereitos que son invocados tanto por Constitucións de Estados como pola Declaración Universal dos Dereitos Humanos.

Todo isto se refire á formulación orixinal do dereito internacional dos dereitos humanos, non ao actual, pois evolucionou bastante desde 1948 e en grao notablemente sensible no que importa ao dereito á cultura propia. Os dereitos humanos viñeron desenvolvéndose na orde internacional, de xeito que, por fortuna, non garda enteira consecuencia cos presupostos fundacionais de Nacións Unidas ou, en concreto, coas mesmas presuncións non sempre humanas da propia Declaración Universal dos Dereitos Humanos. Deben agora interesarnos unhas correccións, pois tocan ao asunto clave do dereito á cultura. Houbo realmente novidades, se non temperás, tampouco moi demoradas.

Os Pactos Internacionais de Dereitos Civís e Políticos e de Dereitos Económicos, Sociais e Culturais, que se acordaron en 1966 e están en vigor desde 1976, representan desde entón a despregadura e a concreción máis relevante da propia Declaración Universal dos Dereitos Humanos. Mais non se limitan a despregar e concretar. Eles introducen algún punto novo que pode resultar clave respecto do dereito á cultura propia, para isto que non era tido en consideración, en troques, pola Declaración Universal. Agora é posible polo desbloqueo no desenvolvemento dos dereitos humanos que fixo posible a adopción en 1960 do dereito á libre determinación dos pobos como principio dunha política internacional de descolonización.

Velaquí a proclamación, daquela, desde 1960, dunha evidencia e dun dereito consecutivamente: "A suxeición de pobos a unha subxugación, dominación e explotación estranxeiras constitúe unha denegación dos dereitos humanos fundamentais, é contraria á Carta das Nacións Unidas e compromete a causa da paz e a 
cooperación mundiais»; «Todos os pobos teñen dereito á libre determinación; ao abeiro deste dereito, determinan libremente a súa condición política e perseguen libremente o seu desenvolvemento económico, social e cultural» (Declaración sobre a concesión da independencia aos países e pobos coloniais, arts. 1 e 2). A partir desta proclamación pode non só desbloquearse o desenvolvemento da orde internacional dos dereitos humanos, senón tamén producirse unha nova abordaxe.

A novidade para o dereito estrito á cultura propia prodúcese en 1966 no Pacto sen dúbida principal entre os dous principais, o de Dereitos Civís e Políticos. Antes de os dereitos culturais de terceira xeración compareceren no pacto correspondente, resulta que un dereito á cultura de primeira xeración, pois o é á cultura propia, aparece entre os dereitos civís e políticos. Non se trata dun erro na sede, senón dunha rectificación parcial da Declaración Universal dos Dereitos Humanos. A novidade contense nun artigo que ten en consideración un suxeito realmente novo no ámbito concreto do despregamento internacional dos dereitos humanos ata o momento. Velaquí: «Nos Estados en que existan minorías étnicas, relixiosas ou lingüísticas, non se lles negará ás persoas que pertenzan ás ditas minorías o dereito que lles corresponde, en común cos demais membros do seu grupo, a teren a súa propia vida cultural, a profesaren e practicaren a súa propia relixión e a empregaren o seu propio idioma» (art. 27). Recońécese práctica de comunidade, mesmo con dereito tan só de individuo, de persoa pertencente a ela.

Velaí en todo caso o dereito á cultura propia como dereito primario recoñecido a aqueles que pertencen ás que son cualificadas, con termo en por si desigualitario, como minorías. «Minoría» era categoría que servía para identificar no organigrama de entón un organismo de Nacións Unidas de cometido tuitivo (a xa inexistente Subcomisión para a Prevención de Discriminacións e Protección ás Minorías), mais é categoría que só en 1966 fai a súa aparición no corpo normativo da orde internacional dos dereitos humanos. Pola función que vén agora cubrir, substitúe a máis digna de «comunidade» que, como ámbito do desenvolvemento da personalidade, vimos aparecer na Declaración Universal (art. 29.1).

O dereito individual á cultura propia de minoría, un dereito así tan redutivamente concibido, é un dereito que tende a quebrar os moldes no mesmo seo de Nacións Unidas. Tende a se entender como dun alcance superior ao literal dos seus termos de referencia, os de lingua e relixión. O Comité de Dereitos Humanos, o organismo internacional que supervisa o cumprimento polos Estados e a reclamación por parte 
de individuos das liberdades consideradas no Pacto Internacional de Dereitos Civís e Políticos, interpreta o dito artigo sobre «minorías étnicas, relixiosas ou lingüísticas», particularmente cando se trata de indíxenas, estendendo o obxecto do dereito á cultura propia a un ámbito material, o de terras e recursos, necesario para o exercicio «en común» das expresións culturais de carácter inmaterial, como esas do idioma e a relixión, que se rexistran de forma expresa.

Para unha xurisprudencia internacional, cultura humana no seu sentido básico, non só resulta así un conxunto de habilidades persoais do suxeito humano individual, senón tamén toda unha serie de medios materiais da comunidade humana que concorre á dita mesma capacitación do individuo. É así tamén cultura o despregamento dos recursos colectivos precisos para a vida do agrupamento humano que a presta e a encomenda a aqueles que nacen e medran no seu seo. Dito doutro xeito, hai cultura material tan importante coma a intanxible para a propia existencia colectiva e individual, para as comunidades humanas e para os individuos humanos. Por ilustrar digamos que cultura non só é o dominio dunha lingua na sociedade, senón tamén o control duns recursos no territorio. Conforme a propia doutrina do Comité de Dereitos Humanos de Nacións Unidas, é cultura a concorrencia e interrelación entre unhas dimensións e outras, entre as materiais e as inmateriais.

Hai máis signos de potenciación do dereito á cultura propia, malia que sen tales efectos prácticos. En 1989, adoptando a liña de fondo contraria á Declaración dos Dereitos do Neno de trinta anos antes, a Convención Internacional dos Dereitos do Neno estende á infancia e á adolescencia os dereitos declarados para a xente adulta. Cando chega ao dereito de persoas pertencentes a minorías, isto é o que di: «Nos Estados en que existan minorías étnicas, relixiosas ou lingüísticas ou persoas de orixe indíxena, non se lle negará a un neno que pertenza a teles minorías o dereito que lle corresponde, en común cos demais membros do seu grupo, a ter a súa propia vida cultural, a profesar e practicar a súa propia relixión e a empregar o seu propio idioma» (art. 30). O suposto indíxena, o de xente anterior aos Estados no propio territorio, destácase con entidade propia para os efectos de garantía do dereito á propia cultura. O Comité dos Dereitos do Neno, o organismo supervisor desta Convención, vén prestando atención diferenciada, para garantía redobrada, ao dereito á cultura propia da infancia indíxena.

Outro signo é o que ofrece, en 1992, a Declaración sobre os dereitos das persoas pertencentes a minorías nacionais ou étnicas, relixiosas e lingüísticas, que expresa- 
mente desenvolve o artigo 27 do Pacto de Dereitos Civís e Políticos, o referente ao dereito á cultura propia. Non é un gran paso adiante. Fronte a canto se propuxo e se debateu durante o proceso de elaboración, non se fai distinción expresa do suposto indíxena nin tampouco se recolle o concepto integral da cultura como material e non só inmaterial. Agora fálase de «minorías nacionais ou étnicas», con ese novo cualificativo de «nacional» que pode estar a mirar ou vir aplicarse para o caso dos pobos indíxenas. Nunha organización que constitutivamente identifica nación e Estado, pois á fin e ao cabo Nacións Unidas é unión entre Estados, algo é que se amose disposición a recoñecer que poden ser por si mesmas «nacionais» unhas «minorías», mais pouco pode un mero xesto fronte ao progreso galopante de expropiación masiva de recursos tanto intelectuais como naturais propios de culturas indíxenas.

A disposición máis favorable está a se incubar no seo de Nacións Unidas desde que comezaron a se pór en práctica en 1976 os Pactos de Dereitos Humanos ante a propia evidencia de que o caso indíxena se acomodaba mal no molde do artigo sobre o dereito á cultura propia do Pacto de Dereitos Civís e Políticos. De diversa forma, tanto o Comité de Dereitos Humanos como a Subcomisión para a Prevención de Discriminacións e Protección ás Minorías empezaron logo a experimentalo. Persoas pertencentes a grupos indíxenas e os grupos indíxenas mesmos mostran a súa insatisfacción por seren reducidos a minorías e porque o seu dereito, así, sexa considerado por un artigo de excepción e non polo que se refire en termos xerais a "pobos», o primeiro de ambos os Pactos. É un artigo, este primeiro, que tamén interesa ao dereito á cultura.

Xa cońecemos o seu parágrafo inicial, pois procede da declaración de 1960 que adoptara a política de descolonización. Os Pactos de Dereitos Humanos presentan un pronunciamento primeiro en común, o que rexistra o dereito de libre determinación dos pobos: «Todos os pobos teñen dereito á libre determinación; ao abeiro deste dereito, establecen libremente a súa condición política e perseguen libremente o seu desenvolvemento económico, social e cultural». Malia o rexistro da cultura seguir sempre a quedar para o final, tras a política, a economía e a sociedade, a libre determinación tamén se estende á determinación cultural. Non se confían as culturas duns pobos a un Estado de cultura recońecidamente allea, como no caso das minorías.

Velaí graficamente a diferenza substancial de fondo entre dereito de pobos e dereito de minorías no estadio actual da orde internacional. As persoas perten- 
centes a estas, a unhas minorías, contan cun dereito á propia cultura cuxa garantía corresponde ao Estado, a un Estado de cultura allea, mentres que as persoas pertencentes a aqueles, a uns pobos, contan coa garantía do dereito do propio pobo. Ante Nacións Unidas, coma noutros foros internacionais, representantes indíxenas veñen opoñéndose á redución a minorías. Veñen contribuíndo ao desenvolvemento dunha orde internacional de dereitos indíxenas que conduciu á elaboración dunha Declaración de Dereitos dos Pobos Indíxenas finalmente aprobada pola Asemblea Xeral das Nacións Unidas en setembro de 2007.

En 2006 a Comisión de Dereitos Humanos fora elevada á categoría de Consello de Dereitos Humanos, xa non subsidiario do Consello Económico e Social. Na súa primeira sesión procedeu á adopción do proxecto da Declaración de Dereitos dos Pobos Indíxenas e elevouno á Asemblea Xeral para a súa aprobación, que levou un ano longo. Xa é unha peza máis do dereito internacional dos dereitos humanos. Nos termos máis resumidos pode dicirse que, no seo desta orde superior aos Estados, ela traslada os pobos indíxenas desde o réxime de minorías ao de pobos, comprendéndose desde logo con isto o dereito de libre determinación política, económica, social e cultural: «Os pobos indíxenas teñen dereito á libre determinación; ao abeiro deste dereito, determinan libremente a súa condición política e perseguen libremente o seu desenvolvemento económico, social e cultural» (art. 3). Con toda consecuencia, malia a cualificación como xenocida estar suprimida do proxecto final, proscríbese o xenocidio cultural: «Os pobos e as persoas indíxenas teñen dereito a non sufriren a asimilación forzosa ou a destrución da súa cultura» (art. 8.1). O dereito colectivo de libre determinación cultural pode así por fin recońecerse no corpo normativo dos dereitos humanos como expresión e garantía do dereito individual á cultura propia.

O dereito á libre determinación cultural, con todo o que comporta, non chega agora como exclusiva de ninguén, xaora, senón todo o contrario precisamente. Dise para os pobos e para os individuos indíxenas o que estaba dito para todos os pobos e todos os individuos polos Pactos Internacionais de Dereitos Civís e Políticos e de Dereitos Económicos, Sociais e Culturais. De «todos os pobos» viñan excluíndose os indíxenas, como, de todos os individuos, os indíxenas. Agora trátase de reparar a postergación para establecer a igualdade. Non tería que haber necesidade de ser declarado para os indíxenas o que está declarado nos termos máis xenéricos, sen expresión de exclusións, mais o caso é que a nova Declaración se fai precisa porque a igualdade non existiu. 
A Declaración de Dereitos dos Pobos Indíxenas non recoñece dereitos a indíxenas que non teñamos os que non o somos. Podería mesmo vir ofrecéndose a impresión de que pasaba ao contrario. Resulta que as persoas indíxenas en particular e as pertencentes a minorías en xeral teñen recońecido na orde internacional, como vimos, o dereito á cultura propia que, en cambio, non consta nos instrumentos internacionais de dereitos humanos para as persoas non indíxenas nin pertencentes a minorías. Na realidade, tal mesmo dereito á cultura propia non é que non exista para estoutra xente, senón que veu sobreentendéndose para ela, só para ela e non para minorías nin para pobos indíxenas.

A aparencia de discriminación inversa ou acción positiva a favor de indíxenas e membros de minoría por lles ser recońecido o dereito á cultura propia realmente o que veu é encubrindo a persistencia da discriminación sen máis, a sinxelamente negativa, contra elas. As persoas non indíxenas nin membros de minorías contamos co dereito á cultura propia sen necesidade de que se veña recońecendo, pois xa nolo garante, sen necesidade de o proclamar, o Estado que se identifica con ela, coa nosa cultura. É un dereito que agora poderá abranguer a todos os pobos. Para uns, os non-indíxenas, non fai falla insistir, mentres que para outros, os indíxenas, a Declaración específica, a de Dereitos dos Pobos Indíxenas, fai preto dunha trintena de referencias explícitas a este elemento da cultura propia.

En fin, dereito á cultura propia habelo haino, só que non foi necesario declaralo para parte da humanidade, para aquela parte que ten a sorte de contar cun Estado da súa cultura. Os Estados veñen certamente amparando e sostendo as culturas coas que se identifican e, xa que logo, o dereito a elas das xentes individuadas e socializadas grazas a elas, ao tempo que puideron perfectamente acometer políticas xenocidas co resto coma se se tratase dunha mesma empresa de construción de cidadanía para a participación de dereitos. Velaí en definitiva a razón esquizofrénica pola que un dereito tan esencial como o dereito á cultura propia non foi cualificado ata hoxe como dereito humano de alcance xeral. É efecto, ao cabo, de que a orde internacional siga a ter o seu último fundamento nos Estados e non nos dereitos.

O problema, en suma, non radica en que falte entre os dereitos humanos algún dereito que debese ser engadido, senón que vén fallando o dereito que pode articular o conxunto dos dereitos humanos e particularmente os de carácter individual cos de alcance colectivo. É problema que non se presenta cos dereitos humanos en si, abofé, senón coa actual orde internacional e a correspondente filosofía servicial. 
Nota: Tense en libre acceso en Internet unha versión máis desenvolvida con rexistro de bibliografía: http://www.euskomedia.org/PDFAnlt/riev/47/47035062.pdf.

\section{DOCUMENTOS PRINCIPAIS}

\section{Declaración Universal dos Dereitos Humanos}

Artigo 2: Toda persoa ten os dereitos e liberdades proclamados nesta Declaración, sen distinción ningunha de raza, cor, sexo, idioma, relixión, opinión política ou de calquera outra índole, orixe nacional ou social, posición económica, nacemento ou calquera outra condición.

Ademais, non se fará ningunha distinción baseada na condición política, xurídica ou internacional do país ou territorio de cuxa xurisdición dependa unha persoa, tanto se se trata dun país independente como dun territorio baixo administración fiduciaria, non autónomo ou sometido a calquera outra limitación de soberanía.

Artigo 27: 1. Toda persoa ten dereito a tomar parte libremente na vida cultural da comunidade, a gozar das artes e a participar no progreso científico e nos beneficios que del resulten. 2 . Toda persoa ten dereito á protección dos intereses morais e materiais que lle correspondan por razóns das producións científicas, literarias ou artísticas das que sexa autora.

Artigo 29.1: Toda persoa ten deberes respecto á comunidade, xa que só nela pode desenvolver libre e plenamente a súa personalidade.

\section{Pacto Internacional de Dereitos Civís e Políticos}

Artigo 1.1: Todos os pobos teñen dereito á libre determinación. Ao abeiro deste dereito, establecen libremente a súa condición política e perseguen libremente o seu desenvolvemento económico, social e cultural.

Nos Estados en que existan minorías étnicas, relixiosas ou lingüísticas, non se lles negará ás persoas que pertenzan ás ditas minorías o dereito que lles corresponde, en común cos demais membros do seu grupo, a teren a súa propia vida cultural, a profesaren e practicaren a súa propia relixión e a empregaren o seu propio idioma. 


\section{Pacto Internacional de Dereitos Económicos, Sociais e Culturais}

Artigo 15.1: Os Estados partes neste Pacto recoñecen o dereito de toda persoa a a) participar na vida cultural; b) gozar dos beneficios do progreso científico e das súas aplicacións; [...].

\section{Declaración de Dereitos dos Pobos Indíxenas}

Artigo 3: Os pobos indíxenas teñen dereito á libre determinación. Ao abeiro deste dereito, establecen libremente a súa condición política e perseguen libremente o seu desenvolvemento económico, social e cultural.

Artigo 5: Os pobos indíxenas teñen dereito a conservar e reforzar as súas propias institucións políticas, xurídicas, económicas, sociais e culturais, mantendo á vez o seu dereito a participar plenamente, se o desexan, na vida política, económica, social e cultural do Estado.

Artigo 8: 1. Os pobos e os individuos indíxenas teñen dereito a non ser sometidos a unha asimilación forzada nin á destrución da súa cultura [...]. 


\section{IDEOLOXÍA E HUMOR EN TEMPOS ESCUROS: NOTAS DESDE SIRIA \\ Lisa Wedeen \\ University of Chicago}



No número de xaneiro de 2011 da revista anglófona Happynings, anunciada polos seus editores como «a revista de estilo e luxo máis prestixiosa de Siria», incitábase aos lectores a contar entre os seus accesorios con artigos de camuflaxe, os imprescindibles da tempada: «Desde a aparencia cool das prendas de combate ao ton chic do vestiario de aviadora, o estilo militar tomou por asalto as pasarelas deste outono. Amosámosche como prometerlles lealdade ás tendencias máis actuais da tempada e conferirlle á túa imaxe un acento de combate» ${ }^{1}$. Fíxose eco deste imperativo estético un vídeo de Husein Al Dik, irmán dun famoso crooner rexional, no cal os artistas aparecían vestidos con uniforme de faena negro e gris, sombreiro a xogo e botas acordoadas e bailando ao ritmo da suxestiva canción Nater bint al madrasi ("Agardando pola rapaza da escola») ${ }^{2}$.

Deste xeito, e en contraste co ascetismo e a austeridade que caracterizaban a realidade da década de 1980, cos seus tanques polas rúas, esta mudanza na visión da roupa militar, signo de control coactivo primeiro e equipamento ofrecido polo mercado despois, resultou ser efémera, socavada pola reaparición dos soldados na vía pública cando se puxeron en marcha as protestas a mediados de marzo. A medida que as manifestacións ían in crescendo e o réxime respondía en parte tentando esmagar a resistencia, a relevancia pública dos intereses mercantís polo estilo e o luxo deu paso aos temores xurdidos arredor das conspiracións e os disturbios, polo menos entre os adiñeirados defensores do réxime. No entanto, para aqueloutros que soñaran coa fin do sistema ou que estaban máis preocupados polas malas colleitas ou pola relaxación dos valores morais que por que roupa levar ás festas, a volta da milicia ás rúas puxo ao descuberto algo no que se adoita recoñecer un dos trazos fundamentais da autocracia: o recurso ao poder coactivo para sufocar o descontento. Por moito que a estética se desprazase recentemente cara a intereses tales como a oferta do mundo da moda, deixou de ter a capaci-

\footnotetext{
${ }^{1}$ Happynings, xaneiro do 2011, p. 46; p. 41.

${ }^{2}$ http://www.youtube.com/watch?v=5VNzmyBAOPg.
} 
dade de distraer a atención da xente das inxustizas que comporta a apertura dos mercados e o fracaso das aperturas políticas; como tampouco puido ocultar a preferencia do réxime por tratar de controlar as protestas con promesas de reforma e esmagando aquelas que percibía como ameazas para a súa supervivencia. E, con todo, nas dúas cidades máis importantes de Siria, Alepo e Damasco, non houbo — polo menos ata datas recentes — unha cantidade significativa de cidadáns que se mobilizasen. Ante isto, o que un se pregunta é por que non e, dun xeito máis provisional, por que isto podería estar a mudar ${ }^{3}$.

Talvez se trate de que Alepo e Damasco están tan vixiadas polas forzas de seguridade que ata agora o medo impediu que se desenvolvese un movemento de resistencia a grande escala. Non cabe dúbida de que se exerce mediante coerción un control destinado a evitar rebelións nestas dúas cidades, pero os esforzos feitos por suprimir a disidencia noutros lugares non serviron para disuadir os protestantes ${ }^{4}$; e é máis: malia a represión se intensificar no último mes tanto na capital como no núcleo comercial clave de Siria, Alepo, a resposta foi que a contestación non minguou, senón que medrou. Para nos facermos eco da observación de Basam Hadad, os ataques coordinados lanzados polos comerciantes de ambas as cidades como reacción á masacre de Hula, á que se lle deu unha ampla cobertura nos medios, marcan unha escalada do conflito en zonas que antes se mantiveran inactivas e nas que desta vez membros da clase media participan nunha loita política sobre a cal en público calaran ${ }^{5}$.

Outra posible resposta é que o réxime, malia en Occidente se afirmar o contrario, conserva a súa «lexitimidade», polo menos nas circunscricións das dúas cidades que lle son vitais. Pero o termo «lexitimidade», como argüín extensamente noutro traballo, resulta confuso de máis para ser de axuda ${ }^{6}$. Polos problemas conceptuais, metodolóxicos e epistemolóxicos que suscita, no seu uso acostuma

\footnotetext{
${ }^{3}$ Para que quede claro: non estou dicindo que a poboación destas cidades non vaia acabar por manifestar un apoio xeneralizado ao derrocamento do réxime, senón que aínda non o fixo moi publicamente.

${ }^{4}$ Se se desexa consultar un documento descuberto en datas recentes no que se describen as precaucións adoptadas para impedir que os protestantes ocupasen as principais prazas de Damasco, véxase http:// www.aljazeera.net/home/print/f6451603-4dff-4ca1-9c10-122741d 17432/1e033d23-caa8-41c7-a6971394608eff05. O feito de que, por exemplo, tantos infiltrados conseguisen este obxectivo en Alepo pide a pregunta de por que isto ocorreu alí e non noutras partes.

${ }^{5}$ Correspondencia por correo electrónico, 2 de xuño de 2012.

${ }^{6}$ Véxase o prólogo deste libro. Consúltese tamén Ambiguities of Domination: Politics, Rhetoric, and Symbols in Contemporary Syria, Chicago, University of Chicago Press, 1999.
} 
mesturarse a popularidade coa obediencia, o cal nos impide chegar á aprehensión duns fenómenos moi diversos entre si e necesitados de escrutinio, como son o apoio, a conformidade e a docilidade.

Outra posibilidade sería que nestes centros metropolitanos houbese máis protestas das que adoita recońecerse, o cal é certo. Porén, segundo os activistas que se atopan sobre o terreo, mesmo uns actos de contestación que recibiron tanta publicidade como os acontecidos na zona rica de Mezze en febreiro de 2012 atraeron multitudes procedentes de áreas veciñas máis pobres que xa estaban afeitas á rebelión ${ }^{7}$; noutras palabras, as protestas tenderon a coincidir cun espazo xeográfico delimitado en función de factores económicos ${ }^{8}$. Así, os habitantes das zonas rurais golpeadas pola seca, das cidades de menos recursos e dos arrabaldes amosaron unha constancia digna de destacar á hora de faceren patente a súa oposición, a miúdo correndo un altísimo risco para a súa persoa, mentres que as familias burguesas tradicionalmente acomodadas e as filas, cada vez máis numerosas, de novos ricos residentes nos barrios céntricos de xente requintada e con diñeiro semella que tiñan maior interese en agardar a que pasasen as loitas.

Con isto non se quere dicir que o conflito poida reducirse a unha insatisfacción dos desposuídos. De feito, nas zonas pobres as esixencias presentadas non son simplemente, nin sequera principalmente, de natureza económica: así, ademais de reclamarse a «caída do réxime», a «liberdade» e a «dignidade» e afirmarse que «Alá é grande», un lema rimado que se cantou a finais de marzo de 2011 durante unha manifestación que tivo lugar nunha área empobrecida da cidade costeira de Lataquia puxo en dúbida as interpretacións puramente económicas da revolta. En referencia a Buzaina Shaaban, daquela destacada voceira do presidente sirio, a xente coreaba: «Ya Buzaina wa ya Shaaban al shaab al suri mush yawaan» («Buzaina Shaaban, o pobo sirio non ten fame!»). Con flashmobs de gran creatividade e outras formas de resistencia outorgóuselles un carácter interclasista ás manifestacións pequenas ${ }^{9}$, e as recentes protestas universitarias vistas en Alepo

${ }^{7}$ Entrevista con activistas, febreiro do 2012.

8 Debo darlle as grazas a Kevin Mazur pola pregunta que formulou nunha presentación realizada anteriormente na Princeton University en novembro do 2011, a cal me obrigou a considerar máis polo miúdo a distribución xeográfica das protestas en función de factores económicos.

${ }^{9}$ Por veces as protestas tamén amosaron unha notable creatividade. Por exemplo, nalgunhas das que se produciron no centro de Damasco, mesmo no primeiro ano da rebelión, estiveron presentes mozos ben espelidos que se valen de tácticas contemporáneas como os flashmobs (nun caso, vinte e pico protestantes apareceron todos eles vestidos de branco) ou a solta de pelotas de pimpón rotuladas coa palabra «íde- 
e o activismo da xuventude en barrios damasquinos de renda mixta apuntan ás importantes dimensións xeracionais da contenda e talvez á crecente disposición da xuventude de clase media a se botar ás rúas. Algunhas fontes de fiar afirman que mesmo algúns dos comerciantes que participaran no estilo de capitalismo de amiguińos característico do réxime están a financiar a resistencia. Fronte ao notable fracaso obtido en maio de 2011, o éxito da recente convocatoria de folga indica que as posturas de clase ante o conflito se achan nun estado de flutuación; e, máis aínda, non se poden abrazar as explicacións materialistas —as que consideran que simplemente se comprou a vontade das persoas adiñeiradas - sen ter en conta tamén as aspiracións, moito máis amplas, de gozar dun pracer consumista (que agora adoita expresarse en termos de nostalxia do pasado inmediato e temor ante o futuro) que viron a luz baixo o signo do mercado. Porén, esta nova fonte de apoio non levou aínda á clase de protestas presenciadas en Exipto, Iemen e Libia en datas anteriores; na linguaxe da política comparada, ata agora en Siria non se dan as dúas condicións, necesarias mais insuficientes, que noutros lugares pesaron á hora de derrocar o réxime, a saber: un número significativo de individuos nas rúas e divisións entre os altos mandos das forzas armadas.

Neste relatorio abordamos a primeira desas condicións centrándonos na importancia que reviste a ideoloxía no presente. Mesmo cando os aspirantes a protestantes deixaron de crer nos compromisos do réxime de levar a cabo reformas políticas e na súa capacidade de garantir a riqueza e a orde, as conexións emocionais que se establecen coa "boa vida», combinadas cos temores que suscitan os disturbios, inspiran unha resposta política cargada de ambivalencia, ambivalen-

vos» desde o cumio do monte Qasiyun, na capital. Así mesmo, houbo anuncios anónimos de denuncia do réxime que supostamente se emitiron desde un altofalante manexado por control remoto e situado nun punto estratéxico, unha praza do centro, e tamén se oíu a voz dun famoso cantante de Hama, Kashkush (cuxo cadáver apareceu sen larinxe), desde o interior dun edificio municipal onde se filmaron as reaccións da xente, mesmo os frenéticos intentos dos axentes de seguridade por localizar a fonte da música, para logo as subir a YouTube. Estes casos de creatividade son importantes, mais tiveron efectos limitados. Véxanse as obras recentes de Donatella Della Ratta, tales como "Creative resistance challenges Syria's regime», en http://www.aljazeera.com/indepth/opinion/2011/12/20111222162349451619. html; «Irony, Satire and Humor in the Battle for Syria», http://muftah.org/irony-satire-and-humor-inthe-battle-for-syria/; «Syria: The virtue of civil disobedience», http://www.aljazeera.com/indepth/opinion/2012/04/20124283638298672.html; e «Dramas of the Authoritarian State», http:// www.merip. org/mero/interventions/dramas-authoritarian-state, artigo que se centra nos enredos dos produtores da televisión siria co réxime e no que a autora refire así mesmo algúns intentos por «explotar os puntos febles» do sistema (tomando prestada a feliz frase de Judith Butler). 
cia que non pode separarse do actual modo de funcionamento do capitalismo en tanto que ideoloxía (e non simplemente como conxunto de relacións materiais). Lonxe desa idea apuntada por algúns entendidos e estudosos de que vivimos nun mundo postideolóxico, quero considerar aquí o dinámico papel que desempeña a ideoloxía á hora de gañar o apoio dalgúns individuos, xerar ambivalencia en moitos e manexar uns termos no seo dos cales se produce un alto grao de disensión - e mesmo repugnancia.

A parte inicial ábrese co tratamento dos argumentos que presentei no meu primeiro libro, Ambiguities of Domination ("As ambigüidades da dominación»), no contexto da era actual, e resúmense as afirmacións fundamentais do estudo e identifícanse as súas limitacións. A seguir, na segunda parte debátense os méritos do termo "neoliberalismo» e as condicións ideolóxico-materiais ás que fai referencia. Aínda que anteriormente defendín a pertinencia de desagregar as compoñentes do termo, aquí considero as vantaxes de concibir o neoliberalismo como parte dunha formación ideolóxica xeral, malia as súas especificidades e diversas manifestacións en función dos lugares. Inspirándome en Slavoj Žižek e Michel Foucault, presento o argumento de que se debe repensar a ideoloxía no contexto dunhas reformas mercantilistas e de ausencia de alternativas a elas, mesmo en situacións de protesta aínda en curso. Quero entender a ideoloxía na era contemporánea non como unha visión coherente do mundo que está «aí fóra»e que un pode saír e adoptar, basicamente igual que se se tratase da plataforma dun partido político, senón, polo contrario, como unha ratificación sedutora, particularmente insinuante e en gran medida implícita do que, no caso concreto do neoliberalismo, son experiencias de risco e pracer que nos chegan polo conduto do mercado: o neoliberalismo satura sen se naturalizar por completo, organizando os mundos vitais duns xeitos que suscitan máis interrogantes para as ciencias humanas. Finalmente, e con miras a comprender o tenaz e incompleta que é a reprodución ideolóxica, a terceira parte céntrase en como actúa a risa na era autocrática e de mercado en que viven uns cidadáns que saben moito da televisión de Bashar Al Asad; en particular, no traballo de Hayu dáse conta tanto das crúas realidades desa década como das súas aparentes tentacións, nunha comedia por veces profética e por veces dolorosamente sombría na que o autor lles abre a porta a alternativas aos impulsos máis conservadores que ela mesma manifesta, para demostrar, así, a potencia e a irregularidade da saturación ideolóxica. 


\section{PRIMEIRA PARTE. AMBIGUITIES... NO PRESENTE}

Como talvez saiban algúns lectores, en Ambiguities of Domination examinábase o «culto á personalidade» que arrodeou o presidente sirio Hafez Al Asad (1970-2000), coas prácticas retóricas e as imaxes que serviron para apartar os grandes problemas políticos do centro do debate público. Durante unha extensa parte do goberno de $\mathrm{Al}$ Asad a súa figura foi omnipresente: nos xornais, na televisión e no transcurso de espectáculos orquestrados enxalzábase o dirixente cos epítetos de «pai», «nobre cabaleiro» e mesmo "farmacéutico primeiro» do país. Porén, a maioría dos sirios, incluídos os que crearan a retórica oficial, non crían o que esta afirmaba. E en Ambiguities... preguntábase: por que un réxime vai gastar uns recursos xa escasos nun culto cuxos rituais de obediencia son, a todas as luces, unha farsa?

$\mathrm{Na}$ mesma obra argüíase que o culto sirio a Hafez Al Asad actuaba non xerando unha crenza ou un compromiso emocional — que se dan por presupostos nos conceptos de lexitimidade e hexemonía-, senón definindo tanto a forma como o fondo da obediencia civil. Alén do canón das armas e dos confíns das cámaras de tortura, o culto a $\mathrm{Al}$ Asad servía de artefacto disciplinario e daba así pé a unha política de disimulo público na cal os cidadáns actuaban «coma se» reverenciasen o seu dirixente. Ao inundar de simbolismo instrutivo a vida cotiá, o réxime exercía unha forma de poder sutil, mais efectiva. O culto valía para impoñer obediencia, inducir á complicidade, illar os sirios os uns dos outros e establecer unhas directrices para o discurso e a conduta públicos.

A miña investigación, resultado de dous anos e medio de traballo etnográfico de campo, tamén revelou que, baixo o mandato de $\mathrm{Al}$ Asad pai, os sirios eran quen de recońeceren os aspectos disciplinarios do culto e, ao tempo, achaban xeitos de os socavaren. É máis: ante o feito de que se publicasen ou circulasen tantas viñetas, filmes e comedias televisivas críticos coa realidade política cabe formular outra pregunta, a de por que un réxime vai tolerar afrontas simbólicas ás súas afirmacións oficiais de omnipotencia; ou, por expresalo doutro xeito, ata que punto esas «vitorias» artísticas illadas poden constituír un método politicamente eficaz de presentar resistencia ante o réxime e o seu goberno do «coma se»? Neste sentido, o meu argumento é o seguinte: por unha banda, tales prácticas artísticas resultaron politicamente eficaces na medida en que contrarrestaron a 
atomización e o illamento que fomentaba o disimulo público, pois, mentres que ao ver que os demais obedecen, un séntese só na súa incredulidade, unha risińa colectiva, unha sátira popular e a divulgación de tiras cómicas e relatos transgresores permitiron que a poboación fose consciente de que esas condicións que propiciaban a incredulidade estaban xeneralizadas entre a colectividade. Así, os métodos de facer patente a resistencia, permitidos e prohibidos por igual, resultaron efectivos en parte no sentido de ratificaren esta experiencia de incredulidade amplamente compartida: no momento en que se conta un chiste, cando o riso resoa no cuarto, a xente fai que queden sen efecto ese illamento e esa atomización fabricados por unha política do «coma se», e afirma ante si e ante os demais a súa condición, compartida, de mal dispostos recrutas.

Por outra banda, e de modo paradoxal, é precisamente este recońecemento común de obediencia involuntaria o que pode outorgarlle tanta forza a un culto. Noutras palabras, o culto a $\mathrm{Al}$ Asad tiña forza nin máis nin menos que porque resultaba imposible de crer. Con actos de transgresión talvez se poida contrarrestar a atomización e o illamento que produce unha política do «coma se», pero tamén se alimenta outro mecanismo disciplinario, que é o de como ese culto dependía dunha obediencia externa xerada a través da incredulidade de cada cidadán individual. Neste sentido, o culto a Al Asad disciplinaba os cidadáns propiciando continuas demostracións de obediencia externa, a cal, a diferenza do que ocorre co bo discernimento, coa convicción ou coa lexitimidade, se basea nunha submisión vergoñenta á autoridade que ten os seus fundamentos na, precisamente, ausencia de crenza. Ao se recońecer, xa que logo, o estado compartido de incredulidade, reprodúcese esa inhibición sen a cal dificilmente podería manterse un política do «coma se». Dito en poucas palabras, talvez a resistencia contrarrestase os efectos atomizadores dun culto á personalidade, pero tamén lles confería máis forza aos propios métodos dos que se servía o culto para impoñer obediencia. Como sinala o filósofo Slavoj Žižek, mesmo se un individuo mantén as distancias con ironía, mesmo se dá a entender que non toma en serio o que fai, aínda así está a facelo. Está conformándose. E a conformidade é, en última instancia, o que conta na política ${ }^{10}$.

${ }^{10}$ Véxase Ambiguities of Domination: Politics, Rhetoric, and Symbols in Contemporary Syria, Chicago, University of Chicago Press, 1999. Advírtase que estas pasaxes (pp. 8-10) son fragmentos lixeiramente modificados das observacións que se presentan en "Conceptualizing Culture...», APSR, decembro do 2002. 
O problema de Ambiguities of Domination non radicaba, como afirmaron algúns críticos, en que na obra non se tivesen en conta as variacións, en que se tratase os sirios dun xeito monolítico de máis, no canto de se recońecer a existencia de diversas situacións de fondo. Iso é falso e vai desencamiñado. Hai que dicir que na investigación non só se fixeron todos os esforzos posibles por poñer de manifesto o estado xeneralizado de incredulidade, pois gardaba relación co culto, senón que ademais, e o que é máis importante, a baseei nunha análise de asertos flagrantemente ficticios que, por definición, resultaban incribles. O problema da obra vińa do reducido do tema, ao se abordar un pequeno subconxunto da retórica oficial, e por outra banda abranguía un período en que esa retórica, controlada principalmente polo que semellaba un anquilosado Partido Baaz, se tornara notablemente acartonada e quedara pasada de moda. E, nestes dous sentidos - $\mathrm{O}$ reducido da cuestión tratada no libro e as particularidades do período (unha era posrevolucionaria e poscolonial na que o cansazo do estilo soviético aínda non acabara de dar paso ás promesas mercantilistas dunha xeración máis nova)—, a obra anticipa só en parte as complexidades do momento presente ${ }^{11}$.

Por outra banda, as complicacións actuais obsérvanse nunhas manifestacións públicas de apoio que resultan máis difíciles de interpretar, nas cales as multitudes, aparentemente desalentadas (polo menos ata hai pouco) polas directrices do réxime, inundan as rúas ataviadas con camisetas que levan a face do presidente, ondeando bandeiras e facendo soar as bucinas. Os testemuńos de carińo polo presidente tamén quedan patentes en páxinas do Facebook, en tweets e nos sitios web dos Minhibaks, nome derivado dun lema das «eleccións» presidenciais do 2007 co que se designaba a devoción que sentían os cidadáns polo seu dirixente. Para alén disto, tamén se aprecia ás claras a complexidade da que falabamos nas numerosas creacións dos usuarios da Rede que se burlan do presidente (algo que antes non resultaba posible), en tiras cómicas que establecen analoxías entre el e outros ditadores xa desaparecidos, na posta en dúbida do relato oficial dos acontecementos por parte de cadeas de televisión por satélite como Al Yazira e Al Arabiya e nos chamamentos á fin do réxime emitidos en todo tipo de medios sociais. Se o meu

${ }^{11}$ Talvez resulte irónico que, no mesmo momento en que deberían quedar máis á vista as limitacións da obra, a súa tradución para o árabe a convertese nun texto especialmente salientable entre os estudosos e os activistas da «primavera árabe». Para a miña gran sorpresa (e fonda ambivalencia), vai pola súa terceira edición, continúa a ser invocada con regularidade na prensa internacional de lingua árabe e foi obxecto de varios especiais televisivos. 
primeiro libro constituía unha radiografía das evidentes ambigüidades dunhas lóxicas da dominación abertamente autoritarias, as imprecisións do período contemporáneo apuntan ao intricado que se presenta o goberno nunha era mercantilista e a rebordar de información na cal as varias formas de soberanía — tanto persoais como colectivas - se ven ameazadas non só polas manifestacións de violencia, senón tamén por novas formas de desorientación e incerteza.

As estratexias baseadas na obediencia que caracterizan os réximes autoritarios poden dar paso (como no caso da Europa Oriental) ou ir aparelladas (véxanse a China, Singapur ou Siria) a mecanismos de mercado que comportan a aparición de modos do que Althusser (1971) denominou «interpelación», de «acoller»os cidadáns no mundo da iniciativa privada e do consumo ostentoso. En Siria estas técnicas mercantilistas de produción de valor foron ligadas ás figuras retóricas, xa familiares, de unidade nacional e diversidade multiétnica, e xuntas deron lugar a uns mecanismos novos e sumamente heteroxéneos de control social... e de protesta contra eles. E, o que é moi importante, na década que comezou co ano 2000 a ideoloxía deixou de ser o ámbito privilexiado dos partidos políticos; no canto diso, as producións e a publicidade emitidas pola televisión siria contribuíron a diversificar o que se tiña por «boa vida». Así, en cultivar desexos por posuír determinados artigos de consumo, albergar novas ambicións de ascender na escala social e elaborar programas filantrópicos individuais que defendesen a asunción do poder por parte dos cidadáns mediante o cońecemento das propias limitacións achábase o tipo de efectos disciplinarios que tendía a xerar esta era mercantilista ${ }^{12}$. E acaso o exemplo máis espectacular de vigorización das campañas de relacións públicas estivo nos firmes intentos de vender a imaxe do presidente e da primeira dama como membros da elite política cosmopolita, intentos que culminaron no inoportuno artigo publicado no número de Vogue de finais de febreiro do 2011. Esta reportaxe xa non está dispoñible no sitio web da elegante revista, actuación que lembra ás estratexias soviéticas de esquecemento (pénsese na memorable escena da obra de Milan Kundera Kniha smichu a zapomnéni [ «O libro da risa e o esquecemento»] en que se fai desaparecer da foto un camarada desacreditado). Como vimos con motivo da «primavera árabe», esta época tamén

12 Véxase Burawoy, Michael (1979): Manufacturing Consent: Changes in the Labor Process under Monopoly Capitalism, Chicago, University of Chicago Press; como perspectiva oposta, consúltese Przeworski, Adam (1985): Capitalism and Social Democracy, Cambridge, Cambridge University Press. 
trouxo consigo outras oportunidades de transgresión e resistencia, voces que ata agora non acharan ouvidos en zonas de abandono, maneiras imaxinativas de permanecer a salvo e unha mudanza nos límites do que semella razoable, cuestionable, pronunciable... ou mesmo concibible.

\section{SEGUNDA PARTE. O NEOLIBERALISMO COMO IDEOLOXÍA: «ZO- NAS DE ABANDONO»/ZONAS DE GOZO/ZONAS DE PROTESTA}

Durante os primeiros dous meses das revoltas non resultaba estraño oír os cidadáns de clase media e alta das dúas cidades máis grandes de Siria repetir o diagnóstico "rah tinhal», "xa se amañará en por si», unha ilusión do presente baleira de toda visión política optimista para o futuro. Ata certo punto, tal ilusión reflectía a actitude dos que tiraran beneficio ou imaxinaran acadar a prosperidade na conxuntura da reforma neoliberal previa ás revoltas. Como teño apuntado noutras obras, o termo "neoliberalismo» resulta controvertido, en parte porque tende a se referir a polo menos catro fenómenos da economía política que adoitan ir da man: 1) estabilización macroeconómica (políticas que incentivan un baixo nivel de inflación e unha reducida débeda pública e desaconsellan as medidas contracíclicas keynesianas); liberalización do comercio e desregulación financeira; 3) privatización de bens e empresas de titularidade pública, e 4) redución do estado do benestar. Malia por veces estes catro aspectos actuaren en conxunto, a miúdo non ocorre así, e o impacto que teñen na poboación é variable ${ }^{13}$. Indagar na natureza

\footnotetext{
${ }^{13}$ Por exemplo, en América Latina a imposición de políticas de estabilización macroeconómica beneficia os pobres, que experimentaran unha dramática erosión dos salarios e aforros, xa precarios, durante a crise da hiperinflación dos oitenta. A bibliografía dedicada ao neoliberalismo e a o fenómeno asociado da globalización resulta simplemente vasta de máis para que poidamos facerlle xustiza aquí; no entanto, o que resulta intrigante é que o importante traballo feito nos eidos da historia, a antropoloxía, a socioloxía, a xeografía e os estudos culturais, por unha banda, non semellan relacionarse cos transcendentais estudos realizados en ciencia política e economía, pola outra, e a maioría das obras comprendidas na primeira categoría tenden a ser críticas, o cal pode constituír unha das razóns polas que se manteñen tan poucas relacións. Para consultar unha listaxe de traballos sobre o neoliberalismo na antropoloxía, véxase Peet (2002: 62-66). Moita da bibliografía sobre a globalización e o neoliberalismo solápase ou trata fenómenos semellantes, como o crecemento do comercio internacional, a proliferación de fluxos e instrumentos financeiros (Sassen 1999, 2001) e a integración de Estados-nación que anteriormente se consideraban máis autónomos ou delimitados. Entre os estudos que poden axudar a poñer orde nestes argumentos compréndense os seguintes: Gilpin, Robert (2000): The Challenge of Global Capitalism: The World Economy in the 21st Century, e Harvey, David (2005): A Brief History of Neoliberalism. En materia laboral,
} 
do termo permítelles aos estudosos captar a existencia de importantes variacións, non só entre países senón tamén dentro deles ${ }^{14}$, mais impón a consideración da orde neoliberal como proxecto ideolóxico diferenciado, con capacidades propias para conseguir que os cidadáns lles presten o seu apoio a novas formas de regulación, intervención e protesta ao servizo do que Michel Foucault denomina «a arte xeral de goberno» (Foucault 2010: 131) ${ }^{15}$.

Nesta lińa, pensemos no «neoliberalismo» como ideoloxía na que as prácticas cotiás, as obras académicas e as políticas oficiais invocan a «linguaxe da eficiencia», a «escolla do consumidor», o consumo ostentoso, os cálculos de rendibilidade e a iniciativa persoal dun xeito que «supón un cambio na asunción de riscos, que pasa dos gobernos e as empresas para os individuos» e as familias. Esta definición artéllase con diversos aspectos da economía política característicos dos fenómenos arriba indicados, a saber: a privatización de bens antes públicos, financeirización e desregulación, e recorte do estado do benestar. Se con isto temos unha caracterización aceptable do concepto, podemos considerar a cuestión de como esta lóxica de mercado o que fai, na práctica, é non só crear «zonas de

véxase Golden, Miriam / Michael Wallerstein (2006): «Domestic and International Causes for the Rise of Pay Inequality: Post-Industrialism, Globalization and Labor Market Institutions». The Age of Extremes (1994), de Eric Hobsbawm, permitiume aprehender a importancia do fracaso de Bretton Woods na década de 1970; se se desexa consultar unhas vehementes observacións sobre os fallos da mentalidade do «consenso de Washington» feitas por unha persoa que ten acceso ás entrañas do Banco Mundial, véxase Stiglitz, Joseph E. (2002): Globalization and its Discontents; os comentarios de Gérard Roland verbo da privatización (2000) presentan unha útil perspectiva xeral da drástica mudanza experimentada polas institucións da Europa Oriental e da antiga Unión Soviética, cunha descrición das consecuencias que tiveron para o benestar as vendas de bens públicos: Transition and Economics: Politics, Markets, and Firms; Jonas Pontusson, en Inequality and Prosperity: Social Europe vs. Liberal America (2005), ofrece un resumo desde a perspectiva dun socialdemócrata. Not in Our Lifetimes (2011), de Michael Dawson, fai un brillante tratamento de moitas destas obras e expón os efectos do neoliberalismo nas cuestións de raza, desigualdade e reorientación ideolóxica nos euA. Agradézolles a el e a Charles Boix que me axudasen no meu periplo por esta rica bibliografía.

${ }^{14} \mathrm{O}$ antigo viceprimeiro ministro sirio de Asuntos Económicos, Abdulá Al Dardari, cualificou de reforma do «mercado social» esta liberalización económica. Como repaso xeral dalgunhas das obras dedicadas á economía de Siria durante o goberno de Bashar Al Asad e, en particular, á influencia exercida por $\mathrm{Al}$ Dardari, véxase Marshall, Shayna, «Syria and the Financial Crisis: Prospects for Reform?», en http://www. mepc.org/journal/middle-east-policy-archives/syria-and-financial-crisis-prospects-reform; Hadad, Basam (2004): "The Formation and Development of Economic Networks in Syria», en Steven Heydemann (ed.), Networks of Privilege in the Middle East: The Politics of Economic Reform Revisited, Nova York, Palgrave Macmillan, e o máis recente Business Networks in Syria: The Political Economy of Authoritarian Resilience, Palo Alto, Stanford University Press, 2011.

${ }^{15}$ Véxanse uns convincentes intentos feitos por comprender este termo en Sewell e Evans e Brenner. 
abandono social» (Biehl 2005) e desafección —dado que as redes de seguridade familiar desaparecen ou se reforman nun contexto de crecente desigualdade e de importación de bens de luxo-, senón tamén levar ao establecemento de novos enclaves de riqueza, formas de sociabilidade, conexión emocional, optimismo (Berlant 2011) e gozo. Pensar no neoliberalismo como ideoloxía que conta coas súas propias técnicas de goberno e normas que rexen o éxito e o fracaso pon sobre a mesa o problema que supoñen as formas contemporáneas de explotación e precariedade vital e, ademais, as razóns polas que perduran os investimentos emocionais e a ambivalencia, en particular entre aqueles que gozaran de novas formas de prosperidade, sociabilidade e consumo, ou que chegaran a imaxinar a posibilidade de o faceren no futuro, neses mundos das zonas céntricas de Damasco e Alepo que os anunciantes denominan barrios «A+», «A» $\mathrm{e}$ «A-».

Ata que non comezaron as protestas en marzo parecía que o contraste fundamental se daba entre o Damasco de múltiples restaurantes e hoteis boutique da década do 2000 e a capital ascética e gris dos oitenta e primeiros dos noventa. No «novo Damasco» da década do 2010, por modificar o termo empregado por Christa Salamandra (2004), nas áreas pobres as ringleiras de mendigos dos oitenta eran máis curtas e nas áreas prósperas foran substituídas por unha profusión de croissantarías. «Nin mesmo Hafez Al Asad tińa plátanos na casa» durante os anos malos da carestía de alimentos, ou iso é o que din as lendas urbanas; un exemplo que se converteu nunha cantilena cońecida entre os damasquinos de clases sociais diversas nun intento por plasmar o que mudara na década do 2000. E, segundo o que así se conta, o que mudara fora non só a oferta de plátanos, senón tamén o valor positivo que se lle outorgaba ao feito de pasar sen eles en tempos de escaseza.

Os habitantes adińeirados e de clase media das dúas grandes cidades, moitos armados con computadores e iPhones, deixaban transcorrer o serán a fumaren pipas de auga (dispońibles tamén para entrega a domicilio) e latricando sen o medo palpable que caracterizara o mandato de Hafez Al Asad. Na década do 2000, os cidadáns mesmo podían mencionar sen se inquietaren o nome do mozo presidente en público. As novas formas de vida social recibiron o pulo dos rapaces que non vían contradición ningunha en poñeren música do estilo de Dr. Dre a todo volume diante da mesquita omeia mentres realizaban coa bici acrobacias salpicadas de xuramentos. As poucas casas de café antes frecuentadas por anciáns que tiñan todo o tempo do mundo para xogaren ao backgammon deron paso a novas cafetarías que 
servían bebidas, ao xeito de Starbucks, a unha animada clientela multixeracional; é o fenómeno ao que os propios damasquinos se refiren agora denominándoo nacemento dunha "cultura da cafetaría». Se ben nos inicios da década de 1990 poucos se aventurarían á noite por gran parte da zona vella ante o temor de lles serviren de alimento ás varudas ratas de Damasco, no 2010 o barrio histórico presumía de vivendas otomás rehabilitadas e destinadas a local para bares, clubs e restaurantes que, ata datas recentes, atraían cidadáns locais e turistas por milleiros. Dun xeito semellante, o barrio vello cristián de Alepo pasou a se converter na colocación de renovados restaurantes e hoteis boutique, mentres que nun luxoso Sheraton situado preto da gran mesquita se lle daba aloxamento a unha clientela cada vez máis numerosa de empresarios internacionais.

O xurdimento das protestas en marzo deixou ao descuberto unha fenda na sociedade, que se abría de maneira ostensible entre adiñeirados e desposuídos pero que tamén vińa a darlle máis complexidade a unha imaxe meramente económica do que constituía a boa vida; así, por exemplo, os shabiha, lendarias bandas dunha sorte de matóns que apoiaban o réxime, eran escollidos (e seguen a ser recrutados) de entre os pobres. Tamén as manifestacións e as reaccións do réxime ante o malestar deitaban luz sobre as encarnacións concretas do neoliberalismo nun contexto de constantes desacordos sobre o valor da orde, a natureza das obrigas cidadás, os perigos das afiliacións comunitarias e a aposta dos dirixentes polo control autoritario. Nas semanas anteriores producíranse manifestacións pequenas, así como unha de grandes dimensións preto do mercado central na que se protestara contra o maltrato inflixido por un policía a un tendeiro local. Mais a "primavera árabe» púxose en marcha e cobrou unha forza considerable en Siria a partir do 15 de marzo: inspirados polos sucesos de Tunisia, Iemen, Libia e, sobre todo, Exipto, os protestantes sirios responderon inicialmente ao brutal tratamento dispensado a quince escolares de Daraa que foran detidos por pintaren graffiti nas paredes avogando pola caída do réxime. Este suceso, xurdido talvez a imitación das demandas que os rapaces oíran noutra parte e que moi á lixeira se tachou de simple trasnada de adolescentes aburridos, tornouse un punto de inflexión en gran parte a causa da reacción do réxime: a tortura inflixida aos nenos no cárcere, a falta de respecto demostrada aos maiores que tentaban negociar a súa liberación e a ausencia pura e dura de disposición a renderen contas que amosaron os funcionarios do réxime vinculados á familia dirixente constituían síntomas dunha 
insatisfacción máis fonda cun réxime cuxa corrupción, volubilidade e indolencia ante o sufrimento acabou por lle dar á xente (incluída unha pequena comunidade segrar, liberal e adiñeirada de Damasco, moitos de cuxos membros procedían do colectivo de realizadores de documentais) o valor necesario para reclamar reformas de amplo alcance.

En resposta, o réxime non só deu en esmagar a resistencia, senón que ademais se armou do seu propio aparato de produción cultural, posto ao servizo da preservación do seu goberno. Os programas radiofónicos dedicados ao «estilo»e á importancia de aplicar ben o rímmel cedéronlles o paso a intricados programas de entrevistas e a interpelacións nas rúas nos que inicialmente se negaba a existencia das protestas e ao mesmo tempo se situaba o foco do malestar nas maquinacións orquestradas por gobernos estranxeiros, as cales a miúdo tiñan «os Estados Unidos no centro da conspiración». Recrutouse a actores sirios famosos que fixeron innumerables aparicións televisivas nas que as grandes discrepancias que xurdían entre eles tendían a quedar escurecidas por unha marcada preocupación pola estabilidade do réxime e por demandas de lealdade pública; así, a modo de exemplo, o cońecido actor Basim Yajur, que parecía frustrado ante a actitude dos seus colegas durante unha mesa redonda televisada cuxo tema de debate era unha petición da autoría de Rima Flaihan, guionista, reprobou os seus acompañantes por se centraren nun tema tan provinciano no canto de na "política», referíndose con este termo a que as manifestacións foran «orquestradas» (madrus) desde o primeiro momento ${ }^{16}$. A petición suscitara un debate considerable e comportara unha serie de ameazas procedentes tanto de altos funcionarios do réxime como de produtoras, que avisaban, ao xeito macartista, de que os asinantes que non retirasen o seu nome do documento deixarían de poder traballar en obras sirias. $\mathrm{Na}$ devandita petición facíase un chamamento ao réxime para que permitise a entrada de leite para os nenos da zona sitiada de Daraa e, así, os membros do mundo da escena siria que lle prestaron o seu nome ao documento pasaron a formar parte dunha obra dramática real na que se ameazaba a subsistencia da xente, se facían públicas as divisións e se instaba a presentar retractacións.

Ao ver dos sirios que se identificaban coas reformas políticas pero se abstiñan de condenar directamente o réxime, a petición esaxeraba a situación. Segundo

${ }^{16}$ Televisión Al Dunia, 6 de maio do 2012. «Silsila al jawana al suriyin - Jamsa fananin jawana», http:// www.youtube.com/watch?v=fhfmgn4kH8k, 22 de maio do 2011. 
estes individuos, algúns dos cales visitaran Daraa logo de a zona ser atacada, permitíase o acceso de artigos de primeira necesidade e os nenos en realidade non tiñan que pasar sen leite ${ }^{17}$. Facendo unha concesión, admitían que algúns residentes talvez desconfiasen do exército (que se encargaba de distribuír as provisións), mais, dado o malestar, a súa presenza non constituía en si mesma un problema. En efecto, o famoso actor Durid Laham defendeu en público o despregamento do exército dun modo que incitou a $\mathrm{Al}$ Yazira a elaborar unha peza breve na que se contrastaba a súa actual postura política coas declaracións tamén políticas - feitas ao estilo pallaso, mais con valentía — da súa personaxe Gawar Al Tushi nas obras teatrais e cinematográficas que o converteran nunha persoa tan querida había unhas décadas ${ }^{18}$.

Como en tempos de Hafez $\mathrm{Al}$ Asad, a retórica oficial da época contemporánea non deixara totalmente de lado o impulso de elaborar unhas pautas de discurso e actuación en público co obxecto de impoñer obediencia e inducir á complicidade mediante a emisión de declaracións a todas as luces falaces. Só que esta vez se puña en apuros a estrelas da televisión siria, e moitas delas fixeron patentes as súas opinións de apoio radical e carińo ao presidente, acaso como pagamento por poderen gozar da boa vida nun tempo en que o dirixente sirio cultivaba a súa propia sona recoñecendo e financiando a deles. As personalidades televisivas de renome que pretendían achar o que consideraban un "punto intermedio» entre a denominada "petición do leite» e un apoio acrítico ao réxime foron censuradas severamente pola oposición e polos defensores do goberno por igual, e finalmente emitiron un segundo comunicado declarando a súa fidelidade ao presidente.

Malia esta lea discursiva, e quizais por mor dela, na era de Bashar Al Asad resultaba máis difícil de distinguir o verdadeiro do falso, e esta incerteza é en parte resultado de que mesmo os modos de funcionamento da retórica oficial se tornasen máis diversos e sofisticados e lles deban moito ás novas tecnoloxías de divulgación de información e ás comunidades de debate (como as que ofrece a Internet), aos artistas do triunfal sector panarabista da televisión siria, aos "capitáns da conciencia» que producían anuncios comerciais e, en suma, ás formas de linguaxe mercantil que denotaban unha alianza potente e áxil entre o capital e o réxime ${ }^{19}$.

\footnotetext{
${ }^{17}$ Entrevistas de marzo e abril do 2011.

${ }_{18}$ «Mawquif al fananin al suriyin min al zawra», http://www.alittehad.tv/videos/918/.

19 O termo "capitáns da conciencia» procede da obra de Stuart Ewen (1976) Captains of Consciousness: Advertising and the Social Roots of the Consumer Culture, Nova York, McGraw-Hill.
} 
Esta colaboración xa quedara patente nas orixinais formas de sociabilidade ás que se aludiu anteriormente; na creación dunha nova clase media nos anos centrais da década de 1990 e dos primeiros da do 2000, cuxas aspiracións a vivir a boa vida a ligaban, como de costume, á política do réxime ${ }^{20}$. En Damasco e Alepo semellaba que os cidadáns de posición desafogada renunciaban sen problemas ás liberdades políticas para teren parte nas liberdades sociais que viñan xeradas pola apertura dos mercados e polas promesas do réxime que evocaban unha idea laica da prosperidade (incluída a protección das minorías que gozaban de vantaxes comerciais) ${ }^{21}$.

Esta visión foi levada á pantalla en Marra Ujra («Máis unha vez»), filme sirio producido no ano 2010 cuxa importancia é máis etnográfica ca cinematográfi$\mathrm{ca}^{22}$. Centrada nunha historia de amor entre unha cristiá libanesa e un musulmán sirio, ambos fillos dos anos da guerra do Líbano, a película describe a vida do pai do director, Yawad Saaid, no seu tempo de militar neste país e as escuras circunstancias que arrodearon a súa morte ${ }^{23}$. Mais, para o tema que nos ocupa, o que nos interesa especialmente é a celebración que se fai no filme do ascenso na escala social e da riqueza sen límites. A película, unha defensa da alianza do capital financeiro (os amantes, e tamén unha terceira persoa que queda plantada, traballan nun banco) coa autocracia neoliberal, constitúe unha fantasía na que a «boa vida» se torna unha realidade grazas ao cambio xeracional.

O protagonista mora nun piso de luxo con vistas a todo Damasco e equipado coas últimas innovacións tecnolóxicas, que comprenden un televisor de pantalla plana de grandes dimensións, aparellos de videoxogos e, o máis importante, dispositivos de vixilancia para seguir as conversas mantidas por Internet e Skype. Trátase dun filme no que a vixilancia pública se privatizou ao típico estilo neoliberal, se internalizou e, na práctica, se «deslocalizou» para lles ser encomendada a novos ricos. Mayd, álter ego de Yawad Saaid e personaxe principal, espía outras persoas voluntariamente e sen recibir instrución ningunha de arriba, nun esforzo

${ }^{20}$ Máis información en Hadad, Basam (2011): Business Networks in Syria: The Political Economy of Authoritarian Resilience, Palo Alto, Stanford University Press.

${ }^{21}$ Con isto non se pretende dicir que todos os membros das minorías (como as comunidades cristiás ou alauítas) se identifiquen co réxime ou vivan na prosperidade.

${ }^{22}$ Entre outras recensións do filme, houbo unha que o comparaba coa «televisión de mala calidade».

${ }^{23}$ Talvez sexa posible establecer conexións coa morte de Gazi Kanaan. Debo darlle as grazas a Rasha Salti polas conversas sobre a película e a súa relación con este pasamento. 
por se facer co control; é unha persoa que arrastra padecementos, pero capaz de redención grazas a un amor que tamén sutura as feridas de guerra nunha nova era de colaboración posterior á ocupación siria, na cal sirios e libaneses poden traballar xuntos, mesmo amar, superando divisións sectarias, históricas e rexionais. Cando Israel ataca o Líbano «máis unha vez», o obxecto do amor de Mayd, Joyce, perdóao por espiala e el é a persoa cuxos contactos e cońecementos lle permiten a ela volver á casa. Na última escena, de gran torpeza, os dous amantes detéñense nunha ponte colgante que une Siria co Líbano, mais a película en xeral evita servirse de imaxes haxiográficas dos tempos de Hafez $\mathrm{Al}$ Asad; por exemplo, a intervención siria no Líbano de 1976 nárrase sen os floreos retóricos típicos do discurso do Partido Baaz, e da invasión israelí do ano 2006 tamén se dá conta sen recorrer a esa linguaxe.

Os prescindibles momentos documentais e a incesante atención que lle presta o filme ao estilo retratan a clase adińeirada como un sofisticado grupo de entendidos en viño, whisky e automóbiles potentes que viven nunha época ideoloxicamente neutral na que os conflitos clasistas non existen e que se ve propiciada pola apertura dos mercados. A diferenza do pai, a quen «o novo mundo [o] supera» e que entende que «o [seu] tempo xa pasou», o fillo esperta literalmente (levaba anos en coma) nun clima político de alteración no que o poderío militar foi desprazado polo poder adquisitivo. Mayd forma parte dunha xeración máis nova cuxo éxito radica na capacidade de xerar unha riqueza sen precedentes e consumila de xeito ostentoso nun mundo en que as festas cheas de glamour ao bordo da piscina e as excursións de caza constitúen a norma. O mozo, ademais, ten contactos entre os altos mandos da vella garda, superviventes que encarnan o matrimonio do capital financeiro e o poderío militar e cuxa carreira no exército lles permitira facer a transición ao sector bancario dirixido polo réxime, banca na que tamén son benvidos os mozos de mentalidade empresarial e amantes do risco que proceden dunha xeración máis nova.

As fantasías da película ofrecen unha versión particularmente crúa da avinza entre neoliberalismo e autocracia, un acordo que, polo que parece, apoia a desigualdade ou fai caso omiso dela cunha actitude que non adoptarían os directores televisivos sirios que apostan polas reformas, nin mesmo os que devecen por que se impoña unha orde. No entanto, no contexto das protestas que teñen lugar en Siria na época contemporánea, a ideoloxía actúa mantendo moita xente fóra das 
rúas mediante distintas formas de investimento emocional: nostalxia por unha sensación de seguranza perdida mais memorable, experiencias de liberdade social, compromiso de defensa dun laicismo multicultural que protexa as minorías, a alegría de vivir fomentada pola apertura de mercados, mesmo a promesa de reformas aprazadas unha e outra vez. Os investimentos afectivos gardan relación con incentivos materiais, non só para aqueles que poden custealos senón tamén para os que non teńen esa capacidade, mais mediante un proceso de persuasión, chegaron a se identificar cunha noción consumista do pracer e da categoría social. Por exemplo, os mozos estudantes cos que traballei, malia seren de orixes diverxentes e teren ambicións radicalmente distintas —esperanzas que ían desde ser profesor de ioga ata empresario, pasando por activista dos dereitos civís ou policía-, compartían a aspiración uniforme de posuíren automóbiles de gran potencia. Por outra banda, a liberalización do mercado tamén estrutura os termos con que se poñen sobre a mesa agravios e alternativas, co cal, para empezar, resulta difícil imaxinar que poida facerse unha política de oposición con visión de futuro ou que existan posibilidades alén do capitalismo mercantilista; e, para seguir, á alianza establecida entre o capital consumista e publicista e o Estado, a diferenza do que ocorre con diversos aspectos do capital industrial ou militar, resúltalle daniño un réxime que prexudica os seus cidadáns-clientes. Acaso a inclinación de tal réxime por definir os inimigos con termos tan xerais e a súa incapacidade para exercer un goberno que garanta ou sequera permita as aspiracións á «boa vida» axuden a explicar por que algúns consumidores-cidadáns de Alepo e Damasco — cada vez máis pero aínda relativamente poucos— están a deixar constancia política da súa indignación moral.

Neste sentido, a ideoloxía neoliberal non é un conxunto de "proposicións abstractas», unha visión do mundo allea á vida cotiá; trátase, pola contra, de algo que se torna corpóreo e se consome de diversos xeitos: por medio das estrelas televisivas que amosan un apoio entusiasta ao sistema ou navegan con ambigüidade polas súas augas, personaxes cinematográficas que representan esas aspiracións de fantasía e todas as empresas creativas que se poñen en marcha para ofrecer unha alternativa. Tomando prestadas as palabras de Slavoj Žižek, «a ideoloxía é a propia densidade deste mundo vital que "esquematiza" as proposicións abstractas, que as torna "habitables" ${ }^{24}$. É algo que estrutura o que entendemos por risco,

${ }^{24}$ Žižek, «Denial: The Liberal Utopia». 
interese e gozo e que, lonxe de ficar á marxe de cálculos e aspiracións, inflúe en como facemos os primeiros e temos as segundas. Nesta medida, a ideoloxía é un elemento "constitutivo» da orde social; e é «transpersoal», ao ir non só da man dos intelectuais senón tamén, de xeito anónimo e acéfalo, nas prácticas diarias dos pobos, como apunta William H. Sewell ${ }^{25}$. Con todo, o que resulta interesante é que esta capacidade que ten a ideoloxía para causar saturación, para levar consigo asolagamento e estruturación, pode quedar plasmada con especial precisión no tempo presente; xa que, en efecto, vivimos nunha época en que hai moito que se desbotaron as alternativas políticas desexables que moitos individuos de esquerdas antes recoñecían e coas que se identificaban, e as novas aínda non apareceron no horizonte (e poida que non aparezan). No seu lugar temos as demandas, loables mais limitadas, de fin da tiranía.

Porén, talvez esta formulación delate un sentimento de angustia que fai que se simplifiquen cuestións e bandos demasiado á lixeira con opinións que fan fincapé en reproducir e non nas posibilidades de innovar. Hase de ter presente que o Damasco de 2011 e 2012 non é o Damasco de 2010, e a reticencia dos cidadáns das zonas céntricas a se uniren ás protestas pode xustaporse á abraiante resistencia dos manifestantes dos barrios pobres da cidade, dos arrabaldes e de tamén de moitas outras áreas urbanas e rurais de Siria. Así, o enxeño dos habitantes de Kafr Nabil, aldea pouco coñecida antes do levantamento, foi obxecto de constantes comentarios e deu paso a un novo sentido do público, de gozo compartido e de orgullo; e os discursos do xeque Karim Rayih, crego musulmán sen papas na boca, aos que se lles deu ampla difusión e nos que se vincula a «liberdade» co benestar económico, indican o importante que resultan as desigualdades nas protestas actuais sen nos permitiren reducir estas loitas a un conflito de clase $e^{26}$. Nos discursos de Rayih recoñécese o esgotamento duns cidadáns que teñen dificultades para faceren cadrar todas as contas ao tempo que se condena o medo e a arbitrariedade que non tardan en asociarse cun estilo de goberno autoritario: «Hoxe a xente paga a electricidade, quero dicir a electricidade e o móbil, a entre 10000 e 12000 libras, e o soldo de 6000 que cobran non chega a nada. E estas palabras díxenllas cara a cara ao presidente. Non queremos cousa ningunha: queremos vivir, queremos liberdade, queremos dignidade; que as persoas sintan que poden durmir sen medo no peito». Rayih presenta unha descrición da vida cotiá na que se documen-

\footnotetext{
${ }^{25}$ Véxase o debate de Sewell con Skocpol.

${ }^{26} \mathrm{http}: / /$ www.youtube.com/watch?v=nUPLiy1B59s\&feature=related.
} 
tan diversos aspectos da violencia exercida baixo un réxime autócrata, como ataques aos fieis ao saíren da mesquita, pero tamén invoca algúns dos efectos — máis xerais e crueis — da liberalización do mercado, e condiciona a posibilidade de os paliar a que o Estado ofreza unhas reparacións, a unha acción que garanta a liberdade e que, ademais, pareza corresponderse co auténtico significado desa palabra ${ }^{27}$.

Estas apelacións populares (das que a de Rayih constitúe simplemente un caso exemplificativo) indican que Siria está moi lonxe do "hedonismo espiritualizado» que Slavoj Žižek identifica co Occidente contemporáneo (e do que defende a película de Saiid $)^{28}$. Andan a circular diversas reflexións sobre a xustiza social, unhas vinculadas expresamente co islam e outras coas propias versións difundidas polo réxime —imbuídas de modernización laica - do progreso e o atraso; porén, aínda que talvez a meirande parte da xente non estea tan «vendida» como por veces suxiren filósofos como Žižek, en parte porque os efectos materiais do neoliberalismo son moi desiguais, tampouco as protestas ofrecen aínda un programa político coherente para un futuro non neoliberal. Os mesmos protestantes poden, no seu momento, facerlle acenos á xente para que vexan unhas realidades que tiveran diante dos ollos todo o tempo e, así, forxadas na protesta política, esas persoas quizais sexan quen de descubriren a «liberdade» que reclamaban traéndoa ao mundo elas mesmas, creando unhas visións de futuro que se enfronten ás forzas da reprodución ao tempo que transforman os momentos de acción espontánea en constantes posibilidades para a política.

Con todo, neste momento a oposición segue fragmentada ${ }^{29}$. Tales divisións débense en parte aos esforzos por matar a política que sistematicamente se fixeron nas décadas que precederon aos levantamentos, así como á preocupación pola falta de soberanía, de que as cousas se descontrolen. $\mathrm{O}$ réxime sacou partido destes temores - é dicir, as loitas sectarias, unhas condicións semellantes ás da guerra de Iraq e as posibilidades de que se producise unha partición do país, de décadas de conflito co veciño Líbano-, o cal pode dicirse que nalgunhas zonas contribuíu a causar as propias vulnerabilidades para as que en principio,

${ }^{27}$ http://www.youtube.com/watch?v=L17cYVbOKe0. Véxase tamén a súa alocución do Ramadán: http:// www.alittehad.tv/videos/1353/.

${ }^{28}$ Entrevista a Slavoj Žižek en Al Yazira: http://www.youtube.com/watch?v=6Qhk8az8K-Y.

${ }^{29}$ Entre os protestantes cóntanse membros de partidos políticos prohibidos (comunistas, nasseristas, socialistas e os Irmáns Musulmáns), intelectuais disidentes, activistas islámicos non afiliados aos partidos convencionais e mozos de diversas tendencias políticas que ven como diminúen as súas oportunidades de atopar emprego e reducidas a cinascos as súas esperanzas de gozar un día dunha boa vida. Véxase Dahi, Omar S. (2011): «A Syrian Drama: A Taxonomy of a Revolution», Syria Comment, sábado 13 de agosto. 
daquela, se require a protección do $E \operatorname{stado}^{30}$. Os intentos do réxime certamente serviron para levar algúns sectores localizados a un punto morto, deron pé a unha tendencia a expresar preocupación en declaracións «a favor» ou «en contra»e desembocaron nunha violencia de proporcións semellantes ás dunha guerra civil. Os manifestantes apuntan a un obxectivo particular cando esixen a «marcha» do presidente ou, máis recentemente, a súa «execución», e neste sentido as protestas xa tiveron a súa importancia política ao poñeren en dúbida a suposta evidencia da popularidade deste autócrata e o seu dereito a gobernar indefinidamente, o cal constitúe o que Alain Badiou denomina «poder negativo»: «que se vaian» ${ }^{31}$. Con todo, aínda hai que artellar un programa político serio, que non existe nin sequera en lugares onde os protestantes se teñen contado por centos de miles. Malia as particularidades sirias (por exemplo, exceso de coacción, distribución das protestas en función de factores económicos e o tempo que lle leva callar a unha oposición unificada), esta ausencia tamén apela a un fenómeno internacional, que talvez inadecuadamente se anuncia co termo «neoliberalismo». Trátase dunha situación ideolóxica en que un sistema político e económico difuso que xera tanto gozo como inxustiza non ofreceu ata agora (e quizais non ofreza nunca) unha alternativa universalista de resonancia ao capitalismo de mercado.

\section{TERCEIRA PARTE. A RISA NA AUTOCRACIA}

Nos tempos escuros tamén se vai cantar?

Si, tamén se vai cantar sobre os tempos escuros.

Bertolt Brecht

A comedia non consiste en cantar e os «tempos escuros» aos que fai referencia Brecht non son as varias formas de escuridade que se apuntaron aquí: o pacto entre o capital consumista e a autocracia do réxime na era neoliberal; a ausencia

\footnotetext{
${ }^{30}$ Kalamun, 5, inverno de 2011.

${ }^{31}$ Véxase Alain Badiou, http://wrongarithmetic.wordpress.com/2011/02/02/alain-badiou-on-tunisia-riotsrevolution/.
} 
dun programa alternativo ao capitalismo de mercado mesmo cando tal mercado xa deixou de facer o seu traballo de instrumentalización; e a perda da imaxe de pacto multicultural a medida que Siria afunde nunha guerra civil sectaria e cada vez máis sanguenta. Con todo, o retruque de Brecht lémbranos que nunhas condicións de espanto non só non se lle poñen atrancos ao material que inspira á creatividade, senón que esas mesmas condicións fornecen o material. Neste punto a agudeza do autor indica como a comedia e a risa permiten e suscitan un distanciamento que fai posible a realización de diagnósticos incisivos e aperturas políticas.

Pódese dicir que isto tamén o consegue a obra de Al Laiz Hayu, un dos directores de televisión máis coñecidos de Siria, entre cuxas variadas achegas á escena do país se contan os rompedores sketchs cómicos de Buqaa dawa («No centro de atención»), cos que inaugurou a súa carreira de dirección no 2001. Aclamado como un dos realizadores de máis talento dos que compoñen unha nova xeración de profesionais provocadores e afeccionados ao experimental, Hayu pasou logo a crear o humor negro dos cáusticos sketchs de Amal ma fi («Esperanza non hai ningunha», 2005) e dúas tempadas de Dayaa Daayaa («Unha aldea esquecida»), que gozou de enorme popularidade.

Ambientada nun casal ficticio da costa noroeste de Siria, Dayaa Daayaa (2008, 2010) recorre á lixeireza das bufonadas clásicas para abordar os temas da corrupción cotiá, a volubilidade do réxime, a pobreza e as incongruencias da retórica política en tempos escuros. Esta produción siria, que parodia o réxime, os cidadáns e os mecanismos de control social en que ambos están enredados, é o exercicio de burla do autoritarismo das circunstancias que maior éxito acadou. Considérese, por exemplo, o episodio cuxo título sería «No máis escuro da noite bótase de menos a lúa chea», inspirado na apropiación irónica dun poema cuxo argumento principal é que só valoramos o que temos cando o perdemos ${ }^{32}$. Este tropo, xa cońecido, de suspirar por amores do pasado enxértase con perversidade nunha historia en que é a marcha do delator da aldea o que desencadea unha valoración inesperada dos seus servizos e, en última instancia, unha arela colectiva de que volva. Deste xeito, o episodio documenta como a información, o medo e as expectativas sociais sobre os individuos serven para reproducir as condicións dun Goberno autoritario nun contexto en que todo o mundo leva anteolleiras ou se conduce, mantendo a metáfora do título, na escuridade. Na primeira parte o

${ }^{32}$ http://www.sobe3.com/vb//showthread.php?t=18596. Agradézolle a Al Laiz Hayu esta referencia. 
informante da aldea, ofendido por como o tratan, marcha do lugar, o que move a policía a buscar un substituto entre os residentes. Na segunda parte dáse conta da preocupación que experimentan os aldeáns agora que o coñecido «axente secreto» — que de secreto non ten nada — se foi e ninguén pode ter a seguridade de que o seu substituto non sexa un deles: un amigo, o cónxuxe ou un vecińo; todos declaran publicamente que rexeitaron o traballo, mais é imposible saber de certo se alguén di a verdade. A terceira parte trae a solución que lles dan os aldeáns ás súas coitas: optan pola certeza dunha coacción que coñecen en detrimento da insoportable incerteza de non saber. Así, se o comisario de policía de Jean Genet era o único que non sabía que todo o mundo sabía que levaba topete, aquí invértese a situación: é a policía a que sabe que ninguén sabe que todos rexeitaron o posto. A desconfianza mutua dos cidadáns da bondade dos outros anula a posibilidade de emprender medidas colectivas máis prometedoras que a decisión de escoller unha solución que manteña o statu quo.

Para empezar, pois, trátase dunha historia desalentadora que pode perfectamente ser parte das mesmas condicións de opresión sobre as que chama a nosa atención; por outra banda, se, como suxire Lauren Berlant, a traxedia refire o afundimento dun sistema que funcionou ben de máis e a comedia consiste en recoñecer con brincadeiras que o sistema nunca funcionou ben dabondo, son precisamente as posibilidades políticas inherentes a ese recoñecemento — «os "e se...?" hipotéticos que se bifurcan en todas as direccións» (Boyd 2002) — as que nos invitan a apreciar o potencial da comedia, as súas dimensións de construción do mundo. Con isto non se pretende arrodear as sátiras cómicas permitidas dun halo de romanticismo, nin negar que poden servir de válvulas de seguridade dándolles un descanso tanto aos cidadáns como aos funcionarios gobernamentais no medio da deprimente conxuntura imperante; mais si subliñar que a capacidade da comedia de levar á escena o que xa sabemos e invitarnos así a nos distanciar de aspectos da vida ordinaria que xa non fan nada bo por nós. A comedia pon ao descuberto algúns dos factores que obstaculizan a prosperidade humana. Hai nela certa calidade creativa, de ratificación do mundo: unha esperanza nada dun sentimento compartido — repetimos, compartido— do que está mal e unha tendencia non normativa a tentar descubrir como facer mellor as cousas. Neste contexto, pódese entender que os aspectos de Dayaa Daayaa que resultan desmesurados serven para deixar en suspenso, dun xeito particularmente desafiante, 
as realidades ordinarias, constituíndo así un modo de chamar a atención sobre o afeitos que estamos a elas.

Forma de estabilización e modo de apertura de alternativas ao mesmo tempo, o atractivo popular de Dayaa Daayaa debería entenderse nun contexto de transformacións históricas da comedia siria e das implicacións que estas teñen para a política. Xa escribín noutras obras sobre a comedia siria desde os setenta ata os noventa ${ }^{33}$; abonda dicir aquí que a apreciada figura de Gawar Al Tushi, esa figura que evoca un pallaso interpretada por Durid Laham nas décadas de 1970 e 1980, é á vez un cidadán común e corrente e unha persoa que pode dicirlle as verdades ao poder con elocuencia. Nos primeiros anos da década do 2000, os sketchs experimentais de Hayu en Buqaa dawa conservaron esta figura do bufón na personaxe de Ayman Rida, mais para 2008-2010 Dayaa Daayaa supuxo unha desviación desta estratexia cómica; así, no canto do home corrente que se ri do Goberno e esixe que os cidadáns sexan tratados con dignidade, os individuos de Dayaa Daayaa non son de ningún modo alleos ás condicións que os oprimen: simplemente non asumiron o distanciamento de Gawar. Nesta obra son o guionista e o director os que lle din as verdades ao poder, e son eles en tanto que narradores omniscientes, non os personaxes da serie, os que contan coa vantaxe de se manteren a unha distancia crítica que posibilita a análise.

Malia isto, sería un erro esaxerar a amplitude desta mudanza. En comedias anteriores, os textos tamén apuntan a que a xente non tan poderosa pon da súa parte no sistema ao estar afeita a el, pois coa súa autocomplacencia e desesperación lles dá poder aos que xa o teńen; mais en comedias contemporáneas existen poucas liñas como as que caracterizaban as tomas de conciencia de Gawar, nas cales o cidadán normal recoñece a súa propia participación na violencia da que tamén é vítima. En contraposición a isto, en Dayaa Daayaa os aldeáns son polo común cidadáns de bo corazón que saben distinguir en certa medida o bo do malo, pero que xa non teñen esa capacidade narrativa precisa para reflectiren sobre as condicións máis xerais —ou a microdinámica! — da súa opresión; aquí os veciños mesmo buscan como facer, dun xeito creativo, para restableceren (nada menos!) as relacións de poder vixentes cando estas se tornan inestables e a súa ausencia crea demasiada preocupación. Nas primeiras series identificábase os poderosos como responsables e os cidadáns comúns como vítimas, mais os poderosos tamén

${ }^{33}$ Véxase Ambiguities of Domination (1999). 
chegaran a selo por obra dun sistema que apoiaban tanto os seus defensores como os seus prexudicados. En Dayaa Daayaa hai pegadas desta sensibilidade. E, aínda así, aquí gobernante e gobernados convertéronse en bufóns, e a crítica do réxime vai aparellada a un diagnóstico que sitúa «o pobo» no centro do problema.

Este argumento preséntase en toda a súa elegancia nun episodio titulado «Tamaluq» (que denota loanza excesiva, afagos, comportamento adulador, a práctica de «lamber cus»): chega unha orde de arriba pola cal aos aldeáns xa non se lles permite lamberlle o cu a ninguén e a xente queda perdida de todo. Poucos entenden sequera a orde e a maioría dos que si teñen demasiado medo a abandonaren as súas prácticas anteriores e a se expresaren con liberdade; e deste xeito, preocupados por unha medida que lles esixe que adopten uns modos de ser cos que non están familiarizados, aos aldeáns dáselles mellor deixar de dicir afagos que manifestar sen restricións as súas opinións. Á fin, como en «No máis escuro da noite...», os veciños atopan unha solución enxeñosa que reproduce o seu estado de opresión pero serve para eles controlaren o seu temor: prefiren a seguridade dos límites da cela do cárcere ás incertezas dun mundo exterior que acaba de se tornar voluble. Este episodio, que é á vez unha incisiva crónica de como os cidadáns se habitúan ás ficcións dos afagos que permiten o mantemento dun sistema de goberno autócrata, suscita ademais importantes preguntas: preguntas referidas á natureza da liberdade de expresión e as cargas que supón, a atmosfera de desconfianza que van creando as autocracias, a arbitrariedade e o absurdo das ordes que veñen de arriba e os mecanismos cos que a xente vai aguantando: o apego dos cidadáns a posturas de compromiso que non melloran senón que socavan as súas posibilidades de levar unha vida gratificante (Berlant 2011).

Se as series de televisión menos convencionais cargan a responsabilidade dos problemas actuais — corrupción, medo, vixilancia, maltrato corporal e excesos retóricos - en gobernantes e gobernados por igual, quédalle ao humor negro da Internet sen censuras (alimentado por membros dunha crecente oposición) a tarefa de emitir parodias dos discursos do réxime dun modo que presenta unha crítica deste máis abertamente mordaz e, dependendo da perspectiva de cada un, redimen o pobo ou presentan unha visión romántica del. Por exemplo, nun vídeo que circulou por Facebook e outras redes sociais desde finais de xuño ata primeiros de agosto do 2011, aparecen tres enmascarados que agarran muletas e paus coma se fosen armas, con grilandas de quiabo no pescozo e no torso que imitan unha res- 
tra de balas. Un deles guinda unha berenxena cativa, que claramente pretende ser un sucedáneo de granada, e outro leva dúas colgadas ao pescozo. O vídeo, que se burla das afirmacións do réxime de que os protestantes son matóns armados que toman parte nunha insurrección violenta, válese da retórica dun dos discursos presidenciais para insistir na fenda que existe entre o discurso oficial e as actividades dos protestantes: «Velaquí os xermes e os infiltrados que Bashar Al Asad di que son matóns e terroristas», declara un home que finxe ser reporteiro da televisión siria. «E iso que é? E logo vas liberar o país con quiabo?», pregunta. Por outra banda, en comedias difundidas recentemente pola Internet téndese a evitar facer burla dos asertos do réxime que falan dunha resistencia violenta, xa que quedou moi claro que a oposición tomou as armas e que o país está inmerso nunha guerra civil, mais existen agudos remixes dos discursos do presidente e parodias a alto ritmo do machos que se consideran os matóns do réxime que demostran unha creatividade cultural que escapa aos límites dos censores do sistema. Algunhas destas parodias beben explicitamente dos traballos anteriores de Hayu, aínda que poucas presentan as múltiples capas ou dan conta das ambivalencias que lle confiren á obra deste director un valor que non teñen algunhas desas atrevidas pezas efémeras que agora se ofrecen. Os sketchs satíricos de afeccionados cos que se apoia a revolución, titulados Hurriya wa bas ("Ou a liberdade ou nada!») e patrocinados pola canle de televisión Orient, dos Emiratos Árabes Unidos, identificada coa oposición, están baseados directamente nos breves sketchs de Hayu Amal ma fi, «Esperanza non hai ningunha", título que hai que dicir que pode parecer de todo menos ambivalente. Non obstante, mesmo aquí eses fragmentos paródicos de dous minutos son ricos e polivalentes: abertos a interpretacións (e apropiacións) revolucionarias, mais tamén a unha desesperanza que non só transmite a sensación de os personaxes estaren «atascados», senón que ademais, con certa falta de confianza na natureza humana, semella gardar relación con este feito ${ }^{34}$.

Nalgunha medida, a xustaposición que se percibe nas tendencias cómicas entre as ousadas pero toleradas comedias da escena siria e os intentos vistos recentemente na Internet por facer mofa do réxime e rehabilitar os cidadáns comúns e correntes revela a existencia dunha tensión de fondo na política do país. Os sirios, ao avaliaren os sucesos de actualidade, tenden a dividirse seguindo as liñas argumentais de dúas suposicións opostas referidas á «xente»: está, por unha banda, a postura que

\footnotetext{
34 "Atasco» (stuckness) é a palabra que usa Lauren Berlant.
} 
sostén que a xente ten a capacidade de acadar a liberdade política, e está, pola outra, a que argúe que é cedo de máis, que a xente aínda non ten conciencia dabondo para proclamar a súa liberdade... ou non acabou de artellar o significado deste termo. A segunda postura pode recordar aos discursos do colonialismo e a modernización segundo os cales determinados individuos, antes de poderen ser libres, teñen que ascender na escala evolutiva e tornarse máis «civilizados»; mais tamén apela ás particularidades do que Michael Dawson denomina «distopias neoliberais», a sedución e a corrupción simultáneas que están presentes na «boa vida» e que poden levar mesmo a que produtores do sector cultural ben intencionados pero pragmáticos acaben atopándose baixo moita presión para daren conta de calquera cousa que denote máis entusiasmo do que un ambivalente apoio ao cambio político ${ }^{35}$. Agora que o réxime vai deixando de lles garantir a seguridade económica ou existencial aos seus antigos defensores, aqueles que prevían a chegada de reformas no contexto da autocracia ou que imaxinaran que o réxime iría cedendo terreo pouco a pouco ante os individuos que tiñan ambicións democráticas xa non albergan tales esperanzas. Os excesos do réxime contradín a súa imaxe de garante da «boa vida», co que rompe o trato que lle permitira gobernar, se non con total apoio, polo menos coa aquiescencia de moitos dos que se beneficiaran del. Isto pode contribuír a explicar por que cidadáns que ata hoxe ficaran en silencio están a dar sinais, botándose á rúa, de tomaren conciencia do intolerable que resultan as circunstancias actuais; e, aínda así, ante a palpable ausencia dunha oposición que apoiar, a moitos, sobre todo individuos que levan unha vida próspera nesas principais cidades que son Damasco e Alepo, resúltalles difícil concibir un futuro político optimista no contexto das revoltas de hoxe.

Malia todo, o que as comedias de Hayu nos invitan a facer é considerar as políticas de reprodución ideolóxica que, polo menos en parte, se van atopando en perigo. O seu traballo preséntanos conclusións cargadas de escepticismo e tamén xeitos de ver as cousas con novos ollos, o que nos permite chegar a un cońecemento prohibido que, de feito, xa temos (como se ramifica a paranoia, por exemplo). Ofrécenos non só un relato ambivalente das capacidades da "xente», mais tamén, xa que logo, unha crítica da soberanía popular; pois, en efecto, cando as comedias se burlan do pobo con humor e insinúan que este aínda non está listo para gozar de liberdade política, isto equivale a argumentar que o réxime non

${ }^{35}$ Blacks In and Out of the Left: Past, Present and Future, Cambridge, Harvard University Press, 2013. 
puido ou non quixo erixir institucións estatais capaces de asegurar a educación da xente... e superar as rúas cegas que fan que resulte tan difícil construír un mundo de maneira conxunta. A de Hayu é unha empresa pedagóxica, unha tarefa que, nos seus mellores momentos, tenta atraer a nosa atención sobre os aspectos propios da comedia como xénero e da risa como actividade política, no sentido de que a risa é inconfundiblemente humana, nos chama a «mirar a vida como espectadores desinteresados» e precisa da participación dos demais. Como escribe Henri Bergson (2005: 3) no seu famoso relato, a risa «semella ter necesidade dun eco [...]. Por moi espontánea que pareza, sempre comporta unha especie de francmasonaría secreta, ou mesmo complicidade, con outras risas, reais ou imaxinarias». A risa presupón a presenza dunha comunidade, mais tamén fai referencias sobre ela, e nesta dupla actuación pode, ademais, chamarnos á existencia.

En suma, o meu argumento consiste en que a comedia e a risa que esta provoca serven, abofé, para levar a cabo un importante labor ideolóxico, unhas veces reforzando as convencións políticas e outras presentándolles grandes desafíos. Nos seus momentos máis retorcidos, a comedia de Hayu sinálanos o que Theodor Adorno denomina o "podería ter sido doutra maneira» do compromiso: as teorías e os xéneros creativos que teñen a capacidade de producir o nacemento da actividade política — non necesariamente un programa político orixinal— no tempo presente ${ }^{36}$.

\footnotetext{
${ }^{36}$ Adorno aparece citado en Berlant (2011): Cruel Optimism, Durham/Londres, Duke University Press, 13. Véxase Adorno, Theodor (1974): «Commitment». Traducido para o inglés por Francis McDonagh. New Left Review, I, 87-88.
} 
HISTORIA, LITERATURA, BIOGRAFIA: OS ESPAZOS DUN DIÁLOGO ${ }^{1}$

Isabel Burdiel

Universitat de València

${ }^{1}$ A base deste texto provén da miña contribución ao libro de homenaxe a Manuel Pérez Ledesma editado en 2015 por Marcial Pons. Introducíronse modificacións na trama argumental e reflexións adicionais sobre a biografía e a novela. 

Cando os organizadores deste ciclo me propuxeron participar nel, suxeriron que falase das relacións entre historia, literatura e biografía. O que vou presentar aquí a discusión son unhas reflexións moi provisionais e abertas e que están estreitamente relacionadas co meu traballo e cos meus intereses historiográficos. É dicir, coa constitución do que Lionel Trilling chamou hai xa tantos anos «a imaxinación liberal $»^{2}$. Non podo falar con competencia doutros ámbitos de traballo. $\mathrm{O}$ que me parece pertinente, polo tanto, é propoñer algunhas reflexións xerais, a partir de estudos concretos, sobre as maneiras posibles en que a integración de materiais literarios e da perspectiva biográfica permite abordar de forma máis complexa o universo cultural, en sentido amplo, do liberalismo decimonónico, dos liberalismos, coas súas múltiples facetas e os seus malestares particulares na modernidade. Entendo o liberalismo como algo máis ca unha ideoloxía política e económica, como algo máis ca unha conformación sociolóxica.

En concreto, o meu interese pola novela decimonónica —e en absoluto, por certo, pola novela histórica sobre o século XIX - aséntase na convicción da súa capacidade para desestabilizar as certezas e as ortodoxias, as visións estereotipadas de que cousa foi o liberalismo, ou, máis exactamente, as diversas formas liberais de enfrontarse a un mundo en plena transformación, a unha noción nova do tempo, percibido como un actor sen límite coñecido e en plena aceleración. Interésame «aquilo que só a novela pode dicir», por utilizar a fórmula de Hermann Broch, logo explorada por moitos outros, como Carlos Fuentes ou Milan Kundera. Aquilo que os espazos ambiguos da ficción poden contarnos respecto á conformación cultural de valores e saberes diferenciados durante o século XIX. Das formas posibles de comprensión e apropiación dun presente cada vez máis opaco, dos descontentos e inquedanzas que provocou, das promesas e esperanzas de futuro, das identidades nacionais e do xénero en construción, das emocións

2 Trilling, Lionel (1971 [191950]): La imaginación liberal, Barcelona, Edhasa. Coma a Christopher Domínguez, ler a Trilling a principios do século Xxi tranquilízame: Letras Libres, blog de Ch. Domínguez Michael. 
que as atravesan, constrúen e sosteñen. Dos relatos sobre as razas superiores e inferiores; sobre a definición de que é progreso e que é tradición, a súa longa batalla e o seu longo abrazo. Unha diversa e recargada rede de significados que aínda constitúe hoxe, en moitos aspectos, a trama en que nos movemos ${ }^{3}$.

Nese ámbito de interese, voume limitar a expoñer algunhas reflexións sobre as relacións entre a historia (máis exactamente os historiadores), a literatura e a biografía, coa intención de responder unha vez máis a unha vella pregunta do historiador norteamericano Dominick LaCapra que Justo Serna e mais eu empregamos hai xa máis de quince anos como título para un traballo conxunto ${ }^{4}$. A pregunta era "Por que deberían os historiadores molestarse en ler novelas?». Menos triste e máis interesante para a evolución actual da historiografía sería unha segunda pregunta en que espero facer desembocar a primeira: como deberiamos os historiadores ler novelas desde o punto de vista dos nosos intereses profesionais e que tipo de cuestións teóricas e metodolóxicas poden suscitar esas lecturas? A terceira pregunta refírese a de que forma todo iso pode contribuír á renovación dese "xénero" borroso, incómodo e sospeitoso que é a biografía.

Talvez pague a pena comezar cunhas consideracións básicas arredor da idea de que quizabes (propóńoo para a discusión) aquilo que a historia deixou de contar no seu longo proceso de distinción da literatura (culminado no século XIx) foi o que creou o espazo para a consolidación dun novo xénero, a novela, ao tempo que favorecía tamén ese borroso espazo entre historia e ficción que, polo menos inicialmente, se atribuíu á biografía.

Ao coidado de ambas as dúas, pero sobre todo da novela, quedarían a exploración do significado social dos personaxes singulares e anónimos pero inmediatamente recońecibles; as zonas da experiencia humana que atinxen ao íntimo, ao subxectivo, ás relacións máis persoais, ás emocións e aos sentimentos; as múltiples maneiras de ver e estar no mundo que tiñan un carácter irredutiblemen-

${ }^{3}$ Scarpetta, Guy (2003): «La littérature, miroir de l'histoire? Ce que seuls les romans peuvent dire», Le Monde Diplomatique, 30 de marzo.

${ }^{4}$ Burdiel, Isabel / Justo Serna (1996): Literatura e historia cultural, o por qué los historiadores deberíamos leer novelas, Valencia, Episteme, vol. 130, e LaCapra, Dominick (1985): «History and the Novel», en History and Criticism, Ithaca, Cornell University Press. 
te individual e que quedaban fóra da historia oficial. Un proceso estreitamente asociado, e coadxuvante, á construción das esferas, artificialmente separadas, do público e do privado, do persoal e do colectivo, das paixóns e dos intereses.

Este enfoque, moi sumariamente exposto, quedaría incompleto e sería parcial se non advertise que, nese proceso de distinción, opera tamén o fenómeno paralelo da impregnación recíproca, do cruzamento de intereses, obxectivos e estratexias narrativas entre a narración histórica e a novela. «Marabíllome a miúdo de que a historia resulte tan pesada, porque gran parte dela debe ser pura invención» é unha frase xa famosa de Jane Austen. Unha novelista que elaborou a súa obra seguindo fielmente os procedementos narrativos da historia en construción, con personaxes plenamente debuxados, perfectamente contextualizados, con nomes e apelidos e incluso, crucialmente, con niveis de renda específicos 5 . Como escribiu François Hartog, nunha obra especialmente interesante para a reflexión que propoño, «a historia moderna e a literatura moderna triunfaron xuntas [...]. Dicir o mundo para os grandes novelistas do século XIX, percibir o seu carácter inédito, é xustamente dar a ler un mundo atrapado pola Historia, atravesado por ela, grávido dela ${ }^{6}$.

En boa medida por isto, e en todo o mundo occidental, o realismo, como artificio narrativo, substituíu, tanto para a historia como para a novela — que foron establecéndose como xéneros radicalmente modernos no transcurso do século XIX-, a epopea e a épica, os arquetipos capaces de representar o universal e o xeral, o mítico e o poético. Invertíase así a apreciación de valor clásica, formulada por Aristóteles, de que a poesía —o relato do que pode suceder ou podería ter sucedido — era superior á historia, que tan só pode contar o que pasou e que, polo tanto, atinxe só ao continxente e particular. Novela e historia, e nos seus intersticios aquel «xénero borroso» da biografía, parecía que non só se repelían senón que tamén se buscaban; ollábanse a través das fracturas que ían creando; tendían pontes, atravesábanas e retrocedían; enriquecíanse e desestabilizábanse mutuamente.

De aquí xorde unha proposta inicial de orde metodolóxica. En primeiro lugar, un historiador debe preguntarse de inmediato para que e por que decide utilizar materiais

\footnotetext{
5 Austen, Jane $(1803,1818)$ : Nothanger Abbey, capítulo xIV.

${ }^{6}$ Hartog, François (2013): Croire en l'histoire, París, Flammarion, 165.
} 
literarios e por que e para que quere facer unha biografía; é dicir, que problema ou problemas históricos substanciais e identificables guían o seu interese. Por iso é historiador e non crítico literario ou biógrafo no sentido distintivo do termo. Aínda que ás veces algunhas das súas tarefas conflúan, o punto de partida é e debe ser distinto. No meu caso, como apuntei máis arriba, o interese pola novela decimonónica —e, máis xeralmente, pola integración de materiais literarios na análise histórica- procedeu sempre menos dunha problemática teórica "pura», ou incluso do infinito pracer da lectura de ficción, e máis por un problema ou problemas históricos significativos. Isto foi así cando traballei sobre Frankenstein, o el moderno Prometeo, de Mary Shelley, hai xa case vinte anos, ou cando, coma agora, estou traballando na biografía de Emilia Pardo Bazán. En ambos os dous casos tentei manter os pés (é dicir, as preguntas) firmemente ancorados na historia ${ }^{7}$.

As diferenzas entre ambas as autoras son moitas en termos do seu contexto de emisión e recepción, a súa cronoloxía, a súa técnica narrativa e a súa concepción da novela. As súas obras, en cambio, e a miña maneira de abordalas, remiten, de maneira moi intensa, á forma en que a redefinición dos papeis asignados aos homes e ás mulleres, ao doméstico e o público, á moral e á ciencia, se interpelan entre si nas orixes dunha modernidade da que se adiviñaba xa que, xunto coas súas promesas de progreso e liberación, se agochaba un potencial monstruoso. Mary Shelley centrouse en analizar como se constrúen os monstros, desde que convencións de identidade e cales eran os resultados. En Pardo Bazán, especialmente nas súas novelas máis naturalistas, hai tamén unha vontade de penetrar nos procesos de construción de identidades socialmente consideradas como aberrantes, marxinais á civilización liberal, ou resistentes ás súas interpelacións de identidade básicas, esencialmente (en ambos os casos) as femininas e masculinas. As súas experiencias vitais e as súas obras convocan todas as preguntas importantes respecto ás relacións entre historia e literatura, e respecto ao potencial heurístico da biografía. Que hai de singular e de distinto nunha muller escritora dentro dunha esfera cultural concibida como esencialmente masculina? É pertinente esa pregunta ou é unha impertinencia sexista que as atrapa nun dilema irresoluble do cal formaría parte a empresa biográfica? Ou, moito máis interesante: como se cruzan as

\footnotetext{
7 Burdiel, Isabel (1996): «Frankenstein o la identidad monstruosa», en Frankenstein o el moderno Prometeo, Madrid, Cátedra, 7-113, e Burdiel, Isabel (2015): «La construcción de la "Gran Mujer de Letras" española: los desafíos de Emilia Pardo Bazán (1851-1921)», en Isabel Burdiel / Roy Foster (eds.), La historia y el "giro biográfico» en Europa: experiencias de escritura, Zaragoza, Institución Fernando el Católico, 343-372.
} 
fronteiras entre a vida e a obra, entre a realidade e a ficción? Como se ve afectada a propia biografía polos personaxes creados, polas posibilidades exploradas na ficción? Como se multiplica o eu, se modifica e se transforma no fluxo vivo da escritura?

Son preguntas que considero básicas no estado de reflexión en que me atopo agora respecto a que fai unha historiadora traballando sobre Pardo Bazán, que pode chegar a significar historicamente a súa vida e a súa obra. Creo que o primeiro e fundamental é complicar, precisamente, o que se entende comunmente por vida e por obra, por política e por cultura, ou por feminismo e por modernidade. Paréceme obrigado preguntarse polo papel que cabe atribuír á novela, e á esfera cultural en xeral, na exploración, fixación e discusión das tensións producidas polo cambio socioeconómico e político na Espańa da segunda metade do século XIX e primeiras décadas do XX. Un período crucial na construción do Estado-nación, no proceso de nacionalización española (incluída a das mulleres), así como na definición dos retos da democracia e do autoritarismo como respostas ao chamado «acceso das masas á política», coa súa intensa redefinición do concepto e a práctica da cidadanía.

Máis en profundidade, a vida e a obra de Pardo Bazán, coma as de Mary Shelley, participan — con todas as súas diferenzas, que non quero, por suposto, minimizar e que son obvias - dese impulso decimonónico da novela que, hai xa anos, Michael McKeon e Jonathan Ray (entre outros) identificaron como esencial: a expresión e busca de solucións para algo que se consideraba substancial ao progreso filosófico, histórico e científico da modernidade; a tensión que aínda hoxe segue vixente entre as cuestións de verdade e as cuestións de virtude ou de moral. Cuestións que a historia parecía querer abandonar ou esquivar na súa aposta por un cońecemento neutro da realidade do pasado. A novela xurdiu aí e daquela, no momento en que as nocións de verdade e virtude comezaban a separarse e empezaba a definirse por xéneros e disciplinas o que antes estivera unido: a reflexión filosófica, ética e estética, científica e política ${ }^{8}$. A poderosa atracción mítica do texto de Mary Shelley e a non menor potencia expresiva das obras de Pardo Bazán residen, en boa medida, entre outras cousas, no xeito en que - transcendendo a distinción entre os espazos público e doméstico- os problemas de verdade, identidade, ciencia e moral se entrecruzan e se desestabilizan mutuamente. A forma en que, na ficción de ambas, a Historia con maiúsculas e

${ }^{8}$ McKeon, Michael (1986): The Origins of the English Novel, 1600-1740, Baltimore, Johns Hopkins University Press, e Ray, Jonathan (1991): Story and History, Londres, Basil Blackwell. 
as historias con minúscula se cruzan e como buscan (e quizais conseguen) facer intelixible simbolicamente a primeira a través das segundas.

O que acabo de escribir creo que permite avanzar a segunda precisión de orde metodolóxica á que me refería máis arriba. Para o historiador que utiliza materiais literarios co obxectivo de construír unha historia máis complexa é necesario lembrar que a literatura non é unha categoría invariable historicamente. Tampouco o é, por suposto, a historia, nin o que se considera evidencia biográfica relevante. Ao longo do tempo, e tamén das sociedades, cambia substancialmente o que é ou non considerado literatura (e historia ou biografía) e mudan tamén as nocións de autor, texto e lectura. É absolutamente necesario preguntarse polas formas históricas concretas que adoptan, sucesiva ou contemporaneamente, esas figuras. As miñas reflexións, polo tanto, tan só en parte poden ter valor para períodos, culturas e xeografías distantes e diversos ao proceso de conformación, na Europa occidental, dun ámbito cultural relativamente autónomo do poder do Estado ou da Igrexa. Un momento clave, pero netamente particular, de conformación do que desde Habermas chamamos a esfera pública liberal e, tamén, de forma estreitamente relacionada, a dos Estados-nación occidentais, a interpelación de identidade nacional como básica na conciencia de si do mundo occidental, xunto, e en estreita relación, coa interpelación de xénero ou, se se quere máis precisión, a redefinición das diferenzas xerárquicas entre os sexos. En todos eses procesos desempeñaron un papel crucial a produción de novelas e a diseminación social da súa lectura?. A diversidade das súas características e do seu impacto sobre as formas culturais previas mantén diferenzas significativas entre países. Hai, porén, algúns riscos comúns que nos atinxen especialmente na medida en que foron cruciais para a comprensión de si dos suxeitos e sociedades modernos.

\footnotetext{
${ }^{9}$ Para unha valoración xeral do papel da novela nos procesos de nacionalización en España, Archilés, Ferrán (2006): «La novela y la nación en la literatura española de la Restauración: región y provincia en el imaginario nacional», en Carlos Forcadell / M. ${ }^{a}$ Cruz Romeo (eds.), Provincia y nación: los territorios del liberalismo, Zaragoza, Institución Fernando el Católico, 161-190. O cal non quere dicir que moitas das preguntas e cautelas metodolóxicas non sexan útiles para outros períodos e formas de literatura. Ver, por exemplo, a interesantísima colección de textos editados por Haan, Binne de / Konstantin Mierau (2014): Microhistory and the Picaresque Novel, Cambridge, Cambridge Scholars Publishing, cunha discusión importante sobre cuestións de referencialidade e construción histórica da marxinalidade a través dese tipo de literatura e a súa incorporación e tratamento de personaxes novos como os esmoleiros, os vagabundos e os ladróns.
} 
Mijail Bajtin lémbranos que a novela é o único dos grandes xéneros que é máis novo ca a escritura e o libro, e só ela está adaptada organicamente ás novas formas de produción, de recepción e de lectura características da modernidade. É o epítome da cultura moderna clásica e a máis prominente forma de linguaxe dialóxica, entendendo por tal a concepción, básica á súa obra, de que a linguaxe só pode ser "acadada», "comprendida» na súa inevitable orientación cara ao outro.

A novela é puro «dialoxismo social» na medida en que a voz do autor, e mesmo do narrador, é unha máis entre as que pugnan por facerse oír nun campo de forzas, de representacións e de voces en conflito que a transcenden. Nese sentido - e aquí fago un novo apuntamento de método para a integración da análise literaria na historia-a novela non atopa o seu significado último nunha voz (a do autor/narrador/protagonista) ou nunha contorna social determinada. A novela (a mellor sobre todo, pero non só ela) acolle, dunha forma ou outra, todas as voces sociais e ideolóxicas dunha época; todas as linguaxes e as identidades conformadas arredor delas, todas as apostas morais que a través da ficción (en personaxes secundarios ou non) reclaman significación. A novela é, en suma, un microcosmos da heteroglosia social e dos seus conflitos ${ }^{10}$.

Penso na novela francesa e espańola dos dous últimos terzos do século XIX. Stendhal, George Sand, Balzac, Eugène Sue ou Zola, Ayguals de Izco, Antonio Altadill, Emilia Pardo Bazán, Benito Pérez Galdós e os novelistas máis célebres da Restauración deberon en boa medida o seu impacto social ao seu «desexo de vencer a opacidade social, de introducir unha luz no corazón dunha sociedade que se convertera, a ollos dos contemporáneos, nun enigma, un labirinto e mesmo un caos» ${ }^{11}$.

A novela —a través, en moitas ocasións, da súa publicación por entregas nos faldróns dos xornais de gran tiraxe- explorou e contribuíu a crear o sentimento de vivir nun período de cambio como nunca antes se cońecera, colaborou substancialmente na busca de reconstitución dunha orde ou dunha suposta harmonía

\footnotetext{
${ }^{10}$ Bajtin, Mijail (1991): Teoría y estética de la novela, Madrid, Taurus (recompilación de textos útiles), e a súa obra clásica (1987 [ $\left.\left.{ }^{1} 1941\right]\right)$ La cultura popular en la Edad Media y el Renacimiento: el contexto de François Rabelais, Madrid, Alianza.

${ }^{11}$ Corbin, Alain (2006): «Préface» en Judith Lyon-Caen, La Lecture et la vie : les usages du roman au temps de Balzac, París, Tallandier, 9-10; Ozouf, Mona (2006): Récits d'une patrie littéraire, París, Fayard, e Oehler, Dolf (2006): Le Spleen contre l’oubli : juin 1848, París, Payot. Para a España isabelina é moi útil Andreu, Xavier (2012): «La cultura», en Isabel Burdiel (coord.), España 1830-1880: la construcción nacional, Madrid, Fundación Mapfre, 335-425. Para a Restauración, aínda que desde unha perspectiva distinta, Labanyi, Jo (2011): Género y modernización en la novela realista española, Madrid, Cátedra, col. Feminismos.
} 
perdida, alertou sobre a necesidade dun novo acordo ou pacto moral e social. Nela expresouse a inquietude ante unha aceleración percibida como desordena$\mathrm{da}$, ante unha mobilidade social que todo o trastornaba, ante a fraxilidade dos réximes políticos, a inestabilidade das conviccións ${ }^{12}$.

Todo iso (con todas as súas voces, en diversa xerarquía de autoridade) atopa o seu camiño na creación do clima de inquietude que provocou, por exemplo, a revolución de 1848 en Francia. Da mesma forma que a literatura e o teatro tiveron tanto que ver coa explosión da revolución de 1868 en España e a asunción, en parte equivocada e presentista, por parte de autores como Pardo Bazán ou Galdós, de que foi daquela cando se inaugurou en España o desasosego na modernidade. Así mesmo, como xa avancei e como foi posto de manifesto nos estudos recentes sobre os procesos de nacionalización no mundo occidental, especialmente durante o século xIx, a novela desempeñou un papel crucial na forxa de identidades nacionais. Como sinalou Franco Moretti, entre outros, a novela axudou a facer intelixible, e a crear, polo tanto, desde a súa forma simbólica, unha realidade nova, abstracta e enigmática. Os grandes «escritores nacionais» foron desprazando os mundos utópicos e introducindo o cotián, a vida familiar, as relacións inmediatas, como unha rede afectiva e vivencial que podía ir configurando a idea e o sentimento de nación ${ }^{13}$. Aínda se trata dun tipo de aproximación que, malia que recibiu unha atención crecente, require un maior esforzo metodolóxico que evite as tentacións máis ou menos «naturalistas» que importan do mundo de ficción evidencias directas.

Un primeiro punto de partida de carácter práctico, para traballar, implica someter a crítica calquera concepción estratigráfica, xerárquica ou compartimentada da realidade histórica. A estas alturas parece obvio. Con todo, na escritura histórica, realmente existente, o obvio non sempre se practica. Facelo supón, ao meu xuízo, atribuír ás prácticas culturais (nos seus dous sentidos) un carácter performativo e dinámico, capaz de crear significados históricos e envolto nos esforzos dos diversos sectores sociais e dos diversos individuos, por controlar o carácter contraditorio, cambiante e fragmentado deses significados. É precisamente a partir de aí como

${ }^{12}$ Hartog, François, «Du côte des écrivains: les temps du roman», en Croire en l'histoire..., op. cit., 165-223.

${ }^{13}$ Para España, antes de 1868, é fundamental a tese de doutoramento de Andreu, Xavier (2015): Mito romántico e identidad nacional en la España liberal (1830-1850), València, Universitat, de onde tomo estas reflexións. Moretti, Franco (2001): Atlas de la novela europea, 1800-1900, Madrid, Trama, e Leersen, Joep (2006), por exemplo, National Thought in Europe: A Cultural History, Amsterdam, Amsterdam University Press, como introdución ao tema. 
a literatura pode ser rehabilitada en tanto que unha forma de representación e de cońecemento do pasado, e do presente, útil para os historiadores ${ }^{14}$. Un fenómeno que tivo un momento de inflexión clave a finais dos anos oitenta do século pasado ata chegar á situación actual, na cal, por exemplo, o chamado «xiro emocional» non pode ser concibido, nin practicado, sen a integración sistemática, e meditada, de materiais procedentes da literatura en sentido amplo: a novela, a poesía e o teatro, sobre todo ${ }^{15}$. A cuestión, non obstante, segue moi aberta na orde da reflexión metodolóxica. Os historiadores e os especialistas na análise literaria seguímonos observando con preocupación cando cruzamos os nosos camiños e as nosas ferramentas.

As notas que seguen son aínda máis provisionais ca as xa apuntadas e pretenden tan só compartir algunhas reflexións sobre non xa o por que deberiamos ler novelas, senón sobre o como facelo. En todo caso, creo que, afortunadamente, non existe un método (eu desde logo non o teño) que se poida aplicar que garanta o éxito desa lectura de novelas desde a historia. Hai, con todo, algúns avisos de navegante que quizais sexan útiles. En primeiro lugar - e seguindo en parte a historiadores pioneiros como LaCapra, Alain Corbin ou Roger Chartier-, o texto literario (coma todo documento histórico, en realidade) pode e debe ser analizado na súa dobre dimensión, que o constitúe como tal. Por unha banda, como produto «monumental» (por utilizar unha expresión foucaultiana) dunha determinada experiencia histórica que nin a abrangue completamente nin é completamente reducible a ela, pero á que tampouco é estraño. Por outra banda, como discurso interno en que pugnan por facerse oír as voces do seu autor, dos seus lectores, dos valores persoais e colectivos. Onde ata pugna por facerse oír o non dito, o ocultado ou o non sabido ${ }^{16}$.

${ }^{14}$ LaCapra, Dominick, «History and the Novel...», art. cit. supra; Poovey, Mary (1995): Making a Social Body: British Cultural Formation, 1830-1864, Chicago, Chicago University Press; Burguera, Mónica (2012): Las damas del liberalismo respetable: los imaginarios sociales del feminismo liberal en España (1834-1850), Madrid, Cátedra, col. Feminismos.

${ }_{15}$ Para o cruzamento de materiais posibles ao respecto, Frevert, Ute (ed.) (2014): Emotional Lexicons: Continuity and Change in the Vocabulary of Feeling 1700-2000, Oxford, Oxford Universty Press, e, para un estudo concreto en España, Sierra, María (2013): Género y emociones en el Romanticismo: el teatro de Bretón de los Herreros, Zaragoza, Institución «Fernando el Católico».

${ }^{16}$ De novo a pegada crítica de Bajtin, Mijail / Roger Chartier (dirs.) (1993): Practiques de la lecture, París, Payot. 
Desde ambos os supostos, sempre estreitamente relacionados entre si, pode e debe descartarse o uso máis tradicional dado á literatura. Refírome á súa consideración como unha posible fonte de datos históricos, máis ou menos velados polas operacións narrativas de ficción. Cando a literatura se utiliza así creo que non rende os seus mellores resultados. O historiador ten (por suposto) outras fontes moito máis fiables desde o punto de vista factual e, de feito, unha aproximación deste tipo corre o risco de crear unha historia narrativa que é menos autocrítica e probatoria ca a narrativa literaria á que se refire. No proceso, a literatura convértese ou ben en redundante ou ben en meramente «suxestiva» e/ou ornamental. Entre outras cousas porque a literatura nunca sinala directamente unha práctica social, nin sequera a súa representación imaxinada. Como indicou Alain Corbin, hai que estar especialmente en garda contra os erros resultantes das tácticas literarias de «ilusión de verdade». Por exemplo, a insistencia nun tema, nunha acción ou unha emoción pode denotar tanto unha ausencia, unha nostalxia, como unha presenza continuada. $\mathrm{O}$ acento no amor romántico na primeira metade do século XIX pode denotar a súa proliferación no corpo social pero tamén unha frustración das súas posibilidades no momento de asentamento da sociedade burguesa ${ }^{17}$. As interpelacións de identidade nacional e de xénero que se discuten de forma case obsesiva na obra de Pardo Bazán poden falarnos dunha nación e dunha diferenza xerárquica de sexos amplamente diseminadas socialmente. Poden facelo tamén dunha frustración, dunha nación (e dunha posición nela das mulleres, coas cales é difícil identificarse, que é difícil dar por construídas). Como advertiu no seu momento George Sand cando discutía as diferenzas entre a literatura romántica e a chamada realista: «O nome de realismo non convén [para establecer esas diferenzas] porque a arte é unha interpretación múltiple, infinita. É o artista o que crea o real, a súa realidade, que é distinta á de calquera outro» ${ }^{18}$.

Isto non quere dicir que a literatura non teña ningún valor referencial. José M.a Jover (un pioneiro neste terreo en España) afirmou nunha das súas últimas intervencións públicas que "para a historia da vida cotiá, das mentalidades, da medida en que unha determinada concepción do mundo permeabiliza e se altera ao impregnar os distintos estratos dunha sociedade, a literatura constitúe unha fonte sinxelamente imprescindible. Obvio é advertir — continúa— que esta importancia sobe de grao cando o período histórico analizado conta cunha literatura que fixo da observación da reali-

\footnotetext{
${ }^{17}$ Sierra, María, Género y emociones..., op. cit. supra.

${ }^{18}$ Citada por Reid, Martine (2013): George Sand, París, Gallimard, 264.
} 
dade social que lle é contemporánea un dos alicerces do seu credo estético; tal é o caso da novela española da Restauración». Máis adiante: «[E]n presenza da obra literaria, o obxecto do interese do historiador é esencialmente distinto do que motiva o interese do crítico literario, do historiador da literatura ou do lingüista. $O$ historiador busca na obra literaria o testemuño vivo dunha sociedade» ${ }^{19}$.

Estou de acordo con Jover, e tamén con Alain Corbin cando alude a algo similar. Pero aquí ademais cómpre traballar con moitas cautelas e evitar inferir evidencias directas. É certo que o historiador busca na literatura o testemuño vivo dunha sociedade, pero faino cunha orientación particular. O historiador sabe, ou debe saber, que ata o realismo máis extremo (ou precisamente el) das novelas máis socialmente orientadas é un artificio narrativo que hai que tratar como tal. Ningunha obra literaria (nin a de Balzac nin a de Galdós, Pardo ou Baroja, por poñer exemplos clásicos) reflicte a realidade que pretende dicir que está reflectindo, nin sequera aquela referida ás representacións, ás mentalidades ou ás emocións. Con todo, e isto é tamén importante, a novela realista, debido precisamente á súa orientación explícita cara á realidade social, necesitará no momento da súa recepción o referendo de verosimilitude dos seus lectores. Así, como di Jover, o modelo acuńado por Galdós en Torquemada, por exemplo, ou os de Balzac e Sue, tiveron que contar no seu propio tempo cun dobre referendo. Por unha banda, o dun ambiente, xa que os seus autores querían explicitamente representar unha realidade contemporánea, viva, que os seus lectores podían ou non aprobar. Por outra, e en estreita relación, dunha estética particular que requiría unha fidelidade aceptable, un "xogo de verdade», na observación dos costumes vixentes na sociedade que os seus lectores coñecían ${ }^{20}$.

Por iso, para a análise histórica dunha novela o que interesa non é o período en que se sitúa a trama, senón o período e a sociedade nos que esa novela se escribe e se publica. As novelas históricas tan só teñen interese polo momento elixido para falar e escribir do pasado. Por que agora se revive ese pasado? Que di dos problemas dese agora? Como se fai, que elementos da discusión do hoxe se incorporan? Penso, por exemplo, no éxito do capitán Alatriste de Arturo Pérez Reverte ou —noutro mundo e orde de cousas - o que significou no seu momento a publicación e o éxito de Tranvía

\footnotetext{
${ }^{19}$ Jover, José María (1992): «De la literatura como fuente histórica», Boletín de la Real Academia de la Historia, CLXXXIx:1, 33.

${ }^{20}$ Jover, José María, «De la literatura como fuente histórica», art. cit. supra, 36.
} 
a la Malvarrosa, de Manuel Vicent, para falarnos dos anos finais da ditadura franquista, nun momento de lúa de mel da xeración da Transición consigo mesma e coas súas nostalxias de mocidade. Moito máis preto, que papel están tendo nestes momentos, no debate sobre o esgotamento do réxime da Transición e os seus custos morais e políticos, as dúas novelas máis recentes de Javier Cercas ou de Javier Marías? ${ }^{21}$.

Trataríase, polo tanto, de achegarse ás novelas, e aos seus procedementos, como a unha práctica social produtora de significados e de identidades colectivas e individuais en conflito ou en diálogo, como se prefira. Unha práctica, e isto non hai que esquecelo nunca, que ten a súa propia lóxica. Por iso non hai contradición en considerar os escritores, os seus temas e os seus personaxes —e as posibles lecturas que suscitaron- como actores históricos por dereito propio, aínda que con características expresivas peculiares. Neste sentido (e paréceme importante recalcalo), utilizar a literatura en historia non quere dicir reducir a literatura á historia, senón que, de feito, implica o contrario: entrar na propia lóxica da literatura, non alterala, reconducila ou reducila a outra lóxica distinta, sexa esta sociolóxica, histórica ou filosófica. Implica, pois, e sobre todo, entender a literatura como literatura. Por iso, o problema non pode reducirse só a unha función dicotómica entre vontade estética ou de coñecemento. É certo que hai algo de verdade evidente na afirmación de que a novela está construída baixo dominante estética, mentres que a historia o está baixo dominante de coñecemento histórico; é dicir, nunha novela importa máis o como se conta ca o que se conta; a trama de calquera gran novela queda reducida á nada —e convértese nunha trivialidade - se a obra se valora exclusivamente polo que pasa nela. Con todo, e como xa dixen, a primeira novela tivo un fortísimo compoñente de vontade de cońecemento do que estaba ocorrendo no momento da súa produción, unha vontade de explicar os cambios sociais, económicos e políticos producidos ao fío das grandes revolucións decimonónicas, de orientarse e orientar no medio da tremenda inquietude que aqueles cambios producían. Creo que, de xeitos moi diversos, seguiu tendo esa vontade de cońecer ao longo de toda a historia contemporánea occidental, pero esa é outra historia sobre a que outros especialistas poderán falar.

Por outra banda, e isto complica aínda máis o esforzo de posta ao día en saberes que non son os convencionalmente transitados pola historiografía, aínda que o historiador

${ }^{21}$ É interesante neste ámbito a tese de doutoramento de Santamaría, Sara (2013): La palabra como acontecimiento: Segunda República, Guerra Civil y posguerra en la novela actual (1990-2010), Valencia, Universitat. As últimas novelas ás que me refiro son Marías, Javier (2014): Asi empieza lo malo, Madrid, Alfaguara, e Cercas, Javier (2014): El impostor, Madrid, Random House. 
se achega ao fenómeno literario orientado por intereses distintos aos do crítico literario ou ao historiador da literatura, hai unha serie de problemas de análise nos que os tres se poden dar a man. Como xa dixo Lionel Trilling, non se trata dunha cuestión de libre elección sobre se o historiador cultural quere ou non quere familiarizarse cos procedementos de análise do crítico literario. En ámbitos decisivos non ten máis remedio que facelo porque na análise interna dun texto se suscitan cuestións que non poden resolverse sen o cruzamento de fronteiras disciplinares ao que aludía antes.

Os historiadores viñémonos queixando, con razón, da concepción demasiado clásica, pouco atenta aos debates e ás diferenzas, dunha disciplina como a historia, en pleno proceso de renovación. Con todo, para que o diálogo sexa frutífero, os historiadores non podemos (tampouco) adoptar unha noción preempaquetada e decimonónica das operacións da crítica ou da historia da literatura. Agora máis ca nunca, a reflexión sobre que cousa é literatura —e como abordar a súa análise- é un campo de debate, máis ca un método ou un corpo de doutrina firmemente constituído que os historiadores poidamos simplemente ir buscar e incorporar sen máis ${ }^{22}$. Nin agora nin nunca (pero menos agora que nunca) a historia e a literatura constitúen terreos firmes desde os cales se observaren mutuamente. Ambas son campos de debate que é necesario explorar. Con todo, e a risco de reiterarme demasiado, nesa exploración o historiador incorpora dous elementos fundamentais que lle son específicos. En primeiro lugar, o problema histórico que guía a súa procura, selección e tratamento dos textos literarios porque estes, para el, non se presentan nunha serie (canónica ou non), senón que debe ser o mesmo historiador o que constrúa a serie, en función das preguntas e dos problemas históricos e historiográficos que elabora e cuxa pertinencia quere defender. Como fai, por certo, con outro tipo de documentos máis convencionais. En segundo lugar, para o historiador é central a función social do texto dentro da cal adquire significado, tanto a serie construída como tal como o seu lugar dentro dunha tradición literaria. Por iso, para un historiador (desde certo punto de vista) é necesario continuamente cuestionar o canon literario, as fronteiras entre alta cultura e cultura popular, as que existen (e sen dúbida hai que telas en conta) entre, por exemplo, as novelas rosa por entregas e obras canónicas como Ana Karenina ou Madame Bovary.

As condicións de produción e de recepción convértense así en cruciais. Desde as máis obvias —os procesos e mecanismos de edición, os textos que a acompañan, o soporte material, a posición das novelas respecto doutros xéneros e do autor respecto

\footnotetext{
${ }^{22}$ Spiegel, Gabrielle (1997): «History, Historicism and the Social Logic of the Text», Speculum, 65, 23-56.
} 
doutros autores etc. - ata as máis complexas que cuestionan a dicotomía entre texto e contexto, a metáfora de dentro e fóra, que non por criticada deixou de ser operativa. Para o historiador a tentación, o perigo máis grave é o de disociar texto e contexto e, ao mesmo tempo, suxerir equivalencias fixas entre ambos. Isto é así porque, ao facelo, a Historia (con maiúscula) se converte en fonte de significado para unha historia (con minúscula) e para uns personaxes e unha trama convertidos en símbolos de algo que non son eles mesmos ou que, en todo caso, está situado fóra deles. Nese proceso o que ocorre, paradoxalmente, é que o relato de ficción queda fóra da Historia á que supostamente alude e coa que se pretende explicalo.

Ao meu xuízo (e son consciente das dificultades e da falta dunha metodoloxía concreta para facelo), convén lembrar que a natureza histórica dunha obra literaria non se atopa fóra dela mesma; a Historia (con maiúscula) ocorre dentro do relato de ficción e, como tal, inevitablemente, ocorre como conflito. Aí reside, precisamente, o significado da súa existencia histórica como texto de ficción e a potencia social e cultural do que é capaz de $\operatorname{crear}^{23}$. Para min pensar nestes termos foi esencial no caso do Frankenstein de Mary Shelley — desbloqueoume a análise crítica e histórica da novela- e está séndoo nestes momentos para comprender a lóxica profunda, e tamén as contradicións, os conflitos de identidade, que subxacen a unha obra e unha figura pública tan complexa como son as de Pardo Bazán. Nela, o cruzamento de alusións e batallas entre os textos críticos e de ficción é constante. Son mundos permeables pero non idénticos e cómpre analizalos así e identificar ese enigmático «aquilo que só a novela pode dicir».

É a través do texto, no centro mesmo do proceso creativo, como as condicións históricas da súa produción colocan as súas demandas sobre o autor, os seus rexeitamentos, as súas expectativas, as súas oportunidades e os recursos para zafarse do terror á indiferenza. Máis concretamente, na medida en que o autor forma parte dun campo cultural determinado define o seu proxecto creativo, consciente ou inconscientemente ${ }^{24}$. Penso, de novo, nunha novela aparentemente tan intemporal como Frankenstein: a súa aparente intemporalidade traizoa unha profunda

${ }^{23}$ Montag, Warren (1992): «The Workshop of Filthy Creation», en Johanna Smith (ed.), Mary Shelley. Frankenstein, Boston, St. Marin's Press, e Isabel Burdiel, «Frankenstein o la identidad monstruosa», art. cit. supra, 74 .

${ }^{24}$ Segue sendo útil, con precaucións, Pierre Bordieu e a súa conceptualización dos campos culturais en (cito da edición inglesa) «Flaubert's point of view», Critical Inquiry, 14 (1988), 539-593, e Las reglas del arte: génesis y estructura del campo literario, Barcelona, Anagrama, 1995. 
imbricación nas condicións da súa época e nas tensións desta. Neste sentido, Frankenstein fálanos das ansiedades implícitas nun mundo que a súa autora vive a través dunha vangarda radical que é, a un tempo, a súa detractora e a impulsora dalgúns dos seus trazos míticos básicos.

Argüír que a literatura participa dos valores do seu momento de produción (ata cando se opón a eles) non é outra cousa que argumentar que as súas obras son actos de comunicación e que, como tales, implican espazos de posibilidade, linguaxes dispoñibles. Valores e linguaxes que non son unívocos e pechados, senón que sempre se presentan na forma de diálogo ou conflito, na procura da súa imposición sobre outros valores ou de resistencia a eles. Isto lévame á cuestión do autor. Creo que toda a literatura crítica sobre «a morte do autor» foi útil no seu momento para conmover os cimentos dunha historia literaria biográfica, inxenua e reducionista. Con todo, creo que non é posible analizar historicamente un texto sen pensar no seu autor. Isto soa moi clásico ou inxenuo, pero temo que estou de acordo con Stanley Fish (e antes ca el con Virginia Woolf) en considerar que significado, intención e biografía son inextricables ${ }^{25}$.

Con iso entro, para acabar, no problema da biografía en relación co dito ata aquí sobre a historia e a literatura. Como xa advertiu Stanley Fish, considerar que significado, intención e biografía son inextricables non ten, desgraciadamente, consecuencias metodolóxicas determinadas. Non nos dirixe inevitablemente a preferir un método interpretativo ou outro. Non soluciona o debate sobre a biografía, senón que é o terreo sobre o que comeza o debate ${ }^{26}$. Todas as cuestións tradicionais permanecen: que é unha biografía, que é ou non é evidencia biográfica pertinente, como distinguila e como tratala; que tipo de conexións somos capaces de propoñer entre vida e obra, que entendemos por vida e por obra. Son realmente dous planos absolutamente distinguibles, distintos? O recurso á biografía, contra o que algúns críticos literarios quixeron supoñer (desde Roland Barthes ata agora), non permite escapar cara ao mundo dourado do sentimento nin cara a unha historia dos produtos culturais, da novela, máis

${ }^{25}$ «Biography and Intention», en W. H. Epstein (ed.), Contesting the Subject: Essays in the Postmodern Theory and Practice of Biography and Biographical Criticism, Purdue University Press, 1991, 9-16; Woolf, Virginia (1981): Las mujeres y la literatura, Barcelona, Lumen, especialmente «George Eliot» (1919), 174-185.

${ }^{26}$ Burdiel, Isabel, «La Dama de Blanco...», art. cit. supra. 
doada e menos analítica. Máis aínda, por máis esforzos que fagamos, os historiadores non podemos sortear a biografía a menos que consideremos posible ler unha obra $\mathrm{e}$ interpretala sen referencia a unha intención e, polo tanto, a un suxeito que escribe, a un contexto de escritura e de recepción. A menos que consideremos posible divorciar o significado dunha novela das intencións (por moi alteradas que cheguen a estar nos procesos de lectura) dos novelistas que as escribiron. Eu non creo nesa posibilidade.

Si creo, con todo, que esa «necesidade dun autor», como dicía Virginia Woolf, debe entenderse e analizarse (tamén) como parte do impacto dunha obra de ficción na sociedade en que se produciu. As dificultades aquí son, se cabe, maiores ca nos pasos anteriores. En todo caso, o que me interesa recalcar —e con iso acabo- é que, no esforzo de contestación ás críticas pertinentes, os historiadores interesados na biografía (e na incorporación de materiais literarios á historiografía) deixaron de ser inocentes. Reflexionouse xa moito nos últimos anos (e non pretendo ser exhaustiva nin establecer unha orde de prioridades e causalidades) sobre a posición do biógrafo e a súa capacidade para construír e argumentar a significación histórica dunha vida individual; sobre a ampliación e reformulación das nocións de individuo e suxeito histórico; a problematización das nocións de experiencia, identidade, subxectividade, representatividade, privado e público. Traballouse tamén moito sobre a cuestión crucial das técnicas argumentativas e dos recursos expresivos da narración/narracións biográficas, sobre o problema das relacións entre o tempo histórico e o tempo individual e, ultimamente, sobre o papel estratéxico que pode desempeñar a perspectiva biográfica no desafío da chamada historia global ás fronteiras nacionais e aos marcos cronolóxicos convencionais. Unha perspectiva, esta última, sobre a que reflexionou recentemente Anaclet Pons nun estado da cuestión brillante para Historia de la historiografía ${ }^{27}$.

O potencial común de toda esa masa crítica creo que xa permite distanciarse da celebración autocompracente de prácticas historiográficas xa superadas e, tamén, da crenza inxenua en que a biografía pode resolver por si mesma as aporías que suscita o carácter circular do coñecemento na súa tensión constante entre o todo e as partes, o individual e o colectivo. Só desde ese dobre distanciamento pode a historia biográfica demostrar a súa capacidade para converterse nun observatorio

\footnotetext{
${ }^{27}$ Toda a reflexión posterior constitúe un extracto de Burdiel, Isabel (2014): «Historia política y biografía: más allá de las fronteras», Ayer, 93:1, 47-83. Alí pódense atopar todas as referencias bibliográficas sobre os autores aos que aludo e que agora obvio.
} 
e un terreo de engarzamento útil para o cruzamento consciente e ben sopesado de diversos marcos de análise. Unha pluralidade de marcos e de recursos que, como xa advertiu Marc Bloch, constitúe a condición sine qua non para entender historicamente; algo que eu creo que a historia biográfica favorece de forma moi notable.

Da mesma forma que ocorre na utilización de novelas para a historia, non hai biografía que interese sen un ou varios problemas (interesantes) que a orienten e a sosteñan. É aí onde debe ancorarse o esforzo por explicar a singularidade dunha vida individual, sen sometela a un relato que a transcenda e anule pero sen renunciar tampouco a enlazar os destinos persoais e as estruturas e institucións sociais. Resulta aquí especialmente pertinente a advertencia clásica da microhistoria respecto de que os problemas deben ser xerais, e en ocasións universais, pero que as respostas que damos e podemos dar os historiadores son sempre particulares e locais.

Desde ese punto de vista, a biografía pode ser un bo observatorio para lembrar o carácter aberto que o estudo dunha traxectoria individual confire á historia, a forma en que rescata a pluralidade do pasado e permite sondar as posibilidades e os límites da acción dos homes e das mulleres a través, precisamente, da análise coidadosa das condicións en que esta pode desenvolverse e iluminar tanto as desviacións como as prácticas habituais. A cuestión, polo tanto, non é só de representatividade (se é que chegamos a poñernos de acordo sobre que quere dicir ese termo), senón que é o que podemos aprender dunha vida específica.

É precisamente desde aquí desde onde a historia biográfica actual coadxuvou - xunto con outros enfoques historiográficos - a desestabilizar o chamado «modelo heroico» da biografía e tamén da historia convencional. Parécenme importantes tres aspectos. En primeiro lugar, a expansión dos suxeitos posibles da historia que desborda os chamados "grandes personaxes». Algo que non só implica a inclusión da chamada "xente corrente» (incluídas as mulleres pouco correntes), senón que provocou unha reflexión máis ampla sobre os mecanismos que propician tanto as exclusións como as inclusións e que remiten, entre outras cousas, ao punto de vista do historiador e á definición de que é «o grande» e que é «o pequeno» ou «o común» ou «o corrente».

En segundo lugar, e en estreita relación, a insistencia en que non existe nada que sexa un marco ríxido, coherente, un pano de fondo que permita comprender de forma lineal e necesaria a traxectoria individual e reconducir dalgunha forma as súas especificidades ás normas ou á súa transgresión. O que chamamos contextos, coas súas 
interpelacións de identidade, son algo activo e potencialmente múltiple, poden cruzarse entre si e ata entrar en conflito total ou parcialmente. Por iso, cada individuo é sempre (aínda que con maior ou menor complexidade segundo os casos) un híbrido e unha encrucillada de redes de relación e de poder, de tempos e opcións posibles. Unha fráxil mestura de esforzos cambiantes e en contraste. A recente recuperación da obra de S. Kracauer e a súa lectura por Sabina Loriga para o tema da biografía parécenme moi importantes neste senso. É dicir, para pensar que a posibilidade de non pertencer, a extraterritorialidade, é unha posibilidade fundamental da vida humana, como o é a de sucumbir á irreversibilidade de pertenzas consideradas (autonarradas persoal e colectivamente) como esenciais e insuperables, ou abrazar tal irreversibilidade. Unha forma de ollar, de ollarnos, que me parece especialmente importante nos tempos en que vivimos e en cuxa exploración han ter un papel fundamental a historia das mulleres e toda a reflexión arredor da categoría de xénero ${ }^{28}$.

$\mathrm{O}$ interesante, o esencialmente interesante ao meu xuízo, é que toda esa reflexión crítica demostra a necesidade de afacérmonos a lidar co que constitúe a tensión constante, constitutiva, da biografía e da historia. Un individuo non pode explicar completamente un grupo, unha comunidade ou unha institución e, viceversa, un grupo, unha comunidade ou unha institución non pode explicar completamente a un individuo. Hai unha interdependencia recíproca, pero esta non é nin lineal nin univalente, nin fixada dunha vez e para sempre. A biografía, entón, pode ter saudables efectos para lembrar que os individuos están «situados» pero non necesariamente prisioneiros ou cegos dentro de estruturas sociais, políticas, económicas ou discursivas.

Por todo iso, a renovación da historia biográfica non debería suscitarse só, nun sentido profundo, en termos de se os seus personaxes son ou non "grandes homes» — os heroes do modelo clásico_ ou suxeitos máis ou menos anónimos e «non poderosos» no sentido convencional. A cuestión é máis complexa porque o que está en xogo non é o quen senón o como. Advertiuno tamén Joan Scott cuestionando algunhas posturas demasiado inxenuas respecto diso:

A historia non se descentra simplemente porque se lles outorgue visibilidade aos que ata agora estiveron ocultos ou nas súas marxes. Os relatos, ás veces mesmo dos poderosos, revelan a complexidade da experiencia humana, ata o punto de que impugnan as categorías coas que estamos afeitos a pensar o mundo.

\footnotetext{
${ }^{28}$ Bolufer, Mónica (2014): «Multitudes del yo: biografía e historia de las mujeres», Ayer, 93:1, 85-116.
} 
Ou, en palabras de Natalie Zemon Davies: é a combinación de «formar parte» de algo universal e o recońecemento do particular o que nos fai humanos, o que nos alonga para alcanzar o pasado, "porque a diferenza é a base da nosa común humanidade» ${ }^{29}$.

Nese ámbito, gustaríame suscitar unha última reflexión sobre a cuestión das relacións entre as chamadas "vida pública» e "vida privada» e o papel que pode desempeńar a historia biográfica na reflexión respecto diso. Unha reflexión que, nas súas mellores formulacións, implica exactamente o oposto ao sensacionalismo, ao interese morboso polo íntimo e o secreto, ao psicoloxismo banal do que a novelista e biógrafa Joyce Carol Oates denominou "patografía».

En primeiro lugar, paréceme fundamental recoñecer, non só no terreo teórico, senón tamén no práctico, o carácter historicamente construído, e polo tanto flutuante, da dicotomía entre público e privado. O cal implica resistir a tentación de crer que no ámbito do chamado privado se atopan maiores doses de «verdade» ou «realidade» sobre un personaxe. Un erro, moito máis frecuente do que se quere recoñecer, que é produto, precisamente, da potencia, dos «efectos de verdade» da noción moderna de individuo (polo menos nas sociedades occidentais), co seu fincapé no ámbito do privado como o máis próximo á natureza, o dominio da pura humanidade, a fonte última do eu.

A idea de que é posible desprenderse do «ser social» e ser único, puro, individual, transparente no ámbito do privado é en si mesmo un código cultural e, máis concreta e distintivamente, un código cultural romántico e roussoniano. Hai moito que desde a historia das mulleres sabemos que o privado é político.

Unha formulación deste tipo facilita, por exemplo, e en situacións históricas concretas, discutir os xeitos diversos, posibles e peculiares de transitar entre as esferas, pública, privada e íntima, e subverter o seu suposto carácter natural e pechado. Penso en estudos como os de Mónica Burguera e M. ${ }^{a}$ Cruz Romeo sobre a condesa de Espoz y Mina, ou desta última sobre Concepción Arenal, así como os de Lucy Riall sobre os homes do Risorgimento (especialmente os irmáns D’Azeglio e o propio Garibaldi), de María Sierra sobre Gabriel García Tassara e sobre Bretón de los Herreros ou de Anthony La Vopa sobre Fichte. Ou o que eu procurei con Mary Shelley, con Salustiano de Olózaga e Isabel II e estou intentando agora con Pardo Bazán.

${ }^{29}$ Scott, Joan W. (2011): «Storytelling», History and Theory, 50, 208-209, e entrevista con Natalie Zemon Davis, Clionauta, 4 de abril de 2012. 
Todo iso remite, ademais, a unha das múltiples decisións que debe tomar o historiador biógrafo. Quere ou debe, en función dos problemas históricos que se suscitan, integrar ou non materiais e espazos de experiencia tipificados historicamente como privados na súa análise da acción política? Creo que neste aspecto cómpre evitar as posicións maximalistas nunha ou noutra dirección e atender a variables concretas de análise e ás demandas específicas do problema ou os problemas que guían a investigación. Decisións, por certo, que non están exentas dunha dimensión ética sobre a que tamén se discutiu xa moito e na que xa non me podo deter.

Por todo iso, o estado actual da práctica e da reflexión sobre a historia, a literatura e a biografía é dunha complexidade que rexeita as valoracións doadas e estereotipadas. Unha das súas virtualidades é a de establecer un escenario propicio para suturar as vellas feridas, que quizais nunca deberon producirse, entre a historia social, cultural e política; cruzar fronteiras entre elas e potenciar, no camiño, unha visión máis humanista e máis democrática da historia. Unha visión que lles axude a recońecer o principio de «individualidade significativa» a todos os seres humanos, salientando, polo tanto, o principio de responsabilidade individual e liberando o mundo histórico da súa inevitabilidade fatal. Aí é, precisamente, onde o historiador ten que usar a imaxinación. Non no sentido de inventar o que ocorreu ou puido ocorrer, nin no sentido de confundir a ficción coa realidade, senón no sentido de utilizar todos os seus recursos para alongar a súa humanidade e deixarse impregnar o máis posible da riqueza e da estrañeza do pasado. 
CARA A UNHA CULTURA

DA SUSTENTABILIDADE

(VALORES, MUDANZA

CULTURAL E ECOSOCIALISMO NO SÉCULO DA GRAN PROBA)

Jorge Riechmann

Universidad Autónoma de Madrid 

Nas condicións actuais o probable é o catastrófico. Non sei baixo que forma, pode ser unha mestura de guerra e de catástrofe ecolóxica [...]. Porén, tamén existiu o improbable na acción humana [...] Sobre o futuro non hai certeza ningunha [...]. Abofé, fáltanos a conciencia de humanidade planetaria que se atopa en xerme nas grandes relixións universalistas, e no humanismo occidental, que aínda non está desenvolvida. A humanidade concretouse a través dunha mesma comunidade de destino e atópase, desde agora en diante, ante ameazas mortais. A metamorfose non é probable...

Edgar Morin ${ }^{1}$

Penso, logo estorbo.

Lema da Academia de Pensamiento Crítico ${ }^{2}$

O séptimo dos Obxectivos de Desenvolvemento do Milenio — eses importantes compromisos internacionais que os países ricos asinan cerimonialmente coa firme intención de non os cumpriren - reza así: «Garantir a sustentabilidade do medio natural». Xa esta formulación nos remite á notable embrolla, repleta de ambigüidades e equívocos, que rodea a cuestión do desenvolvemento susten-

${ }^{1}$ Morin, Edgar (xunto con Patrick Viveret) (2011): Cómo vivir en tiempos de crisis, Barcelona, Icaria, 26 e 29.

${ }^{2}$ http://academiapensamientocritico.org/. 
table: pois non resulta difícil pensar que induce a un duplo erro. En primeiro lugar, apunta cara a un «medio natural» circundante e distinto de nós, e así apuntala unha errónea idea de separación entre natureza e sociedade. En segundo lugar, por suposto que non é a sustentabilidade dos sistemas naturais o que hai que garantir: é a sustentabilidade dos hoxe moi insostibles sistemas humanos. Non son os ecosistemas os que están a dar problemas, senón as sociedades humanas as que están a chocar violentamente contra os límites biofísicos do planeta.

Como se ve, resulta preciso tratar de disipar os numerosos equívocos que penden sobre o concepto de «desenvolvemento sustentable», e a iso se dedicará a reflexión que vai a seguir.

A crise ecolóxica non é un problema ecolóxico: é un problema humano. Trátase de quecemento climático antropoxénico, de sobreconsumo de recursos polas sociedades humanas, de extinción masiva de especies por causa da conduta humana... O impacto non procede de — digamos — ningún enorme asteroide que chocase, por algún mal fado, contra a Terra (tal e como sospeitamos que ocorreu en anteriores crises biosféricas): o impacto causámolo nós. Por iso deberiamos falar sempre de crise socioecolóxica ou ecolóxico-social. E ter sempre claro que, no canto de "xestión» dos recursos naturais ou «xestión» das crises ambientais, para saírmos do atranco o que precisamos é basicamente autoxestión humana. Unha maneira diferente de nos conducirmos — tanto individual como, sobre todo, colectivamente.

A idea de que podemos vivir facendo caso omiso das constricións ecolóxicas e termodinámicas é nova —apenas se abriu paso nos últimos douscentos anos, o período da Revolución Industrial—; é insensata; e terá unha vida breve (en termos históricos). Creamos unha lamentable economía da expansión material continua, e unha lamentable cultura da xeración constante de apetencias que buscan 
satisfacción inmediata. Semellante economía e cultura (capitalismo e consumismo, para abreviar) resultan extraordinariamente disfuncionais para o medio onde de xeito irremediable se desenvolven: a biosfera. O reaxuste é inevitable e todo indica que vai resultar terrible. Este Homo sapiens tan escasamente sapiens vai ter que aprender — rápida e brutalmente- a vivir de novo baixo constricións ecolóxicas: iso ou perecer. Ora ben, os seres humanos somos perfectamente capaces de vivir baixo constricións ecolóxicas: de feito, levamos moitos miles de anos facendo así. Hoxe trátase en boa medida de redescubrirmos eses equilibrios entre natureza e sociedade - esas pautas de sustentabilidade, diriamos en linguaxe máis contemporánea-e de os aplicarmos á crítica situación en que nos atopamos.

\section{4}

Xa o desfacérmonos dalgunhas crenzas falsas sería darmos un enorme paso adiante. A miúdo o mellor xeito de orientarmos os nosos pasos é desbotar os peores camiños equivocados (docta ignorantia). Refírome a crenzas tan básicas para a nosa sociedade produtivista/consumista como as seguintes: A) a economía pode crecer indefinidamente dentro dunha biosfera finita; B) os mercados competitivos permiten facer fronte eficientemente ás situacións de escaseza; C) a nosa tecnoloxía, para efectos prácticos, fainos omnipotentes. Se deixásemos de enganarnos respecto a estas cuestións básicas, estariamos en mellor situación para avanzarmos rapidamente cara á sustentabilidade.

Un cartel publicitario en espazos públicos madrileños, en 2010: «No Ano Internacional da Biodiversidade faLA DE BIODIVERSIDADE. Porque algo é importante cando empezas a falar diso». (O lema principal era CONSUMIMOS EN OITO MESES O QUE A NATUREZA TARDA UN ANO EN PRODUCIR, xunto cunha foto dunha mazá mordida, que figura á vez o planeta Terra.)

É certo... Para os seres falantes que somos os seres humanos — carne que fala-, é certo que as valoracións sobre o importante e o insignificante se constrúen nas conversas, os diálogos, o intercambio de razóns. E un problema só chega ao espazo público —ou se mantén nel— se falamos del...

Algo é importante cando empezas a falar diso. FALA DE CAPITALISMO... 
Como formulaba elocuentemente George Monbiot en 2002:

O capitalismo é un culto milenarista, elevado ao rango de relixión mundial [...]. Igual que os cristiáns imaxinan que o seu Deus os salvará da morte, os capitalistas cren que os seus os librarán da finitude. Aos recursos do mundo, aseveran, foilles garantida a vida eterna. Abonda unha reflexión breve para amosar que isto non pode ser verdade. As leis da termodinámica impoñen límites intrínsecos á produción biolóxica. Mesmo a devolución da débeda, o prerrequisito do capitalismo, resulta matematicamente posible só a curto prazo. Heinrich Haussmann calculou que un simple pfennig investido ao $5 \%$ de xuro composto no ano cero da nosa era sumaría hoxe un volume de ouro de 134000 millóns de veces o peso do planeta. O capitalismo persegue un valor de produción conmensurable co reembolso da débeda [...].

A produción material non pode crecer ao ritmo do xuro composto con que se acumulan as débedas (ou os retornos dos investimentos): mais ese imposible é un suposto básico do capitalismo.

(A organización do crédito, nunha economía ecoloxizada, debe ser radicalmente diferente á actual. Hai toda clase de boas razóns para socializar a banca - e canto antes mellor.)

\section{6}

Redución do uso da enerxía e materiais precisa para as economías dos países ricos seren máis ou menos sustentables: $90 \%$ (segundo os cálculos do proxecto Towards a Sustainable Europe en 1993-1996). Se isto se quere lograr con medidas de ecoeficiencia, sería posible — comenta Joachim Spangenberg- en medio século, operando cun «factor 10 ».

Mais, se neste tempo a economía segue a crecer ao $2 \%$, precisariamos un «factor 27» e, se crece ao $3 \%$ — limiar da creación neta de emprego nunha economía como a espańola! - , un «factor $45 » \ldots$ O crecemento expońencial dentro de ambientes finitos presenta problemas que simplemente non teñen solución. 
Nun planeta finito, con seres finitos como somos os humanos, a sustentabilidade é incompatible cun sistema económico que precisa vender cantidades sempre crecentes de mercadorías — sen límite — para subsistir. Podes ter sustentabilidade ou podes ter capitalismo, mais non podes telos ambos á vez.

Unha cabana, xunto dun luminoso mar azul, con bandexas de froita baixo as palmeiras e a compańa de amigos ou amigas con quen perder saborosamente o tempo xuntos, a xogar e a conversar... Alucina constatar na publicidade dos resorts turísticos máis exclusivos como o ideal de descanso que ofrece o capitalismo non é outra cousa que a vida sinxela das vilas precapitalistas, destruída vesanicamente no mundo enteiro só para ser ofrecida máis tarde — na súa forma privatizada e mercantilizada, claro está- ás elites de multimillonarios que poden acceder a ese luxo supremo. De xeito xenérico, e pese aos matices que sen dúbida cabe introducir, a economía capitalista non crea riqueza: crea escaseza, unha escaseza de orde superior.

«Canto é suficiente?» é unha pregunta que non ten sentido dentro do capitalismo (porque o dinamismo cego da acumulación de capital non pode deterse sen o derrubamento do sistema). Non hai sustentabilidade sen autocontención; e non hai posibilidade de autocontención colectiva dentro do capitalismo. Tal e como sinalan Santiago Alba Rico e Carlos Fernández Liria na interesantísima reflexión antropolóxica que propoñen en El naufragio del hombre:

Unha das necesidades máis imperiosas do sistema capitalista é a de se reproducir sempre en escala ampliada. Por iso é polo que as nosas clases políticas viven sempre obsesionadas co crecemento, vixiando se a economía crece ou non dabondo. A este respecto, Immanuel Wallerstein, tras acabar o seu inesquecible estudo sobre o capitalismo histórico, concluía dicindo que, visto no seu conxunto, se trata dun sistema "patentemente 
absurdo», pois "prodúcese capital para producir máis capital». $\mathrm{O}$ de menos é se polo camiño se satisfán as necesidades humanas ou sociais. $\mathrm{O}$ capitalismo precisa producir capital para acumular e producir aínda máis capital. «Os capitalistas», dicía Wallerstein, "son coma ratos nunha roda, que corren cada vez máis á présa a fin de correr aínda máis á présa» ${ }^{3}$.

No nivel de consumo de España, o planeta non podería soportar máis ca 2400 millóns de habitantes. Sobrarían, xa que logo, máis das dúas terceiras partes da humanidade...

Aínda máis: nun mundo que utilizase os seus recursos naturais e servizos ambientais ao nivel en que o fan os EUA hoxe - que se propoñen como modelo ao resto do mundo!- - só poderían vivir 1400 millóns de persoas. Se continuamos pola senda deste «modelo de desenvolvemento», os xenocidios están preprogramados.

Os «catro motores asociados e, ao mesmo tempo, descontrolados» que — a dicir de Edgar Morin - moven a nave espacial Terra, a saber: ciencia, técnica, industria e capitalismo, conducíronnos a un violento choque cos límites biofísicos do planeta. É hora de revisar a fondo eses motores. É hora dunha economía de «equilibrio biofísico e crecemento moral», por exemplo esa economía de estado estacionario (quizais sería mellor traducir steady-state por «homeostática») reivindicada por Herman E. Daly, quen precisa: «Vai ser moi difícil definir a suficiencia e construír o concepto no interior da teoría económica, e da práctica. Mais creo que aínda sería moito máis difícil seguir a actuar coma se "abondo" non existise».

\footnotetext{
${ }_{3}^{3}$ Alba Rico, Santiago / Carlos Fernández Liria (2010): El naufragio del hombre, Hondarribia/Fuenterrabía, Hiru, 90.
} 
O noso problema non debería ser que facemos cos residuos, senón como organizamos a produción, o traballo e o consumo. O problema dos residuos (a polución, o quecemento climático etc.) é derivado: as causas están na organización da produción, o traballo e o consumo. Principios de organización social como o de suficiencia (ou autocontención), o de biomímese (ou coherencia entre os sistemas humanos e os sistemas naturais) e o de precaución deben figurar na equipaxe que precisamos para avanzarmos cara a sociedades sostibles.

\section{2}

A ecoeficiencia é unha condición necesaria para a sustentabilidade; infelizmente, non só non é unha condición suficiente para esta (como a vulgata empresarial e gobernamental do «desenvolvemento sustentable» parece crer), senón que pode converterse nunha trampa que nos afaste dos nosos obxectivos. En efecto, baixo o capitalismo as ganancias na eficiencia con que a economía aproveita a enerxía e os materiais traducíronse non en diminucións da presión sobre os ecosistemas, senón en abaratamento dos prezos e en aumentos do consumo (nun proceso ben caracterizado polos economistas como «efecto rebote»). No sintagma —xa lexicalizado— «aforro e eficiencia» (referido por exemplo á enerxía) non somos quen de ver o potencial de conflito: a miúdo, na práctica, a eficiencia obra contra o aforro.

\section{3}

Se aspiramos de veras á sustentabilidade, daquela non estamos a falar de melloras incrementais, senón dun cambio de modelo. A científica experta en biomasa Mercedes Ballesteros escribe:

Partimos [no debate sobre os biocombustibles] dunha realidade moi concreta. Centos de millóns de coches móvense no mundo con derivados do petróleo e, gústenos ou non, 
vano seguir a facer durante os próximos anos. Xa que logo, é imprescindible que a análise dos aspectos positivos e negativos dos biocombustibles a fagamos comparando, punto por punto, cos derivados do petróleo.

Estas palabras da xefa da Unidade de Biomasa do CIEMAT delimitan ben os termos do dilema ao que nos enfrontamos. Se aceptamos «gústenos ou non» que o modelo de transporte actual é inamovible nas súas grandes dimensións, como o fai Ballesteros, daquela a política ambiental fica reducida a tratar de lograr melloras marxinais a partir da insostible situación actual. Mais esas melloras marxinais (de ecoeficiencia en sentido amplo) non nos sacan da insustentabilidade: se hai que tirar unha lección dos fracasos de política ambiental nos últimos tres decenios, sería esa. Sabemos que, para avanzar de verdade cara a unha sociedade sostible, o que hai que pór en marcha é un cambio de modelo: outra forma de producirmos, consumirmos, traballarmos, desprazármonos...

Practicar desprazamentos de impactos, facéndoos pasar por reducións de impactos, é o tramposo xogo de mans ao que polo xeral se consagraron estas políticas ambientais «avanzadas» das rexións máis industrializadas do planeta, nos últimos tres decenios. Así, o leitmotiv ou máximo fío condutor destas políticas, o obxectivo de "desacoplar crecemento económico e impacto ambiental», é enganoso: se ben na UE - por exemplo- varios Estados membros lograron no decenio 1995-2005 un desacoplamento relativo entre o crecemento do pIB e o uso de enerxía, iso non se traduciu nunha redución das presións ambientais en termos absolutos, porque o consumo de recursos en termos absolutos se mantivo máis ou menos constante nos últimos dous decenios. Pero o que é máis importante: $o$ "desacoplamento» dentro das fronteiras da UE débese sobre todo ao incremento das importacións de recursos naturais, que compensan a redución da produción ou extracción en Europa. É «externalización» de impactos, exportación de danos, e non verdadeiro desacoplamento ${ }^{4}$.

${ }^{4} \mathrm{O}$ incremento acumulado en emisións de dióxido de carbono de 1990 a 2010 é do $45 \%$; entre 2000 e 2010, do $30 \%$. Os descensos nos países máis ricos compensáronse abundantemente polos aumentos dos 
A inxenuidade idealista — se non o autoengano ou o cinismo- de afirmar que se poden «redefinir os obxectivos da empresa» capitalista para estes, no canto de perseguiren o beneficio privado, serviren o ben común... Mais o certo é que, no plano microeconómico, unha empresa capitalista que non persiga o máximo beneficio, operando en mercados competitivos, será borrada do mapa. E, no plano macroeconómico, a lóxica da acumulación de capital impulsa á vez o crecemento económico e a destrución ecolóxica...

Soberanía do consumidor? Poder dos consumidores? Só se poderían pór esperanzas en algo así se a masa de consumidores non fose ela mesma un produto do capitalismo corporativo. Os conglomerados de poder empresarial manufacturan as subxectividades dos compradores de mercadorías, igual que manufacturan as mercadorías...

Non podemos confiar no poder dos consumidores: só no dos cidadáns e cidadás. $\mathrm{O}$ poder potencial do consumidor — que é real— non pode actualizarse en tanto el ou ela actúan como consumidores: só a través da articulación dos cidadáns.

En sociedades con mercados, a fiscalidade ecolóxica é probablemente a pedra de toque para calibrar a vontade dos sectores dirixentes de avanzar cara a unha sociedade sostible. Mais tanto Gobernos do PSOE como do PP, desde hai dous decenios, se opuxeron a unha carga fiscal crecente sobre os combustibles fósiles harmonizada a escala europea. E nos últimos anos é pouquísimo o que se fixo para avanzar neste eido: apenas o retoque á carga fiscal asociada á matriculación de automóbiles. Infelizmente, tampouco a infausta poxa de rebaixas fiscais á que asistimos na campaña electoral do 9-M de 2008 permite esperar que ningún dos dous grandes partidos dea desde o Goberno central, nestes anos próximos, os pasos firmes cara a unha verdadeira reforma fiscal ecolóxica que precisamos. E, en 2011-2012, a violenta reacción de case o mundo enteiro —incluíndo os EUA, países «en vías de desenvolvemento", que non deixaron de aumentar o seu uso de carbón e petróleo. De feito, os descensos deses países ricos explícanse en boa parte polo traslado da produción máis intensiva en enerxía a países como a China ou a India: véxase Méndez, Rafael (2011): «Las emisiones no bajan: se mudan», El País, 8 de outubro. 
Rusia, a China e a India - contra o intento da UE de gravar cunha tímida taxa «verde» a aviación comercial dános outra vez a medida do desbocado produtivismo que segue a prevalecer.

O marketing perverte, e o "marketing verde» perverte de forma especializada. Os seres humanos somos moi bos á hora de nos autoenganarmos e de disociarmos as nosas condutas dos nosos valores, mais ao longo dos últimos oitenta anos a mercadotecnia capitalista exacerbou e refinou estas disposicións ata as converter nunha tremebunda patoloxía social. Unha sociedade onde a maioría confunde a vida cunha cinta de debuxos animados está a renunciar aos recursos con que podería evitar a autodestrución.

O desenvolvemento sustentable era unha boa idea; a perspectiva dos servizos ecosistémicos é outra boa idea. Mais no contexto político-cultural en que nos atopamos, dentro do marco conformado pola ideoloxía neoliberal que prevalece, estas boas ideas acaban producindo resultados contrarios aos propósitos dos que as puxeron en circulación: convértense nunha ferramenta adicional para a destrución da natureza. (Erik Gómez-Baggethun amosouno ben, no caso dos ecosystem services, coa súa tese de doutoramento.)

Se a economía xa parecía unha "ciencia lúgubre» hai máis de século e medio (a Thomas Carlyle, no seu ensaio de 1849 «Occasional Discourse on the Negro Question»), que dicir da economía ecolóxica, coa súa insistencia na natureza entrópica do noso mundo, na limitación dos recursos, na necesidade de austeridade? De aí que debamos insistir decontino non só nas constricións materiais 
que veñen impostas pola finitude da biosfera, senón nas enormes posibilidades de liberdade humana e boa vida que se abren cando aceptamos formas de vida máis igualitarias, cooperativas e coidadoras da natureza. Ecoloxizar a economía e a sociedade non é só apertar o cinto: tamén é vivir mellor.

Falar moito sobre o medio natural non significa estar a actuar eficazmente contra a crise ecolóxico-social. Intoxicámonos de realidade virtual, mentres a devastación continúa. E adormecemos cos datos demoscópicos que nos falan dunha conciencia ecolóxica crecente — aínda que estea divorciada da conduta—, e coas medidas gradualistas que prometen unha mellora incremental nalgún aspecto ambiental - malia que o que precisariamos son momentos de ruptura para producirmos, traballarmos e consumirmos doutro xeito.

O 4 de abril de 1992, nos prolegómenos do «Cumio de Río» sobre medio natural e desenvolvemento (UNCED polas súas siglas en inglés), Maurice Strong — secretario xeral dela — declaraba: «O noso modelo de desenvolvemento, que conduce á destrución dos recursos naturais, non é viable. Debemos mudalo». A desoladora resposta chegaba dos beizos de George Bush (pai), presidente dos EUA: «O noso modo de vida non é negociable». Máis de tres lustros despois, seguimos aí. A camarilla nihilista que non acepta a necesidade de transformar a nosa way of life aínda segue ao mando, mentres que os problemas empeoraron dramaticamente.

Non era ningún ecoloxista radical, senón o secretario xeral de Nacións Unidas, Ban Ki-moon, quen perante os máis de 1500 delegados presentes na reunión da Organización Mundial de Meteoroloxía, último foro preparatorio do Cumio de Copenhague en decembro de 2009 (pola súa vez, quizais, a última oportunidade para tratar de evitar a catástrofe climática que estamos a urdir), afirmaba: «Temos o pé atoado no acelerador e rodamos cara ao abismo». Isto é sobrio e veraz. 
O signo dos tempos —os nosos tempos terribles—: dous cargueiros alemáns chamados Fraternity e Foresight abren por vez primeira o "paso do noroeste» en setembro de 2009, aproveitando que o quecemento global desxea ominosamente o Ártico en verán. Trátase da ruta que une Europa con Asia a través de Siberia, e - con arrepiante simbolismo- o que transportan ambos os buques son senllas turbinas de gas para unha central eléctrica que Rusia está a construír na cidade siberiana de Surgut. Vale dicir material para incrementar aínda máis as emisións de dióxido de carbono e así realimentar o quecemento global. Máis leña, en suma, para a pira onde imos arder.

Cara ao abismo a toda máquina, co pé encaixado no pedal acelerador.

Insistir na boa conduta ecolóxica individual, en ser cidadáns e cidadás «ecoloxicamente virtuosos»? Xaora. Mais non porque — como reza o tópico- «cada gran de area conta», de xeito que os "xestos sinxelos» e indoloros poidan irse sumando ata «salvar a Terra»; non porque converténdonos un a un en "consumidores verdes» vaiamos deter a devastación da biosfera. Ningunha suma de mudanzas nos hábitos individuais de consumo pode substituír as transformacións estruturais (nas institucións políticas, no sistema de crédito, na economía produtiva) que son urxentemente necesarias.

De modo que as razóns que podemos invocar a prol da "virtude ecolóxica» son outras. En algures exploreinas con certo detalle. Aquí só quero apuntalas telegraficamente:

Un, construírmonos como suxeitos que manteñan a súa decencia básica: que poidan mirarse ao espello sen sentiren vergoña. Unha sociedade que busca manter as súas satisfaccións a custa de depredar o pasado e o futuro, a custa de arrebatar os recursos que precisan os pobres e famentos de hoxe en día, e de ocupar o espazo ambiental que corresponde ás demais especies vivas, non pode estar integrada maioritariamente por suxeitos decentes.

E dous, non esquecer nunca que pequenas causas - en certas condicións críticas, cando un sistema complexo non lineal pode bascular dun estado para outro- poden producir grandes efectos. Esta é unha perspectiva sobre a que Edgar Morin insiste a miúdo... 
Se se acepta o básico do razoamento anterior, está claro que unha economía que «faga as paces coa natureza», unha economía ecoloxizada, haberá ser unha economía subordinada á sociedade e á biosfera: unha economía ecosocialista. Mais como pensar a transición? En primeiro lugar, resulta desalentador comprobar como as numerosas experiencias cooperativas e comunitarias ensaiadas desde hai dous séculos dentro do marco capitalista acabaron, na gran maioría dos casos, sendo reabsorbidas por este. E, en segundo lugar, resulta deprimente constatar que as experiencias de xestión económica non capitalista, con planificación central imperativa, que seguiron á revolución soviética en 1917 conduciron á derradeira a monumentais desastres sociais e ecolóxicos. Non é este o lugar para desenvolver unha análise crítica de tales fenómenos. Valla simplemente sinalar, xunto cos marxistas estadounidenses Foster e Magdoff, que a transición hoxe precisa hai que a concibir como un proceso difícil e probablemente moi longo, non como un «asalto ao Palacio de Inverno». Pois

a loita é en última instancia contra o sistema do capital. Porén, ten que comezar opóndose á lóxica do capital, esforzándose aquí e agora pola creación, nos intersticios do sistema, dun novo metabolismo social arraigado no igualitarismo, a comunidade e unha relación sustentable coa Terra. As bases para a creación dun desenvolvemento humano sustentable deben xurdir desde o interior do sistema dominado polo capital, sen seren parte del, como a mesma burguesía o fixo desde os «poros» da sociedade feudal. Ao cabo, estas iniciativas poden tornarse o suficientemente poderosas para constituíren as bases revolucionarias dun novo movemento e unha nova sociedade.

Reteñamos a última analoxía sobre a transición que precisamos: a comparación correcta non sería con tal ou cal comuna autoxestionada que en última instancia acaba sendo devorada pola dinámica de mercantilizar todo o divino e o humano, senón co longo proceso de xestación da sociedade burguesa nos intersticios da sociedade feudal. 
O capitalismo global, e sobre todo o capitalismo financiarizado que non deixou de crecer desde os anos oitenta do século xx, é a máquina da cobiza. É autodestrutivo nun grao case inimaxinable..., mais autodestruíndose destrúenos. As rodas desa máquina deixaron de xirar.

$\mathrm{Na}$ perspectiva da sustentabilidade, a mudanza valorativa máis importante é pasar de «máis é mellor» a o suficiente abonda.

\section{E 25 (FINAL CON EDGAR MORIN)}

Cando un sistema é incapaz de resolver os seus problemas vitais por si mesmo, degrádase, desintégrase, a non ser que estea en condicións de orixinar un metasistema capaz de o facer e, daquela, metamorfoséase. O sistema Terra é incapaz de se organizar para tratar os seus problemas vitais: o perigo nuclear, agravado pola diseminación e, talvez, privatización da arma atómica; a degradación da biosfera; unha economía mundial carente de verdadeira regulación; o retorno das fames; os conflitos étnico-político-relixiosos que tenden a dexenerar en guerras de civilización... A ampliación e aceleración de todos eses procesos poden ser consideradas o desencadeante dun formidable feedback negativo, capaz de desintegrar irremediablemente un sistema.

O probable é a desintegración. O improbable, malia que posible, a metamorfose. Que é unha metamorfose? O reino animal fornece exemplos. A eiruga que se encerra nunha crisálida comeza así un proceso de autodestrución e autorreconstrución ao mesmo tempo, adopta a organización e a forma da bolboreta, distinta á da eiruga, mais segue a ser ela mesma. O nacemento da vida pode ser concibido como a metamorfose dunha organización físico-química que, acadado un punto de saturación, crea unha metaorganización vivente, a cal, aínda cos mesmos constituíntes físico-químicos, produce calidades novas. A formación das sociedades históricas, no Oriente Medio, a India, a China, México ou o Perú, constitúe unha metamorfose a partir dun conglomerado de sociedades arcaicas de cazadores-recolectores que produciu as cidades, o Estado, as clases sociais, a especialización do traballo, as relixións, a arquitectura, as artes, a literatura, a filosofía... E tamén cousas moito peores, como a guerra e a escravitude. 
A partir do século xxi, preséntase o problema da metamorfose das sociedades históricas nunha sociedade-mundo dun tipo novo, que englobaría os Estados-nación sen os suprimir. Pois a continuación da historia, é dicir, das guerras, por uns Estados con armas de destrución masiva conduce á quasi destrución da humanidade. A idea de metamorfose, máis rica ca a de revolución, contén a radicalidade transformadora desta, mais vencellada á conservación (da vida ou da herdanza das culturas) [...]. Para elaborar as vías que confluirán na Vía, temos de nos desfacer das alternativas redutoras ás que nos obriga o mundo de coñecemento e pensamento hexemónicos. Así, é preciso, ao mesmo tempo, mundializar e desmundializar, crecer e decrecer, despregar e repregar [...].

Hai razóns para a esperanza? Podemos formular cinco:

1. O xurdimento do improbable. A vitoriosa resistencia, en dúas ocasións, da pequena Atenas fronte ao poderío persa era altamente improbable, mais permitiu o nacemento da democracia e a filosofía. Tamén foi inesperado o arrefecimento da ofensiva alemá ante Moscú, no outono de 1941, e improbable a contraofensiva vitoriosa de Zhúkov, iniciada o 5 de decembro, que viría seguida, o 8, polo ataque de Pearl Harbor e a entrada dos Estados Unidos na guerra.

2. As virtudes xeradoras-creadoras inherentes á humanidade. Igual que en todo organismo adulto existen células nai dotadas de aptitudes polivalentes (totipotentes) propias das células embrionarias, mais desactivadas, en todo ser humano, e en toda sociedade humana, existen virtudes rexeneradoras, xeradoras e creadoras dormentes ou inhibidas.

3. As virtudes da crise. Ao tempo que as forzas regresivas ou desintegradoras, as xeradoras e creadoras acordan na crise planetaria da humanidade.

4. As virtudes do perigo. "Aló onde medra o perigo, medra tamén o que nos salva». A dita suprema é inseparable do risco supremo.

5. A aspiración multimilenaria da humanidade á harmonía (paraíso, logo utopías, despois ideoloxías libertaria/socialista/comunista, máis tarde aspiracións e revoltas xuvenís dos anos sesenta). Esta aspiración renace no fervedoiro de iniciativas múltiples e dispersas que poderán alimentar as vías reformadoras destinadas a confluír na vía nova... 
O LUGAR DAS EMOCIÓNS

NA POLITICA

Victoria Camps

Catedrática de Filosofía

Universitat Autònoma de Barcelona 

Nada grande se fixo nunca sen entusiasmo.

Ralph W. Emerson

O propósito xeral do meu libro El gobierno de las emociones foi investigar cal é o lugar das emocións ou dos sentimentos na ética. Partía de dúas intuicións: 1) que só as emocións nos moven a actuar e 2) que as emocións son gobernables e o dito goberno é unha das tarefas da ética. No que vai a seguir, expoño as liñas xerais da devandita investigación e a súa aplicación ao discurso da política.

\section{AS EMOCIÓNS NA FILOSOFÍA MORAL}

«Emocións» é un vocábulo de gran difusión actual, que designa unha serie de termos análogos, utilizados con frecuencia na linguaxe da filosofía moral: «sentimentos», «paixóns», «afectos». Non todos os filósofos estableceron unha relación positiva entre o comportamento moral e a parte afectiva do ser humano. Polo xeral, sobre todo na modernidade, a ética foi entendida como a expresión da actividade racional máis pura. Herdamos unha ética sobre todo «de principios» ou «de consecuencias» e, moito menos, unha ética das virtudes, é dicir, unha ética perfeccionista, centrada nos hábitos que ha de adquirir o ser humano para lograr a excelencia. Para alén da filosofía, os estudos sobre o cerebro pońen de manifesto que este non é unha máquina de pensar de acordo con certas regras, senón que primariamente serve para «sentir».

Aristóteles é o mellor expoñente dunha ética das virtudes, a maioría das cales coloca na parte sensitiva da alma, máis ca na racional. Para Aristóteles, a ética 
non debería ser unha tarefa especulativa, senón práctica: a formación do ethos ou carácter das persoas. Outro filósofo que non concibe a ética separada das «afeccións» do corpo é Spinoza, para quen a ledicia e a tristura son os afectos que explican o aumento ou a diminución da potencia de actuar do ser humano. O terceiro filósofo que merece ser destacado pola súa valoración dos sentimentos por riba da razón é Hume, cuxa teoría moral se resume na coñecida frase «A razón é escrava das paixóns». Ao xuízo de Hume, non é a razón a que explica a distinción entre o ben e o mal, senón o sentimento de simpatía ou empatía cos outros, que é intrínseco á natureza humana.

É importante que a ética do noso tempo recupere as leccións dos tres filósofos mencionados e preste máis atención ao lugar que o sentimento ten nela. É un xeito de nos fixarmos nos móbiles do comportamento moral, un tema pouco abordado polas teorías filosóficas e dependente, talvez, dunha concepción excesivamente pesimista da condición humana, por causa da súa vulnerabilidade e continxencia. Fixarse nas emocións é tamén un xeito de corrixir a idea, témome que xeneralizada de máis, de que abonda con elaborar códigos morais ou lexislar para as condutas mudaren. Efectivamente, a función dos principios e as normas é transformar os comportamentos individuais e sociais, mais esa transformación depende, así mesmo, da vontade, que ha de se acostumar a querer o ben, o cal require unha aprendizaxe e unha formación non só no cońecemento de dereitos e principios, senón no de como xestionar e administrar os sentimentos. O «que é o que debemos facer» non pode discorrer á marxe do «que é o que debemos sentin». A educación dun neno consiste en gran medida en lle aprender a sentir as emocións adecuadas para cada ocasión: chorar e rir cando o caso o pide, avergońarse e indignarse ante o que está mal, confiar en quen o merece e sentir compaixón de quen sofre. A moral non consiste só en realizar algunhas accións boas, senón en ter unha «alma sensible» que induza a actuar en consecuencia. Dicía Hutcheson: "Aquilo que se sente como bo constitúe un deber; quen carece dunha alma sensible é incapaz de recoñecer deber ningún».

Precisamos unha ética porque sabemos que a realidade humana é social e que non temos máis remedio que entendérmonos. É o que levou a filosofía moral a procurar principios universais, comúns a toda a humanidade e definitorios, ao mesmo tempo, desa humanidade. Semella lóxico que eses principios presupoñan, pola súa vez, unha comunidade de sentimentos. Unha comunidade que 
comparta ideas como que as desigualdades, as discriminacións, as tiranías, as distintas expresións da violencia non son xustas. Unha comunidade que, pola súa vez, sinta rexeitamento e repugnancia cara a quen non vive de acordo con tales ideas e se entusiasme, en troques, ante as manifestacións da xustiza. A visión racional do mal debería producir un rexeitamento emotivo do que está mal; ou, ao revés, o rexeitamento emotivo de certas realidades levounos á convicción de que as rexeitamos porque non son como deberían ser.

Mais a apreciación positiva do papel das emocións non pode levarnos a substituír a ética racionalista por unha ética emotivista. Porque iso sería relativizala e subxectivizala, exaltar o sentimento por si mesmo e deixalo que se exprese tal cal é. Ou situar o fundamento das conviccións morais na adhesión sentimental a elas, como fixo na súa época o emotivismo. Algo de todo iso hai no actual culto ás emocións, o cal, para Michel Lacroix, «representa o apoxeo do culto ao eu». Desde tal perspectiva, a educación parece que segue unha traxectoria errada, non formativa, ao lle dar máis valor á espontaneidade do neno ca á necesidade de a orientar. A función da educación moral é ensinar a gobernar as emocións póndoas ao servizo dos fins da vida humana: vivir xustamente e vivir ben. Facer algo parecido ao que propuxo Aristóteles na súa Retórica: analizar cada unha das paixóns vendo os aspectos positivos e negativos delas e o xeito de as potenciar. Xa que, como se di na Ética a Nicómaco, «[c]alquera pode anoxarse, iso é algo moi sinxelo. Mais anoxarse coa persoa axeitada, no grao exacto, no momento oportuno, co propósito xusto e do modo correcto, iso, certamente, non é tan sinxelo».

Inspírome nos que afirman que as emocións teńen unha compońente cognitiva fundamental. Justin Oakley, no libro Morality and the Emotions (1992), define as emocións como «un complexo de afectos, cognicións e desexos». Emocións como o medo ou a compaixón consisten, en efecto, en modificacións corporais ou psíquicas que indican que a idea de algo visto, oído ou pensado afecta á persoa. A afección prodúcese por causa de pensamentos ou crenzas que relacionamos con determinados fenómenos, os cales, pola súa vez, derivan no desexo de evitar ou, pola contra, manter a causa da emoción. O temor a sermos vítimas dun roubo nunha rúa concorrida dunha gran concentración urbana ten o seu fundamento en crenzas derivadas de experiencias oídas ou vividas na propia pel. Esa crenza xera, como é lóxico, o desexo de evitar que o roubo se produza. $\mathrm{O}$ amor a outra persoa baséase na crenza de que esa persoa o ten todo: pódese con- 
fiar nela, é atractiva, é interesante, é guapa. Un desexa ao mesmo tempo que esa crenza non se vexa frustrada, senón alimentada polo contacto coa persoa querida. As emocións poden proceder de crenzas ou cognicións erradas; de feito, moitas veces ocorre así. En calquera caso, a causa dunha emoción determinada é certa visión (cognición) das cousas, que xera rexeitamento ou desexo de permanencia.

Tanto a compońente cognitiva das emocións como a desiderativa interesan especialmente para a perspectiva moral sobre elas. Impórtanos saber que as provoca e como inflúen na conduta, que crenzas as alimentan e que motivacións para actuar derivan delas. Desde tal punto de vista, as emocións foron definidas tamén como «disposicións mentais» que xeran actitudes (Richard Wollheim [1999]: Sobre las emociones). A súa vinculación co desexo convérteas, efectivamente, en disposicións a obrar, que lle fornecen á persoa unha orientación, a cal vén dada polas crenzas que un ten sobre a realidade e se proxecta cara a un obxectivo propiciado polo desexo. As crenzas provén a persoa dunha «imaxe do mundo que habita», mentres que os desexos lle fornecen «obxectivos ou cousas a que aspirar». A ponte que vencella as crenzas ao desexo é o estado emotivo. Dito doutro xeito, as crenzas crean un mapa do mundo e os desexos apuntan a percorrelo ou, pola contra, a evitalo.

Investigando sobre as emocións máis clásicas —a vergoña, o medo, a ira, a compaixón, a confianza-, descubrimos dúas características constitutivas da emoción: a ambivalencia e a vinculación delas coa vulnerabilidade do ser humano. A ambivalencia pon de manifesto que ningunha emoción é, por si mesma, inadecuada, se ben pode chegar a selo dependendo das circunstancias que a suscitan, como pode ser tamén, pola contra, un estímulo excelente para o comportamento correcto e xusto. Por outra banda, coa emoción exprésase a subxectividade de cada persoa, é dicir, o que hai en nós de máis feble, continxente e vulnerable. "As emocións son a expresión de verse necesitado, da falla de autosuficiencia», escribe Martha Nussbaum. Tal é a explicación de que os sentimentos fosen desvalorizados pola filosofía moral e se potenciase, pola contra, a razón, pretendidamente universal e capaz de descubrir o que debería ser necesario e non continxente: a lei moral.

Ambas as características, a ambivalencia e a vulnerabilidade das emocións ou os sentimentos, poñen de manifesto, así mesmo, a posibilidade de os moldear e transformar. Se en certas circunstancias cumpren unha función positiva, para o 
individuo e para o conxunto da sociedade, e noutras non, quere dicir que é posible utilizalas e orientalas cara ao fin que pretendamos. Algo que non pasou desapercibido e que levou a instrumentalizar certas emocións ou a silenciar outras en beneficio dun statu quo ao servizo dos intereses dominantes. A vergońa, por exemplo, padecérona máis as mulleres ca os homes, o medo foi e é politicamente instrumentalizado, reprimiuse a indignación dos cidadáns cando lle molestaba ao poder dominante etc., etc. Se pensamos que as emocións son gobernables, é porque son, así mesmo, unha construción social que as moldea, crea ou destrúe en función dos costumes e necesidades predominantes.

\section{II}

\section{AS EMOCIÓNS NO DISCURSO POLÍTICO}

Tras analizar a campaña de Obama ás eleccións presidenciais dos Estados Unidos, Manuel Castells conclúe dicindo que, se a campańa se converteu nun «caso de política insurxente», na era da información, foi pola «capacidade do candidato para inspirar emocións positivas (entusiasmo, confianza, esperanza) nun amplo segmento da sociedade, conectando directamente coas persoas ao tempo que coas organizacións en redes e comunidades, de forma que a súa campaña tamén era en gran medida a deles» (Manuel Castells [2009]: Comunicación y poder, Madrid, Alianza).

É evidente, en efecto, que, para alén da calidade política do candidato, para alén da solidez do seu programa, para alén da ilusión de ver un presidente negro nos Estados Unidos, no caso de Obama produciuse unha empatía, unha esperanza e un entusiasmo que lle fallou á rival, Hillary Clinton, pese a contar no seu haber con máis experiencia política e coa novidade nada trivial de poder chegar a ser a primeira muller presidenta do mesmo país. A linguaxe emocional é importante non só para a ética; éo tamén, e especialmente, para a política.

Os políticos non o ignoran, soubérono sempre, e tamén os teóricos da política. Sóuboo Aristóteles cando escribiu a Retórica entendendo a arte da elocuencia como a capacidade para mover vontades para fins políticas. Sen esa capacidade de arrastre que 
ten unha comunicación emocional e afectiva, a política nin convence nin conmove. Ocorreu en todos os tempos, non só agora, cando os medios de comunicación de masas propician a circulación de mensaxes máis emotivas e pasionais. Insisto en que subliñar a importancia da emoción non implica contrapor a paixón á razón, senón amosar que a razón necesita da paixón e esta daquela. Mais a imbricación de ambas non é doada. A paixón pura e desbocada é perigosa na vida do individuo e máis aínda na da colectividade. Pola súa vez, a razón estrita e fría é ineficaz e carece de magnetismo para atraer as persoas cara ás causas que merecen algo de atención e un mínimo de entusiasmo colectivo. Xabier Etxeberria recoñece que «os sentimentos, en si subxectivos, teñen unha gran capacidade de impactar no espazo público, cando se expresan como vivencias compartidas que serven obxectivos políticos». Por iso engade que os sentimentos, na vida pública, son «ineludibles» e "necesarios», mais son, así mesmo, "perigosos» (Xabier Etxeberria [2008]: Por una ética de los sentimientos en el ámbito público). O primeiro paso para conxurar o perigo será contar con eles analizando o poder e a influencia que teñen no sentir e o actuar colectivos.

\section{OS «CADROS CONCEPTUAIS»DA DEREITA E DA ESQUERDA}

George Lakoff fíxose célebre coa aplicación ao eido da política da teoría do framing ou "encadramento», desenvolvida previamente polas ciencias cognitivas. Os «cadros» son estruturas mentais que lle permiten ao individuo entender a realidade. Irving Goffman foi un dos primeiros en utilizar a teoría dos cadros para explicar as nosas interactuacións co mundo. Todas as institucións e espazos onde as persoas se atopan unhas con outras teñen os seus cadros específicos que establecen algo así como as regras do xogo das distintas relacións. Os hospitais, por exemplo, posúen un cadro específico, no cal hai un tipo de persoas - médicos, enfermeiras, enfermos - e uns espazos — salas de espera, quirófanos, camas- e onde teñen lugar unhas accións —intervencións cirúrxicas, consultas, terapiasque non se dan noutros lugares. Cada cadro determina unha lóxica interna, unha maneira de funcionar, exclúe certos comportamentos, establece unhas xerarquías entre os actores. Polo que fai ás institucións políticas e á actividade política mesma, tamén estas se estruturan a partir de cadros específicos. Lakoff dedicouse a estudar e analizar cales son os cadros que enmarcan a actividade política, que 
os caracteriza e que os distingue. Concretamente, desenvolveu as diferenzas que separan os cadros que contextualizan o discurso da dereita conservadora cos da esquerda progresista. Importa sinalar que os cadros adoitan ser inconscientes, non sabemos que están a estruturar o noso pensamento. Configuran o sentir común dunha sociedade. Cando un partido político consegue que os seus cadros dominen a esfera pública, fai que mude o sentir común dos cidadáns. É o que, ao xuízo de Lakoff, fixo a dereita (polo menos nos Estados Unidos) sen a esquerda se decatar disto nin facer nada por llo impedir. Os cadros, pola súa banda, son necesarios porque sen eles os feitos non din nada. Son os cadros os que lles dan sentido aos feitos. A expresión «inmigración ilegal», por exemplo, define a inmigración actual e confírelle un significado que nos leva a vela con reticencia e desconfianza. A «carga fiscal» constitúe un cadro para pór de manifesto que pagar impostos é algo molesto, incómodo e opresivo. O discurso que se refire só a feitos nus, o discurso máis apreciado pola maioría dos políticos, e que se estende en longas e soporíferas listaxes de cifras e estatísticas, non logra transmitir nada con sentido. Carece de cadro. Máis aínda, o propósito de negar o cadro do adversario ou de se zafar dunha acusación só consegue reforzar o que se trata de ocultar. Cando Nixon dixo «Non son un escamoteador», todos o viron como un ladrón.

A teoría dos cadros que estruturan o pensamento con cosmovisións e metáforas xeralmente inconscientes refuta as ideas defendidas polo racionalismo segundo as cales existe unha razón universal e o pensamento é só verbal, é un reflexo da realidade e é sempre consciente. Nada disto é exactamente así. Lakoff corrobórao ao pór de manifesto a irrelevancia dos feitos puros:

Se se cre no racionalismo, crese que os feitos nos farán libres, é dicir, que abonda con fornecer toda a información sobre os feitos e a xente, sen necesidade de cadro ningún, razoará ata dar coas conclusións pertinentes. Sabemos que non é así: se os feitos non se axustan aos cadros, a xente quedará cos seus cadros (que están fisicamente no seu cerebro) e ignorará ou esquecerá os feitos ou razoará en contra deles. Os feitos teñen que estar encadrados de maneira que teñan sentido e poidan converterse en elementos do razoamento. (George Lakoff [2008]: Puntos de reflexión: manual del progresista)

Dito doutro xeito, cando o discurso político descoida as valoracións, os símbolos, as emocións que en realidade están a encadrar a linguaxe e a lle dar sentido, 
a xente non sente que o que se lle propón está ben ou merece ser considerado. Non o sente porque o político non chega a transmitir ese sentimento que posiblemente el posúa mais non sabe comunicar. Os políticos demócratas, ou socialistas, que constitúen o albo preferido de Lakoff, seguramente saben por que é bo crer no socialismo. O problema é que non o fan explícito cando explican as decisións que toman. Ao revés, moitas veces toman prestados argumentos da dereita, coma cando explican que a inmigración hai que a aceptar porque economicamente é conveniente e os inmigrantes cargan cos postos de traballo que os autóctonos desprezan, no canto de diciren, como lles correspondería, que todos, veñan de onde veñan, teñen dereito a un traballo digno. Así, ao non ver destacados os principios morais que determinan a adhesión a unhas determinadas políticas, o cidadán deixa de se ver afectado polos programas e as propostas que lle chegan. Non lle din nada nin o mobilizan en sentido ningún. Os conservadores sempre foron máis directos e menos acomplexados ao poren de manifesto cales son os seus valores máis queridos: a patria, a familia, a vida, a seguridade. Os progresistas, pola súa banda, temen desvelar as súas crenzas, de xeito que prefiren ocultalas. Por iso a súa linguaxe non conmove.

En definitiva, propón Lakoff, caemos nunha serie de trampas que a esquerda debería evitar. Unha delas é a trampa do "tema propio», pois non hai temas propios da esquerda ou da dereita, senón, máis ben, maneiras progresistas ou conservadoras de os tratar. Tamén son unha trampa as enquisas, a «listaxe de propostas», como o son a linguaxe técnica, o menosprezo do outro e as descualificacións mutuas. E é unha gran trampa ese racionalismo que consiste en crer que «a razón é algo completamente consciente, verbalizado, lóxico, universal e libre de emocións». Non só é unha trampa, senón que é falso, como se ocuparon de amosar as ciencias cognitivas. En política case todo é opinable e, en cuestión de opinións, as emocións preceden as razóns; é dicir, que, en primeiro lugar, escollemos o candidato; despois, buscamos razóns para lle votar.

Nunha liña semellante á de Lakoff, Drew Westen afirma que o «cerebro político» é emocional. É emocional porque a xente quere identificarse cos seus candidatos, poder dicir: "gusto del», "é coma min», "non é un privilexiado», "entendo o que me di». Ronald Reagan dominou coma ninguén a identificación emocional. En xeral, Westen coincide con Lakoff: os republicanos nos Estados Unidos dominan «o mercado das emocións», en tanto que os demócratas se centraron no 
«mercado das ideas», que non ten nada de apaixonante (Drew Westen [2007]: The Political Brain).

Como se apela ao circuíto emocional? Lakoff e Westen non o dubidan: desintelectualizando as mensaxes, que é o que non soubo facer a esquerda. As campañas electorais dos demócratas non foron boas por racionais, ideolóxicas e intelectuais de máis. As declaracións de intencións abstractas non emocionan como o fan as situacións concretas que se refiren a persoas de carne e óso, identificables. A mellor campaña é a que "conta historias» e "fala desde as tripas», non a que calcula sobre a base de enquisas ou pretende convencer con cifras e estatísticas. Máis aínda, «a xente vota polo candidato que estimula os sentimentos correctos, non polo que presenta os mellores argumentos». Por iso é importante para un partido "ter un relato». Que é ser socialista? Hai que o explicar non a partir duns temas e unhas razóns — traballadores, desigualdade, discriminación-, nin por medio dunha listaxe de políticas, senón contando historias, mediante unha narrativa que amose plasticamente que un está contra algo ou defendendo algo. Vivimos na era da imaxe e as mentes afixéronse a isto. A apelación a principios ou dereitos universais a maioría das veces só serve para acentuar os enfrontamentos entre as distintas faccións políticas. O que deben facer os demócratas é «personalizar o rostro da inmoralidade, a hipocrisía e a indiferenza ante o sufrimento propias dos republicanos». Ante un caso de eutanasia, como os que se deron recentemente en distintos países, un caso que suscita debate e demanda ao político que tome posición, a pregunta pertinente non é se debe haber ou non un dereito a morrer, teórica e impersoal de máis para atraer a atención, senón algo coma isto: «Gustaríache que fixesen contigo o que fixeron, por exemplo, con Lucía Echevarría?». Enquistarse nunha linguaxe de ideas é falarlle á parte errada do cerebro. As campañas gánanse máis coas vísceras ca cos temas.

\section{DEMASIADAS CONCESIÓNS AO EMOCIONAL?}

Para calquera que conserve unha mínima fe no papel das ideas e o intelecto para mellorar o mundo, o dito ata agora é todo menos alentador. Enténdese que ocorra o que ocorre, mais déixanos coa impresión de que non hai máis remedio que empobrecer o discurso político para este ter garra e arrastrar os electores. 
Pois non só o noso cerebro non está feito só para a abstracción e os argumentos racionais, senón que a retórica do mercado e da publicidade nos afixeron non a razoar, senón a sentir, e iso é o que finalmente conta. Á falla de ideoloxías, non pensemos xa en achegar novas ideas para entendermos o mundo e sinalarmos para onde imos. Abondará con que adoptemos unha retórica sentimentalista, que suscitemos o amor e compaixón polos que sofren e polos desposuídos, que nos identifiquemos coas vítimas e nos solidaricemos co seu malestar. Posto que provocar emocións é sinxelo, o problema non é tanto apelar a elas, senón facelo do xeito incorrecto. "O problema sobrevén — comenta Manuel Cruz verbo disto- cando a xente se emociona máis ante as cores do seu equipo ca ante o sufrimento alleo. E é aquí onde, infelizmente, parece que xa estamos» (El País, 26/09/2009). O perigo é real no mundo, onde o único que realmente lles dá cohesión ás multitudes é un partido de fútbol. Ou na era da comunicación audiovisual, na cal os contidos perden relevancia ante o poder das imaxes, os sons, a música, o ruído. Se as ideas e as razóns non conseguen trabar con eficacia nos problemas que nos angustian, os afectos poden turbiar a mente, impedir a obxectividade e a deliberación. Pois xa se viu que moitos afectos se nutren de prexuízos e estereotipos que configuran a nosa visión dos outros. As investigacións neurolóxicas confirman que a imaxe dun rostro negro activa a amígdala do home branco e fomenta nel actitudes racistas. Non cabe dúbida de que os partidos xenófobos que aparecen e mesmo triunfan en países que se consideran civilizados utilizan todos os recursos que teñen ao alcance do seu maxín para manter os estereotipos e provocar actitudes emocionais de rexeitamento ante certas realidades. Se é certo que o elector dista de ser desapaixonado, a diferenza do que a ciencia política quixo interpretar, que tende a escoitar só aquilo do que gusta oír e a desoír aquilo do que non gusta, se os nosos xuízos se basean en constricións cognitivas e emotivas ao tempo, xa que un tende a obviar a información que lle desagrada, ¿haberá que seguir, mesmo fomentar, desde a política tales tendencias ou máis ben habería que tentar modificalas? É máis difícil suscitar emocións favorables e empatía con propostas ou relatos revulsivos e rompedores. Por iso a publicidade é conservadora: porque o público maioritariamente o é e se identifica doadamente cos aspectos máis conservadores da realidade. Imos, pois, sacrificar unha linguaxe ilustrada, con contidos, ao interese de suscitar adhesións da maneira máis fácil, que é bloqueando a actividade de pensar? Deberemos prescindir da discusión 
tranquila a prol das formas de expresión iracundas, agresivas e malsoantes porque son máis atractivas? Ignoraremos arrogantemente as formas en que os políticos e os medios de comunicación manipulan as emocións dos cidadáns para os seus fins? Non é tal indiferenza o modo idóneo para impulsar iso que veu chamarse "populismo», o enaltecemento acrítico de personaxes que teñen máis de pallasos ca de auténticos seres razoantes?

Unha resposta ao temor que reflicte esta pregunta é que non son as campañas, nin sequera os discursos políticos mediáticos, o instrumento máis acaído para incitar a pensar. O obxectivo das campañas é a propaganda, cativar o elector e persuadilo, iso si, a prol dunhas causas e unhas políticas que se consideran xustas e boas para o interese xeral. É dicir, quen debe ter un pensamento elaborado e argumentado é o político, se ben a comunicación dese pensamento ha de se adecuar ao contexto en que fala — que, polo xeral, é imaxe e espectáculo- e aos que o escoitan, os cales buscan por riba de todo alguén en quen poder confiar, alguén que represente os valores que un mesmo cre manter e alguén que atenda algún dos intereses ou das preocupacións que un ten. Drew Westen resume así as necesidades do elector:

O que un elector debe saber para votar por un candidato ou outro son catro cousas. Primeiro, comparten os candidatos os valores que máis me importan e preocúpalles a xente coma min? Segundo, podo confiar en que me vaian representar fielmente? Terceiro, posúen as calidades persoais que me levan a crer que van actuar de acordo cos meus valores e intereses, como a integridade, o liderado e a competencia? E cuarto, se existe algún tema que realmente me concirne, que pensan del, podo esperar que pensen niso e que tomen as decisións que eu tomaría se tivese toda a información que eles teñen como representantes meus?

Saber suscitar todas estas emocións no elector é unha habilidade que o político terá que engadir ao seu coñecemento dos temas e políticas que forman parte da súa axenda. Unha habilidade que ten que ver con estratexias lingüísticas ou discursivas distintas das habituais, como o facer uso do storytelling, un mecanismo máis infantil pero máis directo e comprensivo ca as abstraccións ou os números. Mais ten que ver tamén con outras cousas que responden menos á moda do momento e teñen máis calado intelectual. Ten que ver cun saber facer 
capaz de amosar a coherencia de quen promete cousas, a integridade do que un di e fai, un saber facer capaz de xerar confianza. Tense dito frecuentemente que unha das mellores formas de espertar o entusiasmo por parte dun líder é dicindo a verdade. A autenticidade e a transparencia amósanse, non se argumentan con razóns. O político que defende a escola pública mais leva os fillos á privada carece de poder de persuasión porque non se mostra coherente cos principios que proclama. Ter a coraxe de recoñecer que un se enganou é outra forma —insólita na política - de mostrar a propia integridade. É distinto o erro do corrupto que pretende enganar do erro honrado e involuntario, que a xente esquece facilmente, sobre todo se quen se equivocou se desculpa.

En definitiva, trátase de poder contrarrestar o que expresa o poema de Yeats recollido por Michael Walzer:

Os mellores non teñen conviccións, e os peores

rebordan de intensa e apaixonada enerxía.

En efecto, a falla de fe nos propios intereses e principios é o que fai que os mellores non poidan oporse á «apaixonada enerxía» dos peores. Para o lograr, haberá que «racionalizar as paixóns e arrequecer a razón coa paixón» (Michael Walzer [1999]: Razón, politica y pasión). Dalgún xeito, o recurso a un discurso máis emocional leva a utilizar as armas dos outros, que son máis eficaces. Non está mal que se utilicen se, como dicían os bos sofistas — Gorxias, Protágoras-, se poñen ao servizo das mellores causas. Cando ese fin se esvaece, si que haberá que temer que o recurso ao emotivo acabe por anular a sabedoría da razón.

\section{O SENTIMENTO PATRIÓTICO}

Nun capítulo sobre os afectos na política non pode obviarse, nestes momentos, o afecto que por antonomasia centra moitos dos nosos desvelos políticos ocupándonos moito máis tempo do que quereriamos. Refírome, como non, ao sentimento de pertenza a un país ou sentimento patriótico, xerme de boa parte dos conflitos da nosa aínda inmatura democracia. Non somos, pese ás nosas singularidades, unha excepción á regra: os últimos decenios mostráronse prolífi- 
cos en conflitos étnicos e culturais, especialmente en Europa. Non só as vellas e asentadas nacións amparadas por Estados se viron interpeladas por afáns nacionalistas emerxentes, malia que todos eles seculares, senón que os movementos migratorios puxeron de relevo a urxencia de artellar dentro de cada nación as diferenzas culturais dun xeito civilizado e democrático. A filosofía política foi á zaga de todas estas mudanzas propondo alternativas ao liberalismo, algunhas das cales se centraron na celebración das diferenzas e da diversidade como valores en si mesmos e inxustamente ignorados durante os dous últimos séculos.

Como adoita ocorrer, a alternativa máis conspicua ao liberalismo -o comunitarismo- puxo a tónica no extremo oposto á idea dunha cidadanía cosmopolita que proviña directamente da Ilustración e da fe nunha razón universal. O sentimento de pertenza é defendido polos comunitaristas como a condición imprescindible para unha auténtica democracia de cidadáns, na cal estes se sintan identificados cun proxecto común que vencelle todos os membros da comunidade, herdeiros dunha mesma tradición cultural. Os seus adversarios, os cosmopolitas, renegan de pertenzas limitadas e dos nacionalismos que as fundamentan pola tendencia destes a dexeneraren en chauvinismos, racismos e actitudes intolerantes, do mesmo xeito que renegan das relixións pola deriva fundamentalista que adoitan propiciar. Pensan que, en tales casos, os sentimentos veñen substituír valores máis fundamentais e universais, que son os que efectivamente deberían manter a cohesión nunha sociedade. A humanidade, que é o noso obxectivo ético, un non a recońece — veñen dicir - a través de sentimentos como o de españolidade ou catalanidade, senón máis ben transcendendo esas diferenzas e considerando o que hai de común nos humanos. Non é a cultura nacional a que debe servirnos de guía moral, senón a razón universal.

A necesidade de estimular os sentimentos patrióticos non só se manifesta nas nacións máis febles, as que carecen dun Estado que as sustente xuridicamente, senón mesmo naquelas que naceron como nacións poderosas: Francia ou os Estados Unidos, por exemplo. Tamén os Estados-nación paradigmáticos carecen na actualidade dunha identidade nacional clara, que entusiasme os seus cidadáns e lles confira o orgullo e a lealdade que a nación provocou noutros momentos. Como resultado dun célebre foro de discusión sobre a debilidade nacional estadounidense, publicouse hai uns anos un libro que recollía unha serie de comentarios verbo dun escrito de Martha Nussbaum en defensa do cosmopolitismo (Martha C. Nussbaum [ed.] [1999]: Los limites del 
patriotismo). Se algo poñen de manifesto os defensores e detractores dunha ou doutra opción no dito libro é que ambos os extremos, nacionalista e cosmopolita, son teóricos e abstractos, que a realidade é máis complexa ca a teoría e, en definitiva, debe poder participar de ambas as ideas. Se o nacionalismo comporta unha carga excesiva de sentimentalidade, ao cosmopolitismo o que lle falta é emoción. O contraste, pois, entre ambos os polos non é senón máis un exemplo da reiterada tendencia do pensamento occidental a manter opostos e en liza continua a razón e os sentimentos.

O escrito de Nussbaum que abre a discusión da referencia comeza cunha cita da novela de Rabindranath Tagore The Home and the World, na cal o personaxe Nikhil contradí á súa muller, Bimala, partidaria da causa swadeshi, cuxo lema é Vande Mataram ("Viva a patria»), con estas palabras: «Estou disposto a servir o meu país; mais a miña veneración resérvoa para un dereito que é moito maior ca el. Venerar o meu país coma se fose un deus é lanzar sobre el unha maldición».

O problema do sentimento patriótico é a desmesura. O perigo é que se converta nun valor en si mesmo que deixa de lado calquera outro horizonte. Unha desmesura que afecta ao mesmo sentimento, polo que ofusca calquera outra dimensión e a converte en subsidiaria da lealdade ao territorio; e unha desmesura da crenza que, como se viu ao longo deste libro, está no punto de partida dos sentimentos e lles serve de sustento. O sentimento patriótico aliméntase, en efecto, de verdades que o patriota considera indiscutibles: dereitos lingüísticos, tradicións ancestrais, unidade lingüística. $\mathrm{O}$ esforzo por manter o que non son senón dogmas convértese con facilidade no único obxectivo polo que merece a pena loitar, pois preséntase revestido dunha aura moral ou natural. As raíces románticas da nación confírenlle unha autoridade moral superior á propia comunidade política. Por iso ás persoas adóitalles importar máis a nación ca o Estado, que é unha entidade xurídico-política, que sempre foi teorizada como algo artificial, necesario só na medida en que serve para nos regular a vida.

Mais a artificialidade do Estado contraposta á naturalidade da nación carece, pola súa vez, de fundamentos convincentes. A nación non é máis «natural»ca calquera outra construción teórica humana. Suponse que a conxunción Estado/ nación foi pensada para adecuar as fronteiras arbitrarias dos Estados coas fronteiras «naturais» das nacións. Pero non é máis arbitraria a nación ca o Estado?, pregúntase o cosmopolita Kwame A. Appiah. A nación non é nin máis nin menos ca unha "comunidade imaxinada» á procura da súa expresión política, como 
a definiu Benedict Anderson. Comentando a cita de Tagore, Immanuel Wallenstein fai para si a seguinte reflexión: «Se non existise o movemento swadeshi, a India seguiría a ser unha colonia británica. Sería isto máis acorde coa moralidade kantiana? Gandhi así o entendeu, mais Tagore non».

Gandhi e Tagore tiñan posicións distintas pese a ambos pertenceren ao mesmo país. Os sentimentos son subxectivos e as razóns ou crenzas que os manteñen teñen distinto peso segundo quen sexa o que se adhira a elas. Ora ben, se non é razoable querer universalizar os sentimentos, tampouco o é universalizar o desarraigamento que propugna o cosmopolitismo. Precisamente foi como reacción a un mundo profundamente desarraigado e reducido a relacións mercantís e xurídicas entre suxeitos de necesidades e capacidades abstractas como os comunitaristas propuxeron o papel humanizador das políticas identitarias que vencellan os individuos a circunstancias concretas. Quizais Dióxenes estaba en condicións de se sentir un individuo comprometido baixo a súa condición de «cidadán do mundo", tal e como gustaba de se identificar, mais ese é un compromiso que non está ao alcance de todos. Non todos os cidadáns son Dióxenes; a maioría precisa estímulos menos visionarios e máis prosaicos. É dicir, que se a deriva nacionalista, máis sentimental ca racional, ten os seus perigos, non son menores os da deriva a favor dunha razón universal, desinteresada e desafectiva.

Mais o importante, ao meu xuízo, é sinalar que a dicotomía é falsa. Como é falsa a dicotomía entre razón e emoción. O patriotismo e o cosmopolitismo non son antagónicos, nin a educación do cidadán ha de se situar na tesitura de ter que elixir entre un localismo sentimental e unha humanidade indiferenciada e descońecida. Desincentivar as tradicións nacionais porque conducen ao chauvinismo e á exclusión é, como explica Hilary Putnam, "confundir un pretexto para a agresión e a crueldade humanas coa agresión e a crueldade mesmas». O pretexto está latente en todas as perspectivas. Que desencadee ou non as peores consecuencias non é culpa do fervor nacionalista, relixioso, ateo ou cosmopolita, senón dun mal goberno de tal fervor.

Dito doutro xeito, a desmesura pode perverter tanto a racionalidade como a emotividade. Unha das citas máis repetidas de Hume é a que di que «non é irracional preferir a destrución do mundo a ferirme nun dedo». Con esta frase abundaba na súa idea de que as opcións morais non derivan da razón, senón dos sentimentos. De feito, foi Adam Smith o que lle brindou a imaxe cando quixo 
explicar que o ideal dunha cidadanía mundial non é contraditorio coas lealdades locais. Vexamos como o di:

Se ao día seguinte vai perder o dedo maimiño, o home pasará a noite en vela; no entanto, como nunca os viu, a ruína de centos de millóns dos seus irmáns non lle impedirá roncexar tranquilamente, xa que simplemente a destrución desta inmensa multitude lle parece un asunto máis nimio ca o seu propio mísero infortunio. Porén, para evitar tan mísero infortunio, estaría disposto o home humano a sacrificar as vidas de centos de millóns dos seus irmáns, xa que xamais chegou a velos? (Adam Smith [1996]: La teoría de los sentimientos morales)

A resposta que dá Smith a esta pregunta retórica é negativa. O persoal e próximo, sen dúbida, conta e moito, mais non impide atender ao universal cando é prioritario. En definitiva, pois, cualificar os sentimentos patrióticos de positivos ou negativos sen máis, contrapóndoos a unha orde xurídica racional máis estable e universalizable, é unha postura miope. Nin o sentimentalismo nacionalista nin o racionalismo universalista valen para nada se non se guían por outros valores, como a democracia ou a igualdade. A pregunta é a seguinte: que estratexia é mellor para romper a fenda entre pobres e ricos?, que orientación, nacionalista ou cosmopolita, axuda a realizar mellor os proxectos políticos que significan un progreso real para a humanidade? Son preguntas que carecen dunha resposta xeral. Depende. Gandhi creu que defendía mellor a dignidade humana apuntándose á causa nacionalista, mentres que Tagore minimizaba esa causa seguramente apuntando aos mesmos ideais. Relativizalas ambas procurando que as emocións sexan razoables e as razóns non perdan a carga de emotividade imprescindible para influíren na acción é a forma de dar prioridade non ao local sobre o mundial nin viceversa, senón á igualdade e á liberdade. 
A POLÉMICA ENTRE CAMUS

E SARTRE: RAZÓNS DUN

DESACORDO

Rosa María Rodríguez Magda

Catedrática de Filosofía 



\section{BREVE PERFIL BIOGRÁFICO, ENCONTRO, RIVALIDADE IMPLÍCITA}

Jean-Paul Sartre e Albert Camus foron dúas das máis emblemáticas figuras do intelectualismo francés do século xx, coas características propias dun perfil que foxe de todo academicismo: escritores, filósofos, autores teatrais, xornalistas, implicados politicamente, aclamados polo público, protagonistas da vida nocturna, creadores de estilo e ambos os dous posuidores do Premio Nobel. As súas relacións non só teñen importancia a nivel persoal, senón que, na súa confluencia, deron nome propio a unha das correntes máis innovadoras do pensamento: o existencialismo, e, no seu distanciamento, representaron dúas posturas ideolóxicas cuxos temas de debate se prolongan no noso presente.

Mesmo cando ambos os dous autores tiñan coñecemento das súas respectivas obras, o encontro persoal produciuse en 1943 con motivo da estrea da obra As moscas, de Sartre. Camus trasladárase a París e traballaba na editorial Gallimard, que os dous compartían. El realizara anos antes, en 1938, cando aínda residía en Alxeria, unha eloxiosa crítica do libro de Sartre La Nausée («A náusea»), no cal achou unha proximidade existencial parella á que el mesmo tentaba plasmar na súa novela $O$ estranxeiro, que nese tempo andaba a escribir. Concomitancias arredor da experiencia da nada e o absurdo, que máis tarde o propio Sartre puxo tamén de manifesto no texto que escribira comentando o citado libro de Camus xunto con Le Mythe de Sisyphe ("O mito de Sísifo»). Mais xa neste primeiro intercambio literario aparecen motivos de disonancias, que plasmaron os ditos autores nas súas correspondencias. Sartre seguramente se sentira ignorado ao non ser nomeado por Camus xunto a Nietzsche, Schopenhauer e Jasper senón como «un escritor contemporáneo», o que o levou de maneira prepotente e despectiva a afirmar que Camus non sempre parecía entendelos ben. Sartre, elevado xa ao cumio, normalien, de orixe burguesa, mira cunha certa displicencia o alxeriano, de extracción humilde. Mais, a pesar diso, Camus foi aceptado no círculo de amizades de Sartre e De Beauvoir: Olga, Wanda, 
Queneau, Bataille, Leiris... e pasaron a verse con cada vez maior asiduidade. Outro elemento de rivalidade subrepticia representábao o terreo erótico: Camus, aposto, tiña éxito coas mulleres; Sartre, fisicamente pouco agraciado, debía basear as súas conquistas no seu magnetismo intelectual. Mesmo disque De Beauvoir pretendeu algún encontro con Camus, que este rexeitou, nun ambiente de seducións cruzadas e receos común ao grupo. Abonden estes datos para constatar que, desde o principio, a amizade Sartre-Camus naceu agachando zonas espińentas que, co pasar do tempo, acabarían por desgarrala.

O período de maior proximidade entre ambos os autores coincidiu coa época da resistencia francesa á ocupación alemá e a liberación. Camus, experimentado xa desde Alxeria no xornalismo e as loitas políticas, funda o 21 de agosto de 1944 Le Combat e asume a súa dirección. É el quen, invertendo os papeis da tutela, lle ofrece a Sartre a posibilidade de se implicar politicamente e publicar algúns artigos. Estes apareceron asinados por De Beauvoir e Sartre, malia que, xa anciá, Simone recoñecería que os escribira só ela. A experiencia política de Sartre reducíase á malograda formación do grupo Socialisme et Liberté, composto por el mesmo, Simone de Beauvoir, Maurice Merleau-Ponty, Bost, Pouillon..., no cal tentaron, sen conseguilo, incorporar a André Guide e André Malraux e que se disolveu nun santiamén. Como moi ben soubo mostrar Ronald Aronson ${ }^{1}$, Sartre logrou reverter a súa exigua loita política, exemplarizando nela a resistencia calada, mais igualmente heroica, de todo o pobo francés, que así atopou unha imaxe tranquilizadora e ética na que se recońecer; o seu texto «La République du silence» entroniza e perpetúa a imaxe que a Francia da posguerra desexa ter de si propia.

O 15 de outubro de 1945 aparece o primeiro número de Les Temps modernes. $\mathrm{O}$ grupo de amigos colabora indistintamente en ambas as publicacións, se ben desde o comezo Le Combat está máis pegada á actualidade e Les Temps modernes ten un ton máis filosófico. As súas respectivas obras sucedéronse profusamente: Caligula ("Calígula») e Lettres à un ami allemand ("Cartas a un amigo alemán»), de Camus; Huis-clos («Entre catro paredes») e L’âge de raison ("A idade da razón»), de Sartre; O sangue dos outros e Les Bouches inutiles ("As bocas inútiles»), de De Beauvoir... Canda o seu satisfactorio recoñecemento, a famosa conferencia de Sartre «O existencialismo é un humanismo» desencadeará unha verdadeira

\footnotetext{
${ }^{1}$ Aronson, Ronald (2013): Camus y Sartre, València, Universitat. Este é un dos libros fundamentais para entender a relación entre ambos os escritores, e seguiremos as súas informacións ao longo desta conferencia.
} 
moda mediática, que conecta perfectamente coa sensación de baleiro das novas xeracións e a súa visión iconoclasta, afastada de convencionalismos e desexosa dunha estética nimbada de intelectualismo desencantado. Camus reaccionou prontamente con desapego, pois non quería que a súa imaxe e a súa obra individual quedasen eclipsadas polo protagonismo sartreano; reiteradamente afirmará: «Non, non son un existencialista».

A literatura comprometida, o ideal de intelectual engagé, considerouse un imperativo moral para os escritores do momento, pero "contra que»e, máis aínda, "xunto con quen» había un de se comprometer empezou a afondar a liña de fractura entre os dous amigos. Fronte á defensa da Unión Soviética que Merleau-Ponty realizara nas páxinas de Les Temps modernes, coa aquiescencia de Sartre, Camus reaccionou violentamente equiparando o comunismo ao asasinato. Así, mentres este vía no comunismo o maior inimigo da liberdade e do futuro de Europa, Sartre achegábase progresivamente a el, xustificando a súa violencia na loita contra o Occidente capitalista. Cada vez máis, o autor de L'Être et le néant $($ «O ser e a nada») convertíase no autor de Critique de la raison dialectique ("Crítica da razón dialéctica»), distanciábase das súas antigas posturas existencialistas para situar o reto da ética no terreo político e histórico, no cal un debía «manchar as mans», admitir a violencia como paso necesario para transformar a realidade. $\mathrm{E}$ isto é precisamente o que Camus non ía aceptar nunca.

\section{O ENFRONTAMENTO, A CRÍTICA A L'HOMME RÉVOLTÉ}

O distanciamento estoupou a raíz da publicación de L'Homme révolté ( $\mathrm{O}$ home revoltado»), que foi celebrado apoteoticamente por parte da crítica como un «libro capital» ou a obra de maior valor «aparecida en Francia despois da guerra», apreciacións deste teor que podemos atopar realizadas por Émile Henriot e Jean Lacroix en Le Monde, Claude Bourdet en Le Nouvel Observateur ou Henri Petit en Le Parisien libéré. Unha acollida que se estendía en sectores socialdemócratas ata a esquerda antiestalinista, mais que foi recibido con suspicacia, se non franco rexeitamento, por aqueles que apoiaban a Unión Soviética ou se atopaban próximos ao PC francés, como comezaba a ser a liña de Les Temps modernes, malia que a publicación marcara distancias con este último. 
Antes de proseguir quixera facer unha matización. Utilicei como título da obra en español El hombre rebelde, pois así se traduciu nas súas obras completas ${ }^{2}$; non obstante, o termo español non recolle todas as connotacións do francés révolté. Se Camus quixese dicir simplemente 'rebelde' empregaría a palabra rebelle. Révolté ten o sentido de rebelión, mais tamén o de conturbación, movemento interno que nos revolve as entrañas e nos fai sublevarnos, ese dinamismo que salta, nega e actúa.

A obra comeza cunha definición do rebelde (révolté) como o home que di non, desde unha dimensión metafísica que reformula o cogito cartesiano: «Eu rebélome, logo somos». Ese primeiro momento de negación fronte ao poder é seguido inmediatamente por un movemento afirmativo cara a unha liberdade que debe ser conseguida co esforzo de todos, nunha conciencia de estrańeza e loita que inclúe a todos os homes, a "realidade humana na súa totalidade». O home rebelde sitúase fóra da orde sagrada e dos seus valores absolutos; ante «o silencio do mundo» o absurdo tórnase un primeiro momento para a acción, unha dúbida metódica que nos incita a construír humanamente unha saída ao rexeitamento do mal para escapar do nihilismo. $\mathrm{O}$ absurdo non nos pode levar ao suicidio ou á lexitimación do asasinato. O home, nesta rebelión metafísica, álzase contra a súa condición e a creación enteira; máis ca un ateo é un blasfemo e denuncia ante Deus o supremo escándalo do mal. Para Camus este rexeitamento comeza a se articular teoricamente a finais do século XVIII, para se exemplificar en Sade, e, en datas posteriores, no Romanticismo, a arte será a súa moral. Cando todo está permitido, o ser humano bordea o seu propio abismo. A moral converterase, en Nietzsche, na última face de Deus que debe ser destruída. O rebelde, que, en principio, nega a Deus, aspira a substituílo. Será a poesía, desde Lautréamont pasando por Rimbaud, ata os surrealistas, desde onde se tenta un camińo inzado de atracción cara ao maléfico. Mais, contrariamente á valoración que dos ditos autores realiza boa parte da intelectualidade do momento, Camus, como resaltou Michel Onfray, tómaos como unha mostra dentro da elaboración da súa «xenealoxía do nihilismo contemporáneo». Camus "propón unha xenealoxía intelectual, unha arqueoloxía conceptual dos crimes literarios, filosóficos, conceptuais que prepararon os espíritos e as conciencias, as intelixencias e os entendementos

${ }^{2}$ Edición de José María Guelbenzu (1996), Madrid, Alianza Editorial. Non obstante, por coherencia co resto do texto, consideramos pertinente a tradución das citas ao galego. [N. do editor]. 
para os crimes históricos» ${ }^{3}$. Así, pois, todos os escritores arriba mencionados configuran para o autor unha longa lista de profetas do nihilismo.

Mais será na súa análise da rebelión histórica onde Camus vaia encararse cun dos problemas cruciais que o enfrontará a boa parte dos intelectuais engagés: a aceptación da morte e o asasinato como formas lexítimas da revolución. Toda revolución comporta o terror, «as rebelións servís, as revolucións rexicidas e as do século XIX aceptaron así, conscientemente, unha culpabilidade cada vez maior na medida en que se propuñan instaurar unha liberación cada vez máis total» ${ }^{4}$. Camus fai un percorrido: Rousseau, Saint-Just, Hegel, Marx, Bakunin, Nechayev, Lenin, Stalin... para constatar como as ideas trazaron un camiño que levaba ao terror totalitario, renegando do primeiro impulso rebelde que as animou. Deste xeito, se a reivindicación da rebelión sería a unidade, en troques, a da revolución histórica foi a totalidade, e mentres que a primeira era creadora, a segunda tornouse nihilista. «O terror e os campos de concentración son os medios extremos que utiliza o home para escapar da soidade. A sede de unidade debe realizarse, inclusive na foxa común $»^{5}$. Un mesmo impulso metafísico que foi pervertido, violentado, subvertido ata a cínica ignominia por aqueles que entronizan a historia como criterio moral/amoral, como obxecto de culto. Sobre as cinzas do antigo rebelde álzase a súa nova transfiguración revolucionaria e, deste xeito, o rebelde convértese en policía e funcionario da morte. Nin sequera na súa querenza libertaria salva o individualismo libertario de Stirner nin o comunitario de Bakunin pola súa apelación á violencia.

Mais Camus non se resigna; alén deste horizonte de nihilismo, esculca un novo renacemento; fronte aos «totalitarismos do norte» — hegeliano, xermánico, nocturno, sanguento- propón un "pensamento do mediodía» - latino, solar-, que é tamén un pensamento dos límites, da mesura, pois a desmesura só conduce á destrución universal. As grandes teorías revolucionarias naceron nun mundo de certezas totais, que non se corresponde, constata o autor, co noso cońecemento real de magnitudes relativas; hoxe todo, afirma, desde a ciencia mesma, nos fala dun principio de incerteza e de cautela, que debemos aplicar ao exercicio da liberdade e a felicidade dos homes. Ao «rebélome, logo existo» e ao

\footnotetext{
${ }^{3}$ Onfray, Michel (2012): L'Ordre libertaire : la vie philosophique d'Albert Camus, París, Flammarion, 340.

${ }^{4}$ El hombre rebelde, O. C., op. cit., 135.

5 Ídem, 289.
} 
«existimos sós» da rebelión metafísica, a rebelión contra a historia engade que, «no canto de matar e morrer para producirmos o ser que non somos, temos que vivir e facer vivir para crearmos o que somos» ${ }^{6}$. Todo isto implica un desafío ético e realista. Cando Camus fala de mesura e límites, mesmo da liberdade, non está a recuar dun xeito timorato ante as esixencias da revolta, non se está a converter nun morixerado, senón que establece un aliñamento sutil e realista, iluminando as antinomías morais que levan da reacción á barbarie, baixo o propio estandarte da moralidade. A virtude separada da realidade convértese en principio do mal, aínda que tampouco pode asimilarse ao real sen se anular. Unha virtude allea á realidade, ideal, mais aburguesada ou reaccionaria, esquece os homes de carne e óso que sofren a inxustiza; unha virtude que condiciona a súa salvación futura ás condicións históricas acaba lexitimando a tiranía e negándose a si propia. Para Camus, debemos constatar que os valores están intercalados co devir histórico, non existe a pureza. A mesura convértese así nun criterio esixente de realidade, na constatación de que non somos nin enteiramente inocentes nin enteiramente culpables, senón que estamos manchados, á par que iluminados, por esa mesma mistificación. "A moral enteiramente pura é mortífera», mais "toda moral precisa unha parte de realismo». "O home non é enteiramente culpable, pois non comezou a historia; nin enteiramente inocente, pois continúaa. Os que traspasan este límite e afirman a súa inocencia total terminan no furor da culpabilidade definitiva. A rebelión, pola contra, ponos no camiño dunha culpabilidade calculada. A súa única mais invencible esperanza encárnase no límite, en asasinos inocentes». E é a partir de aquí desde onde debemos emprender a acción colectiva, desde un individualismo que se inscribe nunha dignidade común, nunha "compaixón orgullosa». Unha rebelión, pois, realista, realizada de abaixo a arriba, encamiñada a minorar a dor, que para Camus, lonxe de se inscribir no mero terreo das ideas, bebe das loitas sindicalistas e libertarias, e que, se non pode lograr o freo da inxustiza sen violencia, si o fará no rexeitamento do terror. Unha rebelión vixilante, un pensamento do mediodía, mediterráneo e antigo. «O que resoa para nós nos confíns desta longa aventura rebelde non son fórmulas de optimismo, inútiles na nosa extremada desdita, senón palabras de coraxe e de intelixencia que, preto do mar, son mesmo virtude» ${ }^{7}$.

${ }^{6}$ Ídem, 293.

7 Ídem, 354. 
Malia a resonancia da súa obra e da relación co autor, Les Temps modernes gardou silencio durante varios meses. Finalmente, Sartre encomendoulle a recensión ao seu colaborador, o mozo Francis Jeanson, e aquela publicouse no número de maio de 1952 - a obra achábase distribuída desde outubro do ano anterior ${ }^{8}$ - A crítica foi minuciosa e atacou o libro en diversas frontes: por unha banda, introduce a sospeita de que, se compraceu a tanta xente, incluíndo a dereita, é porque ten unha mensaxe conservadora. $\mathrm{O}$ coidado estilo será tamén para Jeanson unha proba de que a forma prevalece sobre o contido e o crítico centrarase posteriormente en desbaratar as referencias filosóficas que, tomadas dun xeito superficial, teñen un único fin: demonizar a historia. Quedará así Camus retratado como un literato idealista que, de forma reaccionaria, se subtrae ás condicións materiais da loita política. En toda esta descualificación Jeanson non entra realmente a refutar a lexitimación da morte que é o leitmotiv da súa crítica ás ideoloxías revolucionarias.

Camus séntese profundamente ofendido porque ve a man invisible do seu, xa desde este momento, antigo amigo Sartre. E replica cunha misiva en que evitará nomear a ambos os dous, dirixíndose ao «señor director» da publicación, en referencia ao «autor» do artigo publicado. Non obstante, o seu texto mostra a vulnerabilidade da ferida; xustifícase, deféndese, as súas palabras translocen o nerviosismo da indignación e, ao meu modo de ver, perden contundencia. Non foi entendido, e denuncia a mala fe do seu axuizamento.

Agora será o propio Sartre quen asine a contrarréplica, coa súa «Resposta a Albert Camus», nun ton directo que comeza dando a súa amizade por rematada. O texto é demoledor: ataca directamente a Camus pola súa inseguridade interior e a súa falta de competencia filosófica cun paternalismo altivo e desdeńoso: «A túa combinación de vaidade monótona e vulnerabilidade sempre disuade a xente de che dicir a verdade pura e simple. O resultado é que te convertiches na vítima dunha prepotencia deprimente que agocha os teus problemas íntimos e que ti, coido eu, denominarías como moderación mediterránea».

Con respecto á denuncia dos campos de concentración soviéticos, Sartre apóiase no argumento de que ao se situar un contra eles se faría culpables aos

\footnotetext{
${ }^{8}$ Utilizarei a tradución espańola da polémica, editada en 1964 pola revista El Escarabajo de Oro (Bos Aires), na que se recollen os dous artigos de Jeanson, a réplica de Camus, a resposta de Sartre e o artigo publicado por este tras a morte de Camus.
} 
comunistas, e, por outra banda, reparte a responsabilidade nos dous bloques, pois as accións dos Estados Unidos provocan o rearme e o rigor no outro bando. Por debaixo de todo isto está a falacia, mil veces repetida durante as décadas seguintes, de que unha crítica ao comunismo beneficia a dereita e converte a quen a fai en cómplice desta.

Durante as semanas posteriores, mentres todos os medios se facían eco da ruptura, Camus sentiuse angustiado, humillado. Se Sartre a partir deste momento pasa páxina na súa relación, en troques Camus parece que mantivo a ferida aberta durante moito tempo; redactou unha "Défense de L'Homme révolté» («Defensa de $O$ home revoltado») que, porén, ficou inédita ata logo da súa morte, e algún dos seus biógrafos aínda le a súa novela La Chute ("A caída», 1956) como unha rememoración do pasado enfrontamento 9 . Malia o éxito do seu libro, este oponse aos mitos dos intelectuais do momento, o que lle granxea o seu descrédito. Como de novo resalta Onfray ${ }^{10}$, a súa visión de Sade enfróntase á lectura dun Apollinaire que o presenta como revolucionario e liberador, e que seguramente fose aceptada por Maurice Blanchot, Pierre Klossowski e Georges Bataille. Critica o surrealismo, opóndose por isto a Breton, Éluard, Aragon, Soupault... Descabalga do seu pedestal a Rimbaud e Lautréamont. Ao deostar a Hegel, está a poñer en causa as lecturas de Hyppolite e de Kojève, tan valoradas polos seus discípulos daquela, como Lacan, Caillois, Aron, Whal, Levinas, Leiris... Co seu rexeitamento a unha parte de Marx, desencadea as iras de Sartre, De Beauvoir, Merlau-Ponty e todos os marxistas. O seu libro, pois, non só é acusado de ambigüidade política, senón tamén de inconsistencia filosófica polo groso do mandarinato intelectual da época.

Sartre unicamente volverá escribir sobre o seu antigo amigo no artigo recordatorio que publicou co gallo da súa morte ${ }^{11}$. Alí, malia inscribir a Camus na lista dos moralistas franceses e intentar salvar a súa actitude vital, non deixa de retratalo dun xeito un tanto mesquińo. «O seu humanismo teimudo, estreito e puro, austero e sensual, libraba un combate dubidoso contra o acontecemento masivo e deforme deste tempo». Decididamente, nin tan sequera no seu canto funerario o filósofo abandona o seu ton displicente.

\footnotetext{
${ }^{9}$ Para consultar un seguimento minucioso dos feitos, véxase Aronson, op. cit., caps. 7 e 8.

${ }^{10}$ Op. cit., 338-339.

${ }^{11}$ Publicado no France Observateur o 7 de xaneiro de 1960.
} 


\section{DÚAS POSTURAS TEÓRICAS IRRECONCILIABLES. OS CAMPOS DE CONCENTRACIÓN}

Mais, volvendo aos seus protagonistas, máis alá do momento da polémica e as súas secuelas, se esta se produce é por un distanciamento de formulacións que se viña xestando desde tempo atrás e que se faría máis patente a partir de entón, unido á rivalidade soterrada presente desde o comezo da súa relación.

Se ben o Sartre existencialista fora criticado polos comunistas e Les Temps modernes mantivera unha lińa de esquerdas pero afastada do PC francés, Sartre xa adoptara unha posición favorable ao bloque soviético ao comezo da Guerra Fría e manifestara no verán do 52 a súa adhesión ao comunismo, mesmo na lexitimación da súa violencia. Pola súa banda, Camus expresara con anterioridade o seu rexeitamento á Unión Soviética, e certamente as críticas ao «culto da historia» presentes en L'Homme révolté parecen estar escritas, sen o nomearen, directamente contra Sartre. Se Camus declarara en "Révolte et conformisme» que "se a verdade residise na dereita, [el] estaría alí», Sartre afirmaba con toda contundencia: «Un anticomunista é un fillo dun can». Na segunda parte de «Les communistes et la paix», aparecida en outubro-novembro en Les Temps modernes, o filósofo parece seguir replicando a Camus e rexeitando calquera crítica ao PCF.

Camus denuncia na súa obra o horror dos campos de concentración. Unha realidade que fora obviada, se non xustificada, e que continuaría a selo durante moito tempo polos intelectuais de esquerda, con Sartre á cabeza. Con isto adiántase en máis de vinte anos á denuncia do gulag de Solzhenitsin, que desencadeou a eclosión de les nouveaux philosophes con obras como La Barbarie à visage humain («A barbarie de rostro humano»), de Bernard-Henri Lévy, ou Les Maîtres penseurs («Os mestres pensadores»), de Glucksmann. Se lemos hoxe estas obras podemos comprobar que a crítica de Lévy a este humanismo que xustifica o totalitarismo é a mesma tese de Camus, e que as sementes do terror que Glucksmann desenmascara na súa lista de pensadores canónicos é practicamente a mesma que guía a xenealoxía do nihilismo realizada por Camus no seu L'Homme révolté, o cal, por unha banda, cuestiona a novidade de les nouveaux e, pola outra, constata como, a pesar das advertencias de Camus, precisamente polo rexeitamento que sufriu, non foron escoitadas pola intelectualidade, nin a francesa nin a internacional, que, con diversos matices, sucumbiu tamén ao maoísmo. Abonda con 
lembrar como o máis escolleito dela volveu dunha viaxe á China vestida ao xeito de $\mathrm{Mao}^{12}$. Mais existe unha diferenza: se os novos filósofos iniciaron coa súa crítica un xiro cara ao liberalismo, Camus, por máis que fora acusado de conivencias coa dereita, mantense nunha postura de esquerdas, confiado no poder transformador do sindicalismo libertario.

Certamente a cegueira dos intelectuais do século $\mathrm{xx}$ no tocante ao comunismo foi rechamante e así o denunciou o propio Lévy no seu libro Les Aventures de la liberté («As aventuras da liberdade»), no que, por certo, se proclamaba fervente seguidor de Camus e afirmaba: "Camus e Sartre. Camus, que sempre tivo razón fronte a Sartre. Non se dirá, non se repetirá nunca dabondo canta razón tivo Camus fronte a Sartre e a cuadrilla de Les Temps modernes. Camus e L'Homme révolté. Camus e os gulags. Camus negándose a distinguir, cando toda a esquerda o convidaba a facelo, entre bos e malos mortos, entre vítimas sospeitosas e verdugos privilexiados» ${ }^{13}$. Porén, esta adhesión será matizada na súa posterior obra, Le Siècle de Sartre («O século de Sartre»), na cal, se ben mantén a valoración da súa lucidez na denuncia dos totalitarismos, recoñece a maior envergadura filosófica de Sartre. Só o título do apartado en que trata o tema é xa mostra elocuente e paradoxal: «Pourquoi l'on a, tout de même, raison d'avoir tort avec Sartre plutôt que raison avec Camus» ${ }^{14}$.

Mais Camus non foi a única voz que clamou no deserto. A súa análise segue ao respecto a argumentación filosófica de Essai sur l'esprit d'orthodoxie, do seu mestre Jean Grenier. E xa en novembro de 1949, David Rousset publicara en Le Figaro littéraire un artigo denunciando o gulag, ao cal seguiu o testemuño persoal de Margaret Buber-Neumann, a nora de Martin Buber, denunciando a súa prisión nun campo de concentración nazi e noutro soviético, unha circunstancia que sería glosada por Rousset na súa obra Pour la vérité sur les camps concentrationnaires $^{15}$, exemplificando a realidade que xa articulara no seu relevante $L^{\prime}$ Univers concentrationnaire ${ }^{16}$.

${ }^{12}$ Roland Barthes, en Carnets du voyage en Chine (publicado en España como Diario de mi viaje a China, Paidós, 2010), relata a rolda organizada pola embaixada maoísta en París en 1974, do 11 de abril ao 4 de maio, que realizou canda outros membros do grupo Tel Quel: François Wahl, Philippe Sollers, Julia Kristeva e Marcelin Pleynet.

${ }^{13}$ Lévy, Bernard-Henri (1992): Las aventuras de la libertad, Barcelona, Anagrama, 283-284.

${ }^{14}$ Lévy, Bernard-Henri (2000): Le Siècle de Sartre, París, Grasset, Poche, 472 e ss.

${ }^{15}$ Éditions du Pavois, 1951.

${ }^{16}$ Éditions du Pavois, 1946. 
Non se pode achacar, pois, descoñecemento —o mesmo Sartre descualifica a Rousset na xa citada réplica a Camus-, a aceptación da represión e a tortura como algo necesario para o advento dunha ditadura de éxito do proletariado, pois obedecía a unha consciente posta entre parénteses da ética e da liberdade en función dunha xustiza social futura, da suspensión da empatía a prol do ethos revolucionario, coa épica sanguenta que acompañou calquera totalitarismo. E é sobre a base desta suposta lucidez sobre a que Sartre minimizará o terror da Revolución cultural chinesa, defenderá o terrorismo palestino do Setembro Negro e apoiará o réxime castrista, a banda Baader-Meinhof e mesmo o ditador norcoreano Kim Il-sung.

\section{ALXERIA E O ANTICOLONIALISMO}

O maio do 68 xa atopou un vello e caduco Sartre, que dificilmente achaba un espazo entre a xente nova liderada por Daniel Cohn-Bendit. O filósofo, ademais dos militantes, foi un dos poucos que lamentou que tras as revoltas non se alzase co poder o PCF. O seu tempo de gloria como suposto intelectual lúcido en Europa estaba a chegar á súa fin; quizais só o seu apoio e prólogo á biblia do anticolonialismo, Les Damnés de la Terre, de Frantz Fanon, mantivo certa vixencia, pola prolongación das ideas de Fanon nas correntes poscoloniais.

E, a este respecto, o posicionamento contrario de ambos os escritores verbo da guerra de Alxeria marcou outro punto de distanciamento entre dous autores que decidiran ignorarse.

A partir de 1956 o clima político en Alxeria fíxose insostible polos continuos choques entre as guerrillas do FLN e as tropas francesas; os Pieds-Noirs vían a súa posición perdida a causa do que consideraban un Goberno francés pusilánime e a campańa contraria da intelectualidade de esquerdas. Les Temps modernes publicou unha serie de artigos sobre o colonialismo e Alxeria, e Sartre manifestouse dun xeito contundente contra o dominio colonial francés, se ben persoalmente, e no caso alxeriano, desconfiaba do excesivo nacionalismo e escaso ímpeto revolucionario comunista. Francis Jeanson, enlace e apoio clandestino do FLN en Francia, recońecería máis tarde que tivo que lle insistir a Sartre para que se 
implicase e que a actitude do PCF foi bastante fría ${ }^{17}$. Mentres isto ocorría e os acontecementos se precipitaban, Camus, alxeriano-francés, calaba. No prefacio ás súas Chroniques algériennes, 1939-1958 («Crónicas alxerianas, 1939-1958») dá conta da súa prudencia, posto que a traxedia paira sobre «os seus» e as críticas e consideracións nun ou noutro sentido poderían ser utilizadas polo contrario. Curiosamente, non reclama a inocencia en ningún bando. $\mathrm{O}$ horror, o sangue e as represalias salpican a todos, e esa humillación de «asasinos inocentes» haberá de ser asumida, mais non xustificada. Camus critica o esquerdismo do intelectual francés que comodamente desde a República golpea a súa culpa no peito doutros; semella que a metrópole non soubo atopar outras políticas que as que consistían en lles dicir aos franceses de Alxeria: «Rebentade. Tédelo merecido» ou «Rebentádeos. Téñeno merecido» ${ }^{18}$. A fin da violencia, a reconciliación, a reconstrución da convivencia nun modelo federal é a solución que o escritor propón: "Unha Alxeria constituída por poboacións federables e ligadas a Francia paréceme preferible, sen comparación posible, atendendo á simple xustiza, a unha Alxeria ligada a un imperio islámico que non representaría para os pobos árabes senón unha adición de miserias e sufrimentos, e que arrincaría o pobo francés de Alxeria da súa patria natural» ${ }^{19}$.

Son estas e outras manifestacións as que o converteron no albo das críticas e alimentaron as acusacións de colonialista, mais, como moi ben destaca outro famoso Pied-Noir, o franco-xudeo-alxeriano Jacques Derrida ${ }^{20}$, tales apreciacións poden facerse tamén desde «un punto de vista autenticamente anticolonialista e socialista». A "complicidade obxectiva» implica en moitos sentidos a moitos dos sectores, máis ca os «silencios atormentados» de Camus, quen no seu esforzo de lucidez se atreveu a dicir verdades que a ortodoxia anticolonialista non desexaba oír. Isto é, certamente, o que non se lle perdoou.

O resumo do seu debate moral, o de alguén que coñece a situación e non adopta posturas dogmáticas distantes nin fanatizadas polo odio, o de quen desexa un futuro para o país que o veu nacer, vén dado polas palabras que lle dixo a un

${ }^{17}$ Lévy, Bernard-Henri (1992): «Conversación con Francis Jeanson», en Las aventuras de la libertad, Barcelona, Anagrama, 285 e ss.

${ }^{18}$ Camus, Albert (1996): Crónicas argelinas (1939-1958), en Obras, Madrid, Alianza Editorial, 460.

${ }^{19}$ Ídem, 466-467.

${ }^{20}$ Derrida, Jacques (2012): «Mon cher Nora ...», carta de Derrida en Pierre Nora, Les Français d'Algérie, París, Christian Bourgois, 292-296. 
xornalista mentres se achaba en Estocolmo a recibir o Premio Nobel. Foi acusado de excesivamente personalista, mais pode facerse algunha política xusta abstraéndose un da traxedia dos que están a vivir a inxustiza?

«Sempre condenei o terror. Tamén debo condenar un terrorismo que se leva a cabo de maneira cega, nas rúas de Alxer, por exemplo, e que poida que algún día alcance a mińa nai ou a min. Creo na xustiza, mais defenderei a mińa nai por riba da xustiza» ${ }^{21}$.

\section{QUEN TIÑA RAZÓN?}

Pasado xa o tempo e volvendo a vista atrás, podemos asumir a afirmación de Lévy de que debemos enganarnos con Sartre antes que ter razón con Camus?

A polémica entre o escritor e non só Sartre, senón case todo o staffintelectual francés, a conto de L'Homme révolté, pareceu perdela Camus e, de feito, como recoñece nos seus Carnets, despois desta obra abandona o ensaio filosófico sensu stricto para volver á literatura, reducindo o seu apuntalamento teórico ao aforismo. Nunca o abandonou a inseguridade nun campo en que os profesionais lle botaran na cara a súa mera actitude de «afeccionado». Tampouco o seu esperanzado futuro para Alxeria se cumpriu; houbo certamente guerra, barbarie, expulsión dos franceses alxerianos, independencia e substitución dos valores da République polos dun islamismo autóctono ou importado.

Mais ninguén lle pode negar a Camus a súa lucidez á hora de denunciar o totalitarismo comunista, mentres que o groso dos intelectuais persistiron en pechar os ollos ou mesmo en xustificalo. Unha realidade que cada vez se fixo máis evidente, e así nalgunha medida o recoñeceu Sartre cando, ancián e decrépito, en 1979 se uniu a diversos pensadores: Raymond Aron, André Glucksmann... no seu pedimento a Giscard d'Estaing para que apoiase os refuxiados vietnamitas que fuxían como boat people do réxime comunista do seu país.

A estrela de Sartre estaba en decadencia, igual ca o marxismo como corrente ideolóxica hexemónica entre a intelectualidade; unha nova xeración de filósofos acantoaba a anterior. A analítica e microfísica do poder foucaultiana derruíu a tópica marxista ao respecto e tornou caduca a Critique de la raison dialectique.

${ }^{21}$ Citado por Aronson, op. cit., 286. Camus, Essais, 1882. 
O postestruturalismo en bloque substituíu a dialéctica polo esquema saussureano significante/significado, describindo un mundo rizomático e nómade (Deleuze). O gran relato marxista caía ante a condición posmoderna (Lyotard). Derrida elixía inspirarse en Heidegger para a súa critica ao logocentrismo e mesmo Bourdieu ataca a interpretación sartriana de Flaubert da súa monumental L'Idiot de la famille na súa Les Règles de l'art. O intelectual específico substitúe o intelectual orgánico e Nietzsche convértese nunha nova guía anarquizante. Por se faltaba algo, a irrupción de les nouveaux philosophes dinamitou os restos do prestixio teórico que lle quedaban ao marxismo. Unido a isto, a caída do muro de Berlín en 1989 marcou unha definitiva estocada no descrédito do comunismo real. Ningunha das bases teóricas nas que fundamentou a súa filosofía e o seu compromiso político o segundo Sartre ficaban en pé, e a súa postergación durante décadas foi o resultado.

Non obstante, que Camus pareza, á luz de todo isto, ser o que tivo razón non o fixo saír triunfante. As críticas a L'Homme révolté dinamitaron o seu prestixio filosófico e a súa postura ante a guerra de Alxeria converteuno en politicamente incorrecto para a nova ortodoxia multicultural. Queda o Camus escritor, posuidor do Premio Nobel, imbatible no seu propio prestixio literario, ético e luminoso. Sartre, para alén do asasinato do pai que realizou a xeración posterior, retorna, desculpándoselle os seus erros políticos, ao lugar filosófico que lle corresponde como autor de L'Être et le néant, desa pequena peza de referencia que é «O existencialismo é un humanismo», como xigante intelectual dun século, que algúns, vímolo, non dubidan en designar co seu nome.

A posteridade e o recoñecemento de Camus, no que teñen de ambiguo e problemático, puideron verse co gallo do centenario do seu nacemento.

\section{A CELEBRACIÓN MALOGRADA DO SEU CENTENARIO}

O 7 de novembro de 2013 cumpriuse o centenario do nacemento de Albert Camus. Para o conmemorar tíñase prevista a realización dunha grande exposición-homenaxe co título Camus, l'homme révolté ou L'étranger qui nous ressemble, que se inauguraría en Aix-en-Provence no marco da capitalidade europea da cultura Marsella-Provenza 2013. A actividade non se levou a cabo sobre todo pola polémica xurdida arredor da súa posición na guerra de Alxeria. 
A crítica á súa postura de entón foi un tema recorrente; ás controversias do momento seguiron ataques posteriores, como a acusación de Edward Said do seu «inconsciente colonial» ou as do escritor alxeriano Kateb Yacine. En 2010, a caravane Camus que debía percorrer Alxeria presentando a súa obra foi boicoteada e interrompida por unha campaña en contra do autor; o panfleto "Alerte aux consciences anticolonialistes» ${ }^{22}$ foi asinado por múltiples intelectuais alxerianos, que denunciaban unha manobra neocolonial.

Para levar a cabo a exposición conmemorativa elixiuse, primeiramente, o historiador Benjamin Stora, que, como especialista na guerra de Alxeria, presentou un proxecto que incidía de xeito especial sobre este suceso, cousa que desagradou a Catherine Camus, filla do escritor, así como á propia alcaldesa de Aix-en-Provence, da UMP, o partido de Nicolas Sarkozy, quen con anterioridade tivo a intención de trasladar os restos do escritor ao Panteón, o cal tampouco tivo lugar pois causou polémica, alén da negativa do seu fillo.

Stora abandona o comisariado. En declaracións posteriores a Le Figaro ${ }^{23}$ comentaba que, aparentemente, para certos nostálxicos do pasado colonial, moi activos en Aix, el non tińa o perfil axeitado, mais sinala tamén a molestia doutros ante a lucidez de Camus ao se adiantar ao fracaso das grandes ideoloxías colectivas revolucionarias.

O proxecto pareceu retomarse co nomeamento de Michel Onfray como novo comisario, mais finalmente, ante as presións e as polémicas, este tamén renuncia, co cal a iniciativa foi así suspendida.

Quizais, logo de tanta mesquindade e mistificación, un libro acabado de editar achegue unha comedida lectura pacificadora no que parece ser o punto máis conflitivo: as relacións entre o francés e o alxeriano. Refírome á novela Meursault, contre-enquête, do escritor alxeriano Kamel Daoud ${ }^{24}$, quen fai falar o irmán do «árabe» asasinado por Meursault en $O$ estranxeiro. A ese árabe sen nome, sen rostro e case sen importancia, pois é só un pretexto para mostrar o desapego de Meursault ante a vida, a morte e mesmo o asasinato, élle devolta unha identidade: chamábase Moussa. Haroun, xa ancián, conta a historia do seu irmán «morto nun libro» e, á vez, a propia historia dun país con nome propio: a guerra, a independencia, o futuro incerto, e quizais un mesmo baleiro

\footnotetext{
${ }^{22} \mathrm{http} / / /$ www.hoggar.org/index.php?option=com_content\&view=article\&id=982:face-aux-menees-du-lobbyneocolonial-autour-de-camus-alerte-aux-consciences-anticolonialistes\&catid=94:hoggar\&Itemid=36.

${ }^{23} \mathrm{http} / / /$ www.lefigaro.fr/livres/2013/11/07/03005-20131107ARTFIG00404-le-centenaire-d-albert-camusdivise-autant-qu-il-federe.php\#.

${ }^{24}$ Éditions Barzakh, Éditions Actes Sud, Prix François Mauriac, Prix des cinq continents.
} 
existencial que o asemella ao protagonista de $O$ estranxeiro. Kamel Daoud coa súa obra interpela, e completa, a visión de Camus a través do tempo; faino con xustiza mais sen rancor, como unha homenaxe a un Camus que soubo coa súa literatura ir alén das posicións concretas, atinadas ou non ${ }^{25}$.

\section{POR QUE CAMUS É UN SUXEITO DE POLÉMICAS?}

Resulta, pois, paradoxal que, na consideración da valía de ambos os autores, o que foi un erro en Sartre, tras o seu esquecemento, se minimice agora, sen manchar a súa contribución filosófica, e as posicións de Camus sigan a ser consideradas un pecado ou un acerto do que un pode apropiarse.

Os nostálxicos do colonialismo queren facelo un dos seus. Á UMP molestáballe o tema colonial por conflitivo, mais desexaba acentuar o seu rexeitamento do comunismo. Os antigos esquerdistas reconvertidos en socialdemócratas desexan recuperalo. A esquerda tradicional non lle perdoa a súa crítica ao comunismo. A esquerda poscolonial, a súa postura ambigua fronte á guerra de Alxeria. Os alxerianos considérano un colonialista por defender que Alxeria fose un estado federado de Francia. Para a convivencia entre franceses e franceses de orixe magrebí é un tema que resulta espiñento e máis aínda co crecemento do lepenismo, aínda que non hai que esquecer que Le Pen chegou a chamarlle pederasta. Os ácratas actuais non se recoñecen no seu sindicalismo libertario e os fillos teñen un sentido estrito do que representa defender o seu legado moral.

Con todo ese cóctel non pode estrańarnos que Camus siga a ser polémico, síntoma de que tratou temas que aínda son medulares, na ética, na política, na toma persoal de posición. A súa figura álzase con toda a forza do individuo guindado á nada que celebra o pensamento do mediodía. Incontestable na súa calidade literaria. Rebelde fronte a todas as ortodoxias. E, malia que tampouco escapase á cruel ironía do malentendido, no fondo, sabémolo, Sísifo sorrí.

\footnotetext{
${ }^{25}$ Véxase a excelente crítica do libro realizada por Amira Armenta, http://amiraarmenta.com/2014/09/01/la-respuesta-del-arabe-a-el-extranjero-de-camus/, e a entrevista ao autor no xornal alxeriano $E l$ Watan: http://www. elwatan.com/culture/la-litterature-est-ce-qui-nous-reste-pour-interroger-le-monde-02-11-2014-276343_113. php.
} 
O NOVO SISTEMA

INTERNACIONAL E OS RETOS

DO HUMANITARISMO:

A XESTION DA CRISE

HUMANITARIA E MIGRATORIA

E DAS NOVAS FORMAS DE

VIOLENCIA DIRECTA NON

POLÍTICA

Rafael Grasa

Universitat Autònoma de Barcelona 



\section{A CRISE HUMANITARIA NON É UN FEITO ILLADO, É UNHA CRISE INTERNACIONAL E NON SÓ EUROPEA, QUE AFECTA Á CREDIBILI- DADE DA UE}

A actual crise humanitaria e migratoria non se trata dunha simple crise europea ou comunitaria. É unha crise internacional, que debe analizarse, pois, no marco das mudanzas que están en curso no sistema internacional desde a fin da guerra fría.

\subsection{A crise dos refuxiados no Mediterráneo ha de se inserir nun contexto glo- bal, que desde hai anos presenta cifras moi esixentes para un sistema de axuda humanitaria internacional que xa hai moito que funciona de xeito precario, insuficiente}

Datos recentes de ACNUR (Alto Comisionado das Nacións Unidas para os Refuxiados, 2013, 2016) lémbrannos que o mundo conta actualmente con máis de 60 millóns de desprazados e refuxiados, unha cifra que só pode compararse, e en termos relativos, coas xurdidas logo da Segunda Guerra Mundial. Unha cifra que vai manterse ou mesmo aumentar nos próximos anos.

Tres comparacións "personalizadas» permiten entender a transcendencia do reto e á vez do drama humanitario que a magnitude abstracta e dura da cifra podería agochar. Primeiro, unha de cada 120-122 persoas do mundo é un refuxiado, un desprazado interno ou unha persoa que pediu asilo. Segundo, seis anos despois do inicio da guerra interna en Siria e da súa rexionalización, existen desde hai un par de anos máis desprazados internos e refuxiados sirios ca cidadáns sirios que viven aínda na súa casa. E, terceiro, nos últimos tres anos chegan ao Mediterráneo pedindo acollida ou asilo arredor de case un millón de persoas ao ano e no intento de chegar ás nosas costas morren unha media de 4500 persoas ao ano, polo menos. E a UE recibe unha media de 700000 peticións de asilo polo menos. 
Quixera advertir ao respecto que neste caso o de menos son as cifras concretas, que varían dunha fonte a outra; o crucial son as tendencias, consolidadas e de longo alcance, incluíndo o próximo decenio, polo menos no relativo á emigración de orixe subsahariana, como logo veremos.

A crise afecta, pois, á libre circulación das persoas que pasan fronteiras, un dereito que, de maneira xenérica, non recoñecen a Declaración Universal nin os pactos internacionais posteriores. $\mathrm{O}$ que teñen en consideración as lexislacións internacionais vinculantes son só situacións concretas relativas a ese dereito, como, por exemplo, aquelas en que está en risco a vida dun (dereito marítimo, dereito humanitario e de guerra) ou os casos que afectan a persoas que se viron obrigadas a se desprazaren. Estes casos, ou estas condutas asociadas, si que están suxeitos ao dereito internacional e a moitos dereitos internos (dereito de asilo, convención para protexer de torturas e tratos degradantes...).

En suma, desde hai anos enfrontámonos a unha crise de facetas múltiples: $h u$ manitaria e, recentemente, migratoria, que debe entenderse nas mudanzas pos guerra fria das relacións internacionais.

Adicionalmente, debemos lembrar que o sistema internacional humanitario ${ }^{1}$, que sempre foi fráxil, está desde hai anos nunha situación particularmente precaria. Un estudo recente e importante sinalaba que hai que pór o sistema novamente sobre os seus pés, posto que, pese aos seus éxitos relativos no pasado, o sistema (conformado basicamente por países do norte global, organismos internacionais, a Cruz Vermella/Media Lúa Vermella Internacional e organismos privados especializados) non dá sido eficiente e adoita chegar tarde a satisfacer as demandas imperativas, fronte á axuda liderada polos países afectados. $\mathrm{O}$ estudo sinalaba concretamente que, malia a evidencia de que era preciso investir máis en prevención, formación de capacidades e axuda aos sistemas locais (mixtos, é dicir, público-privados), seguía a haber unha media de investimento orientado aos actores locais, entre 2007 e 2013, de arredor do $2 \%$, insignificante. Os expertos coinciden en soster que hai que mudar radicalmente o sistema, o financiamento e a estrutura, mais, por riba de todo, o liderado e a coordinación, que deben pasar aos actores locais en cada crise de forma eficaz e garantida. Pese á urxencia, sinalada antes da crise migratoria, pouco se moveu. É urxente e, porén, non semella doado que vaia pasar algo.

\footnotetext{
${ }^{1}$ Gingerich, Tara R. / Marc J. Cohen (2015): Turning the Humanitarian System on its Head, Oxfam America, July (https://www.oxfam.org/en/research/turning-humanitarian-system-its-head).
} 
Hai que lembrar tamén que as cifras de axuda oficial ao desenvolvemento (AOD) quedaron fortemente afectadas pola crise económica iniciada coa creba das subprime en xullo de 2007, cunha redución especialmente significativa no continente europeo, como amosan de forma significativa os casos español, catalán ou galego.

A situación paradoxal é que, cos Obxectivos de Desenvolvemento Sustentable aprobados en 2015, cunha Axenda 2030 esixente e universal para todos os países que marca fitos que lograr nun prazo de 15 anos, a crise financeira e de obxectivos do sistema de axuda ao desenvolvemento vese agora acompañada dunha crise estrutural e do sistema de axuda humanitario.

1.2. A crise dos refuxiados é unha crise internacional e europea de longo alcance, non unha emerxencia conxuntural ou que aparece de improviso. Había e hai suficiente información, coñecemento e razóns obxectivas para aceptar que se trata dunha crise humanitaria de grandes proporcións, esperable e que non se disolverá a curto e a medio prazo coma unha pedra de azucre. En suma, sabemos sen dúbida ningunha que debería aplicarse a normativa existente (dereito de asilo e disposicións europeas e nacionais que protexen de tratos degradantes) e, sobre todo, innovarse

Insisto, non se sostén de xeito ningún cos feitos falar de emerxencia conxuntural e imprevisible, nin sequera comparar a crise actual con crises anteriores, considerala unha versión corrixida e aumentada de episodios previos de chegada de migrantes ou refuxiados á uE, fenómenos en que o factor fundamental fora a busca de traballo, un factor que, con todo, segue presente na actual crise, como amosa a presenza de persoas de Senegal ou de Gambia. Tampouco é comparable, pola súa magnitude, e pola procedencia mixta (véxase o punto seguinte), ás chegadas de emigrantes e refuxiados derivadas das guerras dos Balcáns, iniciadas a principios do decenio dos 90 do século $\mathrm{xx}$.

A crise actual caracterízase polos seguintes trazos:

a. por estar vencellada a situacións de conflito e de inestabilidade de cinco ou seis anos de duración (ou máis en certos casos) no Oriente Próximo e o Oriente 
Medio (primaveras árabes, guerra en Siria, Iraq, guerra no Iemen), Asia (Afganistán, Bangladesh) e África (Licia, Eritrea, os Sudáns, Somalia);

b. por ter raíces europeas desde 2011, coas chegadas masivas de migrantes produto das primaveras árabes á illa de Lampedusa, a 70 quilómetros da Tunisia;

c. por ter vencellos con actores ilegais, que se aproveitan das necesidades dos refuxiados (é dicir, delincuentes transnacionais, mafias, grupos terroristas que se lexitiman mediante lecturas do Islam relixioso ou político fundamentalistas, todos eles con crecentes vinculacións entre si);

d. por vencellar, de forma difícil de separar claramente, migrantes por razóns económicas e persoas que procuran refuxio ou asilo político;

e. por se incrementar notoriamente desde o ano 2015, e

f. por estar a xerar unha crise política e institucional, e unha incipiente crise de valores e de finalidades, na Unión Europea.

Facticamente, a crise amosa unha mudanza radical das tendencias migratorias en Europa, dinámica, non acabada aínda. O fenómeno iniciouse en 2011, cando milleiros de tunisianos tentaron chegar ilegalmente a Lampedusa, e no 2012, con milleiros de subsaharianos que chegaron a Libia para intentar o último «salto", como volve pasar agora. En xeral, o groso dos movementos proceden de Siria, Afganistán e Eritrea.

Concretamente, a procedencia dos refuxiados está moi concentrada, como tendencia. Entre o $85 \%$ e o $87 \%$ proceden de 10 países, aproximadamente repartidos así: $51 \%$, Siria; $14 \%$, Afganistán; $8 \%$, Eritrea; $4 \%$, Nixeria; $3 \%$, Iraq; $2 \%$, Somalia; $2 \%$, Sudán; $1 \%$, Gambia; $1 \%$, Bangladesh; $1 \%$, Senegal.

Esta drástica mutación das tendencias, cuantitativas e cualitativas, ten un impacto claro nas demandas de acceso á UE e de protección internacional, as cales, segundo datos da Comisión, desde 2014 superan de media as 700000 ao ano, a demanda máis alta desde 1992, cando estourou a crise e logo as guerras dos Balcáns.

Canto ás rutas, deixareinas de lado, mais os gráficos amosan mudanzas importantes; abonde con este: 
O NOVO SISTEMA INTERNACIO

\section{Routes to a better life}

Main migration routes into Europe from Africa and the Middle East.

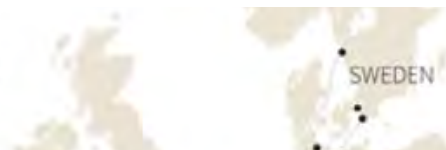

$$
\text { - }
$$

and the Middle East.

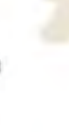
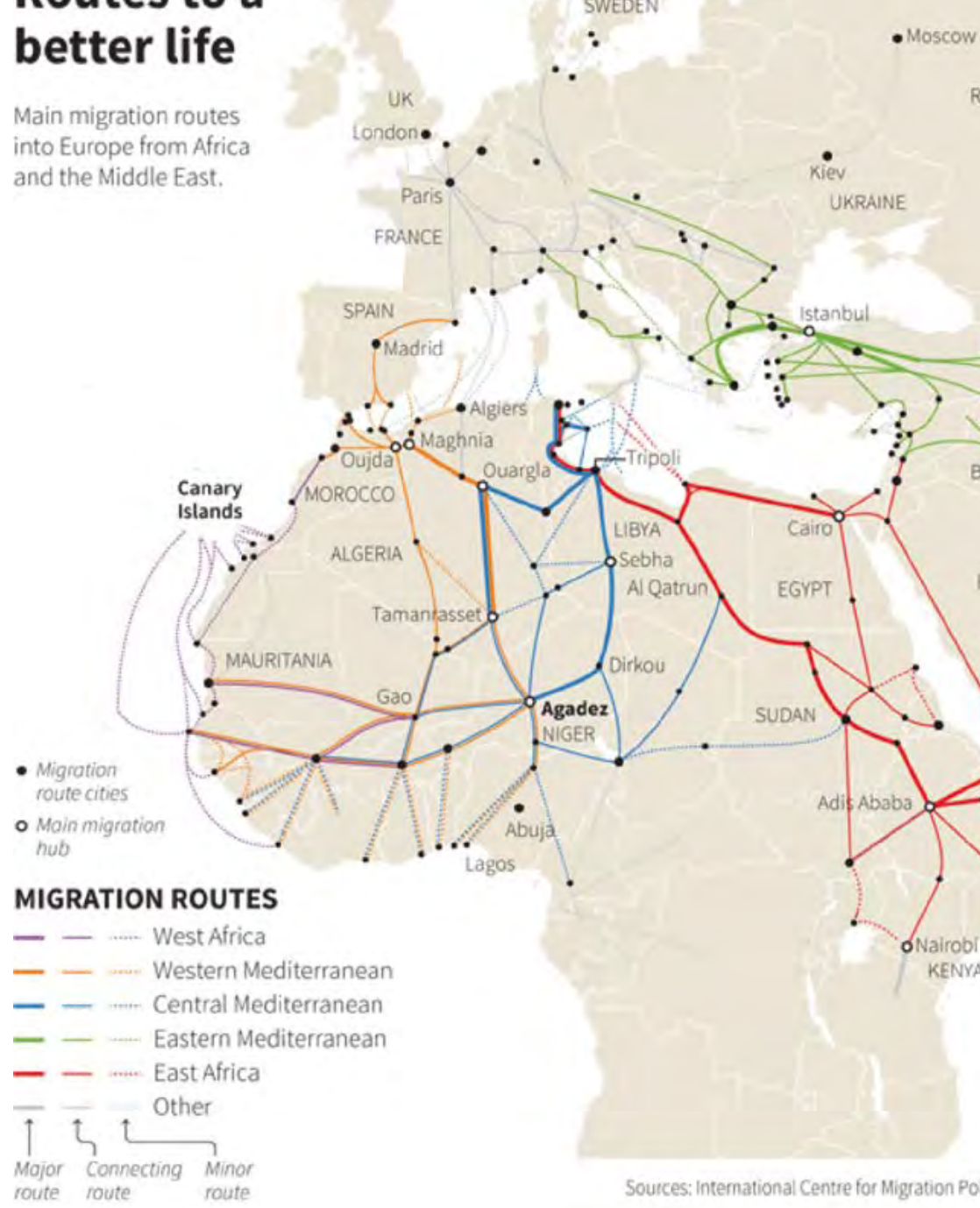

Parece obvio o que se mostra; os lugares elixidos para chegar son as fronteiras orientais e meridionais de Europa, con especial fincapé nas illas gregas e Italia. Recentemente, o punto crucial é o paso central do Mediterráneo, o que pon a Italia no medio da crise, para as persoas que veñen de Siria, Iraq, Eritrea, Exipto e Somalia. Isto supón unha mudanza clave con respecto ao que pasaba no 2012, 
cando máis do 50 \% das chegadas, segundo datos de Frontex, se daban en Grecia, que segue a ser un punto destacado de chegada.

Non obstante, convén lembrar que os fluxos de refuxiados non chegan nin exclusiva nin soamente ás fronteiras da UE: Turquía recibiu máis de dous millóns, o Líbano máis de 1,5 millóns, Xordania máis dun millón e centenares de miles chegaron a Exipto e Iraq. E ningún deses países, excepto Turquía tras o embarazoso e vergonzoso acordo coa UE, recibiron axuda por isto, malia que neste momento case un $30 \%$ da poboación libanesa sexan actualmente refuxiados. Especialmente grave é o caso dos países do golfo Pérsico, onde Arabia Saudita, Kuwait, os Emiratos Árabes e Qatar, pese ao seu papel nalgúns conflitos de xeito directo ou indirecto, non reciben refuxiados e nalgúns casos retiraron o permiso de residencia a cidadáns sirios que tińan anos de presenza. Non houbo a suficiente presión da UE e dos EUA para eses países mudaren as súas políticas de acollida.

A conclusión resulta obvia e cada vez máis clara para a opinión pública: a presión da crise humanitaria está mal repartida, de certo, mais tampouco é a UE a que tivo e ten o impacto maior. Catro países da subrexión acollen xa case cinco millóns de refuxiados, polo que o limiar de saturación, sen os países do golfo, semella próximo. Alén diso, algúns países, nomeadamente Turquía, negan ou dificultan o permiso de traballo, recoñecido na convención sobre persoas refuxiadas.

Se a situación perdura, Europa e os países do golfo deberán incrementar a acollida, non só a nominal (UE), senón a real, asegurando estadías relativamente longas mentres non se solucionen as causas estruturais, vencelladas á conflitividade armada, factor clave, aínda que non único, nos desprazamentos forzados de poboación.

\subsection{A crise dos refuxiados é unha crise política da UE, que socava a súa credi- bilidade ante os seus cidadáns e ante o mundo}

Como se dixo, o crecente número de migrantes e de persoas que solicitan asilo escapando de conflitos no Oriente Próximo e África presenta retos moi cruciais aos decisores da UE, nun contexto no que o nulo ou baixo crecemento económico, o auxe da extrema dereita e a xenofobia e a persistencia de políticas estatais fracturadas e enfrontadas dificultan a toma de decisións de forma obxectiva. 
Un informe da Organización Internacional para as Migracións de $2014^{2}$ consideraba Europa o destino máis perigoso para a migración irregular e o Mediterráneo o lugar máis perigoso do mundo para tentar cruzar fronteiras. Dito doutro xeito, constatábase unha gran contradición entre a percepción xeneralizada entre os migrantes de que a UE, certos países en particular, son un espazo de prosperidade, seguridade e riqueza, e, xa que logo, un lugar axeitado para buscar refuxio ou asilo, e a realidade: ata agora, a resposta colectiva das institucións da UE e dos Estados membros foi serodia, insuficiente, ad hoc e reactiva. A razón, para os analistas independentes, parece clara: a ausencia de políticas e estándares compartidos, e tamén que se priorizaron as políticas orientadas a protexer/asegurar as fronteiras da UE antes ca as que derivarían de primar a obriga legal e moral de protexer os dereitos dos refuxiados e migrantes.

A favor da uE pódese dicir que, de certo, non é doado distinguir nunha crise á vez humanitaria e migratoria entre persoas que buscan refuxio ou asilo político, que teñen dereitos internacionais recoñecidos e que a UE debería protexer, e persoas que buscan simplemente mellorar a súa situación económica, onde as decisións legalmente dependen do que acordasen as institucións comunitarias e os Estados membros. De certo, como acontece sempre, existen zonas grises, indefinidas, alegais mesmo. Non obstante, diversos estudos deixaron claro que entre os 28 Estados membros actuais se usan estándares e métodos de decisión sobre a concesión do dereito de asilo claramente incoherentes ${ }^{3}$, o cal agrava a percepción de estar fronte a unha crise política e de toma de decisións da UE. Alén diso, cada vez máis cidadáns de moitos países da UE manifestan a súa vontade particular de acolleren e critican a falla de coherencia, a inacción e as decisións tacticistas, así como o incumprimento das escasas decisións. En suma, creceu, malia que con certa polarización, o apoio a políticas de acollida sen restricións, dada a urxencia extrema, unha actitude que impregnou a práctica de moitas autoridades gobernamentais non centrais (cidades, rexións, en terminoloxía da UE) e da sociedade civil.

Discútese sobre o efecto de chamada, mais parece claro que é selectivo e nel inflúen noticias e percepcións, por veces erróneas, verbo de en que sitios hai menor rexeitamento ou maiores probabilidades de traballo, o cal explica a atracción

${ }^{2}$ http://publications.iom.int/bookstore/free/FatalJourneys_CountingtheUncounted.pdf.

${ }_{3}^{3}$ Véxase http://www.unhcr.org/4bac9ae19.html. 
por Alemaña. Que existan posicións diferentes, cotas diferentes, realidades diferentes para solicitar o reagrupamento familiar ou para se cumpriren os procedementos administrativos para cada trámite... parece influír moito. Algo que unha maior coherencia nos estándares dos Estados membros evitaría.

Todo isto permite suxerir unhas teses conclusivas:

1. A UE enfróntase non só a unha crise humanitaria, e parcialmente migratoria, senón tamén a unha importante crise politica e institucional, con consecuencias graves a medio e longo prazo.

2. A crise está a socavar a percepción da UE como espazo de seguridade e de benestar, e como actor internacional tradicionalmente defensor de políticas avanzadas en materia de dereitos humanos, cooperación ao desenvolvemento ou construción da paz, algo que xa percibe parte da cidadanía europea e tamén a doutros países.

3. O socavamento da percepción positiva da UE afecta á súa lexitimidade, posto que a súa xénese e historia adoitan presentarse como un proceso que institucionaliza a resolución pacífica de conflitos e a creación dunha comunidade de seguridade, unha idea que exporta ao mundo, que inspira a súa acción exterior, mais que, agora, resulta contraditoria coa súa maneira de afrontar a crise humanitaria, cun sistema decisional progresivamente ineficiente en grao sumo. Lembremos que xustamente as razóns para a concesión do Nobel da Paz á uE foron as que acabo de expresar.

4. A solución pasa por combinar accións e politicas que se orienten ás diversas causas: estruturais e de longo alcance; multiplicadores e aceleradores e detonantes.

Dito doutro xeito, non hai solución posible sen prestar atención non só aos síntomas e problemas inmediatos, senón tamén ás causas de fondo. Volveremos sobre isto nas conclusións.

Ocuparémonos agora de por que o sistema internacional, o seu xeito de funcionar, dificulta obxectivamente a resolución dos problemas e, en concreto, de como mudou na pos guerra fría. 


\section{O NOVO SISTEMA INTERNACIONAL DE POSGUERRA FRÍA: MU- DANZAS EN CURSO E O PROBLEMA DA XESTIÓN DA VIOLENCIA DIRECTA NON POLÍTICA}

O mundo cambiou fortemente nos últimos decenios e esa mudanza reflíctese na esfera internacional de forma clara, vinte e cinco anos despois da fin da guerra fría.

2.1. A pos guerra fría e o seu impacto na axenda global, na seguridade e na conflitividade violenta

De feito, a mudanza do sistema internacional non concluíu e diferentes acontecementos, entre eles a crise económica e financeira iniciada no 2007, estana a acelerar. As ditas mudanzas xeran novos contextos e novos retos no sistema internacional, ao se transformaren a axenda, os actores e as interaccións de conflito e de cooperación que se dan nas relacións internacionais e influír, pola súa vez, as ditas mudanzas na esfera das políticas internas. Asistimos á progresiva substitución dun sistema internacional clásico, con fronteiras e regras de funcionamento bastante precisas, por un sistema social globalizado, no que se producen fenómenos parcialmente contraditorios á vez: globalización, rexionalización, fragmentación e localización. E, naturalmente, eses contextos e retos afectan á esfera da seguridade na que debemos inserir o debate actual sobre os retos da axenda teórica e práctica da construción da paz e, no noso proxecto, a súa eventual aplicación con enfoque de seguridade humana aos problemas de seguridade interna.

Podemos resumir os eixes básicos desa mudanza, para os efectos deste texto, así:

Grandes mudanzas do sistema internacional na pos guerra fría

a) no centro do sistema atópanse agora os factores económicos, xa non os políticos;

b) a concepción do poder transformouse, así como a súa distribución e difusión, a nivel de Estados, rexións e actores transnacionais e non gobernamentais;

c) os países emerxentes, e en xeral o Sur, están a gañar unha crecente centralidade, cuantitativa e cualitativa; 
d) o desenvolvemento, entendido xa de forma plural e non só como crecemento económico, está no centro das preocupacións do sistema, máis ca antes, canda os novos rostros da pobreza e a desigualdade, e

e) xurdiu unha nova concepción da seguridade —entendida como proceso multidimensional, orientada tamén ás persoas e non só ás nacións-, que debe prestar atención a novos riscos e perigos, como as novas formas ou rostros da violencia. Adoita aludirse a ela, como veremos, coa denominación de seguridade humana.

Adicionalmente, mudaron a concepción e a práctica do poder, así como a súa difusión e as relacións de poder entre os actores. Por unha banda, o poder fundamental procede agora do que se chamou "poder estrutural» (a capacidade de conformar as regras do xogo) e "poder suave» (a capacidade de persuadir, de convencer), cunha clara erosión do poder «duro» (militar). Dito doutro xeito, o poder non depende só, ou non tanto, do que tes (poder como recursos), senón das túas relacións (poder relacional), da túa capacidade de conformar o sistema (poder estrutural) e da túa capacidade de ofrecer insumos e relacións atractivas, de interese mutuo, para outros actores (poder «suave»).

Por outra, estanse a alterar as estruturas do poder internacional mediante a combinación de tres fenómenos, interrelacionados: 1) a debilitación progresiva, polo menos en termos relativos, das grandes potencias do Norte; 2) a crecente centralidade de potencias emerxentes (BRICs, por exemplo), con sistemas febles de articulación entre elas, e a formulación rexional e subrexional das potencias rexionais e de países con alto potencial de crecemento, e 3) a presenza de diferentes liderados (potencias hexemónicas e aspirantes) nas diferentes dimensións da vida internacional (política, militar, económica, financeira, tecnolóxica...).

Esas mudanzas da estrutura do poder internacional poden describirse, en tanto que tendencia forte, como unha «desoccidentalización» do mundo, cunha presenza crecente —non só económica- do Sur e do Oriente, un transvasamento do eixe de gravitación da actividade económica e do poder mundial do Atlántico ao Pacífico. Existen, no entanto, dúbidas verbo de se o futuro leva cara a unha situación de repartimento do poder crecentemente multipolar, a un «G-2» (cos EUA e a China á fronte) ou mesmo a un «G-0», unha orde na que ningún Estado ou organismo multilateral queira ou poida gobernar o sistema. 
As mudanzas afectan particularmente aos dous bens públicos básicos dos que deben prover os Estados, o benestar ou desenvolvemento e a seguridade, nomeadamente física da cidadanía. Non nos ocuparemos neste contexto das mudanzas relativas ao desenvolvemento, entendido como proceso multidimensional orientado a satisfacer necesidades humanas mediante actores privados e públicos, que segue a ocupar unha posición central no sistema, concibido como un dereito humano. Si, porén, dos que teńen que ver coa seguridade e a xestión da conflitividade violenta.

A nova concepción da seguridade

Respecto da seguridade, xurdiu unha nova concepción dela, entendida como proceso multidimensional que afecta a actores múltiples e non só aos Estados, con especial incidencia sobre persoas e comunidades, e que esixe instrumentos e actores múltiples.

\section{Trazos da nova concepción da seguridade}

Esta nova concepción pódese caracterizar rapidamente mediante diversos trazos distintivos.

Primeiro, debe atender sobre todo a ameazas, retos e perigos que afectan ás persoas, unha vez que diminuíron os conflitos armados e a violencia mortal con intencionalidade política ${ }^{4}$. Xurdiron, adicionalmente, novas facetas ou manifestacións da violencia. Por unha banda, a violencia homicida sen intencionalidade política directa. Por exemplo, segundo datos do informe Global Burden of Armed Violence $^{5}$, as mortes por arma de fogo supoñen unha media de 500000 baixas ao ano. Un oitenta por cento delas non se deben a violencia intencionalmente política (é dicir, a conflitos armados de diferente tipo e a terrorismo), senón a outras

\footnotetext{
${ }^{4}$ Para consultar unha análise máis polo miúdo, véxase Grasa, Rafael (2007): «Los vínculos entre seguridad, paz y desarrollo: la evolución de la seguridad humana», Afers Internacionals, 76, 9-46 (monográfico sobre seguridade humana coordinado por Rafael Grasa e Pol Morillas).

${ }^{5}$ Geneva Declaration, Global Burden of Armed Violence 2011. Véxase http://www.genevadeclaration.org/ measurability/global-burden-of-armed-violence.html. En 2014 e 2015 a porcentaxe de mortes en conflito armado subiu por mor do caso da Siria, mais isto non afecta á tendencia sinalada.
} 
razóns (delincuencia nacional e transnacional organizada, inseguridade cidadá, narcotráfico, bandas xuvenís...). Mesmo en países que solucionaron os seus conflitos armados internos mediante negociacións políticas ou procesos de paz hai xa décadas, o reto que supoñen estes novos rostros da violencia é moi importante, como sucede na América Central.

Segundo, debe facer fronte á proliferación do que se chamou «violencia crónica», un fenómeno que describe o feito de a poboación, nalgúns países, se atopar enfrascada nunha espiral crecente de violencia social, que afecta ás relacións sociais, o desempeño da democracia e a práctica cidadá na rexión. Estudos recentes amosan os mecanismos polos que unha gama de forzas profundamente enraizadas estimulan e reproducen a violencia crónica e destrúen ou erosionan o tecido social de comunidades e países vulnerables, ata o punto de se correr o risco de que tales tendencias poidan devir en normas sociais de facto, tendo en conta que a miúdo se dan casos en que tres xeracións de persoas non cońeceron outro contexto vital ca esa violencia crónica.

Terceiro, producíronse mudanzas na natureza e na situación dos conflitos armados no mundo, cunha clara diminución dos conflitos armados interestatais fronte aos internos, se ben unha porcentaxe significativa destes últimos se internacionalizan. Podemos resumir esas mudanzas así: por unha banda, malia todos os conflitos armados seren multicausais, en todos eles pode singularizarse, polo menos en cada etapa, un factor predominante, territorial ou político. E na pos guerra fría obsérvanse unha maior presenza de factores políticos e un descenso dos factores territoriais. Por outra banda, a situación xeográfica dos conflitos armados, variada e oscilatoria, mudou. Ata 1990 destaca a continuada presenza en alto grao na Asia e a escasa presenza, en tanto que conflito armado, na Europa. Na pos guerra fría, o característico é a reaparición do continente europeo como escenario importante de conflitividade armada e a redistribución no Sur, nomeadamente o seu incremento en África e Asia e o seu descenso nidio e claro na América Latina.

En suma, a pos guerra fría acentuou algo que xa era visible desde os anos 70: a existencia de dúas zonas diferenciadas, unha de paz e outra de turbulencia. Unha zona de paz, nidia, formada por uns cincuenta ou sesenta países, que non tiveron guerra ningunha desde 1945 e que parece altamente improbable que a teñan no futuro (deixando de lado a zona fronteiriza a Rusia, en particular Ucraína). A razón é simple: son países que presentan sistemas democráticos consolidados e for- 
te vinculación económica entre eles, tanto que probablemente, se non recorren á guerra a pesar de teren diverxencias moi fortes, é porque mesmo o vencedor sairía perdendo dada a interpenetración existente.

Mais tamén unha zona de turbulencia ou conflitividade violenta alta, a zona do Sur, na cal adoitan darse tres características, sen se establecer necesariamente relación de causalidade: 1) sistemas democráticos dubidosos, o que algúns politólogos denominan «democracias incertas» ou «anocracias»; é dicir, países con grandes carencias democráticas mesmo no sentido máis formal da palabra democracia; 2) economías enormemente fráxiles, e 3) poboación cunha forte compoñente de fractura étnico-cultural. África, pese á mellora, segue a estar, globalmente, na zona de turbulencia. Podemos dicir, pois, que a conflitividade armada da pos guerra fría se dá, en pequena escala, no Norte e no Sur (xeralmente Sur-Sur). A isto hai que lle engadir algúns conflitos onde o factor transnacional, moi ligado á dimensión económica, resulta crucial, como sucede no caso paradigmático da República Democrática do Congo.

Por último, na pos guerra fría acentuouse de forma moi importante unha tendencia que existía xa desde mediados dos anos setenta nos conflitos armados, perceptible tanto na súa situación xeográfica e fronteiriza como no número de vítimas que causaban: descenso dos conflitos interestatais e incremento dos internos. A primeira década da pos guerra fría agudizou a dita tendencia, ata o punto de que entre un $90 \%$ e un $95 \%$ dos conflitos armados, segundo o rexistro que se use, son de tipo interno. Todo isto marcou a reflexión teórica e deu pé a que se cuñasen diversas denominacións para o fenómeno, como, sen pretensión de exhaustividade, as seguintes: a época das "guerras pequenas» (Singer, Zartman, Bloomfield), as "guerras de terceiro tipo ou de guerrillas» (Rice), as "guerras non clausewitzianas ou non trinitarias» (Kaldor, Holsti) ou as «novas guerras».

E, en cuarto lugar, produciuse unha importante presenza de actores privados de seguridade, derivada de diversos fenómenos que se atopan en curso. Entre eles, citaremos os seguintes: a) a perda parcial do monopolio dos medios masivos de violencia por parte do Estado, pola man de actores privados, en boa medida ilícitos (grupos terroristas, narcotraficantes e grupos de delincuencia organizada etcétera); b) o crecente recurso legal a actores privados de seguridade (empresas privadas, mercenarios), e c) a presenza en moitos conflitos armados de grupos armados non estatais. 
En resumo, e en quinto lugar, todo isto conflúe nunha mudanza da concepción da seguridade, que agora se entende como un proceso multidimensional (con dimensións ecolóxica, sociopolítica e económica, e non só militar), centrado en retos, perigos e ameazas de natureza moi diversa, que afectan non só aos Estados, senón, en particular, a comunidades, formas de vida e persoas. A miúdo a comunidade internacional e o mundo académico refírense a isto empregando nocións como «seguridade humana» e «responsabilidade de protexer», e conceptos que explican como, en determinadas situacións, certas ameazas ou retos non directamente vinculados coa seguridade se acaban «securitizando». En suma, estamos nunha época caracterizada por conflitos complexos e onde as interpretacións simplistas, maniqueas ou en branco e negro resultan imposibles.

Nestes 25 anos de pos guerra fría, os conflitos armados e as manifestacións da violencia evolucionaron moito, de maneira que actualmente son de natureza moi heteroxénea, con tendencia, en moitos casos e zonas, a estaren vencellados a diferentes causas, e, alén diso, non só afectan a Estados, senón tamén a persoas. 


\section{A POLÍTICA INMIGRATORIA ESPAÑOLA NO NOVO ESCENARIO: CONSIDERACIÓNS \\ E PROPOSTAS}

Antonio Izquierdo Escribano

Universidade da Coruña 

Na política migratoria o criterio ético ben podería ser o de «failles aos outros o que che gustaría que che fixesen a ti».

Paul Collier

\section{INTRODUCIÓN. TRAZOS DA PAISAXE INMIGRATORIA ESPAÑOLA E PROPÓSITO DESTE TRABALLO}

A pegada estatística que deixou a política española ao longo destas tres décadas de inmigración (1985-2015) sintetízase en dous resultados que cabe avaliar. $\mathrm{O}$ primeiro amosa que nos atopamos nunha situación de certo equilibrio entre a estranxeiría cultural e os dereitos cidadáns. Noutras palabras, o stock de residentes estranxeiros divídese, a partes iguais, entre persoas incluídas no réxime comunitario e as inscritas no réxime xeral. E, como é ben sabido, os primeiros gozan de máis dereitos e vantaxes — como cidadáns da Unión Europea- ca os segundos, é dicir, os non-comunitarios. E o segundo dato salientable é que a trasfega migratoria que tivo lugar entre 2008 e 2015 foi moi intensa. Noutras palabras, que asistimos a fluxos de entradas e saídas realmente copiosos, malia que de parecida estatura ${ }^{1}$.

Así, pois, os dous resultados apuntan cara ao equilibrio e a vitalidade. De tal maneira que o saldo final, é dicir, o depósito de inmigrantes, se baleirou pouco, apenas un $10 \%$ do total. O que resulta máis significativo, cando se trata de pensar nas políticas migratorias, é que foi o stock de estranxeiros (non tanto o

\footnotetext{
${ }^{1} \mathrm{O}$ caudal dos fluxos presenta algunhas variacións se no canto da estatística de variacións residenciais (EVR) se toma como fonte de análise a estatística de migracións (EM), mais a tendencia e a interpretación non varían, posto que o volume anual de entradas se situou ao nivel do total de nacementos e o de saídas na contorna da cifra de defuncións. É dicir, o groso dos fluxos, na súa dupla dirección, foi moi notable e sitúase como un fundamento básico na reprodución da poboación.
} 
de inmigrantes) o que minguou nunha medida maior. E esa diminución da estranxeiría respecto da inmigración está vencellada ao proceso de naturalización por residencia, ou, dito doutro xeito, ao cambio de estranxeiro a cidadán español, e, en consecuencia, impulsa a inclusión do «naturalizado de orixe estranxeira» no ámbito das políticas públicas.

No terreo das percepcións dos cidadáns asentadas tras a gran recesión, son tres as ideas que quedaron gravadas na opinión pública espańola. A primeira cre que, por mor da crise, unha gran parte dos inmigrantes estranxeiros retornaron ao seu país de orixe. A segunda constata que non houbo conflitos racistas cos estranxeiros, pese á enorme taxa de desemprego. E, por último, malia que sexa a idea máis propagada nestes últimos anos, esténdese o estado de ánimo segundo o cal os españois, maioritariamente novos e cualificados, emprenderon un novo ciclo emigratorio cara a Europa, que rememora o de metade dos sesenta. Volvendo ao ámbito da política migratoria, que é o que nos ocupa, estas tres ideas interpelan, respectivamente, 1) á evolución dos fluxos, 2) ao modelo de integración e 3) á valoración da emigración como un fracaso social.

Á vista desa discreta diminución do stock de inmigrantes e desa maior redución da estranxeiría, este traballo ocúpase da política que cabe facer, nun novo escenario, tendo en conta o variado e variable estado da opinión pública e o evidente proxecto de asentamento dos inmigrantes.

A evolución dos datos pódese sintetizar en tres pasos. Primeiro, durante tres décadas (1985-2015) a política de "estranxeiría laboral» impúxose á política de inmigración e de cidadanía. Segundo, a experiencia acumulada e os resultados colleitados aconsellan que se leve a cabo un debate público cuxo fin sexa configurar un modelo migratorio para Espańa. Este modelo ha de se traducir nunha política de Estado. E terceiro, na súa vertente política, este acordo migratorio de carácter estratéxico ha de se manifestar non só na xestión da estranxeiría laboral, senón tamén, sobre todo, na elaboración dunha política de inmigración e de cidadanía.

Gran parte do dito ata aquí condénsase nestas tres ideas, a saber:

1) Tras oito anos de gran recesión, o depósito inmigratorio apenas minguou. E sobre este primeiro estrato migratorio edificarase unha parte da sociedade futura. Dado o poder de atracción desta primeira capa de poboación foránea, é preciso estudar, polo miúdo, o seu proceso de adaptación, (máis ou menos) segmentado. 
2) A permanencia dos inmigrantes de orixe estranxeira callou como un dos ingredientes básicos na anovación da estrutura social. E desde agora cabe xestionar as migracións non só como man de obra, senón, principalmente, como un investimento cívico e social a medio e longo prazo.

E, por último,

3) os fluxos demostraron o seu vigor, mesmo nos anos máis duros da crise. O cal evidencia que non é só, nin acaso primordialmente, a chamada do emprego o que atrae os inmigrantes, senón que o que impulsa as xentes a emigrar é, por unha banda, a busca de seguridade vital en calquera das distintas etapas do ciclo de vida, e, pola outra, a satisfacción, máis ou menos impaciente, das expectativas que as súas aptitudes e carácter estimulan.

\section{O NOVO ESCENARIO MIGRATORIO: CONXUNTURAS E TEN- DENCIAS DE FEITO NA OCDE E EN ESPAÑA}

Repensar a política migratoria nun novo escenario require sintetizar os trazos básicos dese novo contexto e interpretar a evolución dos feitos. Este escenario caracterízase por unha revolta contra a inmigración por parte daqueles que se senten máis danados pola crise. E, neste sentido, pensamos que unha das consecuencias da gran recesión foi a desmaterialización das percepcións sobre a inmigración entre os cidadáns do común. De maneira que, se antes da crise as opinións públicas puñan a tónica nos beneficios económicos e nos prexuízos sociais que comportaba a aceptación de inmigrantes, agora, tras a ampla redución do benestar que se produciu nesta crise, as actitudes de rexeitamento cara aos foráneos concéntranse na distancia cultural e na inseguridade urbana. Nunha frase, hoxe sinálase a condición de estranxeiría onde onte primaba a concepción de utilidade laboral. Por resumilo, o inmigrante detrae benestar material e rompe a identidade cultural. Noutras palabras, a gran recesión económica, democrática e social engadiu o repregamento relixioso — no seu sentido doutrinal e patrióticoá debilitación do Estado de benestar.

Nos países que integran a OCDE, e tamén no conxunto da UE, os fluxos de inmigración e os de solicitantes de asilo aceleráronse nos dous últimos anos. É máis, ao longo de 2014 a inmigración permanente alcanzou os niveis de 2008 — cando nos atopabamos no limiar da crise-, con máis de 4,3 millóns de entradas. E os peti- 
cionarios de asilo excederon as 800000 demandas, das cales 600000 se dirixiron aos países da UE. Todos os prognósticos, baseados nos datos aínda provisionais que manexa a OCDE, auguran que para 2015 se van superar eses niveis tanto no tocante á inmigración de carácter permanente como, e sobre todo, no que atinxe ao fluxo de asilados. No seo desta formidable chea, a inmigración irregular tamén aumenta e resulta máis difícil de controlar ${ }^{2}$.

O conxunto da UE enfróntase, desde o punto de vista fáctico, á enchente desa dupla corrente, a dos refuxiados potenciais e a dos migrantes tradicionais. E tamén se topa coa fraxilidade e a inestabilidade da recuperación económica, e co aumento da vulnerabilidade dos mercados de traballo. Nos bastidores, o que está en disputa é cal vai ser o lugar do poder político na configuración do modo de vivir e que evolución vai seguir o sistema democrático. É dicir, o grao de colonización da razón pública respecto da privada, ou, se así se quere ver, a mercantilización da sociedade civil e o grao de subalternidade da política estatal respecto do poder financeiro.

Desde o punto de vista emocional, a uE está aterrecida por outra dupla presión, a mediática e a que atinxe á seguridade da vida cotiá. As poderosas imaxes dos nenos afogados que as ondas arriman ás praias e as de longas columnas de solicitantes de asilo que se arrastran polos camińos e deixan a esperanza entre os aramados polarizan — dividen e segmentan — as actitudes respecto da acollida de inmigrantes e de asilados. Mais, polo outro costado, a proliferación das accións terroristas avala o xiro restritivo que experimentan as políticas de asilo e de inmigración, e enturban as actitudes de empatía dos cidadáns «correntes» cara aos foráneos.

A tensión entre a alza dos fluxos e o rexeitamento da opinión pública pódese esquivar no curto prazo electoral, mais as políticas de inmigración, na UE, han de se guiar, tamén, polo longo prazo da reprodución social. É a tensión que se produce entre o interese partidario e o interese xeral, entre o autointerese e o ben común. Que a migración é unha compoñente estrutural das sociedades avanzadas pódese soster a teor dos testudos feitos e malia a axitación das emocións. $\mathrm{O}$ cal, e para volvermos ao ámbito das políticas migratorias, ha de levar os Gobernos a liderar unha política educativa que sirva para conformar as actitudes do común das xentes e procure suavizar os prexuízos e presentimentos que se constrúen, en

2 Nos seis primeiros meses de 2015, 137000 persoas desembarcaron nas costas gregas, italianas, españolas e maltesas. No mesmo período do ano anterior fixérono 75000 (OCDE, Editorial). E unhas estimacións do Pew Research Center, publicadas en agosto de 2016, calculan en 1,3 millóns o número de refuxiados que se dirixiron cara a Europa en 2015. 
gran medida, a través dos medios que forman (deforman) e constrúen a opinión pública.

E, por seguirmos con outro exemplo pegado á pel do que aquí nos trae, recoméndase que os Gobernos tomen decisións sobre a regulación dos fluxos distinguindo entre o curto e o longo prazo. E, pola mesma razón, aconséllase que teñan en conta a heteroxénea natureza dos fluxos e a súa distinta composición. Dito noutros termos e de forma breve, sobre os refuxiados potenciais pódese actuar nos países de orixe, acurtando a guerra e contribuíndo a reparar a destrución. Sobre a migración tradicional tamén se pode influír potenciando a migración circular e seleccionando a migración permanente.

\subsection{O novo escenario en España}

A longa e profunda recesión desembocou noutro contexto laboral e social. Mais o estrato inmigratorio, na súa maior parte, aguantou e, sobre todo, madurou e sedimentou. A inmigración que chegou nos anos previos á recesión cambaleouse ou marchou durante o trienio máis duro e negro da crise (2011-2013), pero o groso dos que viñeron durante o primeiro lustro do século xxi ficou. Hoxe os residentes foráneos teñen como media máis de 13 anos de residencia ${ }^{3}$. E, cando un supera a década de vida nun país que non é o do seu nacemento, hase de recoñecer que ten arraigamento dabondo para actuar, de pleno dereito, como parte desa sociedade.

En España o que acontece, ademais, é que os datos de feito e as emocións están empapadas de anacronismo. Polo lado dos feitos, os fluxos de entrada minguaron, pero menos do que se percibe, e os de saída aumentaron, mais non tanto como se fantasía. En consecuencia, o saldo migratorio foi lixeiramente negativo, pero só durante tres anualidades, pois outra vez volve ser, en 2015, levemente positivo. Sen sabermos aínda se se vai confirmar a repunta inmigratoria, o que si se pode afirmar é que a circulación durante os últimos oito anos foi e é moi intensa. Para dar conta dese grande intercambio no seu duplo sentido, abonda con facer a suma de entradas e saídas. Comprobaremos que o que máis resalta, durante o longo período de crise, é a contía do caudal na dupla dirección, pois produciuse unha media de 800000 movementos anuais.

\footnotetext{
3 Dato extraído da EPA e tirado da presentación ao número 24 da revista Panorama Social. Número dedicado a afondar nos procesos de integración e a ofrecer novas perspectivas de análise.
} 
Como acabamos de sinalar, no último ano o saldo é lixeiramente favorable ás entradas; é dicir, veñen uns poucos máis dos que se van. A conclusión que cabe tirar destes algarismos é que ese copioso movemento reclama un maior esforzo das políticas de control, tanto en canto á súa cantidade como no tocante á súa composición. E iso co fin de evitar non só que entren masivamente os que logo non van ter acomodo digno, senón tamén que os que o fagan sexan os axeitados para unha emigración, sexa ela de signo permanente ou circular ou, de ser o caso, de carácter temporal. Ha de ficar claro que esa política de selección e regulación de fluxos resulta tamén necesaria para evitar que as saídas sexan indiscriminadas e se perda un potencial que pode xerar emprego e riqueza, mais tamén ha de se preocupar de enriquecer o tecido comunitario. Isto significa que as políticas de control (selección e regulación) han de pensar tamén en termos de integración, é dicir, en familias, en menores, en idioma, en formación.

A vertente emocional da cidadanía española empapouse coa imaxe da emigración de xente nova de «clase media», formalmente instruída — con estudos medios e superiores-, que vai na procura dun emprego que se adecúe ao seu nivel formativo. É dicir, unha saída de rapaces, culturalmente ben equipados, que queren evitar o seu desclasamento e a frustración das súas expectativas. Esa imaxe revolveu o pouso pesimista — de fracaso social e nacional - que impregnou tradicionalmente a emigración española ao exterior (e, por certo, tamén a interior) durante o século xx. Unha percepción que vinculou e identificou correctamente a emigración (interna e internacional) coa pobreza, a represión política e o bloqueo da mobilidade social e ocupacional. Mais que errou ao identificar calquera movemento de saída con emigración. Cando a mobilidade se agranda, a emigración achícase. Por iso hoxe, a diferenza dos anos sesenta, a emigración non come a mobilidade, senón que rivaliza con ela, e perde ante ela.

Se nos situamos no lado da produción de emocións e sentimentos patrios, tamén cabe acentuar a política de comunicación e de socialización da opinión pública espańola. Pois non só aumentou o rexeitamento, e o menosprezo, á inmigración española no Reino Unido, ou en Francia e Alemaña, senón que tamén están crecendo as trabas á mobilidade, sobre todo, pero non só, respecto dos migrantes menos cualificados. Hai que sinalar que o contaxio proteccionista alcanzou os países nórdicos e o Benelux, que antano eran países de xenerosa e multicultural acollida. Alén diso, e polo que tamén nos atinxe, os sentimentos de perda dos recursos humanos nativos máis novos e cualificados xeran identidades 
de pertenza, repregamentos rexionais e actitudes nacionalistas, os cales dificultan unha política migratoria ecuánime e equilibrada. Unha política que pense en termos de estrutura da sociedade e de interese xeral.

\section{DE ONDE VIMOS: A XESTIÓN E O XIRO CONCEPTUAL E IDEO- LÓXICO}

A acción dos sucesivos Gobernos socialistas e populares respecto da inmigración estranxeira tivo a súa orixe na xestión administrativa, e iso dotouna de realismo desde a súa orixe. Durante o primeiro lustro que seguiu á aprobación da primeira Lei de estranxeiría de 1985, é dicir, entre 1986 e 1990, despregouse unha política enfocada ao mundo laboral que se inspirou na experiencia que tiveron os socialistas exiliados coa emigración de traballadores españois en distintos países europeos ${ }^{4}$. Esa política de inmigración, que pilotaba o Ministerio de Traballo e Seguridade Social, pódese caracterizar como compasiva, empática e de clara raíz social. Mais, dado o nivel administrativo en que se trazou —a Dirección Xeral de Migracións—, carecía dunha perspectiva global. Foi unha política de man de obra, sen modelo migratorio de Estado.

Durante a década dos noventa produciuse unha paulatina mudanza de acento desde a política de inmigración cada á de estranxeiría. Desde a sensibilidade social e laboral cara ao control cultural e a seguridade urbana. O decenio iniciouse coa proposición non de lei de 1991, que levou o Goberno do PsoE ao Congreso dos Deputados. A proposta — que foi elaborada, principalmente, pola Dirección Xeral de Política Interior-, culminou cunha regularización masiva. A dita legalización multitudinaria o que pretendía era "poñer o contador a cero» e inaugurar unha fase de estrito control dos fluxos. A dirección política pasou das mans do Ministerio de Traballo e Seguridade Social ás do Ministerio do Interior. Este tránsito ministerial simbolizaba unha mudanza de concepto, na dirección da política e nas prioridades. Naquel tempo, estranxeiría era sinónimo de control policial dos estranxeiros que residían en España. Esa era a nota dominante.

\footnotetext{
4 Solidaria e protectora en correspondencia cos valores da cultura obreira e de oposición ao réxime ditatorial. Esta política que encarnaba Carmen García Bloise na Secretaría de Emigración do Psoe contrapúnase á política do franquismo respecto da emigración, cuxos fundamentos foron o control das saídas - a emigración asistida - e o paternalismo nos seus vencellos cos emigrados — as casas rexionais.
} 
$\mathrm{O}$ decenio que puxo fin ao século $\mathrm{xx}$ inaugurouse cunha regularización masiva en 1991 e pechouse con outra legalización, tamén multitudinaria, no ano 2000. Foi unha década na que o fincapé se fixo en tratar de canalizar os fluxos laborais a través dos chamados continxentes anuais de traballadores estranxeiros. Estas cotas foron, na realidade, un xeito de baleirar a bolsa de inmigrantes en situación de irregularidade documental. Os inmigrantes sen permiso de residencia ou sen contrato de traballo acumulábanse nas obras, os servizos e o agro. Os topes numéricos deses continxentes estaban supeditados á capacidade de xestión das Administracións e non se fixaban atendendo ás demandas detectadas nos mercados de traballo. É dicir, o límite aos continxentes non foi político senón administrativo.

A cantidade de traballadores estranxeiros que se admitían cada ano foi establecida sobre a base das partidas orzamentarias e estaba en relación co persoal funcionario dedicado a esta tarefa, xunto cos contratados para tramitaren a documentación. De modo que as cotas non se dirixían a regular nin conter a entrada dos inmigrantes que viñan de fóra, senón a resolver a indocumentación dunha pequena fracción dos moitos que xa estaban a traballar aquí. Foi aquel un esforzo político-administrativo, tan loable coma fraco, co obxectivo de pońer orde na abundante inmigración inesperada.

En realidade, foi unha década de xiro conceptual para os sucesivos Gobernos do PSOE e do Pr. Deuse o paso desde a xestión sociolaboral da inmigración a unha concepción policial do control migratorio. A xestión ordinaria da man de obra foi reactiva e correspondía ao Ministerio de Traballo. En troques, o punto de vista político era represivo e quedou nas mans dos ministerios de Interior e de Exteriores. Unha proba irrefutable deste xiro controlador foi o feito de as fontes e rexistros estatísticos seren usados pola oposición como munición contra o Goberno que estaba no poder. $\mathrm{O}$ partido que non se atopaba no Goberno abrazaba o padrón elaborado polo INE (que superaba en número ao rexistro de permisos en vigor que producía o Ministerio do Interior) e brandíao como proba da incapacidade do Goberno para controlar e reducir as entradas de estranxeiros ao país. Os dous grandes partidos apropiábanse dunha ou doutra fonte estatística segundo lles conviñese nese momento.

A outra cara desa mudanza conceptual, que por outra banda era compartida polos dous partidos que se alternaban no Goberno do Estado, foi a construción dunha imaxe negativa da inmigración e o uso da dobre linguaxe co fin de manipular a opinión pública segundo e cando conviñese. Aparentábase controlar os fluxos, mais, na práctica, seguían a entrar sen medida mentres se establecían en 
situación irregular. Enganábase a opinión pública mediante a aparencia de que se estaba a exercer un control dos fluxos ao tempo que se medía, máis que cal era o estado de animo daquela, cal era o grao de aceptación da negativa imaxe que se ía construíndo sobre a base da inmigración ilegal ou indocumentada.

Claro que unha cousa son as declaracións públicas e outra a xestión concreta. Pódese predicar o control máis estrito, como ocorreu en 2006, e permitir que entren máis de 600000 inmigrantes. No tocante a esa dobre linguaxe que supón dicir unha cousa e actuar noutra dirección, non houbo tampouco grandes diferenzas entre os Gobernos que se alternaban no poder. Podía ser o PSOE o que propugnase un férreo control e un retorno incentivado, como expresou o ministro de Traballo, Celestino Corbacho, tras a crise de 2008. Ou proceder a unha xenerosa regularización cando a economía demandaba man de obra abundante, tal e como aconteceu con outro ministro de Traballo, Jesús Caldera, en 2005. Podía actuarse freando o fluxo marroquí, como fixo o Goberno de Aznar, ou proceder a unha dupla ou tripla regularización coma as que despregaron, cando despuntaba o século, Jaime Mayor Oreja e Mariano Rajoy cando exercían como ministros da seguridade interior.

Por aquel tempo, e durante todo o decenio que pechaba o século $\mathrm{xx}$, non se dispuxo de ningunha medida directa da cantidade de inmigrantes que chegaban cada ano. Noutras palabras, ignorábase a magnitude dos fluxos de inmigración. E discutíase verbo de cal era o volume de estranxeiros que residían en España. A contabilidade do stock de estranxeiros residentes foi unha tarefa encomendada á Comisión Interministerial de Estranxeiría, a cal en 1992 fixo público o primeiro Anuario Estadístico de Extranjería. Con esta publicación empezou a análise ordenada e sistemática da inmigración estranxeira. A Comisaría Xeral de Documentación, dependente da Dirección Xeral de Policía, era a unidade que lideraba esa comisión interministerial, se ben os datos estatísticos máis detallados e precisos eran os que se elaboraban no Ministerio de Traballo e Seguridade Social'.

\footnotetext{
$5 \mathrm{Na}$ Comisión Interministerial de Estranxeiría estaban presentes os ministerios de Interior, Exteriores, Xustiza e Traballo e Seguridade Social. Que se encargaban, respectivamente, de compilar os datos sobre residentes, estudantes, asilados e refuxiados, visados, concesións de nacionalidade e traballadores estranxeiros. Con anterioridade a esta estatística de estranxeiría, o Ministerio de Traballo e Seguridade Social publicaba o Anuario de Migraciones, do cal se encargaba a Dirección Xeral de Migracións, e a «Estadística de Permisos de Trabajo a Extranjeros» (1986), elaborada pola Subdirección Xeral de Estatística, encadrada na Dirección Xeral de Informática e Estatística.
} 
Logo da primeira lei de dereitos e liberdades dos estranxeiros en España, en 1985, e, sobre todo, desde a aprobación da proposición non de lei de 1991, a política real, é dicir, a que se practicou durante os trinta anos seguintes — nos cales se alternaron os Gobernos do PSOE e do PP-, oscilou entre acentuar a estranxeiría ou a inmigración laboral. Houbo, porén, unha lexislatura, entre 2004 e 2008, na que o Goberno presidido por J. L. Rodríguez Zapatero, a través do Ministerio de Traballo, pretendeu desenvolver unha política de inmigración respecto dos fluxos e outra de cidadanía dirixida á integración do $s t o c k^{6}$. Mais o certo é que as accións gobernamentais fixeron fincapé, segundo a conxuntura económica e o momento emocional, ben na diferenza cultural (estranxeiría) ou ben no beneficio que reportaba a inmigración de man de obra. Esta regra foi seguida en todas as quendas de goberno. Uns e outros executivos regularizaron os traballadores inmigrantes cando a economía crecía e estranxeirizaron os foráneos cando pintaban bastos e na opinión pública se encollía a empatía.

A oscilación entre unha política de inmigración e outra de estranxeiría estivo presente durante os tres primeiros lustros do século Xxi. É interesante observar que as etiquetas adscritas aos Gobernos populares e socialistas (os primeiros máis dispostos ao nacionalismo cultural, máis proclives á política de estranxeiría, por así dicilo, mentres que os segundos parecían ser máis sensibles á cuestión social) se sosteñen sobre todo na construción da súa imaxe para a opinión pública. Dito con toda claridade, o PP tamén regularizou (política de integración social), e moito, entre 2000 e 2004 . O que sucede é que, de cara á opinión pública, a segunda lexislatura do presidente Aznar estivo marcada polas declaracións fortes en contra da inmigración ilegal e por xestos duros cara ás expresións relixiosas e culturais. Polo mesmo, o PSOE alternou as medidas de integración coas expulsións aéreas, as detencións incentivadas e os internamentos disuasorios dos indocumentados. Nun e noutro caso foron a proximidade electoral e a presión dos medios de comunicación e dos grupos de presión dos seus homólogos europeos os que modulaban os discursos e as accións. Incluso, como xa se sinalou, as mesmas fontes estatísticas (o padrón e os rexistros policiais) se utilizaban e se analizaban co mesmo ánimo limitador, prescindindo de cal fose a cor política, cando se estaba na oposición ou no Goberno.

${ }^{6} \mathrm{Na}$ Secretaría de Estado dirixida por C. Rumí elaborouse unha política de regulación de fluxos laborais baseada na preparación dun Catálogo de Ocupaciones de Difícil Cobertura (CODC) e do primeiro Plan de cidadanía e integración, que se preocupaba das primeiras e segundas xeracións de inmigrantes. 
Se nos cinguimos ao século Xxi, que é aquel no que se produciu a afluencia masiva de inmigrantes, non sería exacto sinalar tres etapas imbuídas por principios doutrinais distintos. Foi o momento económico polo que atravesaba o país, e non a tradición ideolóxica do partido de goberno, o que orientou a política de inmigración. A tradición ideolóxica sucumbiu ante a conxuntura económica. De xeito que establecer cortes con nitidez, segundo a orientación (ou desorientación) ideolóxica do partido gobernante, sería borrar os importantes matices que se produciron na acción política real. Se distinguimos as accións de goberno que denigren a imaxe do inmigrante e as denominamos como políticas de estranxeiría, e as contrapoñemos a aqueloutras medidas que contribúen á súa aceptación e integración (políticas de cidadanía), comprobamos que PP e PSOE comparten políticas de estranxeiría e de cidadanía.

Non sería, pois, exacto caracterizar os períodos de goberno como 1) de estranxeiría (2000-2004, Goberno do PP), seguida por outra quenda de 2) inmigración e cidadanía (2004-2008, Goberno do PSOE) e, de novo, 3) unha terceira estranxeiría (2009-2017, Gobernos do PSOE, ata finais de 2011, e do PP); polo seu contido, establecen similitudes, e tamén diferenzas, entre os dous partidos de goberno. Por exemplo, o aludido bienio negro do ministro Corbacho, que logo foi temperado pola razoable xestión de Anna Terrón na Secretaría de Estado de Migracións. Ou a exclusión da sanidade pública dos inmigrantes por parte do Goberno popular. Certamente, se só nos fixamos nos discursos, o pP foi máis partidario da política de estranxeiría, mentres que o PSOE se mostrou máis proclive á política de inmigración e cidadanía. Pero, nos feitos, un e outro puxeron en práctica — iso si, con distinta intensidade— a combinación de máis estranxeiría e menos cidadanía. Ou, o que é equivalente, estiveron máis ocupados en controlar os fluxos ca en impulsar a integración.

No lado positivo da integración, se ben todos os Gobernos — tanto do PP como do PSOE - realizaron regularizacións masivas, as taxas de legalización foron inferiores cos Gobernos populares. Alén diso, e sobre todo, o apoio á integración dos inmigrantes que tivo un alcance máis estrutural foi o empadroamento (obra do PSOE) como fonte de dereitos sociais. Do lado do pp está tamén o pulo dado á naturalización durante a última lexislatura. En resumo, e en termos xerais, na política de inmigración prevaleceu o concepto de estranxeiría — que pon a tónica no control de fluxos, a seguridade e a diferenza cultural— fronte á concepción da inmigración como paso previo á cidadanía plena. Ningún dos dous grandes partidos liderou un discurso nin 
emprendeu unha política que establecese a necesidade da inmigración como unha fonte clave na reprodución da poboación e no anovamento da sociedade, ou como elemento fundamental na profundización da democracia. En suma, na mente dos Gobernos non predominou unha comprensión clara e profunda do feito migratorio, nin unha avaliación positiva dos inmigrantes como seres humanos plenos.

\section{UN CAMBIO DE TÓNICA NA POLÍTICA MIGRATORIA}

O fío argumental que nos servirá para enfiar esta reconsideración da política migratoria é o da inmigración como parte da sociedade. Unha conceptualización que entronca coa nosa historia emigratoria.

Esta consideración da inmigración como unha parte da estrutura da sociedade despraza a tónica das políticas migratorias en dous sentidos. Un, político e moral, e o outro, a prol dunha boa xestión. O primeiro supón pasar do inmigrante como mercadoría ao inmigrante como cidadán. Facer do fortalecemento da sociedade, e da súa cohesión, o eixe reitor das políticas migratorias. Pór límites ao crecemento da desigualdade. É o paso, ao cal xa se aludiu, da estranxeiría á cidadanía. E o segundo aspecto da política migratoria é aquel que ten un sentido máis administrativo e institucional e que, necesariamente, ha de se mover cara arriba e cara abaixo. Hai que desprazar cara arriba, é dicir, cara á UE, as políticas de recepción ou aceptación, que deben ser coordinadas nese ámbito, e hai que desprazar cara abaixo as accións de inserción e integración, que indubidablemente han recaer nos municipios, rexións e comunidades autónomas. Noutras palabras, os requirimentos para o acceso enfócanse cara a fóra, mentres que cara a dentro se programan as condicións para o arraigamento.

Desprazar a tónica da estranxeiría á inmigración é acentuar a cidadanía e logo ordenar a súa inserción social e cultural. Considerar a persoa como cidadá e como produtora de bens e reprodutora de vida. Tela e aceptala como vecińa activa con plenos dereitos para contribuír á convivencia e á conformación do espazo público. O cidadán con dereito a aprender a lingua e practicala ou criticar os costumes, tanto os propios como os do lugar de acollida. Inmigrante é persoa con emprego, familia e dereitos plenos. En primeiro lugar, os dereitos de todos e, despois, o recońecemento recíproco das diferenzas e das discrepancias culturais. Isto polo que toca á filosofía que inspira as políticas de inserción dos inmigrantes. 
No entanto, un cidadán con familia, con traballo e con Seguridade Social require que a política de fluxos se fundamente nalgúns criterios de selección. Criterios públicos, debatidos e — na medida do posible — consensuados, mais que se ateñan ás condicións materiais para integrar os que están por vir. En síntese, ocupación, fogar, saúde, educación e dereitos políticos plenos, primeiro no ámbito municipal e logo no rexional, o estatal e o europeo. Separando as políticas humanitarias das de inmigración, distinguindo as de asilo das de traballo (malia que sexa difícil separar as motivacións para emigrar). De tal xeito que a necesaria e conveniente regulación dos fluxos —o tope numérico e a composición daqueles-, é dicir, tanto a cantidade como a selección, teña como obxectivo final a integración estrutural e estea programada para ela. Noutras palabras, que a política de fluxos estea orientada por e cara á cidadanía.

Permítasenos repetir, a modo de resumo, este cambio de tónica, que implica unha corrección do punto de vista, do sentido e do concepto. Este desprazamento da tónica desde o mercantil (o inmigrante como mercadoría) cara aos dereitos (o inmigrante como persoa que ten familia) supón considerar por separado as políticas de recepción ou acceso e as de inserción ou asentamento. E propor políticas coordinadas de acceso e políticas descentralizadas de integración. Porque os asuntos de inserción veciñal, e de sanidade ou educación, é dicir, os «feitos de benestar», se producen no espazo local, mentres que, pola contra, os «documentos de cidadanía» se dan no ámbito estatal e no europeo. Debe subliñarse que este poñer a tónica na cidadanía e na seguridade que proporciona a integración social non vai en menoscabo do recoñecemento e valoración das diferenzas relixiosas e culturais. Senón que ha procurar tratar as diferenzas —e as diverxencias - en diferentes instancias político-administrativas. Trátase de programar a inmigración estrutural, recońecendo e respectando a diversidade cultural.

\section{A CORRECCIÓN DO PUNTO DE VISTA: DA ESTRANXEIRÍA Á IN- MIGRACIÓN, MAIS MIRANDO CARA Á CIDADANÍA}

A primeira cuestión sobre a que é conveniente discorrer versa sobre os conceptos de inmigración, de estranxeiría e de cidadanía, co fin de elucidar cal dos tres inspirou, en maior medida, as políticas despregadas durante estas tres décadas. 
Unha vez despexada a concepción que sostén durante máis tempo a xestión inmigratoria, habemos decidir se estas actuacións son máis propias dunha política de Estado ou de actuacións de goberno. É dicir, se se artellou sobre a base dun modelo migratorio consensuado ou se, pola contra, pivotou en sintonía coa conxuntura. $\mathrm{O}$ terceiro punto que cabe aclarar ten que ver coas funcións de 1) unha política de estranxeiría, 2) unha de inmigración e 3) unha de cidadanía. Noutras palabras, se o que se practicou foi unha política de natureza cultural, unha de carácter social ou unha política pública de cidadanía.

O uso común, da rúa, do termo «inmigrante» refírese aos chegados desde outros países para traballaren e, nunha medida moito menor, apunta cara aos que viñeron na procura de seguridade ou de ampliaren a súa educación. Dicir «inmigrante», para a maioría da xente, é pensar en traballadores subalternos. Sen dúbida, este concepto así entendido é o que máis nos aproxima á nosa historia pasada; en particular — e por permanecer máis viva entre nós—, remítenos á historia da emigración española a Europa ${ }^{7}$. De xeito que nos coloca en situación de comprendermos os así nomeados e de nos sentirmos próximos (empatía) a eles. Pola contra, o concepto de estranxeiría, seguindo a Fernández Buey, acentúa o halo de estrańeza nos costumes, a separación cultural e, en especial, a diferenza relixiosa. Por veces, mais poucas, cando se utiliza esta palabra pénsase nos estranxeiros ricos, eses que fan a súa vida á parte, sen se mesturaren cos nativos ${ }^{8}$.

Se levamos esta distinción ao noso obxecto de análise, que son as políticas migratorias, fixemos leis para usar a inmigración, pero envolvémolas na bandeira da estranxeiría. En realidade, pretendemos regular a xestión da man de obra de baixo prezo, mais fraxilizámola e estigmatizámola mediante a etiqueta da distancia ou alleidade cultural. En suma, a nosa política inmigratoria manexou esa mestura de

\footnotetext{
7 Para certificar que a emigración se ve con certa tranquilidade e normalidade tanto desde a óptica administrativa e gobernamental como desde a científico-social, abonda con acudir aos varios informes sobre a emigración que foron elaborados por técnicos do Ministerio de Traballo, así como reparar nos resultados da Encuesta sobre determinantes de la emigración de 1966 e a levantada pola Fundación FOESSA de 1970.

${ }^{8}$ É frecuente, cando se xuntan expertos de distintas disciplinas sociais e xurídicas para falaren sobre o tema (xuristas, economistas, sociólogos, demógrafos, xeógrafos ou antropólogos), que uns se refiran á condición laboral, outros á etiqueta nacional, que aqueles se fixen no lugar de nacemento ou nos costumes, e outros na presenza externa; en fin, cuestión de tónicas e de compartimentos disciplinares. Non é doado entenderse sen facer explícito o enfoque, e aínda menos doado resulta o acordo para aterse ao uso de «migrante» e «estranxeiro» tal e como se expresa na rúa. Pois o chamado uso común depende do círculo ou clase social en que se inscriba o interlocutor.
} 
«estranxeiría laboral» para a súa comenencia, segundo primasen as conveniencias empresariais ou as electorais; isto é, segundo a ocasión e o propósito requirisen favorecer uns ou outros intereses. Eran estranxeiros cando se trataba do exercicio dos dereitos e da captura de votos. Mais convertíanse en inmigrantes cando había que encher o baleiro provocado polo desinterese dos traballadores nativos ante empregos pouco apreciados por mor das súas condicións laborais e salariais. $\mathrm{Ou}$, dito de forma máis estrita e precisa, cando había que duplicar a man de obra debido ao aumento (conxuntural) da demanda, mais abaratando os custos desa forza laboral suplementaria ou ocasional. Eran traballadores sobrantes, «supernumerarios», por así dicilo, respecto daqueles que figuraban nos cadros de persoal.

Canto ao segundo aspecto, cabe dicir que desde 1985 non houbo unha política de Estado, senón accións de goberno. A confusión explícase pola falta dun debate público a respecto do lugar que ocupa a inmigración na reprodución da sociedade, mais tamén se debe ás similitudes nas actuacións dos Gobernos populares e socialistas. As accións enfocáronse en exclusiva, e case obsesivamente, sobre o control dos fluxos. Houbo diferenzas, de certo, entre os Gobernos do PSOE e do pP, e delas algo xa se dixo e se falará deseguida, mais non foron nin de fondo nin continuadas, senón máis ben de tónica e circunstanciais. E esas distincións debéronse á conxuntura económica, aos vaivéns nas relacións exteriores cos países implicados e, por fin, malia que nunha medida menor, á cultura política do partido de goberno. O fondo do asunto é que esas diferenzas nas accións dos sucesivos Gobernos non se sustentaban nun modelo acordado, é dicir, nunha política de Estado. Noutras palabras, xestionouse a inmigración sen ter definido un modelo de anovamento da sociedade. Máis ben actuouse a golpe de conxuntura e dentro da atmosfera dominante no ámbito da UE, aínda que, iso si, con diferenzas de tónica e de estilo entre o pSOE e o PP.

Esas similitudes nas actuacións foron basicamente dúas, a saber: os límites ou cotas para introducir os traballadores inmigrantes de modo legal e as regularizacións de indocumentados para remendar os fallos na regulación dos fluxos. Mais o que a política tivo pouco en conta é que os fluxos migratorios non se reducen á entrada de man de obra foránea. Pola contra, os fluxos son, na realidade, máis plurais e abranguen tanto a reagrupación de familiares como a captación de estudantes e a canalización de inmigrantes temporais ou a acollida de nenos desacompańados. Todos eles son fluxos de distinta natureza e carácter, o cal demanda 
políticas que se axusten máis ás súas motivacións e propósitos. E, xaora, non cabe esquecer a cada vez máis avultada circulación dos migrantes polo espazo europeo e o retorno aos países de orixe. De xeito que o ocuparse dos fluxos laborais só é unha parte, se ben importante, das políticas inmigratorias.

E, neste sentido, a política de goberno que se despregou durante o ciclo alcista da inmigración foi, no mellor dos casos, de man de obra subalterna, de baixo custo. Unha xestión gobernamental que oscilou entre a estranxeiría e a inmigración, é dicir, entre a diferenza cultural e a inferioridade laboral. E ese foi o importante matiz que diferencia as actuacións no eido migratorio segundo cal fose o Goberno que se atopase nese momento no poder. Os Gobernos do PSOE acentuaron a condición laboral, mentres que, cando a xestión lle correspondía ao PP, se incidiu na distancia cultural. Porén, o común denominador foi, para alén das tónicas, o dunha concepción que podemos chamar, para resumir, de «estranxeiría con utilidade laboral». Baseada na conveniencia dunha forza de traballo ocasional e prescindible, sen asumir — en todas as súas consecuencias - a súa permanencia, o seu arraigamento e a súa participación como cidadáns de pleno dereito. É dicir, guiada pola ganancia económica inmediata e despreocupada do beneficio, ou prexuízo, social.

As políticas migratorias desbordan o tempo de exercicio dun Goberno e a canalización dos fluxos de entrada e de saída. É dicir, as políticas migratorias non acaban co migrante acollido xa no interior dun Estado, senón que perseguen a súa integración e a súa inclusión na cidadanía. Ou, o que vén sendo equivalente, esas políticas buscan a progresiva desaparición da condición migratoria como estigma ou síndrome de inferioridade civil, social e cultural. A política migratoria ten por finalidade a de deixar de selo, a da súa disolución e esgotamento no seo das politicas públicas. Dito con toda claridade, se as políticas migratorias son máis ben reactivas e conxunturais, accións que segmentan e sitúan o designado nun lugar xuridicamente subalterno, as políticas públicas encárganse da extinción da condición migrante e apostan decididamente pola plena inclusión cívica e a participación no repartimento da riqueza social, sexa cal for a súa orixe nacional e a súa condición étnica.

E é aquí onde procede reflexionar sobre os conceptos de estranxeiría, inmigración e cidadanía. A utilización da estranxeiría como nome da primeira lei reguladora en 1985, cun Goberno do PSOE, xa entrañaba o estigma. Estranxeiro é un estraño, un diferente cultural, un foráneo que causa rexeitamento. Mentres 
que «migración» é unha palabra que apela ao seu costado laboral, á condición de traballador, e, simbolicamente, nos achega a comprender a súa situación porque nos retrotrae a un pasado que aínda segue vivo. Colócanos nunha posición de empatía polo duplo feito de ser un Estado multinacional e multicultural, enfiado durante o século xx por migracións interiores, que foron seguidas por migracións ao exterior. Primeiro, ultramarinas e, na metade do século $\mathrm{xx}$, tamén intraeuropeas. España como un Estado feito sobre a base de comunidades culturais e de sucesivas emigracións socioeconómicas tanto internas como exteriores. En definitiva, a estranxeiría ten unha tónica que nos separa, mentres que o concepto de migración ten unha resonancia que nos aproxima. Por último, está o traxecto que acaba na cidadanía política, é dicir, que nos iguala en dereitos e deberes, malia que culturalmente non nos torne homoxéneos?.

Pois ben, durante os Gobernos do pp predominou a acepción de estrañeza cultural, a noción de «estranxeiros». Pola contra, durante os Gobernos do psoe o que dominou foi a condición de traballadores complementarios e subalternos. Mais, tanto nun como no outro caso, operaron baixo o principio da "preferencia nacional» dos nativos, é dicir, sen a perspectiva de fondo da naturalización, do arraigamento familiar e, por fin, da participación política na democracia como cidadáns completos. Faltou un modelo, un sistema migratorio de Estado que asumise a condición da súa permanencia e da súa necesidade para a reprodución da sociedade e o anovamento da democracia. Un sistema baseado nas oportunidades de emprego si, mais tanto conxunturais ou temporais como duradeiras e definitivas. Un sistema no que encaixen, coas variacións debidas, tanto os ciclos de bonanza como as conxunturas adversas. Un modelo migratorio que non perdese de vista a vertente estrutural das migracións como un dos fenómenos inscritos no haber da globalización económica, política, social e cultural, que require e necesita o longo tempo para o seu despregamento.

${ }^{9}$ O termo de «inmigración» úsase, no seu sentido demográfico máis técnico, para un se referir a persoas que están a vivir en España, mais que naceron fóra do país. Pero, cando se fala de fluxos de inmigración, neles inclúense todos os vidos desde o exterior, con independencia de que nacesen ou non fóra do país ao que chegan. Os estranxeiros, en cambio, son aquelas persoas que teñen unha nacionalidade distinta á do país en que viven, nacesen ou non fóra del. Por iso hai estranxeiros nados en España e españois nados fóra. De xeito que inmigrante estranxeiro é aquel que naceu no exterior e que chega a España con outra nacionalidade. Os inmigrantes españois (nados fóra, mais de nacionalidade española) distínguense, pola súa vez, segundo a súa españolidade sexa de «orixe» ou fose «adquirida» seguindo distintos procedementos. 


\section{FEITOS E RECONTOS: O DEPÓSITO ACUMULADO E OS FLUXOS HABIDOS}

\subsection{A experiencia recente: silencios e esaxeracións}

Fagamos un balance cuantitativo e interpretativo do acontecido. Primeiro, sobre o acontecido durante os tres lustros de inmigración que durante o século XXI se levan percorridos. E, en segundo lugar, do medio século de España como sociedade emigratoria. Esta memoria dunha España desarraigada, cunha enorme migración interior, produto das secuelas políticas e represivas da Guerra Civil e da «liberalización económica» nos sesenta. Empezando polos exiliados e seguindo polos desprazados cara a outras zonas de España, que non volveron á súa vila rural para non quedaren sinalados e sufriren o duro castigo. A isto sumouse a derrota da reforma agraria, que frustrou as esperanzas no cambio de propiedade da terra. Todo o cal apuxou ás cidades masas de xornaleiros pobres e de desposuídos da terra (Richards 2013).

O feito é que, desde os anos 40 e máis aínda nos dous decenios seguintes, os espańois se moveron de maneira masiva e violenta polo interior de Espańa. Logo, nos sesenta, coa posta en marcha do Plan de estabilización da economía, foi cando a esa migración interna se engadiron os emigrantes que deron o salto ao exterior. De xeito que aos perseguidos e exiliados pola guerra (á emigración política) se sumou a emigración de man de obra atraída pola forte industrialización e a reconstrución en distintos países europeos. Toda esta trasfega interna e internacional constitúe o pano cultural de fondo que nos permite entender a permisividade e a empatía social con que foron acollidos, no século XXI, os seis millóns de inmigrantes e os cinco de estranxeiros. A marca migratoria é un trazo cultural dos españois vulnerables, que son os que se rozan cos inmigrantes estranxeiros ${ }^{10}$.

O balance numérico refírese a dúas fases e mestúraas. A primeira, que percorre practicamente o primeiro decenio do século Xxi, é a fase de crecemento da inmigración e da estranxeiría. E a segunda é a que, provisionalmente, resulta logo de máis dun sexenio (ata 2015) de recesión económica, social, política e cultural. A avaliación cuantitativa apóiase en tres fontes: a enquisa de variacións residen-

\footnotetext{
${ }^{10}$ Ensaios recentes como La España vacía ou Historias para después de una guerra dan conta desa enorme trasfega interior. Aínda que onde se reflicten polo miúdo a repercusión e a violencia que comporta a emigración no mundo da vida (a sociedade civil) é en películas como Surcos, de 1951, ou en novelas como Tiempo de silencio (1961).
} 
ciais, o padrón municipal continuo e a enquisa de poboación activa. $\mathrm{O}$ noso exame das políticas migratorias apoiarase na repercusión que teñen as accións de goberno na evolución das estatísticas.

Gráfico 1. Evolución da poboación nada no estranxeiro segundo a súa nacionalidade, 2000-2015

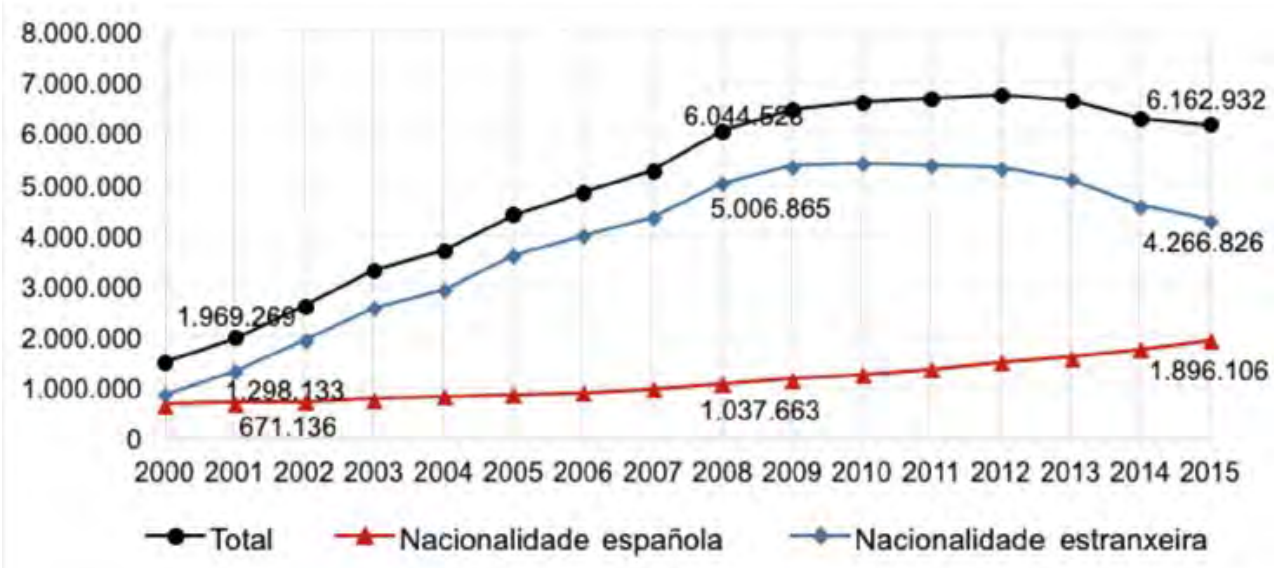

Fonte: elaboración propia a partir dos datos do padrón municipal de habitantes (2000-2015). Instituto Nacional de Estadística (INE).

O balance interpretativo arrinca da toma de partido por un dos dous sentidos e conceptos a partir dos cales se analizan os desprazamentos humanos: o da inmigración e o da estranxeiría. Tras considerar o momento que atravesamos e a información dispoñible, este traballo decántase polo primeiro. A dita información dispoñible apunta a que o stock de estranxeiros (4,7 millóns) está ao mesmo nivel que en 2007, antes da gran recesión, e que a cifra da inmigración supera os 6,1 millóns de persoas. Realmente o volume de estranxeiros diminuíu nun millón respecto do teito que se alcanzou en 2011. E a cantidade de inmigrantes reduciuse en 600000 persoas, se comparamos 2015 co reconto de 2012, que constitúe o rexistro máis elevado en toda a serie. De tal xeito que o peso dos estranxeiros é do $10 \%$ sobre o total da poboación (dous puntos menos ca na súa cima en 2011) e o da inmigración do $14 \%$, logo de ceder tan só un punto por debaixo da cúspide alcanzada en 2012. En resumo, o baleirado da inmigración apenas tivo lugar e o da estranxeiría é 
o resultado, na súa maior parte, dunha transferencia á cidadanía. Neste mesmo sentido, a saber, a consolidación do arraigamento xurídico, o que si se produciu é unha evolución desde o réxime xeral ao comunitario e desde a condición de estranxeiros á de cidadáns naturalizados, así como, na liña da sedimentación sociolóxica, de persoas solitarias a familias ancoradas nas súas respectivas comunidades.

O momento en que vivimos caracterízase polo «silencio verbo dos fluxos de entrada» protagonizados — maioritariamente- polos foráneos, e a esaxeración dunha parcela minoritaria dos fluxos de saída, é dicir, aquela porción que está integrada por españois nativos. A toma de partido favorable ao concepto de inmigración fundaméntase nunha práctica que impregna unha idea. A práctica é a que nos conduce a unha política migratoria que non tente clausurar a mobilidade en ningunha das súas direccións, senón que, pola contra, atenda ao medio prazo, no canto de se pregar ao instinto do momento. A idea é aquela segundo a cal a estranxeiría, como a estrańeza que denota, nos atemoriza e nos conduce, talvez sen o advertirmos, ao racismo, mentres que a inmigración, pensada como estrutura da sociedade, nos dirixe cara á convivencia e á análise dos retrocesos e avances na integración. É un soporte histórico e anímico que aniña na memoria do común dos españois e que produce un pouso ético e cultural que anima á razón práctica.

Durante estes dezaseis anos (2000-2015) pasamos dunha fase de obsesión polos fluxos a unha de silencio ominoso sobre eles. E non só respecto do seu respectable volume, senón tamén no tocante ás mudanzas de composición e ao sentido dos ditos fluxos (Miyar Bustos 2016). Dun primeiro período de intensidade formidable na chegada de inmigrantes estranxeiros (2000-2008), con fluxos asombrosos (entre 600000 e máis de 900000 altas residenciais anuais), a outro período caracterizado por unha caída non menos brusca dos fluxos de entrada, mais aínda caudalosos. Poderase pensar que na primeira das fases era difícil esaxerar a chegada de inmigrantes, pero mesmo así fíxose, por exemplo a respecto da inmigración africana que chegaba en pateras. Logo vivimos un período de grande ocultación e despreocupación verbo do volume e a composición das correntes de inmigrantes estranxeiros en ambos os sentidos. Durante a recesión económica abandonámonos á memoria esaxerada. A reavivar a memoria emigratoria de hai medio século. En poucas palabras, silenciouse que anualmente chegaban máis de 350000 estranxeiros e ocultouse que se ían nunha cifra semellante, mais, a cambio, construíuse unha imaxe avultada da saída de xente nova española altamente cualificada. 
Na primeira fase mostrouse o impoñente da corrente e a impotencia na súa regulación. O resultado foi tanto a irregularidade masiva como a irregularidade «sobrevida». É dicir, tanto a indocumentación social como a impotencia administrativa, o cal —e de feito— tivo como resultado unha produción institucional de irregularidade ${ }^{11}$. No que se refire ao segundo período, que transcorre desde 2009 e ata 2016, o que se destacou —en termos mediáticos e respecto dos inmigrantes - foi a política de retorno incentivado e a política de exclusión do acceso á sanidade pública. Ambas as medidas resultaron ser máis aireadas ca estatisticamente significativas. En particular, e verbo da primeira, esta foi formulada nun sentido propagandístico, porque en termos cuantitativos aquilo que se silenciou foi que o retorno pola propia conta dun foi moito maior ca o politicamente impulsado. Mais, sobre todo, o que se puxo en sordina é o altísimo nivel de desemprego, así como as estratexias de resistencia despregadas polos inmigrantes antes de teren que emigrar cara a outros países ou que retornar ao lugar de orixe.

A fase de ingreso de inmigrantes estranxeiros caracterizouse por ser certamente desorbitada, tendo en conta a dimensión demográfica do país e a fraxilidade da economía espańola. O que se demostrou é que a «urxencia» dos fluxos e o crecemento do stock tiveron a súa xusta réplica na admirable capacidade de absorción que despregou a sociedade española. Apelando, outra vez, ao recordo e á vivencia na cultura do pobo común, da profunda experiencia emigratoria.

É importante subliñar, co fin de reconsiderar as políticas migratorias, que as insuficiencias no control fronteirizo, xunto coa política de consolidación dos stocks (regularizacións masivas) produciron unha mediática desorde migratoria que fraguou nunha actitude de asolagamento. Alimentado polo incesante fluxo televisivo de desembarcos inesperados e desesperados. Considero relevante subliñar que esa mediática desorde e as conseguintes actitudes e sensacións de abafo son o que se reflicte e se rexistra nas enquisas. E foron o argumento lexitimador para armar o discurso dos Gobernos a favor do control fronte á permisividade, amortecendo ou ocultando o eixe predominante e real —e criterio quasi único- das políticas de recepción, que non é, nin foi, outro ca a utilidade e rendibilidade da man de obra foránea para o precarizado e segmentado mercado de traballo.

\footnotetext{
${ }^{11}$ A diverxencia entre a evolución dos fluxos e o sostemento do stock explícase polo obrigatorio anovamento do empadroamento e o sistema de baixas. Se este sistema de baixas automáticas e o endurecemento no control das inscricións no padrón teńen como resultado o aumento da irregularidade é un dato que aínda non estamos en situación de calibrar.
} 
De feito, o discurso oficial de carácter restritivo formulouse antes da gran recesión - practicamente desde os primeiros noventa do século $\mathrm{xx}$-, cando o volume de inmigrantes era reducido. Xa desde aquela, 1990 e 1993 (cando os estranxeiros supuñan o $1,5 \%$ da poboación), as enquisas do cIs rexistraban que os entrevistados se mostraban convencidos de que había "demasiados estranxeiros» en Espańa (Izquierdo 1994). Entón ese desequilibrio entre percepcións e medicións titulouse como "as enquisas contra a inmigración». A ensinanza que cabe tirar deste recordatorio é que a estranxeiría produce inquedanza, con relativa independencia do seu número.

A fase de acollida masiva estendeuse ao longo de case un decenio (2000-2008), se ben se preparou no anterior. En efecto, durante a última década do século xx producíronse dúas regularizacións explícitas e catro ou cinco principios de regularización (continxentes) que puxeron as bases reticulares para o brusco e enérxico impulso dos fluxos ao despuntar o século xxi. En contra da hipótese da atracción que exerceron as redes están a pequenez, naquel tempo, do reagrupamento familiar e as probas acerca da escasa influencia que revisten as redes de vecińanza (Laparra 2012). No entanto, desde aquela ata hoxe aparecen evidencias que sinalan a influencia das redes comunitarias e de veciñanza na chegada e nos primeiros pasos. A explicación máis razoable e completa conduce a pensar que as redes acompañaron a descarada demanda empresarial, que contou co beneplácito e a complicidade dos Gobernos que se atopaban neses momentos no poder.

As vías de ingreso legal ao emprego foron, segundo un informe do Ministerio de Traballo, o réxime xeral (33\%), os continxentes ou cotas anuais (12\%) e, sobre todo, as frecuentes e repetidas regularizacións de traballadores sen contrato, responsables de máis da metade do total de incorporacións ao mercado de traballo ${ }^{12}$. Todas estas vías de ingreso ao dito mercado de traballo estiveron fundamentadas nas demandas (urxentes e insatisfeitas, malia que fragmentarias e volubles) do mercado.

E aconteceu que os traballadores vulnerables atraeron a súa familia, e a inmigración laboral converteuse, ao cabo, en poboación establecida, é dicir, en parte da estrutura societaria de Espańa. Un indicio, aínda que sexa insuficiente, dos

\footnotetext{
${ }^{12} \mathrm{O}$ lector debe ter en conta que, no período de tempo considerado por este informe realizado polos servizos da Administración (do 30 de xuńo de 2003 ao 30 de xuńo de 2006), pesou poderosamente a normalización de 2005.
} 
medios que utilizan os inmigrantes con maior asiduidade para buscaren emprego móstranos que son os amigos e cońecidos (entre o $41 \%$ e o $47 \%$ ), seguidos por algún familiar directo (entre o $13 \%$ e o $17 \%$ ), os que aparecen como as canles máis usadas e de máis éxito. Apenas un $15 \%$ dos inmigrantes obtén o seu emprego a través de medios virtuais ou por causa dos seus méritos (Internet, envío de currículos). E son tamén unha minoría, por agora, os que poden xerar o seu propio emprego como autónomos ${ }^{13}$.

A esta fase, esquematicamente debuxada, seguiuna a gran recesión, pola cal, no social, aínda deambulamos, coa súa enorme destrución de emprego e benestar, de dereitos laborais e sociais (sanidade, ensino e dependencia). Ao principio operou o estado de resistencia, é dicir, o agardar a que revertese a situación de deterioración sociolaboral. De aí que seguisen as entradas por inercia e se operasen mudanzas nas estratexias familiares co fin de aguantar fronte a unha mala situación que se esperaba que fose pasadía ${ }^{14}$. Mais, cando se normalizou esa gran desvalorización do benestar, é dicir, cando esa situación de rebaixa social se estabilizou, daquela foi cando se produciron a reemigración e o retorno.

E nesas estamos e andamos. Só que agora, e desde hai catro anos, no que nos fixamos, porque así o publicitan os medios de formación da opinión pública, é na saída (non sabemos en que proporción se converterá en emigración duradeira) de xente nova e menos nova española. O resultado é que os fluxos de emigración de estranxeiros e, en menor contía, de españois (nativos e naturalizados) teñen lugar no medio dun veloz avellentamento, o cal reduciu a dimensión da poboación activa entre 2009 e 2015 en case un millón de persoas. Pois, se en 2009 había 31171500 persoas de 15-64 anos, en 2015 a cifra rebáixase a 30174300 (EPA, IIT).

${ }^{13}$ Este indicio pódese tirar do barómetro do cis de febreiro de 2016. Hai unha pregunta que busca elucidar: «Como conseguiu Vde. o seu actual traballo?». E respecto da cal se pode distinguir se a persoa entrevistada ten unicamente a nacionalidade espańola ou tamén é titular doutra nacionalidade. Así mesmo, pódense diferenciar aqueles que teñen a nacionalidade española por nacemento ou a adquiriron con posterioridade. Os dous cruzamentos dan unha base numérica moi parecida e reducida (arredor de corenta casos), mais o certo é que os resultados acadados por ambas as clasificacións son moi semellantes. Iso si, esta pista ha de se tomar con todas as cautelas dado o exiguo da cantidade de españois doutra nacionalidade ou que se naturalizaron con posterioridade ao nacemento e que son captados pola mostra. Agradezo a Félix Requena o poder dispor desta información.

${ }^{14}$ As estratexias familiares foron, sucesivamente, a incorporación da muller a un emprego de servizos, o abandono da formación por parte dalgún dos fillos, a repatriación do esposo acompanado por algún dos descendentes e, ao cabo, o alugueiro de parte da vivenda para compartir gastos con algún dos compatriotas que pasaba polas mesmas dificultades. 


\section{TRES DESAFÍOS CONCRETOS: O BLOQUEO SOCIAL, O EDUCA- TIVO E O DEMOCRÁTICO}

A seguir resúmese, en tres pasos, o itinerario que envelenou a integración dos inmigrantes nas sociedades europeas, e que a pode apodrentar na española. O primeiro paso empeza así. Os inmigrantes desempregados atoparán o próximo traballo, na súa maioría, nos mesmos sectores e ocupacións nos que antes estiveron empregados. É dicir, nos mesmos nichos laborais nos que agora se encontran os traballadores inmigrantes que se manteńen ocupados. Iso revela que a segmentación laboral os encadea durante longo tempo. No peor escenario, o desemprego prolóngase por máis dun ano, e daquela o destino del e dos seus fillos é o de marxinados.

Logo, nun segundo paso, o camiño cara á integración empínase, pois ese bloqueo na mobilidade social ascendente dos proxenitores repercute nas actitudes e nas aptitudes dos fillos escolarizados. Os descendentes vense desviados do ensino superior cara a outras ensinanzas formais e profesionais de grao medio, e iso faise prescindindo das súas aptitudes intelectuais. A subestimación dos pais transfírese xeracionalmente. Logo do cal son desclasados ou subempregados na súa incorporación ao mercado de traballo, por debaixo da súa titulación, capacidades e experiencia. Por último, ao bloqueo social e formativo súmase, como terceiro paso, a barreira da inferioridade cívica, o penoso itinerario de seren tratados como non-cidadáns, ou cidadáns atípicos sen a plena igualdade de dereitos políticos. Un status discriminatorio que se prolonga durante máis ou menos tempo segundo o país de orixe e a nacionalidade do afectado.

Non semella preciso subliñar por que a cohesión social e política é un requirimento básico para o bo funcionamento das sociedades democráticas. Neste sentido, aparecen tres prioridades na política de inmigración. A primeira e máis básica é a integración política dos estranxeiros como cidadáns de pleno dereito, o cal é unha consecuencia da súa naturalización. A segunda prioridade ten un longo percorrido, pois apunta cara ao desempeño escolar do alumnado inmigrante como parte do futuro da sociedade, cousa que repercute no benestar social, no aumento da produtividade e na mellora da seguridade na vida urbana. E, por fin, mais da maior urxencia, está a recuperación laboral dos damnificados pola gran recesión. 
Estras tres áreas de acción da política pública constitúen as guías da política de inmigración. Son as vigas mestras para que, nas sociedades democráticas, desapareza a condición de estranxeiro como réxime de inferioridade. Noutras palabras, co paso dunha política de estranxeiría laboral a unha de cidadanía o que se pretende é suprimir a estranxeiría, evitar o desclasamento social e promover a inclusión ocupacional. Aínda hai unha cuarta pata para o modelo migratorio de reprodución cívica e social ser realmente sostible, a saber: unha política de selección de fluxos cun rango de entradas en que se fixe un teito migratorio.

No que vai a seguir examinaremos a evidencia empírica inmediatamente dispoñible e farémolo a través de tres indicadores que resumen, respectivamente, unha viable integración cívica, unha aceptable socialización e unha mellor inserción laboral. Estes tres indicadores son as naturalizacións, o desempeño escolar e a situación no mercado de traballo.

\subsection{A cidadanía crecente}

A evolución das naturalizacións de estranxeiros, que os converten en cidadáns españois de orixe inmigrante, segue unha pauta marcada polas decisións políticas. Neste percorrido sobresaen dúas impresións: a tendencia crecente desde os inicios do século, que se acentúa durante o trienio 2010-2012, e o pico extraordinario observado en 2013, con máis de 260000 solicitudes favorablemente resoltas. Este rebentón na bolsa de demandas acumuladas foi produto da encomenda feita aos notarios e aos rexistradores da propiedade para eles resolveren con celeridade as solicitudes de naturalización que encoraran polos atrasos na resolución. 
Gráfico 2. Evolución das naturalizacións por residencia: 2000-2015

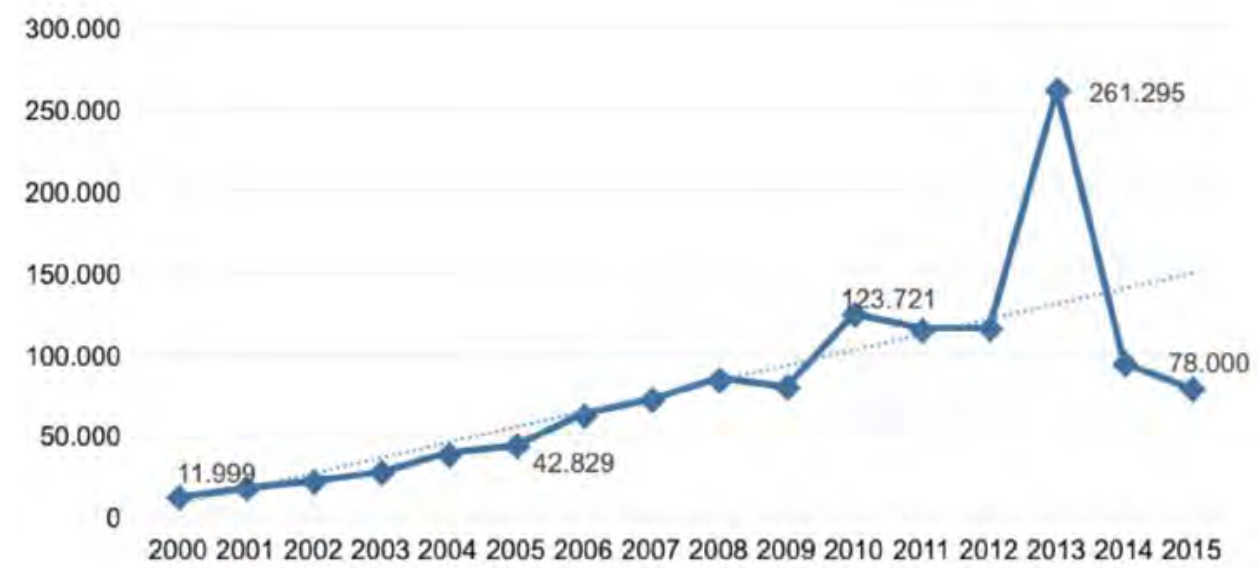

Fonte: elaboración propia a partir de datos de nacionalizacións do Ministerio de Emprego e Seguridade Social (2000-2015).

A lexislatura de goberno popular que transcorre entre 2010 e 2015 esforzouse por resolver as demandas de nacionalidade que se acumularan no Ministerio de Xustiza. Neste período concedéronse máis de 700000 solicitudes de nacionalidade por residencia. Desde principios de século foron máis de 1250 000, aínda que, se se engaden as adquisicións de nacionalidade que foron tramitadas a través da Lei de memoria histórica, supérase a cifra de 1,5 millóns de novos españois procedentes da migración. Domina a naturalización de inmigrantes de orixe latinoamericana, por mor da redución do tempo de residencia, mais é de notar que case 200000 marroquís conseguiron naturalizarse entre 2000 e 2015. A altura do pico marroquí no ano da externalización da xestión explícase pola acumulación que se produce no caixón das solicitudes, e é o resultado da discriminación na duración da súa residencia respecto de, entre outros, os latinoamericanos. Durante o tempo da gran recesión, é dicir, o que transcorre entre 2008 e 2015, practicamente un millón de estranxeiros obtiveron a nacionalidade española. Esta é a principal explicación da redución no número de estranxeiros con permiso de residencia.

O volume de naturalizados non é o produto dunha integración efectiva, senón que opera como unha ferramenta da que se serven os máis beneficiados 
para ficaren no país e poderen circular máis libremente pola UE. Non é a consecuencia dunha taxa de naturalización que se concede unha vez que a persoa coñece os costumes. Máis ben ao contrario, a taxa de concesión de naturalizacións é moi baixa e, na maioría dos casos, os naturalizados levan pouco tempo a vivir en España. O ritmo de evolución da naturalización é o resultado de tomar atallos legais para sortear as trabas burocráticas e aproveitar as contradicións do réxime de estranxeiría. Semella unha contradición, para alén dunha inxustiza, que a uns inmigrantes estranxeiros se lles esixan dez anos de residencia (é o caso dos marroquís), mentres que a outros (aos latinoamericanos) lles abonda con dous anos de estadía. E que resulte máis doado o acceso á nacionalidade a través do matrimonio que por medio dunha residencia continuada. Ademais, a naturalización facilita a mobilidade internacional. A mobilidade transnacional é un capital dos migrantes, que se revaloriza nesta época de restricións, ben sexa para probar fortuna noutro país europeo, ben para retornar, aínda que sexa de modo provisional, ao país de orixe.

Destas consideracións verbo do uso e das formas de acceso á nacionalidade despréndense dúas propostas para a política inmigratoria, a saber: que se han de homoxeneizar os criterios para o acceso á nacionalidade a prol dun itinerario máis equilibrado na integración e que, na política de selección de fluxos, a perspectiva da naturalización ha de ocupar un lugar preferente. Que a condición de estranxeiría dure varias xeracións non é de xustiza, nin tampouco é boa, como se puido comprobar, para a cohesión social e a identidade nacional. Dese xeito tamén se conseguiría que a opinión pública aceptase de mellor grado a chegada do foráneo. É sabido que o establecemento e a publicidade de regras claras e equitativas proporcionan tranquilidade tanto ao candidato como ao tribunal.

\subsection{Apostar pola formación e atender ao desemprego do presente}

O alumnado estranxeiro é a outra cara da moeda da mudanza sociocultural que produciu a inmigración estranxeira na sociedade española. Para alén da intensa achega de nacementos, que chegou a representar entre o $20 \%$ e o $25 \%$ do total de nados en España, hai máis de 700000 alumnos estranxeiros matriculados nos ensinos non universitarios. A tendencia é lixeiramente descendente desde hai catro anos, mais a redución, de apenas 70000 escolares, aínda nos sitúa, en 
2015, ao mesmo nivel ao que estabamos en 2008, é dicir, antes de que estalase a gran recesión.

Esa redución dun $10 \%$ nos menores escolarizados explícase tanto polas naturalizacións como polo retorno ao país de orixe. É probable que tamén sexa o produto dun prematuro abandono escolar debido á diminución e á carencia de recursos económicos que sufriron as familias durante a crise. $\mathrm{O}$ incremento nas solicitudes de axuda social por parte da poboación foránea, e a súa maior visibilidade nas filas de repartición de comida e bens de primeira necesidade, é o resultado da maior repercusión da destrución de emprego e da rebaixa de salarios entre a poboación máis pobre e vulnerable, como é o caso dunha gran parte dos inmigrantes que se ocupaban na construción e na industria conexa.

Gráfico 3. Evolución dos/das alumnos/as estranxeiros/as matriculados/as en ensinos non universitarios (réxime xeral)

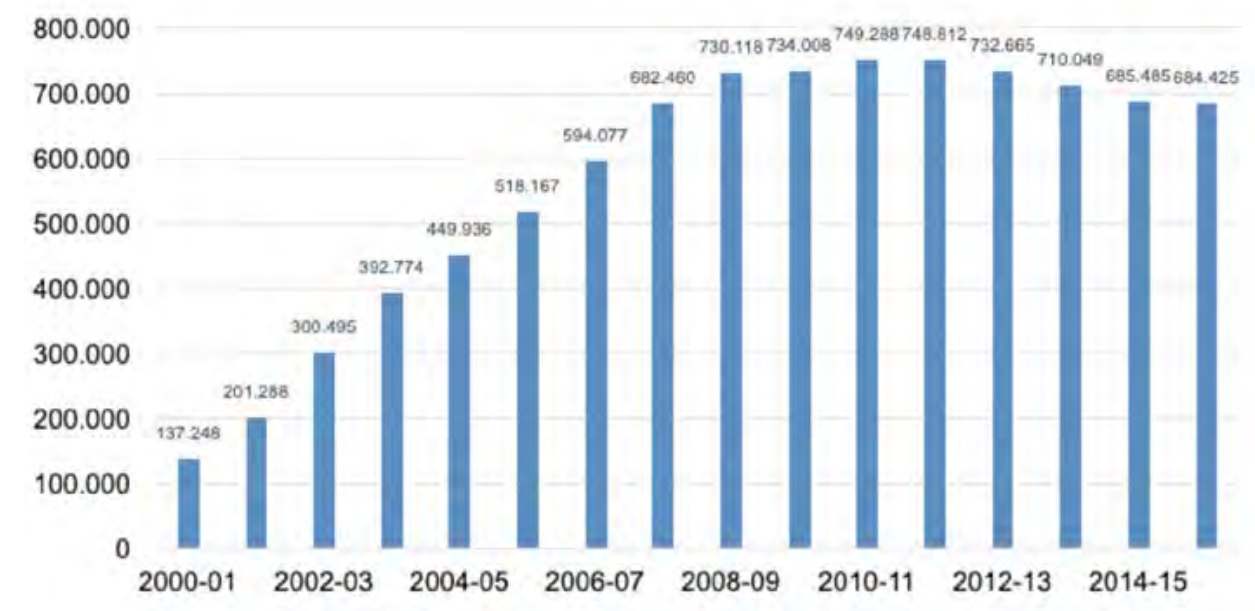

Fonte: elaboración propia a partir de «Estadísticas de la Educación», do Ministerio de Educación, Cultura e Deporte.

As evidencias dispoñibles indican que o menor rendemento educativo dos fillos da inmigración se explica pola orixe social dos pais. E, referíndose aos tres grandes continentes de orixe, sinalan con rotundidade que son os africanos, e en particular os marroquís, os que acumulan máis desvantaxes, mentres que os 
europeos están ao nivel dos autóctonos e os latinoamericanos se colocan nunha posición intermedia. Hai dúas boas novas a este respecto. A primeira é que a repartición do alumnado segundo o continente de orixe se mostra bastante equilibrada entre europeos, africanos e latinoamericanos, coa importante excepción asiática, a cal nos distancia do que ocorre noutras sociedades europeas avanzadas. A segunda distribución favorable di que o $56 \%$ dos alumnos matriculados se atopa nos primeiros niveis educativos, de xeito que aínda se está a tempo de reducir esta desvantaxe por clase social. Por último, e no tocante á política de inmigración, cabe lembrar que, se é o status socioeconómico o que ten máis influencia no risco de fracaso escolar, daquela unha política de fluxos guiada por criterios de integración, e non só de man de obra abundante, podería suavizar o lastre educativo que atenaza os fillos da inmigración estranxeira.

\subsection{Máis tempo parados, pero co mesmo mono de traballo}

Finalmente aparece a cuestión máis urxente e a que impregna as demais, a saber: que facer para procurar a inserción laboral dos inmigrantes máis danados por esta longa e profunda crise. Tracemos un bosquexo da evolución e da situación en que se atopa a poboación inmigrante no mercado de traballo tras a gran recesión. Un resumo, incompleto, dos trazos que máis sobresaen é o que vai a seguir.

A enquisa de poboación activa capturaba na metade de 2015 máis de cinco millóns de persoas de 16 e máis anos que non naceran en España. Nesa data contábanse case 2700000 traballadores inmigrantes con emprego e arredor de 1150000 desocupados. En suma, arredor de catro millóns de foráneos activos. A taxa de actividade era do $75 \%$, a de paro roldaba o $30 \%$ e a de ocupación o $52 \%$. Nun só ano, e sen que variase apenas a poboación activa inmigrante, a taxa de desemprego diminuíra tres puntos e crecera un dous por cento a taxa de ocupación. Desde 2013 —o peor ano na crise- a situación dos inmigrantes respecto do emprego mellorou, tanto para os homes como para as mulleres. Iso é o que ocorre se avaliamos esta situación a través de indicadores brutos. Sen maior desagregación, comparación nin detalle sobre as condicións laborais e salariais. Pois, se a comparamos con 2008, daquela a taxa de ocupación roldaba os dous terzos $(64 \%)$ e a de paro era practicamente a metade $(16,5 \%)$. Mais non cabe ocultar dúas tendencias xerais: 
1) a ocupación está a crecer para os inmigrantes de forma máis acelerada ca para os españois, malia que tamén diminuíu de maneira máis rápida e aguda cando se produciu a recesión, e 2) as condicións laborais empeoraron para todos; é dicir, tivo lugar unha igualación por deterioración e por abaixo.

Se imos ao detalle por sexo e por continente de nacionalidade, e desde o inicio da recesión, veremos que a poboación activa inmigrante diminuíu en 700000 persoas e hai un millón menos de inmigrantes ocupados. A crise golpeou máis os inmigrantes masculinos ca as mulleres, e iso reflíctese no maior descenso da ocupación (20 puntos fronte a 11) e tamén, aínda que en menor proporción, no aumento da taxa de paro (que subiu 19 puntos nos homes, fronte a 16 puntos nas mulleres). É razoable pensar que «elas» acudiron ao rescate familiar incorporándose ao mercado de traballo, e de aí que a súa taxa de paro aumentase tanto.

A ocupación caeu máis entre a inmigración latinoamericana, que foi a máis danada canto a perda de emprego, se ben o paro afectou máis a inmigración africana, que xa antes da crise era a máis marxinada en termos de emprego e que segue a selo tras esta fase crítica. Os europeos comunitarios e os asiáticos son os inmigrantes que saíron mellor parados da sacudida recesiva.

No último ano, é dicir, en 2015, como xa dixemos, produciuse unha mellora destes indicadores (ocupación e desemprego) tanto entre a poboación autóctona como entre a foránea, pero beneficiáronse máis os inmigrantes ca os nativos desta recuperación. Probablemente sexa a maior vulnerabilidade da man de obra inmigrante a que estea detrás da súa maior adaptabilidade ás desmelloradas condicións salariais e laborais. De aí a súa maior incorporación a un emprego que é máis inestable e que está peor remunerado do que o estaba antes da crise. O outro trazo desta «recuperación por desvalorización da forza de traballo» é o feito de ela beneficiar máis os homes ca as mulleres inmigrantes. $\mathrm{O}$ cal pode apuntar a que o emprego se crea nos mesmos nichos onde antes da crise se ocupaban os inmigrantes masculinos, mais tamén a que o papel da muller no fogar e nos ingresos familiares retorna á condición subalterna e substitutiva.

O problema máis urxente é o do millón cento cincuenta mil parados que hai en 2015 e que se reparten, metade por metade, entre homes e mulleres. A distribución deses empregados segundo os meses transcorridos desde o seu último emprego amosa que a crise golpeou con especial forza os inmigrantes. Pois, se en 2008 tres de cada catro foráneos permanecían nesa situación de desemprego 
menos dun ano $(72,6 \%)$, fronte a dous de cada tres autóctonos $(63,6 \%)$, ocorre que, en 2015, as proporcións empeoraron moito e, alén diso, se igualaron naquilo que non é desexable. De tal xeito que non chegan ao $40 \%$ os españois $(39,2 \%)$ nin os inmigrantes $(38,3 \%)$ que achan emprego antes de transcorrer un ano. Pola contra, a situación agravouse moito e o paro ten unha duración desmesurada, de modo que máis dun terzo dos espańois (38 \%) e unha proporción moi parecida de inmigrantes $(34 \%)$ superan os dous anos en situación de desemprego.

Táboa 1. Número de meses transcorridos desde o seu último emprego segundo o país de nacemento, 2008-2015

\begin{tabular}{lllll}
\hline & \multicolumn{2}{c}{2008} & 2015 \\
\hline$<1$ ano & 1101834 & 470634 & 1563329 & 442716 \\
\hline Entre 1 e 2 anos & 193923 & 54195 & 510310 & 159114 \\
\hline$>2$ anos & 280420 & 58078 & 1521831 & 390157 \\
\hline Resto & 156683 & 65781 & 397111 & 164441 \\
\hline Total & 1732860 & 648688 & 3992581 & 1156428 \\
\hline
\end{tabular}

Fonte: elaboración propia a partir de datos da enquisa de poboación activa (EPA), segundo trimestre de 2008 e 2015. Instituto Nacional de Estadística (INE).

Por último, e para respondermos á pregunta de a que sectores se pode incorporar esta poboación desempregada, repasaremos as distribucións dos inmigrantes que levan parados menos dun ano segundo o sector ou rama de actividade en que tiveron o seu último emprego. E comprobaremos que, en 2015, os 442000 parados de curta duración atoparon o seu último traballo nos mesmos sectores en que tradicionalmente se empregou o conxunto dos inmigrantes. É dicir, na hostalaría, o comercio, a agricultura, a construción e o servizo doméstico. A agricultura parece que operou como un sector de resistencia para os traballadores da construción e da industria, mentres que o comercio, as tarefas administrativas e o servizo doméstico acollen as novas incorporacións. 
Táboa 2. Actividade do establecemento no que traballou (se está desempregado desde hai menos dun ano)

\begin{tabular}{|c|c|c|c|c|}
\hline & \multicolumn{2}{|c|}{2015} & \multicolumn{2}{|c|}{2008} \\
\hline & Abs. & $\%$ & Abs. & $\%$ \\
\hline Agricultura, gandaría, silvicultura e pesca & 72625 & 16,4 & 67906 & 8,9 \\
\hline Industria extractiva & 1126 & 0,3 & 155 & 0,0 \\
\hline Industria manufactureira & 23025 & 5,2 & 74868 & 9,8 \\
\hline Subministración de enerxía, gas e auga & 2762 & 0,6 & 674 & 0,1 \\
\hline Construción & 54476 & 12,3 & 182148 & 23,8 \\
\hline Comercio & 67585 & 15,3 & 102908 & 13,5 \\
\hline Transporte e almacenamento & 13257 & 3,0 & 21176 & 2,8 \\
\hline Hostalaría & 71724 & 16,2 & 122461 & 16 \\
\hline Información e comunicacións & 2122 & 0,5 & 9867 & 1,3 \\
\hline Actividades financeiras e inmobiliarias & 4994 & 1,1 & 11560 & 1,5 \\
\hline Actividades profesionais, científicas e técnicas & 6930 & 1,6 & 11032 & 1,4 \\
\hline Actividades administrativas e servizos auxiliares & 29326 & 6,6 & 32590 & 4,3 \\
\hline Administración pública e defensa & 12563 & 2,8 & 7886 & 1,0 \\
\hline Ensino & 4906 & 1,1 & 11638 & 1,5 \\
\hline Actividades sanitarias & 4630 & 1,0 & 4329 & 0,6 \\
\hline Actividades asistenciais e servizos sociais & 5049 & 1,1 & 13076 & 1,7 \\
\hline Actividades artísticas e extraterritoriais & 11932 & 2,7 & 10487 & 1,4 \\
\hline Outros servizos & 6841 & 1,5 & 9438 & 1,2 \\
\hline Servizo doméstico & 46844 & 10,6 & 70375 & 9,2 \\
\hline Total & 442716 & 100,0 & 764574 & 100,0 \\
\hline
\end{tabular}

Fonte: Elaboración propia a partir de datos da enquisa de poboación activa (EPA), segundo trimestre de 2008 e 2015. Instituto Nacional de Estadística (INE).

\section{EN QUE ACERTARON E EN QUE FALLARON AS POLÍTICAS MI- GRATORIAS: 1985-2015}

1.- Respecto dos fluxos, errouse na temperanza das entradas, se ben se atinou no equilibrio de procedencias nacionais e continentais. Á vista dos datos do stock, 
subestimáronse a natureza permanente e o proxecto de asentamento da maioría dos inmigrantes. Verbo da conveniente moderación dos fluxos cabe establecer, polo menos, tres principios, que son os seguintes: os de establecer topes numéricos, aplicarse na composición ou selección e todo iso pensando na integración (cidadanía e redes sociais). Parece claro que os teitos e limiares cuantitativos (topes) dependerán da velocidade de integración e esta, pola súa vez, será debedora da composición e, xa que logo, da selección dos admitidos.

É dicir, non se fixaron uns límites numéricos nin un intervalo de acollida cuantitativo. Así, os fluxos saltaron dos 100000 en 1999 aos máis de 900000 en 2017. E, aínda en anos recentes (2014), os fluxos de entrada superan folgadamente os 350000 . Tampouco se acertou en que os suramericanos e os romaneses se inclinarían pola naturalización, a reemigración ou a circulación e —nunha medida que aínda non é posible aquilatar- polo retorno definitivo. Existen indicios de que se decantaron máis polo retorno temporal á espera dunha recuperación que, malia que rebaixada no nivel social, lles resulta comparativamente vantaxosa. Mentres que o proxecto migratorio dos marroquís, africanos e asiáticos vence cara ao costado da instalación duradeira. Os preferidos esfúmanse, sequera provisionalmente.

Tomando boa nota dos proxectos migratorios duns e doutros, habería que procurar facilitar a reunión familiar nos fluxos legais e duradeiros. Atraer máis capital en formación - estudantes - e seleccionar consonte o criterio (se van quedar, convén que sexan versátiles nas súas capacidades profesionais) da inmigración como estrutura.

Canto á selección dos fluxos (que non se debe practicar cos refuxiados ou asilados, nin cos familiares), requírese, para a súa discusión ser acordada de modo público e razoado, a oferta de canles axeitadas para a entrada. A selección vértese sobre a composición (e sobre o número), mais tamén respecto da taxa e da velocidade de absorción. Aí os criterios de idade, aptitudes lingüísticas, instrución e profesión deberían prevalecer, ou polo menos gardar o equilibrio, respecto de marcadores culturais tales como a identidade étnica e as crenzas ou prácticas relixiosas.

2.- No tocante aos stocks, hai que axudar — e non só acompañar - a sociedade na súa integración. Quere isto dicir que, por exemplo, hai que facilitar e custear a aprendizaxe do idioma cando o inmigrante xa é un traballador adulto e non 
vai inserirse no sistema educativo. Seguir o exemplo alemán. Mais é significativo que, ata agora, os efectos sociais benéficos ou adversos fosen menos analizados e difundidos ca os efectos económicos positivos (crecemento) e negativos (desemprego, pobreza e redución de salarios). Sinal do escaso valor que se lle concede ao desenvolvemento social en comparación co crecemento do diñeiro. Os estragos sociais e políticos negativos, tales como o racismo e a ruptura da solidariedade ou a conformación de paisaxes de exclusión social, non foron, para o ben e para o mal, os máis publicitados.

Así, pois, o segundo reto é o de analizar a fragmentada e asimétrica integración na sociedade e informar acerca dela. E, neste senso, non se pode simplificar a política de inmigración ignorando a importancia que ten a compońente relixiosa e étnica. As dúas políticas, a de inclusión social e a de relación intercultural, van intimamente unidas se se ten un concepto estrutural das poboacións inmigradas.

\section{DESAFÍOS QUE ASOMAN}

\section{O primeiro desafío é aprender dos erros e avaliar, en termos xerais, a experiencia.}

1.- Esa avaliación non se levou a cabo tras a longa experiencia española na emigración e, particularmente, logo da emigración durante os anos sesenta aos países centrais da - agora - Unión Europea. Sinaladamente, non se reparou na evolución que seguían os españois en Francia, Bélxica e Alemaña Occidental. A emigración española forneceu preciosas indicacións sobre os resultados, para a inserción laboral, dos fluxos «acompañados» polos técnicos da Administración española. Nin sobre a dificultade de controlar a «saída libre», é dicir, a corrente de espańois que se foi sen coñecemento nin asistencia do Instituto Español de Emigración. Así mesmo, pódense tirar leccións da integración lingüística e educativa dos fillos das familias españolas e da súa repercusión na mobilidade social, tanto nos seus países de acollida como no seu eventual regreso a Espańa. Por último, tampouco se analizou cal foi a experiencia que seguiu ao retorno.

Estas leccións poden ser útiles nos tempos presentes. En primeiro lugar, porque aumentou o número de españois que viven fóra de España e que poderían querer vir se houbese condicións para iso. A diáspora no exterior é unha fonte para a política inmigratoria en termos de integración e de capacitación. E, en 
segundo lugar, porque constitúen unha inxección de cosmopolitismo para a sociedade.

Outra das ensinanzas que se desprenden da comparación entre ciclos migratorios é a necesaria adecuación conceptual á época, á motivación e ao contexto.

2.- A motivación dos candidatos segundo cales sexan o carácter e a natureza do seu proxecto migratorio é un criterio para diferenciar a migración temporal da estrutural. $\mathrm{O}$ abaratamento dos transportes e o acceso á información convidan a facilitar a mobilidade e a circularidade, en contra das políticas que as obstaculizan e as traban. O contexto de recesión e de receo nas poboacións europeas aconsella poñer en práctica políticas de selección que se baseen en criterios claros e que proporcionen seguridade e confianza aos cidadáns maltratados (máis danados) pola crise.

E, situados neste momento, é dicir, nos anos que levamos vividos do século XXI, a información dispoñible aconsella que as políticas diferencien as migracións suplementarias (temporal e circular) das emigracións permanentes, estruturais e complementarias. Esta distinción entre a inmigración como prótese ou como transplante (Livi Bacci 2012), ou, dito doutro xeito, como man de obra ou como parte do tecido social, é a que adopta a OCDE nos seus informes anuais. As primeiras —as temporais e circulares — están máis supeditadas aos ciclos económicos e ao modelo produtivo, mentres que nas segundas poida, e quizais convén, que pese tanto ou máis a inserción na sociedade. Expresado con outras palabras, nunha sobresae a facilidade e a rapidez da taxa de inserción laboral e na outra aténdese máis ben á maior ou menor dificultade e lentitude na taxa de absorción social (Collier 2013).

3.- Por fin, repensar os conceptos require e esixe boas fontes de información e medición. En particular, se se pensa nas migracións como diversidade instalada, como parte constitutiva do modelo social, como fonte de reprodución da poboación; en definitiva, como estrutura desta sociedade. É necesario, por iso, xerar datos lonxitudinais de poboación de orixe estranxeira, é dicir, información que inclúa os inmigrantes que antes eran estranxeiros e que se converten en cidadáns naturalizados. Por exemplo, seguir a evolución segundo os recursos socioeconómicos (e a distinta comunidade cultural) do alumnado de orixe estranxeira, aínda que de nacionalidade española, durante o seu tránsito polo ensino primario e medio, para a comparar coa do alumnado comunitariamente espańol e de distin- 
ta orixe social. $\mathrm{Ou}$, por poñer outro exemplo, este a respecto dos fluxos, requírese saber cantos se van, quen se vai e canto durou a súa estadía. É dicir, pensar na migracións en termos de sistema migratorio no que a modificación dunha peza repercute sobre outra, así como sobre o conxunto e a contorna.

O que conta como proposta e reto de futuro é reconstruír ou recompor un sistema de información e de observación que nos permita afrontar o porvir con menos dependencia das sensacións mediáticas, e máis perspectiva baseada nun xuízo razoado. Pensar en inmigración como estrutura, e non en estranxeiría como inimigo cultural. Redistribuír as políticas de recepción e de inserción. Hai que desprazar a tónica da obsesión polo control cuantitativo dos fluxos de entrada (e pouca polos de saída) ás políticas de inclusión social e integración cívica nunha sociedade que está penetrada pola globalización. Porque Europa é un continente multiétnico e multiconfesional. 


\section{REFERENCIAS BIBLIOGRÁFICAS}

Cebolla Boado, Héctor (2015): «Las trayectorias educativas de los hijos de los inmigrantes en España: ¿qué sabemos y qué podemos esperar?», en Cristóbal Torres Albero (ed.), España 2015, Madrid, Centro de Investigaciones Sociológicas (CIs), 225-233.

Collier, Paul (2013): Exodo: inmigrantes, emigrantes y paises, Madrid, Turner.

FERnÁNdez Buey, Francisco (2005): «Inmigración: propuestas constructivas», La Insignia, xullo.

González Ferrer, Amparo / Clara Cortina Trilla (2015): «Los nuevos españoles: inmigración, integración y acceso a la nacionalidad», en Cristóbal Torres Albero (ed.), España 2015, Madrid, Centro de Investigaciones Sociológicas (CIs), 234-242.

IzQuierdo Escribano, Antonio (1994): «Las encuestas contra la inmigración», en Luisa Martín Rojo / Concepción Gómez Esteban / Fátima Arranz / Ángel Gabilondo (eds.), Hablar y dejar hablar: sobre racismo y xenofobia, Cantoblanco (Madrid), Ediciones de la Universidad Autónoma de Madrid.

IzQuierdo Escribano, Antonio (2016): Crítica de la inmigración imaginada, Barcelona, Bellaterra.

LAPARRA, Miguel (2012): «Redes, mercados y políticas: combinación de factores en el proceso migratorio de Ecuador a España», en Antonio Izquierdo / Wayne A. Cornelius (eds.), Políticas de control migratorio, Barcelona, Bellaterra.

Livi BaCcI, Massimo (2012): Breve historia de las migraciones, Madrid, Alianza Editorial.

Martinello, Marco (2003): La Europa de las migraciones, Barcelona, Bellaterra, colección «La Biblioteca del Ciudadano".

Molino, Sergio del (2016): La España vacía, Madrid, Turner.

OCDE (2015): Perspectives des migrations internationales 2015, Paris, Éditions oCDE (http://dx.doi. org/10.1787/migr_outlook-2015-fr).

Miyar Bustos, María (2016): «La continuidad de los flujos migratorios en tiempos de crisis», Panorama Social, 23 (primeiro semestre), 141-156.

RichaRds, Michael (2013): Historias para después de una guerra: memoria, politica y cambio social en España desde 1936, Barcelona, Pasado y Presente.

Rius Sant, Xavier (2007): El libro de la inmigración en España, Córdoba, Almuzara.

Secretaría de Estado de Inmigración y Emigración. Dirección General de Inmigración (2007): Informe sobre a inserción dos estranxeiros no mercado de traballo español, Madrid.

vv. AA. (2016): «Migraciones», en Cristóbal Torres Albero (ed.), España 2015: situación social, Madrid, Centro de Investigaciones Sociológicas (CIs). 
OS REFUXIADOS NA ERA DE TRUMP: UN PROBLEMA POLÍTICO, NON UNHA CRISE HUMANITARIA

Javier de Lucas

Institut de Drets Humans

Universitat de València 



\section{INTRODUCIÓN}

Quizais o máis interesante do que agora case todo o mundo coincide en recoñecer como mal denominada «crise dos refuxiados» é o que esconde. Tras o tópico teimudamente reiterado, o punto de partida que non debemos esquecer é a existencia de necesidades de protección de dereitos (de bens xurídicos de primeira orde) de millóns de persoas. Refírome sobre todo aos protagonistas de dúas manifestacións da mobilidade forzada con respecto ás cales, por certo, existe unha crecente zona gris, os que chamamos refuxiados e/ou desprazados, por un lado, e a maioría dos inmigrantes irregulares, polo outro, a respecto dos cales se ignora a inexistencia de garantía do primeiro dereito, o dereito a non emigrar ${ }^{1}$. Por non falar do que, sen dúbida, debería ocupar os esforzos da comunidade internacional nos próximos anos, isto é, esa nova categoría de desprazamentos forzados para a que aínda non dispoñemos dunha resposta xurídica adecuada, os millóns de persoas que van desprazarse como consecuencia das transformacións das condicións naturais (fames, secas, contaminación, terremotos, inundacións etc.), os mal chamados «refuxiados ou desprazados medioambientais», que outros prefiren denominar (ao meu xuízo, con desacerto) «inmigrantes climáticos».

Pois ben, o que me parece máis grave é que non só existe na UE (nin en boa parte dos Estados occidentais aos que se dirixen as demandas de inmigración e asilo) a máis mínima vontade política de ofrecer unha resposta adecuada á necesidade de recońecemento e protección de dereitos básicos de refuxiados e inmigrantes, senón que, ademais, rexeitemos teorizar adecuadamente o que a todas luces é, como mínimo, o síntoma dunha profundísima crise do modelo político europeo (se non, incluso, unha crise da democracia mesma).

\footnotetext{
${ }^{1}$ Véxase, por exemplo, Aguelo Navarro, Pascual / Ángel Gregorio Chueca Sancho (2004): «El novísimo derecho humano de las personas a migrar», Revista de Derecho Migratorio y de Extranjería, 5, 291-293; Chueca Sancho, Ángel Gregorio / Pascual Aguelo Navarro (2013): «Contenido y límites del ius migrandi», Revista Electrónica Iberoamericana, 7:2, 83-111.
} 
Deberiamos empezar por entender que a formulación habitual, que ten toda a aparencia da linguaxe politicamente correcta baixo o eufemismo «crise humanitaria» ou «crise de refuxiados» e que, no mellor dos casos, apela ao humanitarismo paternalista, acaba por contribuír dese modo a ocultar a profunda dimensión política destas manifestacións de mobilidade forzada (das clásicas e, insisto, das que se están a producir cada vez máis, ligadas ao impacto do que denominamos "catástrofes medioambientais» e que non podemos seguir presentando como «desastres naturais»).

\section{A UE, DE COSTAS AOS REFUXIADOS}

A propósito do Consello Europeo extraordinario realizado no último trimestre de 2016 en Bratislava ${ }^{2}$, afirmaba Sami Naïr que era a certificación dun novo apertar do parafuso nas políticas europeas de inmigración e asilo. En efecto, as conclusións dese Consello comportaban unha xustificación da consolidación do enfoque securitario e de defensa en materia de política de refuxiados ${ }^{3}$. Prodúcese así un paso máis na mensaxe de estigmatización de inmigrantes e refuxiados, que

${ }^{2} \mathrm{O}$ texto da denominada «Declaración y hoja de ruta de Bratislava» pode consultarse en http://www. consilium.europa.eu/press-releases-pdf/2016/9/47244647412_es.pdf [última consulta: outubro, 2016].

${ }^{3}$ Un enfoque «securitario» que non só se impón en políticas de migración e asilo, senón tamén noutros ámbitos da acción exterior europea, como a política de cooperación e axuda ao desenvolvemento, tal e como denunciou entre nós o profesor Sanahuja: cfr. Sanahuja, José Antonio (2005): «Seguridad, desarrollo y lucha contra la pobreza tras el 11-S: los Objetivos del Milenio y la "securitización" de la ayuda", Documentación Social, 136, 25-42, e, sobre todo, Sanahuja, José Antonio / Julia Schüneman (2012): «El nexo seguridad-desarrollo: entre la construcción de la paz y la "securitización” del desarrollo», en José Antonio Sanahuja (coord.), Construcción de la paz, seguridad y desarrollo: visiones, politicas y actores, Madrid, ICEI, e Sanahuja, José Antonio (2016): «La Unión Europea y la crisis de los refugiados: fallas de gobernanza, securitización y "diplomacia de chequera”", en Manuela Mesa (coord.), Retos inaplazables en el sistema internacional. Anuario 2015-2016, Madrid, CEIPAZ. Esa é tamén unha crítica constante, así mesmo, nos traballos do profesor Gómez Gil, desde o seu «Desguazando la cooperación española: la construcción ideológica del colapso de la cooperación al desarrollo", Papeles de Relaciones Ecosociales y Cambio Global, 123/2013, 85-95. Desde a perspectiva do dereito internacional público, ao meu xuízo deben consultarse, así mesmo, os traballos da profesora Ramón Chornet: cfr., p. ex., Ramón Chornet, Consuelo (2005): «La política de codesarrollo de la Unión Europea: ¿̨hacia una inflexión significativa?», en vV. AA., Codesarrollo: migraciones y desarrollo mundial, Madrid, CIDEAL. Así mesmo, Ramón Chornet, Consuelo (2010): «Sobre el sentido y función del codesarrollo en la acción exterior», en Joan Lacomba Vázquez / Fernando Falomir (coords.), De las migraciones como problema a las migraciones como oportunidad, Madrid, Los Libros de la Catarata. 
ten o efecto perverso de incitar a unha política de medo e de odio, de xenofobia e repregamento. Un enfoque que vai abríndose camiño e, sobre todo, parece ocupar un lugar de importancia na próxima administración dos EUA, o Goberno de Trump, como apuntarei despois. Fronte a isto, a ben intencionada declaración adoptada pola Asemblea Xeral da ONU tras o UN Summit for Refugees and Migrants do 19 de setembro de 2016 parece pouco máis ca papel mollado ${ }^{4}$.

Está claro, ao meu xuízo, que non podemos aceptar permanecer en silencio ante as falacias e mentiras sobre a resposta ao desafío dos refuxiados. A primeira, que falamos de «refuxiados», cando non o son, non chegan a selo, porque o noso designio é impedirlles ou polo menos dificultarlles enormemente que sexan recońecidos como tales. En realidade falamos de millóns de persoas que son aspirantes a refuxio ou solicitantes del (asylum seekers), que foxen do seu país e vagan polo mundo querendo solicitar refuxio sen que se lles deixe nin iso...

O máis urxente é coñecer as causas que están a producir este incremento dos desprazamentos forzados e actuar para parar os masacres dos que foxen e, pola súa vez, o masacre na fuxida, unha traxedia que esconde datos horribles, como a sorte descoñecida de miles de menores non acompañados (inmigrantes irregulares, refuxiados), denunciada non só por ONG como Save the Children, senón nada menos que pola mesma Europol. Por non falar da sorte das mulleres violadas e maltratadas polas mafias en Libia mentres esperan para embarcar, ás veces durante meses, nunha viaxe na que arriscan a súa vida e a dos seus fillos.

Ao xuízo de moitos de nós, o que se está a producir é, sobre todo, unha gravísima claudicación, un retroceso no mellor do patrimonio europeo, os elementos claves que contribuíron decisivamente á civilización: a garantía e o recońecemento eficaces dos dereitos humanos de todos os seres humanos, o imperio da lei, a construción dun espazo público entendido en termos de liberdade, seguridade e xustiza. Ao baleirar o dereito de asilo, baleiramos o mellor do proxecto europeo, o seu carácter dunha comunidade de dereito, de respecto ao Estado de dereito, da primacía do dereito ao servizo da garantía dos dereitos humanos. Estamos contribuíndo a resucitar o peor da historia europea, a construción dun tópico aceptado acriticamente, a mensaxe de que hai seres humanos que por determinadas condicións non son igual de humanos ca os

\footnotetext{
${ }^{4} \mathrm{O}$ texto da Declaración pode obterse en http://www.un.org/ga/search/view_doc.asp?symbol=A/71/ L.1\&referer=http://refugeesmigrants.un.org/declaration\&Lang=S. Os interesantes documentos preparatorios, en https://refugeesmigrants.un.org/summit-documents.
} 
demais (como advertira o xenial Orwell a través do personaxe do porco Napoleón en Animal Farm). Os inmigrantes irregulares, os refuxiados, son o neno que tiramos coa auga sucia dos nosos medos. Decidimos que non son, non poden nin deber ser iguais en dereitos. Estigmatizámolos, ata o punto de facer dos demandantes de refuxio suxeitos sospeitosos, invertendo o mecanismo de presunción de inocencia e as bases mesmas da tradición xurídica do asilo ${ }^{5}$. Creamos para eles un estado de excepción permanente que, por outro lado, é perfectamente funcional ao estadio de evolución do capitalismo global no que vivimos, como souberon sinalar Saskia Sassen ${ }^{6}$ e Zygmunt Bauman (especialmente en diálogo con G. Agamben ${ }^{7}$, no cal ambos retoman a liña de análise de D. Lochak, aínda que sen citala) e como insiste tamén, desde o seu habitual ton de provocación, Žižek ${ }^{8}$. E así, nós, europeos, camiñamos pola senda dunha política, unha antipolítica en realidade, que traspasa todas as liñas vermellas da democracia e do Estado de dereito.

O que trato de sinalar é que non debemos seguir aceptando a falaz tese da «crise de refuxiados», unha mestura de mentiras e erros de análise que permiten unha operación de «boa conciencia»: falar da "crise de refuxiados», soster que nos atopamos ante unha encrucillada do humanitario e o pragmático, que suporía asumir que nos encontramos ante o dilema de elixir entre o altruísmo de axudar os desesperados do mundo ou sacrificar a nosa seguridade, como o mostraría a crise do sistema Schengen. É dicir, que o noso dilema é elixir entre dereitos humanos deses outros ou a nosa seguridade. Esa falacia, cuxos supostos fundamentos tratei de analizar noutros traballos, cumpre unha función perversa: evitar o esforzo crítico que debería conducirnos a advertir o grave risco que se abre ante nós e que intentarei abordar a continuación.

${ }^{5}$ Creo que o reflicte o feito de que a definición máis apropiada daquilo no que se converteu hoxe un refuxiado, como veño insistindo, sexa a que propuxo hai uns meses o Alto Comisionado para os Dereitos Humanos da ONU, o xordano Zeid Ra'ad Al-Hussein: «refugees [...]. These are people with death at their back and a wall in their face». A nosa achega é esa: poñerlles diante muros, aramados, campos de detención.

${ }^{6}$ Vid. Sassen, Saskia (2014): Expulsions: Brutality and Complexity in the Global Economy, Cambridge, MA, Harvard University Press (trad. francesa, Gallimard, 2016). Hai tradución española (2015): Expulsiones: brutalidad y complejidad en la economía global, Bos Aires, Katz.

${ }^{7}$ Archipiélago de excepciones, unha conferencia impartida no ссСв en diálogo con Giorgio Agamben e que foi despois publicada en Katz Editores (2008). Máis recentemente, Bauman, Zygmunt (2016): Strangers at our Door, Malden, MA, Polity Press, no que trata de analizar as raíces do que considera unha das patoloxías dominantes, "o medo a inmigrantes e refuxiados», e ofrecer alternativas.

${ }^{8}$ Cfr., por exemplo, o seu artigo "What our fear of refugees says about Europe», na revista New Statesman: (http://www.newstatesman.com/politics/uk/2016/02/slavoj-zizek-what-our-fear-refugees-says-abouteurope). Máis especificamente, o seu Refugees, Terror and other Troubles with the Neighbors: Against the Double Blackmail, 2016. 


\section{O QUE ESTÁ EN XOGO: UN MODELO POLÍTICO QUE REFORZA A EXCLUSIÓN}

Para entender o verdadeiro alcance do que está en xogo, recorrerei ás teses dos xa mencionados Saskia Sassen e Zygmunt Bauman, que porei en relación coas sostidas por algúns dos que analizan as migracións en clave xurídica e política, de Sayad a Wihtol de Wenden.

Sassen, no seu traballo máis recente e antes mencionado, subliña a profunda relación entre tres elementos clave das nosas sociedades aquí e agora: as migracións, a desigualdade nas relacións internacionais imposta pola economía globalizada e o proceso de construción do vínculo social e político. Así o expón no seu devandito libro, Expulsiones, no que sostén que o grao actual de violencia (devida en ordinaria) do capitalismo no seu estadio global se explica por esa lóxica de expulsión, que é como deberiamos chamarlle á lóxica que preside a economía globalizada. Para Sassen, asistimos ao final da lóxica inclusiva que gobernou a economía capitalista a partir da Segunda Guerra Mundial e á afirmación dunha nova e perigosa dinámica, a da expulsión. Unha lóxica que fai culminar a contradición xa advertida por Adam Ferguson en 1767 no seu An Essay on the History of Civil Society («Ensaio sobre a historia da sociedade civil»), entre a lóxica do público e a lóxica do mercado ou, por dicilo doutra maneira, entre a lóxica da universalidade dos dereitos e a expansión do Estado de dereito, e aquela outra do beneficio e a "man invisible», que postula o regreso ao máis radical hands-off do dereito e os poderes públicos no ámbito que reclama para si (desregulado), o mercado...

Pois ben, ao meu xuízo, a constante máis destacable na inmensa maioría dos proxectos de xestión do fenómeno migratorio, nas políticas migratorias e de asilo dos países que somos destinatarios de migracións, é o empeño en esquecer, en ocultar unha verdade evidente: a inevitable dimensión política desas manifestacións de mobilidade humana (inmigrantes e, con maior claridade aínda, refuxiados), a súa condición de res politica, tanto desde o punto de vista estatal como desde as relacións internacionais. Fronte a isto impuxemos unha mirada sectorial, unilateral e a curto prazo que se concreta na construción dunha categoría xurídica de inmigrante que, en realidade, é un concepto demediado ou, como 
propón Bauman, un paria9: o inmigrante é só o traballador necesario nun determinado nicho laboral no mercado de traballo formal (coma se non fose utilizado no mercado clandestino ou informal) e mentres se someta a un estatuto precario guiado pola maximización do beneficio da súa presenza. É unha ferramenta, nin sequera un traballador igual ao asalariado nacional. Por iso a súa condición precaria, parcial, de sospeita ${ }^{10}$.

Todo iso acentúase aínda máis no caso dos refuxiados. $\mathrm{O}$ mesmo Bauman, en liña coas teses desenvolvidas por Agamben desde o seu coñecido Homo sacer, explicou como se crea un estado de suspensión da orde xurídica, ausencia de lei, desigualdade e exclusión social, que fai posible que mulleres e homes perdan a súa condición de cidadáns, de seres políticos, e a súa identidade, dentro das fronteiras mesmas do Estado-nación.

$\mathrm{O}$ que me parece máis relevante e criticable, desde o punto de vista xurídico e político, é como, a prol desa mirada, no dereito de migración e asilo se converte en regra a excepción, contravindo principios básicos do Estado de dereito. Ese é un motto crítico que encontramos expresa e cabalmente formulado nos traballos da xurista francesa, defensora dos dereitos de inmigrantes e refuxiados Danièle Lochak ${ }^{11}$, a constante, ao meu xuízo, máis destacable e criticable: o estado de excepción permanente que creamos para os inmigrantes e que recentemente estamos a trasladar, contra toda evidencia do dereito vixente, aos refuxiados. Dese modo negamos a condición mesma de inmigrante, unha categoría universal, á vez que baleiramos un dereito fundamental, o dereito a ser inmigrante, a escoller o propio plan de vida, a circular libremente, que é un corolario indiscutible do principio (por certo, liberal) de autonomía. Pero, rizando o rizo, estamos a desprover os refuxiados dun estatuto xurídico vixente, o propio estándar normativo vinculante que é a Convención de Xenebra de 1951, so pretexto dunha «crise» tan urxente como inabordable.

Creamos políticas migratorias e de asilo, pois, que negan o seu obxecto, que o deforman, o substitúen por unha categoría vicaria: negámonos a aceptar o inmigrante tout court e substituímolo por aquel que queremos recibir. Por iso, para nós, non todo o mundo ten dereito a ser inmigrante, de forma que a nosa

${ }^{9}$ Novos parias, de condición precaria e intercambiable, con data de caducidade, tal e como sostén no seu mencionado Archipiélago de excepciones.

${ }^{10}$ É o que explica o cońecido paradoxo enunciado polo dramaturgo Max Frisch e que ignoran eses modelos de políticas migratorias: queriamos man de obra e chégannos persoas, sociedades, visións do mundo.

${ }^{11}$ Cfr. Lochak, Danièle (2007): Face aux migrants : état de droit ou état de siège ?, París, Textuel. 
lóxica inevitablemente produce inmigrantes «ilegais», non-inmigrantes. Así o explica unha das mellores expertas en política de migracións, Catherine Wihtol de Wenden, nun artigo publicado no ano 2016 sobre as novidades ou as constantes en políticas migratorias ${ }^{12}$, e, ao meu xuízo, é esa a razón dos nosos fracasos á hora de analizar e tamén de dar resposta aos desafíos migratorios no seu sentido máis amplo (inmigrantes e refuxiados).

Pola súa parte, Bauman, en diálogo con Agamben, insistiu unha e outra vez na interpretación da regresión evolutiva que sufriu o modelo de Estado social de dereito nos últimos vinte anos. Como explica con grande agudeza no seu xa mencionado Archipiélago de excepciones — no que non é difícil advertir a pegada de Foucault—, trátase dun proceso que, por mor da lóxica desta fase do capitalismo global, transforma boa parte dos que foron Estados sociais en Estados excluíntes, Estados policial-penais. Créanse así non xa pequenos espazos de infradereito, zonas de no law's land, que escapan á soberanía tradicional do Estado de dereito e que se encontran rexidos por un estado de excepción permanente, senón toda unha rede global desas illas, verdadeiros arquipélagos da excepción. A metáfora do «arquipélago» ten como emblema os campos de refuxiados e os barrios de inmigrantes ${ }^{13}$. Neles pódese comprobar como, se os «Estados sociais» de dereito en certo modo son unha reformulación ou superación do modelo hobbessiano de lexitimidade, por incremento dos seus outputs (é dicir, porque máis alá da garantía da vida fronte á violencia estenden a seguridade, a certeza no

${ }^{12}$ Escribe Wihtol de Wenden:

La réponse aux flux migratoires ressemble ainsi à un vaste Far West, où les États les plus puissants du monde font la loi par les règles qu'ils édictent en matière de droit à la mobilité, et n’acceptent pas que des normes mondiales s'imposent à l'exercice de leur souveraineté que constitue la gestion des flux migratoires. Si l'on est Danois, on peut circuler dans 164 pays; si on est Russe dans 94 ; si on est subsaharien, cette possibilité peut se limiter aux doigts d'une seule main si le pays où l'on est né, et dont on a la nationalité, est considéré comme un pays à risque. Le droit à la mobilité est donc l'une des plus grandes inégalités du monde aujourd'hui, dans un contexte où il devrait constituer un des droits essentiels du Xxi ${ }^{\mathrm{e}}$ siècle. Les riches des pays pauvres peuvent, eux, migrer, car beaucoup de pays d'immigration ont prévu d'attribuer des titres de séjour à ceux qui leur apportent des capitaux, achètent un appartement d'une taille précise, ou créent une entreprise. Les plus qualifiés, les sportifs professionnels, les créateurs et artistes de haut niveau peuvent également migrer, car beaucoup de pays d'accueil ont opté pour une ouverture de leurs frontières à une immigration sélectionnée. Les étudiants se voient aussi entrouvrir les frontières, nombre de pays, européens notamment, ayant compris le risque d'une option sans immigration dans la course à la compétitivité mondiale.

${ }^{13}$ Quizais deberiamos engadir os centros de internamento de estranxeiros (CIE). Bauman escribe que «é posible que a única industria puxante nos territorios dos membros tardíos do club da modernidade sexa a produción en masa de refuxiados. E os refuxiados son o "residuo humano" personificado: sen ningunha función "útil" que desempeñar no país ao que chegan e no que quedan, e sen intención nin posibilidade realista de seren asimilados e incorporados» (Bauman 2008: 32). 
status dos seus cidadáns, que xa non son meros súbditos), os «Estados penal-policiais» privan unha parte da poboación (entre a que se encontran os que ocupan as marxes do sistema, os que foron considerados «clases perigosas») deses «beneficios», redúcena á condición de precariedade e só poden acudir a unha vella argucia para manter a súa adhesión. É a coartada do agresor externo ou do inimigo interior, fronte ao cal defenden todos os seus cidadáns, tamén aqueles que eles golpearon e reduciron á precariedade. Ese recurso, vello argumento da lóxica do medo, é o que Bauman denomina "o escuro espellismo dos outros»: inmigrantes e refuxiados. Eses verdadeiros «excedentes» da man de obra global, e en particular os dos grupos que exemplifican as migracións forzadas e que constitúen o emblema do que, en termos moi duros, denomina "refugallo humano», produto xenuíno da lóxica desta fase do mercado global: os inmigrantes irregulares (mal chamados «ilegais», que é a forma en que son coñecidos os traballadores estranxeiros non expresamente desexados) e os refuxiados: «Un dos resultados máis letais do triunfo global da modernidade é a urxente crise da industria do tratamento do refugallo (humano)», escribe Bauman ${ }^{14}$. Esa é a razón pola que se ven despoxados de todos os elementos de identidade, dos marcadores nacionais: non teñen Estado, non son necesarios/útiles, ou deixaron de selo, non teñen "papeis». Os Estados da UE, explica Bauman, non están dispostos a recibir eses «excedentes doutros Estados» e acoden ao argumento de problemas de orde pública, de seguridade e aínda de defensa da soberanía nacional-territorial. Esgrímese sen rubor o argumento de que son exército de reserva da delincuencia, da violencia, do terrorismo. Iso é o que, ao seu xuízo, explica o inaceptable rexeitamento dos refuxiados. E, así, conclúe: «[O] lixo non precisa de distincións afinadas nin de matices sutís, salvo que haxa que clasificalo para a súa reciclaxe».

$\mathrm{O}$ que trato de dicir é que a ignominiosa resposta dos Gobernos europeos (peor incluso ca a das institucións da UE) non só ha de se entender nos termos da disputa polos medios para estender os nosos deberes a todos aqueles que son titulares de dereitos pero non son nacionais, senón que ten unha lectura, unha interpretación máis profunda. Como sinalou entre nós de forma axeitada Itziar Ruiz Jiménez ${ }^{15}$, habería que recoñecer que ao que asistimos hoxe é a un des-

\footnotetext{
${ }^{14}$ Bauman (2008: 32).

${ }^{15}$ Cfr. entrevista na revista dixital Ágora, http://www.agora-revistaonline.com/\#!ENTREVISTAS-Itziar-RuizGim\%C3\%A9nez-En-Europa-hayuna-batalla-sobre-qui\%C3\%A9n-tiene-derecho-a-tener-derechos/c112t/5714fb870cf2331 db0f847cc [última consulta: 20 de abril de 2016].
} 
mantelamento do ámbito de recoñecemento e garantía dos dereitos e a unha loita feroz por recortar o ámbito dos suxeitos do dereito a ter dereitos, que son os indicadores máis claros dese paradoxo cara ao que corremos o risco de nos encamiñarmos e que expresariamos coa fórmula democracias excluíntes. Primeiro, so pretexto da crise, profundouse na mercantilización dos dereitos económicos, sociais e culturais, as conquistas do século $\mathrm{xx}$, engadindo os propios cidadáns, as clases máis débiles e aínda a clase media, que foi pauperizada. Agora trátase de reducir o ámbito de suxeitos que poden aspirar ao recońecemento mínimo de dereitos humanos fundamentais. Esa é a batalla. Nela, as primeiras vítimas son eses outros máis visibles, os inmigrantes e os refuxiados, expulsados da condición de suxeitos de dereitos.

A conclusión non pode ser máis preocupante: cando avistaramos un futuro de ensanche da democracia, capaz de desancorar o recońecemento da plenitude de dereitos dunha condición etnocultural (a identidade nacional), abrazando así o modelo de democracia plural e inclusiva, sucede que nos asomamos de novo cara a unha comunidade política baseada na institucionalización de amplas zonas de exclusión. E iso non pode ser compatible nin coa democracia nin co Estado de dereito. De novo, haberá que recordar o lema de Heráclito: «Un pobo debe loitar polas súas leis coma polas súas murallas». Pero este pobo xa non é, xa non debería ser, a comunidade etnonacional que se encerra na fortaleza, senón unha comunidade de cidadáns libres que queren acoller, protexer, incluír baixo o seu espazo de seguridade, liberdade e xustiza os seres humanos que o necesitan e que chegan ata as súas portas.

\section{A ASIMILACIÓN CULTURAL, ILEXÍTIMA CONDICIÓN IMPOSTA AO RECOÑECEMENTO DOS REFUXIADOS}

O último apertar do parafuso é a imposición de políticas de asimilación cultural como prerrequisito para o exame da solicitude de refuxio. Fíxoo o xefe de Estado español, Filipe VI, no seu discurso na ONU o 19 de setembro de 2016. Dispuxérono Dinamarca e Holanda a través das reformas do seu réxime de dereito de asilo. O discurso da Coroa o 21 de setembro de 2016, na Haia, que abría o ano parlamentario en Holanda, incluíu un apartado específico dedicado ás tensións 
derivadas da chegada dalgúns miles de refuxiados no marco desta mal denominada «crise dos refuxiados» da que falamos. Nese discurso, lido polo rei na Sala dos Cabaleiros do antigo Parlamento holandés, o documento subliñaba «a igualdade entre homes e mulleres ante a lei e a non-discriminación por razóns de raza, crenza ou ben orientación sexual. Son valores que debe respectar e acatar calquera que queira vivir [nese] noso pais» (recordemos que ese é un leitmotiv do Goberno de Rajoy e do Partido Popular en España, empeñados en continuar co modelo de contrato de integración que Rajoy copiou de Sarkozy). As palabras do rei incluían, non obstante, unha declaración de intencións para evitar malentendidos. "A ninguén se lle pide que renuncie á súa cultura e orixes. Pero as normas establecidas son inviolables e a intimidación e a violencia obterán unha resposta firme». Coma noutras democracias constitucionais, este tipo de documentos lidos por ambos os monarcas son redactados polo Goberno, o cal, no caso holandés, poñía moito empeño en subliñar «as iniciativas privadas e municipais destinadas a animar os solicitantes de asilo a participar na sociedade».

Ninguén ignora as tensións derivadas do importante número de refuxiados que trataron de alcanzar Europa provenientes da guerra de Siria (en menor medida das de Iraq e de Afganistán) durante os anos 2015 e 2016. Por iso o monarca reafirmaba que «Holanda é un país forte nun mundo inestable. Un lugar próspero e atractivo, con boas infraestruturas e servizos e un sistema legal forte». Pero, insisto, o preocupante é que, xusto a continuación, insistise na "preocupación social ante as diferenzas culturais» e a incógnita de se non suporá o fluxo humano «un esforzo excesivo para os servizos públicos». A partir de 2017, o Goberno holandés, de centroesquerda, impuxo aos recentemente chegados a firma dunha "declaración de participación». Concibida como unha especie de contrato entre o migrante e o Estado, obriga os que buscan refuxio a «respectar as normas e valores da sociedade holandesa, en especial os principios democráticos da separación entre Igrexa e Estado, e as liberdades de credo e expresión», pero tamén a equidade entre home e muller. A asociación holandesa que reúne os refuxiados (Vluchtelingenwerk Nederland) calcula que en 2014 ata 82494 persoas contaban coa protección necesaria. En 2015 solicitárona 58800 estranxeiros, segundo a Oficina Central de Estatísticas. Para 2016, o mesmo organismo calcula que chegarán uns 70000 . Haberá que recordar que os partidos da oposición, que inclúe, entre outros, liberais de esquerda, democratacristiáns, ecoloxistas, socialistas 
radicais e o populista antimusulmán Geert Wilders, lamentaron que o Goberno non tivese «nada que ofrecer». Wilders cualificou de «conto de fadas» o discurso. Na súa opinión, o país estaba sendo «destruído». E puxo como exemplo os recortes en sanidade, a subida de impostos e as presións derivadas dos refuxiados. Afortunadamente, as eleccións xerais non lle ofreceron apoio para gobernar.

\section{QUE PODEMOS ESPERAR DA ADMINISTRACIÓN TRUMP RESPEC- TO A INMIGRANTES E REFUXIADOS?}

Se hai que facer caso ás súas proclamas electorais (en realidade Trump non ten un programa migratorio e de asilo en sentido propio), a pregunta pode parecer redundante, pois a resposta é obvia: o peor. Porén, como subliñou a miña compañeira do IDHuv, a profesora Ramón Chornet, nun recente artigo na revista El Temps, o prognóstico é máis complexo. Permítome no que segue resumir os aspectos básicos da súa tese.

A cuestión real é se Trump ten un verdadeiro programa político en materia de inmigración e asilo. E a resposta que podemos adiantar é moi sinxela: non. Se examinamos con algo de detemento as iniciativas políticas nesta materia, o resultado é escaso. E, sobre todo, de carácter simbólico.

Non hai, insiste a mesma autora, nada parecido a un modelo de gobernanza das migracións, que, por definición, ha de ser internacional, pois o carácter dos movementos migratorios - sobre todo se nos referimos aos movementos forzados (o que inclúe, obviamente, refuxiados e desprazados) — móstranos indubidablemente a súa dimensión transnacional e incluso global. Aínda máis, como xa advertiran M. Mauss e outros discípulos de Durkheim, é dicir, os primeiros sociólogos das migracións, e como popularizara Max Frisch («queriamos man de obra e chegáronnos persoas»), lonxe de reducilas ao seu indiscutible aspecto laboral/económico, non cabe ignorar o seu carácter integral, holista: as migracións son un feito social complexo e global: inclúen unha dimensión cultural/ ideolóxica e, por iso, son un fenómeno político que, como se escribiu, interpela, pon en cuestión as nosas categorías políticas básicas, isto é, a forma de entender e xustificar a cidadanía e a soberanía. Constitúen un factor decisivo do incremento da condición plural, multicultural das nosas sociedades. E, sobre todo, 
eses movementos migratorios globais non se van deter. Son xa un trazo estrutural do noso mundo, das nosas sociedades. O proceso de globalización é un factor decisivo a ese respecto. Non hai muros, valados nin fronteiras que vallan para deter eses desprazamentos nunha era na que, como sinalei nun libro conxunto co profesor Sami Naïr (Le Déplacement du monde), non é que se incrementen os movementos, senón que é o propio mundo o que se despraza.

Como se poñía de manifesto no tan ben intencionado como estéril cume mundial realizado na ONU os días 17 e 18 de setembro de 2016 ao que xa me referín, a gobernanza internacional das migracións esixe facer un fincapé — ter un programa - de alcance non só interrexional, internacional, senón global, que require ante todo políticas de coordinación dos países que son os destinatarios destes desprazamentos cos países que xeran tales movementos de poboación e con aqueles outros polos que transitan. Pero, coidado, sen caer no erro de pensar que as políticas de cooperación e investimento en terceiros Estados constitúan o tapón que deterá os fluxos migratorios. E, menos aínda, entender a coordinación internacional como un repartimento simplista de tarefas, un elemental quid pro quo: eu douche axuda económica e ti realizas por min as funcións de policía, como vén practicando, por desgraza, a Unión Europea, tal e como se concretou no cume de novembro de 2015 en La Valetta, no que se adoptaron preacordos nese sentido con algúns países africanos e, sobre todo, coa Turquía de Erdogan en materia de deportación de refuxiados e despois coa desestruturada Libia. O réxime do control do tránsito de fronteiras e do asentamento dos newcomers é importante, desde logo, pero o seu éxito depende do anterior. Dito doutra maneira, mentres permaneza a condición case estrutural de desigualdade nas relacións entre o Norte e o Sur, as migracións non só non se poderán gobernar de forma efectiva e lexítima, senón que serán dificilmente gobernables, xerarán conflitos interminables porque suporán a multiplicación de violacións de dereitos elementais e, á derradeira, resultarán eficaces.

Pois ben, as pistas que ofreceu Trump parecen situarse máis ben no ámbito simbólico, como pretextos para o consumo interno da patrioteira mensaxe de afianzamento na Strongest America, ao igual ca as súas provocadoras declaracións de tintura marcadamente isolacionista nas relacións exteriores, o tipo das súas descualificacións ao actual modelo estratéxico da OTAN. Trump sabe perfectamente que non poderá ser así. A súa aposta polo libre comercio, pola economía 
do mercado global, impide de facto o isolacionismo. Salvo que tales proclamas non sexan outra cousa, en efecto, que pretextos, mensaxes de reforzo ao votante de Estados Unidos de América que rexeita os efectos devastadores da xestión ultraliberal da globalización. Trump exhibe unha mensaxe supostamente antiObama, pois pon a tónica nos plans de regularización da inmigración do anterior presidente (cifrados en «normalizar» a metade dos irregulares, uns cinco millóns, aínda que a reforma migratoria está detida ante o Tribunal Supremo), pero omite o feito de que, en realidade, a Administración de Obama deportou nos seus dous mandatos máis de dous millóns e medio de irregulares.

Por iso, non é crible o que parece o leitmotiv proclamado por Trump para a súa xestión das migracións: o muro e as deportacións. $\mathrm{O}$ argumento, que tratei de sintetizar algunha vez na fórmula onomatopeica «vaias onde vaias, valos», é un engado. Éo no sentido no que la politicóloga Wendy Brown soubo analizalo nun magnífico libro, Walled States, Waning Sovereignty [dispoñible en español: Estados amurallados, soberanía declinante], que convén ler para entender a función real deste discurso que quere resolver a complexísima xestión dos movementos demográficos nos termos simplistas do modelo policial/militar das fronteiras, que se concreta en murallas e expulsións. Engadamos a provocación insistentemente reiterada na campaña por Trump, que prometera obrigar a México a pagar o gasto desa muralla, que, en realidade, será en gran medida un valo, e botar fóra do país nada menos que once millóns de inmigrantes, estigmatizados como ilegais, cos máis groseiros argumentos propios da consabida metáfora de exército de reserva da delincuencia. Apenas dous días tras a súa elección, Trump rebaixou de inmediato esas mensaxes para pasar a falar de deportar tres millóns de inmigrantes que son delincuentes (cometeron delitos polos que foron condenados), mentres «se asegura a fronteira e se normaliza todo», aínda que non se sabe con que medidas se vai asegurar e normalizar. O certo é que o quebracabezas que lle supón a Trump a xestión da presenza dos denominados dreamers está marcando o primeiro tramo da súa experiencia presidencial.

A realidade é moi testuda e amosa que a inmensa maioría dos residentes irregulares nos EUA non son unha ameaza, senón, moi ao contrario, unha peza imprescindible do sistema de vida norteamericano: calcúlase que eses once millóns de persoas achegan medio billón de dólares ao PIB anual dos EUA. Abonde lembrar o experimento do 1 de maio de 2006, en coincidencia co Día do Traballo, 
cando tivo lugar nos EUA o día do boicot, o día sen inmigrantes, para mostrar o impacto da ausencia deses traballadores (e unicamente na dimensión laboral-económica). Os eUA non están en condicións de aceptalo. Trump sábeo. Moi probablemente continuará a emitir mensaxes xenófobas e mesmo racistas, que non contribuirán á unidade e á convivencia. Con todo, as súas provocadoras declaracións son xestos simplistas, eficaces como parte da mensaxe proteccionista, de repregamento, que constitúe quizais o seu principal gancho electoral e o eixe da súa mensaxe interna cara aos electores que lle deron a presidencia - America first'-, mais que non se poden traducir en políticas de inmigración, agás que quixese o suicidio da economía de mercado que el sustenta. Iso si: a estratexia pode desembocar nunha auténtica guerra comercial fronte a aqueles que ve como competidores e non como socios e aliados. 
A PERTENZA: SÍMBOLOS E RITUAIS DA NACION Montserrat Guibernau Berdún University of Cambridge (Reino Unido) 

Nas sociedades modernas existen evidencias dun choque entre as necesidades racionais e instrumentais do capitalismo de mercado e as aspiracións dun dos axentes de mobilización política máis poderosos, a saber: a forza emocional de pertencer á nación en tanto que comunidade política elixida. Se ben o mercado esixe un pensamento calculador e a contención ou desprazamento das emocións, as democracias liberais modernas non poden sobrevivir sen a lexitimidade que emana do consentimento da súa cidadanía, e isto último leva consigo o apoio dun pobo que comparte un sentido de identidade común e de pertenza á mesma nación. Un sentimento de pertenza, para resultar efectivo, tería que cumprir dúas condicións: ser compartido por unha parte substancial da poboación e ter a capacidade de infundir lealdade á nación, así como sentimentos de solidariedade cara aos concidadáns, e eu entendo que estes son atributos indispensables cando se trata de fomentar un sentimento de comunidade entre concidadáns e necesarios para a construción dunha base cultural para o Estado-nación.

Isto non quere dicir que todos os cidadáns experimenten de parecida maneira un sentimento de pertenza, nin que concentren os seus sentimentos de apego nos mesmos elementos nin coa mesma intensidade; no entanto, no anterior dáse por suposto que a existencia dun sentimento de propósito común que comporte un destino compartido xera un vencello emocional entre concidadáns. Compartir un sentimento de pertenza non implica a homoxeneidade da cidadanía, xa que a presenza de certo grao de diferenza segue a ser unha constante.

$\mathrm{Na}$ actualidade, a maioría das democracias liberais occidentais son plurinacionais, multiétnicas ou ambas as cousas, e conteñen algúns grupos que se consideran alleos tanto á nación como ao Estado e distantes deles por razóns de escolla, exclusión ou marxinación ou por motivos económicos, sociais ou políticos. Sempre que a proporción de individuos que fican alienados no seo dun Estado-nación aumenta ata se converter no que eu denomino "grupo significativo» —é dicir, unha cantidade considerable de cidadáns dispostos a actuar como actor político-, queda 
cuestionada a lexitimidade do Estado-nación e contestadas a base mesma do seu sentido de comunidade, a cohesión social e a súa capacidade de construír un futuro en común. En tales conxunturas, o que se espera dun Estado-nación democrático é que reaccione buscando como dar cabida, dalgún xeito, ás diferenzas internas, mediante a xeración de institucións políticas democráticas e inclusivas, e tamén dialogando e respondendo ás demandas do "grupo significativo»; mais, nalgúns casos, o Estado-nación pode decidir facer caso omiso do movemento «opositor», socavalo e mesmo criminalizalo. Todo dependerá do grao de apoio popular que reciba o "grupo significativo» e da vontade de negociación e de alcanzar un acordo pacífico por ambas as partes. Por suposto, haberá que sopesar os motivos xeopolíticos e estratéxicos que van ligados aos intereses da comunidade internacional, e que necesariamente van ter protagonismo con miras ao resultado final.

O Estado-nación, para sobrevivir e demostrar a súa lexitimidade segundo unhas credenciais democráticas, emprende estratexias de construción nacional destinadas a fomentar un sentimento de pertenza e lealdade entre os seus cidadáns. Esta tarefa en concreto desempéñaa a construción da identidade nacional mediante a posta en marcha dun conxunto de estratexias, as máis importantes das cales son as seguintes:

- A creación e diseminación dunha imaxe determinada da «nación».

- A fabricación e difusión dun conxunto de símbolos e rituais aos cales se lles encomenda a misión de reforzar un sentimento de comunidade entre os cidadáns.

- A promoción da cidadanía, o cal comporta un conxunto claramente definido de dereitos civís e xurídicos e dereitos e deberes políticos, así como dereitos socioeconómicos. Ao lles conferir dereitos aos seus membros, o Estado-nación facilita a aparición de sentimentos de lealdade cara a si, e tamén establece unha distinción crucial entre os incluídos e os excluídos, isto é, entre aqueles autorizados a gozar de dereitos de cidadanía e aqueles que están privados deles dentro das fronteiras do Estado-nación.

- A construción de inimigos comúns. Por exemplo, o axuizamento da guerra revelouse esencial para o xurdimento e a consolidación dun sentido de comunidade entre cidadáns unidos contra unha ameaza externa, quer inminente, quer posible ou inventada. 
- A progresiva consolidación de sistemas nacionais de ensino e de medios de comunicación en tanto que instrumentos clave na diseminación dunha «imaxe da nación» concreta, cos seus símbolos, rituais, valores, principios, tradicións, inimigos comúns e, cousa máis decisiva, unha definición do que constitúe un «bo cidadán» ${ }^{1}$.

\section{A POLÍTICA DO SIMBOLISMO E O RITUAL}

A pertenza a unha comunidade ou grupo lévase a efecto mediante o simbolismo e o ritual. Así, os símbolos encarnan entidades como a nación revestíndoas de atributos distintivos pensados para as tornaren senlleiras; e, dun xeito semellante, a pertenza a un credo tamén se expresa mediante o simbolismo e o ritual.

Os símbolos son necesarios para lexitimar e reforzar o poder político; porén, tamén resultan indispensables naqueles procesos destinados a pór en dúbida e derrocar unha orde política dada. En tales situacións, que a nova elite emerxente consiga acadar o poder e se dea consolidado nel dependerá, nunha medida considerable, da súa capacidade para cuestionar radicalmente os símbolos anteriores e os substituír por outros ou ben para lles insuflar aos símbolos vellos un sentido novo e afín á concesión dun aval ao nacente statu quo.

Os símbolos representan ideas, valores, visións do mundo, todos eles definidos como "cousas que importan», ata tal punto que o individuo adoita estar disposto a dar a vida por as preservar; son poderosos porque poden suscitar fortes emocións, e as emocións constitúen un potente desencadeante da acción social, comprendida a mobilización política.

Os símbolos só teñen valor, significado e poder para aqueles que son quen de recońeceren o que representan. Entre os máis potentes atópanse os que indican pertenza a un grupo concreto, sexa a nación, sexa un credo ou algún outro grupo ou comunidade, e mesmo así non é igual ser consciente do significado dun símbolo que identificarse co símbolo. Con todo, alí onde un membro dun grupo ve un símbolo dado como signo de fortaleza, como unha representación de vellas batallas, como memoria dunha inxustiza, sufrimento e temor compartidos, quen non é membro do grupo ve un obxecto material privado dese carácter, significa-

\footnotetext{
${ }^{1}$ Guibernau, Montserrat (2007): The Identity of Nations, Cambridge, Polity Press, 25.
} 
do e valor distintivos que os membros lle atribúen. Unicamente aqueles que se identifican cos símbolos e son conscientes do seu significado se senten ofendidos ante as faltas de respecto que se lles dispensen e, dun xeito paralelo, só eles, poñendo en dúbida determinados símbolos, poden expresar unha declaración de disidencia capaz de cuestionar o statu quo.

Nas sociedades multiculturais existe unha cifra significativa de persoas que son quen de identificaren os símbolos que pertencen a diversas culturas; no entanto, só se senten conmovidas e perciben apego emocional ante aqueles dotados do que eu denomino «significado sentimental», termo co cal me refiro a algún tipo de identificación emocional cun símbolo que está alén das definicións cognitivas e das explicacións históricas relativas á súa orixe e intención. A cognición pode axudarnos a comprender o significado dun símbolo, mais nunca pode comunicar a dimensión emocional que distintas persoas, con distintos matices, lle atribúen e experimentan. A riqueza e a complexidade dos símbolos tolera certo grao de ambigüidade na súa definición, ambigüidade que permite algunha medida de creatividade emocional no nome dos suxeitos individuais ao tempo que estes constrúen o seu propio sentido de pertenza.

O respecto polos símbolos e a súa veneración son produto do contido e do significado que se lles atribúen no seo de distintas comunidades e grupos; compartir símbolos e conmoverse ante eles une os individuos e contribúe, así mesmo, a xerar un sentido de comunidade e a fomentar un sentimento de solidariedade entre eles. Alén diso, os símbolos actúan como organizadores de roles sociais dentro da comunidade e impoñen un sentido de xerarquía e estrutura.

Se ben os símbolos unen os membros dun grupo, tamén alienan as persoas alleas a el que non son conscientes do significado que se lles atribúe, ou que se amosan escépticas, curiosas ou indiferentes ante el. Os símbolos blindan as comunidades mediante un abano de «marcadores visibles e invisibles»; entre os primeiros cóntanse os uniformes, as insignias, os cortes de pelo, os códigos de vestimenta e os saúdos; entre os últimos, os rituais privados ancorados en experiencias de persecución e discriminación pasada ou actual, por exemplo no caso dos pogroms que soportaron os xudeus, o xenocidio de Bosnia, a represión dos católicos en Irlanda do Norte e a dos cataláns en España durante a ditadura franquista.

Con miras tanto a lle dar sentido a unha contorna sociopolítica nova como a transformar ou promover unha visión innovadora do mundo, precisamos ben construír outros símbolos, ben recrear os novos cargándoos de «significado re- 
levante» para os individuos contemporáneos. En efecto, os símbolos teñen un protagonismo crucial na vida colectiva, ofrecen unha interpretación diferenciada do mundo e tamén se tornan puntos de ancoraxe na existencia do individuo mediante o envío de determinadas mensaxes que sistematicamente son modificadas para que se axusten a novas necesidades sociais, e o proceso de construción e modificación dos símbolos e de identificación con estes comporta un forte investimento emocional.

\section{A función dos símbolos: cambio de réxime nunha Alemaña reunificada}

Tras a Segunda Guerra Mundial, Alemaña ficou dividida en catro sectores militares controlados por Francia, o Reino Unido, os Estados Unidos de América e a Unión Soviética. O 23 de maio de 1949, os sectores que se atopaban baixo co control da Francia, o Reino Unido e os EuA convertéronse na República Federal de Alemańa e quedaron na zona de influencia estadounidense, baixo unha economía capitalista. O 7 de outubro de 1949, o sector controlado pola Unión Soviética pasou a ser a República Democrática Alemá e adoptou o comunismo. A Guerra Fría dividiu Alemaña en dúas matades e deu lugar á construción do muro de Berlín, cos seus postos de control como símbolo clave da separación entre a Europa occidental e a oriental. O 9 de novembro de 1989, a sociedade civil berlinesa reclamou coas súas mobilizacións unha reforma política e abríronse os puntos de control que existían entre Alemaña Oriental e Alemaña Occidental, co cal se permitiu a libre circulación de persoas, nunha data que marcou a «caída» do muro de Berlín. Posteriormente tivo lugar o proceso de reunificación alemá, que resultou en extremo complexo nos planos económico, político e cultural, e para sinalar a reunificación da República Federal e a República Democrática nunha soa Alemaña federal instaurouse, o 3 de outubro de 1990, un «Día da Unidade Alemá», festivo nacional marcado por discursos políticos, actos culturais, acontecementos gastronómicos comunais, fogos artificiais e outras actividades festivas; cada ano é unha cidade distinta a que alberga as celebracións nacionais.

A porta de Brandemburgo, o muro de Berlín e o tratado de unificación alemá convertéronse en símbolo clave dunha Alemaña de novo unida. Logo da caída do muro en novembro de 1989, moitos alemáns do leste cortáronlles o escudo ás bandeiras, como fixeran os húngaros en 1956, nun acto xeneralizado ese, o de eli- 
minar o escudo da bandeira da Alemaña do leste, co cal se pretendía representar a tricolor negra, vermella e dourada, sen máis aditamentos, como símbolo dunha Alemaña unida e democrática.

Nos tempos presentes, a vella tricolor negra, branca e vermella do Imperio alemán segue a ser empregada polos monarquistas e por aqueles membros da realeza alemá que anhelan a reintrodución pacífica dunha monarquía democrática alemá. Con todo, da utilización da bandeira antiga apropiouse case por completo a extrema dereita, que é a que fai uso dela predominantemente; en efecto, como a esvástica é ilegal en Alemaña, a extrema dereita viuse obrigada a renunciar a toda bandeira nazi e a usar, no canto delas, a vella tricolor, que os propios nazis prohibiran en 1935. A prohibición dos símbolos nazis nese e nalgúns outros países constitúe a principal razón de que en moitos videoxogos referidos á Segunda Guerra Mundial non figure a bandeira nazi, que por veces se substitúe por outra, anacrónica, da Alemaña anterior a 1918, ou pola moderna tricolor. A utilización desta última, a vella bandeira imperial, por parte da extrema dereita e os seus intentos por asociala aos seus propios ideais antidemocráticos e xenófobos tópanse coa forte oposición da poboación alemá moderna².

\section{A NECESARIA AMBIGÜIDADE DOS SÍMBOLOS}

Os símbolos encarnan aspiracións e valores; evocan momentos de derrota e xúbilo e eríxense como piares da identidade dos individuos axudándolles a lle dar sentido á súa propia vida persoal, así como á vida da comunidade á que pertencen. Para desempeñaren unha tarefa tan ambiciosa, resulta crucial que os símbolos conserven algunha ambigüidade que permita a existencia de diversos significados. Así, recórrese a símbolos e rituais para sinalar puntos de transición na vida do individuo; realízanse un amplo abano de rituais de iniciación co obxecto de infundir orde e predicibilidade nunha transición descońecida ou dificultosa; e o medo ao que se ignora xera sentimentos poderosos que se canalizan mediante o ritual e que adoitan comportar unha serie de probas da aptitude do individuo para ascender a outra categoría, xa sexa a de adulto, xa a de líder, xa a de membro do grupo.

${ }^{2}$ Véxase http://en.wikipedia.org/wiki/Flag_of_Germany\#1989_to_today [última consulta: 12 de xullo de 2012]. 
$\mathrm{Na}$ capacidade de redefinir e construír símbolos novos inflúe, en moi gran medida, a distribución dos recursos; mesmo así, existen persoas físicas, Estados, Igrexas e persoas xurídicas que gozan de poder e influencia e que fan fortes investimentos na xeración dun universo simbólico que lle dea sentido ao mundo, e é mediante a manipulación dos símbolos como os poderosos reforzan a súa autoridade $^{3}$. No entanto, non todos os símbolos fican na mente do individuo e non todos satisfán as aspiracións do seu creador: en efecto, existe certa impredicibilidade verbo do grao de éxito que poidan ter as persoas xurídicas e físicas poderosas que pretendan crear un símbolo capaz de xerar lealdade e fervor entre a xente.

A pertenza a unha nación represéntase mediante o simbolismo e o ritual. Prestar xuramento, levar roupa distintiva, cortar ou amañar o pelo dun xeito concreto, cantar unha canción, adoptar un saúdo específico, pońer uniforme, unha insignia ou un anel: todos estes son símbolos que vencellan o individuo cun grupo ou comunidade dados.

Como advirte Kertzer, durante a Revolución Francesa «[a]s diferentes vestimentas chegaron a representar distintas posturas políticas e ir da cor inapropiada, levar o pantalón dunha longura indebida ou cubrirse cun chapeu impropio podía desembocar nunha liorta na rúa ${ }^{4}$, e a historiadora francesa Lynn Hunt indica que estes símbolos cotiáns non servían simplemente para expresar a postura política do individuo, senón que, «facendo manifesta [esa postura], facían posibles a adhesión, a oposición e a indiferenza» 5 .

É mediante o simbolismo e o ritual como unha colectividade se define en tanto que grupo dotado de denominación; por exemplo, "os ingleses», "os xudeus», «os masóns», «os católicos» etc., e configura a súa propia autoimaxe; e, así, ao gabar o grupo ao cal pertence, o individuo gábase a si mesmo.

Os símbolos fornecen o contido do ritual en tanto que instrumento poderoso non só para preservar a tradición, senón tamén para innovar e transformar cando se cre preciso. Como escribe Mary Douglas: «É imposible ter relacións sociais sen actos simbólicos» ${ }^{6}$. E os símbolos son sacralizados mediante o ritual.

\footnotetext{
${ }^{3}$ Kertzer, David I. (1988): Ritual, Politics and Power, Londres/New Haven, Yale University Press, 5.

${ }^{4}$ Kertzer, David I. (1988): Ritual, Politics and Power, Londres/New Haven, Yale University Press, 158.

${ }^{5}$ Hunt, Lynn (1984): Politics, Culture and Class in the French Revolution, Berkeley and Los Angeles/Londres, University of California Press, 56, 61-68.

${ }^{6}$ Douglas, Mary (1966): Purity and Danger, Nova York, Praeger, 62.
} 
ESPERTARES NACIONAIS, SOÑOS ETNICOS: OS MITOS EUROPEOS E 0 REXURDIMENTO

Joep Leerssen

Universiteit van Amsterdam 

Poisson soluble dans les eaux de la mythologie, le mythe est une forme introuvable: ni genre littéraire, ni récit spécifique ${ }^{1}$.

\section{INTRODUCIÓN: O DESAFÍO NÓRDICO Á ANTIGÜIDADE CLÁSICA}

A palabra «mitoloxía», igual ca a de «folclore» —e o paralelo resulta intrigante-, pode referirse quer a unha práctica cultural, quer ao estudo académico desta. Unha mitoloxía pode ser un conxunto de mitos e crenzas (basicamente no mesmo sentido en que unha antoloxía é unha grilanda de poemas) e tamén o estudo de tales mitos (grosso modo, igual ca a ornitoloxía é o estudo das aves). Voume centrar neste último significado e, na conclusión, retornarei á ambigüidade.

Durante a maior parte da historia europea anterior ás datas que arrodean o ano 1750, o estudo dos relatos sobrenaturais que reflectían a existencia de antigos sistemas pagáns de crenzas dedicouse en exclusiva á antigüidade grecorromana: a narración do nacemento de Atenea, as fazañas de Hércules, a case invulnerabilidade de Aquiles. Ás lendas sobrenaturais procedentes do sistema de crenzas xudeocristián (a torre de Babel, a arca de Noé ou o milagre lingüístico de Pentecoste) non se lles daba a denominación de «mitos», denotadora de escepticismo en demasía; dun xeito semellante, os relatos marabillosos relativos aos santos cristiáns tamén recibían o nome de «lendas», e non mitos. Por outra banda, os sistemas de crenzas que se atopaban no resto do mundo, fóra de Europa, víanse como mera superstición, rara vez dignos da denominación, tirada dos clásicos, de mito, mentres que os antigos sistemas de crenzas pagás da Europa non clásica se coñecían daquela só dunha maneira moi superficial, a través dos relatos de autores da antigüidade ou das crónicas medievais. Só o sistema pagán das vellas ci-

${ }^{1}$ Detienne, Marcel (1981): L'Invention de la mythologie, París, Gallimard. 
vilizacións orientais (a exipcia en primeiro lugar) se clasificaba como «mitoloxía» canda o panteón clásico xa existente.

Así, pois, cando os autores anteriores a 1750 trataban os mitos, era sempre en referencia ao mundo grecorromano e a miúdo recorrendo a esquemas interpretativos e analíticos xa cońecidos na antigüidade (por exemplo, Evémero, do século IV a. C., de quen se deriva a noción de «evemerismo», a idea de que os mitos son lembranzas de importantes acontecementos reais que pouco a pouco se traducen, por se narraren e se volveren narrar, na existencia dun axente sobrenatural). Ao longo de finais do século XVII e do XVIII fóronse cońecendo mitoloxías alternativas procedentes do Oriente antigo e do contemporáneo, e xa con Giambatista Vico (Scienza Nuova, 1724) se tiña a noción de que cada civilización se expresaba, na orixe bigbangiana da súa autoexpresión unha vez chegada ao escenario da historia mundial, creando unha lingua, un sistema xurídico, unha poesía heroica, unha cosmogonía e un sistema de crenzas de seu. Alcanzado o decenio de 1780, o estudoso clásico C. G. Heyne xa transitaba cara a unha perspectiva filolóxica dos estudos mitolóxicos e ao establecemento dunha distinción comparativa entre as distintas mitoloxías.

Eran duplas as mitoloxías que comezaran a chamar a atención dos estudosos de finais do século xVIII. Para empezar, os arqueólogos e anticuarios italianos empezaron a sospeitar da existencia dun substrato pagán que xiraba arredor da cuestión da fertilidade e que subxacía aos mitos clásicos do mundo antigo, presentimento nado dos achados arqueolóxicos de símbolos fálicos nas escavacións de Pompeia e Herculano e do crecente interese ilustrado polos aspectos non clásicos da antigüidade mediterránea: os misterios gregos, o culto a Mitra, a civilización dos etruscos e os fenicios/cartaxineses. $\mathrm{O}$ anterior vińa solaparse cun interese polo exipcio que databa da época de Athanasius Kircher e cos partes traídos da India e de Persia que se referían ás prácticas relixiosas daqueles lugares, como a veneración do linga; o seu estudo adoitaba ser anecdótico (e discreto, dada a súa índole obscena), non sistemático, e quedaba, así, como competencia atribuída a anticuarios especulativos que a miúdo tiñan proclividades masónicas. Se ben logo quedou varrido por un interese máis comparativo-analítico centrado, sobre todo, nos estudos mitolóxicos de Europa que ían ligados á nova disciplina científica da filoloxía comparada, mantivo, con todo, unha existencia semiclandestina que en ocasións se enxergaba en publicacións non académicas, para acabar saíndo á superficie, dunha maneira máis notable, no Mutterrecht de Bachofen (1861), a Primitive Culture de Tylor (1873), o 
Totem und Tabu de Freud (1913), na obra de Frazer e os ritualistas de Cambridge e no período previo ao pensamento New Age do século xx.

En segundo lugar — e este será o aspecto no que nos centraremos neste artigo-, existía unha tradición máis filolóxica cuxa aparición, no decenio de 1760, veu dada por un interese nos relatos sobrenaturais e os sistemas de crenzas nórdico-xermanos. Sobre esta mitoloxía — pois isto é o que era- había documentación de doado acceso: o Prose Edda de Snorri Sturlesson fora publicado en Estocolmo no ano 1765 e o seu Heimskringla en 1697, e foilles presentado aos lectores europeos por Paul-Henri Mallet, pintor e estudoso amador nado en Xenebra que, logo de ser nomeado en Copenhague catedrático de Belles Lettres en 1752, se familiarizou alí cos aspectos da antigüidade nórdica. Na súa obra L'Histoire du Danemarch (1755) tratou, entre outras cuestións, a relixión, usos, leis e costumes dos «daneses antigos», ao que lle seguiu, en 1756, un interese polo que el mesmo denominou «mitoloxía»: Monuments de la mythologie et de la poesie des Celtes, et particulierement des anciens Scandinaves.

É digna de mención a confluencia — ou, máis ben, ausencia de diferenciación- de celtas e escandinavos; naquela altura, os anticuarios xulgaban que todas as sociedades da Europa setentrional se derivaban dos «escitas» que mencionaban, sen distinción, os autores clásicos, e esta visión indiferenciada contribuíu a preparar o escenario no que se chegaría ao esplendor ossiánico de Macpherson, en 1760, e ficaría activa ata o cambio de século. A obra de Mallet apareceu nunha adaptación en inglés efectuada por Thomas Percy (o mesmo home de Reliques of Ancient English Poetry) baixo o título de Northern Antiquities (1770); neste sentido, os lectores de lingua inglesa xa estaban preparados para unha idade heroica nórdica grazas ás Enquiries into the Life and Writings of Homer de Thomas Blackwell (1735), que seguía moi de preto a Vico e elaborou unha liña de pensamento parecida, para chegar á noción de que a antigüidade clásica non era simplemente a orixe universal de toda urbanidade, senón, máis ben, unha civilización antiga entre moitas ${ }^{2}$.

Chegado o decenio de 1760, Europa xa estaba preparada para unha alternativa «nórdica» á tradición clásica mediterránea. Así, no mundo de fala alemá, o anticuario literario Bodmer, de orixe suíza, que no decenio de 1750 instigara

${ }^{2}$ Parker, Joanne (ed.) (2015): The Harp and the Constitution: Myths of Celtic and Gothic Origin, Leiden, Brill. 
a redescuberta do ms de Os nibelungos, vertera o fragmento de «A vinganza de Chriemhild» en hexámetros homéricos, presentando os lais épicos de Siegfried como unha «Ilíada xermana», expresión que pronto achou un grande eco e foi recollida mesmo por Carlyle. O mesmo Ossian de Macpherson logo chegou a ser coñecido como o «Homero do norte», oposición que conservou os seus adeptos incluso tras a caída en desgraza de Macpherson. Madame de Staël, na súa obra La littérature considerée dans ses rapports avec les institutions sociales (1800), entendía que a literatura europea se compuña de dúas metades: a do sur, derivada de Homero, e a do norte, a dos bardos, derivada de Ossian —ou, poderiamos engadir, á falla de Ossian algún outro motivo principal «celtoescandinavo», fose o Nibelungenlied ou a Edda-. A Edda vella ou "poética», cos seus relatos pagáns da creación e da ruína final do mundo, coñeceu a súa primeira edición en 1787; para daquela a intelectualidade xa estaba máis ca preparada para ver a Edda como depósito do que Mallet xa chamara «Mythologie» en 1756. No ano 1806, Per Rasmus Nyerup publicou o seu Edda eller Skandinavernes hedenske Gudelere («Edda, ou o sistema de crenzas pagás dos escandinavos») e N. S. F. Grundtvig deulle continuación, en 1908, con Nordens Mytologi, eller Udsigt over Eddalaren for dannede Mand, som ei selv ere Mytologer ( A A mitoloxía do norte, ou estudo das tradicións da Edda para eruditos que non son persoalmente mitólogos»).

O gran florecer da mitoloxía xermánica, como homóloga do repertorio clásico, empezou desde aquí e foi acollido por nada máis e nada menos ca o ancián Herder en Zutritt der nordischen Mythologie zur neueren Dichtkunst (1803), movemento en gran medida impulsado por unha rivalidade xermano-danesa que cristalizou arredor das figuras análogas dos aniquiladores de dragóns, nórdico e xermano, Sigurð e Siegfried. Todo este traballo culminou no grandioso compendio de Jacob Grimm Deutsche Mythologie, de 1835. O panteón e a cosmoloxía de Thor, Odín, Balder, as valquirias, o Valhalla e o Ragnarök ou Götterdämmerung forneceron un repertorio artístico ao que os compositores de ópera, pintores e escritores do século seguinte, de Wagner a William Morris, recorreron con entusiasmo ${ }^{3}$.

${ }^{3}$ O'Donoghue, Heather (2007): From Asgard to Valhalla: The Remarkable History of the Norse Myths, Londres/Nova York, I.B. Tauris; Roesdahl, Else / Preben Meulengracht Sørensen (eds.) (1996): The Waking of Angantyr: The Scandinavian Past in European Culture / Den nordiske fortid i europeisk kultur, Aarhus, Aarhus University Press; Wawn, Andrew (2005): «The Post-medieval Reception of Old Norse and Old Icelandic Literature», en Rory McTurk (ed.), A Companion to Old Norse-Icelandic Literature and Culture, Oxford, Blackwell, 320-337. 
Este esbozo, superficial e xa coñecido, dos comezos da mitoloxía xermánica serve tamén para ilustrar ata que punto o desenvolvemento dos estudos mitolóxicos seguía de preto os pasos da nacente disciplina académica da lingüística comparada e chegou a ir ligado á filoloxía. Ossian e os celtas foron sacados da mitoloxía do norte en gran medida a causa dunha taxonomía lingüística nova: así, os modelos «escitas», que permitían a existencia dun complexo conxunto celto-escandinavo, foron desprazados por un paradigma de nova aparición, o indoeuropeo, de base sánscrita, no cal o celta e o xermánico eran radicalmente independentes. En efecto, Friedrich Schlegel, na súa pioneira obra sobre o sánscrito e os idiomas europeos (Über die Sprache und Weisheit der Inder, 1808), seguía a ter dúbidas sobre se as linguas celtas formaban parte sequera da familia indoeuropea, familiaridade que non foi restablecida (con fundamentos da lingüística comparada, non "escitas») ata o decenio de 1820 por parte de Adolphe Pictet e Fraz Bopp ${ }^{4}$.

Alén da elaboración lingüística das relacións indoeuropeas, estaban ademais as consecuencias formativas do novo apoxeo da erudición textual ${ }^{5}$. Así, a edición de vellas épicas e manuscritos foi o que impulsou a descuberta do panteón xermánico: Wodan abriuse camiño na imaxinación cultural europea montado no carro de Sifgried e Chriemhilde e, como xa indica o nome de Jacob Grimm, a «filoloxía» que deixou a súa pegada coa edición dunha cornucopia, de recente achado, de antigos manuscritos vernáculos ía tamén firmemente entrelazada co estudo da literatura oral. É ben sabido que Grimm entendía os seus contos de fadas non como mero pasatempo sentimental ou pedagóxico de carácter informal para nenos, senón, para alén diso, como vestixios envilecidos das sagas e, precisamente, os mitos da antigüidade. Así, os seres sobrenaturais, como, en concreto, os ananos e os elfos, el víaos como elementos transmitidos desde os tempos pagáns e reflexo de crenzas precristiás; mesmo a sátira animal medieval do raposo Reynard era, ao seu ver, a reliquia dun relato totémico franco ou mesmo indoeuropeo pertencente a un xénero de «sagas bestiáricas» primixenias.

${ }^{4}$ Leerssen, Joep (1996): «Celticism», en Terence Brown (ed.), Celticism, Amsterdam, Rodopi, 1-20; Leerssen, Joep (2012): «The Rise of Philology: The Comparative Method, the Historicist Turn and the Surreptitious Influence of Giambattista Vico», en Rens Bod / Jaap Maat / Thijs Weststeijn (eds.), The Making of the Humanities, 2: From Early Modern to Modern Disciplines, Amsterdam, Amsterdam University Press, 23-35.

${ }^{5}$ Van Hulle Dirk / Joep Leerssen (eds.) (2008): Editing the Nation's Memory: Textual Scholarship and Nation-Building in 19th-Century Europe, Amsterdam, Rodopi. 
Grimm é famoso por introducir na lingüística a perspectiva reconstrutivo-historicista, retrocedendo no seu traballo desde as variantes da documentación de datas posteriores ata os tipos primarios de raíz, cousa que fixo en varios planos: no lexicográfico e no etimolóxico, reconstruíndo formas de palabras antigas a partir das súas variantes posteriores; no textual, extrapolando un Urtext ou modelo textual putativo mediante un contraste cos seus manuscritos variantes máis serodios, e a través de relatos e narracións, destilando un Stoff ou matière a partir de novas versións producidas con posterioridade a aquel. No seu Geschichte der deutschen Sprache mesmo aplicou este método aos etnónimos e ás tribos dos pobos xermánicos. E no dito método á capa fundamental, a verdadeiramente primixenia, chegábase moi a miúdo, segundo el o entendía, no plano do culto ou o mitolóxico. Palabras, historias, textos, épicas: todos son as secuelas dos nosos días das experiencias primarias colectivas da raza nuns heroicos tempos $U r$, cuxa plasmación máis fiel se acha nas súas crenzas e mitos ${ }^{6}$.

Esa consideración, vindo como viña de alguén recoñecido como o maior filólogo do século XIX, inspirou a realización por toda Europa de estudos mitolóxicos nos que se recorría a antigas epopeas ou relatos heroicos, restos arqueolóxicos, padróns léxicos etimoloxicamente suxeridores ou costumes tradicionais e contos de fadas interpretados cun sentido antropolóxico. As mitoloxías nórdicas que seguiron no ronsel de Grimm, unhas máis extravagantes ca outras, forman un gran fardel que envolve ambas as beiras do Atlántico norte (da Coruña a Nova Inglaterra) ata as chairas de Rusia, Carelia e Bulgaria ${ }^{7}$.

O auxe da mitoloxía nórdica deulle a Europa un modelo mitolóxico no que, antes de máis, se xustapuñan o mito clásico e o nórdico-xermánico (Zeus/Xúpiter e Hera/Vesta fronte a Thor/Wodan/Odín e Freya etc.). Un aspecto crucial radica en que o depósito narrativo-temático de mitos desta índole gardaba unha forte correlación coas familias lingüísticas, neste caso as románicas (que incorporaban os deuses da antiga Grecia) fronte ás xermánicas (nas cales se unían o alemán e os idiomas escandinavos). Este correlato filolóxico entre mitoloxía e familias lingüísticas baséase na suposición de que os sistemas de crenzas pagás reflicten o estadio máis antigo de etnoxénese, no cal as consideracións relixiosas e un vocabulario fundamental cristalizan mesmo antes de a tribo primixenia se

\footnotetext{
${ }^{6}$ Kellner, Beate (1994): Grimms Mythen: Studien zum Mythosbegriff und seiner Anwendung in Jacob Grimms Deutscher Mythologie, Frankfurt, Lang.

${ }^{7} \mathrm{Na}$ actualidade estase a levar a cabo unha análise comparativa deste fenómeno no marco da Encyclopedia of Romantic Nationalism in Europe, http://romanticnationalism.net.
} 
fragmentar en grupos lingüísticos independentes ${ }^{8}$. E con isto automaticamente xorde a pregunta de se as outras familias lingüísticas de Europa —eslavas, celtas e demais - non deberían ter, seguindo a mesma lóxica, mitoloxías de seu propias do seu xenoma lingüístico; deste xeito, a elaboración dunha mitoloxía nórdico-xermánica converteuse nun reto pendente para os estudosos eslavos e as linguas non alińadas de Europa (finés, idiomas bálticos, húngaro, vasco). No continente europeo decimonónico creáronse dúas, tres, moitas mitoloxías, e, efectivamente, parece coma se calquera autoposicionamento nacional que tivese lugar no marco do proceso de toma de conciencia nacional dese século, como foron os casos vasco, letón e albanés, comportase por necesidade unha referencia á mitoloxía antiga da nación ${ }^{9}$.

Resulta moi intrigante que isto sexa así. Parecería que a mitoloxía constituíse o substrato máis fondamente arraigado da cultura e a imaxinación dos grupos lingüísticos, substrato este que se consideraría encerrado no celme da identidade fundamental das familias étnicas de Europa. Este esencialismo mitolóxico ao estilo Grimm tórnase en obxecto de mofa, mais non de contradición, cando un se decata de que, en moitos casos, as mitoloxías eran elaboracións falsas: o mito vasco espurio de Aitor, a falsificación búlgara dun "Veda eslavo» ${ }^{10}$. A existencia de diñeiro falso evidencia o valor real que se lles confire aos cartos, mais que as mitoloxías poidan facerse, digamos, virais e avanzar polo mapa de Europa no curso dun proceso de inspiración, adopción e imitación competitiva presenta problemas máis substantivos e lémbranos que aquelas, ao tempo que aparentan ser entes antropolóxicos fixos, arquetipos dunha relixión arcaica, tamén participan de pleno na dinámica da historia intelectual e literaria decimonónica. Así, mentres

${ }^{8}$ Co estudo mitolóxico das culturas primitivas esta noción ampliaríase ata abranguer grupos enteiros de familias lingüísticas, como o clúster indoeuropeo; é así, por exemplo, na obra de Max Müller e Georges Dumézil. Contra esta esquematización filolóxica outros postularían unha colectividade non lingüística de sociedades primitivas ou prehistóricas, como é o caso de Tylor e Frazer; a arqueoloxía especulativa de Marija Gimbautas constitúe unha transición entre ambas. Neste contexto non imos darlles máis continuidade a tales perspectivas.

${ }^{9}$ Así, o breve tratado formativo albanés de Sami Frashëri What Was, What Is Albania, and What Will It Become? (1899) encomia nas súas páxinas iniciais a nobre mitoloxía dos antigos albaneses. O texto (en versión alemá) está dispoñible en lińa en http://www.spinnet.eu/images/2015-08/frasheri1913.pdf.

${ }^{10}$ Juaristi, Jon (2000): El linaje de Aitor, Madrid, Taurus; Marinov, Tchavdar (2015): «Ancient Thrace in the Modern Imagination: Ideological Aspects of the Construction of Thracian Studies in Southeast Europe (Romania, Greece, Bulgaria)", en Roumen Daskalov / Tchavdar Marinov (eds.), Entangled Histories of the Balkans III: Shared Pasts, Disputed Legacies, Leiden, Brill, 10-117. 
Europa se dedicaba a crear culturalmente as súas variadas identidades nacionais no marco do que noutro lugar denominei "cultivo da cultura» ${ }^{11}$, creou ademais as mitoloxías que, segundo se cría, durmían nas raiceiras da nación. A construción nacional romántica vén, pois, cun espello retrovisor mitolóxico de fábrica.

Para desenvolver máis plenamente esta noción, quixera abordar, en concreto, unha das lińas da ramificación proliferativa da mitoloxía: o nacemento dunha «mitoloxía celta» e a súa aplicación a Galicia, situada no noroeste de España.

\section{A RECONFIGURACIÓN DA MITOLOXÍA CELTA}

A elaboración dunha filoloxía/mitoloxía xermánica e a desaparición do paradigma anticuario escito-celta ou celto-escandinavo do século XVIII fixeron encallar o estudo filolóxico das linguas celtas. A única apreciación temperá que sobreviviu á mudanza do paradigma indoeuropeo foi o feito de que os idiomas gaélicos (escocés, irlandés, manés) e británicos (galés, córnico) estaban, efectivamente, relacionados entre si baixo a denominación de «celtas» e que esta categoría celta tamén abranguía os idiomas da Galia prerromana. (Sobre a condición que tiña o bretón neste complexo persistiron algúns malentendidos: os anticuarios anteriores a 1800 consideraran que este era unha reliquia lingüística do galo antigo e non foi ata datas posteriores cando se aceptou, de maneira xeneralizada, que o bretón é, de feito, un abrocho do galés.)

Todos os demais saberes referidos aos celtas e o seu pasado que databan de antes de 1800 quedaron desacreditados pola chegada do novo paradigma filolóxico histórico-comparativo. Nese recente clima crítico xerado pola filoloxía comparada, os anticuarios do XviII que se dedicaban ás linguas celtas foron desdeñados por «celtómanos» ${ }^{12}$, desdén que ten algún fundamento, pois estas teorías a miúdo foran elaboradas por medio de especulacións disparatadas nas que se comparaba o gaélico co fenicio, o etrusco ou calquera outra lingua que se tivese á man. Alén diso, estaba a vergoña de que os escépticos deixasen a Macpherson ao descuberto e que el fose incapaz de achegar os orixinais gaélicos das súas «traducións» os-

${ }^{11}$ Leerssen, Joep (2006): Nationalism and the Cultivation of Culture», Nations and Nationalism, 12:4, 559-578.

12 Droixhe, Daniel (1978): La Linguistique et l'appel de l'histoire (1600-1800) : rationalisme et révolutions positivistes, Xenebra, Droz. 
siánicas ao inglés. E, por último, malia a súa índole patentemente lendaria, os mitos gaélico-irlandeses documentados que tiñan existencia foran presentados, nos tempos modernos, como narracións historicamente obxectivas do pasado gaélico e foron obxecto de denuncia por parte dos estudosos racionalistas, que os vían como exemplos da extravagante e escasa fiabilidade de calquera cousa que se quixese celta.

O corpus en cuestión derivábase de pseudohistorias medievais e de lendas orixinarias ${ }^{13}$ que se referían aos entregos da raza gaélica, descendentes de Xafé, fillo de Noé, e ás súas andanzas polo Mediterráneo, avanzando, logo de entraren pola costa atlántica española, cara á toma e colonización de Irlanda baixo o mando do seu líder, Míl (de onde resulta que os irlandeses gaélicos fosen cońecidos como «milesianos»). Ademais mencionábanse outras razas que nalgún momento habitaran Irlanda: tribos para cuxo nome non hai explicación, como Tuatha Dé Danaan, Fir Bolg, os fomorianos e demais, aos cales adoitaban atribuírselles calidades monstruosas ou sobrenaturais. Estes relatos medievo-lendarios da «toma de Irlanda» foron vencellados ás narracións heroicas literarias (románticas ou épicas) referidas a personaxes como Fionn Mac Cumhaill e Cú Chulainn, nunha mestura de lenda pseudohistórica e ficción romántico-heroica cuxos únicos elementos obxectivos son as insistentes referencias a puntos xeográficos reais aínda recoñecibles na paisaxe irlandesa.

O sacerdote do século XviI Geoffrey Keating recompilara arredor de 1635 este material lendario tirado da tradición manuscrita; o seu libro foi impreso e publicado, e en tradución inglesa, un século despois (en 1723) como reivindicación da demanda de historicidade e civismo da Irlanda gaélica. A publicación chegou en moi mal momento, dado que para o decenio de 1720 a escrita da historia estaba a se afastar dos vellos relatos lendarios, aprendía a nova arte da crítica das fontes e estaba orgullosa da súa actitude crítica e «filosófica»; e, así, as narracións de Keating foron obxecto de risas: non podían tomarse en serio e ser aceptadas como históricas, e aínda pasaría outro século antes de que puidesen tomarse en serio como mitos.

Non foi ata que as linguas celtas se resituaron na nova árbore familiar indoeuropea — proceso que arrincou no decenio de 1820 e estivo marcado polos estudos

${ }_{13}$ Leerssen, Joep (1996): Mere Irish and Fior-Ghael: Studies in the Idea of Irish Nationality, Its Development and Literary Expression Prior to the Nineteenth Century, Cork, Cork University Press. 
lingüístico-comparativos de Adolphe Pictet, Franz Bopp e Johann Caspar Zeußcando o mito céltico foi sacado do seu enredo ossiánico. No período que transcorreu entre 1800 e 1850, a idea do celta ía ligada esencialmente ás novelas cabaleirescas medievais: figuras como Tristán e Isolda, a cidade bretoa somerxida de Ys e, sobre todo, a matière de Bretagne, centrada no rei Artur. Os estudosos galeses destacaron ese material romántico-cabaleiresco por constituír a principal reivindicación, por parte de Gales, da asunción de protagonismo na base civilizatoria europea, e, así, o crego e erudito Thomas Price argüíu que Gales, por se ter librado dos espolios viquingos, era o santuario desde o cal se difundira novamente a literatura cabaleiresca, a partir de 1200, pola Inglaterra suxeita ao dominio normando e por Francia ${ }^{14}$. Cando lady Charlotte Guest traduciu o Mabonogion (1838), presentouno como un libro de narracións de cabaleiros medievais; só Théodore de la Villemarqué, bretón xactancioso e falto de sentido crítico que plaxiou a obra de Guest nos seus propios Poèmes des bardes bretons du Vle siècle (1850), tentou outorgarlles aos textos unha procedencia máis antiga e mítica, que el denominou bárdica e druídica — co cal se facía eco das últimas vetas que aínda persistían daquela celtomanía á vella usanza, que atopara unha potente voz galesa en Iolo Morganwg, mistificador de mala reputación (1747-1826)— ${ }^{15}$. Para cando La Villemarqué se apropiou do Mabinogion, os filólogos comparativos comezaran a incluír, máis unha vez, a materia celta no seu ámbito de estudo: así, La Villemarqué mantivo correspondencia con Jacob Grimm, e Grimm naquela altura estaba a tratar determinados aspectos recónditos do celta galo con Johann Caspar Zeuß, autor da Grammatica Celtica, de índole filolóxico-comparativa, coa que en 1854 quedou fixada definitivamente a posición taxonómica das linguas celtas no seo da familia indoeuropea ${ }^{16}$.

\footnotetext{
${ }^{14}$ É así nos seus ensaios «sobre a influencia que exerceu a tradición galesa na literatura de Europa»e «sobre os méritos comparados da literatura antiga nos idiomas galés, irlandés e gaélico e o seu valor na elucidación da historia antiga e o cultivo mental dos habitantes da Bretaña, Irlanda e a Galia» (1845), ambos en Williams, Jane (ed.) (1845): The Literary Remains of the Rev. Thomas Price, Carnhuanawc, 2 vols., Llandovery, William Rees, 2, 233 -303; 113-232. 233-303: «An essay», ensaio remitido a concurso no Abergavenny Eisteddfod de 1838 baixo o pseudónimo de Agnach ab Mydno. O xuíz foi Hallam, que lle concedeu o galardón a outro concursante, un tal J. D. Hardinge, mais Bunsen e varios máis valoraron en gran medida a obra de Price; noutros escritos menciónase como gañador a A. Schulz (San-Marte), apadriñado por Bunsen.

${ }^{15}$ Constantine, Mary-Ann (2007): The Truth against the World: Iolo Morganwg and Romantic Forgery, Cardiff, University of Wales Press.

${ }^{16}$ Lauer, Bernhard / Bärbel Plötner / Donatien Laurent (1991): «Jacob Grimm und Th. Hersart de La Villemarqué: ein Briefwechsel aus der Frühzeit der modernen Keltologie», Jahrbuch der Brüder Grimm-Gesellschaft, 1, 17-83.
} 
Arredor desta época, outro correspondente de Grimm era John O’Donovan (1806-1861), autor dunha gramática do irlandés (1845) e editor de varios textos en gaélico antigo. O’Donovan gozaba dun prestixio académico impecable, mesmo no eido dos novos saberes filolóxicos: falante nativo de gaélico, foi contratado por institucións como a Real Academia Irlandesa para realizar labores de arquivo e inventario e axudou na preparación de edicións de textos xurídicos nativos en gaélico; destaca, así mesmo, o feito de que fose nomeado membro correspondente da Academia Prusiana polo propio Grimm. En suma, a carreira profesional de O’Donovan marca a reintegración dos coñecementos sobre o irlandés, no decenio de 1850, no eido dos novos saberes expertos da filoloxía comparada. Dentro de Irlanda, o período previo a este proceso estivo caracterizado por outros tres concorrentes: a) un inventario inicial de fontes da documentación textual e manuscritos existentes da literatura gaélica (O’Conor [1814]: Rerum Hibernicarum Scriptores Veteres; O’Reilly [1820]: «Chronological account of Irish writers», 1820); b) uns primeiros intentos de editar material antigo épico-heroico (empezando coa tráxica historia da doncela Deirdre, ed./trans. de Th. O'Flanagan, 1808), e c) unha longa e agre disputa arqueolóxica entre os vellos celtómanos e as novas xeracións de académicos que atopaban a súa inspiración na filoloxía; este debate, centrado sobre as efixies coñecidas como "torres redondas», concluíu finalmente a favor dos modernistas arredor de $1840^{17}$.

Entre a agonizante raza de celtómanos hai un nome que merece ser destacado aquí (por razóns que resultarán obvias máis adiante) e que é o de Joaquín Villanueva, crego liberal exiliado da Espańa da Restauración e que en Dublín avalou a teoría de que Irlanda fora poboada polos fenicios chegados a través dunha ruta marítima atlántica (Ibernia Phoenicia, 1831). Non é motivo de sorpresa, xa que logo, que as «torres redondas» irlandesas se asemellen a pagodes orientais... De entre este bando moderno, un nome que procede citar aquí é, alén de John O'Donovan, o de Thomas Crofton Croker, quen ficou profundamente impresionado cos contos de fadas de Grimm e compilou del os irlandeses e as supersticións relativas tamén ás fadas; estes, pola súa vez, foron aproveitados con entusiasmo polos Grimm, que os traduciron como Irische Elfenmärchen (1826). Nesa altura os relatos do sobrenatural estábanse a investigar como folclore, con

${ }^{17}$ Leerssen, Joep (1996): Remembrance and Imagination: Patterns in the Literary and Historical Representation of Ireland in the Nineteenth Century, Cork, Cork University Press. 
historias campesiñas sobre leprechauns, pookas e banshees, moi na liña, de feito, do que facían os Grimm cos seus elfos e ananos xermánicos. De certo, Crifton Croker xulgaba que estes contos eran supersticións vulgares apropiadas só para entreter e divertir o lector instruído, e a idea, moi do estilo Grimm, de que tales historias puidesen ser lánguidos fragmentos dun antigo sistema de crenzas pagás non influía nos estudosos irlandeses senón lentamente. Mesmo así, no transcurso do século os contos populares sobre «homiños» e fadas fóronse afastando do rexistro rústico-anecdótico de Croker para se achegaren a algo máis serio e desconcertante: os elfos gaélicos, os sidhe, púñanse cada vez máis en correlación coas referencias lendarias, máis antigas, aos habitantes pregaélicos de Irlanda, os Tuatha Dé Damaan, aos cales se lles atribuían poderes sobrenaturais e que se cría que marcharan ao mundo subterráneo unha vez que Irlanda foi colonizada pola poboación gaélica —os chamados «milesianos», así chamados polo entrego que os trouxera desde España cruzando o mar Cantábrico, Míl.

Deste xeito, o estudo dos contos tradicionais ${ }^{18}$ volveu concederlles importancia ás lendas medievais compiladas douscentos anos antes por Geoffrey Keating e que foran obxecto de risas había un século. Está claro que non había texto ningún que documentase de verdade a existencia dun sistema de crenzas ou dun panteón pagán de índole celta e precristiá plenamente desenvolvidos que fosen comparables aos nórdico-xermánicos, e mesmo así o material lendario que figuraba á marxe da pseudohistoria de Keating e que circulaba no folclore oral deu en ser considerado como tal. A idea dunha Terra dos Novos mítica e inmorredeira situada no distante Occidente (Tír na nÓg); historias de elfos, dos fomorianos e dos Fir Bolgs; o druída dos Tuatha Dé Danaan chamado Mananann mac Lír; a Morrígan de estilo valquirio, espírito feminino da morte na batalla: no transcurso do século, tales temas e tropos foron reunidos no que podería pasar por mitoloxía irlandesa e, por extensión, celta. Foi este un proceso en que a filoloxía textual, os estudos do folclore e a literatura poética foron da man: as

\footnotetext{
${ }^{18}$ En efecto, nun gran número de estudos mitolóxicos e anticuarios realizados no clima do nacionalismo romántico seguiuse un método de inspiración grimmesca consistente en recompilar literatura oral e tratar estas baladas ou contos como fragmentos a partir dos cales se podía reconstruír unha mitoloxía ou epopea antiga. Sobre a extrapolación das mitoloxías tiradas da literatura oral existen exemplos fornecidos polos casos de Finlandia (o Kalevala de Lönnrot), Letonia (Wilhelm Mannhardt) e Polonia-Lituania (Teodor Narbutt, Simonas Daukantas); sobre a extrapolación das epopeas antigas tiradas da poesía oral contemporánea, véxase Leerssen, Joep (2012): «Oral Epic: The Nation Finds a Voice», en Timothy Baycroft / David Hopkin (eds.), Folklore and Nationalism during the Long Nineteenth Century, Leiden, Brill, 11-26.
} 
referencias sobrenaturais dos relatos heroicos de Fionn mac Cumhaill e Cú Chulainn alináronse coas supersticións recibidas das recitacións orais e foron harmonizadas por distintos escritores creativos que fixeron delas un plan narrativo coherente, proceso que rematou a finais do século xIx e que achou unha influente expresión na obra literaria de Standish O'Grady e W. B. Yeats, e máis notablemente en dous volumes sintéticos de lady Gregory, Gods and Fighting Men (1904) e Cuchulain of Muirthemne (1902). As repercusións que tivo naquela nacente escola irlandesa nacional de literatura foron enormes: para W. B. Yeats, a continuidade que ía desde o relato heroico aristocrático pagán á humilde superstición campesińa constituía a xa prolongada negativa de Irlanda a se someter nin ao moralismo cristián nin ao pragmatismo británico e, en tanto que tal, o sobrenatural celta achegoulle a Yeats unha idea nacional para o seu propio programa literario. As figuras lendarias e os seres sobrenaturais (Deirdre, Lír, Medb, a Morrigan) convertéronse no repertorio do que, xurdido arredor do ano 1890, sería coñecido como «Rexurdimento literario irlandés», e mesmo aqueles que non se vían capaces de aprender o gaélico, idioma que ía en declive cara ao seu pasamento, podían aceptar o marco cultural de referencia constituído por nomes derivados de mitos, como Deirdre, Maeve, Diarmuid, Fionn e Aoife.

Nesa altura, a filoloxía celta consolidárase tamén nas institucións académicas; así, en Francia, no ano 1870, déuselle comezo á Revue Celtique, orientada ao folclore; en Alemaña fundouse en 1896 un Zeitschrift für celtische Philologie; en Oxford creouse en 1869 unha cátedra de celta e en París, en 1883, o Collège de France instaurara outra para Henri d'Arbois de Jubainville, filólogo formado na austera École des Chartes e que desde esa cátedra publicaría un Course de littérature celtique en varios volumes; o primeiro deles, Introduction à l'étude de la littérature celtique, apareceu en 1883, mentres que o segundo foi precisamente de índole mitolóxica: Le cycle mythologique irlandais et la mythologie celtique (1884).

\section{VICETTO, MURGUÍA E O PASADO CELTA DE GALICIA}

Que os celtas tamén se estableceran na Iberia prerromana e romana era un feito cońecido desde os autores clásicos. No entanto, e no seu conxunto, a cultura da Península Ibérica (agás no caso das Vascongadas) era rotundamente romance en lingua e tradición; se había algunha conciencia dun substrato cultural prerroma- 
no, entendíase que era ben mourisco (no sur) ou visigodo ${ }^{19}$. A medida que as periferias do reino español cobraban esa conciencia propia, rexional, nacional ou ambas, no transcurso do século XIX, observamos distintos intentos de rastrexar a liñaxe cultural das comunidades de cultura, remontándose ata fontes que non fosen aquelas raiceiras consolidadas e canonizadas no plano estatal. Así, en Cataluña eran simbolicamente importantes a presenza de vínculos mercantís cos gregos e a cidade en ruínas de Numancia, e os vascos tiñan, como é notorio, un fortísimo particularismo de seu referido ao mito ancestral inventado de Aitor $^{20}$; os galegos, pola súa banda ${ }^{21}$, aceptaron o complexo mitolóxico celta.

Tanto José Verea (Historia de Galicia, 1838) como Benito Vicetto (Historia de Galicia, 1865-1873) fixeran fincapé nas raíces celtas de Galicia, mais o seu argumento fora máis anticuario e arqueolóxico ca mitolóxico, por descansar enteiramente no obsoleto paradigma dos anticuarios do século XVIII. Nos seus escritos non hai referencia ningunha aos saberes filolóxicos contemporáneos nin ao significado, agora recalibrado, que se lle atribuía ao etnónimo «celta» no novo paradigma indoeuropeo; o único estudoso contemporáneo que menciona Vicetto nun lugar destacado é Joaquín Villanueva ${ }^{22}$, o citado autor catalán, radicado en Irlanda, de Ibernia Phonicia (1831). Como se indicou antes, nas terras irlandesas Villanueva pasara a formar parte da retagarda da desfasada visión "celtómana» da antigüidade gaélica e tomara nota dalgunhas lendas pseudohistóricas daqueles lugares, mais, na liña das teorías celtómanas do século XVIII, encaixáraas nunha narrativa bíblico-mediterránea de ascendencia e migración a través de Cartago. Vicetto — coma Verea antes del_ segue esta perspectiva, que para 1865 se tornara de todo obsoleta en calquera outro ámbito, e, en consecuencia, refírese á torre de Hércules da Coruña como unha edificación fenicia e non romana:

El faro de Hércules fué fundacion fenicia, no romana: los fenicios construyeron los mas celebres de la antigüedad; los romanos, ni uno. [E na nota a rodapé que acompaña o texto:]

${ }^{19}$ Sobre o historicismo español: Alvárez Junco, José (2001): Mater dolorosa: la idea de España en el siglo XIX, Madrid, Taurus.

${ }^{20}$ Jimeno Martínez, Alfredo / José Ignacio de la Torre Echávarri (2005): Numancia: símbolo e historia, Madrid, Akal; Juaristi, op. cit.

${ }^{21}$ A obra de referencia é Máiz, Ramón (1984): O nacionalismo galego: organización e ideoloxía (1897-1904), Sada (A Coruña), Ediciós do Castro.

${ }^{22}$ Vicetto, Benito (1865): Historia de Galicia, Ferrol, Taxonera, 1:140, n.; 170 e ss. 
La Torre de Hércules es un edificio notable por su antigüedad y que sí, como seguran algunos, existia antes que los romanos se apoderasen de Espańa, debemos considerarla obra de los fenicios ó cartagineses: opinion bastante bien fundada en el espíritu de comercio y navegacion de estas naciones; y que el objeto de la torre seria como hoy, servir de faro ó guia a los navegantes ${ }^{23}$.

Nun momento posterior, Vicetto cita por extenso a Villanueva nun fragmento en que este, pola súa vez, fai o propio con autoridades irlandesas na materia (Charles O'Conor e Geoffrey Keating) referíndose a que unha tribo de brigantes (que el identifica como fenicios), baixo o mando do seu rei, Breogán, se establecera na Coruña e levantara alí a famosa torre, e a usara como posición estratéxica desde a que emigrar a Irlanda para se asentar nesas terras. Vicetto, de feito, móstrase escéptico ante este relato, mais si indica que a ancestral denominación de Fenio, de orixe fenicia, segue viva en Irlanda no nome dos separatistas fenianos, e engade nunha notable nota a rodapé:

Téngase en cuenta la conspiracion hoy de los Fenians, descubierta en Inglaterra para la emancipacion de Irlanda. Igual espiritu de independencia fermenta en el corazon de los hijos de Galicia; al que su literatura da una forma hasta ahora vaga ${ }^{24}$.

Tales fragmentos indican que, na medida en que os rexionalistas galegos querían excluírse dunha narrativa española xeral e elaborarlle un pasado prerromano á rexión, lles valía calquera etnia ou período da antigüidade. $\mathrm{O}$ que pasaba por "celta» era, baixo ese nome, un grupo indiferenciado cuxa identificación se debía só a referencias aos xeógrafos clásicos ou aos cronistas medievais.

A cousa mudou moito coa figura, de importancia cardinal, de Manuel Murguía. É certo que Murguía — que se aliaba con Vicetto e estaba en débeda con el- continúa a tradición do anticuarismo amador carente de sentido crítico e, así, na súa Historia de Galicia (1865 e ss.) compendia datos illados tirados de

\footnotetext{
${ }^{23}$ Ibíd., 147 e n.

${ }^{24}$ Ibíd., 175, n. Os fenianos eran unha organización separatista militante que fora fundada no ano 1848 entre os emigrantes irlandeses nos Estados Unidos. Ao contrario do que asevera Vicetto, o nome non se tomara dunha mítica figura ancestral fenicia chamada «Fenio», senón da antigo termo gaélico correspondente a «guerreiros», Fianna. Non obstante, o aspecto máis destacable é, por suposto, que Vicetto considere que o nacionalismo separatista feniano sexa aplicable á realidade galega.
} 
obras publicadas sen sometelos a unha crítica académica das fontes; mais, ao mesmo tempo, Murguía está en sintonía cos novos avances que se producen noutras zonas de Europa. Menciona (mais cunha ortografía errada) a Felix Dahn, historiador alemán do período das migracións; sinala o valor da nova corrente de escrita da historia nacional instaurada por Augustin Thierry en Francia e rende homenaxe a Alexandre Herculano, adepto portugués da corrente francesa ${ }^{25}$.

Máis aínda, as referencias a un pasado galego "celta», vago e inespecífico — que Murguía herdara dos seus precursores - sitúanse agora, en concreto, no contexto da filoloxía celtolóxica e os estudos mitolóxicos da celtoloxía, de recente creación. Murguía fixo uso do que para daquela se convertera nun corpo académico consolidado da mitoloxía celta dentro do novo paradigma posgrimmesco; así, refírese a Pictet e, de xeito notable, á obra de D’Arbois de Jubainville, o cal torna a Historia de Galicia de Murguía nun híbrido que mestura por igual referencias á anterior tradición anticuario-especulativa (Villanueva fai parte das fontes secundarias que invoca), mais que naquela altura podía xa apoiarse tamén nos novos saberes.

O resultado é notable: Murguía si invoca as referencias que fai Keating a Breogán e ás migracións milesianas, mais non —como ocorre con Vicetto- a través do anticuarismo fenicio de Villanueva, senón de D’Arbois de Jubainville e da idea mitolóxica que este erudito tińa dos relatos milesianos da «toma de Irlanda». E logo Murguía, na súa Historia de Galicia, pode xustapor estes relatos míticos cos restos arqueolóxicos da coruñesa "torre de Hércules» e explicala no que agora constitúe un respectable marco de referencia celta.

O resultado é coñecido. A diferenza do resto de España e en común con Bretaña, Gales, Irlanda e Escocia, Galicia, co seu tempo chuvioso e a música de gaitas, chegou a verse como celta. O celtismo mitolóxico de Murguía recibiu un tratamento literario en Célticos: cuentos y leyendas de Galicia, de Ojea (1883), para o cal Murguía escribiu un prefacio, e desde entón esta fantasía etnohistórica botou raíces no marco dunha autoceltización explícita desta rexión. O nome de Breogán quedou firmemente consagrado no léxico poético galego, grazas, en particular, ao poema de Pondal Os Pinos (o celtismo deste autor estaba influído, por suposto, pola experiencia conxunta das lecturas sobre Ossian nunha tradución francesa de 1867 e, máis ou menos simultaneamente, as historias de Vicetto e

\footnotetext{
${ }^{25}$ Para sermos xustos, habería que indicar que tamén Vicetto se referira a Herculano; mais só no referido a datos históricos, non a programa historiográfico ningún.
} 
Murguía). Desde a torre de Hércules, na Coruña, obsérvase a enorme estatua de Breogán que se ergue fronte a ela; nas tendas de recordos de Santiago de Compostela, as iconas relativas á vella ruta de peregrinación vense superadas en número polos símbolos pagáns do tríscele celta, e Galicia é participante en diversos festivais panceltas ${ }^{26}$.

\section{CONCLUSIÓNS: COMA PEIXES SOLUBLES EN AUGAS NACIONAIS}

Sería case tentador de máis entender o anterior meramente como un exemplo extremo de «invención da tradición», paralelo ao culto á carga vasco de Aitor e ao "Veda eslavo» búlgaro (tal visión podería aplicarse, como moito, á mitopoiese do malogrado Os Eoas de Pondal, que, con todo, é demasiado idiosincrásico para encaixar no seu clima ambiental de celtismo galaico). Vicetto e Murguía non inventaron da nada esa ascendencia celta súa, senón que se apropiaron, para o seu propio contexto, de mitos xa consolidados. Resulta moito máis suxestivo, pois, apreciar a extrema transferibilidade desas mitoloxías, as cales, se ben en aparencia se achan filoloxicamente arraigadas na súa propia etnia, ou, arqueoloxicamente, na súa propia paisaxe, sometidas a un exame rigoroso semellan gozar dunha notable capacidade de desprazamento polo mapa europeo, un pouco coma a gruta de Lourdes, que aparece en réplica por todas as rexións católicas de Europa.

Son tal mobilidade e adaptabilidade as que requiren maior análise. Neste artigo, para alén da modalidade da invención deliberada, atopámonos con outras dúas: unha que poderiamos denominar «eco reprodutivo» e outra que poderiamos chamar «enxerto». Os ecos reprodutivos tiveron lugar cando a filoloxía e a mitoloxía xermánicas desencadearon o desenvolvemento, noutros lugares de Europa, da filoloxía e a mitoloxía celtas: había un método comparativo e unha árbore familiar indoeuropea que se ampliaron para abranguer un outro conxunto de tradicións culturais. Pola contra, entra en funcionamento outro tipo de diseminación cando se toma unha mitoloxía celta relativa á toma de Irlanda, contada

${ }^{26}$ Cfr. McKevitt, Kerry Ann (2006): «Mythologizing Identity and History: A Look at the Celtic Past of Galicia», e-Keltoi: Journal of Interdisciplinary Celtic Studies (http://www4.uwm.edu/celtic/ekeltoi/ volumes/vol6/6_13/mckevitt_6_13.html) [data de creación/última modificación: 2 de xaneiro de 2006; última consulta: 12 de maio de 2014]. Así mesmo, sobre o movemento e os festivais panceltas, véxase Peter Berresford Ellis (1993): The Celtic Dawn: A History of Pan Celticism, Londres, Constable. 
desde a perspectiva da "chegada», e se enxerta, desde a perspectiva da "marcha», nas especulacións galegas referidas aos primeiros asentamentos que se produciron nesa rexión. Coma unha póla nunha árbore, o mito celta é enxertado no anticuarismo rexionalista galego.

O proceso de enxerto pode decorrer no medio dunha total ausencia de atención ás probas lingüístico-filolóxicas. Así, non hai nada lingüístico que apunte a familiaridade ningunha entre o galego e o bretón, o gaélico ou o galés; máis ben, aquí a mitoloxía enténdese como extensión da arqueoloxía (estudo das formas antigas de asentamento mediante os restos materiais). Esta ambivalencia resulta notable: por unha banda, co emprego arqueolóxico de mitos perpetúase unha forma máis antiga, propia do século XviII, de anticuarismo (en tanto que estudo indiferenciado da antigüidade, mediante calquera dato do que se dispońa, sexa material ou textual/documental); pola outra, o novo modelo filolóxico pon en relación os mitos, dun xeito moi rotundo, co celme cultural e lingüístico das tradicións étnicas. Existen outros casos en Europa que ilustran esta característica ambivalencia da mitoloxía, dacabalo entre a arqueoloxía e a filoloxía: así, as mitoloxías bálticas (lituanas, estonianas) sitúanse nun panorama lingüístico en cadea que presenta solapamentos históricos e arqueolóxicos entre familias lingüísticas fondamente divididas, desde as eslavas (polaco, ruteno/ruso), pasando polo lituano e o letón, ata o estoniano e o finés. Deste xeito, a celtización do pasado galego non era ningunha singularidade.

En efecto, sometida a un exame máis polo miúdo, a indefinición disciplinar da mitoloxía, entre a filoloxía e a arqueoloxía, semella indicar un estado amorfo aínda máis arraigado. A mitoloxía non é só o nivel radical máis profundo do esencialismo etnolingüístico, ou o significado cúltico/cultural que se lles atribúe a uns restos materiais arqueolóxicos; a mitoloxía é tamén, por toda Europa, o fin polo cal se explotan as lendas, os contos populares e os costumes tradicionais; é, así mesmo, o que serve para encher os capítulos iniciais da escrita da historia nacional, eses que se refiren ao período arcaico (seguindo a Thierry, Vicetto e Murguía $^{27}$ ), e opera nunha constante interacción coa literatura creativa. En resumo, a mitoloxía parece ser o pano de fondo especulativo, postulante de orixes sobre-

${ }^{27}$ Cfr. Leerssen, Joep (2010): «Setting the Scene for National History», en Stefan Berger / Chris Lorenz (eds.), Nationalizing the Past: Historians as Nation Builders in Modern Europe, Basingstoke, Palgrave Macmillan, 71-85. 
naturais, sobre o cal transcorren case todas as demais empresas culturais, desde a filoloxía ata o folclore e desde a arqueoloxía ata a etnografía. Algo que é o pano de fondo de todo o demais non se pode traer doadamente ao primeiro plano; tórnase confuso e inaprehensible cando tentamos centrarnos nel ou identificalo como actividade intelectual ou erudita discreta e ben delimitada. Así, a mitoloxía é o "peixe soluble» que se menciona na divisa deste artigo, un peixe que está en todas as partes e en ningunha nos movementos de rexurdimento vernáculo que tiveron lugar na Europa decimonónica.

Con todo, o que constitúe unha característica destacada da mitoloxía é o notable intercambio bidireccional que se dá entre o estudo académico das mitoloxías e ese volver narrar os mitos no plano poético. Como indiquei ao comezo deste ensaio, o termo "mitoloxía» pode aplicarse tanto a unha empresa académica (a mitoloxía como estudo académico dos relatos míticos) como ao obxecto desa empresa (a mitoloxía como corpus de relatos míticos). A nórdica de estilo Grimm non representaba simplemente unha maneira científica de entender os antigos sistemas de crenzas, senón tamén a apertura dun depósito de narrativas míticas dispońibles para a súa reciclaxe e reprodución, dun xeito particularmente notable - mais non o único- nas óperas de Wagner. Así, as historias de Wodan, Balder e o Ragnarök pasaron a ser lecturas de lecer para a burguesía culta e un repertorio de temas para artistas visuais, compositores e narradores, e practicamente o mesmo cabe dicir da meirande parte das mitoloxías europeas, que se converteron nun depósito temático-cultural e en obxecto de investigación erudita sobre as relixións precristiás da nación, o que talvez explique as moitas e moi notables semellanzas que existen entre o Rexurdimento literario irlandés e o Rexurdimento galego. Neste sentido, as disputas arqueolóxicas entre os paradigmas fenicio e celta desenvolvíanse arredor das torres redondas en Irlanda e da de Hércules en Galicia; a redescuberta do mito celta forneceulles a ambos os movementos un potente repertorio cultural que contribuíu a distinguilos da Inglaterra anglosaxoa e da España castelá, respectivamente, e quedou consagrado, no caso irlandés, na idea dun «ocaso celta»e, en Galicia, naquel club literario de Murguía que era A Cova Céltica ${ }^{28}$.

\footnotetext{
${ }^{28} \mathrm{O}$ máis notable destes paralelismos é que, polo que parece, ningún dos dous Rexurdimentos foi moi consciente deles; así, malia que Vicetto aínda advirte a presenza dos fenianos, dá a impresión de que Murguía e Yeats, que tanto se asemellaban no seu xiro celta, eran completamente alleos o un á existencia do outro.
} 
Máis aínda, todos estes paralelismos galaico-irlandeses dan mostra do intenso intercambio de inspiración nacional que tivo lugar entre o espírito investigador e o espírito creador. O enxerto de Geoffrey Keating, a toma de Irlanda e Breogán na antigüidade rexional galega era un acto non simplemente de pescuda erudita, senón de vigorización literaria. Resulta moi significativo que os intelectuais que participaron neste proceso (tanto aquí como noutros lugares de Europa) conxugasen o eido da pescuda histórica e anticuaria coa produción de literatura poética; o que lles faltaba de fiabilidade académica compensábano coa súa forza literaria e, así, crearon un pasado historicamente pouco fidedigno mais poeticamente potente. Estudaron a mitoloxía e concibiron mitos, ou, máis ben, acaso o estudo da mitoloxía e a concepción de mitos sexan todo un. 
LEMBRAR O FUTURO.

OS MUSEOS DA MEMORIA E

O SEU ROL NA CONSTRUCIÓN

DAS IDENTIDADES CULTURAIS

Patrizia Violi

Università di Bologna 

Existe unha memoria do futuro? E en que sentido ten que ver coas formas e as modalidades das construcións identitarias? Nas poucas páxinas que seguen tentarei bosquexar unha resposta a estas preguntas, sostendo que as identidades se constrúen non só a partir dunha relectura e interpretación do propio pasado, senón tamén, e quizais dun xeito aínda máis constitutivo, desde un proxecto sobre o futuro e desde unha proxección neste da imaxe identitaria que se quere transmitir. Un rol importante desempeñan, nesta dialéctica entre pasado e futuro, os chamados "lugares da memoria» - mausoleos, monumentos, memoriais, museos e outros semellantes - , dedicados ao recordo do pasado, quer un pasado glorioso, quer, en troques, e máis a miúdo, traumático e doloroso. A tese que tratarei de argumentar é que tales lugares, que exteriorizan no espazo a temporalidade da historia pasada, son lugares-tópicos cruciais na constitución das identidades colectivas e que a súa análise é unha compoñente esencial para unha semiótica das identidades culturais.

Pensar, desde a semiótica, na constitución da identidade, individual ou colectiva, implica un primeiro movemento deconstrutivo. En realidade trátase de que nos desfagamos dunha vez e para sempre da ilusión ontoloxizante e esencialista que leva a ler as identidades como construcións estables, univocamente definidas, obxectivables nos seus procedementos de descrición. As figuras da identidade son, en troques, configuracións, ou sexa, obxectos semióticos construídos, e non dados, a través de continuos procesos de reescritura, transformacións, negociacións entre varios suxeitos sociais, ou varias instancias subxectivas, se falamos de identidades individuais. Esta natureza construída e non dada é, porén, o que a miúdo os discursos identitarios, xa sexan as construcións discursivas sobre identidades nacionais, xa aquelas sobre as étnicas ou relixiosas, tenden a ocultar, recompoñendo a complexidade e, con frecuencia, a contradición dos procesos subxacentes no que poderiamos definir como unha ideoloxía da identidade. E é propiamente tal compoñente ideolóxica dos discursos identitarios o que consti- 
túe a base e a ancoraxe simbólica sobre as cales, pola súa vez, se fundan as políticas identitarias que tan traxicamente caracterizan a nosa contemporaneidade e gran parte dos conflitos aos que asistimos cada día en tantas partes do mundo.

Un primeiro deber do traballo semiótico consistirá entón nunha análise crítica dos discursos sociais que sosteñen as construcións das formas identitarias, a fin de revelar precisamente a natureza de complexas construcións sociais e semióticas, a partir das súas dimensións de entidade temporalmente construída. Poderemos dicir que é precisamente o tempo a dimensión máis esencial para a construción de toda forma identitaria, ou, mellor, máis ca o tempo en si, o xeito en que o tempo é asumido e transformado en memoria de si. Que identidade e memoria sexan estreitamente interdependentes non é, de certo, unha cousa nova: xa Aleida Assmann (1999) subliñaba como a lembranza e a memoria son esenciais para a fundación das identidades individuais e colectivas, e como este proceso identitario é regulado, a nivel social, por políticas precisas do recordo. Do recordo, mais tamén do esquecemento, naturalmente. Porque memoria e esquecemento se colocan, desde o punto de vista da construción de identidade, nunha relación de recíproca imbricación: a construción dunha forma identitaria outra non é, podemos dicir, máis ca a selección e a reorganización narrativa e discursiva de certos elementos do pasado a expensas doutros ${ }^{1}$.

Mais o pasado non é nunca un dato en si, fixo e inmutable: se os feitos pasados, en canto que eventos acaecidos, o son, a súa memoria é, en cambio, variable, decontino transformable e renegociable, e as formas deste traballo de constante reescritura do pasado están sempre ancoradas ao presente. Que o pasado sexa construído a partir do presente e das súas necesidades é probablemente un dos puntos en que máis concordan todas as numerosas reflexións sobre a memoria ${ }^{2}$, o cal é moi importante desde o noso punto de vista, porque incide directamente nas cuestións da imaxe identitaria que unha comunidade quere asumir e transmitir.

Quizais menos investigada estea, no entanto, a contribución que a dimensión do futuro chega a ter nesta dialéctica e a trama que deste xeito se institúe entre

\footnotetext{
${ }^{1}$ Imposible neste lugar dar conta, nin sequera de forma sintética, do vastísimo debate actual sobre o tema da memoria e da súa relevancia para unha reflexión sobre a identidade cultural. Limitarémonos aquí a indicar algúns textos exemplares, comezando por aqueles de corte máis especificamente semiótico: Demaria (2006), Lotman e Uspenskij (1975), Lotman (1990). Outros textos de referencias clásicas son, entre outros, Ricœur (2000), Assmann (1999), Assmann (1992), Nora (1984).

${ }^{2}$ Cfr., entre outros, Todorov (1995) e Augé (1992).
} 
pasado, presente e futuro. A memoria non revisa exclusivamente a reconstrución do noso pasado nin a soa dimensión do presente; a memoria é tamén, e talvez paradoxalmente sobre todo, unha construción prospectiva que mira ao futuro, á imaxe de nós que nese futuro queremos proxectar. A memoria preséntase así, máis ca como rexistro do acontecemento, como un proxecto sobre o que pode acontecer, sobre aquilo que quereriamos que ocorrese, a partir do cal se irá, despois, a reler e a reconstruír o pasado para nos reencontrarmos coas prefiguracións daquela identidade que, en cambio, estamos a reconstruír. Unha dialéctica semellante non vale só para os individuos, senón tamén para as sociedades e as culturas: a construción dunha identidade colectiva funda e presupón ao mesmo tempo unha memoria colectiva. Que tal memoria non sexa só propiedade do pasado común, senón tamén proxección prospectiva do propio perfil identitario sobre o futuro, é o que trataremos de analizar no caso específico dos lugares de memoria.

Mais primeiro debemos aclarar un punto importante: que é exactamente unha «memoria colectiva» e como pode ser nomeada en sentido non metafórico? Onde reside a memoria dunha colectividade? Desde un punto de vista semiótico e a diferenza, por exemplo, doutras aproximacións disciplinares, como as psicolóxicas, a única resposta que nos semella posible é a de pensar a memoria colectiva como resultado dun proceso de exteriorización, que ve nos textos e nas prácticas de interpretación, lectura e tradución recíproca o lugar representativo para a súa análise. Entendendo aquí por texto obviamente non só textos verbais ou visuais, senón tamén, e plenamente, lugares, espazos, paisaxes, monumentos etc. ${ }^{3}$.

Só pensándoa como unha memoria construída, unha memoria colectiva pode tamén devir nunha memoria compartida ou quizais, máis acaídamente, nunha memoria potencialmente compartible, ou sexa, unha perspectiva asumida ou asumible por unha sociedade dada que deste xeito funda un modo común de mirar para o seu propio pasado e de proxectar o seu futuro. Mais como se chega a construír unha memoria compartida e, sobre todo, que relacións ligan e conectan as memorias individuais ás colectivas? Certamente é imposible afrontar neste lugar problemáticas tan complexas sobre as cales existen importantes reflexións desde a primeira metade do século pasado ${ }^{4}$

\footnotetext{
${ }^{3}$ Sobre o concepto de memoria exteriorizada ten traballado desde hai moito tempo o Doutoramento de Semiótica da Università di Bologna. Os primeiros resultados da investigación están en «Memoria culturale e processi interpretativi. Uno sguardo semiotico", Chora, revista do Istituto Italiano per gli Studi Filosofici (2009).

${ }^{4}$ Véxase en particular Halbwachs (1925 e 1950).
} 
e que nos levarían moi lonxe do tema no cal desexaría, en troques, centrarme. Limitarémonos aquí a subliñar que, se por unha banda a memoria colectiva é algo máis diverso e complexo ca o conxunto das memorias individuais e non é redutible á súa pura sumatoria, pola outra, para poder ser compartida, ela deber permitir unha inscrición das memorias singulares, unha posibilidade de recońecemento, so pena de non ser compartida. Por outra parte, de ningún xeito as memorias individuais poden prescindir de dimensións sociais e colectivas: cada un de nós, para lembrar, ten necesidade dos outros; a nosa memoria singular é sempre, tamén, intersubxectiva, culturalizada, porque está sempre entrelazada co ollar dos outros. Neste sentido poderíase dicir que a memoria individual representa un punto de vista particular sobre a memoria colectiva, mais esta última, pola súa vez, condiciona o proceso da lembranza individual, gobernando dinámicas de memoria e de esquecemento, remocións e reivindicacións.

Un proceso dialéctico semellante complícase cando a memoria colectiva é memoria de eventos tráxicos e controvertidos, para os cales subsisten versións contrastantes e conflitivas, especialmente naquelas sociedades nas que o conflito non foi cun inimigo externo, senón no interior dunha mesma comunidade. O pasado traumático devén entón nun pasado polémico respecto do cal é moi difícil a reconstrución dunha memoria compartida, pois coexisten moitas memorias diversas e moi diferentes reconstrucións da propia historia común, a miúdo antagónicas as unhas das outras. Non só iso, senón que outra delicada cuestión se presenta nestes casos, a saber: a dificultade de «lembrar o mal», de volver evocar a dor e o trauma sufrido, de describir o sufrimento propio e dos outros 5 .

Resulta, daquela, extremadamente interesante para unha semiótica da cultura estudar os lugares destinados a construír, conservar, transmitir a memoria do pasado traumático. Noutros termos, os lugares en que o tempo, poderiamos dicir, se espacializa, exteriorizándose nun lugar que se fai un verdadeiro monumento á memoria do tempo. Instáurase aquí unha interesante dialéctica entre pasado e futuro, que devén particularmente crucial se se le nun plano identitario. En efecto, o xeito en que a memoria do pasado traumático é conservada e novamente proposta está directamente en función dunha idea da identidade futura que se quere construír. Noutros termos, poderiamos dicir que é o futuro o que guía a memoria do pasado, a lembranza do trauma, a súa elaboración, ou, en cambio, a súa remoción e cancelación. Lugares-tópicos desde este punto de vista son os museos da memoria, nomeadamente naquelas sociedades onde

\footnotetext{
5 Sobre estes temas véxase Boltanski (1992).
} 
o trauma colectivo que conmoveu a vida civil nacía dun conflito interno a esa mesma sociedade, e non era resultado dunha guerra contra un inimigo externo. Nestes casos é obviamente máis complexa e difícil a construción dunha memoria compartida, e máis forte é a presión de operacións de censura, manipulacións, imposicións ${ }^{6}$, das memorias singulares. Os museos da memoria poden neste marco devir en dispositivos importantes para a reinscrición das diferentes e contrastantes memorias individuais nun cadro unitario e homoxéneo, capaz de funcionar cabalmente como un marco identitario para toda a sociedade. En especial cando a sociedade que sae do conflito interno fortemente traumático ten moita necesidade de se repensar no sentido dunha refundación e dun «novo inicio».

No que vai a seguir presentarei unha breve análise dalgúns destes lugares. A miña análise non ten ningunha pretensión de exhaustividade ou acabamento; é só un primeiro bosquexo dunha investigación que se atopa en curso, mais aínda na súa síntese querería estimular algunhas reflexións posibles sobre a relación entre espazo, memoria, construcións identitarias.

Falando de lugares da memoria, é útil introducir unha primeira distinción entre dous casos moi diversos desde o punto de vista das dinámicas semióticas da reconstrución do pasado e da produción do sentido: en primeiro lugar, monumentos ou memoriais propiamente ditos, construídos despois dun evento dramático para lembrar e conmemorar, por exemplo, os caídos na guerra ou as vítimas dun masacre. Nestes casos constrúese ex novo un monumento á memoria dun acontecemento pasado do cal non ficaba pegada tanxible, a miúdo pola distancia de moitos anos desde o dito evento. A forma e a estrutura do monumento, non menos que o lugar mesmo da súa edificación, son con frecuencia obxecto dun debate público, de negociacións e mediacións entre varios actores sociais (Goberno, veteranos, parentes das vítimas etc.), pode ser materia dun concurso público e, en calquera caso, implica a miúdo un complexo proceso social para acordar cal sexa a forma máis oportuna e compartida que unha comunidade dada decide elixir para transmitir a imaxe do propio pasado doloroso ${ }^{7}$.

Diferente é o caso en que se trata de conservar lugares xa existentes, que foron teatro de eventos traumáticos, de estragos, exterminios, detencións. Este é o caso

${ }^{6}$ Estes termos están tomados de Ricœur (2000), que distingue entre a memoria censurada, manipulada, imposta, entre as varias dinámicas de memoria e esquecemento. Véxase tamén Demaria (2006).

${ }^{7}$ Véxase, como traballo exemplar nesta dirección, a excelente análise de Wagner-Pacifici e Schwartz (1991) sobre o monumento aos caídos no Vietnam erixido en Washington, D. C. 
dos campos de concentración, gulags, prisións e outros lugares terribles que son transformados en lugares de conmemoración, testemuño e lembranza do pasado tráxico, lugares que unha comunidade ou unha nación enteira decide preservar do esquecemento e conservar como monumentos dunha verdadeira e particular memoria colectiva. A conservación nestes casos implica un proceso de verdadeira «museificación», que pode asumir formas diversas, desde a rigorosa conservación filolóxica, pasando pola restauración creativa, ata a eventual reconstrución, parcial ou total, do lugar orixinario.

En ambos os casos trátase obviamente de recordar e conmemorar e en ambos os casos esta operación ten que ver, de maneira directa, coa imaxe da propia identidade que se quere preservar e transmitir para o futuro; mais os dous casos difiren en moi interesantes dimensións e propoñen problemas semióticos parcialmente diversos. No segundo caso, en efecto, o que se move no interior dunha problemática semiótica particular, a da restauración, implica pola súa vez unha reflexión sobre a autenticidade dos signos-pegadas do pasado, sobre a lexitimidade da súa transformación, sobre os sutís límites entre conservación e falsificación, con todos os problemas de natureza ética, máis ca estética, que todo isto comporta. Calquera forma de restauración, xa sexa conservadora ou innovadora, pon, de feito, en xogo unha dialéctica complexa entre reconstrución e destrución dos signos do pasado e implica un proceso semiótico de relectura e interpretación, unha práctica tradutiva entre a «realidade como era» e como queremos que sexa, ou se manifeste.

En ambos os casos, sexa que se constrúa ex novo ou que, en troques, se conserve o que xa existía, estanse tamén a definir as formas da propia identidade colectiva, pasada, presente e tamén futura.

Os tres «lugares da memoria» que hei analizar son moi diversos entre si, quer desde o punto de vista xeográfico, quer desde o histórico ou o político, porque están moi distantes as tráxicas realidades que estes lugares conmemoran e tentan lembrar. Como xa dixen, non se trata de análises completas, senón dos primeiros bosquexos do traballo dunha investigación ata agora en curso; malia que aínda na súa parcialidade, espero que se poidan prover dalgúns útiles apuntamentos sobre un aspecto moi particular da construción de procesos identitarios. Os primeiros dous estudos de caso, o Museo Tuol Sleng, dedicado aos crimes do xenocidio de Phnom Penh, en Camboia, e o Parque por la Paz Villa Grimaldi, en Chile, 
entran na segunda categoría tipolóxica que tracei: trátase, en efecto, da conservación e transformación en museo de lugares de detención, tortura e exterminio; o terceiro, o Salón Memorial de Nanjing polas vítimas do masacre realizado polos xaponeses naquela cidade, é, en cambio, un complexo monumental construído setenta anos despois do tráxico evento que se quere lembrar.

O Museo Tuol Sleng, sobre os crimes do xenocidio de Phnom Penh, en Camboia, é a transformación á esfera de museo do infame S-21, o meirande centro de detención, interrogatorios e tortura da policía secreta do Kampuchea Democrático durante a ditadura do Khmer Vermello, que durou desde 1975 ata 1979. As estimacións do xenocidio camboiano ocorrido naqueles anos son aínda imprecisas, mais parecen xirar arredor dos case dous millóns de mortos, sobre unha poboación daquela de oito millóns de habitantes. O S-21, máis ca unha prisión, era un lugar de interrogatorio e, sobre todo, de tortura; calcúlase que pasaron por alí entre 15000 e 17000 vítimas (aínda que algunhas estimacións falan de 20000 e a cifra ficará sempre ignorada), en gran parte cadros intermedios do partido; despois dos interrogatorios e as torturas, os sobreviventes eran trasladados fóra do campo, ao infame killing field de Choeung Ek, a uns quince quilómetros de Phnom Penh. Os sobreviventes do S-21 son en total sete, os últimos prisioneiros abandonados polo Khmer Vermello en fuga en xaneiro de 1979 e atopados, poucas horas despois do seu ingreso, polas tropas vietnamitas que o 7 de xaneiro daquel ano ocuparon a cidade, dando cabo do réxime de Pol Pot.

A comezos do 79, os vietnamitas e os seus aliados camboianos anti-Khmer Vermello atópanse fronte a un país devastado e reducido á máis completa miseria, sen infraestruturas, sen hospitais, escolas, organizacións estatais de ningún tipo e, sobre todo, sen o persoal humano necesario, desde o momento en que toda a clase dirixente e os cadros intermedios da Administración, do ensino e da saúde foran vítimas do xenocidio. Non obstante esta situación de emerxencia, que podería suxerir outras prioridades, a Administración provisoria e os vietnamitas decidiron transformar inmediatamente o S-21 nun museo: en marzo de 1979, a menos de tres meses da liberación de Phnom Penh, os primeiros visitantes puideron entrar no museo, que estaba aberto aos xornalistas estranxeiros e ás delegacións internacionais. É evidente nesta urxencia a necesidade de utilizar pronto, en forma propagandística, este lugar: para os vietnamitas trátase, obviamente, de lexitimar a súa intervención armada en Camboia, que, fronte aos horrores do 
S-21, aparecerá non só xustificada, senón tamén meritoria sobre o plano humanitario, presentando as forzas de invasión estranxeira como liberadoras e salvadoras dun horror sen fin. Para os camboianos da República Popular de Kampuchea, o novo Goberno que segue á ditadura khmer, resulta igualmente importante facer fincapé na barbarie do réxime que os precedeu e fundar sobre a toma de distancia deste a propia identidade. E xa aquí opera unha estratexia precisa de construción identitaria da nova Camboia, que implica unha complexa reescritura do pasado, da propia identidade nacional, da lexitimación internacional ${ }^{8}$.

Mais vaiamos ao lugar verdadeiro e real, ás súas características espaciais, aos seus efectos de sentido. $\mathrm{O}$ museo conservou perfectamente a estrutura e a aparencia do precedente $S-21$, que se presentaba, pola súa vez, como un lugar sorprendentemente normal e cotián: o infame centro de tortura estaba, nos feitos, instalado dentro dun liceo francés na zona residencial outrora máis elegante e de benestar de Phnom Penh. O edificio ten a súa elegancia arquitectónica, cun amplo xardín adornado con árbores onde se atopaban campos de xogo e deportivos para os estudantes. Non queda ningunha dúbida de que gran parte do enorme impacto emotivo que Tuol Sleng ten sobre o visitante depende do fortísimo contraste funcional e "semántico», poderíase dicir, entre o pasado máis remoto e aquel atrozmente documentado polo museo: aquilo que era un sereno e tranquilo lugar de cultura, ensino e entretemento, nun contexto case refinado, polo menos para a realidade camboiana da época, foi transformado nun inferno de morte, dor e sufrimento. A configuración física mesma dos lugares resulta representada e trastornada: os espazos luminosos que eran antes aulas habitadas polos rapaces e rapazas convertéronse en cuartos onde os prisioneiros foron castigados e torturados, as árbores deixaron de ser tales para se transformaren en ganchos de onde colgaban as vítimas.

Desde un punto de vista máis propiamente semiótico, estamos aquí en presenza dun fenómeno de resemantización espacial, sobre a base do cal o sentido mesmo dun lugar pode sufrir unha profunda transformación, sen que necesariamente ela sexa unha modificación análoga na estrutura ou na morfoloxía espacial en si. A radical modificación do plano do contido produciu nos feitos unha

\footnotetext{
${ }^{8}$ Sobre unha análise de como o complexo traballo verbo da memoria do xenocidio camboiano iniciado polos vietnamitas influíra sobre o desenvolvemento dun discurso do xenocidio a nivel internacional, véxase Hughes (2003).
} 
paralela reconfiguración do plano da expresión, que non se confunde coa pura materialidade da estrutura física. Considerado como entidade semiótica, aquí desde o punto de vista do seu sentido, unha árbore usada como forca non é máis a mesma árbore a cuxa sombra un podía sentar serenamente para ler un libro?.

A perfecta conservación dos espazos e da estrutura de todo o lugar, que non foi modificada case en nada, fai resaltar con máis forza a oposición categorial subxacente e o contraste semántico e valorativo entre as dúas realidades: a escola, lugar de vida e pracer; a prisión, lugar de morte e sufrimento, producindo un fortísimo efecto patémico. Todo está como era: están visibles os instrumentos de tortura, as celas angostas nas que os prisioneiros debían estar axeonllados, os cuartos dos interrogatorios. Nin sequera as manchas de sangue do pavimento e dos muros foron lavadas nin suprimidas. Para alén da conservación dos espazos, fíxose fincapé sobre os materiais visuais e sobre a compoñente iconográfica de maneira moi particular: nas salas finais están expostos grandes cadros pintados por Vann Nath, un dos pouquísimos sobreviventes, que era pintor de profesión, os cales representan escenas de prisión, tortura e asasinatos no $S$-21, xunto con diversos mapas ilustrativos de todos os lugares dos masacres do xenocidio camboiano, ademais dos restos de esqueletos e caveiras. Ata 2002 Tuol Sleng exhibía tamén un gran mapa xeográfico de Camboia composto exclusivamente por cráneos humanos, con ríos e lagos pintados de vermello, coma se fosen trazados con sangue. Sobre a oportunidade de manter tal colección de caveiras nesa forma no interior do museo e exposta a todos os visitantes, ábrese, a partir dos anos 90, unha acesa discusión, na cal intervén mesmo o rei Sihanouk, sostendo a necesidade de cremar os restos seguindo o costume budista. $\mathrm{O}$ debate preséntase particularmente interesante semioticamente polo entretecido de niveis discursivos diversos, desde os que apelan á tradición relixiosa, pasando polos políticos da fundación dunha nova identidade nacional, ata aqueles baseados na lóxica das esixencias museísticas. En marzo de 2002 os cráneos foron removidos e colocados noutro lugar, cunha cerimonia guiada por monxes budistas, e no seu lugar está exposta unha gran reprodución fotográfica do mapa cuestionado. Segundo o que refire Hugues (2003), o director do museo, Chey Sophera, sostén que a remoción do mapa de caveiras daría cabo ao sentimento de terror que os visitantes mostraban ao visitaren Tuol Sleng. Tal afirmación parécenos ben distante da realidade. O efecto patémico máis intenso de Tuol Sleng depende,

\footnotetext{
${ }^{9}$ Sobre unha discusión verbo deste punto, véxase Violi (2009).
} 
máis ca da exposición directa dos restos humanos, da visión dos miles de fotos retrato do rostro das vítimas encarceradas naquel lugar dispostas ao longo das paredes dos catro edificios principais do museo, mais, en particular, ao longo de todos os muros do edificio B. Os retratos fotográficos eran realizados por un corpo especial do Khmer Vermello no momento de ingreso de cada prisioneiro ao S-21, e tiñan aquí unha función precisa de documentación da contabilidade do horror. As fotos estaban acompańadas do rexistro puntual dos datos de cada arrestado, coas indicacións persoais e a rexión de proveniencia, como certificación da eficacia do traballo cumprido. Outras fotos, en troques, remiten ás imaxes dos cadáveres e representan os rostros e os corpos dos prisioneiros mortos durante a súa permanencia no centro. As fotos son na súa gran maioría retratos frontais, de rostros que aparecen todos estrañamente desapaixonados, sen unha pegada explícita das emocións que esperabamos ler (medo, horror, tristura, anguria?). É precisamente quizais o contraste entre a polo menos aparente ausencia de emocións e o cońecemento que os espectadores teñen do lugar (mais que tamén os prisioneiros non podían non ter) o que suscita o forte efecto patémico que estas fotos producen. É coma se aqueles rostros apáticos nos falasen dunha separación entre o patémico e o cognitivo experimentado polas vítimas, da súa certeza dunha fin atroz e inminente e dunha apática resignación fronte a iso. É soamente no ollar turbado do espectador onde saber e sentir se reunifican, restituíndo en todo o seu horror o «sentido do lugar».

Mais outros elementos concorren ao forte impacto emotivo destas fotos. En primeiro lugar o seu número, o sucederse de milleiros e milleiros de rostros todos diversos na súa singularidade, se ben dalgún xeito idénticos. Neste caso un dato meramente cuantitativo transfórmase en calidade, producindo un particular efecto de sentido que poderiamos definir como tipificación xeneralizante. A proximidade destes milleiros de fotos, todas diversas malia que todas iguais, produce unha sorte de sumatoria horizontal en que, paradoxalmente, a propia multiplicación das numerosas identidades individuais cancela as singularidades, para restituír un único rostro, unha sorte de tipo xeral, sobreposto ás ocorrencias singulares. $\mathrm{O}$ que nos atrae e que interroga de moitas maneiras o noso status de espectadores é o rostro da Vítima. Boltanski (1992), no seu famoso traballo sobre a representación da dor, falaba de tres roles temáticos e narrativos distintos: o Verdugo, a Vítima e o Espectador ${ }^{10}$.

\footnotetext{
${ }^{10}$ Sobre este punto, cfr. Pezzini (2008).
} 
Ora ben, certamente os mortos do S-21 son vítimas, pero quizais as cousas non son tan simples e o seu status actorial é máis complexo. Sabemos en realidade que o S-21 non era un centro de investigación calquera, senón que estaba especificamente dedicado, sobre todo, aos cadros khmer, medios e intermedios, sospeitosos de traición, especialmente na última terrible fase da ditadura, caracterizada por unha sempre máis acentuada paranoia tamén nas confrontacións dos mesmos khmers vermellos ligados ao partido. Aquí a pertenza á categoría de vítima antes ca á de verdugo era para algúns quizais máis o froito dunha tráxica casualidade ca dunha predestinada situación, como foi o caso en tantos outros xenocidios da nosa contemporaneidade, e en primeiro lugar o holocausto. Quizais tamén por esta razón pretendeuse disuadir da práctica de recońecer e escribir sobre as mesmas fotos o nome das vítimas por parte de parentes e amigos, común nos primeiros tempos logo da apertura de Tuol Sleng. Segundo a interpretación de Hughes, a prohibición desta práctica é retornar ao feito que se quería evitar, un excesivo fincapé na singularidade individualmente recońecible das vítimas que diminuiría, temíase, o fincapé narrativo sobre a xeneralidade colectiva do xenocidio.

A interpretación paréceme interesante e vai na mesma dirección do que observaba hai pouco sobre o efecto de tipificación xeneralizante que as fotos producen. Alén diso, suxire unha implícita e complexa dinámica, se non unha verdadeira oposición, entre memorias individuais e memoria colectiva: as memorias singulares, sen dúbida fortemente problemáticas e controvertidas dado o ambiguo rol das mesmas vítimas, eran obxecto de disuasión por mor da súa forzada inscrición no interior dunha memoria colectiva dalgún xeito manipulada e imposta, se non censurada (Ricœur 2000). Trátase aquí dunha operación exquisitamente ideolóxica no sentido suxerido por Eco (1975), que propón considerar a ideoloxía como a selección de só algúns dos significados dos niveis de lectura posibles a partir dunha realidad múltiple e infindamente máis complexa. Sacando o nome das vítimas xunto coa singularidade das súas respectivas historias, tráxicas e contraditorias coma toda a historia da nación camboiana naqueles anos terribles, restablecíase, se ben forzadamente, unha única memoria común, a dunha ditadura duns poucos tolos sobre unha multitude de vítimas inocentes, ofrecendo categorías unívocas para interpretacións fortemente dicotomizadas e netamente distintas. É evidente como esta operación era funcional á necesidade de refundar unha nova identidade nacional colectiva, sostida por un novo Estado, en forte descontinuidade co pasado e capaz de se presentar cun rostro unívoco. 
Finalmente, e para volver cunha última observación ás instantáneas de Tuol Seng e ao seu efecto de sentido, as fotos para as que nós miramos son fotos de mortos. Son vítimas que, no momento en que foron retratadas, estaban por morrer, mais cuxa morte xa aconteceu para nós, que as miramos. O que se mira, no momento en que nós observamos o seu rostro, $x a$ está morto, e nós, como espectadores, non só o sabemos, senón que estamos alí propiamente para isto, estamos alí para ollar o rostro de quen está morto. Paréceme que tocamos aquí un punto moi delicado e complexo, que é quizais a base dunha ambigüidade de fondo que atravesa todos os museos da memoria que expońen directamente non só o testemuño, senón tamén a visibilidade mesma das pegadas do corpo de quen naquel lugar perdeu a vida. E non se trata aquí unicamente da profecía do propio destino inscrita nas fotos das persoas desaparecidas de que falaba Barthes (1980), para quen, cando ollamos a foto do que está morto, non podemos non recoller xa o anuncio daquela morte. De certo, este coñecemento está na base do particular efecto que a visión destas fotos produce (Barthes falaba de punctum nestes casos) porque a competencia cognitiva do espectador se entrelaza inelutablemente cun valor patémico, repropoñendo aquela fusión entre saber e sentir da que falabamos antes. Pero hai tamén algo máis, que causa directamente non só as nosas reaccións patémicas, senón o noso mesmo status de espectadores e as compoñentes voyeuristas implícitas nisto, dado que nós visitamos estes lugares precisamente para vermos a morte, nalgunha medida para a reactualizarmos no noso mesmo acto de ver.

Neste acto os roles de vítimas, verdugos, espectadores volven confundirse peligrosamente: a posición do espectador non pode ser só aquela dun observador externo, pateticamente modalizado. Paréceme que a visión que, en canto espectadores destes lugares, exercitamos sobre a dor doutros nos fai estar contemporaneamente e paradoxalmente tanto no lugar da vítima como no do verdugo: empatizamos, por veces no noso mesmo corpo ata o fastidio físico, co sufrimento amosado, mais ao mesmo tempo observámolo desde o exterior, case como o observaban os verdugos. O duplo posicionamento instalado na nosa visión interróganos a fondo e sutilmente, facéndonos a máis desacougante pregunta: nós non estabamos alí —o mal non está nunca onde estamos nós—, mais, se estivésemos alí, que lugar ocupariamos?

O acto mesmo do ollar ábrese a lóxicas inéditas e imprevistas, que non revisan só Tuol Sleng, senón que nalgunha medida atravesan todo o así chamado «turis- 
mo da memoria» e nos levan a interrogar unha práctica hoxe bastante difundida. Pode un lugar como Tuol Sleng ser visitado como outro punto turístico entre tantos, despois do museo arqueolóxico e antes da feira?

Estas consideracións, pola súa importancia, comportan unha reflexión de máis amplo rango sobre a cultura e a práctica turística contemporánea, e levaríannos certamente demasiado lonxe do obxecto máis específico da nosa análise. Volvemos aquí ao noso, para concluírmos con algunhas observacións sobre o rol de Tuol Sleng na construción identitaria nacional. Pódese dicir, sen dúbida ningunha, que representa un monumento central da Camboia de hoxe, e como tal é percibido. Mesmo se Camboia non axustou nunca plenamente as contas co seu pasado e co período da tráxica ditadura khmer vermella, abonda pensar que non se tentou ningún proceso de verdade contra os líderes daquel período, nin moito menos unha relectura colectiva da historia común; Tuol Sleng representa un monumento nacional constitutivo da identidade nacional, un lugar fortemente patemizado e intensamente investido de valores identitarios. Poderiamos adiantar a hipótese de que quizais iso pasou precisamente por causa da ausencia dun verdadeiro proceso de revisión e relectura histórica e, malia que lle pese, case para superar e suturar o sentido daquela falla. Tuol Sleng é un lugar que compensa, nalgunha medida, o baleiro dun non acordado xuízo político e xurídico e en verdade por iso puido devir, para usar as palabras de Hughes (2003: 186, tradución miña), «o lugar simbólico central da fundación da moderna nación camboiana, do gobernante Partido Popular de Camboia (срP) e, oficialmente, da gratitude da poboación ao Vietnam e ao CPP pola derrota dos khmer vermellos».

O proceso non está privado dunha intrínseca ambigüidade: a sacralización dun lugar tan intensamente simbólico consente en parte en ocultar a falla de profundización nas causas e as responsabilidades; neste aspecto Tuol Sleng constitúe unha resposta ideolóxica, no sentido precedentemente definido, a unha interrogación de verdade máis profunda. Mais ao mesmo tempo, e precisamente por esta capacidade de substitución, Tuol Sleng pode hoxe presentarse como lugar central da autorrepresentación identitaria que o país quere dar de si ao mundo: non por casualidade todas as guías o indican como visita fundamental e imperdible para o turista que queira cońecer a realidade da Camboia contemporánea. Como xa se sinalou, pódese obxectar que a reescritura do pasado posta en acto en Tuol Sleng ten un carácter ideolóxico, oculta o complexo xogo de complicidade entre 
vítimas e verdugos, mais sobre todo non dá instrumentos para entender como puido suceder o que sucedeu; ela limítase a poñer en escena o horror, sen nos dar verdadeiras claves de lectura, nin tampouco reconstruír criticamente responsabilidades e razóns. Porén, non pode non recoñecer que a operación aconteceu, no sentido que se arrisca a traducir, en gran parte grazas á súa eficacia patémica, nunha potente selección identitaria transversal a toda a sociedade camboiana.

Completamente distinto se presenta o caso da Villa Grimaldi, en Santiago de Chile. A vila, situada na periferia da capital e orixinariamente propiedade dunha rica familia chilena, os Vasallo, era unha gran vila de estilo italiano, no centro dun amplo xardín de magníficos rosais, dotada dunha piscina, fontes e moitas árbores valiosas, alén dunha torre de madeira para depósito de auga. Despois do golpe de Pinochet, o 11 de setembro de 1973, foi adquirida pola DiNa e transformada en centro de tortura e prisión para os opositores políticos; calcúlase que os detidos na Villa Grimaldi foron arredor de 4500, dos cales 226 están desaparecidos, asasinados durante as torturas ou botados ao mar aínda vivos. En 1988, dous anos antes da fin da ditadura de Pinochet, a propiedade foi transferida e todos os edificios, en particular a mesma vila, foron completamente destruídos, na tentativa de eliminar todas as probas dos delitos alí cometidos. O Goberno non tomou posesión ata 1995, cinco anos despois da fin da ditadura, e só dous anos despois, tamén pola presión dunha parte da poboación, foi transformada no Parque por la Paz, inaugurado o 22 de marzo de 1997 e aberto ao público na súa forma actual.

Sete anos, daquela, pasan entre a caída de Pinochet e a institución deste museo da memoria, fronte aos apenas tres meses en que estivo listo Tuol Sleng. Mais non é esta a única diferenza. A comparación entre estes dous lugares de memoria é moi interesante precisamente porque o contraste extremo permite ler, en filigrana, o rol profundamente diverso que a memoria dun pasado igualmente tráxico desempeńou na sucesiva construción identitaria dos dous países.

A primeira diferenza con Tuol Sleng consiste na localización espacial dos dous centros: mentres que Tuol Sleng se atopa no centro da capital, nunha zona residencial particularmente coidada, a Villa Grimaldi está nun barrio periférico da capital chilena. Naturalmente a oposición centro/periferia non depende da oposición museal, porque estaba definida precedentemente, cando estes lugares foron elixidos para seren usados como prisións, escolla probablemente ditada pola lóxica policíaca de natureza variada, coma a maior ou menor visibilidade 
nas operacións contra os civís e o diferente efecto de terror producido. Mais a localización dos respectivos museos aos que deron orixe vén desempeñar un rol na percepción de conxunto que diso resulta. Mentres que Tuol Sleng é un lugar típico para Phnom Penh, por todos coñecido, a Villa Grimaldi aparece case descońecida e ocultada. Partamos da dificultade para a alcanzar: mesmo se existe unha lińa de ómnibus na zona, polo menos na mińa experiencia foi extremadamente difícil obter indicacións precisas e atopar sequera un taxista que coñecese a exacta situación do lugar. Tampouco as guías turísticas poñen moitos sinais do Parque por la Paz, que no seu conxunto non reviste, na imaxe turística que a cidade dá de si mesma, un rol minimamente comparable co de Tuol Sleng en Phnom Penh. A competencia cognitiva socialmente difundida respecto a estes dous lugares aparece aquí fortemente diferenciada.

Pero é sobre todo un lugar que culpar por aquilo que poderemos definir como un «baleiro de sentido» ou, máis precisamente, un «sentido baleiro», que de feito vén coincidir cun baleiro de memoria histórica. Naturalmente, esta impresión de falla é directamente consecuencia da destrución case total de case todas as pegadas dos horrores cometidos no lugar, pero parécenos que hai tamén algo máis.

A elección da reestruturación optou pola construción dun xardín, máis ca dun museo da memoria que testemuñase a realidade dos estragos a partir da mesma denominación: non é casual que a Villa Grimaldi, a diferenza de Tuol Sleng, "Museo dos Crimes Xenocidas», non sexa definida como museo, nin se faga referencia no seu nome a algún crime, senón que sexa denominada como "Parque por la Paz». E, en efecto, é o tema do parque e aquilo da paz e da serenidade o que parece que guiou os arquitectos que contribuíron á reestruturación do lugar. Estamos fronte a un parque moi tranquilo, non moi frecuentado, con moitas árbores e mosaicos coloridos. Os signos da memoria do pasado son poucos e discretos: un muro con inscricións de nomes, mais ningunha imaxe das 226 vítimas mortas na Villa Grimaldi; algúns pequenos carteis, postos entre os mosaicos, que indican que cousas exactamente, nese lugar hoxe tan idílico, se perpetraron nos tempos da ditadura, e que tipos de tortura tiveron lugar; a piscina baleira, onde os prisioneiros eran torturados mais onde ao mesmo tempo os gardas, coas súas familias, se bañaban nos días calorosos; e sobre todo a torre, único lugar entre todos que mantén, coas súas angostas celas, a pegada tanxible das prácticas de violencia e atropelo. 
O resto do parque é verdadeiramente tal, un gran xardín con mosaicos cuxa función, sexa de tipo práctico, cognitivo ou estético, se nos escapa; algunhas explanadas como o Patio e o Teatro por la Paz, roseiras e fontes. Falta, porén, en todo isto un percorrido de lectura e de sentido, unha clave interpretativa dos varios elementos, que resultan, así, non conectados por algunha lóxica interna, senón máis ben aliñados os uns aos outros sen un deseño preciso. O lugar aparece baleiro, privado tanto de imaxes como de rastros reais do tráxico pasado, soamente evocado acó e aló de xeito elusivo. Poderiamos dicir que é un espazo ao mesmo tempo cognitivamente pobre e pateticamente desapaixonado, que non suscita fortes emocións, nin activa a curiosidade no plano do saber. Resúltanos un texto opaco, indescrifrable e de difícil lectura, que produce un efecto de sentido total curioso, porque o que parece ausente deste «lugar da memoria» é ao final precisamente a memoria mesma, con todas as súas compoñentes emocionais, sensoriais, cognitivas. Certamente quíxose crear un lugar coa marca da isotopía patémica da «serenidade», máis que provocar interrogantes ou suscitar fortes emocións ligadas á dinámica do recordo, pero a paz á que alude o nome do lugar non parece reenviarnos a unha efectiva pacífica reconciliación, senón á opacidade do esquecemento.

Canto nos pode dicir este lugar da identidade dunha nación, extraviada, dividida e ferida por unha durísima ditadura e por un desacordo civil que aínda non parece resolta a elaborar? Independentemente da intencionalidade específica coa que o Parque por la Paz foi construído, non se pode non reencontrar na opacidade á que facemos referencia un reflexo da mesma dificultade que Chile aínda hoxe atravesa nas confrontacións do seu tráxico pasado e dun futuro que aparece incerto e privado dunha precisa identidade. Á distancia de case vinte anos da fin do réxime, unha das principais rúas do centro de Santiago chámase aínda 11 de Septiembre, en memoria do golpe de Pinochet, e as numerosas tentativas das forzas democráticas de lle mudar o nome resultan todas malogradas fronte á obstinación da Administración de dereita daquel barrio, que ten a facultade de decidir a toponomástica da área da súa competencia.

Un país aínda dividido, separado, non reconciliado, lonxe de ter reconstruída unha memoria común emerxe, por outra banda, tamén dos informes oficiais das comisións instituídas polo Goberno chileno despois de $1990^{11}$. A primeira

${ }^{11}$ Para consultar unha análise detallada dos informes, en particular do segundo, o Informe Valech, véxase a de Demaria (2006, capítulo 4). 
comisión de 1990, Comisión de Verdade e Reconciliación, produce un informe coñecido como o Informe Redding, co cal o Goberno, logo da renuncia de Pinochet, trataba de evitar un proceso de democratización «que se revela polo de pronto difícil e controvertido», como observa Demaria, pola presenza, tamén no interior da mesma comisión, alén do Goberno, de numerosos expoñentes do vello réxime. Houbo que agardar ata 2003 para que fose instituída unha nova comisión polo daquela presidente da República, Ricardo Lagos Escobar, a Comisión Nacional sobre Prisión Política e Tortura. O resultado foi un novo informe, o Informe Valech, que recolle numerosos testemuńos, todos anónimos, de detidos e torturados, mais ningunha confesión dos torturadores. Un testemuño en particular falta aquí, onde non emerxen as responsabilidades individuais, nin se arriba a unha verdadeira e completa denuncia de todos os crimes daquel período.

Non é daquela sorprendente que, á falla dunha memoria compartida, ou polo menos compartible, tampouco os monumentos á memoria poidan devolvernos unha imaxe incisiva e precisa do pasado. Mais non é só o pasado o que non é lexible: a incapacidade de xulgar e asignar as responsabilidades polo que sucedeu depende, máis unha vez, dun presente confuso e, quizais sobre todo, da imposibilidade de proxectar no futuro a imaxe dunha identidade nova e radicalmente distinta ${ }^{12}$.

Desde este punto de vista Tuol Sleng e o parque da Villa Grimaldi dan respostas diversas e case opostas a un mesmo problema, o de construír e transmitir unha memoria común nun país dividido e que aínda non saldou todas as contas co propio pasado tráxico. Alí onde Tuol Sleng testemuña con forza os signos daquel pasado, o parque da Villa Grimaldi tende a os ocultar, co cal resulta finalmente un lugar do esquecemento máis ca da memoria. $\mathrm{O}$ museo camboiano, mediante unha denuncia desapiadada e aterradora, marca unha ruptura e unha descontinuidade simbólica co pasado e, pese ao moi ideolóxica e non correspondente coa «realidade» que a operación poida ser, ábrelle de feito o camińo a unha realidade nacional forte. $\mathrm{O}$ parque chileno preséntase, en cambio, como un lugar que se esforza por lles atopar unha colocación ás propias lembranzas dolorosas e nisto, quizais coma o país que reflicte, carece dunha precisa identidade.

\footnotetext{
${ }^{12}$ A modo de confirmación abonde aquí lembrar que arredor de 60000 chilenos renderon homenaxe ao féretro de Pinochet, por ocasión do seu funeral, acontecido o 11 de decembro de 2006, funeral que se levou a cabo na Academia Militar de Santiago, como testemuño do profundo vencello que aínda hoxe liga as forzas armadas chilenas coa ditadura pasada.
} 
Quixera concluír as miñas análises cunha brevísima recensión do Salón Memorial ás Vítimas do Masacre de Nanjing polos Invasores Xaponeses, en Nanjing (a China). Trátase dun lugar profundamente distinto dos dous ata agora examinados, en canto que pertence á primeira tipoloxía que delińei precedentemente, de monumentos ou museos construídos ex novo, que non previron a conservación ou a restauración dun ambiente xa existente e marcado por tráxicos eventos. Mais hai tamén outra razón, quizais aínda máis importante, para a diferenza: mentres que en Camboia ou en Chile eran lembrados xenocidios e asasinatos consecuentes a sanguinarias ditaduras e golpes de Estado internos ao país, que dividiran a poboación en forma de cruentos conflitos civís, no caso de Nanjing o acontecemento para conmemorar era, en troques, a terrible matanza realizada polos xaponeses nos tempos da súa invasión á China. O 13 de decembro de 1937 os xaponeses entran a Nanjing, abandonada polos soldados do exército chinés que se deran á fuga, e durante seis semanas cumpren unha das matanzas de civís quizais máis feroces de todos os tempos: estupros, asasinatos e torturas de mulleres, nenos, vellos, todos civís. As vítimas son máis de 300000 .

Estamos aquí en presenza dun episodio atroz, que excede as regras "correctas» da guerra segundo as cales a vida dos civís debería preservarse, mais que se sitúa sempre mellor no interior dun conflito "clásico», que ve opostos dous pobos e dúas nacións, dos cales un cumpre claramente o rol de agresor ou invasor. Unha situación moi distinta da camboiana ou a chilena; neste caso non se dá o problema de memorias controvertidas ou conflitivas para «sandar» ou pacificar: os roles da vítima e do verdugo, para utilizar a categoría temática de Boltanski, están clara e netamente definidas; a memoria é, en certo sentido, unívoca e non ambigua.

O memorial reflicte esta certeza celebrativa e constrúe, para todos os efectos, un gran monumento á identidade nacional chinesa, identidade afirmada como unitaria e en certa medida «superior» precisamente pola capacidade de conxugar e unir a extrema heteroxeneidade de elementos, repertorios, materiais e estilos estéticos diversos que compoñen o mausoleo. En realidade, máis ca dun mausoleo, trátase dun verdadeiro complexo de numerosos edificios e monumentos diversos, extremadamente articulado, unha sorte de "parque temático», que abrangue máis alá da súa forma orixinaria, un museo precedente, aberto en 1985. O actual Salón Memorial, aberto ao público o 13 de decembro de 2007 no aniversario dos 70 anos do masacre de Nanjing, ten unha extensión de 74000 metros cadrados, dos cales «só» 9800 están ocupados polo museo propiamente dito. Todo o resto 
do Memorial está constituído por un particular percorrido, que se desenvolve a través dunha serie de espazos de natureza variada ${ }^{13}$.

O percorrido comeza cunha gran praza, composta pola súa vez por varios monumentos e pezas, con simboloxía moi heteroxénea que vai da cruz á campá budista. Desde a praza accédese ao museo propiamente dito, extremadamente amplo e rico en todo xénero de documentos, fotos e pezas achadas concernentes ao masacre, á historia do Memorial mesmo e, en particular, á inclusión, nos anos 90, do repertorio de pezas e restos de vítimas, expostas nun edificio contiguo ao Memorial.

Á saída do Museo o fiel visitante está só no comezo do verdadeiro percorrido do Memorial, que se desenvolve primeiro a través da Site Square, unha grande extensión en leve pendente cuberta de callaos coma ríos brancos, con grande efecto estético e estésico, pechado ao fondo por un gran muro con inscricións dos nomes das vítimas do masacre. Desde aquí accédese a un primeiro edificio baixo en forma de sarcófago, desde o cal se pasa á sala na que están expostos parte dos restos dos 10000 corpos atopados durante os anos 90, a Exhibition Room of the Remains of the Victims, que debería representar o sitio das escavacións exactamente como era, aínda que é, en cambio, evidente unha sagaz e experimentada decoración escenográfica. Seguidamente vén despois a Memorial Square, unha sorte de templo de relixión indefinida, composto por un gran patio pechado por unha alta parede negra e por un altar en mármore negra, diante do cal se poden desenvolver prácticas «case relixiosas», como acender bastoncińos de incenso ou axeonllarse en recollemento e pregaria. Finalmente, o último edificio é o Meditation Hall, un gran cuarto completamente escuro, agás por pequenas luces que se prenden desde o teito e algúns recadros luminosos con inscricións de ideogramas, cuxo pavimento cuberto de auga se atravesa sobre pequenas pasarelas colgantes.

Á saída da Sala da Meditación chégase á última parte monumental do Memorial, o Parque da Paz, constituída por unha gran pía de auga, baixa, longa e estreita, que termina cunha alta estela e dúas enormes estatuas de mármore branco que representan a paz, en estilo socialista neorrealista. Do lado dereito da pía o percorrido está pechado por un alto muro, o Wall of Victory, onde está entronizada outra grande estatua de estilo socialista dun soldado que toca o clarín.

\footnotetext{
${ }^{13}$ A que presento aquí é unha descrición extremadamente sumaria e certamente insuficiente para dar conta da totalidade do lugar, que requiriría unha análise máis profunda. Un traballo pormenorizado sobre o Memorial Hall está en curso de preparación actualmente e debería ser publicado durante o 2009.
} 
O longo percorrido a través de todos estes edificios, outras tantas etapas dun ideal Via Crucis civil, pode ser lido como un preciso percorrido narrativo e paixonal ao mesmo tempo, dirixido á transformación modal do visitante que o percorre. $\mathrm{O}$ suxeito adquire unha primeira competencia cognitiva sobre o plano do saber, na visita ao Museo propiamente dito, e vai sendo progresivamente modalizado e transformado tamén sobre o plano estético e patémico a través de paisaxes sucesivas, na travesía da explanada dos callaos e a vista dos restos das vítimas, pasando pola purificación do templo e da sala de meditación, ata chegar á sanción positiva final do parque da paz e da vitoria. O percorrido de cońecemento do pasado e de reconstrución da memoria acompánase paso a paso cara a un correlativo percorrido de sensibilización sobre o plano paixonal, onde a sanción final dos valores da paz vén coincidir cunha vindeira fase de moralización, semioticamente entendida ${ }^{14}$ como o momento que conclúe o percorrido paixonal dun suxeito e inscribe as emocións nun rexistro valorativo e patémico colectivamente compartido e regulado.

O sentido profundo deste percorrido, non menos ca de todo o Salón Memorial, é a revisitación da memoria dun tráxico acontecemento do pasado no sentido dunha reconstrución identitaria forte do pobo chinés e isto ten importantes consecuencias sobre o gozo mesmo do lugar: o punto de vista do espectador resulta, de feito, totalmente orientado nunha focalización prospectiva que bloquea aquela dupla identificación coa vítima e o verdugo que tiráramos, en cambio, no caso de Tuol Sleng. Non só iso. O visitante modelo deste lugar non é un turista estranxeiro, senón un cidadán chinés, porque este é, en primeiro lugar, un monumento á capacidade do pobo no seu conxunto para soportar feitos terribles e resultar vencedor, non só no plano bélico, senón no que máis importa, no plano moral e histórico. Insístese moito, en varias partes do Museo, na ausencia de vinganza ou desquite da parte dos chineses, por exemplo nas comparacións cos orfos xaponeses do conflito, e na capacidade do pobo para perdoar e para mirar cara ao futuro: nunha sala do museo aparece finalmente, en coloreadas cifras luminosas, a longa serie dos anos que están por vir, para indicar unha capacidade de reconciliación e unha vontade de paz da nación proxectada nun futuro ilimitado. O Salón Memorial é un monumento para lembrar, mais é tamén, e quizais sobre todo, un monumento de fundación coral e colectiva que sobre a dor e a memoria do pasado constrúe a identidade do futuro dunha nación.

${ }^{14}$ Cfr. Greimas e Fontanille (1991). 


\section{REFERENCIAS BIBLIOGRÁFICAS}

Assmann, Aleida (1999): Ricordare: forme e mutamenti della memoria culturale, Bolońa, Il Mulino.

AssmanN, Jan (1992): La memoria culturale: scrittura, ricordo e identità politica nelle grandi civiltà antiche, Turín, Einaudi.

AugÉ, Marc (1992): Non-lieux : introduction à une anthropologie de la surmodernité, París, Seuil.

Barthes, Roland (1980): La Chambre claire : note sur la photographie, París, Gallimard/Seuil.

Boltanski, Luc (1992): La souffrance à distance, París, Éditions Métailié.

Demaria, Cristina (2006): Semiotica e memoria: analisi del post-conflitto, Roma, Carocci.

Dottorato di Semiotica dell'Università di Bologna (2009): «Memoria culturale e processi interpretativi: uno sguardo semiotico", Chora. Rivista dell'Istituto Italiano per gli Studi Filosofici, 16, Milán, Symposium.

Eco, Umberto (1975): Trattato di semiotica generale, Milán, Bompiani.

Greimas, Algirdas Julien / Jacques Fontanille (1991): Sémiotique des passions : des états de choses aux états d'àme, París, Seuil.

Halbwachs, Maurice (1925): Les Cadres sociaux de la mémoire, París, Alcan.

Halbwachs, Maurice (1950): La Mémoire collective, París, Alcan.

Hughes, Rachel (2003): «Nationalism and Memory at the Tuol Sleng Museum of Genocide Crimes, Phnom Penh, Cambodia», en Katharine Hodgkin / Susannah Radstone (eds.), Contested Pasts, Nova York/Londres, Routledge.

Lotman, Yuri M. (1990): Universe of the Mind: A Semiotic Theory of Culture, Londres, I.B. Tauris \& Co Ltd. Lotman, Jurij M. / Boris A. Uspenski (1975): Tipologia della cultura, Milán, Bompiani.

Nora, Pierre (1984): Les Lieux de la mémoire, París, Seuil.

PeZzINI, Isabella (2008): Immagini quotidiane: sociosemiotica visuale, Roma, Laterza.

Ricceur, Paul (2000): La Mémoire, l'histoire, l’oublie, París, Seuil.

Todorov, Tzvetan (1995): Les Abuses de la mémoire, París, Arléa.

VIOLI, Patrizia (2009): «Il senso del luogo: qualche riflessione di metodo a partire da un caso specifico», en Massimo Leone (ed.), La città come testo: scritture e riscritture urbane, Roma, Aracne.

Wagner-Pacifici, Robin / Barry Schwartz (1991): «The Vietnam Veterans Memorial: Commemorating a Difficult Past», American Journal of Sociology, 97:2, 376-420. 

PAISAXISMO E IDENTIDADE

NA ARTE ESPANOLA

CONTEMPORÁNEA

Carmen Pena López

Universidad Complutense de Madrid 

A paisaxe é o resultado da mirada humana sobre determinado medio ambiental. A natureza existe sen o home, mais a paisaxe non. De aquí que nas paisaxes, nos seus métodos e técnicas descritivos e interpretativos, na perspectiva desde a cal son miradas en cada época ou en cada territorio cultural, na primacía duns escenarios sobre outros ou na súa selección se delaten os sentimentos e ideais dos que as pintan, esculpen, constrúen ou axardinan ou interveńen nelas desde diferentes disciplinas, ocultando á vez sutilmente a intencionalidade ou o compromiso que no seu modo de as interpretar puidese haber (Schama 1995).

Cada nova interpretación da paisaxe, se se anova e se moderniza, os seus novos modos e rexistros sensibles constrúense sobre substratos de anteriores versións, sobre ruínas ou fragmentos de emocións de modelos do pasado. A nosa mirada e interpretación das paisaxes vai rompendo con modelos construídos anteriormente, para crear os do futuro desde un tratamento teórico e práctico innovador, se ben a súa ruptura cos modelos periclitados nunca vai ser total: coma en toda manifestación estética do novo, as teorías e estéticas anteriores perduran dalgún xeito, desde a súa revolución vangardista ou desde a cita posvangardista máis ecléctica. No caso da arte contemporánea, gran parte dos seus obxectos e conceptos son resultados de miradas do pasado, revolucionadas cara ao presente e o futuro.

Desde o punto de vista da teoría e a historia da arte, a idea de que a paisaxe é unha proxección de sentimentos tería o seu clímax na pintura e a literatura do Romanticismo, baseado esencialmente nas ideas prerrománticas do pintoresco e do sublime. As máis remotas bases de tal idea estaban no Renacemento, en Petrarca ou en Leonardo, se ben habería ser o século XIX romántico o que fixese daquelas referencias unha lectura moderna, co cal a paisaxe adquiriu un protagonismo estético, que a levou a ser declarada nas academias de belas artes «xénero maior» dentro da pintura, cando ata daquela o fora «menor».

Unha das razóns polas cales a teoría do xénero e as súas aplicacións en pintura ou en literatura foron un vehículo importante dos gustos e dos estilos modernos 
de narración e expresión é a de que a historia do dito xénero, ao ser de menor importancia, estaba máis descargada de normativa académica ca os xéneros maiores. Outra causa de que vehiculase máis libremente o novo sería a de que a natureza - coa súa aparencia de inxenuidade e suposta falta de intencións - permitiu clandestinizar máis doadamente ca outros temas pensamentos e prácticas críticos de resistencia ao institucional. Por último, outro dos feitos que afectou á paisaxe para avanzar no concepto do moderno foi, sen dúbida, que a súa sinxela aparencia narrativa fose inclinando máis o paisaxista aos experimentos pictóricos, libres e autónomos no campo da arte ca á narración estrita e mimética da natureza. No caso da pintura, tal consideración do tema habería impulsar neste xénero a revolución das técnicas e dos estilos: efectos de luz, cor ou movemento na natureza servirían para aplicar ás modernas versións paisaxísticas novas teorías cromáticas, ópticas ou físicas, de xeito que, desde este punto de vista, a moderna paisaxe foi básica no avance da idea da «autonomía» da arte e da pintura, responsable importante -xunto co bodegón - do experimentalismo no cal se introduciron as vangardas.

Unha das disciplinas diversas que achegou novidades importantes á mirada do paisaxista contemporáneo cara á natureza foi a xeografía, potenciando a modernización progresiva e nova das paisaxes. A causa orixinaria desta ciencia ter tal papel no anovamento do xénero foi que, logo de nacer como ciencia natural enmarcada dentro das correntes positivistas, superou aquela condición, para acadar tamén as calidades das ciencias humanas situadas no seo do pensamento idealista. Segundo aquela escisión das ciencias, os chamados humanistas propiciaban cos seus métodos e termos a proxección subxectiva do pensamento individual ou dos sentimentos colectivos sobre a natureza; no entanto, as ciencias estritamente positivas analizaban esta desde os métodos empíricos, tratando de obxectivala e describila científica e rigorosamente. A fusión na xeografía de ambos os enfoques faría dela un referente constante para a paisaxe.

A xeografía aparecera como ciencia dentro do marco do positivismo na segunda metade do século XIX, mais comezaría xa no século XVIII a estender e ampliar os seus métodos e termos ao terreo das ciencias humanas, por mérito, sobre todo, do gran xeógrafo A. von Humboldt, un dos principais responsables da prolongación desta disciplina ata o terreo da estética: consideraba este que o estudo da natureza era imprescindible para a educación dos pobos, razón pola cal vía preciso incluír nos textos xeográficos consideracións estéticas, poéticas e 
morais. A nova orientación desta ciencia faría posible que a paisaxe combinase termos humanísticos e empíricos, feito que afectou tanto á teoría estética como á práctica pictórica. Con esta fusión e intercambios no terreo das interpretacións e descricións da paisaxe, no seu territorio combináronse obxectividade e subxectividade, sobre todo a partir do realismo, con inclinación cara a unha ou outra, segundo a época e a cultura en que se situase cada versión (Pena 1978).

Todo o que ata aquí fomos desenvolvendo explicaría a radical modernidade que foi asumindo o xénero ao longo da súa historia, ata romper os límites que se lle marcaran tradicionalmente (Pena 1997). De modo que, no que foi o proceso da arte contemporánea, a paisaxe constituíu unha peza fundamental, xa que o avance da contemporaneidade artística foi crebando os límites dos xéneros, os das artes e os do concepto de arte, sendo a paisaxe dos principais responsables destas preguntas: que é arte e que non é na cultura contemporánea? Onde están as súas fronteiras? Que é paisaxe e onde están os seus límites?

\section{IMPORTANCIA ACTUAL DA PAISAXE E DO PAISAXISMO}

Con todas estas bases na súa modernización non debe estrañarnos que, dentro do terreo das artes, novos conceptos de paisaxe se inserisen, por exemplo, no da escultura - a partir do surrealismo especialmente-, nin de que adquirise un papel cada vez maior no campo da arquitectura e o urbanismo; tampouco nos asombra que fose asumido polos termos da xeografía humana, ou analizado con novos ollos e novos conceptos teóricos no plano da publicidade e do turismo. A multiplicación das imaxes consideradas paisaxes saltou hoxe os marcos tradicionais do repertorio típico dos estereotipos do pasado. Tal ampliación do concepto levou á necesidade de denominacións novas no seu campo, máis coherentes para a realidade actual e a teorización daquel, e aceptouse o termo de "paisaxismo» para todos aqueles rexistros nos cales a paisaxe se estendeu da arte a outros territorios, o cal obriga a unha interdisciplinariedade na súa análise.

A complexidade actual deste paisaxismo estaba xa nas bases e nas fontes teóricas orixinarias de paisaxe de outrora. As poéticas de todas as áreas dedicadas hoxe a contribuír desde o paisaxismo a crear unha economía sustentable, que preserve o patrimonio natural, monumental e ecolóxico, montáronse sobre a aplicación ao mundo actual de 
teorías que arrincan dos séculos XVIII e XIX, en boa medida, e que deron pé a novas formulacións daquelas, aplicables ao noso tempo (Ábalos 2009, Brinkerhoff 1995).

$\mathrm{O}$ interese na paisaxe desde as perspectivas dos nosos días fai precisa a reflexión teórica, crítica e histórica sobre ela. Neste sentido, a importancia da historia da arte e dos seus exemplos de paisaxes simbólicas e históricas é evidente, xa que o paisaxismo abrangue tanto o feito físico como a construción estética ou o seu sentido cultural, así como as súas posibles identificacións, entre as cales están as territoriais -locais, rexionais, nacionais e globais_- as de clase ou as de xénero, coas súas implicacións políticas nun sentido moi amplo, xa que o recońecemento da relación entre estética da paisaxe e política do territorio é algo recoñecido hoxe.

Unha reflexión moi integrada no paisaxismo é a de que cada paisaxe —ou fragmento dela - posúe un poderoso "sentido do tempo». Mesmo tendo unha calidade principalmente espacial, é en esencia, ademais, imaxe da historia dese espazo. Tal idea non é unha invención do noso tempo, senón que orixinariamente foi concretada no século XVIII por Alexander Pope, nun poema dedicado a lord Burlington no ano 1731 . $\mathrm{Nel}$, na denominada literatura augusta inglesa, inaugurouse a visión de que son os lugares os que falan ao paisaxista "auténtico», que sabe escoitalos.

Aquela idea prerromántica daría vía a que o pleno Romanticismo, desde os seus sentimentos individuais -expresión en moitas ocasións dunha colectividade — vehiculase sentimentos de identidade nacionais, desde os nacionalismos reivindicativos da época da revolución romántica, crítica fronte ao poder napoleónico e defensora do diferencial de cada paisaxe e de cada pobo, que aspiraba a ser nación e aínda non tińa o seu Estado ou fora colonizado. Aquelas paisaxes románticas eran entón expresión da historia diferencial, reivindicada simbolicamente por medio da pintura deste xénero ou da literatura, así como da xeografía.

Mais aquela teoría e a súa terminoloxía ficaron soterradas durante longo tempo, en especial por causa das terribles consecuencias históricas e políticas dos nacionalismos para o século $\mathrm{xx}$, tras a primeira e a segunda guerras mundiais, as cales delataron traxicamente o sentido máis reaccionario daqueles co monstruoso exemplo do nazismo alemán. Todo o mundo progresista política e culturalmente anatematizaría o termo desde o canto aos ideais do internacionalismo, proclamado desde a loita de clases, cuxo ideario era sustentado polo socialismo, o comunismo e, ao seu xeito, polas democracias occidentais. $\mathrm{Na}$ arte de vangarda paradigmática e na súa teorización sobre a paisaxe, o obxectivo, consciente ou in- 
consciente, implícito na nova estética e ética daquela sería o da súa internacionalización de formas e espazos, mediante o reforzamento teórico e práctico da idea da autonomía da pintura e da importancia sobre todo do experimental, a cal xa comentamos anteriormente. Nese novo e rompedor ideal da paisaxe plástica importaba a materia, a construción e as estruturas propias da arte e a súa orixinalidade, non as identidades territoriais e menos nacionais. Un precedente deses modelos de paisaxe foi, por exemplo, A montaña de Sainte-Victoire, de Cézanne, intemporalizada como forma plástica nas súas diferentes versións, para alén da súa representación como lugar da historia da rexión. Iso era, polo menos, o que a crítica e a nova versión do moderno na historia da pintura lía naquelas paisaxes, desde a perspectiva da crítica e a historia da arte das vangardas na posguerra. A paisaxe de Cézanne foi unha lección para o cubismo de Picasso e Braque e para todo o seu ronsel, que habería ter longa herdanza e diferentes versións.

As abstraccións plásticas da paisaxe pasaron a un maior grao de universalización entrando na representación do cósmico, caso das Constelacións de Miró ou do Monumento a Apollinaire de Picasso, unha paisaxe celeste trasladada ao campo da escritura.

Mais a condición posmoderna, así como todo o que histórica e politicamente fixo precipitar e fragmentar a idea de progreso e modernidade, faría reflotar no terreo do paisaxismo as teorías e lecturas abandonadas do Prerromanticismo e do Romanticismo. Naturalmente, non é unha volta atrás, nada ten que ver cos rexistros identitarios da segunda metade do século XIX, se ben as ideas do XVIII e do século seguinte son aproveitadas nas teorías e prácticas do paisaxismo actual, a partir da fragmentación e a revisión de puntos de vista actualizables. $\mathrm{O}$ mundo globalizado precisa unha busca nas paisaxes do "sentido do tempo», da historia do lugar no cal se ha construír ou se ha erixir unha escultura, sexa a paisaxe urbana, a rural ou a industrial, de tal maneira que as cuestións sobre o pintoresco, sobre todo, e o sublime se puxeron de novo sobre o terreo do paisaxismo.

Por outra banda, a historia da arte, moi en especial a da pintura, comezaría a repensar o seu relato na posmodernidade, en particular a partir de 1970, e máis claramente nas décadas posteriores. Desde o punto de vista da crenza no moderno como universal, conviñeran ás análises histórico-artísticas termos de tempos estilísticos e de épocas, preferentemente como segue: cada estilo tería un tempo e un centro de emisión, que crearía os modelos para a periferia. A medida que 
aqueles se afastaban do centro emisor ou da época primeira en que apareceran, irían desvirtuándose, converténdose en heterodoxos, ata poder negarse a existencia de tal estilo nas periferias. Caída a teoría difusionista en xeral, falaríase da multiplicación dos centros e dunha clase de interacción diferente entre centros e periferias, manténdose en moitos casos que desde tal perspectiva os modelos periféricos fornecían tamén ao centro os do seu territorio cultural e antropolóxico. Así se cuestionou de forma importante aquel estudo dos modelos e os obxectos artísticos como saídos de centros radiantes, por riba do espazo e do territorio en que se producían. A consecuencia diso, a crítica de arte e a historia da arte, mesmo a referente á arte contemporánea e á vangarda, comezou a utilizar hai unhas décadas, nas súas análises, termos antropolóxicos e territoriais. Por exemplo, nas análises de Rosenblum sobre Picasso, ou nas de Brown sobre este mesmo pintor, aparece a cuestión da identidade antropolóxica do artista e os seus estilos, da súa identidade — no terreo do diferencial — coa cultura artística española (Rosenblum 1999, Brown 1999).

Desde este punto de vista, no que á paisaxe española contemporánea se refire, deberemos, pois, rastrexar, a partir dunha metodoloxía actual e interdisciplinar, non só o universal dela, senón o diferencial na súa historia, marcada por un territorio cultural periférico moi específico.

\section{PAISAXE ESPAÑOLA, PAISAXISMO E IDENTIDADE NACIONAL}

No caso da historia da paisaxe española na arte hai que engadir unha serie de consideracións, para poder comprender a importancia e o valor simbólico que tivo o xénero en España, xa que aquí non foi só apéndice mimético da paisaxe realista francesa ou dos modelos impresionistas, senón que lles achegou a eles unhas diferenzas e heterodoxias, as cales nos abren os ollos á importancia dos «modos» estilísticos das periferias nas análises da historia da paisaxe, desde a perspectiva metodolóxica e terminolóxica da posmodernidade.

En primeiro lugar, o noso país non tivo practicamente unha pintura de paisaxe ata moi serodiamente; desde logo, antes da pintura contemporánea a importancia dela foi pouca, se o comparamos coa maioría das escolas europeas. Mentres que o Premio de Paisaxe Histórica se crearía en Francia en 1817, a primeira cátedra de Paisaxe na Es- 
cuela de Bellas Artes de San Fernando de Madrid creouse en 1844; ocupouse dela Jenaro Pérez de Villaamil, un romántico tardío de grande interese, mais que lles pareceu aos novos discípulos con ensinanzas obsoletas para as ansias de modernidade realista que eles tiñan (Arias Anglés 1980, 1986). Tal era o caso dun dos pintores de paisaxe español máis interesante de fins do século XIX, alumno seu ata marchar para Francia, onde se uniría ao realismo: falo de Martín Rico, quen nas súas memorias se referiría ao anticuado das súas ensinanzas para os tempos que corrían (Rico 1906).

É certo que na Escuela de la Lonja de Barcelona se iniciara un pouco antes a aprendizaxe da paisaxe realista con Martí Alsina, o cal en Cataluña impulsaría o xénero e a súa modernización, se ben tardaría un pouco máis en se producir alí a conciencia da súa identificación coa cultura e a historia catalás, ata que chegase a escola de Olot ou mesmo o Cercle de Sant Lluc; polo resto de Espańa xerouse e estendeuse máis, nun principio, o realismo da Escuela de Bellas Artes de San Fernando, nunha liña de identificación das modernas paisaxes co español.

Sería a partir da toma de posesión da cátedra de Paisaxe na Academia de Bellas Artes de Madrid polo belga criado en Málaga Carlos de Haes cando a paisaxe realista comezase a ensinarse nela, á vez que foron crecendo significativamente os alumnos e o número de cadros deste asunto aumentou de forma sinalada nas exposicións de Bellas Artes. Este feito produciuse en 1857. O concurso de acceso á mencionada cátedra o mestre belga gańaríao cun cadro ben representativo do moderado realismo no cal iniciou os seus discípulos: refírome a Vista do Palacio Real desde a Casa de Campo, hoxe no Museo de la Academia de San Fernando. Esta pintura amosa unha vista de Madrid desde o outro lado do Manzanares co Palacio ao fondo; nela o carácter cromático, o reverdecemento da paisaxe, os rexistros tonais moi graduados, todo o conxunto ambiental está na corrente dun realismo belga decimonónico moi cargado de receitas académicas do xviII, que era o que el aprendera en Bruxelas con J. Quineaux, o cal nunca tivo o radicalismo teórico nin técnico de ningún realista da escola de Barbizon. As ensinanzas do seu mestre belga introducírano nas técnicas novas do realismo do XIX, mais moderadas en Bélxica por unha longa tradición paisaxística, cargada ao longo dos séculos polas normativas oficiais, que finalmente o obstaculizaran para adoptar a moderna radicalidade do realismo francés (lámina 1).

Aquel era o realismo de Haes, escandaloso e moi novo para España, mais cargado de resaibos idealizadores academicistas e de pouca autenticidade á hora 


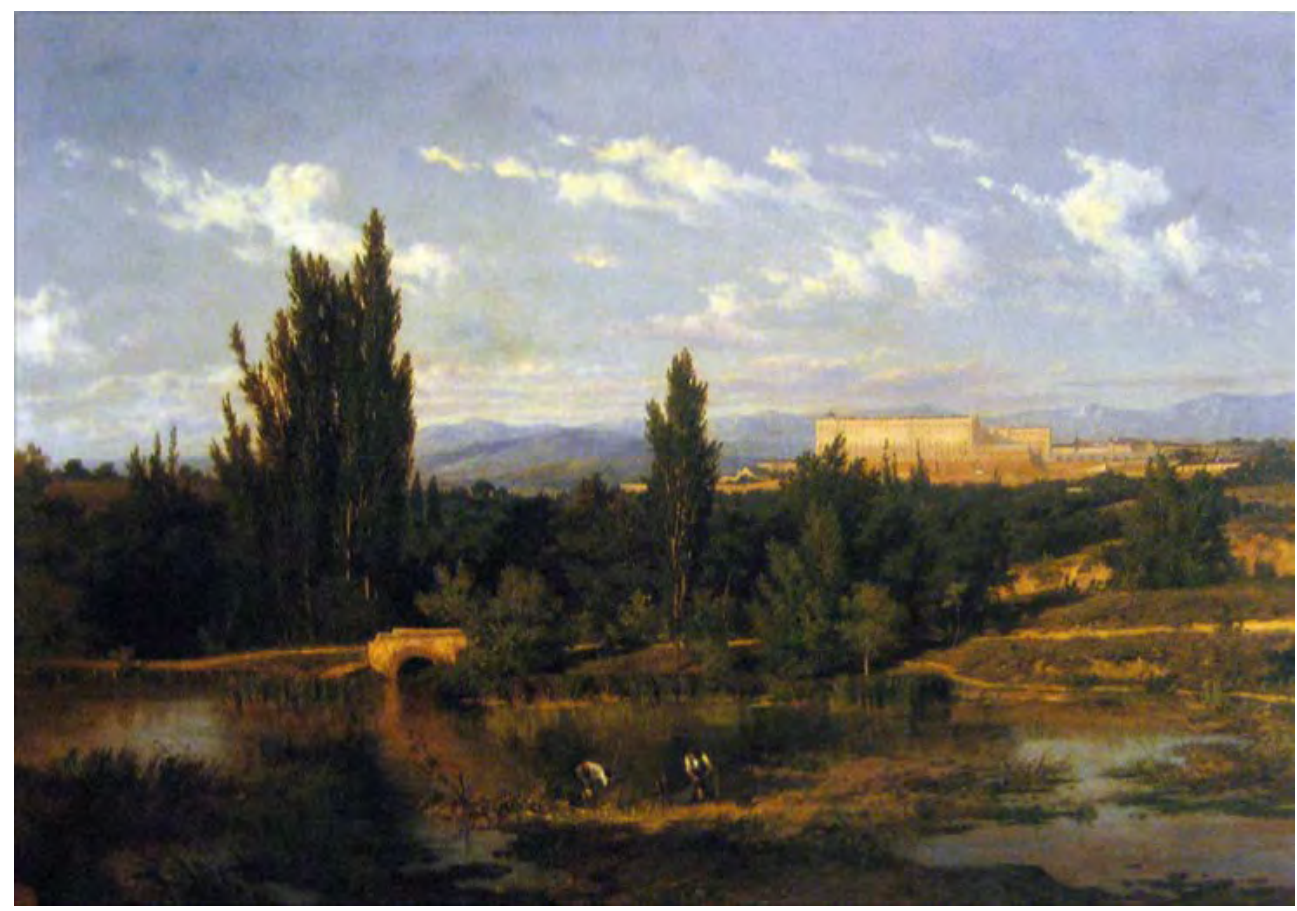

Lámina 1. Carlos de Haes, Vista do Palacio Real desde a Casa de Campo, 1867.

de representar a realidade da paisaxe da meseta española. Con todo, o seu papel foi central no avance da pintura de paisaxe en España cara ao camiño da modernización de finais do século XIx. Foi fundamental como introdutor nos modos realistas europeos modernos, que asombraron os seus compañeiros de oposición e boa parte da crítica, a cal moito non entendía da nova linguaxe do xénero, máxime cando ía avanzando nos seus pequenos estudos cara a unha visión máis auténtica do territorio. Mesmo se comezou a introducir na estética de recreación do solo xeolóxico real de certas paisaxes peninsulares, como resultado do seu contacto coa nova ciencia xeolóxica española, que a través da súa pintura comezaría a se transformar en estética, integrándose nas paisaxes pintadas: os estudos de pequeno tamaño dos Picos de Europa, os das terras de Aragón arredor de Jaraba, Nuévalos e o Monasterio de Piedra, nos cales se sentía moi liberado dos resaibos académicos, autentificando os picos graníticos, os terreos calcarios, as curiosas formacións do territorio aragonés acendido e terráqueo, son bos exemplos disto. 
As razóns do avance nos seus estudos cara a esa autentificación xeolóxica do terreo foron o seu contacto coa xeografía e a xeoloxía, a partir do coñecemento dos textos de Casiano de Prado — sobre os Picos de Europa e a provincia de Madrid - e da súa menos coñecida amizade con Federico de Muntadas, membro da familia do mesmo apelido, propietarios do Monasterio de Piedra tras a desamortización, importante naturalista e espeleólogo catalán, responsable do conxunto da descuberta das grutas pintorescas do mencionado mosteiro - como a de Iris_- unha paisaxe subterránea resultado dun fenómeno kárstico, así como da creación do primeiro centro de piscicultura de España, para naturalizar no río Piedra a troita común e o caranguexo ibérico. Por fin, nos últimos anos da súa vida Haes comezaría a pintar cadros do Guadarrama desde a visión do máis novo naturalismo, aprendido dos seus máis avanzados e novos alumnos (Pena 1978, 1983b, 1985; Gutiérrez Márquez 2002; Casado de Otaola 2010) (lámina 2).

Moitos foron estes: entre os primeiros estaban Aureliano de Beruete y Moret, Jaime Morera y Galicia —o máis fiel ao estilo do mestre-, Agustín Lhardy e Francisco Gimeno, entre outros moitos; dentro do grupo dos máis novos atopábase Darío de Regoyos. O conxunto de todos eles foron os artífices da creación dunha moderna paisaxe española con características moi propias, cun profundo sentido simbólico, agochado tras a sinxeleza que oculta as súas intencións representativas.

Estas construcións pictóricas fóranse alimentando do pensamento liberal español máis crítico xurdido da Revolución de 1868, a cal fora un fracaso do liberalismo isabelino. Ante tal feito e en plena decadencia espańola ao final do seu imperio colonial, a corrente do novo liberalismo procuraría no marco do rexeneracionismo unha nova política, unha nova ética e unha nova estética, para unha España rexenerada e moderna, desde as fontes da súa auténtica cultura, a súa verdadeira e máis propia tradición, unida á asimilación das novas correntes científicas e estéticas europeas, que finalmente se haberían expresar a través da identificación dunha nova imaxe da nación, que quería deixar atrás as enfáticas e alienadas imaxes da pintura de historia, por máis que esta seguise a ter un prestixio nas exposicións nacionais, como era o caso de Pradillo.

Unha serie de personaxes e de institucións tiveron o protagonismo no arrinque desa idea: inicialmente en Madrid o Colegio Internacional, fundado por Nicolás Salmerón, no cal participaría Giner de los Ríos; máis tarde, este último 


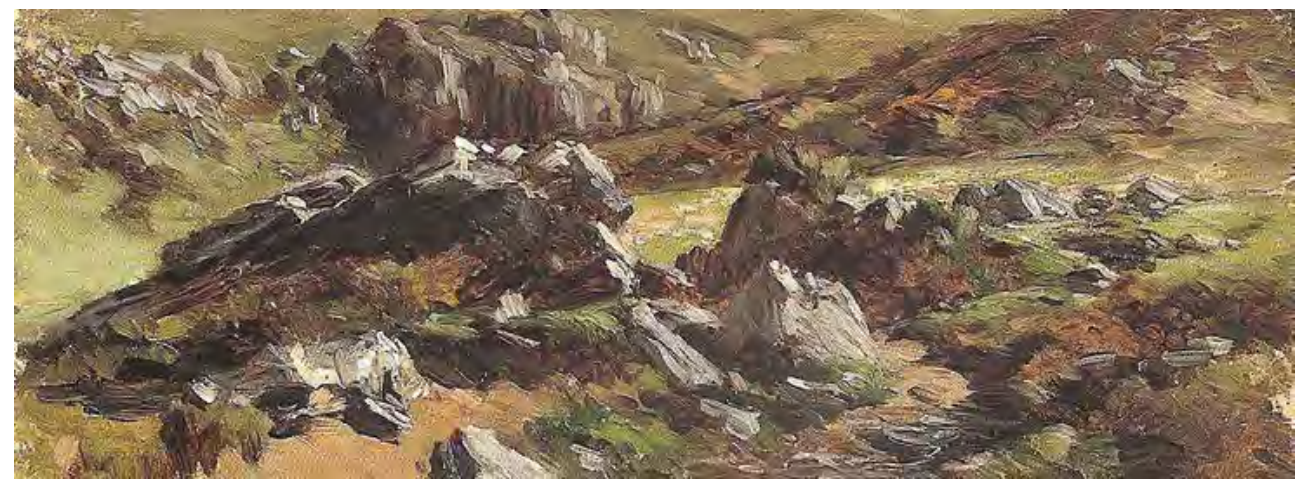

Lámina 2. Carlos de Haes, Pedriza (Picos de Europa), c. 1872.

intelectual, como fundador e protagonista da Institución Libre de Enseñanza (ILE), iniciaría o relato intelectual, científico e político sustento da nova estética dunha boa parte da moderna paisaxe española. Unha das razóns polas cales a paisaxe tivo un rol esencial no novo relato de España sería a de que o pensamento krausista, no cal se fundou gran parte do pensamento de Giner, consideraba que boa parte da rexeneración dun país e da súa solidez estaba nunha boa educación. Nela a xeografía debía ter un papel fundamental: coñecer cientificamente os territorios e paisaxes de cada país e nación era para os institucionistas básico á hora de autentificar os sentimentos de liberdade nacionais. O cońecemento da xeografía moderna non impedía — como vimos xa- que a través da representación do territorio desde os procedementos descritivos da ciencia se expresasen tamén os sentimentos correspondentes a cada paisaxe, e simultaneamente afirmaba as bases positivistas e realistas das novas correntes estéticas daquela. Deste xeito a xeografía moderna foi asumida polos xeógrafos da Institución e afíns a ela, de maneira que un dos máis destacados e europeístas dos xeógrafos españois, José Macpherson —ilustre membro da Institución — habería ser fundamental na descuberta de novas paisaxes españolas e de novas maneiras estéticas, as cales directa ou indirectamente pasarían á pintura e logo á literatura finisecular.

Un dos descubrimentos desta nova estética foi o do espazo central peninsular ocupado pola meseta, descuberta polo xeógrafo Von Humboldt nunha viaxe a España a fins do XviII. O éxito en pór de moda - en España e en Europa- Castela foi do institucionismo: un modelo de territorio feo segundo as consideracións an- 
teriores do concepto de paisaxe, non aceptado esteticamente ata entón, foi elevado polo ideario da ILE a unha categoría estética superior, para ser difundido en especial un pouco máis tarde polos escritores da Xeración do 98 e traspasarse tal sublimación do espazo central ás xeracións subseguintes; esa idea deixaría o seu ronsel aínda nas xeracións de artistas abstractos españois da década dos cincuenta e sesenta, nunha secuencia continua de versións e lecturas estilísticas diversas da mesma terra, que se situou xerarquicamente durante longo tempo en primeira posición, como unha das imaxes máis representativas de España e das súas paisaxes.

As paisaxes periféricas representaríanas secundariamente, agás no caso da paisaxe valenciana representada por Sorolla, o cal logrou competir en españolidade co castelán durante a fin de século e aínda máis, porque este pintor era a outra cara da Espańa daquela época, representando a sensualidade lúdica do mediterraneísmo do levante, a través dun rexionalismo potente pola fermosura da súa luz e tamén pola saneada economía da rexión, alén de que o artista valenciano soubo dar ás súas imaxes unha publicidade e unha venda non só nacionais senón tamén internacionais, que levaron o sorollismo a estenderse a toda España; aparecéronlle discípulos ao valenciano de norte a sur, ata chegar a América do Norte e á Hispanic Society, para a cal por encomenda de Huntington pintaría os murais que representaron as diferentes rexións do noso país (lámina 3).

Volvendo á descuberta estética de Castela: as primeiras versións pintadas dela, seguindo a mentalidade estética do institucionismo, habería dalas o pintor Aureliano de Beruete y Moret. Este artista foi socio fundador da Institución Libre e grande amigo de Giner e participou en tarefas de ensinanza pictórica nas aulas da ILE e nas súas excursións pedagóxicas; foi tamén un dos principais protagonistas da Sociedad para el Estudio del Guadarrama, que tivo a súa iniciativa en Giner, alentado inicialmente polo matrimonio Riańo-Gayangos, o cal o introduciu no amor polo excursionismo moi á inglesa e no seu fervor pola serra do Guadarrama, como paisaxe ata daquela sen explotar polo paisaxismo espańol.

Beruete tivo unha biografía privilexiada, xa que era de familia rica e aristocrática, conectada ademais co poder político por medio do seu tío Segismundo Moret. Todo isto permitiríalle dedicarse aos seus afáns artísticos como pintor, historiador da arte, crítico e coleccionista, sen precisar supeditarse a normativas oficiais para conseguir unha viabilidade económica da súa vocación pictórica, que puido exercer moi libremente. Foi deputado ás Cortes, mais abandonou a política. Licenciado en Dereito, 


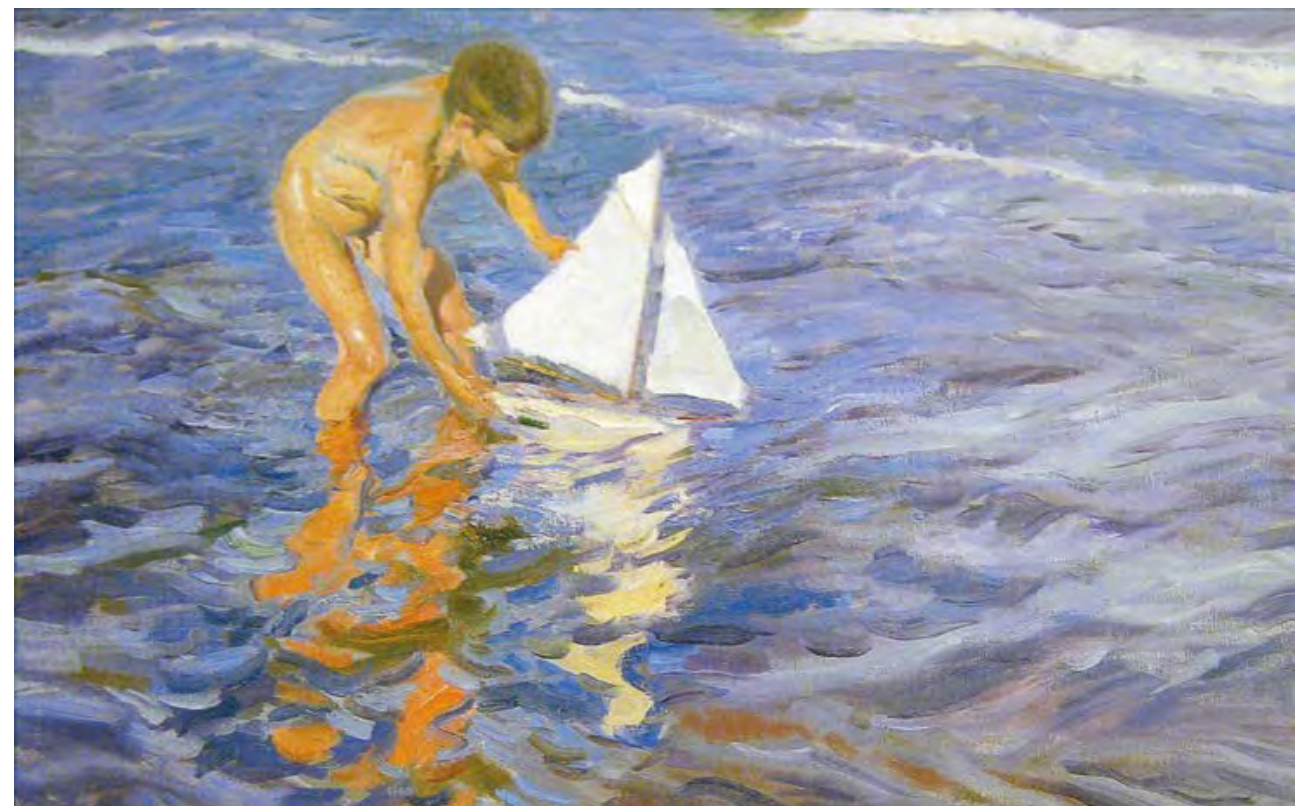

Lámina 3. Joaquín Sorolla, O balandriño, c. 1905.

realizou a súa tese de doutoramento sobre a Prusia, mais a súa principal actividade habería ser a de pintor e intelectual, interesado no ideario liberal rexeneracionista e na nova paisaxe e paisaxismo. Como crítico escribiu numerosos artigos e participou en varias comisións de exposicións nacionais e internacionais, apoiando decididamente o mozo Sorolla, quen realizou na súa casa e estudio de Martínez Campos en Madrid a máis completa mostra da obra deste pintor, tras a súa morte en 1912. Viaxou por Europa en numerosas ocasións en viaxes de pracer, nas cales se dedicaba á pintura e a contactar cunha boa parte dos críticos e historiadores da arte estranxeiros da época, cos cales mantivo relacións profesionais e de amizade. Un dos seus textos máis importantes foi o seu libro sobre Velázquez, que publicaría en francés, alemán e inglés, e que, moi significativamente, non sería traducido ao castelán ata finais do século xx (Beruete 1898, Calvo Serraller 1990: 58-67).

A súa gran cultura e o seu coñecemento do moderno que se facía en Europa, unido isto a unha moi concreta posición ideolóxica e cultural liberal, farían del un dos modernizadores máis representativos dos novos gustos e orientacións estéticas naquela explosión de paisaxes finisecular. Os seus escenarios españois foron nu- 
merosos e tamén os europeos, en especial os franceses, ingleses e suízos. Con Haes e Entrala pintou nos Picos de Europa, descubertos plasticamente polo primeiro, apoiado nos mapas e sendeiros de Casiano de Prado. Percorreu tamén co seu mestre gran parte de Espańa, pintando en diversas rexións. Mais, de entre todos os seus escenarios, o máis abundante e máis orixinalmente pintado foi o mesetario: Castela poríaa de moda por vez primeira el na pintura española. Representou as paisaxes da chaira inmensa na lińa da estética finisecular europea de Rilke ou Maeterlinck, converténdoos en protagonistas do novo paisaxismo, que asumiu e personalizou; integrou a paisaxe chá, que contrastaba intencionadamente cos fondos montañeses, en especial coa serra de Guadarrama, estudada nos seus camiños, xeografía e xeoloxía polo institucionismo; esa paisaxe desolada expresión do sublime do baleiro, máis a das vellas e históricas cidades castelás vistas a través do rural da contorna e os seus arrabaldes, ou do seu interese xeolóxico, como iconas paisaxísticas e históricas do pasado español, como lugares e escenarios naturais e monumentais nos que latexa o "sentido do tempo», foron imaxes que o mestre cuñou para a rexeneración estética e pictórica do país. Á fin e ao cabo Beruete e o pensamento crítico liberal español rexeneracionista rescatarían parte da visión ilustrada, da mirada de Jovellanos ou Ponz, unindo a ela a influencia estética do decadentismo literario europeo.

Un dos textos fundadores da estética que desenvolveu plasticamente este pintor e unha boa parte dos discípulos de Haes foi Paisaje, de Giner de los Ríos, publicado por primeira vez en 1885 . Nel aparecían as fontes para o pensamento e para a práctica do novo paisaxismo: un canto á meseta, ás súas chairas, ás súas serras e montañas, polas súas calidades xeográficas, xeolóxicas e dunha modernidade estética no conxunto dos novos escenarios finiseculares occidentais, ademais —e isto é moi importanteporque, segundo Giner, alí a beleza acada un sentido moral e espiritual, superior á sensualidade doutras paisaxes; meteuse mesmo en cuestións de xénero, falando da xerarquía superior deste escenario da España central, considerándoo masculino respecto ao carácter estético feminino do norte de España, pońendo de exemplo Galicia. En fin, as consecuencias da mentalidade patriarcal non deixaron de aparecer nin sequera entre os liberais máis radicais, nin tampouco nese territorio tan supostamente falto de intencións da paisaxe realista (Giner de los Ríos 1915; Pena 1983c, 1996).

Beruete estaba empapado daquela estética. El foi quen —compartindo ideas de Giner e de Cossío, ás cales engadiu as súas propias interpretacións delas e as súas calidades pictóricas extraordinarias - se situou nunha lińa de moderniza- 
ción da pintura española, que non quixo esquecer a tradición da nosa pintura do XVI e do XVII, corta e exigua en exemplos paisaxísticos, mais, para esta nova estética, insubstituíbles e esenciais á hora de atopar unha vía diferencial para a escola española da paisaxe moderna, remitíndonos en especial ás paisaxes de Toledo de El Greco, aos fondos madrileños e montańeses do Guadarrama nos retratos de corte de Velázquez e, finalmente, ás paisaxes de Goya. Beruete e a nova estética quixeron modernizarse dentro dos parámetros modernos europeos, mais sen abandonaren as raíces da pintura española. Isto explica que o mestre non aceptase o tecnicismo impresionista francés das cores complementarias ata 1900, malia que os cońecese de moito antes, porque lle pareceu ata daquela que a modernidade intrínseca de Velázquez ou Goya, descubertos como fontes da modernidade pictórica occidental polo romanticismo europeo de Delacroix ou por Manet cando viaxaron a España, era o punto de partida correcto para expresar á vez a modernización da paisaxe española realista en termos europeos e a posibilidade de identificación con ela por parte do novo ideario do nacionalismo liberal español, que xerou esta imaxe identitaria, baseada nunha nova representación emblemática do país, que viría a suplantar á vella representación lentamente.

Beruete comezou a pintar nun estilo moi próximo ao do seu mestre, mais, a medida que foi coñecendo a pintura realista finisecular francesa e inglesa e madurando o seu ideario estético, o seu estilo mudou, modernizouse dentro de novos parámetros, exemplo dos cales sería, por exemplo, Paisaxe de arredores de Segovia; nel a chaira case desértica fai do chan despoboado e terráqueo, así como do ceo, un novo modelo inédito ata daquela, de grande éxito para a pintura das próximas xeracións (lámina 4).

Outro dos numerosos exemplos do gusto de Beruete, claramente ligado ao relato paisaxístico institucionista, sería o daqueles cadros nos cales aparecen El Pardo, El Plantío, os arredores de Madrid coa serra do Guadarrama aló no horizonte. A sinfonía de verdes arboredos nos primeiros planos, recollendo a beleza das acińeiras e do auténtico arboredo castelán, unido á modernidade cromática coa que interpreta a luz sobre a neve dos cumios nos fondos montañeses, nos cales a partir de 1900 fai un xogo de cores complementarias coma as dos impresionistas franceses, dominando o violenta e o morado, que ademais servían para expresar pictoricamente a oxidación de certos minerais, aos cales se referira Giner no texto mencionado. Este escenario, o encadramento e o estilo, só impresionista 
nos planos mencionados, mais de tradición realista e española velazqueña nos primeiros, recolle os fondos de certos retratos de corte de Velázquez, que logo tomaría tamén Goya: do primeiro magnificaron Giner e Beruete, canda toda a estética institucionista, o fondo do retrato de Baltasar Carlos para o Salón de Reinos do Palacio del Buen Retiro coa serra madrileña detrás, efixie do príncipe herdeiro que fora a esperanza da dinastía dos Austrias e de España, a cal iniciaba a súa decadencia, aínda máis imparable pola súa temperá morte. A súa imaxe pintada e a frustración da súa desaparición haberían perseguir historiadores e artistas españois durante tempo e tempo, non só pola súa beleza e orixinalidade na paisaxe, no cromatismo de azuis, verdes e rosas, senón tamén polo seu sentido simbólico e de dó nel pola historia de España (Pena 1998, 1983a; Ortega Cantero 1992).

Ademais estaba neses cadros de Beruete reflectida a descuberta xeográfica do Guadarrama pola xeografía e a xeoloxía, así como a sublimación de toda a cordilleira

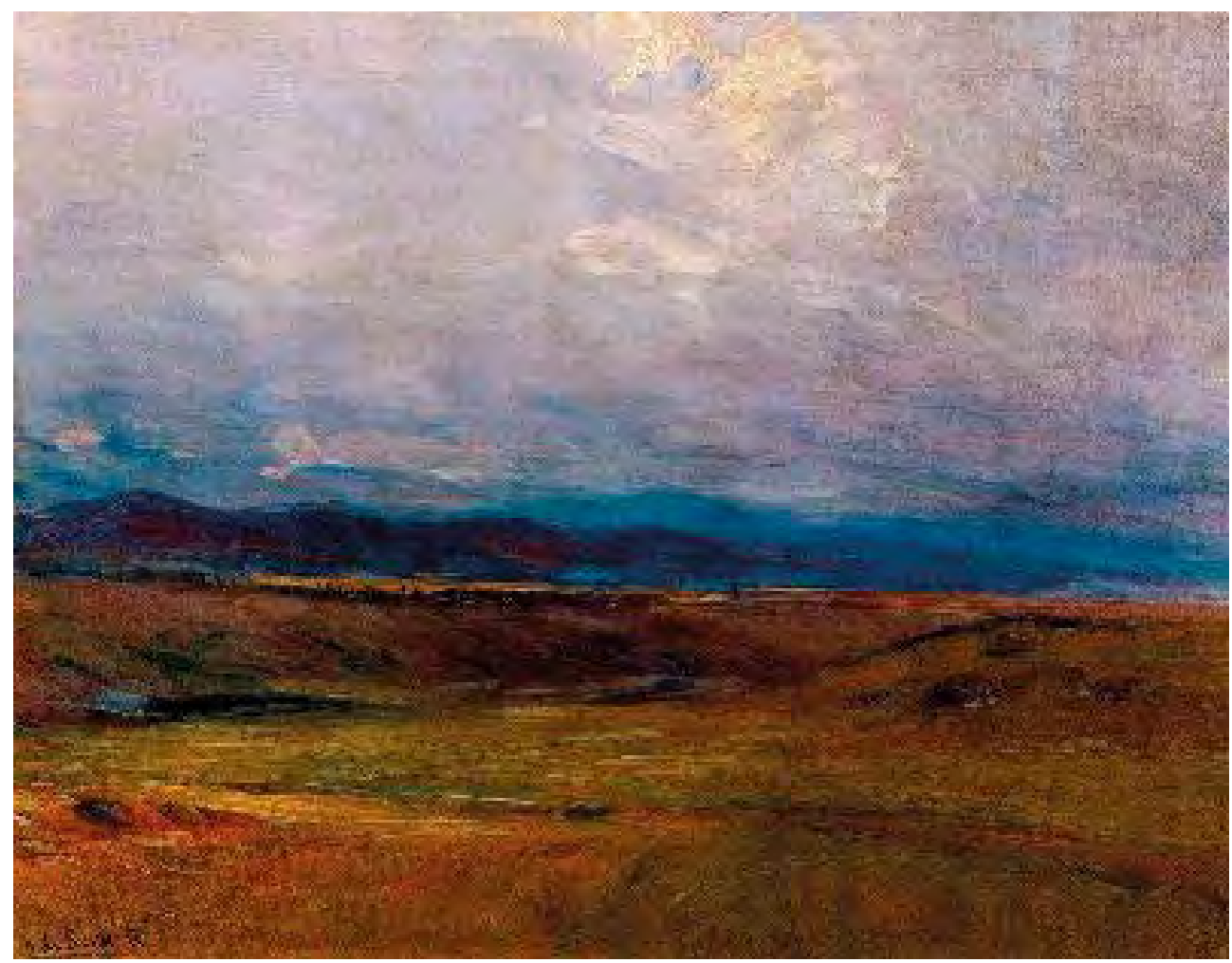

Lámina 4. Aureliano de Beruete, Segovia, 1908. 
central e o amor por ela da súa xeración e posteriores. Comparado unha e outra vez polos estetas do momento cun corpo humano o mapa de España, vían na reprodución e interpretación artística das imaxes da cordilleira a «espiña dorsal» da nación. Todo isto explica que un dos escenarios paradigmáticos do mestre madrileño fosen as varias vistas do Guadarrama desde El Plantío (lámina 5).

Outro dos encadramentos repetidos polo mestre foi o das cidades históricas da meseta: Ávila, Segovia etc. Ve tanto en Toledo como en Cuenca a beleza xeolóxica, que crea cortes bruscos na paisaxe, ribazos, cerros, foces creadas polos antigos ríos, conformando a orixinalidade dunha paisaxe máis identificable coa imaxe diferente de España ca os verdes do norte. Iso e a soidade decadente do patrimonio monumental de todas estas cidades ancestrais, recordos da pasada historia do país e as súas glorias entón caídas, atráeno a el e os escritores da nova Xeración do 98, a cal educarían sentimental e esteticamente o pensamento institucionista e as correntes europeas, como nos haberían dicir Antonio Machado ou Azorín ao falaren da súa identificación coa pintura de Aureliano de Beruete, do cal o segundo posuía polo menos un cadro, que hoxe se conserva na súa casa-museo de Monóvar. Nestes escritores o uso da substitución do pintado polo escrito, polas

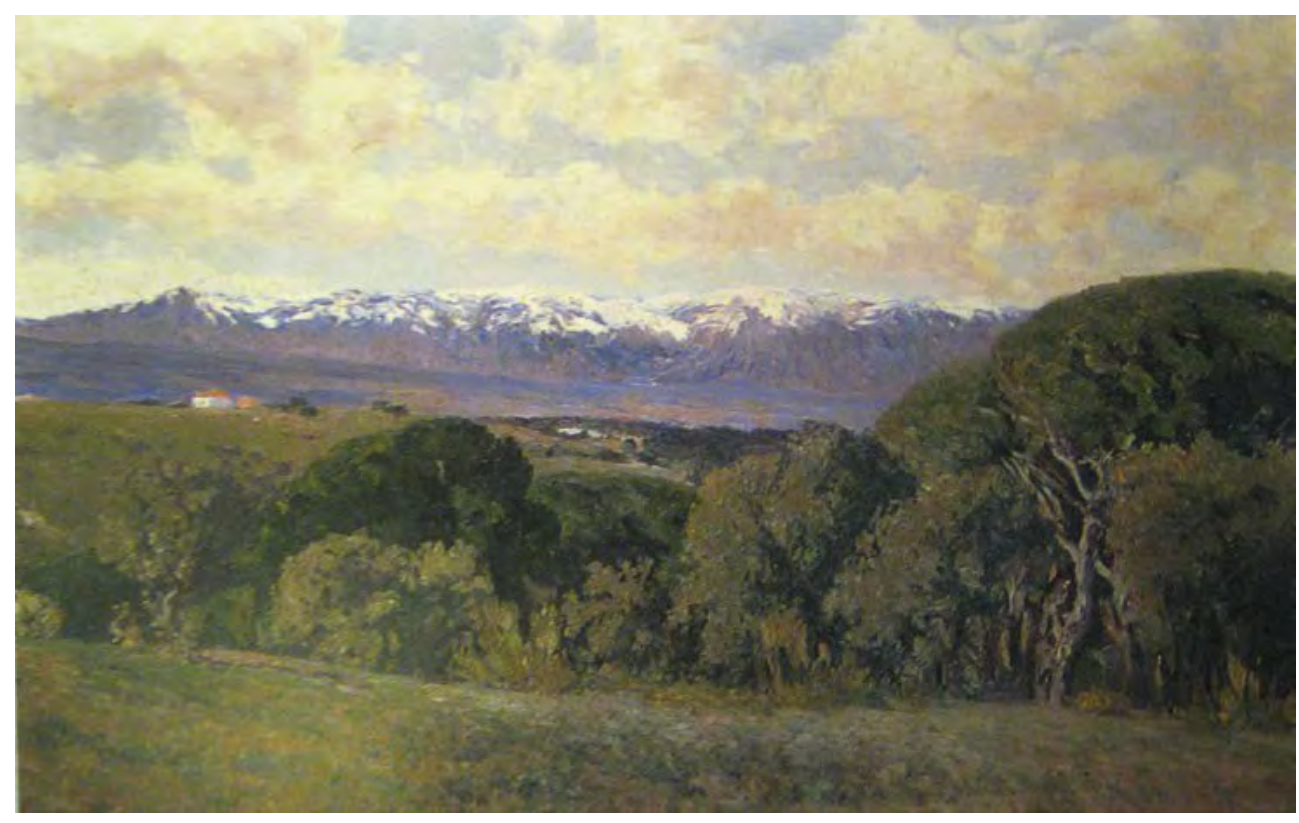

Lámina 5. Aureliano de Beruete, Guadarrama desde El Plantío, c. 1911. 
palabras, aproximaríaos a numerosas paisaxes pintadas polos paisaxistas da época; de feito, o seu coñecemento da pintura española antiga e contemporánea é moi importante neles: ese exercicio de ekphrasis haberíase repetir ao longo da literatura española; Azorín, por exemplo, chegaría a dicir que cando se puña na máquina de escribir se sentía coma cos pinceis de pintor na man (Jurkevich 1999).

Toledo, máis ca ningunha das outras cidades mencionadas, converteríase nun dos emblemas nacionais máis queridos por aquel mundo do pintor, en especial pola liberalidade de ter convivido nela as tres grandes culturas relixiosas do país; tamén polo seu pasado imperial e, alén diso, polo seu enclave dentro dunha foz do Texo de extraordinario valor xeolóxico, ao que se engade a orixinalidade do cigarral como unidade agraria singular, que encinta as contornas rurais do gran cerro. Son marabillosas as vistas de San Juan de los Reyes e de todo o skyline da antiga urbe desde os arredores, perspectiva desde a cal a pintaría en numerosas ocasións, se ben creo máis modernos - radicalmente pegados á nova estética científica da poesía do solo e dos seus minerais - aqueles cadros que enfocan a foz do río en primeiro plano cos seus ribazos refulxentes de micas reverberando ao sol impenitente de Toledo: este fenómeno natural e as súas consecuencias estéticas son máis ca un tema, o que a pintura europea máis moderna habería chamar un motivo para experimentar coa cor, a luz e o movemento da auga (lámina 6).

Darío de Regoyos casaría cunha filla de Beruete e, malia que en relación tan directa con el, este pintor, nado en Ribadesella e afincado durante tempo no País Vasco, amaba máis especialmente a luz do norte. Marchara a París e logo a Bruxelas en 1879, onde entrara en contacto con Albéniz e con Arbós, así como co expresionismo e o postimpresionismo puntillista belga, que compartiría o mundo literario do simbolismo daquel país. Participou no grupo L'Essor e na creación dos xx. Acompañou o escritor Verhaeren nunha viaxe por España, da cal sairía o libro España negra, que el ilustrou con tremendismo expresionista ou con inxenua e candorosa visión de paisaxes urbanas ou rurais. Sería un maldito en España. Só no País Vasco foi considerado debidamente nas exposicións da Asociación de Artistas Vascos. Pois ben, volvendo ao asunto do gusto na paisaxe española polos escenarios da meseta, Regoyos, porén, vería en Castela a imposibilidade de representar os matices cromáticos: non gustaba dela para pintar, non lle interesaba a súa luz esmagadora. Non obstante, acabaría por pintar as súas paisaxes, declarando nunha carta a Losada que llos pedía o seu marchand en París, posto que alí tamén se puxeran de moda. Este dato demostra como entre a 


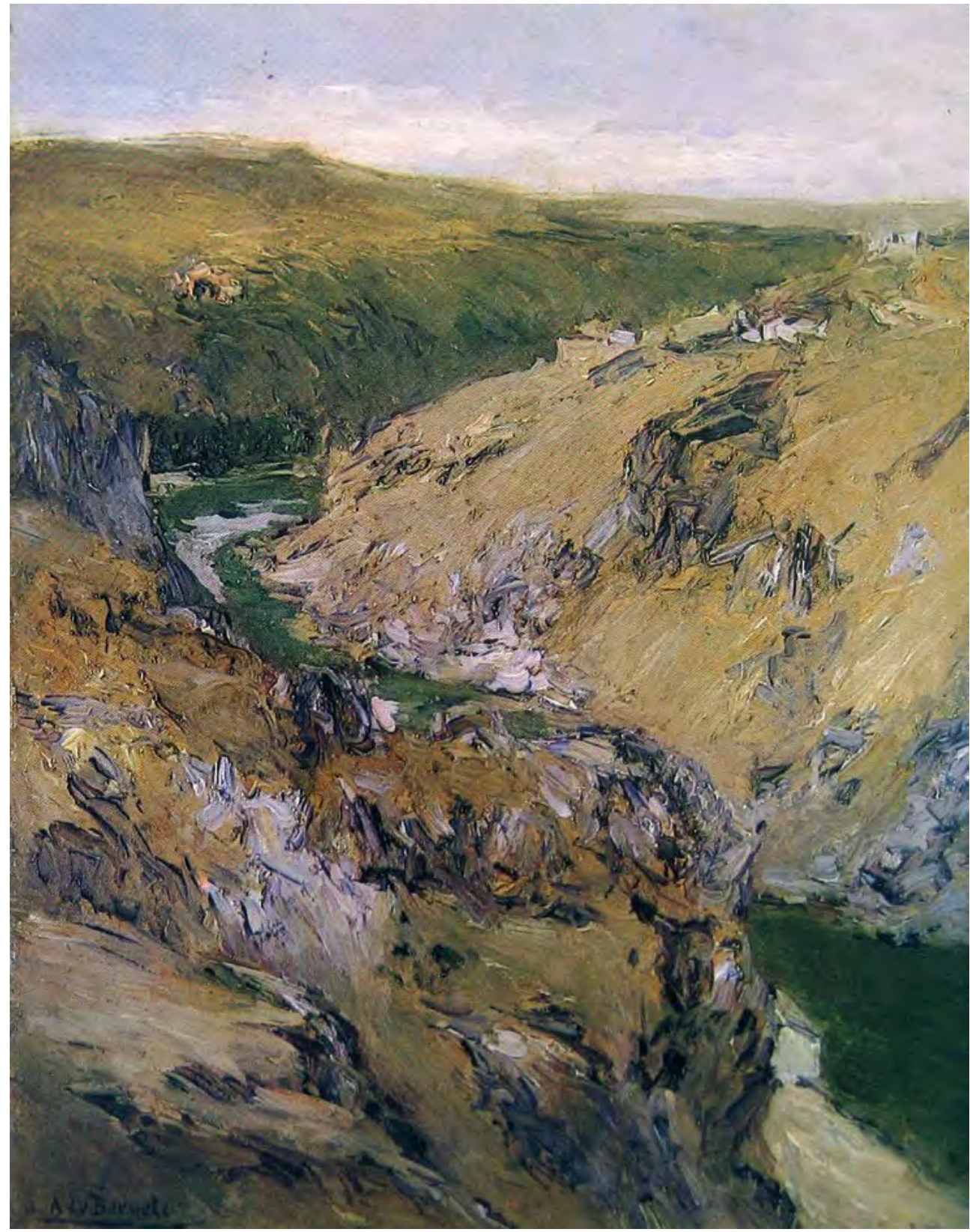

Lámina 6. Aureliano de Beruete, A foz do Texo en Toledo, c. 1911. 
hispanofilia europea, para alén da imaxe de Andalucía —os touros ou o flamenco-, chegara tamén a moda da identificación de España coa Meseta Central. Así que Regoyos faría fermosísimos cadros puntillistas da cidade de Burgos ou de Medina del Campo e Peñafiel (Tussell 1989).

\section{NOVECENTISMO, NACIONALISMOS E REXIONALISMOS}

Así mesmo, a Xeración do 14 e o chamado Novecentismo español haberían ser debedores desta paisaxe: cando Maurice Barrès foi a Toledo por vez primeira en 1902 acompañaríao Beruete para o introducir na cidade, segundo nos conta o escritor no prólogo introdutorio ao seu libro sobre El Greco e o misterio de Toledo (Barrès 1914). Este era outro dos atractivos da cidade, a presenza da sombra de El Greco nela, aquel visionario manierista cretense pasado pola escola de Venecia, que, segundo Cossío escribira na biografía histórica e estudo que faría sobre o pintor, se espańolizou supostamente, integrando nos seus estilos bizantinizante e veneciano un carácter espańolizador, na etapa en que se identificou co misticismo e co seu sentimento relixioso, así como en certos cadros nos cales asumiría unha porcentaxe do realismo hispano, isto segundo o historiador da arte da Institución: esta era unha das ideas daquel nacionalismo liberal da época, a de que existía un estilo español histórico, sutilmente redefinido unha e outra vez a partir dos estilos renacentistas heterodoxos da nosa arquitectura — sobre todo a do chamado plateresco-, do realismo barroco na pintura de Velázquez ou Zurbarán e nas teorías sobre el, ou da heterodoxia de Goya en relación coa modernidade. Esta idea estaba dentro do marco daquel ideario do novo nacionalismo español, o cal coincidiría por entón en tal idea con calquera dos outros nacionalismos europeos. A existencia de supostos estilos rexionais ou nacionais é difícil de encaixar na teoría e na retórica da estilística, se ben os arquitectos e teóricos da arquitectura foron os que máis afinaron na existencia de tales, negándolles o nivel e a calidade de estilos, mais aceptando o da súa existencia como «modos» estilísticos (Hernández de León 1985).

$\mathrm{O}$ Toledo de Barrès era o do seu grande amigo Zuloaga, que tiña auténtica paixón por El Greco e pola cidade. O pintor vasco amaba Castela, Toledo, Segovia, El Greco e o seu misticismo estrafalario, que poría de moda en París, 
onde triunfou extraordinariamente coa representación dunha España moi antiluminista e antisensual ao estilo Sorolla, chea de personaxes populares castizos e con frecuencia esperpénticos, así como de retratos sempre con fondo de paisaxes; así mesmo, tamén pintaría algúns sen figuras. A súa idea da paisaxe castelá en Pedro el Botero ou Mulleres de Sepúlveda sitúase na liña de sublimación da paisaxe central, que asumira definitivamente a Xeración do 98. De feito, os daquela xeración fixéronlle unha homenaxe a Zuloaga en Madrid en 1901, como resposta aos ataques que recibira da crítica española por causa da súa suposta mirada negativa sobre España. Se ben o noventaeoitismo defendeu a interpretación de Zuloaga das paisaxes hispanas, e aínda que Castela fose para o vasco tema central na súa pintura, a súa interpretación estética desta non está dentro do cromatismo de Beruete, nin do seu lirismo austero; máis ca azoriniana é unamuniana e orteguiana (lámina 7).

A pintura do eibarrés habería entrar noutros rexistros estilísticos co coñecemento da pintura simbolista e expresionista europea, aos cales el engadiría unha interpretación moi singular e nova do pasado pictórico español, en especial de El Greco e de Goya. Falaba decontino nas súas declaracións e entrevistas de prensa de pintar unha paisaxe sen ar, así como dunha especie de acromatismo nas súas pinturas, que partiría dunha actualización do Goya escuro. Hai que dicir que se sentía debedor do aragonés menos colorista; de feito, o seu papel na revisión de Goya e da homenaxe a este en Fuendetodos coa colocación na casa natal —a cal el mesmo adquiriría - dunha lápida conmemorativa foi unha iniciativa sobre todo súa. Malia o eibarrés negarse simbolista, identificándose máis cunha figuración expresionista, as atmosferas conxeladas das súas paisaxes, dos monumentais e dos rurais casteláns, están dentro do clima do simbolismo decadentista europeo literario, que captaban os escritores do tempo ao describiren Bruxas, por exemplo, Venecia ou o mesmo Toledo. Esta cidade aparecería nos fondos dos seus retratos de Barrès e de Gregorio Marañón como unha fantasmagoría, non como unha realidade lumínica, senón ausente de luz, con algo de espectral, moi identificables co imaxinario e onírico das visións toledanas de El Greco, que tanto amaba o nacionalista francés (lámina 8).

A pintura de Zuloaga é un exemplo da identificación dos vascos naqueles tempos con Castela: segundo as súas propias declaracións sentíase vasco e español, desde unha posición moi rexeneracionista de se identificar. Confesaba a súa paixón pola pintura española mencionada e tamén pola de Velázquez, á vez que amaba a 


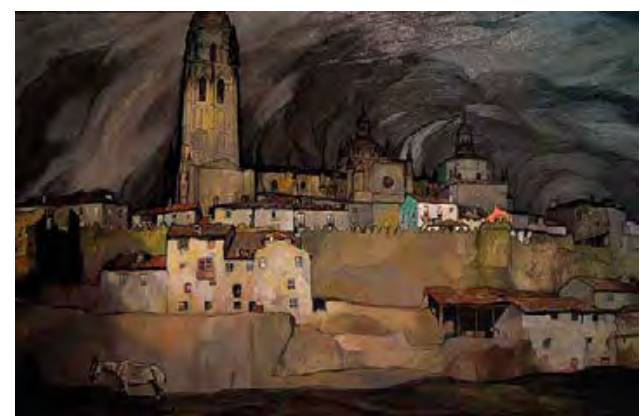

Lámina 7. Ignacio Zuloaga, Segovia, 1909.

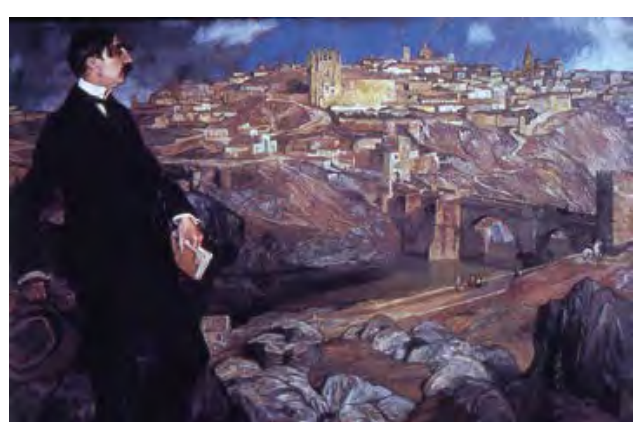

Lámina 8. Ignacio Zuloaga, Retrato de Maurice Barrès, 1913.

paisaxe castelá e a súa casta rural, a cal pintaba totalmente identificada con aquel, fundida cromática e matericamente con el. Logo de París — ao que ficaría ligado toda a vida - e dunha serie de anos en Andalucía, onde o seu afán polos touros o habería levar mesmo a tourear e a se expresar a través deste asunto pictoricamente, unhas longas estadías en Segovia co seu tío Daniel, o gran ceramista da época, así como en Pedraza, levaríano a pintar multitude dos seus cadros con fondos casteláns, como os toledanos, os de Segovia e moitos outros. Igual ca el, os Zubiaurre tiveron unha forte relación con Castela, inspirándose nela en numerosas ocasións, o mesmo ca Gustavo de Maeztu. Ao falar o mestre Zuloaga do seu Cristo do sangue, confesaría que sentía palpitar naquel cadro - escenario paisaxístico abulense e personaxes dun tremendismo relixioso- algo do vasco. Ese latexo sentimental, intuitivo e supostamente espontáneo do castelanismo que expresaba este pintor comentárono e mesmo teorizárono tamén outros artistas e pensadores ou críticos da arte vascos, entre eles Miguel de Unamuno ou Juan de la Encina.

O primeiro identificouse en varias ocasións co pintor, apoiándose para a interpretación positiva da súa pintura nunha das ideas recreadas polo nacionalismo español vascoiberista: segundo aquel ideario, «os vascos eran detedores do misterio das orixes de España» (Juaristi 1992: 101-102). Tal idea fora tamén defendida reiteradamente polo nacionalismo español e expresada en varias ocasións polo 98 e polo pensamento rexeneracionista, como foi o caso de Ramiro de Maeztu. Aquela identificación estética e antropolóxica co castelán crearía tensións enormes desde finais do século XIX co aranismo e abertzalismo nacionalista vasco, que negaba que a cultura vasca fose á vez profundamente española: esa distinta versión do vasco nos 
xermes do diferencialismo subxace dalgunha maneira na radicalidade da defensa posterior de ambas as posicións. Este relato do vasco asociado ao español estaba reforzado pola propia historia do País Vasco, que fixo gran parte da súa historia asociado á Coroa española (Fox 1997, Fusi 1984).

As investigacións etnolóxicas e lingüísticas dos investigadores sobre as orixes vascas máis remotas deduciron, en boa parte, un nexo entre as orixes de Castela e as do País Vasco, ambos unidos supostamente nun tronco ibérico orixinario. En plena industrialización de Euskadi producíase un temor á perda das esencias, que se supuñan no rural; en tal sentido, todo o castelán sería unha reliquia na estética e no pensamento antropolóxico dos vascoiberistas. Contextualizado nestas ideas Unamuno ao clausurar a Primeira Exposición Colectiva da Asociación de Artistas Vascos en agosto de 1912, afirmaría que «a pintura vasca [era] unha nota profundamente española»; estas declaracións son só un dos exemplos dos seus escritos e declaracións nesta liña (Llano Gorostiza 1966: 107).

Canto ao crítico de arte vasco Juan de la Encina, el habería preguntarse se a conexión que establecía Unamuno entre a espiritualidade de Zurbarán e a vasca non proviría «da semellanza positiva entre o espírito vasco e o xeral ibérico» (Juaristi 1992, Encina 1919). Don Miguel titularía un artigo sobre Zuloaga na revista Hermes «La labor patriótica de Zuloaga». Nesta idea do pintor de Eibar mantivéronse as reflexións sobre a estética da súa pintura do mesmo Ortega y Gasset. Incluso a biografía de Enrique Lafuente Ferrari verbo de Zuloaga respira, sobre a base da súa formación na ILE, unha interpretación do pintor herdeira daquel noventaeoitismo, do cal o mesmo don Enrique se sentía debedor: a idea resumida, segundo tales teses, era que as paisaxes castelás eran a memoria dunha Vasconia ibérica perdida case na néboa do tempo pasado, polo cal os seus escenarios rurais e históricos e os habitantes destes, no seu ruralismo e primitivismo, eran mitos vivos das orixes vascas e españolas (Unamuno 1917, Lafuente Ferrari 1990).

En calquera caso, o novecentismo en Madrid, dentro do cal se situaba Zuloaga, canda Romero de Torres, Julio Antonio, Solana ou Anselmo Miguel Nieto, estaba xa inmerso nos debates entre nacionalismos e rexionalismos, aínda que farían universalizables e modernos os seus asuntos internalizando os estilos. Os cafés de Madrid haberían ser aglutinadores da Xeración do 14, que se reunía no Pombo arredor de Ramón Gómez de la Serna ou no Café de Levante derredor de Valle-Inclán. 


\section{CENTRO E PERIFERIAS NA PAISAXE ESPAÑOLA E AS SÚAS IDENTI- DADES}

Non poderiamos seguir a escribir sobre a paisaxe española e as súas identificacións se non comentamos o que distorceu — segundo un termo do historiador francés Pierre Vilar (1984) - a forza dos rexionalismos e os nacionalismos español e periféricos, o conxunto do proceso español cara á modernización, xa que isto crearía unha diversificación da imaxe do país e unha dinámica específica entre o centro e a(s) periferia(s), que afectou tamén á arte e á paisaxe nas súas diversas versións, así como á dinámica entre distintas propostas para a imaxe de España, nas cales a da central e o seu territorio seguiría a dominar no que a paisaxe e costumismo se refire, xunto á das rexións cuxas escolas e modelos foran integrados pola política institucional da capital, como era, a finais do século xx e na xeración novecentista, a de Valencia con Sorolla e a extensión do seu luminismo por toda Espańa, ou a imaxinaría andaluza con flamencos, xitanas e paisaxismo andaluz.

Aquel proceso faise visible na arte coa reacción que os feitos políticos irían producindo, proxectándose, por exemplo, nunha política de exposicións rexionalistas, alén de na crenza de que, o mesmo que existía unha escola española, existían tamén unha catalá, unha vasca, unha galega, unha valenciana, unha andaluza etc.

Todo isto vai xermolando entre moi finais do XIX e os primeiros decenios do século $\mathrm{xx}$, para culminar co novecentismo como momento álxido deste movemento rexionalista español na arte. O éxito da xerarquía superior de Castela ou da Valencia de Sorolla como representacións emblemáticas de España xa cara ao segundo decenio do século xx produciría unha reacción da crítica de arte no tocante á centralización simbólica destes escenarios e paisaxes sobre os das outras rexións: José Francés fixo en varias ocasións críticas aos xurados das exposicións nacionais por favoreceren as imaxes deses territorios, cando xa defender o sentido estético de Castela se convertera nunha certa imposición do gusto oficial e se integrara na representación oficial de España, igual ca a imaxe de Levante. Tamén Valle-Inclán criticaría a oficialización de tales estéticas (Francés 1917, Valle-Inclán 1919, Freixa e Pena 1990, Pena 1993-1994). 


\section{PAISAXISMO ESPAÑOL E VANGARDAS}

As vangardas caracterizáronse en lińas xerais por unha clara linguaxe universalizadora e experimental, na cal o territorial identitario pasaría a segundo termo; porén, no caso das primeiras vangardas periféricas occidentais houbo unha necesidade de integrar dalgún xeito os sinais de identidade orixinarios, que se conservaban nos chamados rexionalismos (Davis 1930: 34-35). Poderíase ver en numerosos exemplos que houbo unha resistencia a abandonar a tradición e o diferencial neses territorios, e que o caso español non foi único neste sentido.

Nos anos vinte os nacionalismos e rexionalismos seguiron en auxe no noso país, e ao final dos anos trinta, coa Segunda República, acabaría por se recoñecer a existencia dos nacionalismos catalán e vasco, coa aprobación dos seus estatutos de autonomía, que no caso de Galicia estivo a piques de ser aprobado nas Cortes, xusto cando estalou a Guerra Civil.

Aqueles nacionalismos periféricos e tamén o español distorceron o camiño das vangardas españolas no interior. As distintas vangardas de España reivindicaron a utilización dunha linguaxe formal universal, vida en especial de París, se ben unhas e outras se negaron a renunciar á súa tradición plástica culta, á súa antropoloxía rural e popular e ás súas referencias primitivas orixinarias. Todo isto produciu unha vangarda española interior con personalidade indubidable, aínda que non estea na primeira fila do vangardismo internacional. Unha das pezas fundamentais na proxección e execución de tal idea foi a da paisaxe e o paisaxismo.

En Madrid, tras a Exposición de Artistas Ibéricos en 1925, cultivaría especialmente a paisaxe a escola de Vallecas na súa primeira etapa, entre 1927 e 1936, en pintura e escultura. Os artistas compoñentes dela usurpáronlles á xeoloxía e á xeografía o termo e o motivo dos «cerros testemuños», así bautizados por S. Gómez de Llarena nos seus Trabajos del Museo de Ciencias Naturales (1923), porque segundo este xeógrafo son esas formacións montuosas (lámina 9) «testemuño[s] da erosión fluvial á que o país foi sometido aínda antes do período actual e do Cuaternario, e que arrasou os niveis superiores das margas samartienses».

Eses cerros nus descubríronos nunha paisaxe ao leste e sur de Madrid, que foi a de Vallecas, unha vila situada entre o industrial e o rural. Chegaban a ela os artistas e intelectuais do grupo desde a estación de Atocha, daquela da Compañía mzA, arrodeada dunha paisaxe industriosa, ata acadar unha paisaxe rural. A estación está 


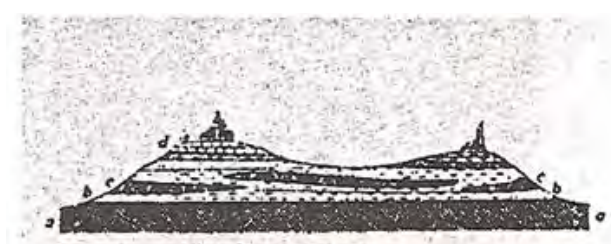

Lámina 9. E. Hernández Pacheco, Cerro de los Ángeles (debuxo estratigráfico), 1923.

situada nun fondal, que antes de se construír fora un vertedoiro. $\mathrm{Na}$ contorna daquel espazo de refugallos, á beira das murallas derrubadas da cidade, había un conxunto histórico e monumental de resonancias culturais e científicas significativas: o santuario de Nuestra Señora de Atocha, o Observatorio Astronómico e o Jardín Botánico de Villanueva, o Hospital de San Carlos e a Facultad de Medicina, así como o Museo Antropológico. En 1892 haberíase de erixir a grande edificación férrea da estación: toda unha paisaxe industrial e ferroviaria foi medrando na súa contorna desde 1917, ano en que se creou unha nova estación de clasificación do material móbil para o tráfico de mercadorías xa nas aforas de Madrid, no Cerro Negro, rematada en 1926 e continuada e ampliada ata 1928; alén do anterior, no sector sur construíronse novos edificios científicos, como a Escuela de Caminos, o Museo de Máquinas e o Instituto Cajal. Combinábase a construción industrial coa científica e intelectual, ademais da rural e popular. Todo levou a facer desa paisaxe urbanística e campestre un campo de experimentación do grupo, no cal participaban como artistas plásticos Alberto Sánchez, Maruja Mallo, Benjamín Palencia e Pancho Lasso, entre outros, así como escritores da Xeración do 27, destacando entre eles Alberti e Miguel Hernández dunha forma directa, que asumían na súa poesía daqueles anos a poética do chan desolado, a cal convertería esta «antipaisaxe» pedregosa e árida nunha paisaxe nova e insólita, situada estilisticamente entre o vangardismo surrealista parisiense - que trouxera da capital francesa Benjamín Palencia- e un realismo e mesmo un inxenuísmo primitivo e popular, que trataba de beber nas fontes da arte do pobo español, no seu primitivismo antropolóxico, así como nun sentido laico da natureza inspirado nas lecturas do xeógrafo Reclus, lido desde o prisma revolucionario do anarquismo, e tamén nun sentido relixioso libre tirado do espírito franciscanista, que pululaba na vangarda literaria, como a que representaba a revista Cruz y Raya, dirixida por Bergamín: por aqueles anos foi traducido ao castelán por Cipriano Rivas Cherif o libro sobre san Francisco de 
Chesterton, o cal amosa o interese daquela xeración polo sentido heterodoxo relixioso do de Asís. Naquel clima cultural e político, aqueles campos de terra e pedras eran sinónimo de liberdade, lugar de acción, cantado polo clima revolucionario dos tempos prerrepublicanos.

Fomentaban todo aquel clima cultural e estético o ambiente da Residencia de Estudiantes e os traballos da Junta para Ampliación de Estudios (JAE), onde traballaban Hernández Pacheco e Gómez de Llerena: Benjamín e Maruja Mallo haberían ter un contacto directo coa Residencia, igual ca Alberti, e haberían achegar a Alberto e a Miguel Hernández aos intereses e ao clima intelectual e científico dela e da JAE. A paixón biomórfica de Palencia apoiábase nunha paixón do grupo polas coleccións do Museo de Ciencias Naturales (lámina 10). A inspiración xeolóxica tomou imaxes científicas de debuxos dos cerros de E. Hernández Pacheco, desde o de Almodóvar ata o dos Ángeles, un exemplo explícito dos cales é a pintura de Alberto Ríos de España desangrándose; ademais, habería coñecer dalgunha maneira os debuxos de Gómez de Llarena do curso do río Texo

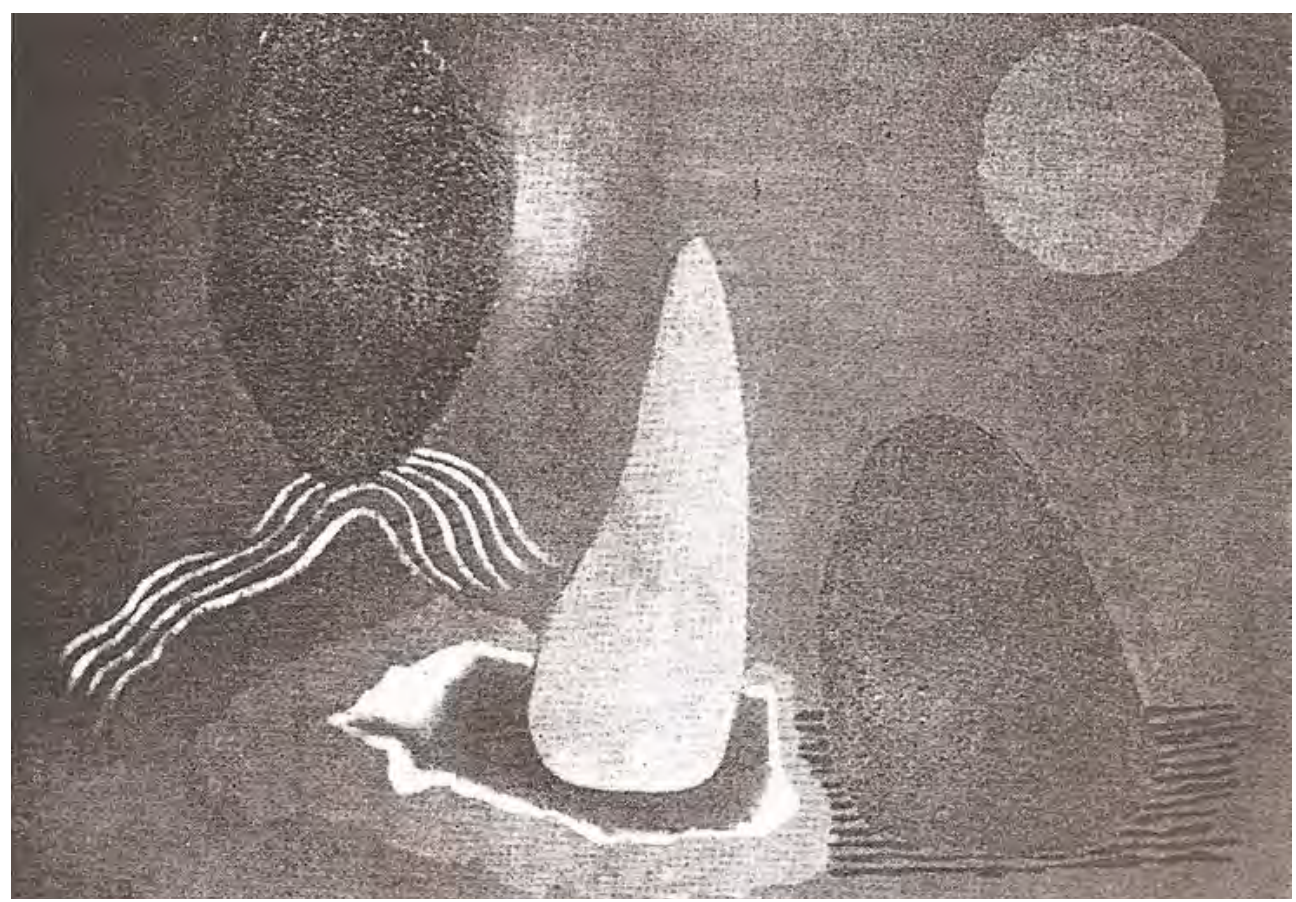

Lámina 10. Benjamín Palencia, Formas elementais, 1930. 
e os seus antigos meandros: as marcas que realizou sobre as súas esculturas son unha poetización das marcas estratigráficas dos diferentes niveis desa paisaxe, que se convertera nun mito xeolóxico do orixinario polo seu remoto carácter cuaternario, dunha riqueza cońecida por toda a xeoloxía europea, mentres que as amplas curvas serpeantes do ritmo do antigo curso nos debuxos xeográficos puido inspirar a paisaxe posta en pé de moitas das súas obras, como a do bosquexo de O pobo español ten un camiño que conduce a unha estrela, para a obra definitiva do pavillón da República na Exposición Universal de París de 1937 (Pena 1989, Alix Trueba 2001, Pena 2012) (láminas 11, 12 e 13).

Namentres, o experimentalismo triunfaba nas vangardas e o nacionalismo español modernizábase cunha visión estética vangardista e española das súas paisaxes, mais tamén os outros nacionalismos estaban presentes na arte dos rexionalismos e dos nacionalismos vasco, catalán e galego. Unha paisaxe coma a de $A$ masía de Miró, pintada entre 1921 e 1922, era a transformación ao estilo surrealista que aprendería en París da estética da terra labrada e santificada das súas experiencias

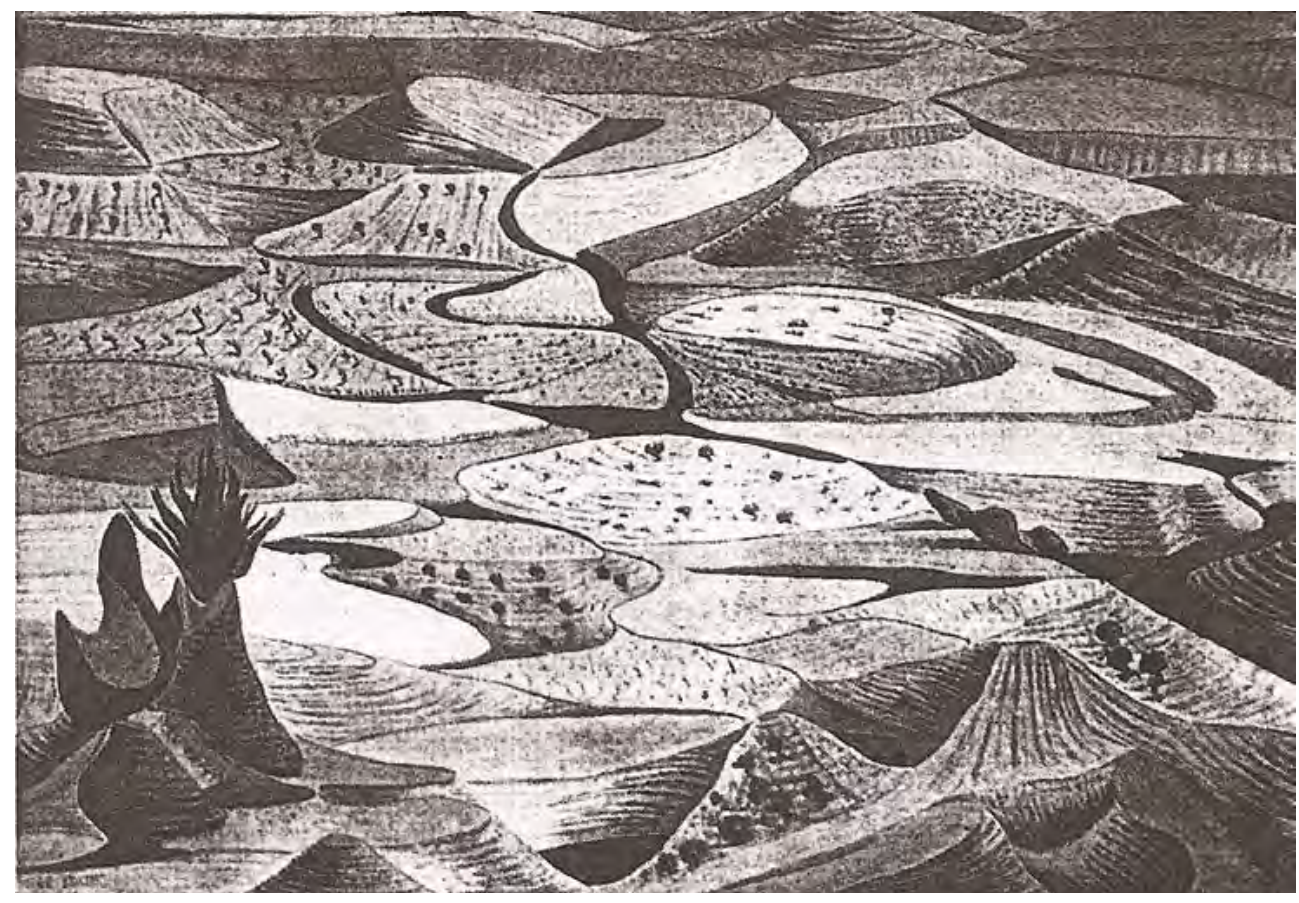

Lámina 11. Alberto Sánchez, Ríos de España desangrándose, 1937-1939. 


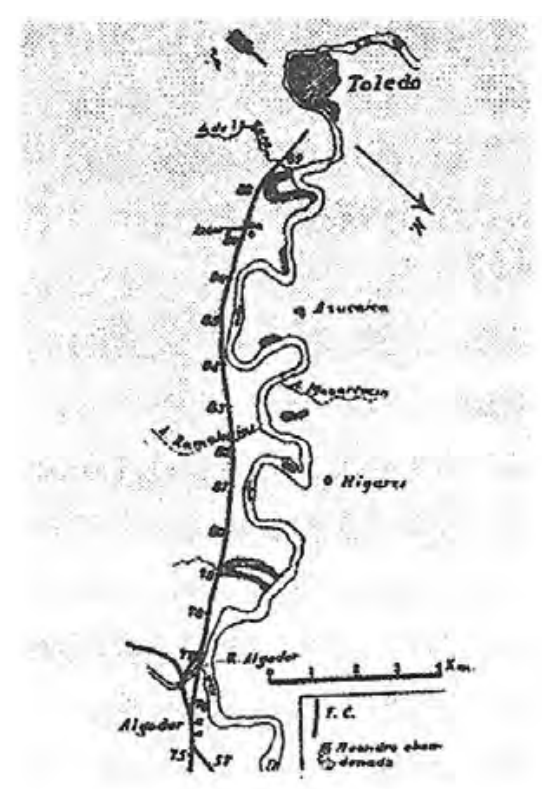

Lámina 12. S. Gómez de Llarena, O Texo entre Algodor e Toledo (debuxo), 1923.
Lámina 13. Alberto Sánchez, 0 pobo español ten un camiño que conduce a unha estrela (bosquexo), 1937.

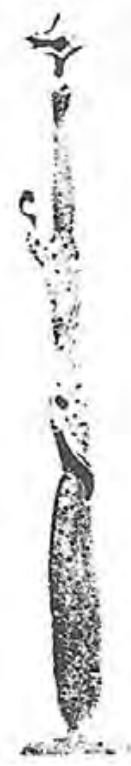

en Montroig: mantínase alí a veneración polo rural autóctono. Hai nesta paisaxe un rexeitamento do folclorismo do XIX, mais no experimento surreal universaliza a intimidade "cósmica» dos seus ámbitos locais, que non deixarían de ser unha pegada do seu catalanismo na súa pintura daquela época (Combalía 1990).

A Galicia de Colmeiro, Laxeiro, Seoane ou Maside mantería tamén as pegadas do diferencial galego cunha linguaxe dunha vangarda ecléctica e moderada, que reaccionaba contra o costumismo do estilo do XIX, mais que buscaba anovarse a partir da modernización de linguaxes orixinarias do primitivismo galego inserido na súa cultura rural e na súa paisaxe, o cal xa fora reivindicado pola poética do atlantismo desde Murguía a Castelao e a eles mesmos; tamén pola mitoloxía do celtismo e as súas formas esencialistas premodernas, así como polo recoñecemento da herdanza medieval e barroca nas súas formas. Os textos teóricos de Castelao ou Seoane ben darían conta daquel ideario, proxectado na pintura e na escultura galegas e afirmado ademais polas poéticas melancólicas da emigración e do exilio (Pena 1994, García Álvarez 2006, López Silvestre e Lois González 2007) (láminas 14 e 15). 
Toda aquela efervescencia dos nacionalismos periféricos e dos paisaxismos revolucionarios e reivindicativos das diversas identidades quedaron coutados pola guerra e reprimidos pola ditadura franquista, para subsistiren de todo aquilo vestixios febles ou un sentido folclórico nun rexistro moi epidérmico, dentro da retórica costumista do fascismo, descargándose de calquera sentido crítico.

Mais, cando o réxime lavou a cara no terreo da arte, integrando na súa imaxe a modernidade da abstracción co grupo El Paso, que gańou a Bienal de Venecia do ano 1958, reflotou a paisaxe da meseta e o suposto misticismo revolucionario seu a partir das novas claves vangardistas da posguerra, que recollían a imaxe daquelas primeiras vangardas arrasadas pola guerra e o exilio, a partir da nova abstracción de inspiración informalista e norteamericana, á cal ademais a crítica lle vería sinais de identidade españois, e os propios textos dos artistas, como os de Saura ou Canogar, tamén; mesmo a presentación dos artistas nos textos de Manuel Conde, o seu crítico español máis destacado, expresou a suposta españolidade da súa pintura con estas palabras, por exemplo: «Antonio Saura, sobrio, complexo e tenso, identificado coa chaira castelá, afiada, punzante coma as súas teas...».

Era unha imaxe plástica moderna e vangardista da identidade da Espańa perdida e prohibida durante un tempo na posguerra, que agora se expresaba a través

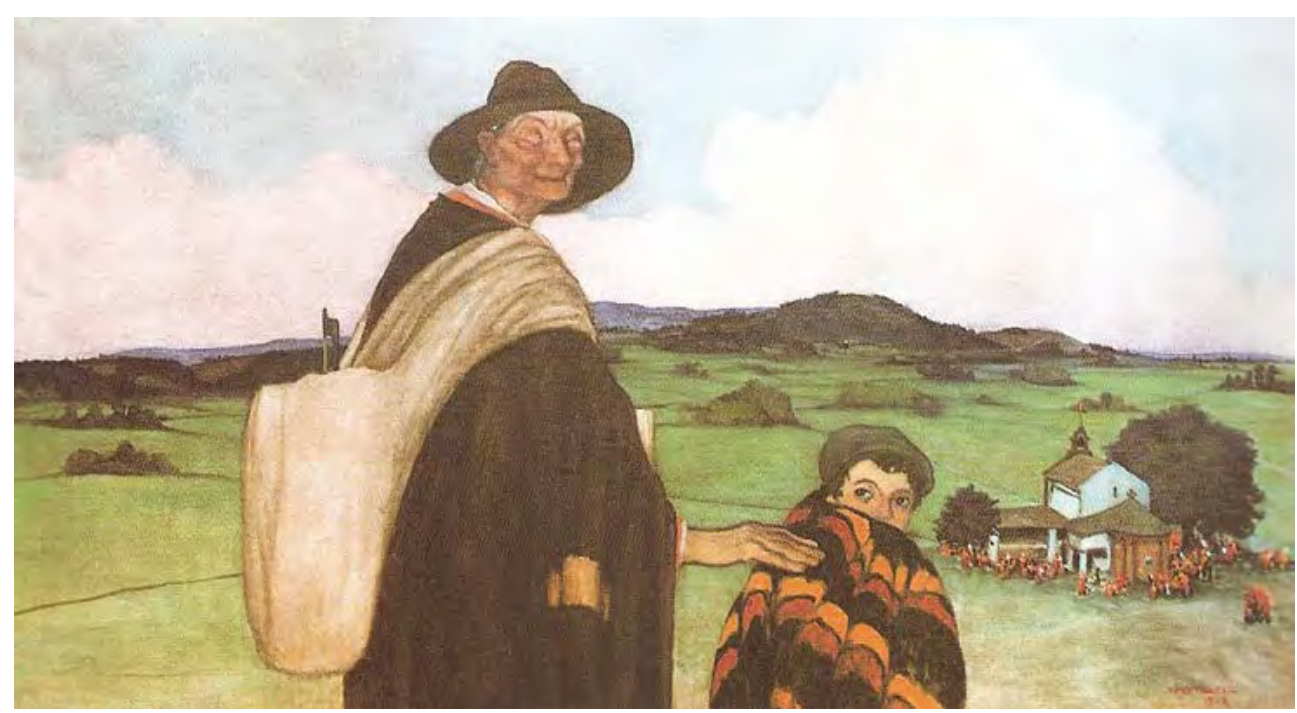

Lámina 14. Castelao, Cego da romaría, 1913. 


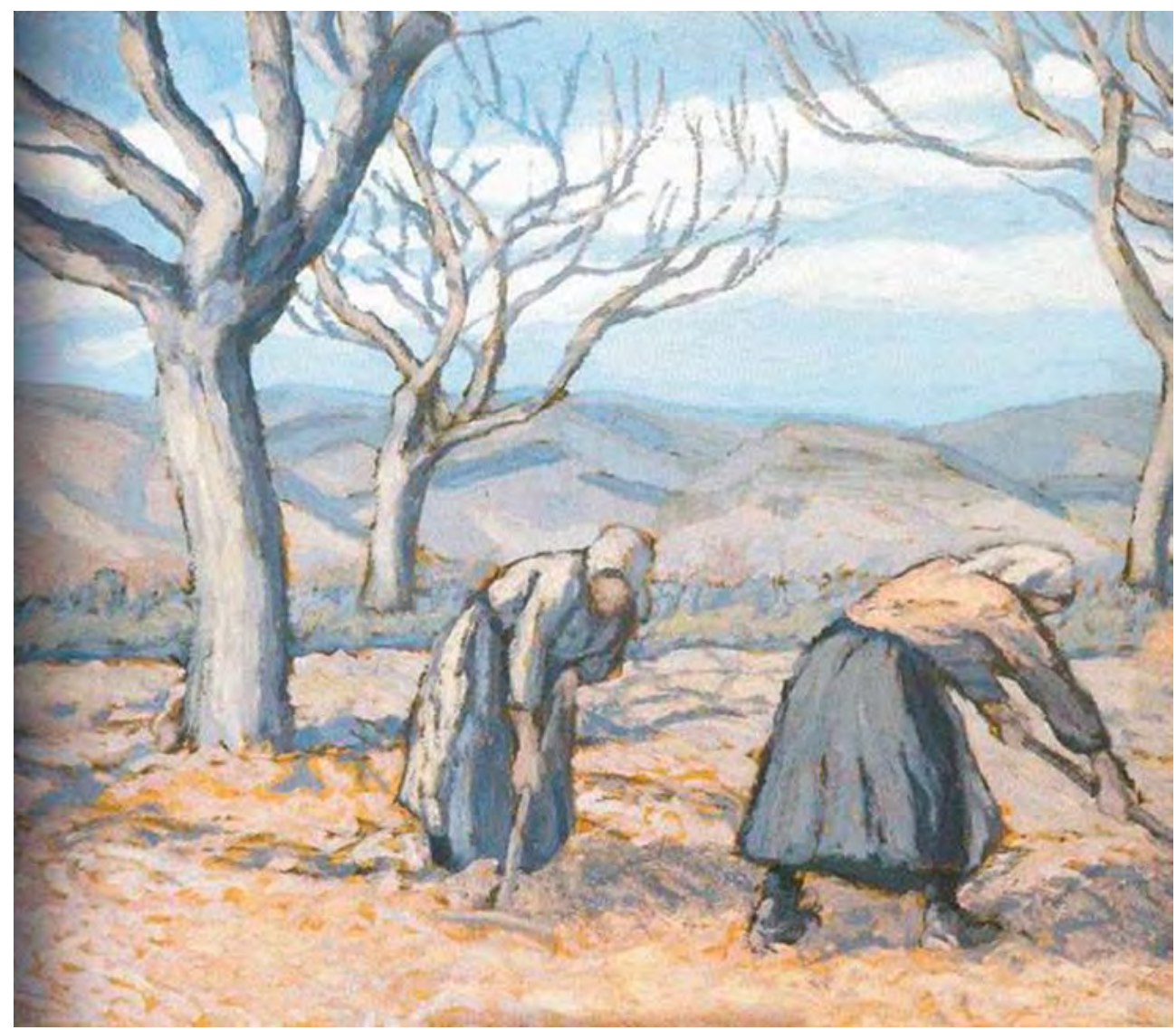

Lámina 15. Colmeiro, Collendo a folla, 1928.

daquelas metáforas abstractas do «outro» español (Toussaint 1983, Llorente 1995, Cabañas Bravo 1996, Cabrera García 1998, Díaz Sánchez 1998). Había unha invisible clandestinidade naquelas pinturas, xa que o vangardismo fora identificado coa República durante os primeiros decenios franquistas, igual que na Alemaña nazi foran consideradas as vangardas alemás e europeas como arte «dexenerada»: o radicalmente moderno foi sempre unha ameaza para as ideoloxías conservadoras, aínda que se exprese só por medio de obxectos estéticos, porque, desde a arte moderna romántica e as súas teorías, a modernidade máis experimental foi expresión de liberdade. Había un anovado desexo naquelas novas vangardas españolas de rexenerar de novo, por medio da abstracción universal, a imaxe de España, dos seus personaxes e das súas paisaxes. 
E namentres a vangarda en Cataluña, representada entre outros por Tàpies a nivel internacional, reclamaría tamén a través de evocacións paisaxísticas unha identidade catalá prohibida pola ditadura, reinstaurando a dinámica inacabada entre o centro e a periferia entre o XIX e o xx: ao falar da súa paisaxe Forme gris bleuâtre (1955) escribiría o seguinte, coa inevitable referencia ao Montseny, un dos reiterados lugares de identificación catalanista (Nogué 2006):

Moi poucos eran os que lembraban, en plena efervescencia dos estilos abstractos internacionais, xa gastados, que nós habiamos dar un acento diferente porque a nosa situación é diferente. Achei pois a miña fonte de inspiración vivindo intensamente Cataluña; no Montseny, no gris verdoso das acińeiras, no gris azulado das súas néboas... (Tàpies 1971: 37)

E de novo a paisaxe española agochaba tras árbores, montañas, chairas de terra e de mar os compromisos ideolóxicos, sentimentais e identitarios dunha España plural (Freixa e Pena 1990). 


\section{REFERENCIAS BIBLIOGRÁFICAS}

ÁвALos, Iñaki (2009): «Introducción», en Ińaki Ábalos (ed.), Naturaleza y artificio: el ideal pintoresco en la arquitectura y el paisajismo contemporáneos, Barcelona, Gustavo Gili.

Alix Trueba, Josefina (2001): Un nuevo ideal figurativo: escultura en España, 1900-1936: Madrid, 14 de noviembre de 2001-13 de enero de 2002 [catálogo de exposición], Madrid, Fundación Cultural Mapfre Vida.

Arias Anglés, Enrique (1980): Jenaro Pérez Villaamil, A Coruña, Atlántico.

Arias Anglés, Enrique (1986): El paisajista romántico Jenaro Pérez Villaamil, Madrid, csic.

BARrès, Maurice (1914): El Greco o el secreto de Toledo, Madrid, Renacimiento.

Beruete, Aureliano de (1898): Velázquez, París, H. Laurens; ed. ingl., Londres, Methen and Co., 1906; ed. al., Berlin, Otto von Holten, 1909 (tradución ao castelán e última edición, Madrid, 1987).

Brinckerhoff, John (1995): A Sense of Place, a Sense of Time, Londres/New Haven, Yale University Press.

Brown, Jonathan (1999): «Picasso y la tradición pictórica española», en Jonathan Brown (ed.), Picasso y la tradición española, Hondarribia, Nerea, 13-38.

Cabañas Bravo, Miguel (1996): Politica artística del franquismo, Madrid, csic.

Cabrera García, María Isabel (1998): Tradición y vanguardia en el pensamiento artístico español (1939-1959), Granada, Universidad.

Calvo Serraller, Francisco (1990): «Aureliano de Beruete y la cultura artística de la Restauración», en Pintores españoles entre dos fines de siglo: de Eduardo Rosales a Miquel Barceló, Madrid, Alianza, 58-67.

CASAdo de Otaola, Santos (2010): Naturaleza patria: ciencia y sentimiento de la naturaleza en la España del regeneracionismo, Madrid, Marcial Pons.

Combalía, Victoria (1990): El descubrimiento de Miró: Miró y sus críticos, Barcelona, Destino.

Davis, Stuart (1930): «Is There an American Art?», Creative Art, 4 (febreiro), 34-35.

DíAz SÁNCHEZ, Julián (1998): La «oficialización» de la vanguardia en la postguerra española. (El Informalismo en la critica de arte y los grandes relatos) [tese de doutoramento], Cuenca, Ediciones de la Universidad de Castilla-La Mancha.

Encina, Juan de la (1919): La trama del arte vasco, Bilbao, Editorial Vasca.

Freixa, Mireia / María del Carmen Pena (1992): "Problema centro-periferia en los siglos XIX y XX», en Comité Español de Historia del Arte (сенA) / Universidad de Extremadura, Departamento de Historia del Arte, Actas del vIII Congreso Nacional de Historia del Arte: Cáceres, 3-6 de octubre de 1990, vol. I, sección 3a, Mérida, Editorial Regional de Extremadura, 371-384.

Fox, Edward Inman (1997): La invención de España, Madrid, Cátedra.

Francés, José (1917) (co pseudónimo de Silvio Lago): «La Exposición Nacional de Bellas Artes», La Esfera, IV: 184, t. II, 7.

Fusi, Juan Pablo (1984): El País Vasco: pluralismo y nacionalidad, Madrid, Alianza.

García Álvarez, Jacobo (2006): «Paisaje, nacionalismo e identidad en la Galicia de preguerra: la visión de Otero Pedrayo", en Antonio López Ontiveros / Joan Nogué i Font / Nicolás Ortega Cantero (coords.): Representaciones culturales del paisaje y una excursión a Doñana, Madrid, UAM, 59-82.

Giner de los Ríos, Francisco (1915; or. 1886): «Paisaje», Peñalara, 15 (marzo), 36-44.

Gómez de Llarena, Joaquín (1923): «Guía geológica de los alrededores de Toledo», en Trabajos del Museo de Ciencias Naturales, serie "Geología», 31, Madrid. 
Gutiérrez Márquez, Ana (2002): Carlos de Haes en el Museo del Prado (1826-1898) [catálogo de exposición], Madrid, Museo del Prado.

Hernández de León, Juan Miguel (1985): «El regionalismo madrileño actual», Arquitectura y Vivienda, 3, 90-93.

JuARISTI, Jon (1992): Vestigios de Babel: para una arqueología de los nacionalismos españoles, Madrid, Siglo XXI.

Jurkevich, Gayana (1999): In Pursuit of the Natural Sign: Azorin and the Poetics of Ekphrasis, Cranbury, NJ, Associated University Press.

Lafuente Ferrari, Enrique (1990 [ $\left.\left.{ }^{1} 1950\right]\right)$ : La vida y el arte de Ignacio Zuloaga, Barcelona, Planeta.

Llano Gorostiza, Manuel (1966): Pintura vasca, Bilbao, Mayfe.

Llorente Hernández, Ángel (1995): Arte e ideología en el franquismo (1936-1951), Madrid, Visor.

López Silvestre, Federico / Rubén Camilo Lois GonzÁLEZ (2007): «La fuerza de un mito: la presencia de un paisaje "nacional" en la publicidad turística gallega en España", Ateliê Geográfico, 1:1 (setembro), $1-24$.

Nogué I Font, Joan (2006): «Paisaje, identidad nacional y sociedad civil en la Cataluña contemporánea: la visión de Otero Pedrayo", en Antonio López Ontiveros / Joan Nogué i Font / Nicolás Ortega Cantero (coords.), Representaciones culturales del paisaje y una excursión a Doñana, Madrid, UAM, 41-58.

Ortega Cantero, Nicolás (1992): «La concepción de la geografía en la Institución Libre de Enseñanza y en la Junta para Ampliación de Estudios e Investigaciones Científicas», en Josefina Gómez Mendoza / Nicolás Ortega Cantero (dirs.), Naturalismo y geografía en España, Madrid, Fundación Banco Exterior, 19-77.

Pena López, María del Carmen (1978): «La nueva estética del paisaje español y el desarrollo de la geografía como nueva ciencia», en Actas del Congreso Español de Historia del Arte, Valladolid, Universidad, 206 e ss.

Pena López, María del Carmen (1983a): «Aureliano de Beruete y Moret, personaje y paisajista español de fin de siglo", en Aureliano de Beruete, 1845-1912 [catálogo de exposición], Madrid, Obra Social Caja de Pensiones, 12-22.

Pena López, María del Carmen (1983b): «La pintura del paisaje español entre el idealismo y el positivismo», Los Cuadernos del Norte, Iv:21, 67-68.

Pena López, María del Carmen (1983c): «El concepto de lo masculino y lo femenino en la teoría del paisaje español», en Universidad Autónoma de Madrid, Seminario de Estudios de la Mujer, La imagen de la mujer en el arte español: Actas de las Terceras Jornadas de Investigación Interdisciplinaria, Madrid, UAM, 141-148.

Pena López, María del Carmen (1985): «Paisaje español del xix: la mirada renovada», Lápiz, III:25, 28-36.

Pena López, María del Carmen (1989): «La Escuela de Vallecas (1927-1936)», Revista de Occidente, 103, (decembro), 61-83.

Pena López, María del Carmen (1993-1994): «La modernización del paisaje realista: Castilla como centro de la imagen de España», en Centro y periferia en la modernización de la pintura española [catálogo de exposición], Madrid, Centro Nacional de Exposiciones y Promoción Artística, 42-48.

Pena López, María del Carmen (1994): «De la voluntad diferencial al destino antropológico: Galicia», en Antonio Bonet Correa, Tiempo y espacio en el arte: homenaje a Antonio Bonet Correa [obra completa], vol. II, Madrid, Editorial Complutense, 1475-1492.

Pena López, María del Carmen (1996): «Estereotipos femeninos en la pintura: pálidas y esquirolas», Astrágalo, 5, 53-60. 
Pena López, María del Carmen (1997): «Paisaje y modernidad en la pintura española», en En torno al paisaje. De Goya a Barceló: paisajes de la Colección Argentaria [catálogo de exposición], Madrid, Fundación Argentaria, 21-33.

Pena López, María del Carmen (1998 [11983]): Pintura de paisaje e ideología: la Generación del 98, Madrid, Taurus.

Pena López, María del Carmen (2012): Territorios sentimentales: arte e identidad, Madrid, Biblioteca Nueva. Rico y Ortega, Martín (1906): Recuerdos de mi vida, Madrid, Imprenta Ibérica.

Rosenblum, Robert (1999): «La españolidad de las naturalezas muertas de Picasso», en Jonathan Brown (ed.), Picasso y la tradición española, Hondarribia, Nerea, 73-110.

Schama, Simon (1995): Lansdcape and Memory, Nova York, A.A. Knopf.

TÀpIEs, Antoni (1971): La práctica del arte, Barcelona, Ariel.

Toussaint, Laurence (1983): El Paso y el arte abstracto en España, Madrid, Cátedra.

Tussell, Javier (1989): "Darío de Regoyos y la introducción del arte moderno en España», Fragmentos, 15-16, 150-192.

Unamuno, Miguel de (1917): «La labor patriótica de Zuloaga», Hermes, I: 8 (agosto).

VAlLe-Inclán, Ramón María del (1919): prólogo a La pintura vasca (1909-1919): antología, Bilbao, Biblioteca de Amigos del País, 3-10.

VILAR, Pierre (1984): «Estado, nación y patria en España y Francia: 1870-1914», Estudios de Historia Social, 28-29, 7-41. 
DE QUE FALAMOS CANDO FALAMOS DE POPULISMO? «MAIS POPULISTA SERÁ A TUA AVOA!»

\section{Francisco Panizza}

London School of Economics 

O título deste artigo alude ao debate, aparentemente de nunca acabar, sobre a definición de populismo e o subtítulo das fortes connotacións negativas asociadas xeralmente ao termo. Como é sabido, non existe acordo no debate académico verbo do significado dun termo que ten sido relacionado, entre outros, con períodos históricos, procesos sociais, políticas económicas e estilos de goberno. Non estou a ignorar neste artigo as distintas perspectivas sobre o populismo nin estou a tratar de pechar o debate sobre el, mais gustaría de apuntar que existe unha considerable acumulación de produción teórica na cal se argumenta que o populismo se caracteriza principalmente pola constitución discursiva dunha relación de antagonismo político entre «o pobo» e algún tipo de estrutura de poder ou actor político opresivos. Margaret Canovan resalta a natureza sistémica dos inimigos do pobo cando define «populismo» como «unha apelación ao "pobo", tanto contra a estrutura de poder establecida como contra as ideas e valores dominantes da sociedade» (1999: 2), mentres que Carlos de la Torre (2009: 24) destaca os actores en conflito cando o define como a construción dun discurso maniqueo e moralista que sitúa o "pobo» en posición antagónica á «oligarquía» na procura de maior participación política e inclusión (ver tamén Laclau 1977, 2005a e 2005b, Panizza 2005 e Peruzzotti 2008). Para esta noción de populismo resulta crucial a súa natureza discursiva ou lingüística (Laclau 1977, 2005a). No seu libro La persuasión populista: una historia americana, Michael Kazin defíneo como «un estilo de retórica política persistente malia que mutable» (1998: 5). Kazin traza a historia do populismo ao longo da vida política norteamericana amosando como aquel muda a identidade reciprocamente construída do pobo e dos seus opresores e como o seu uso por diversos actores fai mutar as súas cores políticas ao ser hexemonizado por progresistas radicais e por conservadores de extrema dereita en distintos momentos ao longo do tempo. Hai outras definicións de populismo, abofé, e moitas preguntas fican abertas con esta definición minimalista, como, por exemplo, se o populismo fai referencia aos líderes, aos movementos ou aos 
réximes políticos, e preguntas relativas aos vencellos entre líderes e seguidores e, sobre todo, aos seus efectos democráticos ou antidemocráticos ${ }^{1}$. Neste artigo tomo como punto de partida a noción discursiva de populismo presentada máis arriba e deconstrúoa para argumentar que 1) para comprender o populismo é preciso ter en conta as súas dimensións retóricas, representativas, políticas e normativas e as relacións entre elas; 2) se o populismo é un discurso político ou, en termos de Kazin, «un modo flexible de persuasión» (1998: 3), ten máis sentido falar sobre «intervencións populistas» que sobre actores ou réximes populistas; 3) o fincapé feito por algúns estudos sobre populismo no antagonismo político como definitorio da súa natureza quita visibilidade aos seus elementos normativos, ou o que Canovan chama a súa dimensión "redentora», e 4) mentres que os xuízos normativos sobre populismo son inevitables, a relación entre populismo e democracia non pode establecerse en termos abstractos, senón que debe ser avaliada en relación co contexto político en que ambos se insiren.

Nas seccións seguintes examino cada unha das dimensións mencionadas de populismo e conclúo apuntando que as diferentes variedades de intervencións populistas teñen relacións de dependencia contextual respecto ás institucións democráticas e que é importante facer explícitos os seus alcances normativos.

\section{FALANDO E VESTÍNDOSE «COMA O POBO»}

Comezo esta sección cunha historia que contén moitos dos asuntos —incluíndo as ambigüidades - que se afrontan ao estudar o populismo. Unha apreciación completa da relevancia da historia requiriría unha longa descrición do escenario referido, mais tratarei de ser o máis conciso posible. A historia refírese á campaña electoral do presidente uruguaio, José «Pepe» Mujica. Nun artigo, publicado en maio de 2009, un economista, Ernesto Talvi, alegou que unha serie de mudanzas estruturais profundas na sociedade uruguaia puideron configurar as condicións socioeconómicas para a emerxencia de "tendencias populistas» no país. Sostén Talvi que unha deterioración nos estándares educativos e a emigración de centos

${ }^{1}$ Sobre definicións de populismo que, ao tempo que fan fincapé na súa natureza política, toman en consideración outros aspectos, ver Freidenberg (2008), Knight (1998), Roberts (1995 e 2007) e Weyland (2001). Verbo dunha discusión das relacións entre populismo e democracia, ver Abts e Rummens (2007), Arditi (2004), Panizza (2005) e Panizza e Miorelli (2009). 
de miles de cidadáns altamente cualificados puideron conducir a unha diminución da clase media tradicional e á expansión dun sector social pobremente educado e pobremente cualificado para o que as oportunidades de mobilidade social son extremadamente limitadas e que se converteu en dependente da asistencia social do Estado. Talvi (2009) argumenta que, dado o aumento en tamaño deste grupo social, non deberían resultar sorprendentes a emerxencia e o éxito político do que describe como "candidatos atípicos cuxa linguaxe, forma de vestir e actitude contrastan coa [sic] dos candidatos de "traxe e gravata", máis formais, característicos da clase política do país».

En todo, menos no nome, Talvi estábase a referir a José «Pepe» Mujica, o daquela candidato presidencial do Frente Amplio (FA). A resposta de Mujica, publicada no seu blog, foi tan rápida como enxeñosa. «Máis populista será túa avoa», retrucou (2009a). O ton coloquial e «politicamente incorrecto» da resposta de Mujica parece darlle creto ao argumento de Talvi de que, polo menos a xulgar polo seu uso da linguaxe, Mujica é, de certo, un populista. No entanto, envolto na linguaxe coloquial, que é parte da súa marca rexistrada política, a resposta de Mujica amosa non só unha perspicaz comprensión das implicancias políticas da afirmación de Talvi, senón tamén dos argumentos sobre o populismo. Paga a pena citar un extracto considerablemente longo da súa resposta para apreciar o seu verdadeiro sabor:

Semella que unha nova e terrible ameaza paira sobre o Uruguai: chámase José Mujica e é portador dun virus tenebroso, o "populismo».

Non esaxero; lean os xornais e vanse atopar co resumo da teoría formulada polo economista Talvi, do instituto CEREs. Van saber que no noso pobre país hai un terzo da poboación que por falla de educación non serve para nada, só aspira a que o Estado lles dea todo e por definición votan a quen ten a pinta de ser bo para facer chover cartos públicos sobre as súas cabezas.

Un chimpiño máis na teoría e sabemos que ese fato de inútiles recoñecen os seus líderes polo mal que se visten, o ordinarios que son para falaren e a falla de alfombras nas súas vivendas.

Non nomearon a ninguén, era só o que faltaba. Probablemente se referían a Ignacio de Posadas ou a Pedro Bordaberry [dous políticos de clase alta, de centrodereita]. Mais como eu teño manía de persecución e alén diso gusto de me facer de vítima, metéuseme 
na cachola que se referían a min. Polo que bulo a responderlle, ao economista Talvi, que máis populista será a túa avoa. (Mujica 2009a)

Hai máis na resposta ca o uso dunha linguaxe popular para deixar sentado un argumento político. Mujica recońece que o termo "populismo» ten múltiples significados e que, dentro de certos contextos, pode ser considerado un eloxio. Comprende claramente, porén, que ese non é o significado en que Talvi utilizou o termo. Citando a Mujica novamente:

Son sabedor que $[s i c]$ no mundo da análise política se usa a palabra "populismo» en máis dun sentido e que nalgún contexto pode considerarse ata un eloxio.

Non é esa a versión á que se referiu Talvi nin menos os xornais.

Dixeron "populismo» no sentido de todos os días, o que está asociado a políticos máis ben baratos, que conseguen votos prometéndolle [sic] o paraíso aos pobres e, unha vez no poder, usan o Estado para lles regalar un tempiño de prosperidade mentireira, ata que todo rebenta. (2009a)

Non sei se Mujica lería algunha vez a definición económica de populismo de Rüdiger Dornbusch e Sebastián Edwards (1991) como a busca do crecemento a curto prazo e da distribución do ingreso á custa do aumento da inflación e de voluminosos déficits fiscais. Mais, diferenzas lingüísticas á parte, as semellanzas entre ambas as definicións son destacables. Mujica (2009a) nega rotundamente ser un populista no sentido económico do termo usado por Dornbusch e Edwards, mais tamén no sentido político común usado por algúns analistas políticos; é dicir, como sinónimo de demagoxia e de manipulación dos sectores de máis baixos recursos da poboación. Dito coas súas palabras: «Nós non usamos os pobres. Se os expresamos politicamente é porque senten que nos importan e imos facer todo o posible, de boa fe, para eles melloraren. Tal e como aconteceu no Brasil con Lula» (2009a).

Hai varios puntos que paga a pena facer notar neste intercambio. Mujica está no certo ao rexeitar que sexa un populista segundo o significado económico do termo de Dornbusch e Edwards ou no equivalente político impregnado da carga normativa da demagoxia. Como político de esquerda foi crítico do neoliberalismo e avoga por máis intervención do Estado na economía, mais nunca apoiou 
a irresponsabilidade fiscal ou outras políticas comunmente asociadas ao populismo económico. Politicamente, establece unha distinción entre «manipular os pobres», acusación frecuentemente formulada contra os políticos populistas, e «expresalos politicamente», o que el reivindica. El compárase a si mesmo co presidente Lula da Silva como xeito de dar un sinal sobre a súa posición nos debates actuais sobre a esquerda "populista» e a esquerda «moderada» na América Latina e sitúase a si mesmo na última categoría. Mesmo así, a súa apreciación de que dentro de certos contextos o termo "populismo» pode ser usado como unha expresión de eloxio presenta a interrogante de se el pode ser considerado o que chamarei aquí un "populista bo», termo que explorarei máis extensamente a seguir.

En que sentido pode daquela dicirse que, malia as súas protestas, Mujica é de certo un populista, posiblemente «un bo»? O primeiro nivel en que isto pode ser sostido é o dalgún dos indicadores de identidade tradicionais ao populismo aos que alude Talvi. Refírese ao uso dun estilo de retórica política distintivo que o separa do establishment político e o achega aos sectores populares. Por mor dos trazos personalistas e antiinstitucionais do populismo, os símbolos, a retórica e o estilo políticos pesaron moito na súa análise. A identificación populista refórzase pola adopción de elementos culturais por parte do líder que son considerados como marcas de inferioridade pola cultura dominante. Non teño espazo aquí para realizar unha análise detallada dos discursos de Mujica, mais o seu discurso transgride permanentemente as regras da retórica do discurso político, particularmente as regras altamente convencionais da linguaxe pública seguida pola gran maioría dos políticos uruguaios. El utiliza unha linguaxe vulgar en dous sentidos, no de lingua plebea dos sectores populares (a «plebe») e mesmo no uso ocasional de termos groseiros en público (Gatto 2009). A súa vestimenta é tamén unha parte integral do seu atractivo político. É sabido que ata antes da campaña electoral nunca usara traxe e gravata en público e cando fixo o primeiro traxe á medida con ocasión dunha visita ao presidente Lula da Silva no Brasil isto converteuse en titulares de prensa. Vive unha vida notablemente austera nunha pequena granxa nun suburbio rural de Montevideo, onde a miúdo recibe os visitantes nun galpón. No estilo de vida simple de Mujica hai unha forte compoñente ética. É un forte crítico do consumismo e, o que é raro nun político, segue o que predica (Nogueira 2009). Mais tamén é un político experimentado e como tal moi consciente de que a retórica e as aparencias son poderosos impulsores de identificación 
política. Non estou a dicir aquí que por si mesmas a retórica e a forma de vestir fan dun político un populista, senón que non se pode comprender a política sen sermos conscientes da importancia dos símbolos na vida política. O uso dunha retórica non política (por exemplo, unha retórica que non se axuste ás normas do discurso político) denota que quen a enuncia é alleo á clase política. Máis aínda, cando esta linguaxe incorpora expresións, formas de fala, estilos musicais e características da vestimenta dos sectores populares, non só transmite unha mensaxe antielitista, senón que inverte as xerarquías sociais ao introducir, na esfera pública, elementos culturais que se consideran características de persoas socialmente inferiores ou sen educación. Na América Latina abundan exemplos deste tipo de xogo simbólico. En Ecuador, a falla de bos modais de Abdalá Bucaram e o estilo pouco ortodoxo da súa campaña electoral, que incorporaba linguaxe irreverente e impropiedades verbais, foi presentado polos medios dese país como unha vergoña para o civismo e unha proba de que Bucaram non estaba á altura da súa investidura. No entanto, como o sinala Carlos de la Torre (2000), ao personificar conscientemente a vestimenta, a linguaxe e os modais da xente común, que era desprezada polas elites e os seus imitadores de clase media, Bucaram atraeu o voto daqueles que vían nel un espello da súa forma de ser e a elevación da súa propia cultura á esfera pública. Nos Estados Unidos, George Wallace pronunciaba mal palabras á mantenta para crear unha imaxe de paduán ignorante, un trazo que destacaba tanto a súa distancia dos centros de poder como a súa proximidade á xente común (Kazin 1998, Lowndes 2005). Nun exemplo máis recente, Hugo Chávez ten un dominio maxistral dos códigos da retórica política que lle permite desprazarse fluidamente dentro do mesmo discurso desde a cita de cifras económicas expresándose como estadista a formas de enunciación coloquiais e persoais e de linguaxe quasi relixiosa de profeta visionario e á retórica nacionalista e antiimperialista, mesturada cun groseiro «que vaia ao carallo» contra o embaixador dos Estados Unidos (Zuquete 2008)².

Unha análise sobre a "política da vestimenta» do populismo, desde a celebración dos «descamisados» con Perón ata os icónicos xerseis de Evo Morales, pode reforzar a evidencia de que, se ben os símbolos son aspectos importantes de calquera xogo político, son particularmente cruciais no modo de identificación populista. As orixes socioeconómicas, a raza, as raíces étnicas e outros marcadores

${ }^{2}$ http://www.youtube.com/watch?v=toKXMcwfOBY. 
de exclusión foron tamén elementos simbólicos importantes que axudaron a políticos como Evo Morales, Lula da Silva e mesmo Barack Obama a ser percibidos polos seus seguidores como «un de nós», en contraste coas elites políticas e económicas tradicionais dos seus respectivos países. Non estou a afirmar que os políticos que falan, que se visten e que son vistos como «o pobo» son necesariamente populistas ou que, á inversa, todos os políticos populistas falan, se visten e se ven como «o pobo». O que digo é que, se o populismo é un modo de identificación, é preciso ser consciente do repertorio completo de marcadores simbólicos de identidade para facer que a identificación cos sectores discriminados e subordinados sexa máis probable.

\section{REPRESENTANDO O POBO}

É necesario transitar agora desde o falar coma o pobo cara ao falar polo pobo; isto é, da retórica á representación. A distinción é, abofé, analítica, xa que a forma e o seu contido non poden ser separados completamente na análise do discurso, mais no populismo hai unha pretensión de falar polo pobo que precisa ser explorada en máis profundidade. Nun discurso improvisado, logo de gañar as eleccións primarias para a presidencia do Frente Amplio, Mujica captura os elementos formais e substantivos da representación política que busco discutir aquí. «Sei o que represento dentro do Frente Amplio e dentro desta sociedade que construíu arquetipos. Hai un negro nos Estados Unidos, un indio en Bolivia e sen odio o digo, que o país saiba que represento os que veñen ben de abaixo» (2009b).

A maioría das definicións de populismo fan fincapé na vontade do líder de interpelar o pobo como "os desposuídos» ou, como o di Mujica, aqueles «que veñen ben de abaixo». É difícil, porén, establecer se existe efectivamente unha relación directa entre o líder e o pobo ou determinar con precisión o que esta implica. Unha apelación directa do líder ao pobo ten máis probabilidades de ser posible en sistemas políticos debilmente institucionalizados, nos que hai poucas instancias institucionais de mediación entre os políticos e aqueles aos que se dirixen. No entanto, mesmo en países con institucións representativas relativamente fortes e estables, particularmente naqueles con sistemas presidenciais, os cidadáns identifícanse directamente con líderes políticos alén ou por encima dos parti- 
dos aos que pertencen. Un caso claro é o de Lula da Silva, quen, na elección de 2006, gañou case o $60 \%$ do voto popular, mentres que o seu partido, o Partido dos Trabalhadores (РT), obtivo apenas arredor do $20 \%$ dos votos. Nos Estados Unidos só unha porcentaxe relativamente pequena da cidadanía se identifica a si mesma como partidaria dun dos grandes partidos, o cal quere dicir que calquera candidato presidencial de éxito debe ter a capacidade de atraer a maioría dos electores independentes. Por outra banda, na Arxentina, o Partido Justicialista (Peronista) foi unha estrutura de mediación forte nas relacións entre os supostamente populistas candidatos peronistas e o pobo arxentino.

O característico do populismo non é tanto a relación directa entre o líder e o pobo, senón a habilidade do líder para chegar a aqueles que senten que non teñen voz no sistema político. Quen son estes desamparados «sen voz»? Para poñelo en termos un pouco simplistas, son os que sofren de exclusión económica, social ou política ou, polo menos, os que se consideran a si mesmos como tales. «Falar polo pobo» é unha construción política que non necesariamente coincide con categorías socioeconómicas. Mais nunha rexión como a América Latina, que ten os niveis máis altos de desigualdade socioeconómica no mundo, os pobres ocupan verdadeiramente o lugar máis baixo da sociedade e calquera pretensión de representar os máis desposuídos ha de procurar mellorar a súa condición e obter o seu apoio electoral.

En moitos países da América Latina as preferencias electorais volvéronse crecentemente determinadas por clivaxes socioeconómicas, segundo as cales as clases medias votan polos políticos do sistema tradicional e os pobres por políticos externos a este. A tendencia á polarización electoral de acordo con divisións socioeconómicas viuse reforzada pola execución de programas sociais focalizados e outras prestacións de benestar que consolidaron os vencellos entre os líderes (agora presidentes) e o pobo, desde as «misións» de Chávez á «bolsa familia» de Lula da Silva. No caso deste último, os programas sociais foron un importante factor contribuínte na mudanza significativa da súa base de apoio electoral, desde as clases medias progresistas e a clase traballadora organizada no polo industrial do estado de São Paulo en 2002 cara aos votantes pobres nas zonas relativamente menos desenvolvidas no norte e nordeste do país en 2006 (Hunter e Power 2007, Zucco 2008), revivindo a vella imaxe varguista do presidente como «o pai dos pobres». No caso do Uruguai, onde o Goberno do Frente Amplio execu- 
tou programas sociais semellantes, as implicacións políticas desta mudanza foron condensadas no argumento de Talvi sobre a nova base social do populismo dos dependentes dos programas sociais, que non teñen educación ou non poden conseguir emprego, e na aguda reinterpretación de Mujica dese argumento en termos de «un terzo da poboación que por falla de educación non serve para nada, só aspira a que o Estado lles dea todo e por definición votan a quen ten a pinta de ser bo para facer chover cartos públicos sobre as súas cabezas» (2009a). Dun xeito máis sofisticado, Kurt Weyland (2007) establece a relación entre representación populista e beneficios económicos cando argumenta que as loitas redistributivas sobre a apropiación das rendas das commodities son a razón do rexurdimento populista na América Latina, o cal é compartido por Joseph Stiglitz cunha carga normativa diferente cando afirma con certa liviandade que, «se por populismo un quere dicir preocuparse polos dous terzos de máis baixos recursos da poboación, daquela o populismo non é unha cousa mala» (2006: 62). A identificación do "pobo" como os pobres e o seu corolario, a importancia da política de redistribución económica para comprender o populismo, son un aspecto importante da representación populista na América Latina contemporánea e esperta un considerable número de interrogantes verbo das relacións entre o populismo político e o económico. Por si sos, no entanto, os beneficios económicos e o apelar aos pobres non dan conta da representación populista. A representación trata de dar voz e recońecemento aos politicamente excluídos tanto como de dar beneficios económicos aos excluídos do sistema socioeconómico. Ao longo da historia do populismo latinoamericano, a política do recoñecemento marcou a irrupción na escena política dos sectores populares urbanos subalternos. Carlos de la Torre amosa exemplos temperáns da política do recońecemento en Ecuador cando lembra que José María Velasco Ibarra introduciu a política de masas en Ecuador incorporando persoas previamente excluídas do sistema á comunidade política. En palabras de De la Torre, «[Velasco] democratizou os espazos públicos traendo a política dos salóns das elites ás rúas. Os seus seguidores, aos que, por vez primeira, lles foi dirixido o discurso nas prazas públicas, afirmaron o seu dereito a ocuparen espazos públicos» (1994: 689; resaltado meu). Unha parecida irrupción plebea no espazo público aínda resoa no imaxinario político arxentino en referencia á mítica ocupación da praza de Maio polos traballadores da periferia de Bos Aires o 17 de outubro de 1945. 
A política do recoñecemento e a política da redistribución foron da man no ascenso de Evo Morales á presidencia de Bolivia. A importancia da redistribución das rendas do petróleo queda testemuñada na campaña do seu partido, Movimiento al Socialismo (MAS), polo incremento das remuneracións por licenza pagadas ao Estado polas compañías de gas e petróleo e polas confrontacións subseguintes entre o Goberno central e as provincias ricas en gas e outros recursos naturais da chamada «Media Lúa» boliviana (Santa Cruz, Beni, Pando e Tarija) pola asignación das rendas dos hidrocarburos. Mais, mentres que a política do recoñecemento e a política de redistribución rara vez poden chegar a se separar completamente, a campaña para o recońecemento da igualdade cultural, política e social da maioría indíxena boliviana foi unha característica dominante do discurso político de Morales. Resulta rechamante na lectura dos discursos de Morales ver como están dominados por universais morais e políticos: «a dignidade», «a equidade», «a soberanía», «a xustiza», «a liberación», no canto de cuestións estritamente económicas. A razón para este fincapé descansa, segundo o discurso inaugural de Morales (2006), na historia da discriminación cultural e racial, a exclusión política e a explotación económica da maioría indíxena boliviana:

Os pobos indíxenas — que son a maioría da poboación boliviana— [...]. Estes pobos, [sic] historicamente fomos marxinados, humillados, odiados, desprezados, condenados á extinción. Esta é a nosa historia; estes pobos xamais os recońeceron como seres humanos, sendo que estes pobos son os donos absolutos desta nobre terra, dos seus recursos naturais. (s/p)

No caso de Venezuela non hai dúbida sobre a importancia dos altos ingresos relacionados co petróleo na explicación da popularidade de Chávez (Coronil 2008, Hidalgo 2009, Riutort 2007, Weyland 2007). Hai tamén argumentos para afirmar que Chávez administrou mal os ingresos petroleiros e que as súas políticas económicas non son sustentables no longo prazo e que poden, en última instancia, socavar a súa base de apoio social. Tamén pode ser lexítimo concibir preguntas tales como se as súas políticas sociais están a atacar as causas subxacentes de pobreza e exclusión no país ou a perpetualas efectivamente (Penfold-Becerra 2007, Riutort 2007). O que resulta importante cuestionar, porén, é unha explicación simplista de natureza economicista verbo do apoio popular de Chávez como resultado exclusivo das prestacións sociais coas que atrae a defensa que lle 
brindan os pobres. Se o conflito social en Venezuela no decenio dos noventa e no decenio do 2000 se definise só polas loitas sobre a distribución das rendas do petróleo, é improbable que aquel conducise a unha ruptura tan radical da orde política coma a representada pola Revolución Bolivariana. Un relato completo do chavismo require pór na mira os seus elementos políticos tanto coma os económicos. Como o expresa Julia Buxton (2009: 2):

En 1998 Chávez non foi elixido sobre a base dunha plataforma de esquerda, pola promesa dunha redistribución económica ou porque prometeu enfrontarse ao neoliberalismo. Basicamente, Chávez foi elixido porque prometeu crear unha forma completamente nova de democracia, un modelo cualitativamente distinto de organización institucional e constitucional e un novo tipo de compromiso político para os cidadáns venezolanos.

Por isto, a definición inicial do proxecto fundacional de Chávez foi bolivariano máis ca socialista. Chávez extraeu da tradición populista a noción dun pobo virtuoso erixíndose, logo dun longo período de opresión, nunha loita de nunca acabar pola xustiza social e, da tradición militar, a noción de si mesmo como un patriota desinteresado, disposto a sacrificar o seu propio interese e benestar pola xente do seu país (Capriles 2008: 9). O seu discurso político pretende que os seus seguidores sintan que son participantes dunha loita de longa data pola liberación do pobo venezolano, do mesmo xeito que Miranda e Bolívar, xunto co pobo venezolano douscentos anos antes, liberaron Venezuela do xugo español (Zuquete 2008: 102).

\section{ANTAGONISMOS POPULISTAS E INTERVENCIÓNS POPULISTAS}

É preciso agora pasar da política da representación ás estratexias políticas na nosa análise sobre o populismo. Executar políticas redistributivas ou dar recońecemento político aos discriminados e excluídos, sexan estes cidadáns individuais ou actores sociais colectivos, son elementos importantes da forma de identificación populista, mais non definen por si mesmos o populismo. O populismo é unha estratexia política (Weyland 2001) tanto como un modo de identificación (Panizza 2005) (ou, mellor dito, unha estratexia de identificación política) e o antagonismo é o 
elemento que define a dita estratexia. A historia de Kazin sobre o populismo estadounidense amosa como diferentes narrativas políticas do conflito entre os poderosos e os máis débiles estiveron presentes ao longo da vida civil norteamericana. Establecer quen son os poderosos e quen son os débiles foi definido e redefinido por versións progresistas e conservadoras do populismo en diferentes momentos no tempo, debuxando así as liñas de forza que caracterizaron e aínda caracterizan as batallas da política norteamericana. Canovan tamén fai notar que o antagonismo político é do celme do populismo cando o define como un chamamento ao "pobo» contra a estrutura de poder establecida e as ideas e valores dominantes (1999: 2). A existencia dun «outro» externo ao pobo é unha condición para a unificación das identidades populares naturalmente fragmentadas e dos intereses diverxentes porque, como o sinalou Glenn Bowman (2005), ao oprimilos a todos o opresor simultaneamente os transforma a todos eles como "parte do mesmo».

Como se constrúe discursivamente o antagonismo político característico das estratexias populistas? Os escritos de Ernesto Laclau (1977, 2005a, 2005b) verbo do populismo ofrecen unha elegante teoría formal sobre a construción dos antagonismos a través da análise do que el chama relacións de diferenzas e relacións de equivalencias. Mentres que ningunha sociedade se estrutura exclusivamente por relacións de diferenzas ou relacións de equivalencias, as relacións de diferenzas predominan nas ordes políticas altamente institucionalizadas, como as democracias pluralistas e liberais, en tanto que as relacións de equivalencias predominan en tempos de crise e polarización, cando as institucións perden o seu poder para estruturar as relacións sociais. Laclau sinala que, cando unha serie de demandas sociais non poden ser absorbidas nunha forma diferenciada polas canles institucionais, aquelas convértense en demandas insatisfeitas que entran nunha cadea de solidariedade ou equivalencia dunhas con outras, como reclamacións igualmente desatendidas. Os líderes populistas plasman as reclamacións comúns (as relacións de equivalencias) arredor dun antagonismo que simplifica o ámbito social na súa oposición en común contra o que eles identifican como responsable do statu quo, tal como o «neoliberalismo» ou «a partidocracia».

Pódese dar algunha substancia a esta elaboración bastante abstracta de cadeas de equivalencias e relacións de antagonismo facendo referencia a acontecementos contemporáneos na América Latina. Nunha formulación que se aproxima moito á cadea de equivalencias de Laclau, Ken Roberts (2008) realiza un paralelismo 
entre a onda actual de incorporación política e a primeira onda, que tivo lugar a mediados do século pasado, un período que tamén foi dominado pola política populista. Roberts (2008: 330) nota a capacidade decrecente das institucións do Estado para responderen ás demandas sociais da cidadanía no medio da crise polas débedas e os programas de axuste estrutural orientados polo mercado no decenio dos 90 e comezos do 2000 para argüír que as necesidades sociais insatisfeitas e as inseguridades económicas intensificadas proporcionaron unha base "para a articulación colectiva de reclamacións políticas» contra o neoliberalismo. A maneira en que as ditas demandas colectivas puideron articularse efectivamente é analizada no estudo sobre as protestas políticas en Bolivia na primeira metade do decenio do 2000 realizado por Moisés Arce e Roberta Rice (2009). O seu estudo amosa como as protestas se caracterizaban pola formación dunha nova identidade colectiva que atravesou clases sociais, etnias, rexións, xeracións e outros sectores sociais, definidos en oposición ao neoliberalismo. Malia que as protestas empezaron por ser específicas e localizadas, como as demandas polos dereitos sobre a auga en Cochabamba, rapidamente se estenderon a outras partes do país e se desenvolveron nunha oposición xeneralizada ás políticas económicas do Goberno e aos chamados partidos tradicionais do país. O que fixo tan efectivas as protestas foi a habilidade dos organizadores dos movementos para vencellaren as demandas de grupos dispares a unha crítica coherente da orde política e económica do país, co poder de mobilizar milleiros de persoas en marchas, bloqueos de estradas e outras formas de acción directa (Arce e Rice 2009, Suárez 2003, Kohl e Farthing 2006). Como foi posible acadar un nivel tan elevado de unidade e de mobilización, en particular tendo en conta que as novas coalicións carecían de canles institucionais de representación social e as mobilizacións ocorrían frecuentemente sen unha coordinación centralizada e con cada grupo da sociedade civil a perseguir a súa propia axenda? A resposta de Arce e Rice (2009: 98) é que o "neoliberalismo» se tornou un símbolo organizacional contra o cal os movementos sociais reuniron apoio para os seus esforzos mobilizadores.

Nas análises de Roberts e de Arce e Rice sobre protestas sociais hai un conxunto de puntos que merecerían maior consideración, sendo o máis obvio o feito de seren os movementos sociais, máis ca os líderes populistas, os actores principais na articulación de demandas. A versión de Arce e Rice sobre a mobilización social en Bolivia subestima o papel dos principais líderes políticos sindicais e indíxenas 
en articularen as protestas e non toma debidamente en conta a habilidade de Evo Morales para cristalizar os antagonismos sociais a un nivel político máis elevado. O importante para o propósito deste artigo, porén, é ilustrar as implicancias das análises de oposición social ao liberalismo na América Latina contemporánea para comprender mellor as políticas populistas.

Na América Latina hai moitos exemplos da estratexia política de dicotomización do espazo social por líderes políticos. Hugo Chávez usou sistematicamente os antagonismos políticos para unir os seus seguidores contra un grupo variado de «inimigos do pobo», desde os partidos tradicionais á oligarquía económica e a oposición e desde o presidente Uribe, de Colombia, ao «diaño Bush». As políticas do antagonismo, enmarcadas na oposición entre o pobo, por unha banda, e as partidocracias e o neoliberalismo, pola outra, tamén desempeñaron un papel significativo nas estratexias políticas de Evo Morales e Rafael Correa. Dada a centralidade do antagonismo no populismo, talvez se podería establecer unha distinción entre os líderes "populistas» e os «populares» arredor da constitución estratéxica dos antagonismos políticos do populismo. Os líderes políticos como Mujica e Lula da Silva (e Obama) poden falar ou ser percibidos "como que son "do pobo"» e "como que falan "polo pobo"", pero son construtores de pontes, máis ca cavadores de trincheiras. Lula da Silva é, seguramente, un dos poucos líderes políticos no mundo que se atopa igualmente cómodo no Foro Económico Mundial (wef) e no Foro Social Mundial. Obama veu personificar a política posracial nos Estados Unidos. E, na súa linguaxe inimitable, Mujica (2009c) presenta un forte argumento a prol da política de compromiso sobre a política do antagonismo e contra o argumento populista de que a mudanza é sobre todo unha cuestión de vontade política:

Gobernar non é facer o que se quere. Gobernar cunha visión progresista é zurcir todos os días. É tecer incansablemente alianzas políticas e sobre todo alianzas sociais, para ensanchar todo o posible a base de sustentación. As contradicións sociais van seguir a existir, mais se un deixa que unha punta mace na outra, sen piedade, terminamos todos magoados e tornando o pastel máis cativo. $(\mathrm{s} / \mathrm{p})$

A distinción entre políticos populistas (o predominio da política do antagonismo) e populares (o predominio da política das diferencias), porén, precisa 
polo menos ser examinada. Se o antagonismo político está na esencia do populismo, quere isto dicir que toda estratexia política que dicotomiza o espazo político é necesariamente populista? Claramente non. No século xIx, a elite urbana na América Latina enmarcaba o discurso político arredor da dicotomía «civilización ou barbarie» para xustificar a súa loita contra os caudillos rurais, sen por iso ser precisamente populista. É máis, o antagonismo é, polo menos de acordo con Carl Schmitt, constitutivo non só do populismo, senón do político; xa que logo, non pode ser, exclusivamente, unha característica distintiva do populismo. Laclau resolve o problema argumentando que, efectivamente, populismo é o mesmo ca política (2005a: 47). Por razóns que non podo elaborar aquí, penso que esta é unha solución tanto teórica como empiricamente insatisfactoria. Desde o meu punto de vista, non se pode dar unha definición puramente formal (ontolóxica) do populismo baseada no papel constitutivo do antagonismo. $\mathrm{Na}$ comprensión do populismo é preciso incluír a súa dimensión normativa, contida na reclamación de que, coa exclusión daqueles que non teñen voz no sistema, a orde política viola principios fundamentais de equidade, xa sexa na súa dimensión política (representación) ou nas dimensións socioeconómicas (redistribución). Se este é o caso, a promesa de reparar a inxustiza (a política de incorporación) é, polo menos, tan crucial para a comprensión do populismo coma a constitución dun antagonismo entre o pobo e os seus opresores. Se a reparación da inxustiza require a destrución do sistema (o aspecto fundacional do populismo) ou traballar dentro do sistema para dar voz política e beneficios económicos aos excluídos, isto depende máis ca nada do contexto. Historicamente, moitos movementos populistas da América Latina actuaron con pragmatismo para incorporar os de máis abaixo ao sistema a través de formas corporativas de representación política, políticas sociais e prácticas de intermediación de natureza clientelar. Paga a pena lembrar que isto foi denunciado historicamente pola esquerda como evidencia da natureza conservadora do populismo. Máis recentemente, os líderes da esquerda radical populista buscaron restaurar a soberanía do pobo a través da mudanza das ordes constitucionais, fundando repúblicas bolivarianas e democracias participativas plurinacionais. $\mathrm{Na}$ práctica, as dúas alternativas — traballar dentro da orde política existente ou buscar unha orde radicalmente nova - atópanse nos extremos opostos dun contínuum que pode estar suxeito a unha variedade de intervencións populistas. 
Nun contexto de crise de representación, como foi o caso en Bolivia, Ecuador e Venezuela cara a finais dos 90 e temperamente no decenio do 2000, os aspectos fundacionais do populismo transformáronse en dominantes, mentres que noutros contextos máis institucionalizados os antagonismos populistas son mediados e constrinxidos polo xogo político institucional. Os Gobernos dos Kirchner na Arxentina son un exemplo de como o contexto define o alcance e límites do antagonismo populista. Para algúns académicos, os Kirchner representan o retorno do populismo á Arxentina. Eles — particularmente o finado Néstor Kirchner-centralizaron o poder na presidencia, lexislando por decreto e usando fondos públicos para aseguraren a lealdade dos gobernadores estatais e para aceitaren as rodas da máquina do clientelismo peronista. Ambos manifestáronse contra o neoliberalismo e a democracia de mercado dos noventa e reviviron a política popular nacional e as políticas da esquerda peronista do decenio de 1970. Néstor Kirchner chegou a ser ben coñecido pola súa propensión a se implicar en querelas políticas cunha ampla variedade de inimigos, desde o FMI ata os militares, e pola súa estreita alianza con Hugo Chávez. Talvez o exemplo máis emblemático da política do antagonismo nas Administracións dos Kirchner fose a confrontación entre os produtores rurais e a presidenta, Cristina Fernández de Kirchner, en 2008, que seguiu ao intento do Goberno de introducir unha nova escala móbil para os impostos á exportación de grans e sementes oleaxinosas. A confrontación polarizou a sociedade arxentina. Tivo unha dimensión normativa forte ao acusar a presidenta Cristina Fernández de Kirchner os produtores (ricos) de lle negaren egoistamente os fondos necesitados polo Goberno para executar os seus ambiciosos programas sociais.

Por un momento a Arxentina pareceuse aos países andinos canto ao seu nivel de conflito social. A confrontación estendeuse polas rúas e os camiños, con agricultores a bloquearen as estradas e os partidarios e opositores do Goberno a marcharen polas rúas de Bos Aires. Tamén evocaba as loitas pasadas entre Perón e a así chamada «oligarquía latifundista», talvez cunha connotación do aforismo de Marx sobre as diferentes formas en que a historia se repite. E, con todo, o Goberno perdeu a pelexa porque o Congreso votou en contra do imposto. A resolución do conflito a través de medios institucionais trae a consideración o argumento de Steven Levitsky e María Victoria Murillo (2008) de que, calquera que sexa o conxunto de semellanzas superficiais entre Kirchner e Chávez, a Arxentina non é Venezuela porque, malia as intervencións populistas de Kirchner e a debilidade 
do sistema de partidos do país, as bases institucionais e sociais do pluralismo democrático na Arxentina son moito máis fortes ca en Venezuela.

Ten sentido falar de populismo en sistemas políticos institucionalizados con controis e contrapesos, cunha sociedade civil forte e activa e bo funcionamento das institucións representativas? Eu penso que ten, sempre que non se faga referencia ao populismo como un réxime político ou como algunha clase de totalidade abranguedora, senón, segundo o suxerido anteriormente, como intervencións populistas realizadas nunha contorna discursiva e institucional política máis ampla. Para comprender o que se entende por «intervencións» é importante ter en mente a observación de Kazin (1998: 3) de que, cando se traza a historia do populismo nos Estados Unidos, el non sostén que os seus suxeitos de estudo eran populistas, no mesmo sentido de que poderían ser unionistas ou socialistas, protestantes ou católicos, demócratas liberais ou republicanos conservadores. Máis ben, a súa premisa é que estes políticos empregaban o populismo como unha «forma flexible de persuasión». Como o expresa con referencia aos seus casos de estudo de populismo, "o populismo, claro, non foi o único elemento na súa retórica, mais coido que é imposible negar a súa importancia» (1998: 6).

Aínda que estou de acordo coa formulación de Kazin, eu usaría «intervencións» antes ca «retórica» para significar un conxunto máis amplo de prácticas materiais e simbólicas asociadas co modo populista de identificación. Nalgúns casos, «intervencións» refírese ás características persoais do líder ou á súa traxectoria política cando o proxectan como alleo á orde establecida, malia que non necesariamente en antagonismo con ela. Abonda con pensar como foi usada a vida de Obama pola extrema dereita nos Estados Unidos para argumentar que nin sequera é un cidadán norteamericano ou, nunha versión menos fundamentalista, como gañou as primarias do Partido Demócrata presentándose a si mesmo como un político alleo á máquina do partido. Non é trivial para comprender o atractivo de José Mujica o ter en conta que foi un líder guerrilleiro tupamaro no decenio de 1970, unha condición da que nunca se arrepentiu ou renegou e pola cal pasou longos anos en prisión baixo condicións arrepiantes. A relevancia do seu pasado é que este non desapareceu completamente, non no sentido de que el estea a avogar por unha revolución violenta ou que os seus electores apoien as metas e os métodos dos tupamaros, senón, máis ben, polo feito de que os tupamaros fosen un movemento antisistémico que desafiou a orde política e económica, non no nome da clase traballadora ou da 
ideoloxía marxista, senón no nome do pobo contra a oligarquía. Non sen razón os seus antigos críticos e actuais aliados, os comunistas, os acusaron de "populistas». Como político, Mujica non denuncia as institucións políticas do seu país como ilexítimas e é un negociador político sagaz. Poida que se transformase nunha especie de vello sabio da política uruguaia e hai pouco no seu programa económico que poida ameazar os intereses empresariais. El traballa dentro do sistema e non contra o sistema, mais as súas raíces políticas e a súa biografía persoal, tanto coma a súa retórica política e a súa afirmación de representar os de máis abaixo da sociedade, fan de Mujica un estrańo, se non ao sistema como tal, polo menos á elite política, e convérteno nun líder que é idolatrado polos pobres, mais que antes de chegar ao Goberno non lles espertaba confianza a importantes sectores das clases medias. Como sostivo no seu momento Jorge Lanzano,

Mujica ten un perfil populista, baseado no carisma, posturas anti-establishment e unha apelación aos pobres, que se viu reforzado polos seus trazos persoais e a súa liñaxe como membro do movemento guerrilleiro tupamaro do decenio dos 60, así como pola súa afinidade polos Kirchner gobernantes da Arxentina e a esquerda «bolivariana». (2009: 2)

Noutros casos, os líderes políticos utilizan as intervencións populistas xunto con outras formas de retórica política, para obteren certos efectos políticos. $\mathrm{O}$ caso de Lula da Silva ilustra este punto. Ao se enfrontar a acusacións de corrupción contra o seu Goberno durante a campańa electoral de 2006, Lula usou ambos: o discurso populista dos excluídos contra a elite política e o discurso institucional das diferenzas para se defender a si mesmo e o seu partido contra as acusacións. Así, durante unha xira polo nordeste, onde tiña un forte apoio popular entre os pobres, o presidente Lula dixo:

A mesma elite que levou Getulio [Vargas] à morte, que levou Juscelino [Kubitschek] ao major processo de acusação e de mentiras, que tirou João Goulart, essa mesma elite tentou me tirar. Só que a diferença básica no meu caso não é que eu fosse melhor. E que tinha um componente que eles não contavam e descobriram que existia chamado povo brasileiro. («Lula diz que...», s/p) ${ }^{3}$

\footnotetext{
${ }^{3}$ «Lula diz que, sem reforma, novos escândalos surgirão», Folha de São Paulo, 24 de xullo de 2006.
} 
Porén, ao día seguinte el argüíu que a corrupción era un elemento estrutural da política brasileira: «Não pensem que o erro de cada um é individual ou partidário. $\mathrm{O}$ que acontece são os acúmulos de deformaçóes que vêm da estrutura política do nosso país» $(\mathrm{s} / \mathrm{p})^{4}$.

Os extractos anteriores deixan en claro que Lula se estaba a presentar a si mesmo como parte do pobo baixo ataque por unha sempre presente elite dominante que xa fixera caer outros líderes populares e, ao mesmo tempo, presentaba a corrupción como un atributo do sistema político do cal o seu partido, o PT, formaba parte. No primeiro argumento el estaba a ser atacado por causa da corrupción porque estaba baixo o ataque do sistema. No segundo argumento membros do seu partido estaban involucrados en actos de corrupción porque eran parte do sistema. Pódese lembrar a tantas veces citada declaración de Lula de que a crise financeira de 2008-09 foi causada por "xente branca, de ollos azuis», e non por "persoas negras, pobres ou pobos indíxenas», para un facer unha idea de por que Lula se converteu "oficialmente» no "político máis popular da Terra" 5 .

Se as sombras dunha vida vivida como un outsider ou a fustrigación ocasional ao sistema fosen todo o que son as intervencións populistas, o atractivo do populismo en sistemas políticos altamente institucionalizados sería real mais limitado, un tipo de populismo leve. Hai, porén, outra característica do populismo que o torna potencialmente unha forza política poderosa en calquera contexto democrático. Canovan argúe que a democracia moderna ten dúas caras, unha redentora e outra pragmática ${ }^{6}$. Sostén, alén diso, que, malia as dúas se opoñeren, as dúas son tamén interdependentes; e que entre elas xace unha fenda na que é presumible que apareza o populismo (1999: 10-11). Canovan establece a distinción entre políticas redentoras e pragmáticas examinando diferentes elementos, como a atribución de

\footnotetext{
${ }^{4}$ Ibíd.

${ }^{5}$ http://www.liveleak.com/view?i=37d_1238723472 [última consulta: 21 de outubro de 2010].

${ }^{6}$ Ela sinala as distincións no traballo de Michael Oakeshott, quen argumentaba que a política en Europa estivo marcada pola tensión entre dous estilos políticos que el denominou «a política da fe» e "a política do escepticismo». Segundo isto, a política é tomada como o camińo de acadar a perfección ou salvación no mundo asumindo que é a acción do Goberno a que pode logralo. "A política da fe», xa que logo, implica a mobilización do entusiasmo popular para esta tarefa, unha procura de maior poder para o lograr e a confianza de que é seguro outorgar ese poder aos seres humanos. A política do escepticismo, pola contra, é receosa tanto do poder como do entusiasmo e ten expectativas moito máis baixas sobre o que os Gobernos poden lograr» (Canovan 1999: 8).
} 
que, pragmaticamente, a democracia é unha forma de goberno e unha maneira de aturar pacificamente os conflitos das sociedades modernas por medio dun repertorio de regras e prácticas, mentres que, para a cara redentora da democracia, o pobo é a única fonte de autoridade lexítima e a salvación prométeselles sempre e cando se fagan responsables politicamente das súas propias vidas. El conclúe que, polo menos nalgún grao, a promesa de salvación da democracia redentora resulta necesaria para lubricar a maquinaria da democracia pragmática e que, se non está presente no interior do sistema político establecido, ben podería reafirmarse na forma dun desafío populista. Hai unha formulación paralela na relación entre a promesa redentora do populismo e a política democrática do día a día na afirmación de Kazin, para quen o populismo «enraíza na fenda entre os ideais americanos e aquelas institucións e autoridades cuxo desempeño os traizoan», e na súa observación de que o populismo é «unha forma de "optimismo retórico"» (1998: 289). Dito nas súas palabras: «Só cando os esquerdistas ou os propios liberais falaron ao estilo populista — esperanzado, sen reservas, ata romántico- é cando foron quen de conceder á súa política unha face de maiorías e de axudar significativamente a mellorar o benestar común» (1998: 6-7).

Para algunhas versións do populismo, a dimensión redentora da democracia non se pode realizar no interior do sistema porque non pode haber espazos políticos comúns entre «o pobo»e os seus «opresores». De aí que a fenda entre as dúas dimensións da democracia sexa insuperable baixo as regras institucionais correntes e débese refundar o sistema sobre bases diferentes. A retórica redentora afonda no pasado para evocar formas de organización colectiva indíxena e deliberación democrática en Bolivia ou ideais bolivarianos selectivos en Venezuela co fin de as contrastar coas inequidades do presente e inspirar as persoas na marcha cara a un futuro mellor. Con todo, o optimismo retórico do populismo tamén pode manifestarse no intento de pechar a fenda entre as dimensións redentoras e pragmáticas da democracia sen alcanzar nunca a facelo por completo ou, alternativamente, escachizando a orde política. Lula da Silva é percibido cada vez máis, en particular dentro do Brasil, como un político ultrapragmático que pacta cos seus antigos críticos de dereita e adoptou o así chamado legado neoliberal do seu predecesor, Fernando Henrique Cardoso. Moitos analistas, ao rastrexar a orixe pública do xiro pragmático de Lula, atópano na súa famosa «Carta ao povo brasileiro» (Da Silva 2002), publicada a comezos da campaña electoral de 2002, 
na que prometeu que, se era elixido, o seu Goberno cumpriría coas condicións fiscais e monetarias impostas polo Fondo Monetario Internacional (FMI). Mais paga a pena lembrar que, no centro da campaña de Lula no 2002, non estaba a promesa pragmática de facer un reembolso ao FMI, mais a promesa redentora de acabar coa fame nun país onde millóns de persoas aínda a sufrían. E, mentres que o seu estilo de goberno se volveu máis e máis pragmático e menos redentor e a promesa de "Fome Zero» se transformou pragmaticamente na altamente efectiva «Bolsa Familia», a dimensión redentora da retórica do presidente Lula aínda pode atoparse, talvez demasiado convenientemente, nas súas intervencións nas arenas internacionais, nas cales fai campaña por un novo equilibrio da orde mundial a favor daqueles que están «debaixo de todo». Como o dixo nun discurso no Foro Social Mundial en 2009:

O que essa gente [as elites políticas e económicas] não percebeu é que hoje o povo mais humilde da América Latina, os índios da Bolívia, os índios do Equador, os índios brasileiros, os seringueiros, os trabalhadores da Venezuela, do Paraguai, as pessoas aprenderam a não ter mais intermediário para escolher os seus dirigentes. As pessoas votam diretamente e escolhem em que elas confiam ${ }^{7}$.

Hai momentos en que un lema electoral capta a mensaxe redentora do populismo. Na campańa electoral de 1989 Carlos Menem dixo ao pobo arxentino: «Síganme, non os vou defraudar». A apelación de Menem pode ser interpretada de moi diversos xeitos. Pode ser vista como unha evidencia da natureza personalista e vertical do populismo e do baleiro programático, se non da duplicidade das promesas da súa campaña. Mais, no momento en que o pobo arxentino sufría de terribles dificultades económicas, o seu lema transmitiu a promesa de sacar as persoas da súa condición e de mellores tempos por viren. En moitos aspectos Obama é a antítese de Menem e así o foi o slogan da súa campaña. «Si, nós podemos» transmite unha mensaxe moi diferente de «Síganme», unha convocatoria a un esforzo colectivo, máis ca o mandato de seguir o líder. Malia Obama ter unha biografía que o sitúa como o candidato presidencial coa historia de vida máis

\footnotetext{
${ }^{7}$ Senhor Luiz Inácio "Lula" da Silva, Presidente da República Federativa do Brasil; Belém, Pará, 29/01/2009. Discurso do Presidente da República, Luiz Inácio "Lula" da Silva, durante o encontro com participantes do Forúm Social Mundial 2009: painel "América Latina e o Desafio da Crise Internacional".
} 
diferente na historia dos Estados Unidos, nunca buscou facer un capital político do feito de non ser parte da elite política, ao contrario de Sarah Palin. Para algúns dos seus críticos, un dos erros de Barack Obama é que procura demasiado o consenso á custa de comprometer os seus ideais, demasiada articulación das diferenzas e demasiados poucos antagonismos, aínda que o seu estilo consensual sexa pouco fiable para a dereita populista, que prospera cos antagonismos ata o límite da paranoia e cre que Obama non é cidadán estadounidense. Malia todo, «Si, nós podemos» captura brillantemente o optimismo retórico que Kazin sostén que fixo do populismo un modo de persuasión tan poderoso e que deu esperanza e voz a millóns de cidadáns afroamericanos marxinados que non se sentían representados por outros políticos.

\section{CONCLUSIÓNS}

Estou a argumentar aquí que os políticos como Pepe Mujica, Lula da Silva e Barack Obama son populistas? Se así fose, non estaría a afirmación a expandir aínda máis un concepto en por si altamente promiscuo? E que dicir das implicancias políticas de chamarlles "populistas» a un grupo de políticos tan dispares? En verdade non estou a soster iso. En primeiro lugar, penso que é importante ter en conta a advertencia de Kazin (1998: 6) de que os debates sobre quen é ou non un verdadeiro populista con frecuencia son unha forma de enunciar as opinións políticas de quen emite ese xuízo, ou debería dicir as aversións desa persoa? En segundo lugar, como sostiven anteriormente, o populismo é un entre a variedade de discursos usados polos políticos para estableceren relacións de identificación cos seus respectivos públicos. É por iso polo que uso o termo «intervencións populistas» para expresar que, en última instancia, o populismo se refire a certa estratexia política, máis ca á personalidade dun líder. Na práctica aínda lles chamamos "populistas» a algúns líderes, malia que, cunhas poucas excepcións, determinar quen son e por que son populistas é algo que é froito de fortes polémicas. Na medida, e só na medida, en que o modo populista de identificación é central para a apelación do líder e para a súa estratexia política, pódese dicir que un líder como Hugo Chávez é populista. En terceiro lugar, o modo populista de identificación ten varias dimensións ás que me referín como 1) «falar coma 
o pobo» (a irrupción simbólica dun indicador de exclusión na esfera pública); 2) «falar polo pobo» (dar voz ás reivindicacións daqueles que non se senten representados no sistema); 3) unha estratexia política (a política do antagonismo), e 4) unha promesa normativa de redención. Pódese pensar nestas dimensións como unha clase de gradiente político que se estende desde os niveis máis baixos de «populismidade» aos máis altos. Pode argumentarse que estas distincións son máis analíticas ca substantivas, mais a maioría dos estudos sobre populismo centráronse na construción discursiva do antagonismo entre «o pobo» e a estrutura establecida de poder como a esencia que o define. No discurso populista, porén, este antagonismo é só parte dun camiño político de redención que conduce á plena incorporación daqueles que se perciben a si mesmos como privados dalgún dereito fundamental, económico ou político, ao corpo político. Nalgúns discursos populistas a liberación do pobo da opresión require refundar a orde política. Outros, no entanto, ao buscaren articular as reclamacións do colectivo constituído polos privados de recońecemento e representación, enmarcan o conflito entre os débiles e os máis poderosos dentro dun conxunto común de normas de procedemento democrático e do recoñecemento de intereses comúns. Existe neles a conciencia de que a equidade e o pluralismo son dous aspectos da orde política democrática que necesariamente inclúen conflito e negociación e buscan promover unha orde política máis inclusiva que dá voz e beneficios a aqueles que se atopan nos niveis sociais máis baixos.

Quizais, con todas as advertencias e excepcións sinaladas antes, aínda se poida falar de dous tipos de populistas ou, polo menos, dous tipos de apelación populista: un é antisistémico, de maiorías, polarizado e baseado na lóxica dos antagonismos, desprovistos de calquera tipo de mediación institucional ou valorativa. O outro é unha mestura de políticas pragmáticas e redentoras que, ao tempo que denuncia as fallas da orde democrática e as limitacións das institucións para redefiniren o verdadeiro significado da democracia, reforza o pluralismo democrático dando voz aos excluídos e creando, no proceso, un demos máis inclusivo. Talvez se lle poida chamar a este "populismo inclusivo» para o distinguir do populismo de maiorías.

Por que, entón, non ir un paso máis aló e chamarlles, aos líderes que loitaron para lle dar ao pobo recońecemento e reivindicación pero que ao mesmo tempo recońecen que aqueles do outro lado da partición populista tamén teńen intere- 
ses lexítimos que requiren compromiso e reconciliación, "populistas bos» para os distinguir daqueles que, valéndose de levar ata o límite a estratexia do «nós contra eles», acaban fracturando as sociedades e creando novas formas de exclusión en ambos os lados da división política? Coido que hai boas razóns para non tomar esta opción á lixeira. Primeiro, no seu uso de sentido común, o populismo é unha marca de tal toxicidade que non debería ser outorgada liviamente a aqueles que a perciben como un termo que implica a descualificación política. Segundo, mesmo se ningunha estratexia política do mundo real pode ser definida puramente en termos de relacións de antagonismos, se cremos que o antagonismo entre o pobo e os seus opresores é o elemento que define o populismo, a vontade de o transcender a través do recoñecemento de lexítimas diferenzas, tanto no interior do demos como entre o pobo e os seus adversarios, significa que o termo "populismo inclusivo» pode, de certo, ser un caso de extensión conceptual.

Finalmente, na análise das variedades posibles do populismo hai tamén un trazo normativo. Algunhas veces, o pragmatismo, a reconciliación e o compromiso poden non ser necesariamente algo bo. Pénsese, por exemplo, no fracaso do estilo político pragmático do presidente Lula da Silva para limpar a fosa séptica de corrupción da política brasileira. Pola contra, algúns académicos teñen defendido as rupturas populistas como necesarias para a creación dunha orde social máis xusta en países como Bolivia e Ecuador e aínda en Venezuela. Hai indicacións que amosan que algúns líderes comunmente vistos como «populistas [radicais] malos» na América Latina son cada vez máis conscientes deste argumento e mesmo poderían estar abertos a seren vistos como populistas. Curiosamente, talvez, este poder transformador do populismo é aquel que o "populista bo» Pepe $\mathrm{Mu}$ jica tivo en mente cando apuntou que, dentro de certos contextos, o populismo pode ser considerado un cualificativo honroso. A distinción entre populistas bos e malos, en última instancia, depende da política de cada un. Cando se trata dunha análise política pode ser imposible evitar os xuízos de valor, mais é importante deixar en claro sobre que bases se realizan e neste artigo busquei resaltar as zonas grises que matizan un tema presentado demasiadas veces en branco e negro. 


\section{REFERENCIAS BIBLIOGRÁFICAS}

Aвтs, Koen / Stefan Rummens (2007): «Populism and Democracy», Political Studies, 55:2, 405-424.

Arce, Moisés / Roberta Rice (2009): «Social Protest in Post-Stabilization Bolivia», Latin American Research Review, 44:1, 88-101.

Arditi, Benjamín (2004): «Populism as a Spectre of Democracy: A Response to Canovan», Political Studies, 52:1 (marzo), 135-143.

Bowman, Glenn (2005): "Constitutive Violence and the Nationalist Imaginary: The Making of 'The People' in Palestine and 'Former Yugoslavia'», en Francisco Panizza (ed.), Populism and the Mirror of Democracy, Londres, Verso, 118-143.

Buxton, Julia (2009): «Venezuela: It's Not the Economy Stupid». Relatorio presentado na conferencia Latin American and the Caribbean in the Global Financial Crisis. Institute for the Study of the Americas and Foreign and Commonwealth Office, Londres, 21-22 April.

Canovan, Margaret (1999): «Trust the People!: Populism and the Two Faces of Democracy», Political Studies, 47, 2-16.

CapriLes, Colette (2008): «The Politics of Identity: Bolívar and Beyond», ReVista. Harvard Review of Latin America (Fall), 8-10.

Coronil, Fernando (2008): «Chávez’s Venezuela: A New Magical State?», ReVista. Harvard Review of Latin America (Fall), 3-4.

Dias Leite, Pedro (2006): «Lula diz que, sem reforma, novos escândalos surgirão», Folha de São Paulo, 24 de xullo (http://www1.folha.uol.com.br/folha/brasil/ult96u80639.shtml).

Dornbusch, Rüdiger / Sebastian Edwards (eds.) (1991): The Macroeconomics of Populism in Latin America, Chicago, University of Chicago Press.

Freidenberg, Flavia (2008): «El flautista de Hammelin: liderazgo y populismo en la democracia ecuatoriana», en Carlos de la Torre / Enrique Peruzzotti (eds.), El retorno del pueblo: populismo y nuevas democracia en América Latina, Quito, FLACso Ecuador/Ministerio de Cultura, 189-237.

GatTo, Hebert (2009): «Cultura villera y política», El País Digital, 2 de setembro (http://www.elpais.com. uy/Paginas) [última consulta: setembro, 2009].

Hidalgo, Manuel (2009): «Hugo Chávez’s Petro-Socialism», Journal of Democracy, 20:2, 78-92.

Hunter, Wendy / Timothy Power (2007): «Rewarding Lula: Executive Power, Social Policy and the Brazilian Election of 2006", Latin American Politics and Society, 49:1, 1-30.

Kazin, Michael (1998): The Populist Persuasion: An American History, Ithaca/Londres, Cornell University Press.

Knight, Alan (1998): «Populism and Neo-Populism in Latin America, Especially in Mexico», Journal of Latin American Studies, 30:2, 223-248.

KoHL, Benjamin / Linda Farthing (2006): Impasse in Bolivia: Neoliberal Hegemony and Popular Resistance, Londres, Zed Books.

Laclau, Ernesto (1977): Politics and Ideology in Marxist Theory, Londres, Verso.

Laclau, Ernesto (2005a): «Populism: What's in a Name?», en Francisco Panizza (ed.), Populism and the Mirror of Democracy, Londres, Verso, 32-49.

Laclau, Ernesto (2005b): On Populist Reason, Londres, Verso.

LanZaro, Jorge (2009): «Social Democracy Lives in Latin America» (http://projectsyndicate.org/ commentary/lanzaro1). 
Levitsky, Steven / María Victoria Murillo (2008): «Argentina: From Kirchner to Kirchner», Journal of Democracy, 19:2 (abril), 16-30.

Lowndes, Joseph (2005): «From Founding Violence to Political Hegemony: The Conservative Populism of George Wallace», en Francisco Panizza (ed.), Populism and the Mirror of Democracy, Londres, Verso, 144-201.

Morales, Evo (2006): discurso de posesión do presidente constitucional da República, Evo Morales Aima, pronunciado o 22 de xaneiro de 2006, Portal de la Presidencia de Bolivia (http://www.presidencia.gob. bo) [última consulta: xuño, 2009].

Mujıca, José (2009a): «Más populista será tu abuela!», Pepe tal cual es [blog], 1 de xuño (http://www. pepetalcuales.com.uy/articulo/14) [última consulta: setembro, 2009].

Mujica, José (2009b): «Represento a los de abajo», Espectador.com, 28 de xuño (http://www.espectador. com/1v4_contenido_print.php?id=155498) [última consulta: xuño, 2009].

Mujica, José (2009c): «Gobernar no es hacer lo que se quiere. Es zurcir, bordar y tejer», Pepe tal cual es [blog], 1 de abril (http://www.pepetalcuales.com.uy/articulo/5/).

Nogueira, Alejandro (2009): «El palo de la colmena», El País Digital, 21 de xuño (http://www.elpais.com. uy/Paginas) [última consulta: xuño, 2009].

Panizza, Francisco (2005): «Introduction», en Francisco Panizza (ed.), Populism and the Mirror of Democracy, Londres, Verso, 1-31.

Panizza, Francisco / Romina Mrorelli (2009): «Populism and Democracy in Latin America», Ethics and International Affairs, 23:1 (primavera), 39-46.

Penfold-Becerra, Michael (2007): «Clientelism and Social Funds: Evidence from Chávez's Misiones», Latin American Politics and Society, 49:4, 63-84.

Peruzzotti, Enrique (2008): «Populismo y representación democrática», en Carlos de la Torre / Enrique Peruzzotti (eds.), El retorno del pueblo: populismo y nuevas democracia en América Latina, Quito, FLACso Ecuador/Ministerio de Cultura, 97-124.

Riutort, Matías (2007): «La economía venezolana en el 2007 y perspectivas para el 2008», Temas de Coyuntura, 56 (decembro), 115-126.

Roberts, Kenneth M. (1995): «Neoliberalism and the Transformation of Populism in Latin America: The Peruvian Case», World Politics, 48, 82-116.

Roberts, Kenneth M. (2007): «Latin America’s Populist Revival», The SAIS Review of International Affairs, 27:1 (inverno-primavera), 3-15.

Roberts, Kenneth M. (2008): «The Mobilization of Opposition to Economic Liberalization», Annual Review of Political Science, 11 (xuño), 327-349.

Sснмiтt, Carl (1988): The Crisis of Parliamentary Democracy, Cambridge, MA, The MIT Press.

Silva, Luiz Inácio da (2009): discurso do presidente da República, Luiz Inácio «Lula» da Silva, durante o encontro con participantes do Foro Social Mundial 2009: panel «América Latina e o Desafio da Crise Internacional», Pará, 29 de xaneiro (http://afinsophia.wordpress.com/2009/01/30/lula-e-presidentes-daamerica-do-sul-desmistificam-a-crise-no-fsm-amazonia-2009/).

Silva, Luiz Inácio da (2002): «Carta ao povo brasileiro», Partido dos Trabalhadores, Dirétorio Nacional, 22 de xuño (http://200.205.248.99/site/jornalismo/openew.asp?IDNews512822\&TPNews53) [última consulta: xuño, 2003]. 
Stiglitz, Joseph (2006): «Is Populism Really So Bad for Latin America?», New Perspectives Quarterly, 23:2 (primavera), 61-62.

SuÁrez, Hugo José (2003): Una semana fundamental: 10-18 octubre 2003, La Paz, Muela del Diablo.

TAlvi, Ernesto (2009): «Tendencias socioculturales y cambio político», CERES. Resumen de prensa (maio), Montevideo, CERES.

Torre, Carlos de la (1994): «Velasco Ibarra and 'La Revolución Gloriosa': The Social Production of a Populist Leader in Ecuador in the 1940s", Journal of Latin American Studies, 26:3, 683-711.

Torre, Carlos de la (2002): Populist Seduction in Latin America, Athens, Ohio University Centre for International Studies.

Torre, Carlos de la (2009): «Populismo radical y democracia en los Andes», Journal of Democracy en Español, 1 (xullo), 24-38.

Weyland, Kurt (2001): "Clarifying a Contested Concept: Populism in the Study of Latin American Politics", Comparative Politics, 34:1 (outubro), 1-22.

Weyland, Kurt (2007): «Politics and Policies of Latin America’s Two Lefts: The Role of Party Systems vs. Resource Bonanzas», preparado para o $26^{\text {th }}$ Congress of the Latin American Studies Association, Montreal, 5-9 de setembro.

Zucco, César (2008): «The President’s 'New' Constituency: Lula and the Pragmatic Vote in Brazil’s 2006 Presidential Elections", Journal of Latin American Studies, 40:1, 29-49.

Zuquete, José Pedro (2008): «The Missionary Politics of Hugo Chávez», Latin American Politics and Society, 50:1, 91-121. 
A DEREITA RADICAL POPULISTA E A INTEGRACIÓN EUROPEA: ANÁLISE COMPARATIVA DOS VÍNCULOS ENTRE PARTIDOS E VOTANTES

Margarita Gómez-Reino

UNED, Madrid

Iván Llamazares

Universidad de Salamanca 

En diversas análises comparativas tense sinalado o importante papel que desempeñan os partidos radicais populistas na politización das orientacións cara á UE; a este respecto, son os partidos da dereita radical populista os que adoptaron as posicións máis euroescépticas desde o decenio de 1990 (Marks et al. 2002), contribuíron á creación dunha asociación entre os temores nacionalistas e as identidades excluíntes, por unha banda, e as orientacións negativas cara á UE, pola outra (De Vries e Edwards 2009), e enviáronlles aos seus votantes os sinais máis potentes no que á UE se refire (Steenbergen et al. 2007). Así mesmo, nunha serie de análises comparativas recentes relativas á estrutura dos conflitos políticos existentes en Europa púxose de manifesto que os partidos da dereita radical populista poden resultar cruciais na activación dunha dimensión nova da contestación política, que deriva nun enfrontamento entre os defensores e os detractores da globalización (Kriesi et al. 2008).

Porén, malia as probas que apuntan ao papel que desempeñan os partidos da dereita radical populista na politización das cuestións relativas á integración europea, aínda non dispoñemos de análises empíricas comparativas referidas ao posto que ocupa a integración europea nos vínculos que existen entre os partidos radicais populistas e os seus votantes. A ese respecto, neste artigo pretendemos encher ese oco e elaborar unha análise comparativa dos vínculos xerados entre os ditos partidos e os seus votantes en once países europeos, para o cal estudamos aquí ata que punto uns e outros formalizaron vínculos programáticos discernibles no tocante á integración europea, feito que pode resultar crucial na redefinición dos conflitos políticos e na competencia entre partidos en Europa. En última instancia, este exame comparativo dos partidos da dereita radical populista pode deitar luz sobre as oportunidades e as limitacións que teñen por diante á hora de redefinir a súa axenda política e ver aumentado o seu apoio electoral. Na nosa análise recorremos a datos tirados da Enquisa Social Europea 
de 2008 (ESS-4 2008) ${ }^{1}$ e da base de datos de expertos da unC-Chapel Hill no referido a partidos políticos e integración europea $(\mathrm{CHES})^{2}$, e incluímos todos os países comprendidos na rolda de 2008 da Ess nos que se identificou algún partido importante que fose caracterizado como pertencente á familia de partidos da dereita radical na base de datos da unc-Chapel Hill, a saber: Francia, Dinamarca, os Países Baixos, Bélxica, Grecia, Finlandia, Letonia, Bulgaria, Romanía, Polonia e Eslovaquia. Os partidos que a antedita base de datos de expertos etiqueta como da dereita radical son o Vlaams Belang flamengo (vB), a Fronte Nacional francesa (FN), o Dansk Folkparti danés (DF), o Partij voor de Vrijheid holandés (PVV), o Laïkós Orthódoxos Synagermós grego (LAOS), o Perussuomalaiset finés (TF), o Prawo i Sprawiedliwość polaco (Pis), o Partidul România Mare romanés (PRM), o Slovenská národná strana eslovaco (SNS), o Tēvzemei un Brīvībai/Latvijas Nacionāās Neatkarības Kustība letón (TB-LNNK) e o Nacionalno Obedinenie Ataka búlgaro (NOA). Todos estes partidos, alén de se situaren á dereita na dimensión xeral esquerda-dereita e seren TAN na nova política no referido á dimensión GAL-TAN, siglas inglesas de «verdes-alternativos-libertarios/tradicionais-autoritarios-nacionalistas» (preguntas 10 e 12 da base de datos da UNC-Chapel Hill), defenden unha postura nacionalista extrema, con valores de 8 ou máis na pregunta 31, nunha escala que vai de 0 a 10 . Cunha única excepción - a do polaco pis-, todos os ditos partidos son favorables a unha política contraria á inmigración en extremo dura, con valores iguais ou superiores a 8 na pregunta 25 nunha escala que vai de 0 a 10. Por último, agás os Verdadeiros Fineses e o TB-LNNK, estes partidos apoian a adopción de medidas moi estritas para combater a delincuencia, con valores de 8 ou máis na pregunta 19 nunha escala que vai de 0 a 10. En consecuencia, coas excepcións parciais do pis, os Verdadeiros Fineses e o TB-LNNK, estes partidos dereitistas e TAN tenden a adoptar unha postura extrema en tres dimensións que resultan críticas para a identificación dos partidos da

${ }^{1}$ Decidimos empregar a Ess4-2008 no canto do estudo das eleccións ao Parlamento europeo de 2009 porque a realización da primeira está temporalmente máis próxima á base de datos de expertos da UNC-Chapel Hill, e tamén porque a información da Ess comprende unha cifra maior de votantes da dereita radical populista ca o estudo dos comicios europeos de 2009 (o duplo, de media, para os países aquí considerados). Nalgúns casos, como o da FN francesa, a cantidade de votantes que figuran no estudo de 2009 é particularmente reducida (oito votantes da FN nas pasadas eleccións xerais e catro nas últimas europeas).

${ }^{2}$ Quedan comprendidos partidos políticos que acadaron polo menos un $2 \%$ do voto nos comicios inmediatamente anteriores ao ano da enquisa ou que elixiron como mínimo un representante ao Parlamento nacional (Hooghe et al. 2010). 
dereita radical populista: cosmopolitismo fronte a nacionalismo, políticas liberais fronte a políticas restritivas e liberdades civís fronte a orde pública.

Somos conscientes da heteroxeneidade ideolóxica e política deste grupo de partidos, que xurdiron en contextos políticos e históricos moi distintos, adoptaron inicialmente distintas combinacións ideolóxicas e formaron vencellos con potenciais electores diverxentes no plano socioeconómico dentro dos seus respectivos sistemas de partidos. En concreto, os partidos enfrontáronse a uns contextos de todo diferentes en función de se apareceran en países poscomunistas ou europeos occidentais, diferenza esta fundamental que explica o feito de moitos dos partidos da dereita radical populista dos países poscomunistas presentaren, en aparencia, características que difiren en gran medida do tipo ideal de partido da dereita radical populista. Claramente, este é o caso do pis, que adopta unhas posturas antiinmigratorias moi moderadas, pode ser considerado tamén partido conservador católico e pertence á Alianza dos Conservadores e Reformistas Europeos no Parlamento Europeo, xunto co Partido Conservador Británico. Poderíanse facer algunhas advertencias sobre o TB-LNNK letón (Mudde 2007: 53), membro tamén da dita Alianza e caso residual ou límite agora fusionado na Alianza Nacional canda un partido de extrema dereita ultranacionalista (Alianza por Letonia), así como sobre o PRM romanés, bastante volátil no plano ideolóxico agás polo seu carácter ultranacionalista e antihúngaro. No entanto, os partidos da dereita radical populista europea presentan tamén importantes idiosincrasias, como fica patente no caso do vB, o cal, igual ca a Lega Nord italiana, se asemella ademais aos partidos nacionalistas periféricos, ou do PVV, que non comparte o carácter moralmente tradicionalista doutros partidos da dereita radical e que tamén podería ser etiquetado como nacionalista neoliberal e populista. De feito, o pis e o PVV son, dos que se abordan nesta análise, os dous únicos que non foron incluídos na listaxe de partidos radicais populistas proposta por Mudde (2007).

Á vista desta diversidade, poderiamos quer tentar maximizar a homoxeneidade dos partidos aquí comprendidos, para acabarmos, así, cun grupo moi reducido de casos, quer adoptar uns criterios máis laxos con obxecto de reflectirmos os padróns de variación que caracterizan uns partidos que, para empregarmos a terminoloxía dos conxuntos difusos, ben "pertencen totalmente» ao conxunto de partidos da dereita radical populista, ben «están máis dentro ca fóra». Na nosa opinión, dada a forte tendencia deste tipo de partidos a presentaren unhas idiosincrasias distintivas nos elemen- 
tos ideolóxicos que arrodean o seu núcleo nacionalista e nativista, ten máis sentido adoptar a segunda estratexia de investigación, menos restritiva; a xustificación desta escolla vese reforzada polo feito de que aumentar a cantidade de casos nos permitirá identificar padróns de variación entre esta clase de partidos no relativo aos vencellos que establecen cos seus votantes verbo da UE. Neste respecto, non esperamos atoparlle desvantaxe significativa ningunha a esta estratexia de investigación, a cal, máis ben ao contrario, podería fornecernos probas engadidas sobre aqueles casos cuxa pertenza á familia da dereita radical populista é cuestionable.

Somos conscientes, así mesmo, de que non incluímos outros importantes partidos da dereita radical populista, como os austríacos FPÖ (Freitheitiche Partei Österreichs) e Bzö (Bündnis Zukunft Österreich) e a Lega Nord italiana, se ben a pertenza desta última á familia da dereita radical populista tamén é discutida (Mudde 2007: 56); facémolo así porque nin Austria nin Italia quedaron comprendidas na rolda de 2008 da ESS. Excluímos tamén da nosa análise outros partidos da dereita radical populista para os que se contou cunha cifra demasiado baixa de entrevistados nas enquisas nacionais, como ocorre co MPF (Mouvement pour la France) francés.

No apartado seguinte preséntanse os debates máis destacados que se xeraron arredor do tema da integración europea e a competencia entre partidos, así como a cuestión da congruencia de opinión entre partidos e votantes, en particular no caso da familia de partidos da dereita radical populista. Sorprendentemente, malia que a maioría dos estudos realizados sobre os partidos radicais populistas desatenderon a cuestión da integración europea, nas investigacións efectuadas sobre o euroescepticismo sublińouse a importancia e a particularidade da dereita radical populista, entre todas as familias de partidos, na súa oposición á integración europea. No apartado que vai a continuación faise un trazado comparativo das posicións absoluta e relativa dos partidos da dereita radical populista e os seus votantes no tocante á integración europea a través dos distintos sistemas de partidos europeos. A seguir, no terceiro apartado ofrécense dous tipos de análises multivariantes dos vencellos existentes entre os partidos da dereita radical populista e os votantes; aquí estudamos primeiramente, mediante unha regresión de MCO, se o voto a partidos da dereita radical populista constitúe un preditor estatisticamente significativo dunhas actitudes euroescépticas e, en segundo lugar, aplicamos unha regresión loxística para observarmos se o euroescepticismo representa un preditor estatisticamente significativo do voto a estes partidos. Ambos os tipos de 
técnicas revelan a presenza, na meirande parte dos casos aquí incluídos, dalgúns vencellos entre os partidos da dereita radical populista e os seus votantes no referido á UE; as probas aquí compiladas e resumidas con tres indicadores empíricos amosan non só a presenza de vínculos no tocante á integración europea, senón tamén a fortaleza deses vencellos. As nosas análises exploratorias tamén mostran que as variacións que se producen na firmeza dos ditos vínculos pode gardar relación con ata que grao os partidos da dereita radical populista adoptaron unha postura extrema con respecto á integración europea. Concluímos sinalando algunhas implicacións que ten a presenza destes vínculos para comprendermos a función que desempeñan os partidos da dereita radical populista na politización da integración europea e na transformación do sistema de partidos en Europa.

\section{A INTEGRACIÓN EUROPEA E O ESTUDO DA DEREITA RADICAL}

Nos últimos dous decenios xurdiu unha cantidade cada vez maior de estudos académicos en que se analiza a familia de partidos da dereita radical populista (Betz 1992; Carter 2005; Hainsworth 1992, 2007; Ignazi 2004; Kitschelt e McGann 1995; Mudde 2007; Norris 2005; Taggart 1995). Existen aínda opinións distintas sobre cal sería a etiqueta máis acaída que lles asignar a estes partidos (extrema dereita, dereita radical populista, dereita radical) ${ }^{3}$, sobre as súas características (nacionalistas, nativistas, xenófobos, autoritarios etc.) e sobre a súa pertenza a esta familia, o cal non é motivo de sorpresa dada a heteroxeneidade que exhiben os partidos de tal familia no referido ás súas orixes, ideoloxía, base social e resultado electoral (Carter 2005; Hainsworth 1992, 2007; Kitschelt e McGann 1995; Norris 2005)4.

${ }^{3}$ A este tipo de partidos téńenselle aplicado moitas etiquetas: nova dereita radical, dereita radical populista, extrema dereita etc. (véxanse, por exemplo, Hainsworth 2007, Kitschelt e McGann 1995, Mudde 2007); neste artigo, seguindo a Mudde (2007), nós optamos pola de dereita radical populista. Preferimos tal denominación á de extrema dereita porque esta última ten matices autoritarios explícitos (Mudde 2007: 23-31) e adoita ir ligada á experiencia dos réximes fascistas e os movementos neofascistas (Ignazi 2004); preferímola tamén á etiqueta, moi estendida, de nova dereita radical porque este termo denota a existencia dun programa neoliberal no económico (Kitschelt e McGann 1995) que non comparten a maioría de tales partidos.

${ }^{4}$ Por mor da presenza de importantes diferenzas de orixe, perfil ideolóxico e base social, ténselles dedicado unha atención considerable á descrición e explicación da heteroxeneidade desta familia de partidos mediante a identificación de distintos subtipos de partidos da dereita radical populista (Carter 2005, Kitschelt e McGann 1995). 
A pesar das diferenzas entre as súas características, pódese establecer unha base común que segue as liñas do nacionalismo, a xenofobia e unhas políticas identitarias excluíntes. Nas obras elaboradas sobre a materia vén existindo practicamente un consenso sobre o feito de o nacionalismo (Hainsworth 2007) ou nativismo - por distinguir o seu tipo de nacionalismo doutros - actuar como elemento ideolóxico central nestes partidos, aínda que se dan outras características ideolóxicas, como o seu populismo e autoritarismo (Mudde 2007), que tamén están presentes entre eles 5 . O seu nacionalismo extremo garda relación directa coa súa xenofobia, actitudes contrarias á inmigración e chauvinismo do benestar (Mudde 2000). Como teñen indicado varios autores (Mudde 2010, Sniderman et al. 2000), estas orientacións van asociadas, así mesmo, aos valores e orientacións dominantes nas sociedades europeas contemporáneas.

A oposición á integración europea tivo maiormente a consideración de cuestión moi secundaria na caracterización das políticas desta familia de partidos, o cal nos parece sorprendente dada a potente relación que existe nas obras publicadas entre unhas identidades nacionais excluíntes, a defensa da soberanía nacional e as orientacións cara á integración europea (Hooghe e Marks 2008). É máis: grazas á prevalencia da súa orientación nacionalista sobre outras clases de adhesións ideolóxicas, estes partidos están en condicións de evitar enfrontarse a tensións ideolóxicas á hora de fixar unha postura con respecto á integración europea ${ }^{6}$. Porén, coa excepción do libro de Mudde (2007) dedicado á dereita radical populista de Europa, o euroescepticismo apenas é mencionado como elemento caracterizador das políticas da familia de partidos da dereita radical populista.

A ausencia da cuestión da integración europea nos estudos feitos sobre a dereita radical populista chama poderosamente a atención á vista de que as publicacións referidas á integración europea puxeron de manifesto o particular que é a postura euroescéptica da dereita radical populista. Así, no primeiro estudo en que se tomaron como obxecto de exame as familias de partidos e a súa actitude cara á

\footnotetext{
${ }^{5}$ Véxanse en particular Mudde (2007: 16 e ss.) e Hainsworth (2007: 7). Existen varios autores que tamén destacaron o feito de a dereita radical populista rexeitar unha serie de elementos clave dos réximes liberaldemocráticos, así como o seu populismo antisistema (Carter 2005: 17-28; Hainsworth 2007: 12; Ivaldi 2004; Mudde 2000: 177; Taggart 1995).

${ }^{6}$ Sobre os efectos que exercen as tensións ideolóxicas na competencia electoral referida a cuestións concretas, véxase Odmalm (2011).
} 
Unión Europea, destacáronse as posicións antieuropeístas da familia de partidos da dereita radical (Hix e Lord 1997: 42) e, máis aínda, desde os primeiros anos do decenio de 1980 o euroescepticismo da dereita radical populista vai en claro aumento, ata o punto de que esta constitúe hoxe a familia de partidos máis euroescépticos e algúns estudosos afirman que «os partidos da dereita radical son, sen excepción, moi euroescépticos» (Hooghe et al. 2004: 133; Steenbergen e Scott 2004).

O concepto de euroescepticismo fai referencia, en termos xerais, a unhas actitudes negativas cara ao proceso de integración europea. Para caracterizar os partidos euroescépticos téñense proposto varias tipoloxías, entre as cales talvez a distinción á que se recorre máis a miúdo sexa a que, cuñada por Taggart e Szczerbiak (no pasado decenio), diferencia entre euroescepticismo "duro» e «brando». O primeiro defínese como «unha oposición por principios á uE e á integración europea e, xa que logo, pode observarse en partidos que consideran que os seus respectivos países deberían renunciar á súa pertenza á Unión, ou cuxas políticas no tocante á UE veñen equivaler a unha oposición á totalidade do proxecto de integración europea tal e como se concibe na actualidade» (Taggart e Szczerbiak 2008: 7), mentres que o euroescepticismo «brando» non comporta unha oposición por principios á UE, mais si «preocupación por un (ou varios) ámbitos normativos» que conduce a «unha oposición, con matices, á UE» (Taggart e Szczerbiak 2008: 7). No plano da opinión pública, existen achegas recentes nas que se destaca o carácter pluridimensional das actitudes cara á UE, o cal revela as diferentes compoñentes e factores determinantes das orientacións afectivas, identidades, xuízos utilitarios e baseados en resultados e opinións sobre o reforzo do proceso de toma de decisións (Boomgaarden et al. 2011).

As investigacións sobre o euroescepticismo de partido experimentaron un considerable incremento no último decenio, o cal deu lugar ao que Mudde denomina «escolas» de Sussex e Carolina do Norte (Mudde 2011), que difiren nas súas definicións, datos, ámbito de aplicación e achados relativos á postura dos distintos partidos ante a integración europea. Así, a definición de Sussex ten os seus fundamentos na distinción antedita, cualitativa e dicotómica, entre euroescepticismo duro e euroescepticismo brando; pola contra, a de Carolina do Norte céntrase na "orientación xeral dos líderes do partido» cara á integración europea, nun contínuum que vai dunha oposición extrema (1) a un apoio total á integración 
(7) (Ray 1999). A partir desta escala é posible establecer unha serie de criterios (substantivos, absolutos ou relativos, ou todos eles) e limiares con que distinguir entre partidos euroescépticos e non euroescépticos (Mudde 2011: 11-12). Entre os exemplos de puntos de corte contaríanse unha posición neutral na escala (4), a expresión dun tímido apoio á integración europea (5) (Mudde 2011:12) e a existencia dunha distancia concreta entre a postura do partido e a postura media ou ponderada do sistema de partidos (De Vries e Edwards 2009: 11). En xeral, porén, como apunta Mudde (2011: 11), os debates definitorios teñen menos importancia nas obras elaboradas pola escola de Carolina do Norte, que se centrou máis en ofrecer respostas explicativas a crebacabezas empíricos que en producir un concepto de euroescepticismo preciso e carente de ambigüidades ${ }^{7}$. Existen, alén diso, notables diferenzas metodolóxicas entre ambas as escolas: así, mentres que a perspectiva adoptada por Sussex se basea na postura oficial dos partidos políticos, os estudos de Carolina do Norte fundaméntanse nas enquisas realizadas entre expertos nacionais. As dúas clases de achegamento presentan vantaxes e limitacións, e as dúas poden conxugarse na elaboración de análises exhaustivas e pormenorizadas da postura dos partidos ante a integración europea (véxase Mudde 2011: 19); no entanto, posto que nas enquisas da UNC-Chapel Hill figuran as mesmas preguntas para todos os países europeos e en distintos puntos temporais, resultan especialmente útiles para a elaboración de análises comparativas sistemáticas das características, os correlatos e a evolución do euroescepticismo entre os partidos políticos, razón pola cal as análises contidas neste artigo se basean, en gran medida, nos datos que ofrece a enquisa a expertos da unc-Chapel Hill.

Outro debate crucial que se refire ao euroescepticismo é o que aborda a cuestión de se a ideoloxía ou a estratexia permiten explicar a postura adoptada polos partidos cara á integración europea (Mudde 2011). Uns autores conciben o euroescepticismo como unha estratexia que adoitan empregar os partidos políticos que se achan nas marxes do sistema de partidos (Taggart 1998), mentres que outros sosteñen que a postura euroescéptica dos partidos ten as súas raiceiras na ideoloxía, a saber: esquerda/dereita ou «nova política» (Hooghe et al. 2004, Marks e Wilson 2000). Canto á dereita radical populista, esta ten motivos tan-

\footnotetext{
${ }^{7}$ Sobre o equilibrio entre precisión definitoria e resolución empírica de problemas, véxase Popper (2002:
} 20-30). 
to ideolóxicos como estratéxicos para adoptar unha plataforma euroescéptica. Neste sentido, no plano ideolóxico, o seu rexeitamento da integración europea fundaméntase na defensa da soberanía nacional e na oposición á erosión dunhas identidades nacionais fortes (e excluíntes) (De Vries e Edwards 2009, Hooghe et al. 2004, Marks et al. 2002); no plano estratéxico, os partidos da dereita radical populista poden aspirar a mellorar o seu resultado electoral presentándose como os únicos defensores da soberanía e a cultura nacionais, ambas as cales están ameazadas polo proceso de integración europea (De Vries e Edwards 2009). Neste grupo de partidos, as consideracións ideolóxicas e estratéxicas poden tratarse como factores que se reforzan uns a outros, e non como alternativos ou mutuamente excluíntes (De Vries e Edwards 2009, Kopecky e Mudde 2002).

No estudo comparativo dos partidos euroescépticos que levaron a cabo Taggart e Szczerbiak baseándose nunha análise pormenorizada dos casos, clasificouse o euroescepticismo de oito dos once partidos da dereita radical populista investigados neste artigo. Así, o VB, a FN e o sNs foron etiquetados como euroescépticos «duros», mentres que o DF, o TF, o pis e o PRM recibiron a clasificación de euroescépticos «brandos» (Taggart e Szczerbiak 2008: 11-12). No cadro 1 enuméranse os partidos da dereita radical populista que analizamos, a súa postura ante a integración europea segundo os expertos do país e, se se dispón dela, a súa clasificación como partidos euroescépticos «duros» ou «brandos» de acordo cos criterios de Taggart e Szczerbiak ${ }^{8}$; tanto as etiquetas cualitativas como as posicións espaciais denotan a presenza de varios niveis de orientacións euroescépticas no seo desta familia de partidos. No mesmo cadro ponse de manifesto a existencia de importantes diferenzas entre a información fornecida polos indicadores cuantitativos e a achegada polos cualitativos (moi especialmente no caso do SNS e o TF).

\footnotetext{
${ }^{8}$ Boomgaarden et al. (2011) deixaron de manifesto o carácter pluridimensional das actitudes cara á UE (véxase tamén Hobolt et al. 2011). Debido ás limitacións dos nosos datos, non estamos en condicións de facermos un trazado das posturas de partidos e votantes en cada unha destas dimensións concretas.
} 
Cadro 1. Partidos da dereita radical populista e a UE

\begin{tabular}{|c|c|c|c|c|}
\hline Partido & $\begin{array}{l}\text { Abr. do } \\
\text { partido }\end{array}$ & País & $\begin{array}{l}\text { Postura } \\
\text { ante a UE } \\
\text { no CHES } \\
2006\end{array}$ & $\begin{array}{l}\text { Clasifica- } \\
\text { ción de } \\
\text { Taggart }\end{array}$ \\
\hline Dansk Folkparti (Partido Popular Danés) & $\mathrm{DF}$ & Dinamarca & 2,33 & Brando \\
\hline Front National (Fronte Nacional) & FN & Francia & 1 & Duro \\
\hline $\begin{array}{l}\text { Laïkós Orthódoxos Synagermós (Con- } \\
\text { centración Popular Ortodoxa) }\end{array}$ & LAOS & Grecia & 2,38 & - \\
\hline $\begin{array}{l}\text { Nacionalno Obedinenie Ataka (Unión } \\
\text { Nacional Ataque) }\end{array}$ & NOA & Bulgaria & 2,46 & - \\
\hline $\begin{array}{l}\text { Partidul România Mare (Partido da } \\
\text { Gran Romanía) }\end{array}$ & PRM & Romanía & 4,20 & Brando \\
\hline $\begin{array}{l}\text { Partij voor de Vrijheid (Partido para a } \\
\text { Liberdade) }\end{array}$ & PVV & Países Baixos & 1,55 & - \\
\hline Perussuomalaiset (Verdadeiros Fineses) & $\mathrm{TF}$ & Finlandia & 1,64 & Brando \\
\hline $\begin{array}{l}\text { Prawo i Sprawiedliwość (Partido Lei e } \\
\text { Xustiza) }\end{array}$ & Pis & Polonia & 3,50 & Brando \\
\hline $\begin{array}{l}\text { Slovenská národná strana (Partido Na- } \\
\text { cional Eslovaco) }\end{array}$ & SNS & Eslovaquia & 3,23 & Duro \\
\hline $\begin{array}{l}\text { Tēvzemei un Brīvībai (Pola Patria e a Li- } \\
\text { berdade) }\end{array}$ & TB-LNNK & Letonia & 4,75 & Duro \\
\hline Vlaams Belang (Interese Flamengo) & $\mathrm{VB}$ & Bélxica & 2,50 & Duro \\
\hline
\end{tabular}

En consonancia co anterior, o noso punto de partida é unha familia global de partidos euroescépticos fundamentada en consideracións tanto ideolóxicas como estratéxicas, mais con algunha evidencia de diferenzas internas no seu grao de euroescepticismo. Na medida en que a oposición á integración europea é non só coherente coa perspectiva ideolóxica xeral destes partidos, senón tamén electoralmente rendible, existen bos motivos para esperar que, no tocante á UE, exista congruencia entre partidos e votantes, así como vínculos entre os primeiros e os segundos, dentro desta familia.

Se ben é certo que nalgúns estudos se subliñou a escasa relevancia que teñen as cuestións europeas nas decisións de voto que se toman en Europa (Van der 
Eijk e Franklin 2004), contamos con análises máis recentes que deixaron de manifesto que o papel electoral que desempeña a integración europea varía significativamente de país a país e que estas variacións dependen de factores tales como o relevo que teña a uE entre o público nacional, a existencia de divisións no seo dun partido sobre este tema, a relación das actitudes cara á UE na dimensión esquerda-dereita (De Vries 2007) e a diseminación do euroescepticismo entre o público nacional (Kriesi 2007). A relevancia da integración europea non se pode dar por suposta tampouco no caso dos partidos da dereita radical euroescéptica ou populista, ou euroescéptica e populista (Green-Pedersen 2011, Steenbergen e Scott 2004: 177); no entanto, as análises das actitudes do público cara á UE amosaron que os partidos da dereita radical populista tenden a lles dar aos seus votantes os indicativos máis potentes verbo desta cuestión (Steenbergen et al. 2007) ${ }^{9}$. E o feito de as actitudes euroescépticas concordaren bastante co núcleo ideolóxico nacionalista destes partidos pode facilitarlles a procura duns vínculos cos seus votantes fundamentándose na súa orientación euroescéptica; en efecto, nalgúns estudos tense mostrado xa que a integración europea si inflúe á hora de explicar o voto por partidos da dereita radical populista en Francia, Suíza e os Países Baixos (Lachat 2008), o cal vai na liña da crecente politización da integración europea que postularon Kriesi et al. (2008) e Hooghe e Marks (2008).

En suma, nos estudos dedicados ao euroescepticismo destacouse a particularidade comparativa da familia de partidos da dereita radical populista con respecto á integración europea no tocante a varios puntos: posturas programáticas, importancia estratéxica e indicativos entre partidos e votantes. Non existen, porén, estudos comparativos nos que se analice concretamente o papel que exerce a integración europea nas relacións entre os partidos da dereita radical populista e os seus votantes, de xeito que tamén carecemos de probas comparativas empíricas sobre como inflúe esa integración no voto por tales partidos e no grao en que os vencellos entre partidos e votantes no referido á integración europea son comúns a todos os partidos adscritos a esta familia. Posto que nos membros de tal familia non se pode presumir a existencia de congruencia entre partidos e votantes nin de vínculos entre estes e aqueles no tocante á integración, cobra aínda maior

\footnotetext{
${ }^{9}$ Este resultado non é independente do feito de as posturas euroescépticas do público estaren a miúdo infrarrepresentadas nos sistemas de partidos nacionais, dado o posicionamento globalmente proeuropeo das familias de partidos maioritarios (Taggart e Sczcerbiak 2008).
} 
relevancia a elaboración de estudos comparativos sobre a fortaleza das relacións habidas entre este tipo de partidos e os seus votantes no que se refire a esta dimensión en concreto.

En última instancia, o estudo do papel que exerce a integración europea entre a dereita radical populista garda tamén relación coa nosa idea das transformacións que están a ter lugar no sistema de partidos europeos. Kriesi et al. (2008: 11) demostraron a importancia que reviste a presenza dunha nova división sociopolítica que enfronta os partidarios da globalización contra os que se resisten a ela, nun conflito en que a dereita radical populista tende a adoptar unha postura radical contra a integración ou a favor dunha demarcación no eido político-cultural (Lachat 2008: 281-282), o cal comporta unha oposición á integración europea e a adopción de posturas restritivas no referido á inmigración (Kriesi et al. 2006: 13). A este respecto, o euroescepticismo «é parte integrante do novo conflito estrutural que se xerou arredor da integración» (Lachat 2008: 290), conflito en que os partidos da dereita radical populista resultan fundamentais á hora de conformar e canalizar as reivindicacións contrarias á integración no ámbito político; por tal motivo, a análise dos vínculos que unen partidos e votantes no plano da dereita radical populista e o seu electorado con respecto á integración europea reviste unha importancia que transcende o interese de afinar os nosos coñecementos sobre as propiedades que teñan, concretamente, estes partidos e os seus votantes.

\section{POSICIÓN ABSOLUTA E RELATIVA DOS PARTIDOS DA DEREITA RADICAL POPULISTA E OS SEUS VOTANTES ANTE A INTEGRA- CIÓN EUROPEA}

Os partidos da dereita radical populista e os seus votantes exhiben un nivel parello de euroescepticismo? $\mathrm{E}$ ata que punto son homoxéneas as posturas dos partidos e dos votantes nunha perspectiva comparativa? Un primeiro paso para abordar o estudo da postura destes partidos e dos seus votante ante a integración europea consiste en recorrer a puntos de referencia uniformes baseados no contido absoluto e substantivo das dúas variables que nos informan da postura 
dos partidos da dereita radical populista e o seu electorado ${ }^{10}$. Para este fin, tomamos os puntos intermedios de ambas as variables (é dicir, 4 no caso da postura dos partidos e 5 no da orientación dos cidadáns) como fronteira que separa as opinións negativas e as positivas sobre a UE. Neste sentido, e antes de máis, os partidos tenden a ser máis euroescépticos ca os seus votantes; todos os partidos adoptan unha postura máis firme ca o seu electorado ante a integración europea e a familia da dereita radical populista non constitúe unha excepción (Mattila e Raunio 2006: 427). En termos absolutos, achamos que, en cinco de once casos, tanto os partidos da dereita radical populista como o seu electorado asumen unha postura euroescéptica (véxase a figura 1$)^{11}$, sendo esta a situación do VB, o LAOS, o DF, a FN e o $\mathrm{TF}^{\mathrm{I}}$; tamén observamos que oito dos once partidos adoptan unha postura euroescéptica.

${ }^{10}$ Para cuantificar as actitudes do público cara á UE recorremos á pregunta B34 da enquisa Ess, que se formula como vai a seguir: «Pensando agora na Unión Europea, algunhas persoas din que a integración debería ir máis lonxe. Outras din que xa foi demasiado lonxe. Empregando esta tarxeta, ¿que número da escala describe mellor a súa opinión ó respecto?». As respostas van de 0 («A integración xa foi demasiado lonxe») a 10 ("A integración debería ir máis lonxe»). Tamén utilizamos a pregunta 1 do cuestionario cHES 2006: «Como describiría vostede a postura que, en xeral, adoptaron os líderes do partido con respecto á integración europea ao longo de 2006?», para a cal as respostas van de «Forte oposición» (1) a «Forte apoio» (7). Como se mencionou anteriormente, non estamos en condicións de situarmos a postura dos cidadáns e dos partidos nas distintas dimensións que subxacen ás actitudes ante Europa (Boomgaarden et al. 2011), mais damos por suposto, con todo, que o noso indicador de euroescepticismo na opinión pública garda especial relación coas actitudes mantidas cara ao reforzo da UE, a ampliación das competencias de toma de decisións, a transferencia das políticas e unha maior integración (Boomgaarden et al. 2011: 258).

${ }^{11}$ Estas medias están baseadas na cantidade de entrevistados que votaran por cada un dos partidos da dereita radical populista nas últimas eleccións nacionais (pregunta B12). A cifra de votantes de cada partido que responderon a esta pregunta referida á integración europea (B34) é como se indica a seguir: DF (127), LAOS (46), LNNK (82), FN (29), NOA (88), PRM (142), PVV (35), vB (97), sNS (88), pis (291) е TF (52). Infelizmente, a cantidade de enquisados correspondente a algúns destes partidos é moi reducida e, como se mencionou antes, de usarmos o estudo das eleccións europeas de 2009, a cifra de entrevistados quedaría aínda máis reducida. Con todo, as posicións medias de voto que aparecen na Ess4-2008 e no estudo dos comicios de 2009 gardan unha forte correlación con estes once casos (correlación de Pearson de +0,88): de 2008 a 2009, os votantes tornáronse máis euroescépticos en nove dos once casos aquí considerados, sendo as excepcións o electorado do pis e o do SNS, e a postura media dos votantes ante a UE (once casos) desprazouse, entre estas dúas enquisas, dun 4,99 a un 4,10.

${ }^{12}$ Entre estes, só os votantes do TF, a FN e o DF adoptan unha postura euroescéptica dura (arredor do $50 \%$ do electorado destes partidos posiciónase por debaixo dos tres puntos na escala de europeísmo, que vai de 0 a 10, que empregamos neste traballo). A porcentaxe de votantes do pVv que asumen unha forte postura euroescéptica (de 3 ou menos) tamén resulta elevada, cun $51 \%$, mais neste caso o partido non adopta postura euroescéptica ningunha. 
Figura 1. Partidos da dereita radical populista e os seus votantes: posturas absolutas ante a UE

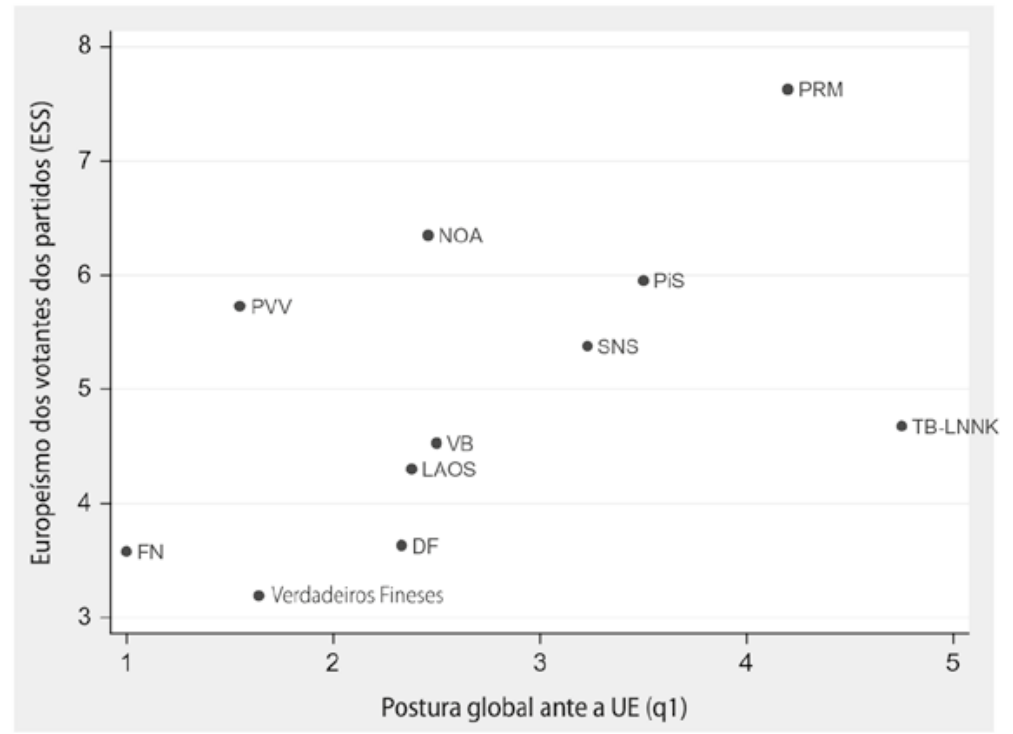

Canto ás combinacións concretas de posturas dos partidos e dos votantes, estes datos poñen de manifesto que catro partidos adoptan unha posición euroescéptica mais teñen votantes favorables á UE (un da Europa occidental, o PVV, e o resto do leste: o NOA, o SNS e o Pis), un exhibe unha postura pro-UE mais ten un electorado euroescéptico (о тв-LNNK) e, finalmente, un partido adopta unha postura favorable á UE e ten votantes que están tamén a favor dela (o PRM). Quere isto dicir que, na lińa do que destacan as obras dedicadas ao euroescepticismo, todos os partidos da dereita radical populista bardante dous adoptan unha orientación substantivamente euroescéptica; no entanto, existen cinco casos en que a postura dos votantes da dereita radical populista non é euroescéptica nun grao substantivo.

Se comparamos a postura destes partidos e a dos seus votantes (véxase a figura 1), achamos unha asociación positiva entre ambas as variables; así, os partidos máis proeuropeístas tenden a contar cun electorado máis proeuropeísta tamén, e os partidos claramente euroescépticos (FN, TF) reciben os votos de cidadáns (comparativamente) euroescépticos. Existen, porén, algunhas excepcións a este 
padrón, como as representadas polo NOA, o PVV e, no caso máis patente, o TB$-\mathrm{LNNK}^{13}$.

Ora ben, cunha análise comparativa estritamente baseada na postura absoluta, nestas escalas, dos partidos da dereita radical populista e os votantes, non fica esclarecida a índole dos vencellos existentes entre partidos e electorado no tocante á integración europea. A orientación dos partidos nacionais e a do seu público son distintas e o que parece constituír unha postura moderada dentro da familia de partidos podería estar, de feito, lonxe do consenso que prevalece no seo dun sistema de partidos nacionais; e, viceversa, unha posición antieuropeísta reflectida nesta escala podería ser compartida por outros votantes ou partidos, ou ambos, no plano nacional. Xa que logo, unicamente tendo en conta as características da opinión pública e os sistemas de partidos nacionais estamos en condicións de avaliar a índole e a dirección dos ditos vencellos.

Un primeiro xeito de realizar unha avaliación da postura relativa dos partidos da dereita radical populista e dos seus votantes consiste en comparar a súa orientación cara á UE coa doutros partidos e o seu electorado nos seus respectivos sistemas de partidos. Neste sentido, na figura 2 preséntase a distancia que existe entre a postura dos partidos da dereita radical populista e a súa respectiva media no sistema de partidos (ponderada en función dos últimos resultados obtidos nas eleccións nacionais) (dimensión horizontal), e a distancia existente entre a posición dos votantes da dereita radical populista e a postura media nacional (dimensión vertical). Nesa gráfica amósase que, no caso de todos os países comprendidos nesta análise, os partidos da dereita radical populista son máis euroescépticos do que é a postura media dos partidos políticos nacionais, e fica patente, así mesmo, que os partidos tenden a se situar máis lonxe da media nacional ca os votantes (sobre todo se temos en consideración que o intervalo da escala é máis amplo no caso dos partidos ca no do público nacional). E danse mesmo algúns casos en que os votantes dos partidos non son máis euroescépticos ca as súas respectivas medias nacionais (PVV e TB-LNNK), ou non o son máis ca marxinalmente (PRM). En termos globais, existe unha moderada tendencia a que os partidos que se afastan da media do sistema de partidos nacionais reciban os votos de cidadáns que son tamén comparativamente euroescépticos.

${ }^{13} \mathrm{O}$ índice de correlación de Pearson que existe entre estas dúas variables é igual a $+0,53$, que ascende a +0,73 cando se exclúe da análise o TB-LNNK. 
Figura 2. Distancia entre os partidos da dereita radical populista e a media ponderada do sistema de partidos (dimensión horizontal) e entre os votantes da dereita radical populista e as medias nacionais do público (dimensión vertical)

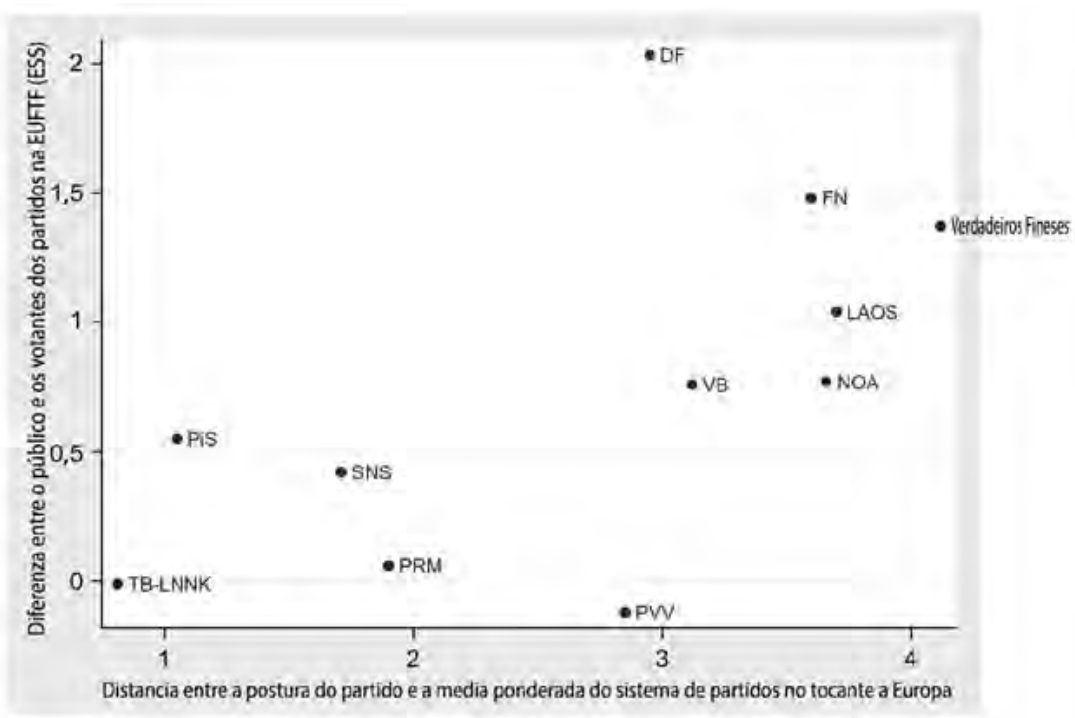

Nas figuras 3 (a-k) móstrase a postura que sobre a integración europea manteñen tanto partidos como votantes (medias da Ess) dentro de cada sistema de partidos nacionais. Estas gráficas deixan de manifesto que a maioría dos partidos da dereita radical populista adoptan unha posición comparativamente euroescéptica, aínda que non por necesidade a máis euroescéptica de todas no seu respectivo sistema de partidos; dito isto, porén, nunha cantidade de casos superior á metade (Bélxica, Bulgaria, Francia, os Países Baixos, Eslovaquia e Romanía), os partidos da dereita radical populista son, en efecto, as forzas políticas nacionais máis euroescépticas. Existe unha tendencia menos marcada a que os votantes da dereita radical populista adopten as orientacións máis euroescépticas dos seus respectivos sistemas de partidos (feito que se dá en cinco de once casos) e constátanse mesmo dous casos (os Países Baixos e Letonia) nos que os votantes da dereita radical populista non son máis euroescépticos ca a media nacional. 
Figura 3. Postura dos partidos e preferencias dos votantes con respecto á integración europea: 3a, Bulgaria; 3b, Bélxica; 3c, Dinamarca; 3d, Grecia; 3e, Francia; 3f, Países Baixos; 3g, Finlandia; 3h, Letonia; 3i, Polonia; 3j, Eslovaquia; 3k, Romanía)
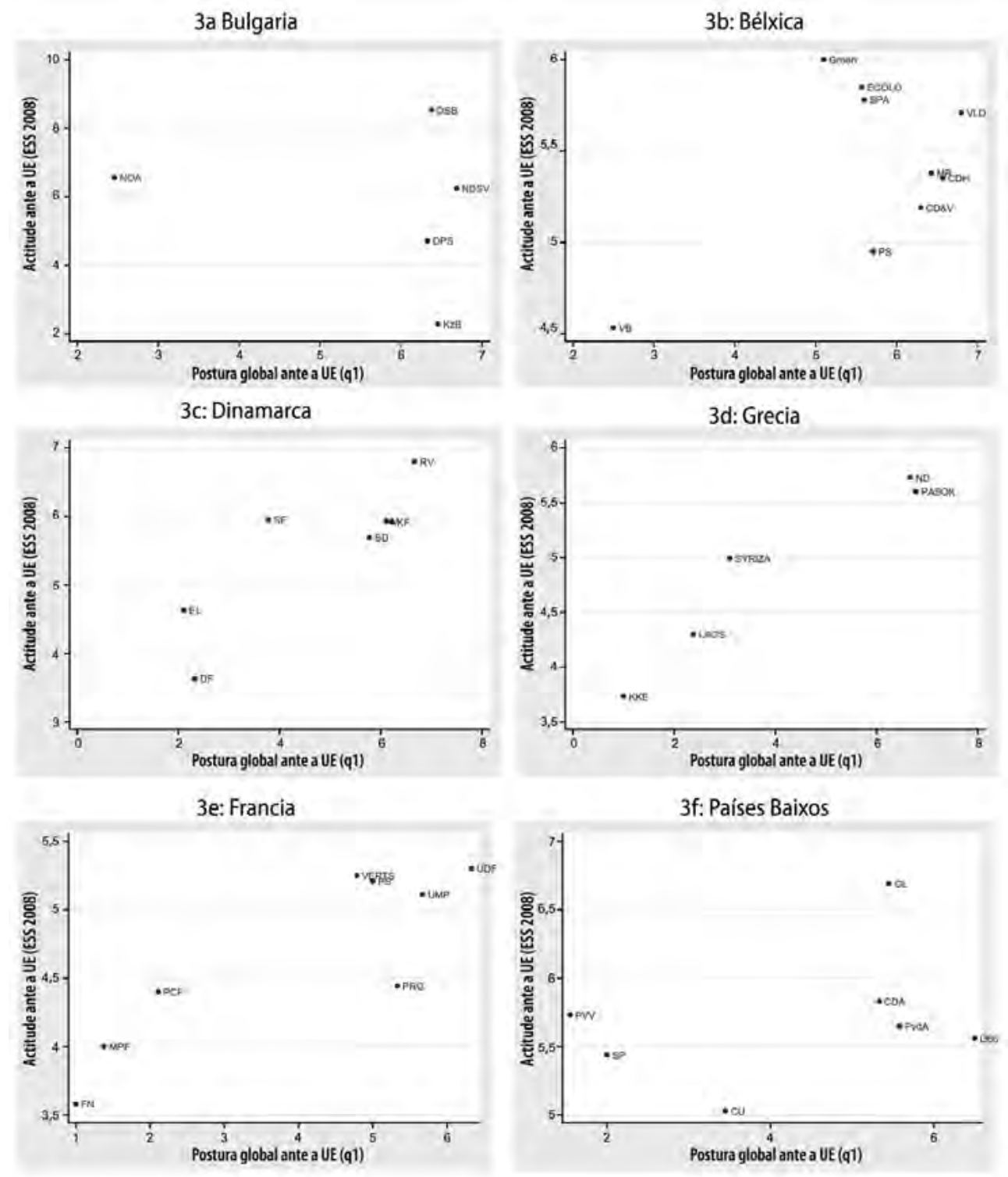
3g: Finlandia

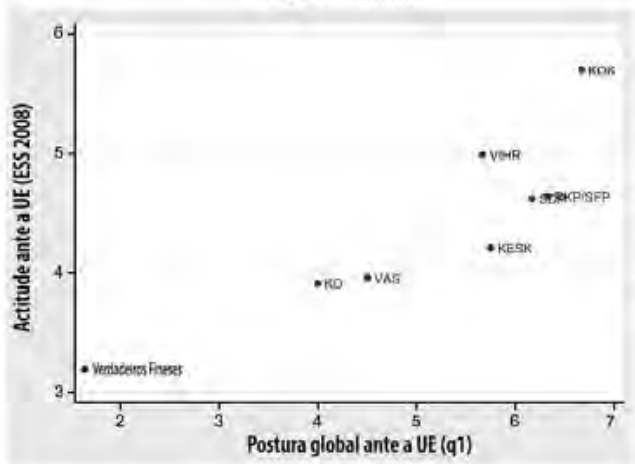

3i: Polonia

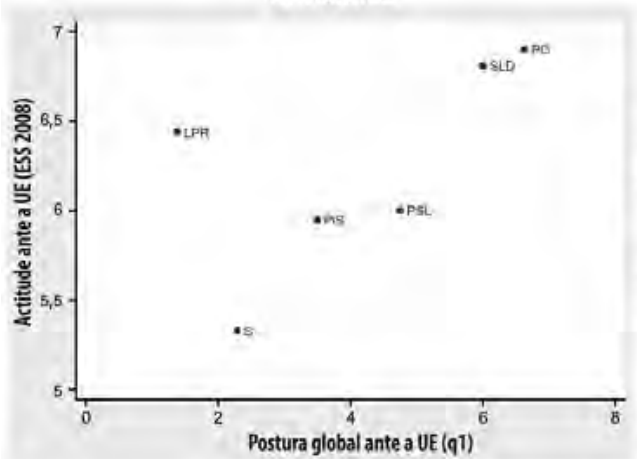

3k: Romania

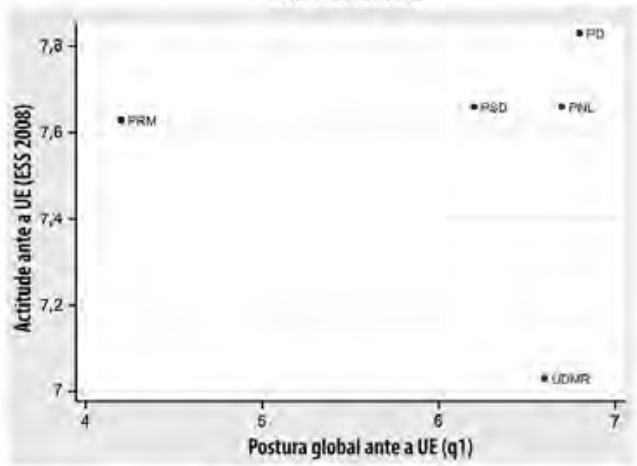

3h: Letonia

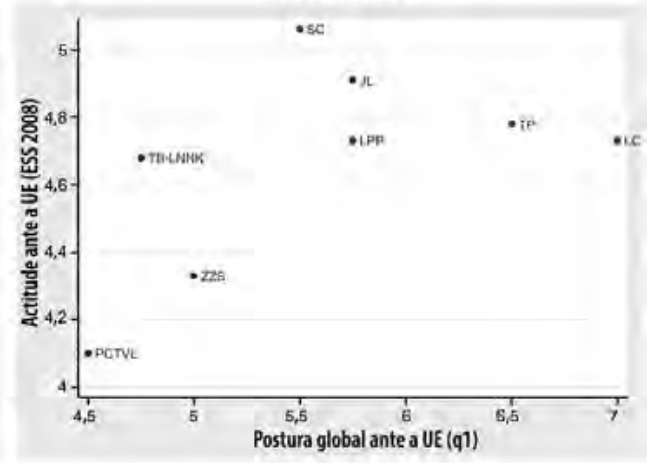

3j: Eslovaquia

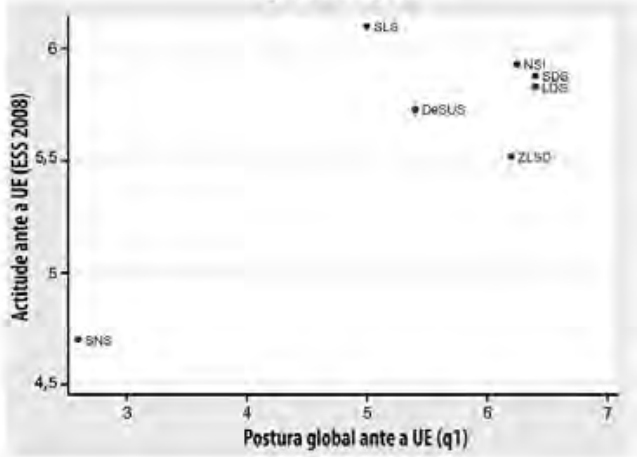


Estas gráficas amosan, así mesmo, que existen distintos perfís relacionais entre a postura dos partidos e a dos votantes en cada un destes países; deste xeito, só nos sistemas de partidos de Dinamarca, Grecia, Francia e Finlandia se observan asociacións patentes e simétricas entre a postura dos partidos e a preferencia dos votantes no referido ao euroescepticismo.

No cadro 2 clasifícanse os casos en función de se os partidos da dereita radical populista ou os votantes, ou ambos, son os máis euroescépticos dos seus respectivos sistemas de partidos. Hai catro casos (VB, FN, SNS e TF) nos que tanto partidos como votantes figuran entre os máis euroescépticos, o cal apunta á presenza de vínculos entre partidos e votantes por mor da orientación euroescéptica extrema duns e doutros (en termos relativos dentro dos seus respectivos sistemas de partidos); este grupo contrasta claramente co caso do Pis, o TB-LNNK e o LAOS, no cal nin os partidos nin o electorado se sitúan entre os máis euroescépticos. Estes dous escenarios opostos son o máis favorable e o máis desfavorable, respectivamente, para a cuestión de se a dereita radical populista goza da titularidade do euroescepticismo. Por último, en oito dos once casos son quer os partidos da dereita radical populista, quer os seus votantes, os que adoptan a postura máis euroescéptica dentro dos seus respectivos sistemas de partidos.

Cadro 2. Orientacións euroescépticas relativas dos partidos da dereita radical populista e os seus votantes

Votantes máis Votantes que non son euroescépticos os máis euroescépticos

\begin{tabular}{lll}
\hline Partido máis antieuropeísta & VB, FN, TF, SNS & NOA, PRM, PVV \\
\hline Partido que non é o máis antieuropeísta & DF & LAOS, Pis, TB-LNNK \\
\hline
\end{tabular}

Nota: destácanse en negriña os casos en que tanto os partidos como os votantes tamén son euroescépticos en termos absolutos.

En termos globais, e malia a presenza de importantes diferenzas nacionais, é evidente que a familia de partidos da dereita radical populista se inclina cara a unhas posturas euroescépticas. Fomos quen de determinar que todos estes partidos agás dous (o PRM romanés e o TB-LNNK letón) manteñen unha orientación euroescéptica manifesta e que o electorado de seis dos once partidos ten tamén unha inclinación substantivamente euroescéptica. Por conseguinte, en cinco dos once casos que con- 
sideramos, tanto partidos como votantes adoptan unha orientación euroescéptica (VB, TF, FN, DF e LAOS); alén diso, todos os partidos da dereita radical populista son máis euroescépticos ca a media ponderada do sistema de partidos nacionais, e todos os votantes deses partidos bardante dous electorados manteñen unhas inclinacións máis euroescépticas ca as respectivas medias nacionais. En última instancia, a nosa análise demostra tamén que son ben os partidos da dereita radical populista, ben os seus votantes, os que adoptan a postura máis euroescéptica dos seus respectivos sistemas de partidos, coa excepción dos casos do pis, o LAOS e o TB-LNNK.

\section{ANÁLISE NACIONAL MULTIVARIANTE DOS VENCELLOS EXISTEN- TES ENTRE OS PARTIDOS DA DEREITA RADICAL POPULISTA E O SEU ELECTORADO}

Ata agora estudamos os vínculos que unen os partidos da dereita radical populista e o seu electorado considerando as variacións transnacionais que se dan nas posturas medias deses partidos, dos seus votantes e do público nacional. No entanto, logo de escrutarmos se existen outros correlatos das actitudes cara a Europa, por unha banda, e do voto por partidos da dereita radical populista, pola outra, non determinamos en que medida existe unha asociación concreta entre a inclinación de tales partidos e a do seu electorado con respecto á UE. Se os votantes destes partidos fosen máis euroescépticos ca outros electorados, despois de tentarmos detectar os mencionados correlatos - como poidan ser a clase social, o nivel educativo, a ideoloxía etc.- poderiamos inferir a existencia de vínculos entre os partidos da dereita radical populista e os seus votantes no eido concreto da integración europea. Esta relación quedaría determinada con independencia de se a fonte desta conexión radica na capacidade de tales partidos para lle enviar ao seu electorado sinais que os inclinen cara a unha orientación euroescéptica (sinais da elite) ou no feito de que, adoptando unha postura euroescéptica, os partidos conseguen captar o apoio de votantes que xa eran euroescépticos ${ }^{14}$.

Con obxecto de estudarmos os vínculos entre os partidos da dereita radical populista e o seu electorado en cada un dos países considerados, recorremos a dous proce-

\footnotetext{
${ }^{14}$ Neste artigo non indagamos en se os partidos da dereita radical lles mandan sinais aos seus votantes na dirección do euroescepticismo ou se apelan a votantes xa euroescépticos mediante a adopción dunha postura antieuropea; para avaliar a fortaleza desde dous fluxos causais faría falla outro tipo de análise.
} 
dementos técnicos complementarios: primeiramente analizamos, mediante unha regresión de MCO, se o voto a partidos da dereita radical populista constitúe un preditor estatisticamente significativo dunhas actitudes euroescépticas, logo de esculcarmos se están presentes unha serie de variables sociodemográficas e actitudinais, e, en segundo lugar, observamos, aplicando unha regresión loxística, se o euroescepticismo constitúe un preditor estatisticamente significativo do voto por partidos da dereita radical populista, unha vez que examinamos se existen outras variables que puidesen gardar unha relación verosímil con ese voto. Para ambos os tipos de análise empregamos datos tirados da rolda de 2008 da Enquisa Social Europea (Ess4-2008) ${ }^{15}$. Xulgamos estas análises complementarias, e non reiterativas, dado que as variables dependentes e independentes que se utilizan nos modelos que prognostican o voto pola dereita radical populista e as actitudes euroescépticas non son idénticas e, neste sentido, ambas as análises fornecen información sobre os vínculos entre partidos e votantes, mais de diferentes maneiras. A primeira amosa ata que punto o voto pola dereita radical populista garda relación coa postura que se adopta con respecto á integración europea, e coa segunda estúdase a influencia que exercen as actitudes euroescépticas no voto pola dereita radical populista. Non son simétricas as expectativas que albergamos verbo das variables de referencia nos dous tipos de modelo: por exemplo, esperamos que as probabilidades de votar por un partido da dereita radical populista aumenten a medida que nos desprazamos de esquerda a dereita na dimensión clásica esquerda-dereita, mais non esperamos atopar unhas inclinacións cada vez máis euroescépticas segundo nos movemos de esquerda a dereita na mesma dimensión.

No referido á nosa análise de regresión de MCO sobre os determinantes das orientacións euroescépticas, tomamos como variable dependente as respostas ofrecidas á pregunta B34 da enquisa Ess ${ }^{16}$. Con obxecto de cuantificarmos a relación existente entre o voto pola dereita radical populista e as actitudes cara a Europa, creamos unha variable binaria correspondente ao voto por eses partidos; nela asignóuselles un valor de 1 aos entrevistados que votan por partidos da dereita radical populista,

${ }^{15}$ Coa única excepción de Bélxica, elaboramos estas análises multivariantes á escala nacional. Nese primeiro país, onde os entrevistados da EsS están divididos entre Valonia e Flandres, realizamos o estudo só cos votantes desta segunda rexión.

${ }^{16}$ Sobre a redacción desta pregunta e a escala utilizada, véxase a nota 10. Como se mencionou antes, damos por suposto que a pregunta garda especial relación cunha dimensión concreta das actitudes cara a Europa, a que se refire ao reforzo da UE, a ampliación das competencias de toma de decisións, a transferencia das políticas e unha maior integración (Boomgaarden et al. 2011:258). 
mentres que o resto dos participantes na enquisa reciben un valor de 0 . Dado que a nosa expectativa é que os votantes destes partidos exhiban unha orientación negativa cara á unificación europea, o coeficiente в desta variable debería ser negativo. Alén dela, incluímos varios comparadores estatísticos máis que é verosímil que inflúan na actitude que esperta Europa; neste sentido, contamos con variables binarias correspondentes aos ingresos (tanto para niveis altos como para niveis baixos) ${ }^{17}$, nivel de ensino (aplicable a enquisados que tivesen estudos universitarios e aos que tivesen estudos primarios, ou inferiores ${ }^{18}$, sexo, idade, afiliación a un sindicato ${ }^{19}$, ideoloxía de esquerdas ou de dereitas ${ }^{20}$, radicalismo ideolóxico de esquerdas ou de dereitas $^{21}$, grao de relixiosidade ${ }^{22}$ e, por último, unha variable coa que se trazan as actitudes cara aos emigrantes ${ }^{23}$.

Como segunda análise efectuamos unha análise loxística na que a nosa variable dependente foi a variable dicotómica do voto a partidos da dereita radical populista. O obxectivo aquí radicou en elucidar se as actitudes amosadas cara á UE contribúen a predicir o voto por estes partidos, logo de introducirmos no noso modelo de regresión todos os comparadores anteditos, coa única excepción do radicalismo ideolóxico de esquerdas ou de dereitas, posto que non esperamos que o apoio aos partidos da dereita radical populista vaia en aumento a medida que a orientación ideolóxica do electorado se despraza cara á extrema esquerda.

\footnotetext{
${ }^{17}$ Estas variables binarias están baseadas nas respostas ofrecidas á pregunta F32 (HINCTNTA). Os enquisados pertencentes aos dous grupos de menores ingresos foron clasificados como de baixo nivel de rendas e asignóuselles un valor de 1 na variable de rendas baixas, mentres que aos entrevistados dos dous grupos de maiores ingresos se lles asignou un valor de 1 na variable de rendas altas. Por causa da ausencia de datos correspondentes á pregunta F32, estas dúas variables binarias non se incluíron nos modelos de MCO aplicables a Bulgaria e a Eslovaquia.

${ }^{18}$ Estas variables están baseadas nas respostas ofrecidas á pregunta F6 (EDULVL).

${ }^{19}$ Esta variable está baseada nas respostas ofrecidas á pregunta F30 (MBTRU). Os enquisados afiliados a un sindicato (nese momento ou nun anterior) recibiron un valor de 1 ; todos os demais, un 0 .

${ }^{20}$ Pregunta B23, que vai de 0 (esquerda) a 10 (dereita).

${ }^{21}$ Para lle asignar valores a esta variable estandarizouse a autoasignación persoal na escala esquerda-dereita (pregunta B23), a escala nacional, e a continuación elevouse ao cadrado.

${ }^{22}$ Pregunta C21, que vai de 0 (nada relixioso/a) a 10 (moi relixioso/a); porén, non demos atopado indicador ningún de intolerancia relixiosa, a cal, segundo se demostrou, exerce unha influencia positiva sobre o euroescepticismo (Hobolt et al. 2011).

${ }^{23}$ Para trazar as orientacións amosadas cara aos inmigrantes escollemos a variable B39 (IMUECLT), que revela as percepcións que existen verbo dos efectos da inmigración na cultura nacional. As respostas dadas para esta variable oscilan entre 0 (os inmigrantes socavan a vida cultural do país) e 10 (os inmigrantes enriquecen a vida cultural do país). A nosa selección dunha variable centrada nas implicacións culturais da inmigración fundaméntase na importancia que ten a demarcación cultural tanto para os partidos da dereita radical populista como para os seus votantes.
} 
No cadro 3 preséntanse os coeficientes do voto polos partidos da dereita radical populista nos modelos cos que se prognostica o euroescepticismo, mentres que no cadro 4 se amosan os coeficientes correspondentes ás actitudes cara a Europa na regresión loxística coa que se predí o voto por estes partidos. Os coeficientes в sempre apuntan na dirección esperada: os votantes de partidos da dereita radical populista tenden a ser máis euroescépticos ca outros votantes (nos modelos de MCO) e o euroescepticismo favorece o voto por estes partidos; no entanto, os coeficientes в non resultan significativos no nivel 0,10 (nos modelos MCO ou loxísticos) no caso de tres países, que son Romanía, Letonia e Grecia.

En consecuencia, a nosa análise estatística deixa de manifesto a presenza de vínculos estatisticamente discernibles, en oito dos once casos aquí considerados, entre os partidos da dereita radical populista e o seu electorado no tocante á integración europea, logo de esculcar a presenza dunha serie de variables explicativas que, verosimilmente, poderían gardar relación tanto coas actitudes cara a Europa como co voto pola dereita radical populista. Nestes oito casos, os nosos resultados concordan co que esperabamos, a saber, que as actitudes despregadas ante Europa son unha das cuestións que vinculan os partidos da dereita radical populista cos seus votantes. Aínda así, a escasa cifra de votantes desta dereita que se presenta nalgúns dos casos aquí analizados —nomeadamente Francia e os Países Baixos — transforma os nosos resultados en tentativos e imponlle algúns límites á validez externa deste achado.

Canto ás tres situacións en que non hai vencellos discernibles desta índole, resultan menos sorprendentes no caso do romanés PRM e o letón TB-LNNK ca no do grego LAOS. Os dous primeiros representan os únicos partidos que non son substantivamente euroescépticos e cuxos votantes non son tampouco os máis euroescépticos do electorado nacional; pola contra, no caso do grego LAOS, tanto o partido como os seus votantes si presentan un substantivo euroescepticismo. Con todo, é posible que o carácter mesmo máis marcadamente euroescéptico do Partido Comunista Grego impida que, con esta análise estatística, resulte discernible vínculo ningún entre o partido e os seus votantes con respecto á $\mathrm{UE}^{24}$.

\footnotetext{
${ }^{24}$ Os nosos resultados concordan cos achados de Lachat (2008) para o caso de Francia, o único país en que o seu estudo abrangue un dos partidos da dereita radical populista analizados aquí. Nese estudo chégase a conclusións semellantes sobre os Países Baixos, mais o traballo céntrase no voto que vai ao LPF no canto de ao PVv, e ponse de manifesto, así mesmo, a presenza de vencellos estatisticamente significativos entre o voto por partidos da dereita radical populista e a integración europea no caso do svp suízo, pero non no do austríaco FPÖ.
} 


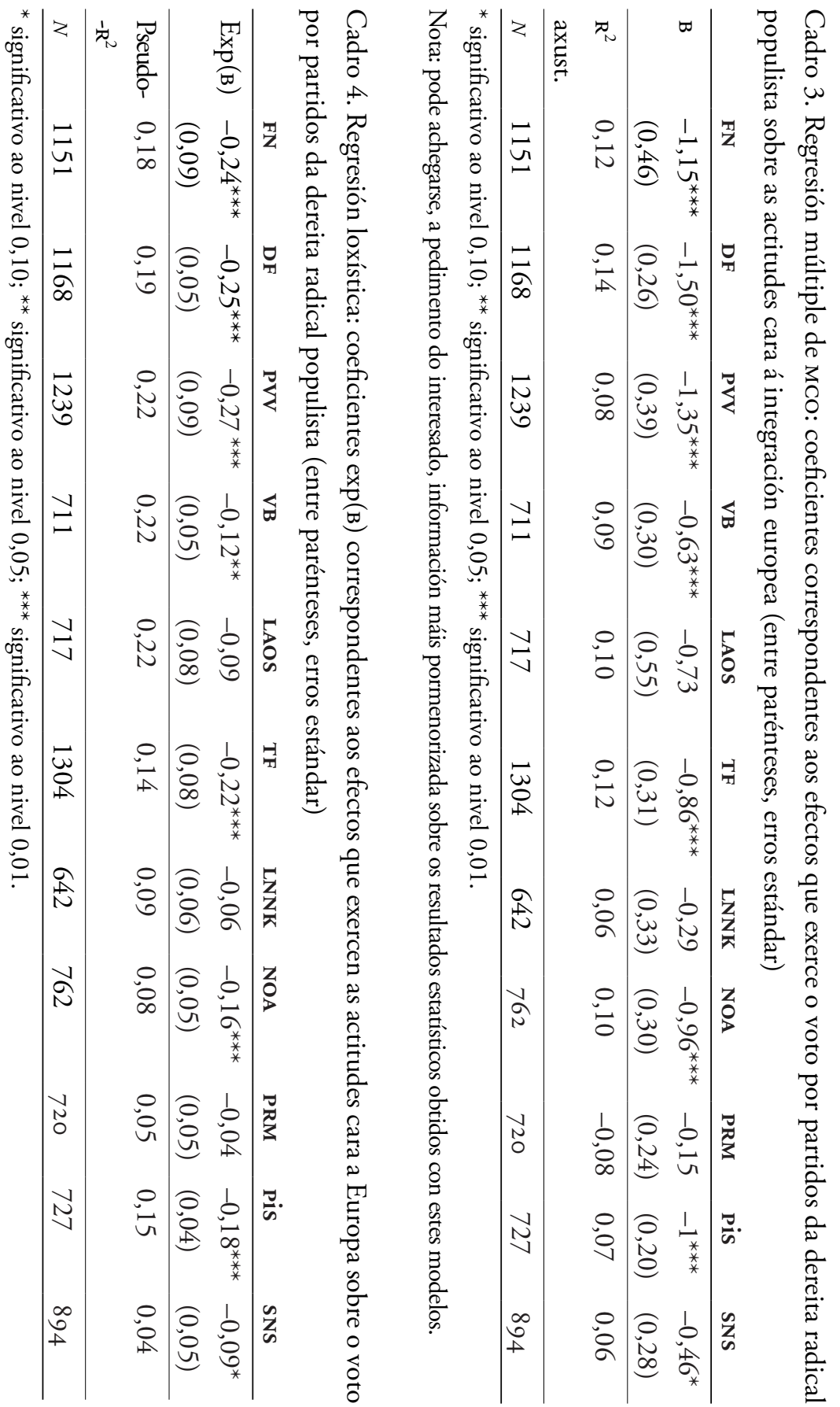


Mediante o estudo das relacións existentes entre partidos e votantes no seo dos seus respectivos sistemas de partidos e, consecuentemente, mediante un exame comparativo da postura absoluta que manteñen eses partidos na dimensión referida á integración europea, fomos quen de detectar a presenza de relacións programáticas entre os partidos da dereita radical populista e os seus votantes nunha dirección sistematicamente euroescéptica, sen prexuízo das importantes diferenzas que separan estes partidos entre si. Máis aínda, resulta tamén revelador que estas conexións se manteñan en modelos nos que se esculca a presenza de actitudes culturais cara aos emigrantes, variable que, segundo se ten demostrado, constitúe un factor determinante fundamental no apoio electoral que reciben os partidos da dereita radical populista (Norris 2005), xunto coa importante compoñente da nova dimensión integración-demarcación (Kriesi et al. 2008), dimensión que os ditos partidos tentan activar no terreo electoral, co cal contribúen á aparición de sistemas triangulares de partidos (Kriesi et al. 2006, Meguid 2005). De feito, nos datos da enquisa que estamos a analizar, as actitudes amosadas ante os inmigrantes van ligadas tamén á orientación dos enquisados ante Europa, como mostran os índices de correlación de Pearson dos que se dá conta no cadro 5.

Xeramos un cadro no que se resumen as tres características que están relacionadas directamente coa presenza de vencellos entre partidos e votantes no tocante á integración europea: as posturas absolutas substantivas conxuntas dos partidos da dereita radical populista e os seus votantes, as súas posturas relativas conxuntas e a presenza de vínculos estatisticamente significativos entre o voto por esa dereita e as actitudes ante Europa nas nosas análises multivariantes. No cadro 6 preséntase, en función da ausencia ou presenza destas tres características, un índice sintético da fortaleza dos vencellos entre partidos e votantes con respecto á integración europea dentro desta familia de partidos.

No cadro 6 amósase que, a excepción do TB-LNNK e o PRM, en todos os partidos se exhibe algunha sorte de conexión entre a súa postura e a dos seus votantes no tocante á integración e, en oito dos once casos, coa nosa análise multivariante detectouse a presenza de vencellos estatisticamente discernibles entre o voto por partidos da dereita radical populista e as actitudes cara á UE, unha vez esculcada a aparición doutras variables. O noso índice sintético demostra que, no caso deses partidos e o seu electorado, a politización da integración europea presenta variacións dentro da familia de partidos, mais cobra especial forza en tres casos — Francia, Finlandia e Bélxica — nos cales están 
presentes todas as características comprendidas no nosa síntese. Así, a FN e o vB son dous partidos da dereita radical populista antigos e prototípicos, caracterizados pola súa postura nacionalista, xenófoba e antiinmigración extrema, e ambos foron clasificados por Taggart e Szczerbiak (2008) como partidos euroescépticos «duros». En cambio, os Fineses, que en datas recentes mudaron de nome (Verdadeiros Fineses), pertencen á última xeración de partidos da dereita radical populista, sendo así que a política finesa se caracterizaba pola ausencia de partidos euroescépticos duros (Raunio 2008) ata a irrupción do TF nas eleccións europeas de 2009 e as nacionais de 2011; de feito, este éxito ténselle atribuído ao discurso antieuropeísta nun contexto de crecente politización da integración europea (Arter 2010: 485, Raunio 2012).

Cadro 5. Coeficientes de correlación de Pearson entre as actitudes cara á inmigración e a integración europea

\begin{tabular}{lllllllllll} 
FRA. & DIN. & P. BAIX. & BÉL. & GRE. & FIN. & LET. & BUL. & ROM. & POL. & ESL. \\
\hline 0,31 & 0,34 & 0,15 & 0,30 & 0,21 & 0,23 & 0,23 & 0,20 & 0,16 & 0,18 & 0,21 \\
\hline
\end{tabular}

Nota: todos os coeficientes son significativos ao nivel 0,01 .

Fonte: Ess 2008.

Cadro 6. Resumo de tres indicadores referentes aos vencellos entre partidos e votantes no tocante á UE

\begin{tabular}{lllll} 
& $\begin{array}{l}\text { Partidos e } \\
\text { votantes, } \\
\text { euroescépticos }\end{array}$ & $\begin{array}{l}\text { O partido máis } \\
\text { euroescéptico e } \\
\text { os votantes máis } \\
\text { euroescépticos }\end{array}$ & $\begin{array}{l}\text { Vencellos } \\
\text { estatisticamente } \\
\text { significativos entre } \\
\text { partidos e votantes }\end{array}$ & $\begin{array}{l}\text { Índice sumario } \\
\text { dos vencellos } \\
\text { dos partidos con } \\
\text { respecto á UE }\end{array}$ \\
\hline FN & 1 & 1 & 1 & 3 \\
TF & 1 & 1 & 1 & 3 \\
VB & 1 & 1 & 1 & 3 \\
SNS & 0 & 1 & 1 & 2 \\
DF & 1 & 0 & 1 & 2 \\
NOA & 0 & 0 & 1 & 1 \\
PVV & 0 & 0 & 1 & 1 \\
Pis & 0 & 0 & 1 & 1 \\
LAOS & 1 & 0 & 0 & 1 \\
TB-LNNK & 0 & 0 & 0 & 0 \\
PRM & 0 & 0 & 0 & 0 \\
\hline
\end{tabular}


No outro extremo, existen dous partidos —o PRM e o TB-LNNK - que non amosan ningunha clase de vencello cos seus votantes a respecto da integración europea. Para alén de estaren situados en dous sistemas de partidos poscomunistas, ambos se caracterizan polo seu claro posicionamento europeísta (o máis proeuropeo desta mostra; véxase a figura 1) e é tamén típico deles que os seus votantes exhiban unha orientación cara á UE que case iguala a media nacional respectiva (véxase a figura 2). As fortísimas actitudes proeuropeístas da poboación romanesa durante ese período — cunha media de 7,5 no noso indicador de europeísmo da ESs- poden contribuír a explicar as posturas proeuropeas adoptadas polo PRM e a súa carencia de vínculos cos votantes nesta dimensión (aínda que a opinión pública búlgara tamén era fortemente proeuropeísta). Con todo, as actitudes nacionais non explican a postura e os vínculos do TB-LNNK, dado o tépedo apoio da poboación letoa á integración europea — cunha media de 4,6 no mesmo indicador-; só cun estudo pormenorizado da política letoa se podería deitar luz sobre os determinantes dos posicionamentos deste partido e os seus vínculos co electorado.

Nas posicións intermedias deste cadro achamos unhas combinacións de características moi diversas. Así, o SNS e o DF, que polo demais son moi distintos, amosan a mesma puntuación global, mais exhiben unha conxunción de valores diferente: o DF e os seus votantes son substantivamente euroescépticos, pero non «os máis euroescépticos», debido á forte postura antieuropea, en Dinamarca, do Partido Popular Socialista (EL), da esquerda radical; pola contra, o sNS e o seu electorado, malia o endurecemento da posición deste partido ante a UE (Henderson 2001, 2008), son euroescépticos só en termos relativos —amosan o maior euroescepticismo do sistema de partidos eslovaco- - De feito, en ningún destes países poscomunistas podemos atopar un caso en que tanto o partido como os votantes adopten unha postura euroescéptica absoluta.

Canto ao grupo de partidos que mostran unicamente unha clase de vínculo (NOA, Pis, PVV, LAOS), estes presentan unha combinación de características incluso máis diversas. O feito de o PVv exhibir só vencellos significativos na análise multivariante pode poñerse en relación coa data da súa aparición, moi recente: o partido creouse no ano 2006 como escisión dos Conservadores dos Países Baixos (Krouwel e Lucardie 2008), cunhas características que levaron a algúns a se preguntar se pode ser considerado un partido claramente populista, como o foi o 
List Pim Fortuyn (Vossen 2010). O pvv fíxose coñecido polo seu posicionamento contrario á inmigración e irrompeu por vez primeira nas eleccións europeas de 2009; o estudo destes comicios amosa que os seus votantes experimentaron, xunto co electorado do PRM, a redución máis acusada nas súas inclinacións europeístas: así, se usásemos ese estudo das eleccións europeas de 2009, o PVV tamén satisfaría o criterio da segunda columna. O LAOs mostra unha forte postura antieuropea en termos absolutos, mais o seu euroescepticismo vese eclipsado polo do poscomunista KKE (Kommounistikó Kómma Elládas), máis duro nese sentido. Canto ao NOA e ao pis, só amosan vencellos entre o partido e os votantes na análise multivariante; o seu electorado non é euroescéptico en termos absolutos e existen partidos ou votantes (ou ambos) máis extremos nos seus respectivos sistemas de partidos.

Faría falla unha análise comparativa pormenorizada para detectar todos os factores sociais e políticos que inciden na índole e na fortaleza dos vencellos entre partidos e votantes no tocante á integración europea, cousa que vai alén dos obxectivos deste artigo. Tanto as análises empíricas como os estudos teóricos levan á conclusión de que os factores provenientes do lado da oferta resultan esenciais para o éxito electoral dos partidos da dereita radical populista. Así mesmo, e baseándonos en análises anteriores, damos por suposto que eses factores (situados ao nivel do partido e ao do sistema de partidos) exercen unha influencia crucial na aparición de vínculos entre tales partidos e os seus votantes a respecto de determinados temas políticos (Ray 2003, Steenbergen et al. 2007). Certamente, as características nucleares ideolóxicas e programáticas destes partidos tamén deben de desempeñar un papel na fixación das súas posturas e no establecemento de vínculos cos votantes arredor desta cuestión; no entanto, o nacionalismo non é condición suficiente para o xurdimento de vencellos fortes entre os partidos da dereita radical populista e os seus votantes no referido á integración europea, pois case todos estes partidos son firmemente nacionalistas ou nativistas e, con todo, amosan moi distintos graos de relación cos seus votantes neste ámbito ${ }^{25}$. Nós partimos, en cambio, da idea de que a postura concreta que adoptan os partidos sobre a cuestión da integración europea debe de exercer unha influencia máis directa na aparición dos vínculos e, en particular, formulamos a hipótese de que, canto máis extremas sexan as

\footnotetext{
${ }^{25}$ De feito, neste grupo de partidos non existe relación ningunha entre o grao de nacionalismo e nativismo, cuantificado nas preguntas 31 e 25 da enquisa de expertos da unc-Chapel Hill, e os vencellos que establecen co seu electorado no tocante á integración europea.
} 
posturas (tanto a absoluta como a relativa) tomadas polos partidos da dereita radical populista, máis probable será a xeración de vencellos fortes cos seus votantes arredor desta cuestión. Un motivo do anterior radica en que, coa adopción dunha postura extrema, aos partidos pequenos resúltalles máis doado acadar unha diferenciación política e aumentar a súa cota electoral (Wagner 2012), e, de certo, esa asunción de posicionamentos extremos garda relación con outras características e escollas estratéxicas dos partidos políticos que as obras dedicadas a esta cuestión tratan como fundamentais para o establecemento de vínculos entre partidos e votantes (Ray 2003, Steenbergen et al. 2007), como son a disensión (condición previa para a adopción de posturas extremas por parte do partido) e a notoriedade do partido, que un pode considerar consecuencia das posturas escollidas (Wagner 2012: 66). Esa toma de posturas extremas tamén debe ligarse ás características xerais da opinión pública nacional e, en particular, á fortaleza das orientacións euroescépticas, que por necesidade inciden nas escollas estratéxicas dos partidos da dereita radical populista e na competencia.

As nosas análises exploratorias demostran que, canto máis extrema sexa a postura euroescéptica dos partidos da dereita radical populista ${ }^{26}$, maior é a cifra de vínculos detectados no noso índice sintético e máis fortes serán os coeficientes в correspondentes, na nosa análise de MCO, aos vencellos entre partidos e votantes (véxanse as figuras $4 \mathrm{e}$ $5)^{27}$. Mesmo así, non todos os partidos se axustan ben a este modelo e, por exemplo, na figura 4 un esperaría que o PVv e o vB exhibisen unhas cifras maior e menor, respectivamente, de vínculos cos seus votantes; o PVv encaixa moito mellor no modelo xeral que se presenta na figura 5, mais neste caso os coeficientes do DF e do Pis son maiores do esperado. Estas discrepancias demostran que achar unha explicación satisfactoria da fortaleza dos vencellos entre partidos e votantes esixiría unha análise comparativa pormenorizada dos determinantes que marcan as escollas de postura e das interaccións

${ }^{26}$ Por motivos de simplicidade, e dado que as posturas absolutas e relativas dos partidos gardan unha forte correlación (correlación de Pearson de $-0,85$ entre as posturas absolutas dos partidos da dereita radical populista e a distancia existente entre esas posturas e a media ponderada dos posicionamentos do sistema de partidos), imos deixar á marxe deste estudo as relacións que se dan entre estes dous indicadores de vínculos entre partidos e votantes e as posturas relativas dos partidos da dereita radical populista nos seus respectivos sistemas.

${ }^{27} \mathrm{O}$ índice de correlación de Pearson entre as posturas dos partidos e o resumo de vínculos entre partidos e votantes é igual a $-0,72$, e o que se produce entre as posturas dos partidos e os coeficientes в da análise de MCo é de $+0,74$. Certamente, os dous primeiros indicadores en que fundamentamos o noso índice sumario xa inclúen información sobre a postura dos partidos (se son ou non euroescépticos e se son ou non os de maior euroescepticismo), mais tamén se teñen en consideración neles a postura absoluta e a relativa dos votantes deses partidos. Canto aos coeficientes B, a priori non gardan relación coa postura adoptada polos partidos a respecto da UE. 
Figura 4. Posturas dos partidos (base de datos da unC-Chapel Hill de 2006) e valores dos partidos no noso indicador sumario correspondente aos vencellos entre partidos e votantes

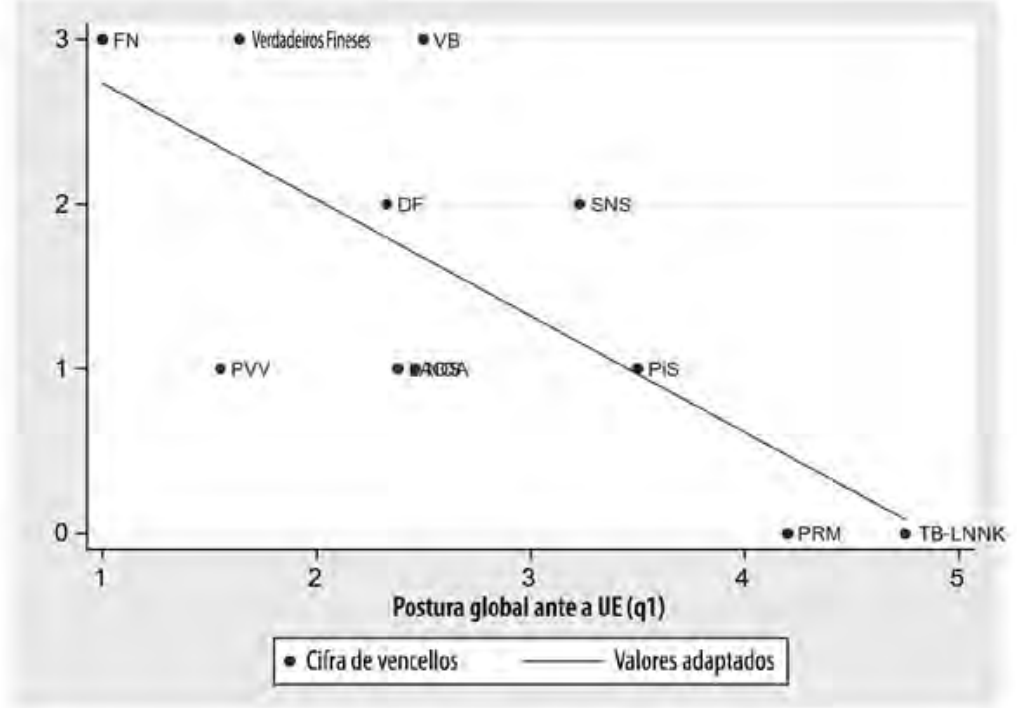

Figura 5. Posturas dos partidos e coeficientes correspondentes aos efectos que exerce o voto pola dereita radical populista sobre as actitudes europeas na análise de MCO

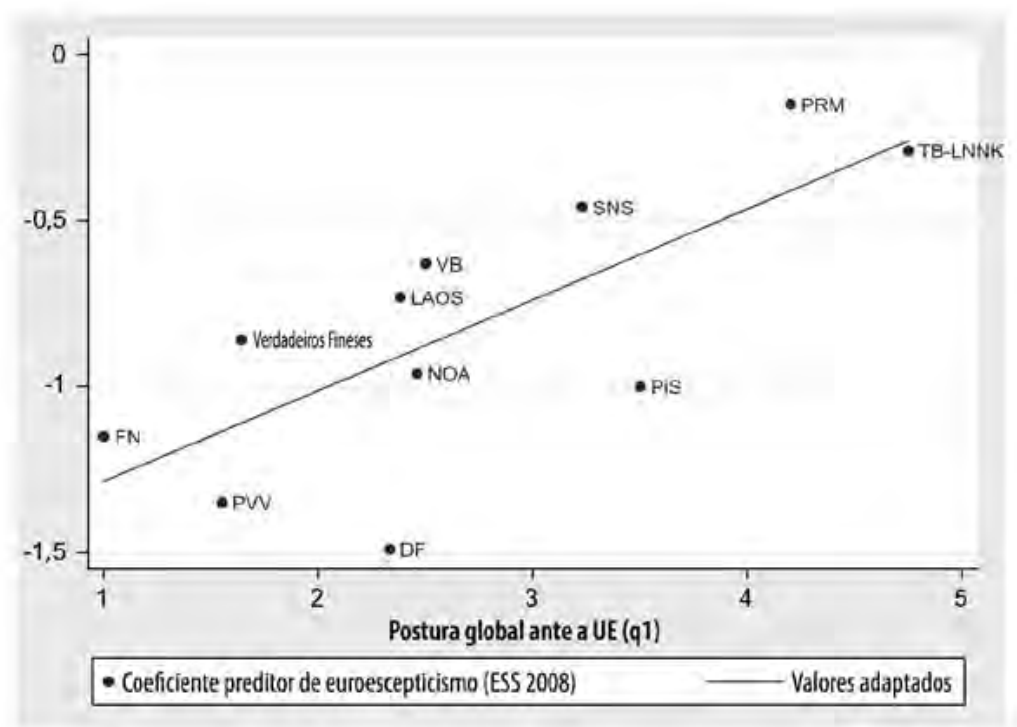


entre estes e outros factores que veñen da banda da oferta e da da demanda, como a disensión no seo do partido, a destacabilidade da cuestión europea ${ }^{28}$, as estratexias adoptadas por outros partidos políticos e as actitudes da opinión pública nacional cara á UE. Esta tarefa fica fóra do ámbito da nosa investigación.

\section{CONCLUSIÓN}

Neste artigo pretendeuse estudar a presenza de vínculos entre unha serie de partidos radicais populistas e os votantes no tocante á cuestión da integración europea. Os nosos achados veñen sustentar a hipótese de que os partidos da dereita radical populista establecen vínculos cos seus votantes a respecto do proceso de integración europea e, en particular, o feito de as nosas análises multivariantes sinalaren a presenza de tales vencellos mesmo despois de se escrutar a posible intervención doutras variables relacionadas co voto por partidos da dereita radical populista indica que, na meirande parte desta familia de partidos, a integración europea se converteu nunha das cuestións arredor da cal artellan a relación que manteńen cos votantes. Este resultado concorda coas probas que xa existían acerca da particularidade que reviste a integración europea para a dirección de voto do partido; deste xeito, os partidos da dereita radical populista lograron distinguirse nese eido da integración e deron posto en contacto as actitudes euroescépticas con outros elementos nucleares do seu discurso ideolóxico, como a súa postura antiinmigración e, nun plano máis xeral, o seu posicionamento nacionalista ${ }^{29}$.

Kriesi et al. (2008) destacan a oposición da dereita radical populista a unha serie de compoñentes clave de índole social e político-cultural da globalización, sobre todo a inmigración e a integración supranacional. $\mathrm{Na}$ análise de Lachat (2008) ponse de manifesto que as actitudes despregadas cara á UE contribúen a explicar o voto que vai a partidos da dereita populista en Francia (FN), Suíza

\footnotetext{
${ }^{28}$ A disensión no seo do partido e a destacabilidade deste xa están relacionadas coa postura do partido ante a integración europea. A correlación de Pearson entre a postura dos partidos da dereita radical populista e a disensión interna é igual a $+0,94$, e a que existe entre a postura do partido e a súa destacabilidade é de $-0,61$ (base de datos de 2006 da UnC-Chapel Hill).

${ }^{29}$ De feito, os índices de correlación de Pearson dos que se dá conta no cadro 4 mostran que as actitudes euroescépticas e contrarias á inmigración gardan unha relación positiva entre si na poboación de todos os países aquí analizados.
} 
(SVP) e os Países Baixos (LPF). O noso estudo revela a importancia que revisten os vínculos mantidos sobre a cuestión da UE entre os partidos da dereita radical populista e os seus votantes nun período máis recente e cunha cantidade maior de casos e, o que é máis, estes vencellos poden observarse nalgúns países poscomunistas da Europa oriental, o cal subliña a presenza de certas semellanzas entre os casos orientais e occidentais. No entanto, non existe exemplo ningún na Europa oriental no que tanto estes partidos como o seu electorado sexan substantivamente euroescépticos e, malia estaren presentes algúns vínculos entre partidos e votantes en tres casos tirados desta rexión europea (sNs, MOA e pis), en dous deles tales vínculos limítanse á existencia de coeficientes estatisticamente significativos na nosa análise multivariante. Isto indica que si se dan vínculos no leste no que á UE se refire, pero tenden a ser máis febles ca na Europa occidental, o cal podería ser resultado da máis recente data de integración destes países na UE, as distintas actitudes e intereses da opinión pública da Europa oriental con respecto á integración europea e o menor grao de estruturación programática dos sistemas de partidos poscomunistas (Marks et al. 2006).

Sen prexuízo destas diferenzas, a nosa análise comparativa mostra a presenza de vínculos entre partidos e votantes no caso de partidos de distinto carácter que pertencen á familia da dereita radical populista, e en escenarios sociais e político-institucionais moi diversos. Como mencionamos anteriormente, este achado vén avalar os argumentos ofrecidos por outros autores sobre a importancia que para a transformación da competencia entre partidos en Europa teñen os conflitos que versan sobre as principais compońentes da globalización, en particular a integración europea (Hooghe e Marks 2008, Kriesi et al. 2008).

Os nosos achados tamén apuntan a outras interrogantes e vías de investigación: no ámbito metodolóxico, veñen pedir tanto un aumento na cifra de partidos da dereita radical populista que quedan comprendidos na análise como a realización de estudos comparativos pormenorizados nos que se trate unha cantidade pequena de casos e se aborden as variacións que se producen co tempo na activación política da cuestión da integración europea (Green-Pedersen 2011). E, de maneira substantiva, fan precisa unha análise dos diferentes factores sociais e políticos, tanto no plano da oferta como no da demanda, que lles dea forma aos vínculos que existen entre os partidos da dereita radical populista e os seus votantes no tocante á integración. O noso estudo concorda coa hipótese de que 
a postura adoptada por estes partidos resulta crucial nos vínculos que establecen co seu electorado con respecto á cuestión da UE, sendo os partidos máis extremos os que tenden a exhibir uns vencellos máis fortes cos seus votantes neste sentido. Con todo, precisamos análises comparativas máis pormenorizadas que nos permitan comprender que influencia exercen este e outras clases de factores (o primeiro deles, a destacabilidade dos distintos temas) na estruturación dos vencellos que establecen estes partidos cos votantes; para avaliar as repercusións que teñen tales factores explicativos, xunto con outros, será necesario elaborar un método de investigación distinto e compilar máis datos, o cal debe constituír o obxectivo de futuras investigacións e análises. 


\section{REFERENCIAS BIBLIOGRÁFICAS}

Arter, David (2010): «The Breakthrough of Another West European Populist Party: The Case of the True Finns", Government and Opposition, 45:4, 484-510.

Betz, Hans-Georg (ed.) (1994): Radical Right-Wing Populism, Nova York, St. Martin Press.

Boomgaarden, Hajo G. / Andreas SchucK / Matthijs ElendaAs / Claes de Vreese (2011): «Mapping EU Attitudes: Conceptual and Empirical Dimensions of Euroscepticism and EU Support», European Union Politics, 12:2, 241-266.

Carter, Elisabeth (2005): The Extreme Right in Western Europe, Manchester, NH, Manchester University Press.

De VRIES, Catherine (2007): «Sleeping Giant: Fact or Fairytale?: How European Integration Affects National Elections», European Union Politics, 8:3, 363-385.

De Vries, Catherine / Erica Edwards (2009): «Taking Europe to its Extremes», Party Politics, 15: 1, 5-28.

Green-Pedersen, Christopher (2007): «The Growing Importance of Issue Competition: The Changing Nature of Party Competition in Western Europe», Political Studies, 55, 607-628.

Green-Pedersen, Christopher (2012): «A Giant Fast Asleep?: Party Incentives and the Politicization of European Integration", Political Studies, 60:1, 115-130.

Hainsworth, Paul (1992): The Extreme Right in Europe and the USA, Nova York, St. Martin Press.

Hainsworth, Paul (2007): The Extreme Right in Western Europe, Londres, Routledge.

Henderson, Karen (2001): «Euroscepticism or Europhobia: Opposition Attitudes to the EU in the Slovak Republic», SEI Working Paper 50, Opposing Europe Research Network Paper 5.

Henderson, Karen (2008): «Exceptionalism or Convergence?: Euroscepticism and Party Systems in Central and Eastern Europe», en Paul Taggart / Alex Szczerbiak (eds.), Opposing Europe?: The Comparative Party Politics of Euroscepticism, vol. 2, Oxford, Oxford University Press, 277-294.

Hxx, Simon / Christopher Lord (1997): Political Parties in the European Union, Londres, Macmillan Press Ltd.

Hobolt, Sara B. / Wouter van der Brug / Claes H. de Vreese / Hajo G. BoomgaArden / Malte C. Hinrichsen (2011): «Religious Intolerance and Euroscepticism», European Union Politics, 12:3, 359-379 .

Hooghe, Liesbet / Gary Marks / Carole Wilson (2004): «Does Left/Right Structure Party Positions on European Integration?», en Gary Marks / Marco R. Steenbergen (eds.), European Integration and Political Conflict, Cambridge, Cambridge University Press, 120-140.

Hooghe, Liesbet / Gary Marks (2008): «A Postfunctional Theory of European Integration: From Permissive Consensus to Constraining Dissensus», British Journal of Political Science, 39, 1-23.

Hooghe, Liesbet / Ryan Bakker / Anna Brigevich / Catherine de Vries / Erica Edwards / Gary Marks / Jan Rovny / Marco Steenbergen / Milada Vachudova (2010). «Reliability and Validity of Measuring Party Positions: The Chapel Hill Expert Surveys of 2002 and 2006», European Journal of Political Research, 4, 684-703.

Ignazi, Piero (2004): Extreme Right Parties in Western Europe, Oxford, Oxford University Press.

Ivaldi, Giles (2004): Droites populistes et extrêmes en Europe occidentale, París, La Documentation française. Kitschelt, Herbert / Anthony McGann (1995): The Radical Right in Western Europe: A Comparative Analysis, Ann Arbor, University of Michigan Press. 
KrIESI, Hanspeter (2007): «The Role of European Integration on National Election Campaigns», European Union Politics, 8:1, 83-108.

Kriesi, Hanspeter / Edgar Grande / Romain LACHAT / Martin Dolezal / Simon Bornschier / Timotheos Frey (2008): West European Politics in the Age of Globalization, Cambridge, Cambridge University Press.

Kopecky, Petr / Cas Mudde (2002): «The Two Sides of Euroscepticism: Party Positions on European Integration in East Central Europe», European Union Politics, 3:3, 297-326.

Krouwel, André / Paul Lucardie (2008): «Waiting in the Wings: New Parties in the Netherlands», Acta Politica, 43, 278-307.

LACHAT, Romain (2008): «The Electoral Consequences of the Integration-Demarcation Cleavage», en Hanspeter Kriesi / Edgar Grande / Romain Lachat / Martin Dolezal / Simon Bornschier / Timotheos Frey (eds.), West European Politics in the Age of Globalization, Cambridge, Cambridge University Press, 296-319.

Mair, Peter / Cas Mudde (1998): «The Party Family and its Study», Annual Review of Political Science, I, 211-229.

Marks, Gary / Carole Wilson (2000): «The Past in the Present: A Cleavage Theory of Party Positions on European Integration», British Journal of Political Science, 30, 433-459.

MARKs, Gary / Carole Wilson / Leonard RAY (2002): «National Political Parties and European Integration», American Journal of Political Science, 46:3, 585-594.

Marks, Gary / Marco R. Steenbergen (eds.) (2004): European Integration and Political Conflict, Cambridge, Cambridge University Press.

Marks, Gary / Liesbet Hooghe / Moira Nelson / Erica Edwards (2006): «Party Competition and European Integration in the East and West. Different Structure, Same Causality", Comparative Political Studies, 39:2, 155-175.

Mattila, Mikko / Tapio Raunio (2006): «Cautious Voters - Supportive Parties: Opinion Congruence between Voters and Parties on the EU Dimension", European Union Politics, 7:4, 427-449.

Meguid, Bonnie (2005): «Competition among Unequals: The Role of Mainstream Party Strategy in Niche Party Success", American Political Science Review, 99, 347-359.

Mudde, Cas (2000): The Ideology of the Extreme Right, Manchester, Manchester University Press.

Mudde, Cas (2007): Populist Radical Right Wing Parties in Europe, Cambridge, Cambridge University Press.

Mudde, Cas (2010): «The Populist Radical Right: A Pathological Normalcy», West European Politics, 36:6, 1167-1186.

Mudde, Cas (2011): «Sussex v. North Carolina: The Comparative Study of Party-Based Euroscepticism», SEI Working Paper 121, EPERN Working Paper 23.

Norris, Pippa (2005): Radical Right: Parties and Electoral Competition, Cambridge, Cambridge University Press.

Odmalm, Pontus (2011): «Political Parties and "The Immigration Issue”: Issue Ownership in Swedish Parliamentary Elections 1991-2010», West European Politics, 34:5, 1070-1091.

Popper, Karl (2002): Unended Quest: An Intellectual Autobiography, Londres/Nova York, Routledge.

RAY, Leonard (1999): «Measuring Party Orientation towards European Integration: Results from an Expert Study», European Journal of Political Research, 36, 283-306.

RaY, Leonard (2003): «When Parties Matter: The Conditional Influence of Party Positions on Voter Opinion about European Integration", Journal of Politics, 65: 4, 978-994. 
Raunio, Tapio (2008): «Euroscepticism in Finland?», en Paul Taggart / Alex Szczerbiak (eds.), Opposing Europe?: The Comparative Party Politics of Euroscepticism. Volume 1: Case Studies and Country Surveys, Oxford, Oxford University Press, 168-180.

Raunio, Tapio (2012): «Whenever the EU Is Involved, You Get Problems: Explaining the European Policy of the (True) Finns». SEI Working Paper 127, EPERN Working Paper 26.

Sniderman, Paul M. / Pier Angelo Peri / Rui J. P. de Figueiredo Jr. / Thomas Piazza (2000): The Outsider: Prejudice and Politics in Italy, Princeton, NJ, Princeton University Press.

Steenbergen, Marco / David Scott (2004): «Contesting Europe?: The Salience of European Integration as a Party Issue», en Gary Marks / Marco R. Steenbergen (eds.), European Integration and Political Conflict, Cambridge, Cambridge University Press, 165-192.

Steenbergen, Marco / Erica Edwards / Catherine de Vries (2007): «Who is Cueing Whom? Mass-Elite Linkages and the Future of European Integration», European Union Politics, 8:1, 13-35.

TAggart, Paul (1995): «New Populist Parties in Western Europe», West European Politics, 18:1, 34-51.

TAgGart, Paul (1998): «A Touchstone of Dissent: Euroscepticism in Contemporary Western European Party Systems», European Journal of Political Research, 33, 363-388.

Taggart, Paul / Aleks Sczcerbiak (eds.) (2008): Opposing Europe? The Comparative Party Politics of Euroscepticism. Volume 1: Case Studies and Country Surveys, Oxford, Oxford University Press.

VAn DER EijK, Cees / Mark Frankuin (2004): «Potential for Contestation on European Matters at National Elections in Europe», en Gary Marks / Marco R. Steenbergen (eds.), European Integration and Political Conflict, Cambridge, Cambridge University Press, 32-50.

Vossen, Koen (2010): «Populism in the Netherlands after Fortuyn: Rita Verdonk and Geert Wilders Compared", Perspectives on European Politics and Society, 11: 1, 22-38.

Wagner, Markus (2012): «When Do Parties Emphasise Extreme Positions? How Strategic Incentives for Policy Differentiation Influence Issue Importance», European Journal of Political Research, 51:1, 64-88. 
O POPULISMO RADICAL: ENTRE AS PROMESAS DE DEMOCRATIZACIÓN E $O$ AUTORITARISMO

Carlos de la Torre University of Kentucky 

O populismo foi vivido polos actores e interpretado polos analistas como un momento excepcional da política. Durante os episodios populistas invócase a soberanía popular, rebordan as canles institucionais e o pobo busca reapropiarse da política. Mais, se ben os analistas comparten a visión do populismo como un momento excepcional, difiren nas súas interpretacións sobre os seus potenciais democratizadores. É así que os liberais, seguindo os reparos e as ambivalencias de Max Weber ao carisma, consideran que os movementos extrainstitucionais populistas poden devir en autoritarismos. Esa foi tamén a preocupación de Gino Germani nos seus traballos sobre o peronismo e de politólogos como Steve Levitsky e Kurt Weyland, que argumentan que, en condicións de fraxilidade institucional, os populismos deveńen en réximes autoritarios competitivos ${ }^{1}$. Outros ven os momentos excepcionais como oportunidades democratizadoras. Segundo Ernesto Laclau, os momentos excepcionais de ruptura populista que son teorizados como a expresión do político non só son precisos para dar cabo de sistemas administrativos e institucionais excluíntes, senón que permiten construír ordes alternativas ${ }^{2}$. Yannis Stravakakis sostén que o populismo de esquerda que non constrúe ao pobo con visións ultranacionalistas e excluíntes dos inmigrantes é necesario para frear os populismos xenófobos de dereita en Europa ${ }^{3}$. Un terceiro grupo de autores considera que as relacións entre populismo e democracia dependen do contexto institucional e social. É así que, mentres que os populismos europeos, coa excepción de SYRIZA e Podemos, son excluíntes, os populismos latinoamericanos polo xeral procuraron a inclusión socioeconómica, política e cultural de sectores antes excluídos ${ }^{4}$.

${ }^{1}$ Germani, Gino (1978): Authoritarianism, Fascism, and National Populism, New Brunswick, N.J., Transaction Books; Levistky, Steven / James Loxton (2013): «Populism and Competitive Authoritarianism in the Andes», Democratization, 20, 107-136; Weyland, Kurt (2013): "The Threat from the Populist Left», Journal of Democracy, 24, 18-32.

${ }^{2}$ Laclau, Ernesto (2005): On Populist Reason, Londres/Nova York, Verso.

${ }^{3}$ Stavrakakis, Yannis (2014): «The Return of "the People": Populism and Anti-Populism in the Shadow of the European Crisis», Constellations, 21:4, 514.

${ }^{4}$ Mudde, Cas / Cristóbal Rovira Kaltwasser (2013): «Exclusionary vs. Inclusionary Populism: Comparing Europe and Latin America», Government and Opposition, 48, 22, CJO doi:10.1017/gov.2012.11. 
Antes de empezar, e para evitar malentendidos, pois o populismo é un termo que polo xeral se usa desde os medios para atemorizar, xa que é visto como irracional e perigoso, teño que explicar a que me refiro cando utilizo o termo $p \circ p u$ lismo. Entendo o populismo como unha retórica que representa a política como unha loita maniquea entre o pobo e a oligarquía. A lóxica populista polariza a política en dous campos antagónicos, simplifica as complexidades da sociedade como a loita entre dous grupos nidios e apunta á ruptura da orde institucional para forxar institucións alternativas. A noción populista de "pobo» incorpora a idea marxista de conflito antagónico entre dous grupos coa visión romántica da súa pureza e bondade naturais. De resultas diso, o pobo polo xeral é imaxinado polos populistas como unha entidade homoxénea, fixa e indiferenciada. $\mathrm{O}$ pobo populista non se enfronta a adversarios, senón a inimigos morais que representan unha ameaza que debe ser erradicada.

O populismo aseméllase, mais non é igual, aos movementos populares e ás insurxencias feitas no nome do pobo. Por exemplo, os indignados españois, o movemento de Occupy Wall Street e as insurxencias bolivianas durante as guerras da auga e do gas utilizaron unha retórica parecida á populista do pobo en contra das elites, experimentaron con formas de democracia directa e sen representantes e foron vividos como momentos excepcionais nos que se puido imaxinar unha nova orde social e política. Pero, a diferenza do populismo, non tiveron un liderado. Máis ben foron insurxencias sen líderes nas que se buscaron formas horizontais de democracia e a participación e a deliberación de todos 5 .

A diferenza destas formas de poder horizontal e disperso, o populismo, como sinala Nadia Urbinati, para pasar «de movemento a goberno precisa unha ideoloxía que polarice e un líder que pretenda transformar o descontento popular e a protesta nunha estratexia para mobilizar as masas co fin de conquistar o goberno democrático» ${ }^{6}$. O líder populista preséntase como a encarnación do pobo e como quen o guiará á redención da dominación oligárquica. Os líderes populistas incorporan os excluídos redistribuíndo recursos materiais, confrontando os valores

\footnotetext{
${ }^{5}$ Arditi, Benjamín (2014): «Insurgencies don't have a plan - they are the plan: Political performatives and vanishing mediators in 2011», en Carlos de la Torre (ed.), The Promises and Perils of Populism: Global Perspectives, Lexington, University Press of Kentucky; Castells, Manuel (2012): Networks of Outrage and Hope: Social Movements in the Internet Age, Cambridge, Polity Press; Zibechi, Raúl (2010): Dispersing Power: Social Movements as Anti-State Forces, Oakland, AK Press.

${ }^{6}$ Urbinati, Nadia (2013): «The Populist Phenomenon», Raisons Politiques, 3:51, 139.
} 
da cultura popular á dominación das elites e dando voz a aqueles que están desmotivados ou excluídos da política.

Nesta presentación discutirei os liderados de Hugo Chávez e do seu sucesor, Nicolás Maduro, en Venezuela; Evo Morales, de Bolivia, e Rafael Correa, de Ecuador. A miña charla desenvolverá tres argumentos: 1) Cando os populismos buscan chegar ao poder poden ser democratizadores, pois cuestionan a lexitimidade de réximes excluíntes. 2) Durante os episodios populistas diferentes actores, como son os líderes políticos e os movementos sociais, din que falan no nome do pobo. Dispútase quen pode falar polo pobo, quen o representa e por veces quen o encarna. Cando os movementos sociais son febles e as institucións da democracia representativa están en crise, o líder populista aprópiase da voz do pobo e di ser a súa encarnación. 3) O populismo devén en autoritarismo cando o pobo é imaxinado como unha entidade homoxénea, fixa e indiferenciada que pode ser encarnada nun líder. $\mathrm{O}$ populismo tamén devén en autoritarismo cando os adversarios son construídos como inimigos morais que representan unha ameaza que debe ser erradicada.

\section{AS PROMESAS DE INCLUSIÓN POPULISTAS}

A bibliografía sobre os Gobernos de esquerda latinoamericana explica a emerxencia dos Gobernos de Chávez-Maduro, Morales e Correa por tres factores endóxenos ${ }^{7}$. O primeiro foi unha crise de representación política. Os partidos tradicionais foron vistos como unha partidocracia corrupta que servía os intereses do Fondo Monetario Internacional. Os partidos políticos tradicionais foron desprazados por outsiders que, unha vez que chegaron ao poder, contribuíron a terminar con eles.

Os populistas de esquerda chegaron ao poder con propostas de como mellorar a democracia. Chávez, coa idea de construír unha democracia participativa e protagónica que resolvería os déficits participativos e representativos da democracia

\footnotetext{
${ }^{7}$ Weyland, Kurt / Raúl L. Madrid / Wendy Hunter (eds.) (2010): Leftist Governments in Latin America: Successes and Shortcomings, Cambridge, Cambridge University Press; Levitsky, Steven / Kenneth M. Roberts (eds.) (2011): The Resurgence of the Latin American Left, Baltimore, Johns Hopkins University Press; Torre, Carlos de la / Cynthia Arnson (eds.) (2013): Populism of the Twenty-first Century, Baltimore/ Washington, Johns Hopkins University Press/Woodrow Wilson Center Press.
} 
liberal. Correa prometeu substituír a democracia formal por unha democracia real entendida como políticas públicas que redistribúan a riqueza. Morales propuxo combinar a democracia indíxeno-comunitaria coa democracia liberal para descolonizar Bolivia.

Con estes líderes retornaron as utopías da revolución e do socialismo. Mais, a diferenza dos modelos antigos asentados no uso da violencia para chegar ao poder, a nova estratexia revolucionaria baseouse no uso dos votos e non das balas. As eleccións permanentes buscaron desprazar as elites e construír un campo hexemónico popular. O socialismo do século Xxi non se baseou na estatalización dos medios de produción, senón en modelos nos que o Estado ten un rol importante na planificación da economía, que combina formas de produción comunitarias, estatais e privadas.

A maior innovación destes líderes foi o basear a súa estratexia na noción de poder constituínte. Desdeñaron o poder constituído e prometeron a refundación das súas respectivas patrias para acadar a segunda e verdadeira independencia. O poder constituínte foi entendido como a capacidade popular para crear institucións e normativas, coa autoridade capaz de refundar a política, a economía, a moral e a cultura. Estes líderes foron elixidos coa promesa de convocar eleccións para asembleas constituíntes participativas que xerasen novas Constitucións entendidas como pactos e proxectos de sociedade. As novas Constitucións, á vez que ampliaron dereitos, concentraron o poder no executivo.

O segundo factor que explica o xurdimento do populismo de esquerda son os movementos de resistencia masiva ao neoliberalismo. O Caracazo de febreiro de 1989 foi unha insurrección popular en contra do incremento do prezo da gasolina. Os sectores populares de Caracas e doutras cidades saquearon comercios e foron brutalmente reprimidos. En Ecuador tres presidentes entre 1997 e 2005 non puideron terminar os seus mandatos porque insurreccións populares e indíxenas en contra do neoliberalismo e da corrupción contribuíron a dar cabo dos seus Gobernos. En Bolivia, entre 2000 e 2003, as guerras da auga e do gas crearon situacións revolucionarias cando coalicións de indíxenas e doutros movementos sociais paralizaron o país demandando a fin do neoliberalismo, da partidocracia e da entrega dos recursos naturais a multinacionais.

A terceira causa que explica a emerxencia do populismo de esquerda son as demandas pola soberanía nacional. Bolivia viviu violacións masivas aos dereitos 
humanos por mor das políticas norteamericanas de extracción forzada da folla de coca. Nun intento desesperado por parar a hiperinflación, o Goberno de Jamil Mahuad en Ecuador cambiou a súa moeda nacional, o sucre, polo dólar americano. Venezuela mudo a orientación da súa política exterior e petroleira, nacionalista e terceiromundista, por unha que apoiaba a globalización. Morales, Correa e Chávez prometeron o retorno dos intereses da nación e concibiron os seus Gobernos como parte dun proceso continental e mesmo global de resistencia ao neoliberalismo. A orientación da súa política exterior foi antiimperialista e creáronse organizacións como o ALBA para contrarrestar os acordos de libre comercio impulsados polos Estados Unidos.

Cando os populismos retan o poder da oligarquía e de elites transnacionais, politizan temas, como o neoliberalismo, que eran tratados como técnicos. Os episodios populistas por veces están asociados a rebelións e insurreccións feitas no nome do pobo. É por estas razóns polas que os populismos son vividos como momentos extraordinarios en que os cidadáns desbordan as canles institucionais para reconstituíren os principios simbólicos e constitucionais da política. Son momentos en que se invoca a soberanía popular e a capacidade do pobo e dos cidadáns de se autogobernaren directa e autonomamente ${ }^{8}$. As insurxencias populistas cuestionan e deslexitiman os fundamentos normativos e simbólicos da autoridade política. Durante estes episodios pódese xerar un novo discurso que conforme unha vontade colectiva?.

\section{QUEN FALA NO NOME DO POBO?}

O pobo, como o sinala Ernesto Laclau, é unha construción discursiva. O pobo é unha disputa entre actores políticos e movementos sociais e intelectuais. Cando se invoca o nome do pobo, hai que se preguntar quen di estar a falar no seu nome, pois a política baséase en quen pode falar no nome do pobo. Os líderes populistas constrúen o pobo e a oligarquía como polos antagónicos. Din que encarnan os desexos e virtudes do pobo e prometen devolver o poder ao pobo e redimilo do

\footnotetext{
${ }^{8}$ Véxase a definición de política extraordinaria en Kalivas, Andreas (2008): Democracy and the Politics of the Extraordinary: Maw Weber, Carl Schmitt, and Hannah Arendt, Cambridge, Cambridge University Press, 6-7. ${ }^{9}$ Ibíd., 65.
} 
dominio de elites políticas, económicas e culturais. Mais os políticos non son os únicos que pretenden falar no nome do pobo: os movementos sociais tamén din ser a voz do pobo. As disputas e negociacións entre líderes políticos que buscan encarnar o pobo e movementos sociais que, no nome do pobo, limitan a tentación populista de un se autoproclamar como a encarnación da vontade popular explican moitas das disparidades entre os réximes de Chávez-Maduro, Morales e Correa.

A diferenza da visión que homoxeneiza os Gobernos de Chávez-Maduro, Morales e Correa como manifestacións semellantes do populismo de esquerda latinoamericana, estes Gobernos teñen diferentes relacións cos movementos sociais. Tamén se diferencian en se crearon espazos institucionais para a participación popular.

Evo Morales chegou ao poder no pico do ciclo de protestas dos movementos sociais en contra do neoliberalismo e da partidocracia. O seu partido, o mas, ten orixes nos movementos sociais e en redes de sindicatos campesińos e de organizacións indíxenas. Estas organizacións comparten unha tradición comunitaria de discusión dos problemas e toma de decisións colectivas ${ }^{10}$. Os movementos teñen unha cultura política de participación activa e presionan para os líderes seren responsables ante os que os puxeron en posicións de autoridade. Alén diso, os liderados non son permanentes, senón que se basean na rotación dos líderes.

O presidente Morales segue as prácticas de democracia comunal cando discute as súas políticas públicas, como a lei do ensino, a política sobre a coca e a seguridade social, cos movementos sociais. Se ben para algúns académicos estas reunións, que poden durar ata vinte horas, están baseadas na participación de todos, outros consideran que se basean na imposición dos criterios de Morales.

A relación de Morales e os movementos sociais é caracterizada polo sociólogo boliviano Fernando Mayorga como «flexible e inestable», pois foi desde a cooptación ata a independencia ${ }^{11}$. Os movementos organizados no Pacto de Unidad tiveron un papel independente do Goberno durante a asemblea constituínte. En 2007 reagrupáronse na Coordinadora Nacional por el Cambio (CONALCAM), presidida por Morales, para mobilizaren os seus seguidores nunha conxuntura de loitas intensas en contra da oposición. Os movementos sociais marcharon para

${ }^{10}$ Crabtree, John (2013): «From the MNR to the MAS: Populism, Parties, the State, and Social Movements in Bolivia Since 1952», en Carlos de la Torre / Cynthia Arnson (eds.), Populism of the Twenty-first Century, Baltimore/Washington, Johns Hopkins University Press/Woodrow Wilson Center Press, 269-295.

${ }^{11}$ Mayorga, Fernando (2012): «Bolivia: populismo, nacionalismo e indigenismo», en Isidoro Cheresky (ed.), ¿Qué democracia en América Latina?, Bos Aires, Clacso/Prometeo, 235-251. 
apoiaren o Goberno e en 2008 estiveron á fronte da campaña a prol de Morales no referendo revogatorio. Porén, os movementos sociais non están subordinados a Morales. En 2011 protagonizaron protestas en contra do incremento dos prezos da gasolina e marcharon en contra do plan do Goberno de construír unha estrada no parque nacional do TIPNIS.

O Goberno de Correa é diferente e case o oposto ao de Morales, pois non se asenta nos movementos sociais e non promoveu institucións participativas a nivel local. Correa chegou ao poder logo de o movemento indíxena perder momentaneamente a capacidade de organizar actos de protesta de longa duración. Ademais Correa viu no movemento indíxena un perigo e buscou cooptalo e sometelo argumentando que xa pasou o momento dos movementos sociais, pois agora o seu Goberno de esquerda representaba os intereses de todo o pobo. Correa criminalizou a protesta e entre 2009 e 2013 arredor de 300 persoas foron acusadas de atentar en contra da seguridade do Estado con cargos de terrorismo, sabotaxe, rebelión ou unha combinación das tres acusacións.

No Goberno de Correa conviven o discurso populista co dominio dos tecnócratas $^{12}$. Unha elite de expertos está a cargo da elaboración de políticas públicas que van desde o plan nacional de desenvolvemento ata políticas de ensino e comunicación do réxime. Os expertos din que falan no nome de toda a nación e non de intereses particulares ou de grupos sociais cualificados como corporativistas, como os mestres, indíxenas ou servidores públicos. O líder actúa coma se encarnase a vontade popular. Os tecnócratas consideran que están alén dos particularismos da sociedade e que poden deseñar políticas que beneficien a toda a nación. O líder e os técnicos ven a sociedade como un espazo baleiro onde poden deseñar institucións e prácticas novas. As reaccións defensivas dos movementos sociais á penetración do Estado reforzan a súa visión de que o seu proxecto de redención universalista se atopa coa resistencia dunha serie de inimigos egoístas, particularistas e corporativistas. Dando por suposto que posúen a verdade que vén do saber dos expertos e da voz unitaria do pobo encarnada no líder, desdeñan o diálogo. De resultas diso, o Goberno de Correa, que prometeu unha revolución cidadá, está a minar as bases que garanten cidadanías autónomas promovendo a formación de masas agradecidas no canto de cidadáns autónomos.

12 Torre, Carlos de la (2013): «El tecnopopulismo de Rafael Correa: jes compatible el carisma con la tecnocracia?», Latin American Research Review, 48:1, 24-43. 
Chávez chegou ao poder nun contexto en que os movementos corporativistas controlados polos partidos políticos tradicionais non incluíron os sectores populares do sector informal. Chávez viu a oportunidade de os incorporar desde o poder creando unha serie de institucións de democracia participativa. O Goberno de Chávez creou varias instancias para institucionalizar a democracia participativa e protagónica. Os máis estudados foron os círculos bolivarianos e os consellos comunais. Os círculos bolivarianos funcionaron entre 2001 e 2004 e tiveron un rol importante nas protestas en contra do golpe de Estado contra Chávez en 2002. Se ben é indubidable que os círculos incrementaron a participación popular e politizaron sectores previamente excluídos, non están baseados na «clase de autonomía que a democracia require» ${ }^{13}$. Funcionaron con criterios clientelares para transferiren recursos e baseáronse en mecanismos de mediación carismática entre o líder e os seus seguidores que non permiten a autonomía das bases.

Logo do triunfo electoral de Chávez en 2006 radicalizouse o proceso co obxectivo de construír o socialismo do século xxi e o Estado comunal. Os consellos comunais son institucións de participación a nivel local onde se elaboran proxectos de desenvolvemento para a comunidade. Foron a base do proxecto chavista de forxar unha democracia piramidal e directa que pouco a pouco dea cabo das institucións da democracia liberal. En palabras de Chávez, «o poder popular é alma, nervio, óso, carne e celme da democracia bolivariana, da democracia revolucionaria, da democracia verdadeira» ${ }^{14}$.

Críticos e defensores dos consellos comunais sosteñen que teñen os mesmos problemas e virtudes ca os círculos bolivarianos. Se ben incrementaron a participación e empoderaron sectores antes excluídos, o liderado personalista e carismático de Chávez reduciu a autonomía das propostas e iniciativas que veñen desde as bases ${ }^{15}$.

Chávez ademais organizou desde o poder os seus seguidores para frear as mobilizacións da oposición. Entre 2001 e 2004 unha coalición de organizacións sindicais e sectores de clase media, organizados co apoio dos medios privados, saíu ás

${ }^{13}$ Hawkins, Kirk / David Hansen (2006): «Dependent Civil Society: The Círculos Bolivarianos in Venezuela», Latin American Research Review, 41:1, 102-132.

${ }^{14}$ Chávez citado por Sosa, Arturo (2007): «Reflexiones sobre el poder comunal», en Margarita López Maya (ed.), Ideas para debatir el socialismo del siglo XXI, Caracas, Editorial Alfa, 52.

${ }^{15}$ Machado, Jesús (2008): Estudio de los consejos comunales en Venezuela, Caracas, Fundación Centro Gumilla; López Maya, Margarita (s. d.): «Los consejos comunales en Caracas vistos por sus participantes: una exploración» (manuscrito non publicado). 
rúas para se resistir ás políticas petroleira, educativa e de reforma agraria do Goberno. O 11 de abril de 2002, nas protestas en contra do despedimento dos técnicos de PDVSA, o líder sindical Ortega pediu a milleiros de persoas que marchasen ao palacio de Miraflores para tombar a Chávez. Este episodio terminou no golpe de Estado malogrado de Pedro Carmona. Os seguidores de Chávez foron organizados para defender a Chávez. Os conflitos nas rúas entre partidarios e adversarios de Chávez contribuíron a que o seu Goberno organizase os pobres e excluídos que se sentiron identificados co proxecto e a figura de Chávez.

\section{OS RISCOS DO POPULISMO}

Os académicos que se centran no aspecto liberal da democracia que garante os dereitos da oposición, o pluralismo e as liberdades civís argumentan que os Gobernos de Chávez-Maduro, Morales e Correa son autoritarios. Estes Gobernos concentran o poder no executivo e someten as Cortes de Xustiza e os Parlamentos, atentan en contra do pluralismo construíndo os opositores como inimigos malignos que atentan en contra dos intereses do proceso revolucionario, están en guerra cos medios privados de comunicación, as eleccións danse en condicións que favorecen os que están no poder sen dar as mesmas garantías á oposición ${ }^{16}$.

Os populistas ven os rivais democráticos como inimigos do líder, do proceso de mudanza e da patria. Xa que a política é construída como unha loita maniquea e sen cuartel entre amigos do réxime e os seus inimigos, créanse situacións de polarización e de politización de todos os aspectos da vida social. Durante a folga xeral da oposición, Chávez, por exemplo, manifestou: «Isto non é entre Chávez e os que están en contra de Chávez, senón que entre os patriotas e os inimigos da patria ${ }^{17}$. Nestas conxunturas de polarización tense que tomar partido e non se aceptan as medias tintas. O discurso populista é moi eficaz en crear identidades populares que son mobilizadas na loita en contra dos inimigos do pobo. O problema é que nunha sociedade complexa e diversa non existen dous campos nidios. A polarización aten-

16 Levitsky, Steven / James Loxton (2013): «Populism and Competitive Authoritarianism in the Andes», Democratization, 20:1, 116-117; Weyland, Kurt (2013): "The Threat from the Populist Left», Journal of Democracy, 24:3, xullo, 18-32.

17 Zúquete, José Pedro (2008): «The Missionary Politics of Hugo Chávez», Latin American Politics and Society, 50:1, 105. 
ta contra o pluralismo de opinións mesmo dentro das coalicións de esquerda. Alén diso, os rivais teñen que ser eliminados. Os populistas latinoamericanos viron o inimigo como un inimigo político e non usaron a violencia para o exterminaren. Mais limitan os espazos de debate democrático, regulan a esfera pública e buscan someter todas as organizacións populares nunha lóxica de confrontación na que, se non apoian o redentor da nación, son inimigos da revolución.

Os líderes populistas actúan coma se coñecesen os intereses do pobo e cal é a súa vontade. A diferenza dos políticos, que actúan coa premisa de que non sempre estarán no poder, a fantasía da unidade do pobo «abre a porta á percepción do exercicio do poder como unha posesión e non unha ocupación temporal» ${ }^{18}$. O seu obxectivo é estar no poder ata transformar o Estado e a sociedade.

Para explicar as características dos populismos que basean a súa lexitimidade en gañaren eleccións, mais que consideran que o pobo é un ente homoxéneo cuxa vontade se encarna nun líder, recorro á teoría da democracia como un espazo baleiro de Claude Lefort. No seu libro Los dos cuerpos del rey, Kantarowicz analizou como o rei, igual ca Deus, era omnipresente porque constituía o corpo da política sobre o que gobernaba. Igual ca o fillo de Deus, que foi enviado para redimir o mundo, o rei era home e Deus, tińa un corpo natural e divino e ambos eran inseparables ${ }^{19}$. As revolucións do século XviII abriron o espazo político-relixioso ocupado pola figura do rei. A democracia, sinala Lefort, transformou o espazo antes ocupado pola figura do rei nun espazo baleiro que os mortais só poden ocupar temporalmente. No seu libro Complicaciones: el comunismo y los dilemas de la democracia, Lefort explica:

A democracia naceu do rexeitamento á dominación monárquica, do descubrimento colectivo de que o poder non pertence a ninguén, que os que o exercen non o encarnan, que só son os encargados temporais da autoridade pública, que a lei de Deus ou da natureza non se asenta neles, que non posúen o cońecemento final sobre o mundo e a orde social, que non son quen de decidir o que cadaquén ten o dereito de facer, pensar, dicir ou comprender ${ }^{20}$.

${ }_{18}$ Arditi, Benjamín (2007): Politics at the Edge of Liberalism, Edimburgo, Edinburgh University Press, 83.

${ }_{19}$ Morgan, Edmund (1988): Inventing the People: The Rise of Popular Sovereignty in England and America, Nova York, W.W. Norton \& Company, 17.

${ }^{20}$ Lefort, Claude (2007): Complications: Communism and the Dilemmas of Democracy, Nova York, Columbia University Press, 114. 
O advento das revolucións do século XVIII, segundo Lefort, xerou pola súa vez un principio que podía pór en perigo o espazo democrático. A soberanía popular entendida como un suxeito encarnado nun grupo, un estrato ou unha persoa podería clausurar o espazo baleiro a través da idea do "pobo como un» ${ }^{21}$. Segundo Lefort, o totalitarismo abandona a noción democrática do pobo como heteroxéneo, múltiple e en conflito, onde o poder non pertence a ninguén, coa imaxe do pobo como un que nega que a división é constitutiva da sociedade. A división, sinala Lefort, dáse entre o pobo, que ten unha identidade e unha vontade únicas, e os seus inimigos externos, que teñen de ser eliminados para manter a saúde do corpo do pobo.

Para Lefort a modernidade móvese entre o espazo aberto da democracia e o totalitarismo que o clausura. O que Lefort non analiza é como e cando os proxectos totalitarios non deveñen en réximes deste tipo debido á resistencia das institucións democráticas ou da sociedade civil. Tampouco considera a posibilidade de que existan réximes que non sexan plenamente totalitarios ou democráticos ${ }^{22}$. Isidoro Cheresky utiliza a noción de poder semiencarnado para analizar os popu$\operatorname{lismos}^{23}$. O poder identifícase nun proxecto ou nun principio encarnado nunha persoa que é case mais non totalmente insubstituíble, pois a encarnación do proxecto pode desprazarse cara a outro líder debido a que as eleccións son o mecanismo que lexitima o poder no populismo.

Se ben as eleccións lexitiman o poder dos líderes populistas, estes non poden aceptar facilmente perder unha elección. Se o pobo é construído como que sempre ten a razón, se o pobo é imaxinado coma se tivese unha soa voz e un só interese, é moralmente imposible que o pobo vote por outro candidato que non sexa o candidato do pobo. Como é posible aceptar que o pobo vote polos candidatos construídos como os inimigos do pobo?

De maneira máis pragmática, populistas como Hugo Chávez e Rafael Correa fixeron todo o posible para que a competencia se dea en canchas electorais desiguais. Por exemplo, usaron os medios estatais para faceren campaña, silenciaron a prensa privada, controlaron os tribunais electorais e incrementaron o gasto estatal clientelar para faceren campaña. Antes da elección de outubro de 2012,

${ }^{21}$ Arato, Andrew (2012): «Lefort, the Philosopher of 1989», Constellations, 19:1, 28.

22 Laclau, Ernesto (2005): On Populist Reason, Londres/Nova York, Verso, 166.

${ }^{23}$ Cheresky, Isidoro (2012): «Mutación democrática: otra ciudadanía, otras representaciones», en Isidoro Cheresky (ed.), ¿Qué democracia en América Latina?, Bos Aires, CLAcso/Prometeo, 33. 
Chávez creou a Gran Misión Vivienda, Mi Casa Bien Equipada, La Gran Misión en Amor Mayor e a Gran Misión Hijos e Hijas de Venezuela. Correa en 2012 usou os medios públicos para facer campaña, usou helicópteros do Exército, o consello electoral censurou a publicidade dos seus rivais. O candidato de esquerda Alberto Acosta manifestou que a elección foi como xogar un partido de fútbol nunha cancha inclinada e cun árbitro comprado polo equipo contrario.

\section{COMO DE ESTABLES SON OS POPULISMOS DE ESQUERDA?}

A extrema personalización do poder nun líder consagrado como o redentor da nación é o talón de Aquiles dos populismos radicais. Se ben Chávez modificou a Constitución para ser reelixido de por vida, non sobreviviu ao cancro e designou un sucesor que, se cremos nas enquisas electorais, perderá a elección de decembro a menos que se dea unha fraude. Rafael Correa está modificando a Constitución para ser reelixido, pois sen el entrarán en conflito os sectores do seu movemento, Alianza País. A extrema concentración do poder na súa figura obrígao a seguir á fronte do proceso, pois sen Rafael Correa terminaría a súa revolución cidadá. A diferenza de Correa, que está a usar mecanismos non constitucionais para modificar a Constitución, Morales impulsa as mudanzas constitucionais para a súa reelección nun referendo. Ao buscar a reelección indefinida, Morales está a contradicir os principios liberais de alteridade no poder e os principios da democracia comunitaria indíxena de rotación do poder. Líderes indíxenas da oposición, como Feliz Patzi Paco, gobernador de La Paz, están á cabeza da resistencia a esta xogada de Morales.

A diferenza da visión de que o poder político do executivo está despersonalizado e que a oficina do presidente non é idéntica a quen a ocupa, líderes populistas como Chávez, Correa e Morales vense e son construídos como mesías liberadores cuxa presenza é fundamental para garantir a continuidade do proxecto revolucionario. A presidencia non é vista como un cargo que se ocupa temporalmente e que está regulado por unha serie de procedementos, incluídos os procedementos para o líder abandonar pacificamente o $\operatorname{poder}^{24}$. A misión do líder populista parécese máis á dos patriarcas

${ }^{24}$ Keane, John (2009): «Life after Political Death: The Fate of Leaders after Leaving High Office», en John Keane / Haig Patapan / Paul 't Hart (eds.), Dispersed Democratic Leadership, Oxford, Oxford University Press, 295. 
que sempre teñen de velar polo benestar dos fillos. A metáfora do pai transforma os cidadáns nos seus fillos, en nenos que, se non recońecen a autoridade do patriarca que os ama, poden ser castigados. Alén diso, os pais, como o anota Karen Kampwirth, son pais de por vida e o seu traballo e misión duran para sempre ${ }^{25}$.

Os populismos de esquerda xurdiron nunha conxuntura de prezos altos dos recursos naturais que lles permitiu non só redistribuír as rendas, senón ademais non seguir os ditados do FMI. Alén diso, beneficiáronse dos intereses chineses na minaría e no petróleo, o cal lles permitiu ampliar as bases das súas relacións comerciais, afastándose da órbita dos Estados Unidos. As políticas públicas foron moi eficaces á hora de demostrar que estes líderes buscaban o benestar dos máis pobres. Por exemplo, as misións de Chávez deron visibilidade ao seu interese por mellorar o ensino, a saúde e a vivenda. Mais non se asentaron en bases sólidas, senón nos altos prezos do petróleo. Ademais, segundo os estudos de Kurt Weyland, foron pouco eficientes e desbaldiron recursos, polo que os beneficios das políticas sociais do chavismo non foron duradeiros ${ }^{26}$. Non cońezo estudos sobre a calidade do gasto público de Morales e Correa. Si teño claro que Correa desperdiciou recursos en proxectos faraónicos, como a Ciudad del Conocimiento, unha universidade que supostamente ha xerar tecnoloxía de punta e que tivo maior financiamento ca as universidades públicas existentes e que malgastou recursos. Por exemplo, cada un dos tres reitores da universidade gañaban 16000 dólares ao mes e dous dos tres residían en California, onde seguiron a exercer as súas respectivas cátedras no California Institute of Technology.

O Alba foi a alternativa de Chávez aos tratados de libre comercio dos EuA. Segundo diversos estudosos, baseouse máis no pacto entre políticos ca entre Estados-nación ${ }^{27}$. Por exemplo, cando Manuel Zelaya foi destituído, Honduras abandonou o ALBA. É pouco claro que esta iniciativa vaia funcionar sen Chávez e con prezos baixos do petróleo.

Se ben as bases económicas do populismo radical latinoamericano foron efémeras, o modelo bolivariano de refundación da nación ten un gran poder simbólico

25 Kampwirth, Karen (2010): «Introduction», en Karen Kampwirth (ed.), Gender and Populism in Latin America: Passionate Politics, University Park, Pennsylvania State University Press, 12-13.

26 Weyland, Kurt (2013): «Populism and Social Policy in Latin America», en Carlos de la Torre / Cynthia Arnson (eds.), Populism of the Twenty-first Century, Baltimore/Washington, Johns Hopkins University Press/Woodrow Wilson Center Press, 117-145.

27 Bagley, Bruce / Magdalena Defort (eds.) (2014): ¿La hegemonía norteamericana en declive?: el desafío del ALBA y la nueva integración latinoamericana del siglo XXI, Cali, Universidad ICESI. 
que ha perdurar á caída dos prezos das commodities. O populismo de esquerda foi unha resposta ás exclusións do neoliberalismo e á corrupción dos políticos tradicionais. Apela ao poder constituínte, á capacidade dos cidadáns de refundaren todas as institucións políticas e as súas normativas. Promete devolver o poder ao pobo e facer que este se autogoberne sen a necesidade de intermediarios políticos. En contextos globais en que os políticos seguen os ditados da banca internacional e do FMI, o populismo de esquerda é visto como a alternativa que, inspirándose no concepto de soberanía popular, promete democratizar a sociedade.

O caso de Podemos é moi interesante, pois os seus líderes son seguidores da teoría de Laclau e tiveron experiencias formativas en Bolivia, Venezuela e Ecuador, onde fixeron as investigacións para as súas teses de doutoramento e foron consultores $^{28}$. Aplicaron con éxito a teoría de Laclau e as experiencias bolivarianas á realidade española. Democratizaron o panorama político español e coido que se esaxera sobre os perigos de Podemos á democracia. Non hai que esquecer que os populismos estudados nesta charla chegaron ao poder cando colapsaron as institucións da democracia e en sistemas presidencialistas que son moi diferentes do sistema parlamentario español. Se é que chega ao poder, Podemos terá que pactar con outras organizacións políticas.

Se ben argumentei que, cando o populismo chega ao poder en contextos de crise dos movementos sociais e das institucións da democracia, pode levar ao autoritarismo, isto non significa que debemos contentarnos con aceptar o poder constituído e as regras do xogo do liberalismo. A idea de revolución realizada no nome dun pobo unitario terminou en experiencias autoritarias. O horizonte da revolución como unha negación total do antigo réxime debe ser substituído pola idea de revolucións autolimitadas que non buscan refundar todas as institucións, senón que aceptan partes do poder constituído ${ }^{29}$. O reto é construír unha democracia radical asentada na diversidade de propostas e demandas dos movementos sociais e de organizacións políticas que non poden ser reducidas á idea populista do pobo como un ente homoxéneo que irrompe da nada para refundar todas as institucións e normativas. Nesta construción plural e democrática da idea de pobo, un líder non poderá encarnar as aspiracións de mudanza.

\footnotetext{
28 Seguín, Bécquer (2015): «Podemos and its critics», Radical Philosophy, 193, setembro-outubro, 20-32.

29 Peruzzotti, Enrique / Martin Plot (2013): «Introduction: The Political and Social Thought of Andrew Arato", en Enrique Peruzzotti / Martin Plot (eds.), Critical Theory and Democracy: Civil Society, Dictatorship, and Constitutionalism in Andrew Arato's Democratic Theory, Nova York, Routledge, 5.
} 
INDIVIDUALISMO POSESIVO E EUROPA ASOCIAL

Luis Moreno

Consejo Superior de Investigaciones Científicas (Madrid) 



\section{INTRODUCIÓN}

Cedeu a Europa social o paso á Europa asocial?; desvincúlanse os europeos do benestar dos seus concidadáns?; existe unha mudanza civilizatoria cara a novas formas de individualismo posesivo?; será a presente Idade do Bronce do welfare preludio dunha volta á prehistoria do benestar social? As respostas a tales preguntas de investigación -interrelacionadas entre si- enmarcan o empeño indagador do presente traballo ${ }^{1}$.

O Estado do benestar (ЕВ) é un conxunto de institucións estatais provedoras de políticas sociais dirixidas á mellora das condicións de vida e a procurar a igualdade de oportunidades dos cidadáns. As políticas sociais, pola súa vez, son intervencións dos poderes públicos que afectan ás oportunidades vitais dos cidadáns e cobren os seus riscos vitais, principalmente nos eidos do ensino, do emprego, da saúde, da seguridade social e das transferencias fiscais. O gasto público destinado aos EB está comprendido nunha franxa de entre un quinto e un terzo do produto interior bruto (РІв) e supón arredor da metade do gasto público dos seus países. Ambos os trazos caracterizan distintivamente os EB europeos².

Durante a segunda metade do século xx, e con altos graos de lexitimidade, o Estado do benestar fixo posible a aspiración cidadá pola mellora das condicións de vida na Europa occidental. Cabe establecer, en retrospectiva, que ás Treinte Glorieuses, ou período da Idade de Ouro $^{3}$ do capitalismo do benestar europeo

${ }^{1}$ Para cuxa elaboración se utilizaron diversas seccións recollidas nos libros redactados polo autor Europa asocial, 2012, e Europa sin Estados, 2014.

${ }^{2}$ Segundo Peter Flora (1993), tales porcentaxes de mínimos e máximos do gasto público social evidencian a distinta madureza e xenerosidade dos Ев europeos. Se se considera o gasto público neto, que ten en conta a tributación das prestacións sociais e os gastos fiscais ocultos (deducións e exencións impositivas), Francia acadaba en 2001 un $29 \%$ do PIB, porcentaxe que contrastaba co $26 \%$ de Dinamarca e o $17 \%$ dos Estados Unidos (Esping-Andersen e Palier 2010).

${ }^{3}$ Tal denominación evoca as catro idades mitolóxicas do Ouro, a Prata, o Bronce e o Ferro narradas polo poeta romano Ovidio ( 43 a. C.-17 d. C.), cada unha das cales cabía interpretar como unha corrupción da anterior, segundo xa sinalara o poeta grego Hesíodo (século vir a. C.) no seu célebre poema Traballos e días. 
(1945-1975), as sucedeu unha Idade de Prata (1976-2007) que mantivo unha encomiable resiliencia ante os persistentes axustes a fin de conter os gastos sociais e en evitación de retrocesos das políticas do benestar.

Tras o crac económico de $2007^{4}$, a cuestión que ponderar nos inicios do século XXI é se a presente Idade de Bronce do welfare (2008-?) poderá manter os trazos constitutivos do benestar social consolidados na segunda metade do século xx. Na próxima sección procédese a unha análise de conceptos chaves na nosa discusión relativos á cidadanía, a asociabilidade e os individuos posesivos. Tras ponderarse os desafíos que confronta o modelo social europeo, baixo asedio polos sistemas alternativos de remercantilización e neoescravismo, os comentarios finais atenden aos vaticinios sobre o final da civilización social europea.

\section{CIDADÁNS ASOCIAIS E CAPITALISMO DO BENESTAR}

A comunidade moral en condicións de modernidade estableceu o principio de pertenza á politeia (Estado nacional) como responsabilidade tanto individual como colectiva dos seus cidadáns. Porén, existen visións teóricas encontradas respecto a cales deberían ser as institucións garantes das responsabilidades individual e colectiva en dereitos e deberes cidadáns. Dúas perspectivas diverxentes do propio pensamento democrático liberal serven para ilustrar tales disparidades á hora de facer efectivo o dito principio civilizador.

Para o pensamento liberal clásico, reciclado a conveniencia polos neoliberais de fins do século $\mathrm{xx}$, non existen medios nin criterios que poidan fixar unha xerarquía colectiva de deberes cidadáns alén da instauración dun marco mínimo institucional que garanta o intercambio ilimitado de ideas e mercadorías ${ }^{5}$. Para

\footnotetext{
${ }^{4}$ Adoita considerarse o 15 de setembro de 2008 como a data do inicio da crise, tras o anuncio oficial de bancarrota de Lehman Brothers, a venda de Merryll Lynch ao Bank of America e o colapso do xigante dos seguros American International Group. Semella máis razoable retrotraer o dito comezo ao martes «negro» do 27 de febreiro de 2007, logo da creba das hipotecas subprime estadounidenses e a forte caída da Bolsa de Nova York. Catro anos despois do crac de 2007, a US Securities and Exchange Commission concluíu que os directivos das dúas grandes hipotecarias, Fannie Mae e Freddie Mac, enganaran os investidores ao non os informaren dos riscos que estaban a asumir coas subprime e as hipotecas de alto risco, iniciadoras da devastadora crise financeira posterior.

${ }^{5}$ Friedrich August von Hayek (1944) criticou contundentemente a economía planificada comunista, a cal impelía a percorrer un camiño de servidume que abocaba indefectiblemente no totalitarismo e na disolución das liberdades individuais.
} 
o liberalismo social ${ }^{6}$, si existe un deber ou obriga moral da comunidade na provisión dos medios que poidan cubrir as necesidades básicas de todas as persoas, xa que a súa inexistencia imposibilitaría o cumprimento dos seus respectivos deberes individuais como cidadáns ${ }^{7}$.

En contraste coa institucionalización dos dereitos civís e políticos implantados tras as revolucións liberais dos séculos XVII e XVIII (Marshall 1950), os últimos lustros foron testemuñas de reiterados intentos por desformalizar dereitos de cidadanía social, así como dun cuestionamento das que parecían conquistas sociais irreversibles. Se ben o proceso de democratización de masas na modernidade apuntaba á consecución da cidadanía social como estadio superior civilizatorio, isto implicaba unha superación das chamadas liberdades negativas, baseadas no principio constitucional de igualdade e imparcialidade.

Nos EB europeos, co acceso a liberdades positivas como a procura de protección social contra os riscos sociais durante os ciclos vitais dos cidadáns, superouse en boa medida a concordancia entre ambos os tipos de liberdades negativas e positivas (Berlin 1958). O liberalismo de corte clásico e o neoliberalismo de novo cuño insistiron teimosamente en que a única aspiración razoable nas nosas democracias avanzadas é a da que os poderes públicos garantan a práctica e o gozo de liberdades negativas, ao tempo que se lles deixa aos individuos a decisión de construíren para si as súas liberdades positivas e, en suma, a súa propia cidadanía social sobre a base dun pluralismo non relativista. Os riscos inherentes á vida social deben ser cubertos, en primeira instancia, polos propios individuos. Segundo palabras de Margaret Thatcher, «existen individuos, homes e mulleres, e existen familias. E ningún Goberno pode facer nada se non é a través das persoas, e as persoas han de se ocupar, antes de máis, delas mesmas. O noso deber consiste en

${ }^{6}$ Algúns dos seus representantes kraus-institucionistas en España, tales como Gumersindo de Azcárate ou Francisco Giner de los Ríos, tamén eran denominados naquela altura como "neoliberais». No entanto, os representantes da Institución Libre de Enseñanza sustentaban as súas propostas de acción nun «racionalismo harmónico» que avogaba por programas que auspiciasen unha coexistencia simbiótica de clases sociais e actores económicos superadora do conservadorismo tradicional, o laissez faire depredador, o corporativismo católico e o colectivismo revolucionario.

7 Nalgunha medida esta visión dos dereitos sociais básicos é compatible coa posición de Robert Nozick (1974), ao soster que tales dereitos comunitarios mínimos non deberían ter como finalidade a consecución de situacións (pre)definidas de benestar individual, senón a evitación de os cidadáns seren privados do acceso aos bens básicos. A visión liberal libertaria de Nozick contraponse á de liberais sociais neocontratualistas como John Rawls (1971), para o cal o maximin de xustiza social debe ser produto de eleccións que vaian a prol dos cidadáns máis desfavorecidos. 
ocupármonos de nós mesmos e, despois, en ocupármonos dos nosos semellantes» (1993: 528$)^{8}$.

Insistiuse, alén diso, na imposibilidade de establecer unha orde transitiva de preferencias como agregación das meramente individuais (Arrow 1950). De todo isto translócese un entendemento asocial da existencia humana que fai fincapé no individualismo, a miúdo posesivo, como norma comportamental ineludible: o individuo é o único propietario das súas destrezas e capacidades, e disto non debe gran cousa á sociedade. Alén do anterior, tales destrezas e competencias son mercadorías que se poden comprar e vender nun mercado libre de interferencias reguladoras. En tal marco asocial conta poderosamente a insaciable pulsión polo consumismo egoísta e a avaricia acaparadora, identificados como inapelables motores da existencia humana e principios guía de toda actividade económica (Macpherson 1962). Abundando na seminal idea do consumismo conspicuo (conspicuous consumerism) conceptualizada por Thorstein Veblen (1899) ${ }^{9}$, Daniel Bell (1974) sinalaba premonitoriamente que o capitalismo consumista facía os cidadáns cativos da industria da satisfacción individual inmediata.

Para a concepción asocial do individualista posesivo, a sociedade é unha construción humana cuxa única finalidade última é protexer os individuos e as súas propiedades, mantendo a orde nas relacións de intercambio entre as persoas como propietarias. A sociedade fica reducida á sociedade de mercado, na cal a independencia persoal prevalece sobre calquera outra consideración. No canto dunha militancia de hostilidade cara ao colectivo social, prefírese unha posición de autosuficiencia en termos persoais cunha evitación de obrigas sociais, as cales si predominan — por paradoxal que poida parecer- en sociedades altamente individualistas, como as escandinavas, mais cunha alta interiorización persoal dos deberes para cos outros ${ }^{10}$.

Cos comportamentos de responsabilización social evítanse procesos de desvinculación social e desafiliación que caracterizaron certos acontecementos que

${ }^{8}$ Segundo unha reportaxe publicada en The Sunday Times do 23 de xullo de 1989, a «Dama de Ferro» revisara un discurso do seu ministro de Sanidade, Kenneth Clarke, do cal eliminou a palabra «sociedade» en todos os fragmentos onde aparecía.

9 Tal consumismo comporta o gasto "compulsivo» de diñeiro a fin de adquirir bens e servizos que, en última instancia, outorgan visibilidade ao poder económico, e establece os mecanismos de obtención e preservación do status social das persoas.

${ }_{10}$ Pode argüírse que se trata dun tipo de individualismo «social» mediante o cal os cidadáns emprazan as institucións estatais do benestar a se ocupar daqueles que precisan axuda (Rothstein 1998). 
tiveron lugar nalgunhas sociedades continentais durante a Idade de Prata do welfare (1976-2007) (Castel 1992). Ha de observarse que o individualismo social nórdico empraza vicariamente as institucións estatais do benestar a se ocupar daqueles que precisan axuda, eludindo quizais unha implicación persoal directa. Mais o alto grao de confianza mutua e capital social das sociedades escandinavas fai posible unha gran solidariedade institucional nunha «sociedade de individuos» (Elias 1990). Todo isto fica patente no pagamento de impostos considerablemente maiores ca no resto das democracias industriais avanzadas ${ }^{11}$.

Instrumentalmente o corpo social ou colectivo é asumido polos individuos asociais como un referente circunstancial en proveito propio. A sociedade de mercado "posesiva" postula a retribución do traballo efectivo, o cumprimento dos contratos, a maximización da racionalidade individual, a propiedade individual e a organización colectiva fundamentada nas posesións, capacidades e enerxías dos individuos. Todo isto está na base dunha funcionalidade na que o individual prevalece a toda consideración colectiva. No límite da asociabilidade, os cidadáns poden chegar a aceptar uns mínimos de convivencia que impliquen institucións comúns, así como a aceptación de estándares colectivos básicos no exercicio supremo do seu albedrío persoal.

Ha de se deixar constancia da diferenciación conceptual entre asocial e antisocial. A última é unha noción utilizada frecuentemente no campo da psiquiatría para significar personalidades e condutas psicópatas que rexeitan a vida en común e cos «outros» e que poden chegar a ser, potencialmente, patolóxicas. A expresión "personalidade psicopática» pasou a ser converter para a escola de pensamento comportamentalista norteamericana (behaviourist school of thought) nunha categoría ampla aplicable aos individuos con trazos de carácter socialmente indesexable. A categoría do asocial, pola súa banda, admite a normalidade psicolóxica e maniféstase en variadas formas, sendo as que afectan ás carencias de empatía social e solidariedade cidadá as que interesan ás análises e reflexións efectuadas neste ensaio.

Os individuos asociais son alérxicos ao EB, e só aceptan unha versión residual del con mínimo custo e máximo beneficio para eles. Tal visión adoita empare-

\footnotetext{
${ }^{11}$ En 2008, por exemplo, a taxa marxinal do imposto sobre a renda das persoas físicas (IRPF) en Dinamarca era do 59 \%, en contraste co 43 \% en España. A menor porcentaxe en Europa correspondía a Bulgaria cun $10 \%$.
} 
llarse coa convicción de que a (pos)modernidade (neo)liberal acadou unha fase de compracente «liquidez»e «reflexividade» en que as persoas forxan para si personalidades flexibles e adaptables ás situacións continxentes e de risco que se lles presentan nos seus cursos vitais (Bauman 1999). Así, o valor heterorreferencial permitiría construír unha autonomía individualizada que, a diferenza dos postulados simmelianos, non precisa imperativamente dos nosos semellantes. Intensifícanse, de tal xeito, procesos de individualización nos cales os individuos son unidades básicas de reprodución social. Os individuos pugnan entre eles aspirando a asegurar a súa propia activación laboral e independencia económica nunha espiral que socava os fundamentos da coexistencia social (Beck e Beck-Gernsheim 2002). A mundialización económica e a difusión do modelo neoliberal de globalización anglonorteamericana reduciría a unha cuestión puramente de gustos a forxa de identidades individuais autosuficientes, orfas do esforzo común cidadán e do condicionamento das institucións públicas (Béjar 2007).

O individualismo posesivo non só proclama a liberación dos individuos dos seus vencellos colectivos, senón que os empraza á construción autónoma das súas propias biografías vitais. Eventualmente, os individuos perden o seu sentido da lealdade institucional, circunstancia que se agudiza coa volatilidade e as incertezas laborais (Sennet 2006). O valor do traballo corróese favorecendo o egoísmo do «murmure a miña veciña e teña o meu fol fariña». Os cidadáns deixan de lado a solidariedade cos seus semellantes alén das mecánicas rutineiras e os hábitos colectivos, o que aumenta a súa asociabilidade. Para un proxecto vital asocial non se precisan maiores compromisos cidadáns e os individuos xestionan os recursos relacionais atendendo ao seu único proveito, e utilizándoos discrecionalmente $\grave{a}$ la carte. Paradoxalmente, produtos e bens culturais postos á venda e ao alcance da súa libre decisión individual deveñen en obxectos homoxéneos e estandarizados colectivamente (Ritzer 1993).

O financiamento xeneralizado no Reino Unido e nos Estados Unidos desde os anos de 1980 foi un dos procesos determinantes da eclosión da enxeñaría financeira causante do crac de 2007. Xa en 1986, as políticas de Thatcher impulsaron os mercados de valores e fixeron da City londiniense o Shangri-La da desregulación coa eclosión de produtos financeiros opacos, logo adoptada con maior tesón, se cabe, por Wall Street durante o longo período de Alan Greenspan á fronte da Reserva Federal estadounidense (1897-2006). A aspiración a unha sociedade de propieta- 
rios e a «miraxe da riqueza» inflaron a burbulla inmobiliaria. Nos anos seguintes, os consumidores nos EUA e no RU intensificaron o uso especulativo dos diñeiros das súas pensións, ou das súas casas, así como doutros mecanismos de investimento e endebedamento. A conversión dos cidadáns en investidores foi un dos procesos máis paradoxais —e non suficientemente analizados— na eclosión de produtos financeiros nos mercados bolsistas (derivados e titulacións). A falla de regulación destes últimos, a opacidade das operacións e a actuación criminal dos responsables das corporacións financeiras que os xestionaban foron determinantes no enorme fracaso hipotecario e rehipotecario que orixinou o crac de 2007.

Lémbrese que, mentres que en 2002 o volume de créditos subprime das entidades financeiras nos Estados Unidos alcanzaba arredor do $7 \%$ do mercado hipotecario, ao inicio do crac a porcentaxe case se duplicara. $\mathrm{O}$ uso descontrolado da titulización (securitization) foi considerado como un dos grandes responsables da crise, dado que moitos créditos subprime se titularizaron. Ao pasaren as entidades dunhas a outras os riscos inherentes destas titulacións «infectadas», contaminouse todo o sistema financeiro norteamericano e, conseguintemente, o mundial. O elevado risco de falta de pagamento dos debedores dos activos foi o principal risco que ocultou a titulización ${ }^{12}$.

$\mathrm{Na}$ nova situación creada durante a Idade de Prata do welfare (1976-2007), o sostemento dos valores emblemáticos de liberdade, igualdade e fraternidade, ideario fundacional da modernidade política en Europa ${ }^{13}$, quedou sometido a unha reinterpretación na que a liberdade (dos máis fortes) prevalecía sobre todo o demais, ou política de «o gañador todo o leva». No tránsito cara á Idade de Bronce do welfare (2008-?), a mundialización do modelo anglonorteamericano puxou con forza cara a un entendemento do autointerese como filosofía e dun hybris individual en permanente negación de límites. Como consecuencia, a compatibilización entre as pulsións do capitalismo e do benestar social mantívose como ecuación non resolta e con novas incógnitas por despexar.

${ }^{12}$ A fins de 2011, o Tesouro estadounidense inxectara diñeiro público que se aproximaba a 200000 millóns de dólares para cubrir os créditos das hipotecarias semipúblicas Fannie Mae e Freddie Mac, as cales posuían ou garantían a metade das hipotecas emitidas nos EuA antes da recesión e máis do $90 \%$ das subscritas posteriormente.

13 Propóńense novas formulacións nas que «singularidade», «comunalidade» e «reciprocidade» adecuarían a vella tríade emancipadora de «liberdade», «igualdade» e «fraternidade» aos tempos posmodernos (Rosanvallon 2011). 
As sociedades modernas outorgaron carta de natureza ao mercado e ao Estado como institucións reguladoras do benestar e a satisfacción vital dos cidadáns. Se ben a primeira institución articula os valores do autointerese individualista e do cálculo económico nas relacións materiais entre os cidadáns, a segunda institución é depositaria da autoridade de carácter coercitivo, asumindo funcións de procura pública. Tanto unha como outra contribuíron a disipar as responsabilidades morais dos cidadáns con respecto ao corpo político, ou politeia, do que forman parte. O sentido de obriga moral dos individuos respecto aos seus concidadáns tendeu a se debilitar quer se puxese a tónica na mercantilización, quer na solidariedade vicaria estatalista. Tales desenvolvementos socavaron en diferentes graos e intensidades o propio concepto de benestar social e contribuíron a difundir a idea de que o ев europeo é un mero epifenómeno da modernidade.

Existe a crenza xeneralizada de que o capitalismo, como expresión do liberalismo económico, é un sistema da Idade Contemporánea. Máis concretamente, asúmese que o seu desenvolvemento en Europa e a posterior extensión mundial se levaron a cabo durante o século XIX coincidindo co industrialismo e a grande expansión imperial vitoriana. Mais capitalismo, nas súas variadas manifestacións e formas, existiu desde que o diñeiro ou capital estruturou as relacións económicas das xentes e dinamizou o decorrer das sociedades humanas.

A antiga civilización romana, referente civilizatorio do devir posterior do mundo occidental, xa afrontou ciclos e crises capitalistas como a do crash de 1929 ou o inacabado crac de 2007. Abonde lembrar, como exemplo entre outros, a situación de crise capitalista suscitada en tempos dos emperadores Augusto (63 a. C-14 d. C.) e Tiberio (14 d. C.-37 d. C.) e descrita por Indro Montanelli na súa celebre Storia di Roma (1957). Como organización social complexa, a antiga Roma xa se debatía entre a acción mercantilizadora e a estatalista. É aventurado discernir ata que punto o desenvolvemento socioeconómico romano, debido á acción do Estado e da iniciativa privada, é un antecedente histórico válido do moderno capitalismo do benestar. Non o é menos preguntarse se a politeia romana era máis individualizadora ca colectivista. Porén, si cabe identificar a pulsión de —e entre— ambas as ideas e prácticas como precursora do que séculos máis tarde serían os modernos Estados do benestar.

Os primixenios teóricos do liberalismo económico contemporáneo interpretaron o capitalismo como a autorización divina para entrar en liza polo mercado 
de bens ou de traballo, sen máis limitacións ca as flutuantes condicións que o propio marcado, institución de intercambio por excelencia, impuxese. Na súa acepción contemporánea, o capitalismo pode definirse tamén como un proceso mediante o cal un empresario - ou un colectivo deles- inviste uns diñeiros, ou capital, nun negocio, do cal obtén uns beneficios que - e este é o seu trazo máis característico- volve investir para conseguir máis beneficios no marco dun mercado, e case sempre en concorrencia con outros empresarios.

$\mathrm{O}$ «capitalismo do benestar», na súa primeira formulación, realizada polo economista alemán Gustav von Schmoller (1838-1917), facía fincapé na necesidade de os poderes públicos proveren de benestar social os traballadores e os cidadáns sen confiaren en que as empresas e os empregadores puidesen realizar a dita tarefa por si mesmos. Durante a primeira metade do século xx, e en modos e traxectorias varios, os sistemas de provisión social dos países europeos seguiron as prescricións de Schmoller, as cales foron a xénese dos EB contemporáneos. Podería cualificarse o dito período histórico como unha fase inicial do welfare, e á cal agora poderían retrotraerse os sistemas de protección continentais tras o crac de 2007.

Tense argüído que o capitalismo do benestar que floreceu en Europa na Idade de Ouro do welfare logo da Segunda Guerra Mundial non mudou en nada a estrutura básica do capitalismo, o cal, segundo a narración marxiana, cabe reducir á máxima de "o capitalista controla e o traballador produce». Un tanto paradoxalmente, e desde posicións ideolóxicas e prescritivas de carácter contraposto, tanto pensadores neomarxistas como neoliberais e inspiradores da nova dereita coincidiron nos decenios de 1970 e 1980 nalgúns dos seus diagnósticos verbo da dificultade de conciliar as lóxicas do Estado do benestar e do crecemento capitalista. Se ben a primeira afectaba a unha institución garante de estabilidade no repartimento desigual da riqueza, a segunda atopaba dificultades nos mecanismos de xeración de beneficios esixibles á eficiencia capitalista. Xa en 1973 James O'Connor avanzou as súas cońecidas teses sobre da crise fiscal do Estado e a sobrecarga orzamentaria das democracias occidentais. Outros autores como Jürgen Habermas (1973), Ian Gough (1979) ou Claus Offe (1984) sinalaron, así mesmo, que o EB provocaba unha contradición entre a lexitimación do sistema capitalista e a erosión dos dispositivos de acumulación capitalista. Pola súa banda, para Milton Friedman a estatalización da actividade económica e o alto nivel de recursos «cativos» polo insaciable sector público da economía supuñan un 
obstáculo para o progreso. A tales disfuncionalidades contribuían un uso excesivo estatal do endebedamento público e un crecemento descontrolado da inflación, prexudiciais ambos para a optimización dos sistemas produtivos (Friedman e Friedman 1980).

Malia as crises económicas, o EB europeo amosaba no tránsito ao terceiro milenio unha encomiable fortaleza institucional evidenciada nas súas altas cotas de lexitimidade cidadá, que permitiran a súa supervivencia (Kuhnle 2000). O éxito do modelo social europeo no mantemento da paz e a cohesión sociais no Vello Continente e o seu incerto futuro reclaman a atención da seguinte sección.

\section{O ASEDIO DO MODELO SOCIAL EUROPEO}

O modelo social europeo (MSE) é un proxecto político artellado arredor dos valores de equidade social (igualdade), solidariedade colectiva (redistribución) e eficiencia produtiva (optimización), e resultante dos procesos contemporáneos de conflito e cooperación no Vello Continente. O MSE promove a cidadanía social entendida como aspiración a unha vida digna e ao benestar social dos individuos, mediante o acceso ao traballo remunerado e á provisión social en situacións de risco, e sobre a base duns estándares vitais lexitimados polo conxunto da sociedade. Como obxectivo estratéxico xeral, o MSE auspicia o crecemento económico sostido e sustentable baseado na cohesión social (Moreno e Serrano Pascual 2009).

Os perfís que delimitan o MSE contrastan cos doutros sistemas socioeconómicos onde o individualismo remercantilizador é o trazo característicos das políticas do benestar (os EUA), ou onde o dumping social se propón como recurso extra para o crecemento económico (a China e outros países emerxentes asiáticos). Para o pensamento individualista estadounidense: «Coa morte do experimento marxista soviético, o socialismo ao estilo europeo, e a súa redistribución de recursos, tornouse atractivo. Mais ningún enfoque colectivista puido ao cabo igualar a capacidade da democracia de libre mercado para producir e crear prosperidade para todos» (Ryan 2011: 11). O modelo de neoescravismo asiático non se refire stricto sensu á propiedade física das persoas, senón á capacidade de as controlar como artefactos 
para xerar beneficios materiais, coa conseguinte exacerbación da desigualdade ${ }^{14}$. A versión contemporánea do neoescravismo, en suma, implica o control das persoas co propósito da súa explotación económica (Bales 2004).

En realidade, o MSE promove a cidadanía social entendida como unha limitación á desigualdade social e económica, unha protección aos máis vulnerables e un parternariado social activo ${ }^{15}$. Ao se plasmar o ideal de cohesión social na práctica das políticas económicas e sociais, así como na organización institucional do benestar, xorde unha diversidade de matices no entendemento do que é o MSE. Para a Confederación Europea de Sindicatos, por exemplo, o concepto de cohesión social implica unha mellora das condicións de vida e traballo dos cidadáns baseada no pleno emprego, traballos de calidade, igualdade de oportunidades, protección social para todos, inserción social e participación cidadá. Para a visión patronal menos oposta á flexiguridade ${ }^{16}$, a cohesión traduciríase nunha combinación de despedimentos máis doados, malia que con altas prestacións para os desempregados e unha política social proactiva cara ao mercado laboral. Naturalmente, hai voces discordantes respecto á plausibilidade de recomendar a adopción dun modelo amplo que puidese funcionar nalgúns países, mais que noutros resultaría contraproducente. Adúcese, así mesmo, que o mSE está a ser socavado pola realidade da mudanza económica global e a presión dos mercados financeiros internacionais ${ }^{17}$.

O propósito da cońecida como Estratexia Europa 2020 pon a tónica na creación de emprego, auténtico desafío europeo para contrarrestar os efectos do crac de 2007. Mais isto, segundo a propia Comisión Europea, ha de se acompañar

${ }^{14}$ Calcúlase que a cuarta parte do PIB da India está nas mans de pouco máis dun centenar de oligarcas, dato que contrasta coa loita pola supervivencia de máis de 800 millóns dos seus compatriotas, os cales dispoñen dun dólar estadounidense ao día.

15 Parternariado é unha tradución do vocábulo inglés partnership, que indica unha asociación de actores varios, en particular entre socios (partners) públicos, privados e voluntarios, con fins cooperativos. O desenvolvemento comunitario local, a cooperación ao desenvolvemento ou a resolución de conflitos foron eidos pioneiros na aplicación das formas de parternariado. No ámbito do EB e as políticas sociais, o parternariado artéllase como estratexia de cohesión social, subliñando a particularidade e a natureza diversa dos partners que o compoñen.

${ }^{16}$ Consistente en manter altos niveis de flexibilización laboral conxuntamente cunha alta protección social.

${ }^{17}$ De acordo con esta visión, o modelo é insostible financeiramente nun futuro a medio/longo prazo. As taxas altas de fiscalidade poderían frear non só o investimento, senón tamén a creación de novo emprego. Así, contrapóńense os exemplos de Bélxica e Alemaña, onde os asalariados sen fillos ao seu cargo pagan a metade dos seus salarios en impostos e cotizacións sociais, mentres que en Nova Zelandia pagan pouco máis do $20 \%$, e aínda unha menor contía en economías de rendas medias, como en México e en Corea do Sur (Shackleton 2006). 
con mellorar as condicións de vida dos cidadáns. Así, o crecemento debe ser inclusivo, sustentable e intelixente, e ha de atopar o xeito de crear novos postos de traballo e de ofrecer unha orientación ás nosas sociedades. Nunha dimensión máis xeral, o MSE é ao tempo recurso e obxectivo do proceso de europeización. Naturalmente, coexisten lexitimidades sociais varias sedimentadas no pasado dos diversos ев nacionais. Porén, o proceso de europeización potenciou a idea común de promover o benestar social dos cidadáns dos Estados membros da UE, malia as diferenzas puntuais entre os seus EB.

O proceso de europeización implica unha confluencia de recursos, representacións sociais e accións entre os países da Unión Europea. Isto é resultado, principalmente, da difusión de ideas comúns, dos procesos de harmonización estrutural económica, da construción dun sistema político transnacional e dun sistema de valores compartidos respecto ao social. A europeización engloba países que comparten unha herdanza común e asumen valores democráticos de igualdade, solidariedade e dereitos humanos. Se ben o concepto de europeización está viciado por falla de precisión normativa, é polisémico e está suxeito a diversas interpretacións, a súa natureza dinámica posibilitou unha progresiva —aínda que incerta - erosión da soberanía dos Estados membros da Unión Europea e un gradual desenvolvemento de institucións comúns supraestatais (Acordo de Schengen, euro, Parlamento Europeo, Tribunal de Xustiza ou Unión Económica e Monetaria, poñamos por caso).

O establecemento dos Estados Unidos de Europa non cabe asumilo como o resultado inevitable dunha europeización á norteamericana. Indubidablemente, é notoria a emerxencia dun nivel europeo de estruturas de gobernanza e a creación de normas europeas de regulación no ámbito da UE. No entanto, a integración institucional en Europa non depende necesariamente dunha asimilación cultural e dunha formación identitaria do tipo melting pot estadounidense, e cuxos teóricos prescriben como necesaria para consolidar a confianza política entre os cidadáns. A miúdo esta visión funcionalista asociouse de forma espuria coa organización estatalista vertical e xerarquizada do "ordeno e mando» (command and control), especialmente na organización nacional-estatal do EB e na provisión de políticas sociais (Moreno e McEwen 2005).

Un enfoque máis pluralista considera que as normas europeas só poden ser lexitimadas tendo en conta os diversos instrumentos de políticas públicas nunha politeia de gobernanza composta como a UE, así como a historia e a diversidade cultural ca- 
racterística do mosaico de pobos que configuran o Vello Continente. As identidades múltiples, así manifestadas polos cidadáns europeos, están suxeitas a un contínuum variable de pertenzas e apegos de carácter comunitario e territorial, mais que está cimentado nos mencionados valores de igualitarismo, solidariedade e dereitos humanos. Boa parte das elites nacionais da UE son proclives a favorecer a europeización e a integración económica, política e social. No entanto, argúese na contenda que a complexidade da edificación sistémica (system-building) depende nunha medida menor do establecemento de institucións e, nunha medida maior, das actitudes, valores e apegos identitarios dos cidadáns. Só unha acción de despotismo ilustrado, apoiada por arredor do $15 \%$ da poboación europea máis europeísta (profesionais con altos niveis de instrución, principalmente), podería efectuar unha construción top-down dunha estrutura supraestatal vista con receo polos cidadáns de a pé.

Existe tamén unha dicotomía entre unidade e diversidade que conforma unha fronteira interior (Máiz 2008). É esta unha dimensión que atinxe á xénese e consolidación do welfare state europeo conformadas pola propia constitución e evolución dos Estados nacionais. A maior competencia na elaboración e provisión das políticas sociais continúa a ser unha responsabilidade exclusiva dos Estados membros da UE. No entanto, e segundo o sinalado no apartado anterior verbo da regulación comunitaria en materia de bens e servizos públicos, a construción de confíns competenciais arredor do welfare é elusiva, incluídos aqueles que afectan a programas nacionais xa maduros e de longa traxectoria, como os relativos á cobertura dos riscos da vellez. A incentivación das pensións privadas complementarias ás prestacións nacionais, e as súas implicacións para os mercados internacionais de seguros, ilustran a osmose e posta en común regulatoria en temas que afectan á unión fiscal europea.

O entendemento do EB como un asunto propio de cada nación europea socava —-mesmo intencionalmente - a idea de unidade e coherencia do MSE. En países europeos onde se desenvolveu máis xenerosamente o modelo universalista de ЕB (países nórdicos), recéase da unidade do modelo europeo, o que podería comportar unha rebaixa dos seus altos estándares, amplamente lexitimados en longos períodos de tempo. A colisión normativa entre unha Europa cada vez máis unificada e unha persistencia soberana dos Estados membros só é viable coa aplicación do principio federalista que establece a conciliación da unidade e diversidade mediante o pacto político entre os países constituíntes da UE. A dita filosofía federalista xa se encar- 
nou nalgunhas institucións de corte federal como son o Parlamento, o Tribunal de Xustiza ou o Banco Central europeos. Mais nacionalismos e populismos de heteroxénea índole recean do «Big Brother» comunitario e pexan, na medida da súa variable forza electoral, o proceso europeizador. A contenda entre ambas as concepcións europeísta e nacionalista é un conflito aberto e inacabado.

O modelo socioeconómico europeo, tal e como se argumenta neste ensaio, descansa fundamentalmente na persistencia dos EB nos países membros constituíntes da UE, os cales son plasmación institucional dun capitalismo de benestar que facilitou altos graos de prosperidade económica e cohesión social desde a Segunda Guerra Mundial. Unha conceptualización tal non esixe a fortiori a plasmación institucional homoxénea e única en todos os países do Vello Continente dun tipo de welfare state. Corporatismo, coxestión, desregulación ou flexiguridade son variantes de diversas institucionalizacións de benestar social en países con parellos niveis de gasto social, tales como Francia, Alemaña, o Reino Unido ou Dinamarca, poñamos por caso. As diversidades do welfare entre estes países son recoñecibles. Tamén o son a efectividade e a lóxica operativa dos seus ев. Os amplos sistemas contributivos galos e teutóns, o Servizo de Saúde británico (National Health Service) ou a protección garantida na rotación de emprego e desemprego son trazos individuais dun modelo europeo común que se mostra en diferentes encaixes institucionais e diversos tipos de EB.

Coa evidencia empírica recollida tras analizar datos lonxitudinais dunha serie de indicadores e variables, tense argumentado que o grao de variación interna entre os EB europeos é maior ca o existente entre o welfare europeo e o norteamericano (Alber 2010). Cabe complementar tal aseveración coa constatación de que, malia a súa diversidade, non se trata de diferentes modelos sociais europeos, senón de diferentes traxectorias internas, mais con fundamentos morais e axiolóxicos compartidos. A pesar da súa diversidade, as variedades do capitalismo do benestar pasaron a compartir uns mesmos obxectivos estratéxicos e unha mesma preocupación pola optimización do capital humano.

\section{CONSIDERACIÓNS FINAIS: EUROPA FÁUSTICA?}

As últimas convulsións económicas mundiais reviviron a discusión arredor do destino da civilización «fáustica» europea. Coa edición en 1918 do primeiro 
volume de Der Untergang des Abendlandes ("A decadencia de Occidente»), xa Oswald Spengler apuntaba que a epopea da modernidade europea se saldaría coa súa morte segura, ao negar os seus propios límites e reafirmar o axioma de que todas as civilizacións son transitorias. Spengler auguraba que a cultura occidental se achaba na última etapa das catro que teorizara sobre as culturas como ciclos vitais: xuventude, crecemento, florecemento e decadencia. Aseveraba que a democracia era un interludio entre monarquía absoluta e novo imperio, ao xeito, este último, como o visionou o fascismo mussoliniano. $\mathrm{O}$ tamén filósofo da historia Arnold J. Toynbee incidiu analogamente na teoría cíclica sobre o desenvolvemento das civilizacións na súa magna obra $A$ Study of History («Estudo da historia»). Mais puntualizou que unha civilización como a europea só decaería como consecuencia da súa incapacidade para se enfrontar aos retos que tería por diante no futuro. Os retos transmutáronse en urxencias coa irrupción do crac financeiro de 2007.

De certo, o asunto da «morte segura» de Europa segue a fascinar pensadores de variadas sensibilidades. As visións máis pesimistas alegan que a mudanza xeracional coincidiu cun menor interese da xente nova polo devir futuro de Europa e cunha desnaturalización civilizatoria europea debida á presenza de inmigrantes portadores doutras culturas, relixións e crenzas alternativas. A combinación de tales factores faría ineludible o epitafio por unha Europa sen confianza, espectadora ensimesmada e impasible do seu declive inevitable (Laqueur 2009). Nun rexistro diferente, o pensador parisiense de orixe xudeu-austríaca George Steiner identificou o perigo da uniformización cultural polo baixo e «o despotismo do mercado de masas e as recompensas do estrelato comercializado» $(2005: 78)^{18}$.

A europea foi sempre unha civilización de vocación e repercusións mundiais, cuxa influencia se impuxo en ocasións mediante a conquista e a colonización. A propia concepción de Europa como sistema mental é, cando menos, controvertida. E é que a súa unidade ontolóxica é un composto de diversidades antropolóxicas, culturais e políticas inherentes á súa historia e por mor do seu extraordinario dinamismo e cosmopolitismo (Todd 1990). Se durante o século XIx Europa —e a etiquetaxe «mundo occidental»— emerxeu como a civilización mundial máis

\footnotetext{
${ }^{18}$ Para Steiner, Europa perecerá se non loita pola diversidade das súas linguas e das súas tradicións locais e polas súas autonomías sociais. Entre os factores esóxenos que ameazan Europa, apúntanse a americanización (en acepción estadounidense) de Europa e a crecente marea deterxente do anglonorteamericano.
} 
rica e poderosa do planeta, eclipsando outras como o Imperio Otomán, a China Qing, a India Mughal ou o Xapón Tokugawa, agora estariamos a asistir á mingua irreversible europea ante o acoso doutros modelos socioeconómicos alternativos (remercantilización anglonorteamericana e neoescravismo asiático). Nos tempos que corren presenciamos un proceso mediante o cal outros valores civilizatorios pugnan por reconducir o Vello Continente ${ }^{19}$ cara a modos alleos á súa propia configuración cultural e institucional. A osmose contaminante do capitalismo de «casino», coa súa corruptora avidez polo diñeiro, sería o acelerador dunha deterioración irreversible para unha Europa conformada co modelo de globalización neoliberal.

Son varias as razóns e factores que inciden no encollemento existencial do Vello Continente. Neste traballo apuntamos á progresiva obsolescencia do Estado-nación como indutor da vida política europea. A súa supervivencia como actor quasi exclusivo do proceso de converxencia europea engade unha dificultade extra á institucionalización política da UE. Porque o obxectivo final da europeización non é outro que constitucionalizar a unión continental mediante a posta en vigor dunha gobernanza multinivel respectuosa cos principios da subsidiariedade territorial e a rendición de contas democrática. En tan prolixa — e inexplorada - tarefa de edificación institucional, o rol que deben desempeñar os Estados membros da UE continúa a ser determinante por mor dos legados históricos e as inercias do pasado.

Certamente, o modelo estatal westfaliano, inaugurado simbolicamente polo tratado de paz asinado en Münster en 1648, estruturou a modernidade europea baseando a súa acción na concentración do poder, a xerarquía, a soberanía e a identidade estatal omniabarcante e homoxénea. Mais a súa data de caducidade foi excedida pola propia incapacidade dos Estados-nación europeos de manteren unha orde continental acompasada ás mudanzas societarias internas e á vida na «aldea global» (McLuhan e Powers 1989). A crecente contorna de interdependencias fai inservible o concepto de soberanía nacional de antano como ámbito exclusivo de decisión estatal. Co tránsito ao terceiro milenio, as novas demandas continentais buscan optimizar o solapamento das autoridades e os Gobernos, compartindo soberanías postestatais e diversificando os encaixes institucionais ancorados nunha multiplicidade de identidades e culturas.

${ }^{19}$ Lémbrese que en 2003 Donald Rumsfeld, naquel tempo secretario de Defensa na Administración de George W. Bush, falaba pexorativamente da Vella Europa en referencia aos países que non apoiaron a invasión estadounidense de Iraq, especialmente de Alemaña e Francia. A Nova Europa, en troques, era a representada daquela pola Italia gobernada por Berlusconi e a España do Goberno de Aznar. 
A adaptación aos novos escenarios de revitalización política mediante a europeización da gobernanza multinivel responde á vella crenza do «móbil perpetuo ${ }^{20}$, tan característico da civilización europea, e cuxa visión contrapón ao fatalismo do determinismo histórico as imprevisibles e continxentes facultades do Vello Continente para se reciclar en modo incesante. Trátase dun anovamento que se realizaría, paradoxalmente, dun xeito semellante ao destino do propio capitalismo contemporáneo, causa da súa aparente doenza terminal (Giner 2010).

Europa unirase máis estreitamente se é capáz de promover o seu modelo socioeconómico como paraugas amplo e integrador dos diversos Estados do benestar europeos (Romero 2011). O trazo cualitativo do EB, unha invención europea á fin e ao cabo, foi a promoción da cidadanía — civil, económica, política e social - como contrasinal da propia supervivencia do impulso europeizador. Alternativamente, e á vista doutra acepción do «fáustico», Europa ben podería ser tentada a «vender» a súa alma libre, fraternal e solidaria en prol de adquirir unha nova vida para gozar dos praceres prometidos polo modelo do neoliberalismo de corte anglonorteamericano. Este modelo, en realidade, non é foráneo na súa xénese conceptual ao pensamento europeo e occidental. Tal circunstancia reforza persuasivamente o poder glamuroso da «miraxe da riqueza» abrazada por amplos sectores sociais. Uns colectivos que, máis cedo ca tarde, descobren o efecto opiáceo e irreal do consumo suntuario que propón a sociedade neoliberal.

A paixón polo coñecemento característica da civilización europea eríxese como o recurso máis importante para apuntalar unha unión política respectuosa co seu impulso creador e vital. Tal impulso ha de ser concordante co distintivo modelo socioeconómico europeo e, en especial, co despregamento dun futuro produtivo baseado na sustentabilidade e a creación de valor engadido. Á marxe de consideracións conxunturais, a Europa fáustica precisa dunha visión que domine a capacidade inhibidora dos nacionalismos estatalistas e o individualismo posesivo dos seus cidadáns fronte ao interese común europeo.

\footnotetext{
${ }^{20} \mathrm{O}$ perpetuum mobile, o cal é concepto utilizado con frecuencia no campo da física teórica que auspicia un funcionamento permanente unha vez asentado o impulso inicial. Alúdese, en parecidos termos, á doutrina da palinxénese ou «eterna recorrencia», mediante a cal, tras o ciclo da existencia e morte, sucede unha reencarnación de valores que asegurarían a continuidade da civilización europea.
} 


\section{REFERENCIAS BIBLIOGRÁFICAS}

Alber, Jens (2010): "What the European and American welfare states have in common and where they differ: facts and fiction in comparisons of the European social model and the United States», Journal of European Social Policy, 20:2, 102-125.

Arrow, Kenneth J. (1950): «A Difficulty in the Concept of Social Welfare», Journal of Political Economy, 58:4, 328-346 (http://gatton.uky.edu/Faculty/hoytw/751/articles/arrow.pdf).

Bales, Kevin (1999): Disposable People: New Slavery in the Global Economy. Berkeley, CA, University of California Press [ed. castelá: La nueva esclavitud en la economía global, Madrid, Siglo XXI, 2000].

Bauman, Zygmunt (1999): Modernidad líquida, Bos Aires, Fondo de Cultura Económica.

Beck, Ulrich / Elisabeth BeСK-GernsheIm (eds.) (2001): Individualization: Institutionalized Individualism and Its Social and Political Consequences, Londres, SAGE [ed. castelá: La individualización: el individualismo institucionalizado y sus consecuencias sociales y políticas, Barcelona, Ediciones Paidós Ibérica, 2003].

BÉJAR, Helena (2007): Identidades inciertas: Zygmunt Bauman, Barcelona, Herder.

BeLl, Daniel (1974): The Coming of Post-Industrial Society, Londres, Heinemann [ed. castelá: El advenimiento de la sociedad postindustrial, Madrid, Alianza, 2006].

Berlin, Isaiah (1958): Two Concepts of Liberty, Oxford, Clarendon Press [ed. castelá: «Dos conceptos de libertad», en Anthony Quinton (ed.), Filosofía politica, México, D. F., Fondo de Cultura Económica].

Castel, Robert (1992): «La inserción y los nuevos retos de las intervenciones sociales», en Fernando Álvarez-Uría (comp.), Marginación e inserción, Madrid, Endymion, 25-36.

Elias, Norbert (1990): La sociedad de los individuos, Barcelona, Península.

Esping-Andersen, Gøsta / Bruno Palier (2010): Los tres grandes retos del Estado del bienestar, Barcelona, Ariel.

Flora, Peter (1993): «Los estados nacionales del bienestar y la integración europea», en Luis Moreno (ed.), Intercambio social y desarrollo del bienestar, Madrid, Csic, 15-27.

Friedman, Milton / Rose Friedman (1980): Free to Choose: A Personal Statement, Londres, Secker \& Warburg.

Habermas, Jürgen (1973): Legitimationsprobleme im Spätkapitalismus, Frankfurt, Suhrkamp [ed. castelá: Problemas de legitimación en el capitalismo tardio, Madrid, Cátedra, 1999].

HaYeK, Friedich August von (1944): The Road to Serfdom, Londres, Routledge [ed. castelá: Camino de servidumbre, Madrid, Alianza, 2000].

Giner, Salvador (2010): El futuro del capitalismo, Barcelona, Península.

Gough, Ian (1979): The Political Economy of the Welfare State, Londres, Macmillan [ed. castelá: La economia politica del Estado del bienestar, Madrid, Blume, 1982].

Kunnle, Stein (ed.) (2000): The Survival of the European Welfare State, Londres, Routledge.

Laqueur, Walter (2009): The Last Days of Europe: Epitaph for an Old Continent, Nova York, St. Martin's Griffin.

Macpherson, Crawford Brough (1962): The Political Theory of Possessive Individualism: From Hobbes to Locke, Oxford, Oxford University Press [ed. castelá: La teoría politica del individualismo posesivo: de Hobbes a Locke, Madrid, Trotta, 2005].

Máiz, Ramón (2008): La frontera interior: el lugar de la nación en la teoría de la democracia y el federalismo, Murcia, Tres Fronteras Ediciones [ed. inglesa: The Inner Frontier: The Place of Nation in the Political Theory of Democracy and Federalism, Bruxelas, PIE Peter Lang, 2012]. 
Marshall, Thomas (1950): Citizenship and Social Class and Other Essays, Cambridge, Cambridge University Press [ed. castelá: Ciudadanía y clase social, Madrid, Alianza, 1988].

McLuhan, Marshall / Bruce R. Powers, (1989): The Global Village: Transformations in World Life and Media in the $21^{\text {st }}$ Century, Nova York, Oxford University Press [ed. castelá: La aldea global, Barcelona, Gedisa, 1990].

Montanelli, Indro (1957): Storia di Roma, Milán, Longanesi [ed. castelá: Historia de Roma, Barcelona, Debolsillo, 2010].

Moreno, Luis (2012): La Europa asocial: crisis y Estado del bienestar, Madrid, Península.

Moreno, Luis (2014): Europa sin Estados: unión politica en el (des)orden global, Madrid, Los Libros de la Catarata.

Moreno, Luis / Nicola McEwen (2005): «Exploring the territorial politics of welfare», en Nicola McEwen / Luis Moreno (eds.), The Territorial Politics of Welfare, Londres, Routledge, 1-40.

Moreno, Luis / Amparo Serrano Pascual (2009): "Modelo Social Europeo y políticas sociales: una evaluación formativa institucional», Gestión y Análisis de Políticas Públicas, 2, 11-32.

Nozick, Robert (1974): Anarchy, State and Utopia, Oxford, Blackwell [ed. castelá: Anarquia, Estado y utopia, México, D. F., Fondo de Cultura Económica, 1988].

O'Connor, J. (1973): The Fiscal Crisis of the State, Nova York, St Martin's Press [ed. castelá: La crisis fiscal del Estado, Barcelona, Península].

Offe, Claus (1984): Contradictions of the Welfare State (ed. John Keane), Londres, Hutchinson [ed. castelá: Contradicciones en el Estado del Bienestar, Madrid, Alianza, 1990].

Rawls, John (1971): A Theory of Justice, Cambridge, MA, Belknap [ed. castelá: Una teoría de la justicia, México, D. F., Fondo de Cultura Económica, 1978].

Ritzer, George (1993): The McDonalization of Society, Thousand Oaks, CA, Pine Forge Press [ed. castelá: La McDonalización de la sociedad, Barcelona, Ariel, 1996].

Romero, Joan (2011): «¿Quiere Europa ocuparse del futuro de su modelo socioeconómico? ¿Puede hacerlo? ¿Europa o los Estados?», Pasajes de Pensamiento Contemporáneo, 35: 15-27.

Rosanvallon, Pierre (2011): La Société des égaux, París, Seuil [ed. castelá: La sociedad de iguales, Bos Aires, Manantial, 2012].

Rothstein, Bo (1998): Just Institutions Matter: The Moral and Political Logic of the Universal Welfare State, Nova York, Cambridge University Press.

Ryan, Paul (2011): A Roadmap Plan for America's Future: Description of the Legislation, Budget Committee Republicans (http://www.roadmap.republicans.budget.house.gov/).

SENnetT, Richard (2006): La corrosión del carácter: las consecuencias personales del trabajo en el nuevo capitalismo, Barcelona, Anagrama.

SHACKLETON, Len (2009): «¿Se ha pasado el momento del modelo social europeo?», en Francisco Beltrán (coord.), Modelos sociales europeos, Madrid, Marcial Pons/Fundación Rafael del Pino, 69-91.

Spengler, Osvaldo (1966): La decadencia de Occidente, t. 1: Bosquejo de una morfología de la historia universal, Madrid, Espasa-Calpe [versión orixinal, 1918].

STEINER, George (2005): La idea de Europa, Madrid, Siruela.

Thatcher, Margaret (1993): Los años de Downing Street, Madrid, El País/Aguilar.

Todd, Emmanuel (1990): L'Invention de l'Europe, París, Seuil [ed. castelá: La invención de Europa, Barcelona, Tusquets, 1995]. 
Luis Moreno

ToynbeE, Arnold J. (1934-1961): A Study of History (12 vols.), Oxford, Oxford University Press [ed. castelá: Estudio de la Historia, Barcelona, Edhasa, 1963].

Veblen, Thorstein (1899): The Theory of the Leisure Class: An Economic Study in the Evolution of Institutions, Nova York, Macmillan (título modificado en 1912 por The Theory of the Leisure Class: An Economic Study of Institutions). [Ed. castelá: Teoría de la clase ociosa, México, Fondo de Cultura Económica, 1944. Tradución de Vicente Herrero]. 


\section{DA MONARQUÍA CATÓLICA A REPUBLICA VIRTUOSA. O IMAXINARIO POLÍTICO NA CREACION DO MUNDO IBEROAMERICANO}

Anthony Pagden

University of California 

Nunca existiu, nin como denominación nin como realidade, un imperio español. Existiu, xaora, o Sacro Imperio Romano, cuxo emperador foi durante un tempo tamén o monarca dos diferentes reinos de España. Durante tres séculos tamén existiu unha vasta extensión de territorio que abranguía o Atlántico e o Pacífico e que estaba baixo o control do soberano de Castela. Frecuentemente isto foi descrito como a «monarquía española» e en ocasións como a monarquía católica. Entre 1580 e 1648, cando os reinos da Península Ibérica estaban baixo un só dominio, estendíase tamén desde Messina a Macau. Era a maior e máis extensa unidade política que o mundo nunca viu, na cal, como o poeta español Bernardo de Balbuena ben expresou en 1604, «España se une á China e Italia ao Xapón» ${ }^{1}$.

En ocasións, os reis de Castela e de Aragón (e por veces tamén os reis de Portugal) asumiron posturas universalistas, presentándose como «señores da cristiandade» ou, menos modestamente, «señores de todo o mundo».

Este conglomerado, sobre o cal gobernaron os Habsburgo e máis tarde os Borbóns, e ao cal desde o século XVIII se fixo referencia como o «imperio español», foi imaxinado como personificación dun só corpo de dereito público adoptado polo imperio e encarnado na persoa, a persona ficta, do propio monarca. Mais, por poderosa que esta imaxe claramente fose, ningún monarca español antes ca Carlos III fixo o máis mínimo intento de moldear os diversos reinos de que se compuña a monarquía en algo semellante, por exemplo, ao Estado unitario, o état unifié, que imaxinou Luís XIV. O propio monarca actuaba máis como un axente de distribución e xustiza comunitaria ca como a autoridade política

${ }^{1}$ Gruzinski, Serge (2004): Les quatre parties du monde : histoire d'une mondialisation, París, Éditions de la Martinière, 49. 
incuestionable e, malia os esforzos centralizadores de sucesivos gobernantes de Castela desde Filipe II ata Carlos III, constitucionalmente a monarquía máis ben semellaba unha federación de estados quasi independentes ca un imperium legalmente indiviso. Como o diplomático Diego Saavedra Fajardo observou en 1639, o que os xuristas españois preferían denominar "provincias» constituíron de feito o que noutros Estados de Europa era designado máis apropiadamente como «nacións» ou «reinos» ${ }^{2}$. Isto era, abofé, principalmente certo nos dominios europeos. Nápoles e Sicilia permaneceron como reinos soberanos, como tamén fixo Aragón; Milán, como un ducado independente e os Países Baixos, como un composto de condados e principados. Cando en 1539 o gran teólogo dominico Francisco de Vitoria, nunha conferencia sobre as orixes do poder civil, quixo ofrecer á súa audiencia exemplos do que os aristotélicos denominaron «comunidades perfectas", é dicir, aquelas que eran politicamente autosuficientes, escolleu como exemplo «Castela, Aragón e outros semellantes», un dos cales era Venecia, o máis ferozmente antimonárquico dos estados europeos da Idade Moderna ${ }^{3}$. «España» era unha "expresión xeográfica». Mesmo as Américas, aínda que incorporadas formalmente á Coroa de Castela en 1523, gozaron en gran medida dunha autoridade política independente e foron invariablemente descritas, antes do século XviII, como «Reinos de Indias» e, a partir de 1680, gobernadas por un código de leis diferente ${ }^{4}$. Carlos $\mathrm{V}$ mesmo facía referencia de xeito concreto a estes reinos entre o resto dos seus numerosos títulos.

De igual maneira ca a maioría dos Estados extensos, a monarquía española amosou continuamente o seu carácter expansionista desde o momento en que deixou de ser unha mera unidade territorial. Para alén disto, como numerosos contemporáneos creron, unha vez que un Estado emprendía unha política de expansión, tiña que continuar a se estender se quería perdurar. O problema era que o crecemento exponencial só podía conducir, en definitiva, a unha fragmentación e colapso final. «Este é o perigo das monarquías», escribiu Saavedra Fajar-

${ }^{2}$ Saavedra Fajardo, Diego de (1976): Empresas politicas: idea de un príncipe político-cristiano, ed. de Quintín Aldea Vaquero, Madrid, Editora Nacional, 75-76.

${ }^{3}$ Vitoria, Francisco de (1997): «De iure belli», 1.2, en Vorlesungen: Völkerrecht, Politik, Kirche, ed. de Ulrich Horst, Heinz-Gerhard Justenhoven e Joachim Stüben, Stuttgart, Kolhammer, II, 552. Esta é actualmente a mellor edición do texto en latín.

${ }^{4}$ A Nueva Recopilación de las Leyes de los Reynos de las Indias, reunida polo xurista Juan de Solórzano y Pereira na década de 1650 mais non promulgada ata 1680 , tras a súa morte. 
do: «que, procurando o repouso[,] dan nas inquedanzas. Queren parar, e caen. En deixando de obrar enferman ${ }^{5}$. A mediados do século xvir, para moitos coma Fajardo, esta era a principal razón pola que a noutrora grandiosa monarquía católica agora parecía estar a se afundir. Era o destino inevitable de todos os grandes imperios que se expandían en exceso.

No entanto, para moitas persoas alleas ao tema, as dificultades reais da monarquía parecían deberse non tanto á súa fragmentación política ou á súa incapacidade para continuar a absorber máis territorio como á súa adhesión ás tensións ideolóxicas que noutro tempo a dotaran de coherencia: a estreita identificación coa relixión católica (malia que non sempre en consonancia coa Igrexa católica) e a busca de supremacía militar. Ambas se exhibiran de xeito prominente desde 1492, ese ano quasi mítico en que a conquista de Granada, a expulsión dos xudeus e a primeira viaxe de Colón impulsaran o futuro «imperio español».

O descubrimento e conquista das Américas tamén tiveron como resultado a fortuíta descuberta dunha gran riqueza mineral. Isto, non obstante, foi tanto unha beizón como unha maldición. Sir Josiah Child, presidente da Compañía Británica das Indias Orientais, apreciou en 1665 que os españois, distraídos pola súa «intensa e senlleira industria nas súas minas de ouro e prata», nunca estiveran en posición de entender completamente o valor de "cultivar a terra e producir mercadorías para o crecemento dela ${ }^{6}$. Foi esta enorme dependencia das materias primas, sobre todo dos metais preciosos, máis ca a excesiva extensión territorial, na opinión de Child, a causa principal do famoso «declive español» do que el mesmo estaba a ser testemuña. Esta converteuse nunha explicación amplamente compartida para as cada vez máis profundas dificultades económicas e militares que aflixían a monarquía. España, reflexionaba o gran teórico social francés Charles-Louis de Secondat, barón de Montesquieu, en 1725, non chegara a entender onde residía realmente a verdadeira riqueza dos Estados. No canto de cultivar a terra, o que significaba ademais mellorar as condicións e o benestar dos habitantes nativos, os sucesivos gobernantes españois centráranse unicamente na extracción de metais preciosos, que eran tan só «un ben ficticio ou banal». Como consecuencia disto, abandonaran «as fontes de riqueza natural polos símbolos de riqueza» ${ }^{\text {. }}$ $\mathrm{Na}$ opinión de Montesquieu, a mediados do século XVIII, cando España perdera todos

\footnotetext{
${ }^{5}$ Empresas politicas: idea de un principe politico-cristiano, 604.

${ }^{6}$ Child, Josiah (1751 [1665]): A New Discourse of Trade, Glasgow, 153.

${ }^{7}$ Montesquieu (1949-1951): Considérations sur les richesses de l'Espagne, en CEuvres complètes, ed. de Roger Callois, París, Bibliothèque de la Pléiade, II, 10-11.
} 
os seus antigos territorios en Europa, converteuse en pouco máis ca dependente dos seus propios asentamentos coloniais. "As Indias e España son dúas potencias baixo a mesma soberanía», escribiu, «mais as Indias é a principal e España simplemente un accesorio» ${ }^{8}$.

A solución a este aperto, suxerida de maneiras diferentes por Child e Montesquieu, consistía en transformar a monarquía española dunha de conquista a unha de comercio, desde unha sociedade ideoloxicamente "pechada» a unha ideoloxicamente «aberta». O libre comercio e a liberdade de consideracións relixiosas eran o único modo en que unha sociedade moderna podería esperar prosperar. Neste sentido, concluíu Montesquieu, «no canto dun gran tesouro, tería un gran pobo». Isto debía traducirse en emular o que xeralmente era considerado como o camiño que os ingleses e holandeses xa adoptaran: a creación de imperios baseados non na conquista, senón en asentamentos supostamente pacíficos, e non sobre a extracción de materias primas, senón sobre o comercio. A modernidade no mundo atlántico, coma na propia Europa, significou a mudanza de sociedades guerreiras arcaicas por outras baseadas no intercambio pacífico. De acordo coa interpretación do mundo moderno que fai o gran economista escocés Adam Smith en $A$ riqueza das nacións e que arrincou coas memorables viaxes de Colón e Vasco da Gama (os «maiores e máis importantes» sucesos na historia da humanidade), o comercio substituiría a guerra ${ }^{9}$.

Houbo, polo menos a primeiros do século xvıII, bastante xente en España que chegara a conclusións semellantes. O moi influente economista político Jerónimo de Uztáriz afirmou en 1724 que só se nese momento Castela elixise adoptar as «novas máximas» con que Jean-Baptiste Colbert, o controlador xeral de finanzas de Luís XIV, lograra transformar Francia dunha nación de guerreiros a unha de comerciantes poderían os españois ter a esperanza de emular o sorprendente éxito dos seus inimigos ${ }^{10}$. Non obstante, adoptar as «máximas» dos seus antigos inimigos é, loxicamente, un asunto nada sinxelo ${ }^{11}$.

Para a segunda metade do século xviII, no entanto, numerosos e importantes personaxes comezaron a insistir nunha reavaliación dos obxectivos políticos e culturais da monarquía española seguindo as directrices dos seus críticos france-

\footnotetext{
${ }^{8}$ De l'esprit des lois, XXI, 22, en Euvres complètes, II, 648-649.

${ }^{9}$ Smith, Adam (1980): The Wealth of Nations, ed. de W. B. Todd, Oxford, Oxford University Press, II, 626-627.

${ }^{10}$ Uztáriz, Jerónimo de (1724): Theoría y práctica de Comercio y de Marina, Madrid, 60-62.

${ }^{11}$ Para os atractivos e os perigos da imitación, ver Paquette, Gabriel B. (2008): Enlightenment, Governance, and Reform in Spain and its Empire, Houndsmills, Palgrave Macmillan, 29-55.
} 
ses e británicos ${ }^{12}$. Tamén recoñeceron que a necesidade de reformar a monarquía se convertera en moito máis ca a simple busca dunha asociación de dominios que fosen á vez produtivos en termos económicos e coherentes politicamente. Tornárase de feito nunha crise de identidade. A máis rechamante e influente destas figuras foi José del Campillo y Cossío, secretario da Mariña e das Indias entre 1741 e 1743, e quen no decenio de 1760 elaborou un proxecto para a completa revisión do imperio de ultramar que levou como título Nuevo sistema de gobierno económico para la América ${ }^{13}$.

A América española, apuntaba Campillo, fora fundada e aínda se dirixía seguindo os intereses do que para mediados do século xviII fora identificado como o malestar nacional primordial: o espirito de conquista. Como Georg Friedrich Hegel observou desde a súa vantaxosa posición en 1830, as diferenzas que separaron América do Norte de América do Sur derivaban todas do feito de que «Sudamérica foi conquistada, mais Norteamérica colonizada ${ }^{14}$. A consecuencia deste, malia que ilusorio, único propósito de busca de riqueza mineral e gloria militar, España obtiña neste momento menos das súas posesións americanas do que a Gran Bretaña e Francia lograban das súas illas de Barbados e Martinica respectivamente ${ }^{15}$. No século xvI, a conquista fora tanto lexítima como, en certa medida, lucrativa para a Coroa. Ambas as características estaban en consonancia co espírito marcial de entón e coa necesidade inmediata de subxugar un gran número de indios ${ }^{16}$. Mais aqueles tempos ficaran atrás con rapidez e o século seguinte, que debería ser unha era dourada, foi, en troques, «un século de desgraza e perda» a medida que os españois, no canto de consolidaren o seu control sobre o

${ }^{12}$ Para os antecedentes deste movemento, ver Elliott, John H. (2009): «Learning from the enemy: early-modern Britain and Spain», en Spain, Europe and the Wider World 1500-1800, New Haven/Londres, Yale University Press, 25-51.

${ }^{13}$ Aínda que non se deu ao prelo ata 1789, o Nuevo sistema circulou amplamente nos círculos administrativos e xudiciais antes desa data. Unha versión do texto, na maioría dos lugares palabra por palabra, tamén apareceu como a segunda parte do Proyecto económico, en que se proponen varias providencias, dirigidas á promover los intereses de España, de Bernardo Ward, publicado por vez primeira en Madrid en 1799. A propia contribución de Ward, que se limitaba a unha discusión da Espańa metropolitana, fora redactada en 1762. Para consultar unha análise da relación entre os dous textos, ver a introdución de Antonio Elorza a Campillo y Cossío (1969 [1741]): Lo que hay de más y menos en España, para que sea lo que debe ser y no lo que es. España despierta, Madrid, Seminario de Historia Social y Económica de la Facultad de Filosofía y Letras de la Universidad de Madrid, 11-16.

${ }^{14}$ Hegel, Georg Wilhelm Friedrich (1956): The Philosophy of History, trad. de J. Sibree, Nova York, Dover Publications, 83-84.

${ }^{15}$ Campillo y Cossío, José del (1789): Nuevo sistema de gobierno económico para la América, Madrid, 2-3.

${ }^{16}$ Nuevo sistema de gobierno económico para la América, 14. 
que xa gañaran e de diversificaren a economía colonial, simplemente continuaron a conquistar ${ }^{17}$. Os conquistadores e os seus sucesores, preocupados só por perpetuar unha sociedade arcaica baseada no valor militar, non deron entendido que a verdadeira riqueza dunha sociedade provińa da orde política e social e non do saqueo. As consecuencias foran nefastas. Observen, dixo Campillo ao Gran Khan (o quasi mítico gobernante da China): con ministros menos capaces ca o rei de España e menos territorios, conseguiu porén mellores resultados e, engade Campillo misteriosamente, «non están os seus vasalos tan asoballados» ${ }^{18}$. As Américas foran botadas a perder polos conquistadores europeos. A mellor e máis apreciada parte do Estado, o seu pobo, fora reducida a unha fracción do seu número anterior e, a consecuencia do abuso tiránico, os escasos indios que aínda quedaban foran convertidos nunha forza completamente improdutiva. O que noutrora foi «unha nación discreta e política nas mans dos nativos e nas tebras da barbarie» fora devastada polos gobernantes cristiáns e agora «están incultas, despoboadas e case totalmente aniquiladas, unhas Provincias que poderían ser as máis ricas do mundo» ${ }^{19}$. Sería moitísimo mellor, argumentaba, se os españois seguisen no seu momento o exemplo dos franceses no Canadá e unicamente comerciasen no canto de, a un alto prezo para eles mesmos, masacraren nacións das cales poderían obter beneficio económico. No entanto, ao se enfrontar España a unha terra asolada, debería agora «seguir máximas totalmente distintas»e, con elas, os indolentes suxeitos da Coroa española terían que «volver a súa atención ao comercio, ao cultivo daqueles preciosos froitos, establecer unha boa policía, e por medio dun bo goberno económico, reducir os Indios á vida civil, tratándoos con benignidade e con dozura, animalos á industria, e por este camiño facer deles vasalos útiles e Españois».

Noutras palabras, os suxeitos medievais deberían transformarse en cidadáns modernos. Non obstante, con pesar, concluía: «[N]ós estamos sempre coas armas na $\operatorname{man} »^{20}$.

A visión particularmente pesimista de Campillo y Cossío das consecuencias a longo prazo do espírito militar espańol era repetida con máis forza por Pedro Rodríguez Campomanes, ministro de Finanzas de Carlos III. En 1762, ao mesmo tempo exacto que o Nuevo sistema de Campillo y Cossío comezaba a circular nos círculos ilustrados de Madrid, Campomanes publicou as súas Reflexiones sobre el

\footnotetext{
${ }^{17}$ Nuevo sistema de gobierno económico para la América, 6-7.

${ }^{18}$ Nuevo sistema de gobierno económico para la América, 2.

${ }^{19}$ Nuevo sistema de gobierno económico para la América, 3.

${ }^{20}$ Nuevo sistema de gobierno económico para la América, 15-16. [N. da T.: todas as citas en español no orixinal].
} 
comercio español a Indias, unha resposta ás críticas ao imperio español feitas polo economista inglés Josiah Child no seu $A$ New Discourse of Trade, e ás observacións de Montesquieu en L'Esprit des lois. "Todas as nacións cren», escribiu, "que a riqueza por medio do comercio, a navegación e a industria é o único manancial da pública felicidade. As guerras actuais máis se emprenden co fin de posuír o tráfico das colonias que por estender o dominio $»^{21}$. Durante séculos o imperio español non fora máis nada ca o medio de transporte de ouro e prata a todas as nacións europeas, do cal a propia España tirou moi pouco. E el tamén atribuía isto ao "espírito de conquista ${ }^{22}$. Cegada pola súa obcecada crenza premoderna na incuestionable necesidade do éxito militar, España no século XVII «non coñecía naquela crise política de Europa os seus verdadeiros intereses» ${ }^{23}$.

Neste aspecto Campomanes coincidía por completo tanto con Child como con Montesquieu. Igual ca Campillo, tamén el estaba convencido de que ultimamente o problema español non podía resolverse tan só facendo pequenos axustes nas estruturas existentes. A monarquía española tiña que mudar o seu interior; tiña, en palabras que empregaba a miúdo, que «mudar o seu ser» ${ }^{24}$. Para isto houbo de se dedicar dunha maneira carente de precedentes ao que se coñecía como "a felicidade pública», unha expresión bastante vaga que circulaba amplamente nos distintos idiomas da teoría política e por toda Europa no século XVIII ${ }^{25}$. Co fin de difundir felicidade a todos os seus súbditos, a arcaica monarquía hispánica tiña que ser reinterpretada como o que en ocasións alegou ser mais na realidade nunca foi, non como un simple «Estado composto» senón unha metrópole con numerosas colonias; noutras palabras, como un verdadeiro imperio ${ }^{26}$. Porque, como J. G. A. Pocock afirmou, moitos no século xvin (e sen dúbida Campomanes foi un deles) consideraban «imperio» e «sociedade civil» como practicamente

${ }^{21}$ Rodríguez Campomanes, Pedro (1988 [1762]): Reflexiones sobre el comercio español a Indias, ed. de Vicente Llombart Roas, Madrid, Ministerio de Economía y Hacienda, 11-12.

${ }^{22}$ Rodríguez Campomanes, Pedro (1775): Discurso sobre la educación popular de los artesanos y su fomento, Madrid, 410.

${ }^{23}$ Discurso sobre la educación popular de los artesanos y su fomento, 412.

${ }^{24}$ Reflexiones sobre el comercio español a Indias, 23.

${ }^{25}$ Sobre isto, ver Paquette, Enlightenment, Governance, and Reform in Spain and its Empire, 56-62.

${ }^{26}$ Sobre o uso deste termo, ver Koenigsberger, Helmut Georg (1986): «Dominium regale or Dominium politicum et regale», en Politicians and Virtuosi: Essays in Early-Modern History, Londres, Hambledon Press, 12. 
intercambiables ${ }^{27}$. Porén, e en primeiro lugar, para se converter nun verdadeiro imperio a Monarchia Hispanica tińa que se reinventar como algo semellante ao Estado transatlántico que os británicos estaban daquela en proceso de construír no norte. Sen dúbida, as consecuencias para ambos ao final poderían resultar desastrosas, mais Campomanes, en 1762, non podería anticipalo.

Con este obxectivo en mente, as Reflexiones propuñan unha nova interpretación da vella distinción entre os Reinos de Indias e os diferentes dominios na propia Europa. Campomanes é un dos primeiros en falar sistematicamente das "colonias» americanas e en consideralas non como unha parte allea a Castela aínda que dependente dela, senón como comunidades comparables ás colonias que a Gran Bretaña, e dalgunha maneira Francia, estableceran en América do Norte; comunidades quasi independentes cuxos beneficios e cuxo propio desenvolvemento interno dependían do comercio e a agricultura. Opinaba que o erro que a Coroa de Castela cometera fora limitar o acceso ao comercio americano aos casteláns de orixe. $\mathrm{O}$ imperio español constituía un vasto mercado interior; no entanto, en 1596, Filipe II negara aos portugueses (que eran naquel momento súbditos da Coroa de Castela) calquera participación no comercio americano e en 1634 Filipe IV prevíraos contra a posibilidade de comerciaren nas Filipinas ${ }^{28}$. As mesmas limitacións se aplicaran a flamengos, italianos e, nalgúns casos, aragoneses. O proxecto de Campomanes, se se levase a cabo daquela, abriría os mercados americanos a todos os súbditos da Coroa de Castela e, dun xeito crucial, liberalizaría o comercio entre eles.

A introdución dunha zona de comercio libre, pois, aínda estaba confinada aos límites do vello imperium español e debía vencellarse a unha política de reestruturación educativa. Os españois, todos eles, habían ser educados, na opinión de Campomanes, para seren suxeitos económicos modernos. Este era o proxecto que había tras o seu Discurso sobre la educación popular de 1775. Un texto que reiteraba moitas das ideas expostas nas Reflexiones e que algúns anos máis tarde foi retomado por Melchor Gaspar de Jovellanos no seu moi influente Informe sobre la Ley Agraria de 1795. A partir de tales comezos, o espírito da sociedade comercial paseniñamente iría substituíndo a vella orde de dominación. E, co es-

\footnotetext{
${ }^{27}$ Pocock, John Greville Agard (1999): Barbarism and Religion, Cambridge, Cambridge University Press, Iv, 220.

${ }^{28}$ Reflexiones sobre el comercio español a Indias, 62.
} 
tablecemento do libre comercio entre todas as diferentes e remotas rexións, Campomanes estaba seguro de que España sería finalmente capaz de mudar o seu ser.

Inicialmente, Campomanes, coma Campillo y Cossío e Jovellanos, defendeu unha mudanza económica e estrutural e non unha mudanza política; mudanza como medio para achegar a monarquía española ao seu novo ser moderno e comercial. No entanto, logo se fixo evidente que a única orde política que faría posible esta nova orde comercial non era unha monarquía antiga (o concepto declinante da comunidade transatlántica, dun ius publicum, encarnado na persoa xurídica do rei). A modo de paradoxo, o novo «imperio» moderno só podería concibirse como unha especie de federación. Quen observou isto con maior claridade foi o conde de Aranda, coñecido de Voltaire e do abbé Guillaume Raynal (autor da Histoire philosophique et politique des deux Indes, a condena máis corrosiva do colonialismo europeo publicada no século XVIII) e presidente do Consello de Castela. En 1783, mentres ocupaba o cargo de embaixador de España en Francia, Aranda preparou un memorando secreto, a «Exposición del conde de Aranda al rey Carlos III sobre la conveniencia de crear reinos independientes en América», verbo do posible desmembramento do sistema colonial americano. «Debe a Vosa Maxestade desfacerse de todas as súas posesións no continente de ambas as Américas», escribiu, mantendo só as illas de Cuba e Porto Rico como base do comercio español. O resto na súa totalidade, suxeriu, deberíase transformar en tres reinos independentes (que corresponderían aos tres vicerreinados) gobernados como unha federación non moi ríxida e non baixo o control do monarca español, senón dun emperador español, ao modo que idearan os titulares do Sacro Imperio Romano Xermánico. Aranda opinaba que esa federación produciría máis para o tesouro español co comercio do que as colonias fixeran coas cargas fiscais. Unha vez unidos, os tres reinos non só non mostrarían iniciativa ningunha por se separaren completamente de España, senón que, alén diso, serían máis capaces de resistir as novas ameazas exteriores e estarían politicamente máis inclinados a facelo; ameazas que Aranda, coma a maioría dos españois, cría, e non sen razón, que supuñan os novos Estados Unidos. Na súa opinión, os estados federados do tipo que propuxera eran a longo prazo moito máis fortes e economicamente máis prósperos ca ningún outro. Os Estados Unidos demostrárano. «Chegará un día», escribiu de xeito profético, «en que [esta república federal] creza e se torne 
xigante e aínda coloso terrible naquelas rexións» ${ }^{29}$. Igual ca o proxecto, non moi diferente, proposto por lord Shelburne para a América británica, o proxecto de Aranda chegou tarde de máis e foi ignorado ${ }^{30}$. Pero o que Aranda observara era que o único modo de salvagardar o «imperio», como se chamaba daquela, era fortalecer as tendencias federalistas que xa estiveran presentes na antiga monarchia habsbúrxica.

O proxecto de Aranda asumía que as colonias xa non poderían ser por máis tempo unha parte totalmente integrada da metrópole e que, se non se tentaba algo radical, o resultado non sería máis ca a insurxencia. Suporía a creación de novos Estados, novas nacións, que poderían tornarse non só independentes da «nai patria», senón abertamente hostís aos seus intereses. En 1776, coincidindo coa guerra americana de Independencia, Adam Smith predicaba un parecido destino para as colonias británicas en América do Norte. Afirmaba que continuar a guerra (condenada en calquera caso ao fracaso) podería tan só conducir en última instancia ao colapso dun imperio que en ningún momento, na súa opinión, significara máis ca un proxecto e que achegara moi poucos beneficios á «nai patria». Grazas ás colonias, a súa independencia, pola contra, persuadiría

a súbditos turbulentos e sediciosos de se converter nos nosos máis leais, afectuosos e xenerosos aliados; e o mesmo tipo de afecto paternal, por unha banda, e respecto filial, pola outra, podería revivir entre a Gran Bretańa e as súas colonias, o mesmo que noutrora existiu entre aqueles da Grecia antiga e a cidade-nai da que descendían ${ }^{31}$.

No mesmo ano, Anne-Robert Turgot, philosophe, economista político e daquela ministro de Finanzas francés, nunha reflexión sobre o posible destino das colonias españolas no período seguinte á guerra americana de Independencia, chegou

\footnotetext{
29 «Exposición del conde de Aranda al rey Carlos III sobre la conveniencia de crear reinos independientes en América», en Muriel, Andrés (1959 [1838]): Gobierno del señor rey Carlos III, ed. de Carlos Seco Serrano, Biblioteca de Autores Españoles, 115, Madrid, Ediciones Atlas, 399-401.

${ }^{30}$ Vee, Eliga H. Gould (2000): The Persistence of Empire: British Political Culture in the Age of the American Revolution, Chapel Hill, University of North Carolina Press, 166, e Elliott, John H. (2006): Empires of the Atlantic World: Britain and Spain in America, 1492-1830, New Haven/Londres, Yale University Press, 367. Benjamin Franklin agradeceu a suxestión de Shelburne co comentario «Con certeza nunha houbo unha quimera máis absurda concibida no cerebro dun ministro».

${ }^{31}$ Mossner, Ernest Campbell / Ian Simpson Ross (1977): The Correspondence of Adam Smith, Oxford, Oxford University Press, 610.
} 
á mesma conclusión. As colonias, formulaba, tan só foran un beneficio económico real para aqueles que comerciaran libre e independentemente con elas, e que polo xeral non eran os seus amos políticos. «Os ingresos», escribiu, «que o Goberno deriva das súas colonias non teñen, xa que logo, valor para o Estado considerado como un poder político» [«Le revenu que le gouvernement tire des colonies, est donc une resource nulle pour l'état consideré comme puissance politique»]. Os Estados que máis se beneficiaran das colonias americanas, tanto do norte como do sur, foron os Países Baixos, as terras austríacas e Suíza, os últimos dous, ademais, sen posesións ultramarinas. Coma Smith, tamén el coidaba que

se debería cuestionar se non sería no seu momento máis vantaxoso para nós [a monarquía borbónica] deixalos á súa propia sorte en total liberdade, no canto de agardar polos sucesos que nos forzaron a tomar ese camiño.

[on sera tenté de douter s'il n'eût pas été plus avantageux pour nous de les abandonner à leurs propres forces avec une entière indépendance, même sans attendre le moment où les événements nous forceront de prendre ce parti.]

«Sabia e feliz», concluíu, «sería a nación que consentise en aceptar as súas colonias como provincias aliadas no canto de como súbditos da metrópole» [«Sage et heureuse la nation [...] qui consentira ne à voir ses colonies que des provinces alliées, et non plus sujettes de la métropole»] ${ }^{32}$. Porén, como ambos os homes xa sabían, o que resulta obvio para un economista político apenas ten sentido para o monarca británico, o francés ou o español.

\section{II}

Logo da primeira insurxencia en México en 1810 e do estalido da guerra no que hoxe é Venezuela dous anos máis tarde, a semellanza entre a posición dos españois naquel momento e a situación en que os ingleses se atoparan en 1776 revelouse de maneira descarnada. Ao permaneceren ambas as monarquías inde-

\footnotetext{
${ }^{32}$ Turgot, Anne-Robert-Jacques (1791): Mémoires sur les colonies américaines, sur leurs relations politiques avec leurs métropoles, et sur la manière dont la France et l'Espagne on dî envisager les suites de l'indépendance des Etats-Unis de l'Amérique [6 de abril de 1776], París, 30-31. Turgot fala de ambas as monarquías, a francesa e a española, como «nós».
} 
fectiblemente ligadas ao "espírito de conquista» (malia os escritos dos seus asesores e mesmo dos seus ministros máis ilustrados), decidíranse máis pola guerra que por reformas e negociacións. «España», declarou o panfletista francés, antigo embaixador napoleónico e defensor de Simón Bolívar Dominique Dufour de Pradt en 1817, «debería preguntarse que será necesario facer cando non poida xa conquistar nin manter o conquistado; se non sería como facer amigos entre aqueles que non pode ter por máis tempo como súbditos» ${ }^{33}$.

Como se sabe, porén, os monarcas españois non consideraron sequera tales cuestións. Carlos III e Carlos IV podían imaxinarse a si mesmos como os gobernantes dun moderno imperio comercial. Mesmo podían aceptar certo grao de autonomía local nas colonias e a posibilidade, vehementemente perseguida baixo o reinado de Carlos III, de os crioulos e os casteláns poderen ter os mesmo dereito aos cargos públicos tanto na metrópole como nas colonias. O que non podían concibir, igual ca Xurxo III, era a existencia de rexións totalmente autónomas dentro dos límites territoriais da monarchy.

O fracaso en levar isto a cabo conduciu, como tamén o fixera no caso británico, a unha guerra civil e finalmente á independencia das colonias. Alén diso, coma no caso norteamericano, esta ruptura non só supuxo a fin da autoridade da antiga metrópole sobre as colonias, pois en última instancia comportou a creación de dous sistemas políticos diferenciados.

Os españois en América estaban, no entanto, nunha situación moito máis precaria ca os seus vecińos do norte. As trece colonias británicas de América do Norte, malia que divididas constitucional e culturalmente (e tamén no relixioso), eran, porén, etnicamente homoxéneas. As poboacións indíxenas, se ben lle serviron a Thomas Jefferson como modelo de valor e independencia "bárbaro», non eran, con todo, un modelo que desexase ver duplicado nos novos Estados Unidos. O exemplo dos iroqueses suxeríralle a Benjamin Franklin que, se mesmo un pobo tan sinxelo daba creado unha sociedade federal satisfactoria, sen dúbida unha sociedade civilizada e europea ilustrada tamén podería logralo. Pero, polo demais, os indios americanos só existían para seren desprazados. Os Reinos de Indias, non obstante, sempre constituíran oficialmente sociedades compostas de

${ }^{33}$ Dufour de Pradt, Dominique-Georges-Frédéric (1817): The Colonies, and the Present American Revolutions, Londres, 384. Bolívar pagou a De Pradt unha pensión e nunha ocasión describiuno como «un filósofo sublime», interpretando a Aristóteles para o seu Alexandre. Bolívar, Simón (1950): carta do 21 de marzo de 1826, en Obras completas, ed. de Vicente Lecuna, A Habana, Editorial Lex, II, 339. 
crioulos e indios e, con posterioridade, tamén de africanos. $\mathrm{O}$ recurso dun pasado «inca» e «azteca», en gran parte imaxinario, que mesmo sustentou o chamado "patriotismo crioulo» ao longo do século xvin no Perú e en México e é aínda unha compoñente poderosa na conciencia nacional mexicana moderna, sería impensable no norte.

Como Simón Bolívar afirmou ao seu correspondente inglés no máis coñecido dos seus escritos políticos, a Carta de Xamaica de setembro de 1815, nun fragmento que repetiu catro anos máis tarde no seu discurso aos lexisladores do novo Estado de Venezuela, os americanos españois «apenas [conservan] vestixios do que noutro tempo foi, e [...] por outra banda non [son] indios, nin europeos, senón unha especie media entre os lexítimos propietarios do país e os usurpadores españois» ${ }^{34}$.

Como claramente o expresou Bolívar, durante trescentos anos, atrapados así entre dúas culturas e separados polo tempo, a raza e agora as aspiracións políticas do seu pasado europeo, «estrańos ao mundo político e separados de todo o que puidese dalgún modo exercitar a [súa] intelixencia [...], os americanos do sur pasaron a través dos séculos coma os cegos por entre as cores» ${ }^{35}$.

Quizais Bolívar estaba a esaxerar. Porén, atinaba sen dúbida na súa alegación de que os Estados Unidos eran, en moitos aspectos importantes, diferentes de todo o que existía no sur ${ }^{36}$. Como comunicou aos futuros lexisladores de Venezuela, as colonias inglesas non só se autogobernaran durante a maior parte da súa existencia: tamén preservaran a súa pureza cultural e racial. "Teñamos presente», advertiu, "que o noso pobo non é o europeo nin o americano do norte [...]. É imposible asignar con propiedade a que familia humana pertencemos. A maior parte indíxena foi aniquilada, o europeo mesturouse co americano e co africano, e este mesturouse co indio e co europeo».

A única solución para tal hibridismo pasa pola súa extinción, no que el denominou «unha perfecta igualdade política» ${ }^{37}$. Non máis crioulos, non máis africa-

34 "Contestación de un Americano meridional a un caballero de esta isla", coñecido como a "Carta de Xamaica», setembro de 1815, en Obras completas, I, 165, e cfr. o «Discurso de Angostura», III, 676-677.

${ }^{35}$ Sobre a complexa e cambiante visión dos Estados Unidos de Bolívar, ver Bushnell, David (2008): «The United States as Seen by Simón Bolívar: Too Good a Neighbor», en David Bushnell / Lester D. Langley (eds.), Simón Bolivar: Essays on the Life and Legacy of the Liberator, Lanham, Rowman and Littlefield.

${ }^{36}$ Discurso de Angostura, en Obras completas, III, 682.

${ }^{37}$ Discurso de Angostura, en Obras completas, III, 682. 
nos nin indios, non máis proliferación de mestizos e de castas, que compuxeran en orixe os Reinos de Indias. Agora só habería venezolanos ou chilenos, mexicanos ou peruanos.

No momento da independencia, non obstante, as identidades crioulas non estaban necesariamente vencelladas a un sentido de separación política. Constituían, segundo a distinción feita polo historiador liberal alemán Friedrich Meinecke a primeiros do século xx e que segue a ser útil, non «Estados nacionais» (Staatsnationen), senón «nacións culturais» (Kulturnationen $)^{38}$. E, na medida en que estas «nacións culturais» formaron parte dunha monarquía composta de varias das ditas nacións e cun só gobernante, evidentemente non existiu intento ningún de separación política. E o que foi certo para, por exemplo, México ou o Perú foino de igual maneira para Aragón ou Navarra. Cada un cooperou secretamente na afirmación de que eran rexións autónomas voluntariamente asociadas cunha entidade política maior que non era, xaora, tampouco unha nación, nin un Goberno federal, senón unha forma simbolicamente personificada: a propia monarquía. Cando, xa que logo, esa monarquía foi disolvida á forza por Napoleón en 1808 e o mesmo monarca enviado ao exilio, esvaeceuse, en efecto, o núcleo tradicional de lealdade. As Cortes de Cádiz que se reuniron en 1812 recibiron a tarefa de crearen, para a orde posnapoleónica, unha Constitución nova e «liberal», un termo que os delegados en Cádiz foron os primeiros en utilizar no seu sentido moderno. Este intento de repensar a antiga integridade de todo o mundo hispano facíase ao declarar que a nova nación española debía incluír a todos os «españois», o cal inicialmente facía referencia a todos os residentes dos reinos antigos en ambos os lados do Atlántico, coa excepción dos escravos africanos e os indios "puros», e garantindo de igual modo, a todos eles, os mesmos dereitos e igualdade na representación ${ }^{39}$. A invasión napoleónica de España, declarou o teórico político liberal Benjamin Constant, puido ser, coma todas as súas conquistas, anacrónica e inxusta, mais serviu para «espertar un pobo xene-

38 Meinecke, Friedrich (1922): Weltbürgertum und Nationalstaat: Studien zur Genesis des deutschen Nationalstaates, Múnic, R. Oldenbourg, 3-22.

${ }^{39}$ Constitución política da monarquía española, promulgada en Cádiz o 19 de marzo, Cádiz, 1812, 23. Ver os traballos en Annino, Antonio / Francois Xavier Guerra (eds.) (2003): Inventando la nación: Iberoamérica. Siglo XIX, Ciudad de México, Fondo de Cultura Económica. Nun intento por reducir o número e a influencia política dos delegados americanos, os dereitos daqueles de ascendencia mixta africana ou india, as castas, foron reducidos progresivamente no documento final ata quedaren efectivamente todos eles excluídos. Ver J. H. Elliott, Empires of the Atlantic World: Britain and Spain in America, 1492-1830, 385. 
roso do seu estupor» [«réveillé de sa stupeur un peuple généreux» ${ }^{40}$. Este espertar inicial, non obstante, demostrou ser moi breve. Cando Fernando VII retornou en 1814, disolveu as Cortes, repudiou a maior parte dos artigos da Constitución e, ignorando o que sucedera no norte tres décadas antes, impulsou o que se converteu nun prolongado, sanguento e, en definitiva, van intento por reconquistar América.

Mais, mesmo se a Constitución liberal chegase a sobrevivir, é dubidoso que fose viable a longo prazo para o mundo hispano na súa totalidade. Os crioulos americanos, a diferenza dos seus homólogos peninsulares, eran incapaces, en última instancia, de describir ningunha futura orde política en termos dunha tradición que puidese remontarse nas súas orixes á suposta «antiga constitución» de Castela, de acordo coa cal o rei supostamente gobernaría coa participación e consentimento dos seus súbditos. A experiencia política da elite crioula, como Bolívar repetiu unha e outra vez, fora só unha, e non de participación, senón de exclusión. En definitiva, non tiñan opción real senón levar a cabo a transición de Kulturnationen a Staatsnationen, para o que se requiría a creación de sociedades políticas ex nihilo. Os norteamericanos, pola contra, fixérono ao revés. Os gentlemen de provincias que encabezaron a revolución foron sempre, en palabras de Jefferson, «británicos americanos». En 1776 afirmaran ser un novo Staatsnation. Pasaría moito tempo, e unha prolongada guerra civil, antes de que puidesen crear unha Kulturnation.

Crear Estados novos, porén, sempre foi, no mellor dos casos, unha empresa arriscada. Sen unha fonte indubidable de lexitimidade, sen unha imaxe, símbolo ou ideoloxía para guiar a imaxinación dos futuros cidadáns, o novo Estado a miúdo estaba abocado á desintegración unha vez que a sempre inestable unidade creada no primeiro momento revolucionario ficaba atrás. Unha solución a este problema, a mesma que as provincias unidas dos Países Baixos tentaran en 1580, era procurar a lexitimidade política a través da herdanza dinástica. Os intentos por importar monarcas europeos, desde a solicitude, en 1825, de Manuel Belgrano da proclamación do infante Francisco de Paula como soberano independente do Río da Prata (que foi denegada) ata o traxicómico reinado de Maximiliano en México en 1864-1867, estiveron, como previra, porén, Bolívar, condenados ao fracaso porque unha monarquía é sempre máis ca un monarca. Ningún destes

\footnotetext{
${ }^{40}$ Constant, Benjamin (1822): «Commentaire sur l'ouvrage de Filangieri», en Gaetano Filangieri, CEuvres,
} París, vi, 71-72. Porén, foi escrito logo da revolución liberal de 1820. 
principiños de importación nin as novas monarquías borbónicas que François-René, vizconde de Chateaubriand, propuxo para América do Sur no Congreso de Verona de 1822 poderían en realidade subsistir unicamente co apoio dunha aristocracia ficticia, «miserable» en palabras de Bolívar, e «cuberta en pobreza e ignorancia» e carecendo das armazóns sociais e culturais que lles permitiran aos europeos esixir a lealdade dos seus súbditos ${ }^{41}$. Un monarquismo reconstituído, aínda que fose liberal, como a maioría dos ideólogos da independencia recońeceron, resultaba unha imposibilidade cultural en sociedades cuxa integridade como comunidades, para os primeiros decenios do século XIX, dependía en gran medida precisamente da súa separación dun réxime monárquico. Como De Pradt sinalou en 1817, «en gran parte das Constitucións americanas que chegaron ao meu cońecemento, non existiu unha que incluíse unha soa palabra no tocante á realeza. Pola contra, todas estiveron marcadas por un forte sentido de republicanismo e inclinadas máis ás institucións dos Estados Unidos ca ás de Europa ${ }^{42}$.

Facéndose eco de Tom Paine, oito anos máis tarde declarou que a revolución americana, ao crear unha república no canto dunha monarquía, puxera «en marcha a reforma social que [resoaría (de alí en diante)] por todo o universo» [«donné le mouvement à la réformation sociale qui s'opère dans l'univers»]. Fose o que for agora o resultado das antigas colonias españolas, non podían deixar de acatar esa «reforma social» ${ }^{43}$. Ou, como o historiador da emancipación do Perú Carlos Lissón expuxo sen reviravoltas en 1867, o Perú «foi independente porque os seus fillos se fixeron homes, e republicana porque a república é a verdade» ${ }^{44}$. É dicir, a emancipación de España creara entre os súbditos das súas antigas colonias o desexo de se converteren en cidadáns, nun sentido parecido ao que Rousseau lle deu ao termo e que tamén era propugnado pola maioría dos ideólogos políticos dos movementos independentes, e estes cidadáns non podían xurdir baixo a tutela imposta pola monarquía.

A temperá aparición destas significativas diverxencias culturais e políticas entre as colonias e a nai patria non garantiu ningún grao de converxencia política entre as colonias mesmas (máis do que existía no norte). Para 1825, o acordo de uti possedetis de 1810, que tratara de reafirmar os antigos límites vicerreinais,

\footnotetext{
${ }^{41}$ Carta ao xeneral O'Leary, 13 de setembro de 1829, en Obras completas, III, 315.

42 The Colonies, and the Present American Revolutions, xii-xiii.

${ }^{43}$ Dufour de Pradt, Dominique-Georges-Frédéric (1825): Congrès de Panama, París, 85.

${ }^{44}$ Lissón, Carlos (1867): La República en el Perú y la cuestión peruana, Lima, 16.
} 
colapsaba definitivamente e os Reinos de Indias disolvéronse con rapidez en diferentes repúblicas dotadas dun forte sentido da súa propia identidade local e límites territoriais. É dicir, unha vez que o monarca, obxecto residual de lealdade, desaparecera, as colonias hispanoamericanas apenas tiñan nada que as mantivese unidas alén do común desexo de independencia e, polo menos nun primeiro momento, un común compromiso, como De Pradt sinalara, co ideal republicano. En nada quedaron os programas disgregadores para algunhas estruturas estatais maiores (o novo «imperio inca» de Francisco de Miranda, que abranguería os vicerreinados do Perú e Nova Granada sometidos a un Estado baseado nunha curiosa mestura entre senado romano e a Casa dos Comúns, ou a non moi distinta «monarquía incásica» de Manuel Belgrano, moi acaidamente chamada «Reino Unido do Río da Prata», de 1825). O maior deles, o proxecto bolivariano da unión da "Gran Colombia», que abranguería de Venezuela a Chile, veuse abaixo mesmo antes da morte do seu creador ${ }^{45}$.

O problema das dúas primeiras destas foi que, malia as alusións de Miranda e Belgrano ao pasado inca, aquelas estaban concibidas esencialmente como sistemas federais e o federalismo, como insistiu o mesmo Bolívar, non podería funcionar no sur como o fixo no norte porque este descansaba sobre un sistema de representación e, desde o punto de vista de Bolívar, «[a] nosa Constitución Moral non tiña aínda a consistencia necesaria para recibir o beneficio dun Goberno completamente Representativo, e tan Sublime canto que podía ser adaptado a unha República de Santos» ${ }^{46}$.

Uns anos antes, o napolitano Vicenzo Cuoco fixera a mesma observación desde a efémera «república partenopea» de 1799 en Nápoles, outro intento de transformar unha monarquía borbónica nunha especie de república representativa. As verdadeiras repúblicas, escribiu, só podían ser fundadas onde xa existise «a memoria dalgún goberno anterior mellor[,] como a Carta Magna fora o compás da revolución inglesa ${ }^{47}$. Non existía tal memoria en Nápoles nin tampouco na América española. En ambos os casos os revolucionarios inclináronse non pola «representación», senón pola «virtude», e non perseguiron unha sociedade comercial moderna, senón o regreso ás repúblicas do mundo antigo.

\footnotetext{
${ }^{45}$ Ver Adelman, Jeremy (2006): Sovereignty and Revolution in the Iberian Atlantic, Princeton, Princeton University Press, 261-263.

${ }^{46}$ Discurso de Angostura, en Obras completas, III, 681.

${ }^{47}$ Cuoco, Vicenzo (1806): Saggio storico sulla rivoluzione di Napoli, Milán, 117.
} 
As marcadas diferenzas canto ás súas orixes culturais entre os británicos do norte e os españois do sur tiveron como resultado a creación de dous tipos de proxecto republicano moi diferentes e que foron convenientemente cualificados como republicanismo «antigo»e republicanismo «moderno». A distinción foi descrita á perfección por Benjamin Constant no seu traballo de 1819 «De la liberté des anciens comparée a celles des modernes» [Sobre a liberdade dos antigos comparada coa dos modernos»]. As repúblicas antigas, sinalou, eran necesariamente pequenas sociedades militarizadas que implicaban a todos os seus cidadáns no proxecto común do goberno e a defensa ${ }^{48}$. A súa forza tenaz, que Montesquieu considerara «o máis importante», era «a virtude». As ditas comunidades estaban compostas, na tan influente nova descrición do modelo antigo que fixo Rousseau, non por homes, senón por cidadáns, e a vida privada dos individuos era asumida enteiramente pola vida pública da comunidade, a res publica. «O que os antigos denominaron liberdade», escribiu Constant, supuña, en efecto, «un sometemento completo do individual á autoridade común» [«l'assujettissement complet de l'individu à autorité de l'ensemble»]. O cidadán antigo, como cidadán, «toma decisións tanto en época de paz como de guerra", mais "como individuo queda circunscrito, observado e criticado en todas as súas accións» [«décide de la paix et de la guerre; comme particulier, il est circonscrit, observé, réprimé dans tous ses mouvements»] ${ }^{49}$.

As repúblicas modernas, pola contra, eran sociedades comerciais extensas cuxos cidadáns gobernaban por representación e cuxa vida privada permanecía diferenciada da pública, e, de feito, a esfera pública existía para protexer e mellorar a privada. Eran constitucionais e, no sentido familiar, tamén liberais. A liberdade concedida pola república moderna e, consecuentemente, pola sociedade democrática liberal deu orixe ao que en termos rousseaunianos era case unha contradición, «o cidadán privado». No que os seus inimigos do século XIX

${ }^{48}$ Constant, Benjamin (1997): «De la liberté des anciens comparée à celle des modernes», en Écrits politiques (textes choisis, présentés et annotés par Marcel Gauchet), París, Gallimard, 595-596. Esta é probablemente a fonte temperá máis importante sobre a moi debatida distinción entre liberdade "positiva» e liberdade «negativa», conceptos que son algo semellantes, aínda que de certo non idénticos, aos de liberdade «antiga» e liberdade "moderna» de Constant. Sobre a explicación máis recente e convincente, ver Nelson, Eric (2005): «Liberty: One Concept Too Many?», Political Theory, 33, 58-78. Tamén ver Castro Leiva, Luis / Anthony Pagden (2001): «Civil Society and the Fate of the Republics of Latin America”, en Sudipta Kaviraj / Sunil Khilnani (eds.): Civil Society: History and Possibilities, Cambridge, Cambridge University Press, 179-203.

49 «De la liberté des anciens comparée à celle des modernes», 594. 
denominaron «a república liberal burguesa», pola contra, aos homes éralles posible ser homes e cidadáns. Non tiñan necesidade de ser virtuosos, só de respectar a lei. Dispuñan de acceso, malia que unicamente como votantes, á vida política, o que lles fora negado no período de monarquías do Antigo Réxime; deste xeito, estáballes permitido converterse en auténticos seres sociais autónomos, aínda que non totalmente súbditos do Estado de que formaban parte. O Estado liberal, noutras palabras, outorgaba aos seus cidadáns non só liberdade política, senón ademais liberdade civil. Para os máis modernos, os trazos máis definitorios do republicanismo foron a súa confianza na representación e a súa dedicación ao comercio. Isto por si só puido asegurarlle ao corpo cidadán a necesaria liberdade respecto da restrición (e, en particular, liberdade contra a interferencia por parte do Estado) necesaria para desenvolver a súa propia vida privada.

Certamente sería unha mera simplificación insinuar que, en tanto que as tradicións políticas e culturais do norte predispuxeron os americanos británicos cara ás concepcións modernas da república, os americanos españois eran arrastrados unicamente polos modelos antigos. Mais, falando en termos xerais, é certo afirmar que os crioulos tan só perseguiran un obxectivo, o libre comercio, polos rápidos beneficios económicos que achegaría sen dúbida. Tiñan pouco cońecemento da confianza que Europa depositaba no comercio como motor civilizador e que xa desacougara a Montesquieu e, a través del, a Campomanes e a Jovellanos, e eran aínda menos conscientes da ambición de exportar os seus beneficios a toda a humanidade. Alén diso, tampouco comprendían a idea de representación ou non amosaban especial simpatía por ela. Porque, malia ser improbable que, como afirmou Bolívar, a constitución moral dos novos Estados aínda non fose apta para a representación, era totalmente certo que a representación implicaba, mesmo no sentido restritivo en que o termo foi empregado a finais do século XviII, unha ampla concesión que sen dúbida ameazaría a hexemonía da elite crioula. Unha especie de «republicanismo antigo», pola contra, parecía ofrecer a posibilidade de rexeneración económica e social dentro dunha comunidade unida na que, dado que a república antiga era oligárquica, as elites antigas podían acumular todo o poder e a riqueza. Unicamente unha república en esencia antiga podería, segundo Bolívar, «rexenerar o carácter e os costumes que a tiranía e a guerra non deu [sic]» e só a dita república sería capaz de crear nas selvas tropicais «un Poder Moral, tirado do fondo da escura antigüidade, e daquelas esquecidas Leis que mantiveron algún tempo a virtude 
entre os gregos e romanos». Mesmo os censores romanos, como instrumento máis prezado de consenso público no mundo antigo, estaban destinados a ser un elemento da nova república americana. En Angostura, Bolívar informou os lexisladores nun fragmento que, polo menos canto aos sentimentos que expresa, puido ser directamente tirado de Rousseau:

Tomemos de Atenas o seu Areópago, e os gardiáns dos costumes e das Leis; tomemos de Roma os seus Censores e os seus Tribunais domésticos, e facendo unha santa alianza destas institucións morais, anovemos no Mundo a idea dun Pobo que non se contenta con ser Libre e forte, senón que quere ser virtuoso. Tomemos de Esparta os seus austeros establecementos e formando destes tres mananciais unha fonte de virtude, deamos á nosa República unha cuarta potestade cuxo dominio sexa a infancia e costumes e o corazón dos homes, o espírito público, os bos costumes e a moral Republicana ${ }^{50}$.

Segundo dixo o xeneral chileno Bernardo O’Higgins en xuño de 1822, aludindo ao $\mathrm{Du}$ Contrat social de Rousseau, esta república antiga e democrática había fundarse no "pacto que debe facer deste mundo unha nación republicana»"

Todo isto podería parecer, como un observador anónimo e hostil referiu en 1820 , pouco máis ca a imaxe dun «mundo que, dalgunha maneira fantástica, semella ser feito para xustificar o pasado e alimentar as esperanzas sobre o futuro ${ }^{52}$. Mais a súa natureza quimérica, que Bolívar xa observou e rexeitou, non foi o seu único defecto. Porque era precisamente esta «fonte de virtude», como o propio Constant recoñeceu nun artigo de Le Courrier français que atacaba «O Libertador» alcumándoo de novo e diminuído Napoleón, o que Bolívar sempre entendeu baixo o termo de «liberal». Era a liberdade que podía estenderse só a aqueles capaces de practicar a "virtude republicana» e esta por definición referíase unicamente a aqueles poderosos dabondo para desempeñaren un cargo na vida po-

${ }^{50}$ Discurso de Angostura, en Obras completas, III, 692.

${ }^{51}$ Obras completas, I, 619. No capítulo vi de Du Contrat social, Rousseau fai referencia ao acordo inicial que transforma un conxunto de individuos nun "corps moral e collectif» como un "pacte». Rousseau, Jean-Jacques (1964): «Du Contrat social», en CEuvres complètes (édition publiée sous la direction de Bernard Gagnebin et Marcel Raymond), París, Bibliothèque de la Pléiade, III, 361. Bolívar era o orgulloso dono da copia de Napoleón de Du Contrat social.

52 Reflexiones sobre el estado actual de la América, ó cartas al Abate de Pradt, Madrid, 1820, iv. O autor é anónimo. Ver tamén Castro Leiva, Luis (1985): La Gran Colombia: una ilusión ilustrada, Caracas, Monte Alva Editores. 
lítica. Do mesmo xeito, a «opinión pública» á que el e outros moitos líderes dos movementos independentistas se referían decontino non era, coma para o resto de pensadores liberais desde Constant a Tocqueville e John Stuart Mill (e como o fora para Montesquieu), unha forza para ser usada co fin de conter as ambicións daqueles que se atopaban no poder. Era, pola contra, a expresión dunha vontade política colectiva, un sinónimo da volonté générale rousseauniana. As novas repúblicas americanas espańolas, desde México ata a Arxentina, eran todas de formas a miúdo diverxentes, intentos por crear sociedades verdadeiramente novas no Novo Mundo. O paradoxal é que os materiais intelectuais en que se inspiraron os seus defensores eran tamén antigos.

Os antigos Reinos de Indias non só se separaran, senón que tomaran unha forma política e abrazaban unha ideoloxía política que era totalmente diferente de todo o que os precedera e nada que fose imaxinable no mundo antigo hispano. Debido a que os ideólogos dos movementos de liberación hispanoamericanos, a diferenza dos angloamericanos, nunca miraron atrás cara a ningún pasado imaxinario como modelo para o seu propio futuro, non puideron apropiarse da clase de institucións de liberalización que podían rastrexarse no pensamento de Jerónimo de Uztáriz, Campillo y Cossío e Campomanes, aínda que só sexa porque finalmente deron lugar non ao tipo de comunidade panhispana que Aranda esperara, senón, pola contra, ás desastrosas reformas borbónicas. E, por isto, o que eles tentaran crear de maneiras diferentes foi unha forma de modernidade que, ideoloxicamente polo menos, tiña moito máis en común coa Revolución Francesa ca coa norteamericana. Os experimentos hispanoamericanos de republicanismo como intentos de modernidade estaban condenados, coma sen dúbida tamén os franceses, a fracasar. Mais ninguén podía sabelo daquela e como experimentos foron moito máis audaces ca ningún dos imaxinados polos pais fundadores dos Estados Unidos, dedicados firmemente a recrear a «Revolución Gloriosa». 
HISTORIA CULTURAL DA

AMBICION: POLÍTICOS E TOLOS NOS INICIOS DO MUNDO CONTEMPORANEO

Javier Moscoso

Instituto de Historia

Consejo Superior de Investigaciones Científicas 



\section{INTRODUCIÓN ${ }^{1}$}

Na súa introdución a $A$ cartuxa de Parma, sostén Lampedusa que o escritor francés a quen cońecemos como Stendhal se contentaba con modestísimos desexos. Fronte ao afán de riqueza e de poder visible, por exemplo, en Le Comte de Monte-Cristo ( $(\mathrm{O}$ conde de Monte Cristo»), de Dumas, e, abofé, na encarnación do arribismo e da ambición desmedida que representa o personaxe de Rastignac en La Comédie humaine ( A comedia humana»), de Balzac, Stendhal recoñece que «as espinacas e Saint-Simon [foran os seus] únicos praceres perdurables» ${ }^{2}$. O autor de Vermello e negro evitaba así caer no universo apaixonado do seu máis egrexio personaxe, Julien Sorel, epítome da ambición no mundo literario da Restauración francesa.

No que segue, quixera presentar un pequeno capítulo da historia xeral das paixóns humanas. Por unha banda, quixera subliñar a significación cultural da ambición a comezos do século XIx. Pola outra, quixera chamar a atención sobre algúns dos tratamentos, xa fosen físicos ou morais, explícita ou implicitamente empregados para combater as paixóns vehementes. Isto levaranos a examinar algúns dos remedios utilizados nos asilos e institucións de saúde mental, mais tamén noutros moitos contextos. Posto que a ambición se atopaba no centro do debate político e dos acontecementos recentes, a Restauración francesa produciu un número moi importante de tratados sobre hixiene e saúde pública que incluían, con frecuencia, recomendacións para evitar, regular ou restrinxir os estados e paixóns inmoderados. Desde tratados de hixiene militar ata guías de turismo, gustaríame explicar non só as formas culturais en que algunhas mudanzas do corpo poden sentirse, expresarse, reprimirse ou conceptualizarse, senón tamén o

\footnotetext{
${ }^{1}$ Este texto foi realizado a partir do material recompilado no meu Promesas incumplidas: una historia política de las pasiones, publicado en Madrid, por Taurus. Alí atopará o lector interesado información adicional sobre a historia e o tratamento da ambición na primeira metade do século XIX.

${ }^{2}$ Lampedusa, Giuseppe Tomasi de (2012): «Prólogo», en Stendhal, La Cartuja de Parma, Barcelona, RBA, 9-27. Este prólogo é un fragmento de Lampedusa (1996): Stendhal, Barcelona, Península.
} 
xeito en que o estudo desas mesmas emocións e paixóns humanas deita luz sobre fenómenos culturais máis amplos.

\section{UN ESTUDO DE CASO}

O paciente que coñecemos como monsieur Nicolas era un home educado, de temperamento nervioso, de constitución delicada e fráxil. Posuía, no entanto, unha intelixencia cultivada; falaba varias linguas e escribía con facilidade tanto en verso como en prosa. $\mathrm{O}$ doutor Leuret, un dos máis importantes alienistas da primeira metade do século xIx francés, descríbeo como unha persoa caprichosa, dominada polas súas paixóns, disposto sempre a atopar razóns para lanzar sobre os demais a culpa da súa propia imprevisión. A súa estraña conduta conducírao ás fronteiras da miseria. Ao parecer dérase aos excesos na comida e abusara do matrimonio. Tampouco a súa entrada no hospital-prisión de Bicêtre cara a 1830 fora a primeira nunha institución semellante. Moito polo contrario, o protagonista desta historia clínica xa se fixera encerrar nunha casa de alienados de provincias, onde permanecera durante dous anos, primeiro como residente e máis tarde, e contra todo prognóstico, en calidade de subdirector.

Leuret cóntanos na súa historia clínica que comezou por interrogalo. $\mathrm{O}$ interno respondeu ás preguntas de bo grado, explicándose de maneira sinxela, elegante mesmo. Transmitiulle ao médico que acudira a París cunha misión do Goberno que non fora recompensada ${ }^{3}$. Como resultado desta traizón, vírase acosado polas débedas. $\mathrm{O}$ seu arresto tivera lugar pola súa propia iniciativa. Entrou na garita de garda e exclamou: "Arréstenme!, non teño medios de subsistencia». A policía conduciuno entón á Prefectura, de onde pasou pouco despois á sección de alienados. Mesmo cando a súa detención fora voluntaria, o paciente dicía preferir a prisión, pois a súa acción tińa como obxectivo humillar o orgullo dos seus pais, que non quixeran facerse cargo das súas débedas. Cando a entrevista estivo a piques de concluír, Nicolas solicitoulle ao médico que lle dixese se o consideraba ou non alienado e volveu expresar o seu desexo de ser conducido a prisión. Leuret, porén, non lle deu resposta ningunha e limitouse a sinalar que volverían verse pronto. Mesmo cando creu observar no seu paciente un estado de confusión moi común nos maníacos, a fasquía do rostro de $\mathrm{Ni}$ -

\footnotetext{
${ }^{3}$ Leuret, François (1846): Des indications à suivre dans le traitement moral de la folie, París, Le Normant.
} 
colas fora correcta, as súas maneiras adecuadas e a súa actitude calmada. Só en ocasións pasara case sen transición da indignación á risa.

Durante o resto do día, no entanto, o interno enfureceuse por todo e contra todos. O doutor foi informado de que o interno entrara nun verdadeiro acceso de manía furiosa, que o seu discurso fora inconexo e a súa faciana vermella, inflamada. Cando foi visitalo ao día seguinte atopouno nunha sala común aos tolos máis violentos, deitado e retido por medio dunha camisa de forza, falando en italiano e en francés, mantendo unha inflexión de voz en harmonía co senso das súas palabras. Repasaba en voz alta a historia da súa vida, unha historia desgraciada e triste, composta de «esperanzas truncadas, expectativas rotas, abandono dos seus, privacións, miseria, detención inxusta, brutalidades odiosas e talvez agora unha morte escura da que os autores quedarán impunes» ${ }^{4}$. Ao dicir do médico, tratábase dun delirio horrible que exaltaba a súa imaxinación e o impregnaba todo dunha anguria inexpresable. O interno queixábase sobre todo do trato recibido de dous vixilantes do hospital. Quería matalos, e dicía: «Che piacere! vedere questi duo corpi morti e ballare! Io faro una vendetta terribile... terribile. Déanme auga. Io faro una vendetta terribile... terribile. Morte ao vixilante! Morte ao médico, e maldición! Sairei de aquí vivo ou morto? Non sei nada». E así continuaba a repetir: «Io faro...» etc., con voz ameazante e sombría.

É importante subliñar, antes de máis, que o noso protagonista non parece un doente mental. Fíxose deter como unha especie de vinganza. Quere ingresar en prisión para humillar o orgullo dos seus pais. Cre que ten dereito a favores que non recibiu. Describe o seu destino en termos de promesas rotas e expectativas frustradas. Afirma que foi traizoado: polos seus pais, polos seus socios, polos seus amigos. Mesmo cando a palabra «ambición» nunca aparece mencionada nesta historia clínica, só a combinación de ambición truncada e de expectativa rota permite entender a súa situación. Da mesma forma ca moitos outros cidadáns franceses da época, Nicolas non está disposto a aceptar que a súa nacenza determine o seu destino. Coma tantos outros, antes e despois del, a súa actitude aliméntase dunha paixón inflamada e vehemente que reclama o que Tocqueville denomina unha «revolución democrática» ${ }^{6}$.

\footnotetext{
${ }^{4}$ Leuret (1846): Des indications..., 35.

5 Ídem.

${ }^{6}$ Tocqueville, Alexis de (1856 [1952]): L’Ancien régime et la Révolution, París, Garnier, 84.
} 


\section{AS FORMAS CULTURAIS DA AMBICIÓN}

A ambición non é, xaora, unha paixón moderna. Malia as múltiples voces que durante a Idade Media e o mundo moderno a teñen asociado coa loucura, co pecado ou co demo, seguiu a formar parte do clima moral e político da Europa dos séculos XVII e XVIII. Os historiadores da economía recoñeceron a súa influencia na formación do capitalismo, o mesmo que os historiadores da política viron a súa sombra no contexto da Revolución Inglesa ou da colonización española das Américas. No Romanticismo, a meirande parte da discusión sobre esta paixón afunde as súas raiceiras nas fontes clásicas, xa sexa no contexto relixioso ou na súa dimensión lai$\mathrm{ca}^{7}$. En calquera das súas formas canónicas, quer identificada co desexo de riqueza, quer co de gloria ou de recoñecemento, a ambición formaba parte das paixóns que conducían á ruína, á loucura ou á deshonra. Ligada á doenza, comparada moitas veces coa peste ou co cancro, resultado dun desequilibrio humoral, a ambición perdeu durante a Ilustración parte das súas connotacións relixiosas para entrar nun discurso medicalizado do corpo, que perdurou ao longo do século XIX.

Esta é a primeira lección que cabe extraer da lectura dun dos textos máis relevantes para o estudo das paixóns, publicado por Jean-Baptiste Félix Descuret en $1841^{8}$. Redactado a partir da consulta dunha enorme variedade de casos médicos e historias clínicas, esta "gramática das paixóns humanas», como a denominaba o seu propio autor, pretendía investigar a súa influencia na aparición e o desenvolvemento de diversos estados patolóxicos. A través de centos de observacións e rexistros, seguindo as directrices doutros tantos alienistas, este médico francés tentaba explicar as principais características das paixóns humanas, así como o tratamento hixiénico e moral dos desarranxos racionais ou sociais aos cales esas mesmas paixóns podían dar lugar. A súa topografía emocional incluía, por suposto, as emocións descritas polos grandes compendios da antigüidade, como a avaricia, a ira ou o orgullo, mais adentrábase tamén nalgúns outros estados da relaxación moral, como a gula, a preguiza ou a libertinaxe. A súa prosa obsesiva e

${ }^{7}$ Verbo do capitalismo e as paixóns, véxase o clásico de Albert O. Hirschman (1977) The Passions and the Interests: Political Arguments for Capitalism before Its Triumph, Princeton, NJ, Princeton University Press. De modo máis xeral, tamén é recomendable Deirdre Nansen McCloskey (2016): Bourgeois Equality: How Ideas, Not Capital or Institutions, Enriched the World, Chicago/Londres, Chicago University Press.

${ }^{8}$ Descuret, Jean-Baptiste (edición de 1851): La médecine des passions : ou, les passions considérées dans leurs rapports avec les maladies, les lois et la religion, Liexa, Lardinois. 
o seu desexo de exhaustividade conducírono igualmente ao estudo do amor e da nostalxia, da ambición e do coleccionismo.

A ambición, porén, non era unha emoción máis entre outras, senón a forza que guiara a historia recente de Francia. Baixo a súa funesta sombra producíranse os acontecementos de 1789 que conduciran primeiro ao Terror e logo á Ditadura. Nisto a posición de Descuret coincidía co xuízo realizado por outras grandes plumas da Restauración. No seu pequeno tratado sobre as paixóns, publicado en Lausana en 1826, madame de Staël, por exemplo, tamén consideraba a ambición como o verdadeiro obstáculo para o benestar das nacións ${ }^{9}$. Como apuntara o médico Alibert, a ambición consistía nunha inopinada necesidade de envexar e desexar a posición dos diferentes en clase ou en nacenza. Era unha paixón composta de orgullo, obstinación e tola esperanza, un desexo violento e continuo de elevarse por riba dos outros, unha sede inmoderada de gloria, de grandeza e de honores, tanto como de riquezas ${ }^{10}$. Para Descuret, que presenciara a epidemia de cólera que se desencadeou en París en 1832, a ambición podía compararse a esa doenza. Para o médico Étienne Tourtelle, a ambición era unha forma de cancro que se alimentaba dos desexos e esperanzas das súas vítimas e que causaba en ocasións unha fatal desesperación capaz de consumir e destruír o corpo ${ }^{11}$.

As mesmas consideracións poden atoparse noutros moitos autores da Restauración. Para Chateaubriand, por exemplo, o rei proletario (que é como este autor se refería a Napoleón) nivelara os rangos sociais, alimentando o orgullo e o amor propio $^{12}$. Para Tocqueville, para Josep de Maistre, para Edmund Burke, ao outro lado do canal, a revolución e a ditadura non podían comprenderse sen a manía da elevación. Para o abate Barruel, por exemplo, a conspiración revolucionaria apoiárase na Enciclopedia, na expulsión dos xesuítas, na aniquilación dos corpos relixiosos, na proliferación de libros anticlericais, nos espolios e na violencia perpetrada e xustificada no nome da tolerancia, mais tamén, e esta é a parte que aquí interesa, sobre

\footnotetext{
${ }^{9}$ Staël, Madame de (1796 [2000]): De l'influence des passions sur le bonheur des individus et des nations, suivi de [1813] Réflexions sur le suicide, París, Rivages Poche, 87.

${ }^{10}$ Véxase Kete, Kathleen (2012): Making Way for Genius: The Aspiring Self in France from the Old Regime to the New, New Haven, Yale University Press.

${ }^{11}$ Tourtelle, Étienne (1823): Élémens d'hygiène, ou de l'influence des choses physiques et morales sur l'homme, et des moyens de conserver la santé, París, Rémon, vol. 2, 523; Alibert, Jean-Louis (1825): Physiologie des passions, París, Béchet, vol. I, 330 e ss.

${ }^{12}$ Chateaubriand, François-René de (1849-1850 [2006]): Memorias de ultratumba, trad. de José Ramón Monreal, 4 vols., Barcelona, Acantilado, vol. 2, 1337.
} 
os honores da academia, sobre a facilidade para satisfacer as paixóns relacionadas co orgullo e a vaidade ${ }^{13}$. Os ambiciosos, escribía Balzac, «teñen sede dun só tipo de auga que se consegue en certa fonte, e en xeral é auga estancada; para a tomaren, venderían as súas mulleres e os seus fillos, venderían as súas almas ao diaño» ${ }^{14}$.

\section{CASAS DE ALIENADOS}

Esta conexión entre paixóns inmoderadas e eventos políticos foi tamén unha das características máis notables das novas institucións de saúde mental. Despois de 1789, os manicomios enchéronse de persoas cuxa condición remitía, dunha maneira ou doutra, á ambición insatisfeita: Anne-Antoniette-Charlotte Blottefière, por exemplo, unha cortesá de Versalles afectada de "delirios de grandeza», permaneceu en Charenton dezaoito anos. O 14 de decembro de 1819, Joseph Heim foi diagnosticado de delirio ambicioso sen axitación. Morreu dous anos máis tarde. En Noitevella de 1819, M. Schuller, un varón de 59 anos, ingresou na mesma institución. Saíra da casa en xaneiro e desde entón caera nun estado de tristura, coa presenza de ideas fixas e violentas. O seu delirio? Pensou que podería abrir a brasserie máis bela de Europa. Morreu un ano despois, sen cura ${ }^{15}$. Malia que algúns dos internos sofren delirios extraordinarios, a maioría dos síntomas refírense a asuntos e expectativas comúns. No caso de François Geoffroy, ingresado o 13 de abril de 1818, os médicos consideran que o estado deste músico do cuarto rexemento é consecuencia das vexacións ás que foi sometido por parte dos seus camaradas. Unha situación parecida preséntasenos no caso de Grégoire Delaroche, antigo alumno da École politechnique a quen os seus superiores someteron a diversas inxustizas durante unha viaxe a Metz. Ao seu retorno, Delaroche comezou a ter delirios, a se crer o autor da natureza, capaz de lles guindar tronos aos seus inimigos ${ }^{16}$.

${ }^{13}$ Barruel, Augustin (1800 [2005]): Mémoires pour servir à l'histoire du jacobinisme, s. l., Elibron Classics, vol. 1, 332.

${ }^{14}$ Balzac, Le Père Goriot, 229.

${ }^{15}$ Todas as historias clínicas proveñen de París, do arquivo do hospital de Charenton: Archives départementales du Val-de-Marne, Créteil; Série X: Régistres d'observations médicales de Charenton. Registres d'observations médicales, hommes et femmes.

${ }^{16}$ Ibídem, Histoire 36. 
Os verbos que se utilizan nos rexistros das observacións médicas non deixan lugar a dúbidas sobre a natureza alucinatoria ou ilusoria do mal que os aflixe. "Il s'imagine»; «il se figure». En moitos casos, o seu estado está acompañado de ideas que se xulgan extravagantes, incoherentes e ambiciosas. $M$. Maurel crese mariscal de Francia. Joseph Chévalayre crese traizoado por todo o mundo. Joseph Ferrand pensa que a súa muller e os seus fillos queren envelenalo. Claude Riambourg, capitán de artillaría, condecorado coa Lexión de Honor, pensa que a súa familia conspira contra el, que queren apartalo da inmensa fortuna que, segundo el, lle legou a súa defunta nai ${ }^{17}$. A mesma situación se atopa no universo das mulleres. Madame Senleac pensa que o diaño quere deitarse con ela. Madame Boulle crese a criminal máis grande da Terra. A madame Blanchet aparéceselle Deus ou cre velo en todas as persoas que se lle presentan. A partir da morte repentina do seu home, madame Henry comezou a concibir ideas extravagantes. Cría que debía casar con Luís XVIII. Nada estraño se se pensa que Jean-François Camiat, empregado dunha refinaría de azucre, de 30 anos, ingresado o 4 de maio de 1818, se ergueu un día berrando que era o fillo de Luís XVI. Máis tarde creuse Xesucristo. Louis-Constant Dubuison non se contentaba con ideas modestas de riqueza ou de grandeur. El cría ser o sol ${ }^{18}$. El era nada menos que o sol: «le soleil». Ignace-François Brosard era a persoa máis vella do asilo. Fixera había pouco os 100000 anos. O seu mal comezou coa morte da muller da que estaba namorado ${ }^{19}$.

A maioría destes pacientes pertencían a zonas rurais ou pequenas cidades. Había moitos militares, desde logo, mais tamén outros asociados a profesións liberais. Se a ambición, razoaba Descuret, atrapa por igual os académicos, os músicos ou os artistas, é tan só porque ningún estaba disposto a aceptar que a súa posición dependese de ningunha outra cousa ca do propio mérito ou da propia capacidade. Se os novelistas, os escritores, os músicos e os artistas, os militares e os funcionarios sucumben aos feitizos desta paixón desmedida, non é só consecuencia do seu carácter específico ou da súa peculiar fisioloxía laboral, senón resultado dunha migración incontrolada desde a provincia á capital e desde o campo á cidade. Todos eles habitan un lugar específico, urbano. O Goberno real, logo de abolir as liberdades provinciais, escribía Tocqueville, e

\footnotetext{
${ }^{17}$ Ibídem, Histoire 234.

${ }^{18}$ Ibídem, Histoire 66.

${ }^{19}$ Ibídem, Histoire 68.
} 
suplantar todos os poderes locais nas tres cuartas partes de Francia, pasou a se ocupar de todos os negocios públicos, desde os máis pequenos ata os máis grandes. Como consecuencia, París deixou de ser a capital e pasou a se converter en Francia. París, sentenciaba Tocqueville, chegou a ser o país enteiro ${ }^{20}$. Era alí onde os novos cidadáns se desprendían da súa pel de provincianos coa idea de acadaren unha posición desde a que divisar un futuro fermoso.

Na súa guía turística dos Alpes, François-Emmanuel Fodéré, catedrático de Hixiene Pública da Universidade de Estrasburgo, explica como, durante a segunda metade do século XVIII, todas as pequenas cidades de Francia tiñan «a manía da nobreza»; unha paixón que chegaba ao punto de que calquera artesán que lograse ter ingresos de mil coroas aspiraba a se converter en conde ou barón. No seu tratado de medicina das cidades e do campo, Jean-Marie-Placide Munaret tamén explicaba como o amor propio recrutaba as súas vítimas no interior das provincias: «É alí — di- onde os profesionais de calquera idade [...] imaxinan que son nomeados cabaleiros da Lexión de Honor, ou membros de dúas ou tres academias provinciais». «Teño a honra de vos facer observar — escribiu Rastignac na novela Le Père Goriot, de Balzac_- así mesmo, que só hai vinte procuradores xerais en Francia e que sodes vinte mil aspirantes ao cargo, entre os cales se atopan moitos farsantes que venderían a súa familia para ascenderen un banzo» ${ }^{21}$.

Non hai nada sorprendente neste contraste entre a vida pura do campo e os perigos emocionais da cidade. Mentres que no campo, explicaba o alienista Esquirol, a meirande parte das doenzas mentais se orixinaban a partir de paixóns simples, como o amor, a ira ou as pelexas domésticas, nas cidades e nos centros urbanos a loucura parecía ser o produto das feridas do honor, das ambicións truncadas e das mudanzas inesperadas de fortuna. Xunto coas paixóns naturais, determinadas polo desexo natural de supervivencia, reprodución e perpetuación da raza, é dicir, xunto coas paixóns vinculadas aos instintos e desexos naturais, hai algunhas outras que os médicos denominan factices (literalmente, paixóns artificiais ou de ficción), que se atopan na orixe da alteración da razón contemporánea: a ambición, a cobiza, o amor á gloria, a celebridade ou a autoestima. Igual ca Julien Sorel, o mozo protagonista da novela de Stendhal, o habitante da provincia soña cunha vida e un futuro diferentes, aliméntase dos desexos da alma

\footnotetext{
${ }^{20}$ Tocqueville, El Antiguo Régimen y la Revolución, 180.

${ }^{21}$ Balzac, Honoré de (2010): Papá Goriot, trad. de Cristina Piña e Mariano Fiszman, Bos Aires, Losada, 279.
} 
antes ca das necesidades do corpo. Os libros, escribía Rousseau, que poderían servirlle de consolo ao campesiño, desgraciado tan só porque cría selo, non semellan feitos máis ca «para que aborreza o seu estado, estendendo e fortalecendo o prexuízo que llo presenta como desprezable» ${ }^{22}$. Non transcorrera unha legua despois de que se despedise de madame de Renal e «xa non pensaba máis ca na dita de ver unha capital, unha gran cidade guerreira como Besançon $»^{23}$.

O caso de monsieur Nicolas tamén é moi revelador neste sentido. Igual ca outros moitos, este mozo saíra das provincias pensando que merecía o que nunca foi quen de obter. Chamábase a si mesmo un león, un tigre. Ameaza con matar os celadores e o propio médico. No seu delirio, mencionaba algúns dos «seus irmáns de infortunio». Un deles é, como é lóxico, Jean-Jacques Rousseau. Envelenados polas falsas ideas que fixeron de si mesmos, «non querendo pasar por pailáns, aborrecen da vila [...] e van á capital, onde [...], despois de levaren unha vida infame, morren na miseria e deshonrados» ${ }^{24}$. A voz de Jean-Jacques Rousseau constitúe, en efecto, unha excepción ao clima xeral que valora a cidade por riba do campo, o sofisticado por diante do sinxelo ou o luxo por riba da felicidade. A súa reivindicación do natural fronte ao civilizatorio percorre, efectivamente, o conxunto da súa obra filosófica: desde os discursos á máis famosa das súas novelas, Julie ou la Nouvelle Héloïse ("Xulia ou a nova Heloísa»), publicada por vez primeira en 1761. Desde as primeiras páxinas, o filósofo móstrase disposto a combater ese frívolo resplandor que cega os necios. Ao abrigo dos praceres imaxinarios, "os habitantes amoréanse, apíñanse en tan só uns puntos do territorio, deixando o resto ermo e deserto» ${ }^{25}$.

\section{O TRATAMENTO DA AMBICIÓN}

Distinguen os tratados entre os remedios denominados «hixiénicos» e os remedios morais. Entre os primeiros recoméndanse a vida campestre, os paseos prolongados, por veces a caza, cando as forzas do doente o permitan. Posto que un dos primeiros efectos da ambición consistía en alterar as dixestións, a alimentación debía ser lixeira e

\footnotetext{
${ }^{22}$ Rousseau (1761 [2013]): La nueva Eloísa, edición de Lydia Vázquez, Madrid, Letras Universales, 130.

23 Stendhal (2015): Rojo y negro, trad. de Antonio Vilanova, Barcelona, Penguin Clásicos, 264.

${ }^{24}$ Rousseau, La nueva Eloísa, 131.

${ }^{25}$ Rousseau, La nueva Eloísa, 132.
} 
a bebida refrescante. Hai que procurar, así mesmo, aumentar as horas de sono e acompañar o descanso con baños tépedos e friccións apropiadas. Para o médico Olivier, da Facultade de Medicina de Montpellier, algúns dos efectos da ambición combátense moderando os desexos e mostrando que a felicidade só se atopa no que el mesmo denomina «a honesta mediocridade» e a grata medianía ${ }^{26}$. Posto que a ambición se incuba na infancia, os tratadistas recomendan combatela non xa desde a infancia, senón desde o mesmo nacemento ${ }^{27}$. No que respecta ao contido da educación, non haberá que se exceder cos fillos nin nas loanzas nin nas recompensas; así como tampouco haberá que gabar en exceso a súa beleza ou a súa intelixencia ${ }^{28}$. A mellor educación moral consistirá, pola contra, naquela que permita fatigar o ambicioso por medio de obstáculos cada vez máis complexos, de xeito que, sendo humillado o seu orgullo, chegue el a comprender a irrelevancia dos obxectos que o seducen e a incerteza das recompensas que o esperan. Haberá que lle facer ver con frecuencia a situación de individuos de posición moito máis infeliz, afastalo das grandes cidades, sobre todo da corte, dos arribistas e dos novos ricos. Haberá, finalmente, que procurar que busque a amizade de homes contentos da súa sorte e da súa fortuna, así como reeducar a súa imaxinación, escribe o médico Ménuret, «mediante o traballo e a mediocridade» ${ }^{29}$.

Sempre que o ambicioso non sucumbise por completo á manía, o mellor medio para evitar os seus desvaríos consistía en distraelo con ocupacións agradables que incluían, en case todos os casos, a recomendación de viaxar ou regresar ao campo. Non hai doenza nin mal orgánico causados polas paixóns para os que o doutor Vitet, no seu monumental Le Médecin du peuple («O médico do pobo»), non recomende o retorno a unha vida rural:

As paixóns, particularmente a cólera, o odio e os celos, cando se acompañan de falta de apetito, perturban sensiblemente as funcións do estómago, o cal adoita conducir a un

${ }^{26}$ Ollivier, Alain (1856): Étude physiologique et médicale sur les passions [tese], Montpellier, Faculté de Médecine, Baldy et Roger, 105.

${ }^{27}$ Munaret (1840): Du médecin des villes et du médecin de campagne : moeurs et science, viii. Para Munaret, non só se esquecen nas escolas as relacións do home san co home doente; tamén se esquece a relación entre a física e a moral, así como a dos elementos físicos cos obxectos externos, e da moral coas fases variables da sociedade. É tamén tarefa do médico, engade, observar a relación da sociedade coa arte de consolar, de preservar e de curar.

${ }^{28}$ Ollivier, Alain (1856): Étude physiologique et médicale sur les passions [tese], Montpellier, Faculté de Médecine, Baldy et Roger, 106.

${ }_{29}^{9}$ Ídem, 31. 
sentimento doloroso na rexión epigástrica e dixestións laboriosas, a miúdo acompañadas de diarreas. Para combater estes efectos, dispoñede que o doente se afaste tanto como sexa posible das ideas que o atormentan, que viva no campo, que monte a cabalo dúas veces ao día, facede que prefira o alimento vexetal, que non frecuente máis ca compañas xoviais e que non consulte con médico ningún ${ }^{30}$.

Nos dez volumes que compoñen esta influente obra, publicada en 1804, practicamente non hai doenza de orixe pasional cuxo remedio non inclúa a recomendación de enviar o doente á contorna rural. A apoplexía, a parálise, o frenesí, a epilepsia, a catalepsia, a eclampsia, a contusión, o espasmo ou a convulsión, cando sexan resultado de paixóns violentas, combátense con viaxes polo campo ${ }^{31}$. No caso dos doentes coléricos, a solución é o campo. Para os melancólicos, os monomaníacos, tamén o campo. Para toda xente de negocios e artistas, particularmente obreiros varudos, de temperamento sanguíneo, que fixesen fortuna abondo para abandonaren o seu traballo e que padezan afeccións hipocondríacas, nada como a honesta actividade labrega e o paseo pintoresco. Para aqueles casos máis extremos, non só cabe recomendar meter o paciente no campo, senón tamén meter o campo, xa sexa por vía oral ou por vía rectal, no corpo do paciente. Os libertinos, por exemplo, non beberán máis ca leite de cabra ou de mula; os hipocondríacos, infusión de valeriana. Nos casos máis graves de síncopes pasionais, haberá que «cubrir cunha compresa de mostaza as pernas e as coxas [do paciente], introducir nos ollos unha ou días gotas de álcali volátil, mesturado con auga a partes iguais, verter no nariz e na boca tintura de asafétida e introducir polo ano unha forte infusión de flores de montaña [bétoine de montagne] $\aleph^{32}$.

A posición de Vitet non é un caso illado. Durante a primeira metade do século XIX, cóntanse por decenas os textos de tratamento moral da doenza nos que se recomenda viaxar ao campo. Ao final da súa tese de doutoramento sobre o tratamento moral, Jean-Côme Piétri declara que os espectáculos e os paseos forman un grupo interesante de remedios morais, pero o máis eficaz de todos eles é o espectáculo da natureza nos seus diferentes aspectos. Só a contemplación da natureza, explica este mozo doutor, é capaz de distraer e de ocupar o doente ata

\footnotetext{
${ }^{30}$ Vitet, Louis (1804): Le Médecin du peuple ou traité complet des maladies dont le peuple est communment affecté : ouvrage composé avant la Révolution française, 10 vols., Lyon, chez les frères Perisse, vol. 4, 9.

${ }^{31}$ Ibídem, vol. 1, 197.

${ }^{32}$ Ibídem, vol. 3, 180-181.
} 
o extremo de el afastar de si o sentimento do seu mal. «Só a contemplación da natureza permite gustar do benestar indefinible que se sente ante a visión dunha bela pradeira ${ }^{33}$. Nunha tese fascinante no tratamento moral da doenza mental, Jean-Jacques-Philippe Mathieu compara as formas de tratamento baseadas na conmoción e a descomposición do paciente por medio do medo coa forza, igualmente sorprendente, producida pola beleza. $\mathrm{O}$ remedio para as ideas fixas atópase na presenza doutras paixóns máis fortes que actúan como un contrapoder fronte á ditadura á que o corpo foi sometido. A combinación do medo e da beleza, da dor e do pracer, servirá, en palabras de Mathieu, para contrarrestar o orgullo co patriotismo, o egoísmo coa relixión, a ambición coa insignificancia ${ }^{34}$.

Esta combinación de dor e pracer, esta correspondencia entre o terror e a beleza, ten un nome. Chamámoslle, a partir da obra de Edmund Burke ou Immanuel Kant, «O sublime», un concepto que adoita limitarse ao eido da estética e a teoría da arte. Mais nin na teoría nin na práctica foi o sublime un concepto alleo ao tratamento moral da ambición. Pola contra, a invocación deste sentimento como unha forma de ébranlement, como unha sacudida estética capaz de aterrorizar a imaxinación ata o extremo de poder reintroducir un equilibrio na economía moral das paixóns, atópase en fontes de moi distintos tipos. O médico Alibert, por exemplo, recórdanos que, na antiga Grecia, os discípulos de Esculapio lles recomendaban aos ambiciosos dirixirse aos cumios do monte Osa e contemplar desde alí os cantís aos que foron guindados os titáns. Neste monte, escalado no seu día por Alexandre Magno, o ruído das correntes do Peneo, mesturado co estrépito do vento, servía para convencer os soberbios de que as glorias futuras estaban lonxe de mereceren a felicidade da seguridade presente. Un dos documentos máis interesantes a este respecto é a tese de doutoramento lida na Facultade de Medicina de Estrasburgo en 1824, obra de Jean-Baptiste Collin. Se ben o comezo da tese se abría cun pequeno tratado sobre as paixóns do home e a súa influencia sobre a economía animal, a segunda parte contiña un ensaio sobre os sentimentos do belo e o sublime considerados como tratamento moral das paixóns $s^{35}$. Ao xuízo des-

${ }^{33}$ Piétri, Jean-Côme (1836): Sur l'influence du moral dans le développement et le traitement des maladies [tese], París, Didot le jeune, 21.

${ }^{34}$ Mathieu, Jean-Jacques-Philippe (1832): Traitement moral des maladies [tese de doutoramento], París, Université, 11.

${ }^{35}$ Collin, Jean-Baptiste (1824): Des passions de l'homme : et de leur influence sur l'économie animal; avec un essai sur le sentiment du beau et du sublime, considéré comme traitement moral des passions [tese sostida na Facultade de Medicina de Estrasburgo, 1824], Estrasburgo, F.G. Levraud. 
te autor, o mellor remedio para combater a epidemia de ambición requiría enfrontarse ao que o filósofo Immanuel Kant chamara o «sublime matemático», un sentimento de dor que xorde da apreciación estética das magnitudes da natureza (ou da historia) e que combina o terror presente na imaxinación co pracer da resistencia da vontade.

Nun estudo pioneiro sobre a relación entre o romanticismo e o alpinismo, a historiadora norteamericana Marjorie Hope Nicholson examinou o que ela mesma denominou unha «revolución do pensamento», a mesma revolución que conducira as primeiras xeracións do século XIX ás mesmas montañas que poucas xeracións antes foran consideradas obxectos desprezables. Anticipando algunhas das formulacións da nova historia das emocións, Hope Nicholson falaba dunha dinámica sensorial que permitira unha modificación das paixóns e emocións estéticas. Nun libro moito máis recente, Ann C. Colley deu conta do esgotamento do sublime no decenio de $1830^{36}$. Entre ambas, téńense publicado importantes obras que relacionan o mundo do alpinismo coa xeoloxía ou coa cultura de masas. As razóns argüídas por todos estes autores relativas ás circunstancias que propiciaron o desenvolvemento do alpinismo son todas sólidas e compatibles coa evidencia proveniente dos textos de viaxes e viaxeiros que comezaron a aparecer a primeiros do século xix, xa fose no ámbito científico ou no comercial. Engánanse, ao meu xuízo, aqueles académicos que pretendan explicar os desexos de elevación sen teren en conta o universo emocional relativo á historia da ambición, por unha banda, e os remedios morais ou os tratamentos hixiénicos propostos para a combater. Nunca a igualdade e a liberdade estiveron máis afastadas entre si ca nos cumios dos Alpes. O xogo dunha vontade libre, capaz de se sobrepor á paixón máis forte que a imaxinación fose capaz de aturar, constituía o epítome do retorno da cidade ao campo. Nunca antes de 1830 se escalou un só monte en Europa movido o individuo pola ambición. Polo contrario, o turismo do sublime formaba parte da regulación romántica das paixóns, da humillación dos mesmos sentidos de todos aqueles que, cegos de ambición, creran igualarse aos deuses.

O retorno ao campo, a subida aos Alpes, a ascensión e a negación da axencialidade fronte ao destino cruel, o medo producido pola observación da inmensidade da natureza e da historia tiveron o efecto sorprendente de humillaren os sentidos, de frearen a imaxinación, de limitaren as paixóns, de mostraren as bondades da humilde medio-

${ }^{36}$ Colley, Ann C. (2010): Victorians in the Mountains: Sinking the Sublime, Farnham, Ashgate. ISBN-13: 978-1409406334 [recibido o 10/10/2014]. 
cridade. Quizais sexa certo, como dicía o pensador liberal Isaiah Berlin, que somos máis os herdeiros do Romanticismo do que o somos da Ilustración. Esta é unha idea sorprendente que foi difícil de discutir, sobre todo porque aínda temos a sensación de que o Romanticismo ten que ver coa arte e os valores estéticos. O que chamamos Romanticismo, porén, quizais poida conceptualizarse mellor se pensamos que con esa palabra nos referimos tamén ao conxunto de prácticas relacionadas co que chamei aquí o tratamento moral da ambición.

\section{CONCLUSIÓNS}

Desde os días en que Lucien Febvre escribiu o seu agora famoso artigo sobre a historia das emocións, o estudo das vantaxes e inconvenientes da historia para a vida, por utilizar a expresión de Nietzsche, converteuse nun problema cada vez máis premente. No último parágrafo dese texto, o historiador francés avogaba por unha nova conexión entre a vella e a nova historia; por unha historia sentimental de rexurdimentos e resurreccións. Debaixo da historia coñecida de Europa, escribiron Horkheimer e Adorno nun fragmento moi pouco citado da súa Dialektik der Aufklärung ( Dialéctica da Ilustración»), «circula unha historia subterránea sobre o destino dos instintos e as paixóns humanas, reprimidos e distorsionados pola civilización». Malia todas as súas limitacións, a historia das emocións ou, como eu prefiro chamarlle, a historia das experiencias pode axudarnos a destapar esas historias subterráneas, esas verdades «sen aparencia [de verdade]», como gustaba de dicir Foucault. Se estamos interesados nas emocións non é porque consideremos que calquera cousa deba ser historizada, ou porque queiramos pór en cuestión a posición universalista dalgúns científicos naturais, senón porque queremos volver á historia explicativa, porque queremos explorar as conexións entre as emocións e a mudanza social, ou, se se prefire unha formulación máis académica, porque, usando as palabras de Jules Michelet, queremos saber como poderiamos administrar os bens dos vivos sen sermos os administradores das emocións dos mortos. «Para xulgar un home — escribía Balzac_- hai que estar polo menos no secreto do seu pensamento, das súas desditas, das súas emocións: non querer coñecer da súa vida máis ca os acontecementos materiais é facer cronoloxía, a historia dos necios» ${ }^{37}$.

\footnotetext{
${ }^{37}$ Balzac (2014): La piel de zapa, trad. de Marcos Mayer, Bos Aires, Losada, 97.
} 


\section{ESCAVANDO TÚNELES: A DANZA NOS ALBORES DO SÉCULO XXI}

Ana Abad Carlés

Membro do Núcleo de Estudios Antropológicos

sobre Danza, Movimiento y Sociedad

(IDAES-UNSAM)

Bos Aires 



\section{INTRODUCIÓN}

A carreira daquelas mulleres que participaron de forma creativa e artística, quer como creadoras, quer como axentes de creación no ámbito do ballet, foi lentamente eclipsada e, en moitos casos, esquecida. Diversos artigos aparecidos na prensa nos últimos anos cuestionan a ausencia de mulleres nos eidos de creación e poder, xa non só na esfera do ballet, senón no da danza en xeral (Garafola 2005, Higgins 2009, Mackrell 2009, Jennings 2013). Nesta breve exposición presentaranse algunhas cuestións que ter en conta á hora de abordar este tema e ofreceranse estatísticas, así como testemuños persoais, que axuden a entender e explicar algúns dos factores que contribuíron a esta mudanza no sector.

\section{U-LAS MULLERES?}

Cando se observa o acontecido nas artes ao longo do século xx, é doado recoñecer unha pauta no xeito en que as mulleres atoparon o seu camiño de forma lenta, mais obstinada, nos diferentes medios artísticos. O camiño é longo e difícil de seguir e a realidade amosa que, malia que as mulleres se introduciron de maneira importante nestes sectores profesionais, continúan a ser unha minoría nos seus postos de liderado. Na Gran Bretaña, o Cultural Leadership Programme (CLP) decidiu realizar un estudo co que poder dar cifras reais á situación actual das artes deste país e descubriu que, por cada líder feminina no sector, había 2,5 líderes masculinos (Carty 2010).

No ballet, e na danza en xeral, as mulleres fóronse facendo cada vez máis invisibles conforme avanzaba o século, ata case desapareceren da escena. A compracencia con que este feito foi recibido é cando menos preocupante.

Virginia Woolf foi quizais unha das mulleres que mellor articularon a situación destas, non só nas artes, senón no campo profesional en xeral. A súa obra 
A Room of Onés Own (Un cuarto de seu) (1929) é unha longa reflexión sobre o papel da muller no seu tempo, pensamento que se estendería a gran parte da súa obra literaria. Woolf comprendeu coma poucas persoas a importancia de entender o noso pasado:

Non podemos comprender o presente se o separamos do pasado. Se queremos entender o que estamos a facer agora [...] debemos esquecer que somos, por agora, nós mesmas. Debemos converternos na xente que fomos hai dúas ou tres xeracións ${ }^{1}$. (Woolf 1978: 8)

Para comprender a realidade actual é necesario pensar no destino que tiveron esas xeracións de coreógrafas que abriron e continuaron camiños durante o s. Xx. Ao mesmo tempo que a súa carreira e obras desaparecían das páxinas da historia, a súa posición como modelos para as futuras xeracións foi perdendo forza. Quizais os seus camiños non fosen continuados polas xeracións actuais ao se esqueceren os seus puntos de vista e as súas posicións dentro do contexto da danza do século pasado.

Estes son tempos de corrección política nos que ás mulleres occidentais se nos lembra decontino que temos igualdade de oportunidades. No entanto, a realidade demostra que as mulleres non posúen a representación que teñen os homes nos postos de poder e decisión. Outro recente estudo realizado por Skillset no Reino Unido demostra que, neste país, «as mulleres teñen moita menor representación e están moito peor pagas nas industrias creativas e culturais» (Arts Professional 2010: 2). A diferenza en salarios é dun $20 \%$ menos, malia que «un $93 \%$ das empregadas teñen unha licenciatura, comparado cun $78 \%$ dos homes» (íd.). Outro estudo realizado por Arts Council England tamén recollía datos como o feito de «só un $25 \%$ dos teatros estaren dirixidos por directoras artísticas» $»^{2}$ (íd.).

A maioría das compañías de ballet estiveron dirixidas por homes durante as últimas dúas décadas. Cando Assis Carreiro, directora de Dance East ${ }^{3}$, organizou

\footnotetext{
${ }^{1}$ "We cannot understand the present if we isolate it from the past. If we want to understand what it is that [we] are doing now [...] [we] must forget that we are, for the moment, ourselves. We must become the people that we were two or three generations ago».

${ }^{2}$ "Women are sorely under-represented and underpaid across the creative and cultural industries [...] 93\% of female employees holding a degree compared to $78 \%$ of men [...] just $25 \%$ of theatres are run by female artistic directors».

${ }^{3}$ Dance East é unha das axencias nacionais de danza do Reino Unido.
} 
nos anos 2003 e 2005 os seus primeiros Rural Retreats para directores de compañías de ballet, os números indicaban que, dos 26 directores de compañías que representaron 15 países no retiro do ano 2005, 19 eran homes. Dos outros 18 que foran invitados, mais que non puideron asistir, todos eran homes (Dance East 2005). O retiro do ano 2005, «Ballet into the $21^{\text {st }}$ Century» ( $\mathrm{O}$ ballet no s. XXI»), amosaba unha realidade clara: das 44 compañías de ballet representadas, só seis tiñan unha muller como directora.

Gráfico 1: Dance East, Rural Retreats: Ballet into the $21^{\text {st }}$ Century (2005). Dirección das compañías de ballet

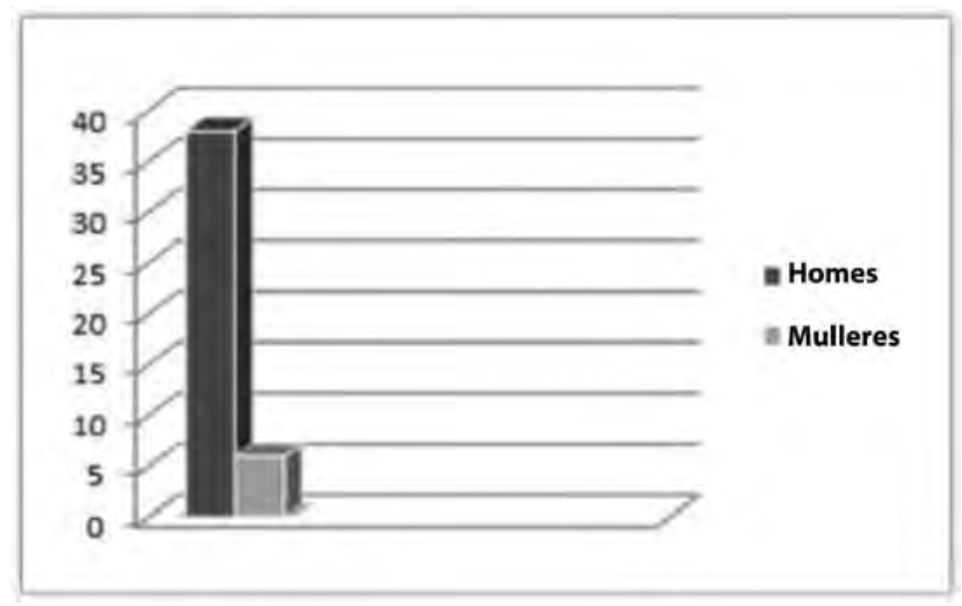

Nunha mesa redonda organizada por Dance Umbrella e Dance UK no ano 2009, a xornalista e crítica Judith Mackrell comentaba os seguintes datos: en 2008, das 59 compañías importantes de danza estadounidenses, 45 estaban dirixidas por homes, 10 por mulleres e as restantes catro estaban dirixidas por un equipo de home e muller. De igual xeito, ao se examinaren as subvencións outorgadas polo National Endowment for the Arts en 2008, as cifras indicaban que, dos 18 coreógrafos que recibiran subvencións, 13 eran homes, cunha media de subvención de 10000 dólares, mentres que a subvención media recibida polas mulleres era de 5000 dólares (Dance Umbrella 2009). 
Gráfico 2: Dirección das principais compañías de danza nos EUA e subvencións do NEA para coreografía (2008)

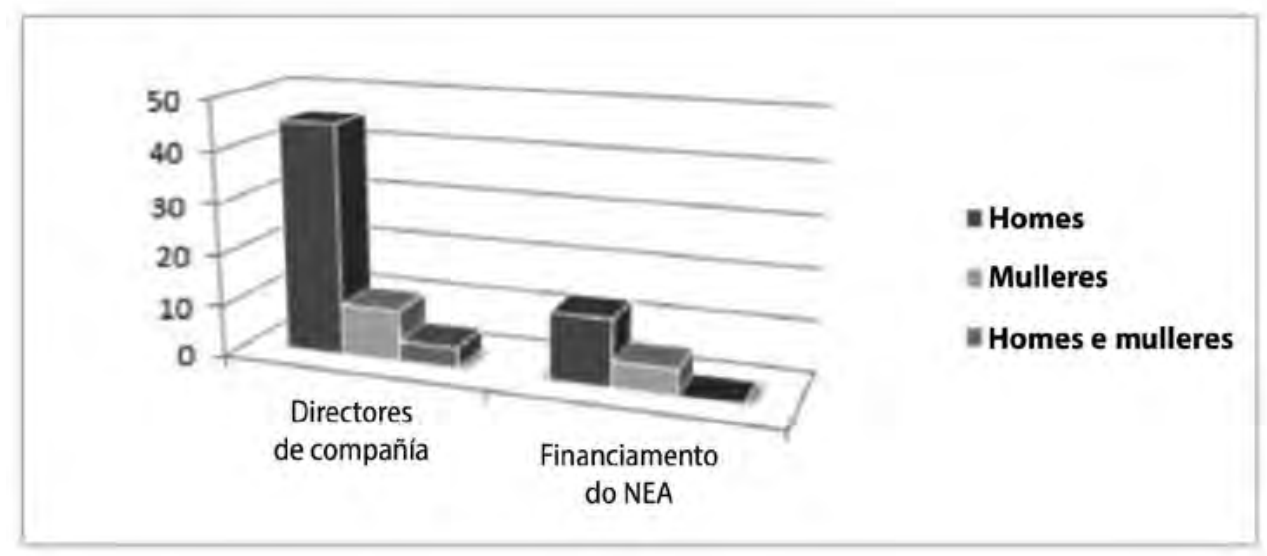

Cando se examina o novo repertorio creado durante este tempo, semella haber un desequilibrio entre as obras creadas por homes e por mulleres. Porén, as rapazas estudan coreografía en moito maior número ca os rapaces ${ }^{4}$. Cando nunha ocasión tivemos a oportunidade de mandar unha pregunta sobre as posibles causas polas que existe unha escaseza de coreógrafas a unha entrevista aberta con Nacho Duato, director daquela da Compañía Nacional de Danza, retransmitida pola Cadena SER, a súa resposta foi a seguinte: «Non sei, mais obviamente non se debe á falta de talento con respecto aos homes» (Duato 2003).

A opinión de Duato, malia demostrar un alto grao de empatía coa situación, quedaba moi afastada da realidade visible da Compañía Nacional de Danza, que, nese mesmo ano de 2003, de entre un repertorio de máis de cincuenta obras, tiña tan só unha creada por unha muller: Trece gestos del cuerpo (1987), de Olga Roriz. Sete anos despois, a compañía incrementou o seu repertorio a noventa obras, de entre as cales unicamente outra obra, Nasciturus (2003), de Yoko Taira, fora creada por unha muller. Isto deixaba unha porcentaxe de produción feminina na Compañía Nacional de Danza do 2,2 \% durante a época de Duato como direc-

\footnotetext{
${ }^{4}$ Ver o artigo "Invisible Women», de Susan Crow. É a nosa propia experiencia tamén tras estudarmos coreografía en diferentes institucións e a diverso nivel. Como profesora de coreografía na actualidade, debo dicir que a situación non mudou. Dos 18 alumnos do curso de licenciatura en danza profesional e musicais (2009-2010) en The Urdang Academy (Londres), só un terzo eran rapaces.
} 
tor (Compañía Nacional de Danza de España 2011). Se o talento das mulleres é realmente igual ao dos homes, como é posible que a creación feminina fose tan escasa dentro da compañía durante tan longo tempo?

Cathy Marston é unha das poucas mulleres que traballa como coreógrafa de ballet nestes momentos. Cando lle formulamos a mesma pregunta ca a Duato, daba razóns moi diferentes á hora de explicar a falta de coreógrafas que traballaban na actualidade: «[S]er bailarina de ballet é moi competitivo. É difícil ser bailarina e coreógrafa ${ }^{5}$ (Marston 2003). Este punto de vista da incompatibilidade de bailar e coreografar ao mesmo tempo estaba apoiado tamén por Susan Crow, exbailarina do Royal Ballet e coreógrafa, cando explicaba:

Creo que ten que ver co traballo [...]. [A] última vez que alguén me preguntou isto foi en 1989 [...] e unha das cousas que dixen daquela era que hai algo que se ten que ter en consideración e é un problema práctico, e é que, co repertorio clásico, as mulleres teñen que traballar máis, e por isto teñen menos tempo ${ }^{6}$. (Crow 2003)

Outra razón na que tanto Crow como Marston coincidían era un aspecto moito máis intanxible e que afecta á educación e desenvolvemento das bailarinas de ballet. $\mathrm{O}$ coidar e educar (nurture) semella ser un termo chave no que ambas as coreógrafas coincidían; a necesidade de ser coidada e educada ou de coidar e educar a outros. Parece coma se no centro da educación feminina na danza quedase esta necesidade enraizada na propia cultura institucional e que pasou a formar parte do desenvolvemento psicolóxico das alumnas de ballet: «[M] esmo se teñen creatividade, elas queren que o seu desenvolvemento se faga a través dos homes» ${ }^{7}$ (Marston 2003).

Dun xeito semellante, e dando un exemplo dunha xeración anterior, Susan Crow formulaba a cuestión de se esta necesidade de coidar era unha característica feminina pola que «[se nos desvía] cara ao coidado do desenvolvemento dunha compañía [...] [e] doutros bailaríns antes que crear obras propias? [...] Non sei» ${ }^{8}$ (Crow 2003).

${ }^{5}$ «[...] it's very competitive to be a ballet dancer. It's difficult to be a ballet dancer and a choreographer».

${ }^{6}$ «I think it has to do with the work [...]. [T] he last time I was asked this question was in 1989 [...] and one of the points that I made then was that there is something that one has to bear in mind and it is a very practical problem and it is that with the classical repertoire, the women are working harder, so then they have less time».

7 «[...] even if they've got creativity, they want to be nurtured by men».

8 «[...] to get diverted into the nurturing of a company [...] [and] other dancers rather than to make their own work? [...] I don't know». 
Esta non é unha noción nova; varios estudos de psicoloxía realizados por Jeanne Block en 1984 e recollidos por Hilary M. Lips cando analizaba a falta de poder das mulleres nos ámbitos institucionais chegaban a unha conclusión semellante: «ás rapazas — comentaba — animábanas a botar raíces, aos rapaces aprendíanlles a botar ás» ${ }^{9}$ (Lips 1994: 90).

Outro aspecto importante mencionado por Crow e moi particular no medio do ballet ten que ver coa dificultade de poder desenvolver unha forte personalidade individual no marco dunha compañía «que baila o repertorio tradicional, onde sempre hai un gran corps de ballet de mulleres [...]. [H] ai unha especie de opresión determinada por este corps de ballet e que exerce moita presión sobre as mulleres no ballet á hora de se axustaren a certo prototipo, principalmente pola competición ${ }^{10}$ (Crow 2003).

Semella que as razóns prácticas e psicolóxicas que poñen obstáculos a que calquera muller adopte a carreira coreográfica son diversas. Como se explicou, se a coreógrafa xorde dentro dunha compañía de ballet institucionalizada, os requirimentos desta arredor da necesidade de a coreógrafa bailar o repertorio clásico dificultan de máis que a creadora realice as súas obras. É certo que tanto Bronislava Nijinska como Ninette de Valois conseguiron facelo, mais as presións en materia técnica hoxe en día son moito maiores. Se a coreógrafa desenvolve o seu interese coreográfico noutro marco, daquela existe unha dificultade engadida á hora de realizar a transición dunha carreira como intérprete a coreógrafa. A meirande parte dos bailaríns masculinos dan este paso cando están na trintena. Para a maioría das mulleres, se planean a fin da súa carreira como bailarinas a esta idade, está a presión biolóxica de empezaren unha familia (Marston 2003). Deste xeito, a maternidade dalgunha maneira convértese no feito fundamental no momento da transición profesional na que a maioría dos coreógrafos comezan a súa carreira ${ }^{11}$.

Mesmo no caso de a carreira como coreógrafa se iniciar, as dificultades de atopar subvencións, financiamento etc. realmente complican a supervivencia na

\footnotetext{
9 "[...] girls, she said, were encouraged to develop roots, boys were taught to develop wings».

${ }^{10}$ "[...] the difficulty of developing a strong individual personality within the framework of a classical ballet company "that dances the traditional repertoire, where there's always a very large corps de ballet of women [...] that there's a kind of oppression that the corps de ballet requires and that there is a tremendous amount of pressure on women in ballet to conform to certain mould, because of the competition"”.

${ }^{11}$ Bronislava Nijinska e Twyla Tharp foron nais e coreógrafas, mais as demandas de coidar un bebé estaban en oposición constante coas necesidades da súa profesión. Tharp, en especial, explicaba todo isto na súa autobiografía Push Comes to Shove (1992).
} 
profesión. Obviamente, este non é un problema endémico na esfera feminina, nin tan sequera específico da danza, posto que afecta a todo o mundo artístico. Porén, poida que todas estas dificultades lle dean á artista algo máis en que pensar á hora de considerar un futuro profesional no eido da coreografía.

Mais, se ben todos estes obstáculos de índole práctica e psicolóxica poden explicar que moitas mulleres decidan non asumir o papel de coreógrafas, aínda non fica moi clara a case total ausencia de mulleres que se dediquen á coreografía na actualidade.

\section{O MITO DA «PIONEIRA»: ESCAVANDO TÚNELES}

Resulta sorprendente que Cathy Marston sentise, ao falar da súa carreira, que estaba «escavando túneles para as xeracións futuras». "Estou abrindo vieiros» ${ }^{12}$ (Marston 2003).

A utilización do termo "pioneira» en referencia ao traballo de calquera coreógrafa debería ser posto en cuestión. Se "pioneira» é aquela persoa que abre vieiros para as xeracións futuras, daquela Marie Sallé sería a "pioneira» das mulleres coreógrafas xa no s. XviII (Abad Carlés 2013). No entanto, parece coma se, sempre que unha muller empeza unha carreira que non está asociada ao seu sexo, se convertese nunha pioneira, malia o número de mulleres que xa ocuparan eses postos con anterioridade ao longo da historia.

É unha situación complexa, mais non semella que sexa unha coincidencia. Se as mulleres ou os homes posúen modelos, calquera tipo de modelo, é máis doado seguilos como exemplos ou, polo menos, ver con normalidade o papel e a posición que representan. Se non se ten un modelo ou exemplo que seguir, comeza un camińo que está máis relacionado coa figura de Isadora Duncan: unha figura solitaria que tenta atopar o seu lugar nun medio artístico hostil. Máis unha vez, a artista ha de "escavar un túnel» que, malia ter sido escavado moitas veces con anterioridade, volveu ser tapado tan pronto como chegou ao seu final. O sentido de continuidade histórica desaparece e á muller tócalle empezar de novo desde o principio. Seguindo aquelas palabras xa citadas doutra gran "pioneira», Martha Graham, «ela ten que atopar o seu propio baile» (Tharp 1992: 78). Abofé, esta

${ }^{12}$ «[...] burrowing the tunnel for future generations. I'm forwarding the path». 
premisa adoita traer consigo a creación de obras de grande orixinalidade, pero igualmente dificulta de máis o proceso de aprendizaxe. Realmente resulta difícil imaxinar a Balanchine atopando o seu propio baile e desbotando o seu pasado nos Teatros Imperiais. De feito, Twyla Tharp, quen si seguiu o principio recollido por Graham, actualmente dá aos futuros artistas un consello moi diferente: «Cariño, fíxose todo xa. Non hai nada realmente orixinal. Nin Homero nin Shakespeare e obviamente ti tampouco. Acéptao»" ${ }^{13}$ (Tharp 2003: 22).

É moi difícil enunciar con certeza e dentro dun aparato metodolóxico concreto a causa pola que a tradición coreográfica feminina chegou a esta pausa. Quizais non é posible atopar unha resposta dentro dos límites impostos pola actual forma de abordar a evidencia histórica e a súa avaliación. Como Susan Bennett comentou: «[M]alia saberse efectivamente que se ten que facer outro tipo de traballo, o método historiográfico tira da nosa historia dun xeito inevitable - mesmo das nosas historias alternativas- e pona na traxectoria do que xa se cońeceu $»^{14}$ (Gale e Gardner 2000: 53).

Semella que existe un consenso xeral no mundo das artes arredor da cuestión da creatividade feminina e a necesidade urxente de facer algo ao respecto, aínda que só sexa por salvagardar figuras que sirvan como modelos para as xeracións presentes e futuras. Esta cuestión ha de traer consigo novas formas de investigación e novas preguntas sobre a validez con que ata agora se mantiveron certos criterios, regras e xuízos considerados sagrados. Algúns permanecerán, mais algúns deberán reaxustarse. Poida que non sexa doado atopar unha conexión entre a perda coreográfica que afectou ao repertorio de ballet nos últimos anos e o sexo dos artistas que crearon as obras. Porén, si semella haber unha conexión entre tal perda e a situación actual neste medio artístico. Novas preguntas xorden arredor deste tema: por que a situación da muller retrocedeu tanto no ámbito do ballet e da danza en xeral nos últimos decenios? Cales foron as causas que levaron as mulleres a unha situación de profundo mutismo nunha arte que crearon e que sostiveron durante décadas? Houbo outros factores de tipo sociocultural que ata agora permaneceron ausentes do discurso teórico e que fixeron que, na época de aparentes políticas de igualdade entre homes e mulleres, estas perdan un territorio no que se vińan movendo, na aparencia, con facilidade?

\footnotetext{
${ }^{13}$ «Honey, it's all been done before. Nothing's really original. Not Homer or Shakespeare and certainly not you. Get over yourself».

14 «[...] despite knowing that there is other work to be done, historiographic method inevitably pulls our history - even our alternative histories - back into the trajectory of what has always already been known».
} 
Ann Daly lembraba a Albert Einstein e a súa crenza en que a formulación de problemas é máis esencial ca a súa solución, xa que as respostas chegan co tempo e o realmente importante é a creación de novas preguntas que nos fagan repensar as nosas propias ideas e metodoloxías: «Porque nunca se van producir novas formas de cońecemento e de mirar e comprender se se seguen a facer as mesmas preguntas» ${ }^{15}$ (Daly 1998: 79).

${ }^{15}$ «For new knowledge or new ways of looking and understanding will never be produced if the same old questions keep getting asked». 


\section{REFERENCIAS BIBLIOGRÁFICAS}

AвAD CARlÉs, Ana (2013): Coreógrafas, directoras y pedagogas: la contribución de la mujer al desarrollo del ballet y el cambio de paradigma en la transición al s. XXI. Tese de doutoramento. València, Universitat Politècnica.

Arts Professional (2010): «The Second Sex?», Arts Professional, 227, 2.

Burns, Susanne / Sue Harrison (2009): Dance mapping: a window on dance, 2004-2008, Londres, Arts Council England.

Carty, Hilary (2010): «Leading women», Arts Professional, 228, 7.

Compañía Nacional de Danza de España (2011 [última actualización]): Repertorio (http://cndanza.mcu. es/esp/repertorio/repertorio.htm) [última consulta: xuño, 2011].

Crow, Susan (2002 [última actualización]): «Invisible Women» (http://Londresdance.com/articles/ features/invisible-women/) [última consulta: xuño, 2011].

Crow, Susan / Jennifer JaCKson (2002 [última actualización]): BIG Discussion: The Role of the Artistic Director (http://www.ballet.co.uk/magazines/yr_02/nov02/big_on_the_ad_0101.htm) [última consulta: xuño, 2011].

DAly, Ann (1998): «Woman, Women, and Subversion: Some Nagging Questions from a Dance Historian», Choreography and Dance, 5:1, 79-86.

Dance East (2015): Rural Retreats: Ballet into the $21^{\text {st }}$ Century, Ipswich, Dance East.

Gale, Maggie B. / Viv Gardner (eds.) (2000): Women, Theatre and Performance: New Histories, New Historiographies, Manchester, Manchester University Press.

Garafola, Lynn (2005): Legacies of Twentieth-Century Dance, Middletown, CT, Wesleyan University Press. Higgins, Charlotte (2009 [última actualización]): «Dance World 'failing to celebrate women'», The Guardian, 11-5-2009 (http://www.guardian.co.uk/stage/2009/may/11/dance-choreographers-womensadlers-wells?INTCMP=SRCH) [última consulta: xuño, 2011].

JENNINGs, Luke (2013 [última actualización]): «Sexism in dance: where are all the female choreographers?», The Guardian, 28-4-2013 (http://www.guardian.co.uk/stage/2013/apr/28/women-choreographers-glassceiling) [última consulta: xuño, 2013].

Lips, Hilary M. (1994): «Female Powerlessness: A Case of “Cultural Preparedness”?», en H. Lorraine Radtke / Henderikus J. Stam (eds.), Power/Gender: Social Relations in Theory and Practice, Londres/Thousand Oaks/Nova Delhi, SAGE Publications, 89-107.

Mackrell, Judith (2009 [última actualización]): «The ladies vanish», The Guardian, 13-5-2009 (http:// www.guardian.co.uk/stage/2009/may/13/dance-sadlers-wells-southbank) [última consulta: xullo, 2011].

Mackrell, Judith (2009 [última actualización]): «Vanishing pointe: where are all the great female choreographers?», The Guardian, 27-10-2009 (http://www.guardian.co.uk/stage/2009/oct/27/where-arethe-female-choreographers) [última consulta: agosto, 2011].

SKILlset (2010): Women in the Creative Media Industries, Londres, Skillset.

Tharp, Twyla (1992): Push Comes to Shove, Nova York, Bantham Books.

Tharp, Twyla (2003): The Creative Habit: Learn It and Use It for Life, Nova York, Simon \& Schuster.

Woolf, Virginia (1929 [2009]): A Room of One's Own, Adelaide, South Australia, University of Adelaide (http://ebooks.adelaide.edu.au/w/woolf/virginia/w91r/index.html) [última consulta: xullo, 2011]. 


\section{Material aUdiovisual}

Dance Umbrella (2009): Where Are the Women? (presentado por Judith Mackrell) [gravación sonora en liña en formato MP3], Londres, Dance UK.

MacGibbon, Ross (2001): Bourne to Dance [gravación de televisión en vídeo], Londres, Channel Four.

\section{COMUNICACIÓN PERSOAL}

Crow, Susan (2003): entrevista con Ana Abad Carlés, Londres, Royal Festival Hall.

DuATo, Nacho (2003): Entrevista Abierta, 24-11-2003 (www.cadenaser.es).

Marston, Cathy (2003): entrevista con Ana Abad Carlés, Londres, Royal Opera House. 

O xuízo e a condena de Galileo constitúen o mellor exemplo do conflito que enfronta ciencia e relixión? A ciencia, baseada na razón e na experimentación, estaba destinada a chocar coa relixión, fundamentada na autoridade e no dogma? Como é que aínda hoxe hai xente honrada que se pregunta por que a Igrexa tratou de silenciar a Galileo?

Roma resistíase a aceptar a idea de que a que se move é a Terra, non o Sol; porén, esta oposición histórica non foi inevitable. Se os teólogos da época aprendesen a respectar os límites do seu verdadeiro ámbito de competencias (como despois fixeron), podería iniciarse un frutífero diálogo mesmo na época de Galileo. De feito, os pioneiros da revolución científica foron persoas ás que lles importaba a relixión; así, Copérnico non foi ordenado sacerdote, mais si era membro do clero e cóengo da súa diocese, en Polonia. Albergaba a convicción de que o movemento da Terra non resultaba incompatible coa fe cristiá e, así, dedicoulle a súa famosa obra De revolutionibus orbium colestium («Sobre o movemento das esferas celestiais») ao papa Paulo III. O astrónomo alemán Johannes Kepler, que descubriu as tres leis que describen como se desprazan os planetas arredor do Sol, tiña intención de facerse pastor da Igrexa luterana e víase como intérprete da obra de Deus na natureza. O home de quen xurdiu a idea da gravitación universal, Isaac Newton, pasou máis tempo a comentar as Escrituras que a traballar nos problemas da física e a matemática.

A tensión entre o que a ciencia comezaba a descubrir e o que a Biblia semellaba ensinar pode estudarse desde diversas perspectivas. Unha delas, moi popular, derívase do modelo de guerra que elaboraron dous historiadores decimonónicos: John William Draper e Andrew Dickson White. History of the Conflict Between Religion and Science («Historia do conflito entre a relixión e a ciencia»), de Draper, apareceu en 1874, e os dous tomos da History of the Warfare of Science with Theology in Christendom ("Historia da guerra da ciencia coa teoloxía na cristiandade»), de White, en 1896; de ambas se publicaron varias edicións e foron traducidas á maioría dos 
principais idiomas de Occidente. Segundo declaraban os autores, ao depositar un a súa confianza en textos autoritarios e no control eclesiástico, xerábase un modo de pensar que impedía adquirir un auténtico coñecemento da natureza; e, así, a guerra non só era inevitable, senón tamén un deber para todo aquel que amase a verdade.

\section{POR QUE TAL INCOMPATIBILIDADE?}

Un dos aspectos máis curiosos do caso Galileo radica nas dificultades que teñen os estudosos para responderen o que parece ser unha pregunta carente de maior complicación: cando se recońeceu a incompatibilidade do copernicanismo coas Escrituras? É importante saber a resposta para entender os riscos (se é que algún había) que corría Galileo ao defender a teoría de que a Terra se move, de modo que preguntémonos que textos bíblicos afirman claramente que a Terra está en repouso e o Sol en movemento. A resposta é que ningún. Achamos pasaxes nas Escrituras como «Unha xeración pasa, outra vén; mais a terra sempre subsiste. O sol levántase, o sol ponse; apresúrase a volver ao seu lugar» (Eclesiastés 1, 4-5), mais expresións tales que «o sol levántase» e «o sol ponse» seguen a ser comúns na actualidade, e a ninguén se lle ocorrería prohibilas por moito que saibamos que, en sentido literal, son falsas. A única pasaxe de toda a Biblia da que se podería dicir que afirma o contrario sen ambigüidade é unha de Xosué, «O sol parou no medio do ceo, e non se apurou a se pór polo espazo de case un día enteiro» (Xosué 10, 13). Se Xosué fixo que o sol ficase quedo, daquela debíase de mover!

Hai tempo que chegamos a recońecer que, se o Sol semella nacer polo leste e pórse polo oeste, non é porque se mova polo ceo, senón porque a Terra xira sobre o seu eixe de oeste a leste. A linguaxe cotiá non debería confundirse coas expresións científicas. Nas Escrituras non se debate sobre astronomía, pois, como expresou un contemporáneo de Galileo, «[a] Biblia ensina como ir ao ceo, non como van os ceos». Xa nos primeiros séculos, os teólogos interpretaban como xeitos populares de falar, e non como modos de expresión científica, as pasaxes da Biblia que se refiren a sucesos naturais. Así, santo Agostiño, o máis famoso dos primeiros Pais da Igrexa, sostińa que os seis días da creación que aparecen no primeiro capítulo da Xénese non son días naturais, senón unha figura retórica coa que se pretendía transmitir a verdade da creación cunha linguaxe sinxela e accesible. Agostiño foi 
aínda máis alá e advertiu de que non se debería apurar de máis a invocar as Escrituras para rexeitar algunha postura da filosofía natural, non fose que a ignorancia dos cristiáns desanimase aqueles que gozan de sólidos coñecementos.

Daquela, que é o que pasou? Por que esa repentina rixidez? Parte da resposta atópase no clima da época. A obra de Copérnico De revolutionibus orbium coelestium saíu en 1543, varios anos despois de que Martińo Lutero iniciase a Reforma protestante que puńa en dúbida a autoridade do papado. Malia a resposta católica ser feble e confusa nun primeiro momento, foi cobrando forza logo do Concilio de Trento, que se celebrou a intervalos entre 1545 e 1563, o ano anterior ao nacemento de Galileo. Desde a antigüidade, a Igrexa católica subscribía a noción de que as decisións adoptadas polo colexio episcopal, reunido en concilio ecuménico, eran vinculantes para os fieis e, sobre todo, para os teólogos que ensinaban a doutrina oficial da Igrexa. Ao tempo que o Concilio de Trento insistía nesta crenza, tamén trataba de se enfrontar á crítica que se lles facía aos católicos desde o protestantismo, no sentido de que non veneraban dabondo as Escrituras; por este motivo, os teólogos católicos aplicáronse con dedicación, e por veces cun exceso de celo, no seu desexo de lles demostrar aos protestantes que si tomaban en serio a palabra de Deus. Ao mesmo tempo, comezaron a recear das teorías astronómicas que semellaban criticar as Sagradas Escrituras. Os protestantes compartían estas preocupacións esexéticas, mais non estaban suxeitos a tanto control; non tiñan nada equivalente á Inquisición e a meirande parte dos países protestantes carecían de competencias para aplicaren veredictos de herexía como facían os católicos, aínda que tamén crían que esta constituía un delito capital polos danos que causaba na sociedade.

\section{UNHA OPORTUNIDADE PERDIDA}

Cun pouco de sorte, Galileo podería convencer as autoridades católicas de Roma de que non existía ningunha incompatibilidade radical entre o que dicía a Biblia e o que empezaba a ensinar a nova ciencia. Como deixou escrito Arthur Koestler,

a menos que creamos no dogma da inevitabilidade histórica - forma de fatalismo marcha atrás-, debemos consideralo un escándalo que se puido evitar, e non resulta difícil 
imaxinar a Igrexa católica adoptando, logo de experimentar unha transición ticónica, a cosmoloxía copernicana uns douscentos anos antes da data en que finalmente a aceptou. O caso Galileo constituíu un episodio illado e, de feito, bastante atípico na historia das relacións entre ciencia e teoloxía; mais as súas dramáticas circunstancias, desproporcionadamente magnificadas, asentaron a crenza popular de que a ciencia defendía a liberdade e a Igrexa a opresión do pensamento.

Que empuxa a Koestler a ofrecer unha reinterpretación tan categórica do caso Galileo? A resposta áchase na vaidade e a arrogancia de Galileo, que o arrastraron a unha insensata oposición á Igrexa. Mentres que Draper e White vían na condena do astrónomo a consecuencia necesaria do orgullo e a estupidez do clero, Koestler deixa a meirande parte da culpa aos pés de Galileo e protesta contra a «mitografía racionalista» que o transforma en Doncela de Orleáns ou, mellor aínda, no san Xurxo que lle deu morte ao dragón da Inquisición.

No seu afán por restaurar o equilibrio, Koestler inclínase de máis cara a outra banda, e a súa irritación con Galileo xorde da convicción de que a ciencia moderna fai demasiadas afirmacións e dá resultados demasiado escasos. Resulta interesante apreciar que este devastador ditame non procede dun católico descontento, pois Koestler non era nin católico nin relixioso no sentido convencional: nado nunha familia xudía de Budapest en 1905, asistiu á Universidade de Viena, onde se sentiu atraído polo sionismo, e marchou a Palestina en 1926. En Xerusalén traballou para unha publicación periódica editada en alemán antes de retornar a Europa en 1931 e, logo de pasar un ano en París, estableceuse en Berlín, nunha época en que Alemaña estaba a atravesar graves dificultades de resultas da Gran Depresión. Koestler afiliouse ao Partido Comunista e foi enviado á Unión Soviética a compilar información sobre os importantes avances que, segundo se dicía, se estaban a producir no país; mais Koestler descubriu que o prometido Paraíso do Traballador estaba aínda lonxe e informou, tan fielmente como puido, dos trastornos que presenciara. Isto non lle agradou ao Partido Comunista alemán, que só publicou parte do seu informe; preso da desilusión, Koestler abandonou o Partido en 1938.

Durante a Guerra Civil española, Koestler estivo na fronte como reporteiro. Foi capturado polo exército franquista en Málaga en febreiro de 1937, condenado a morte e enviado a Sevilla para se enfrontar a un pelotón de fusilamento; 
porén, os ingleses lograron a súa liberación e permitíronlle entrar no Reino Unido, onde traballou para a intelixencia británica no transcurso da Segunda Guerra Mundial. Adquiriu a cidadanía británica en 1945 e posteriormente involucrouse de xeito activo na Guerra Fría. Como fe persoal, non parece que o catolicismo lle interesase moito en ningún momento; o principal obxectivo de Koestler non era tanto escribir unha historia da ciencia como explicar como a revolución científica abrira unha fenda entre a procura do cońecemento e a busca de significado.

A ironía do conto radica en que ambos os dous, Galileo e a Igrexa romana, perderon unha oportunidade. Cando Galileo fixo públicas as súas observacións telescópicas, en 1610, o seu libro, o Sidereus nuncius ( $\mathrm{O}$ mensaxeiro sideral»), foi un éxito inmediato en Roma, onde lle brindaron un recibimento triunfal en 1611. O papa, Paulo V, mesmo fixo que se pintase a nova Lúa de Galileo, cos seus montes e os seus cráteres, na cúpula da capela que ordenara levantar en Santa Maria Maggiore, unha das basílicas máis antigas e importantes de Roma.

\section{QUE É O QUE FALLOU?}

Como moitos profesores, Galileo non carecía do seu punto de arrogancia e non aturaba os babecos de bo grado. O problema é que cría que podía demostrar que a Terra se move arredor do Sol, cando o único de que dispuña era unha enxeñosa teoría: o seu famoso argumento de que as mareas serían imposibles se a Terra non rotase sobre o seu eixe facendo un percorrido de vinte e catro horas, ao tempo que completaba un xiro dun ano arredor do Sol.

Hoxe parece evidente que as autoridades romanas cometeron un erro ao condenaren o copernicanismo. A todos nos educaron no cońecemento de que a Terra xira arredor do Sol, mais a ninguén lle aprendían isto na escola na época de Galileo, e trátase dunha cuestión nada doada de penetrar. Unha cousa é certa: non se achou proba física de que a Terra se move arredor do Sol e xira sobre o seu eixe ata despois da condena de Galileo.

O cardeal Bellarmine, que coñeceu a Galileo en 1616, dixérao con claridade: se se demostrase o movemento da Terra, habería que reinterpretar os textos das Escrituras que semellan negar tal cousa. Persoalmente, Bellarmine tińa moitas dúbidas de que coubese esperar que se achase esa proba algún día, opinión que 
compartía o papa Urbano VIII, quen aconsellou a Galileo que se servise do copernicanismo por constituír unha cómoda ferramenta matemática, sen aceptar que fose válida. Agora ben, se ninguén admite — como fixo Galileo- que o significado literal das Escrituras debería prevalecer sobre as meras conxecturas das ciencias naturais, daquela pode dicirse que Bellarmine e o papa Urbano VIII tiñan razón; só véndoo en retrospectiva somos quen de afirmar que se enganaban. Con todo, non se pode desculpar de todo a Bellarmine e ao papa se analizamos outros dous aspectos do problema. O primeiro é que Galileo, con axuda de amigos sacerdotes e teólogos, foi capaz de achar en santo Agostiño, san Xerome e outros eminentes escritores das primeiras épocas, coñecidos como «os Pais da Igrexa», diversas consideracións que lle abrían a porta a un modo de interpretar a Biblia segundo o cal era a Terra a que se movía, e non o Sol. O Concilio de Trento declarara que as Escrituras habían interpretarse de conformidade co consenso ao que chegaran os Pais da Igrexa, mais engadira prudentemente que «en cuestións de fe e de moralidade». O cardeal Bellarmine era consciente do problema e prevía o argumento que poderían presentar os copernicanos cando lle escribiu a un defensor desta doutrina:

Non se pode dicir que non se trate dunha cuestión de fe, pois talvez non o sexa no referente ao tema, mais si o é no que atinxe a quen fala. Por este motivo, unha persoa que negase que Abraham tivese dous fillos e Xacob doce sería tan herexe como alguén que negase o nacemento virxinal de Cristo, xa que ambas as cousas foron declaradas polo Espírito Santo por boca dos profetas e os apóstolos.

O problema, como se ve, era moito máis complicado do que por veces se pensa. Un segundo aspecto da cuestión é a ameaza que supuña o copernicanismo para aqueles que identificaban a visión xeocéntrica do mundo coa cosmoloxía cristiá, algo que nega rotundamente o historiador vaticano Walter Brandmüller:

Ao contrario do que se adoita afirmar, as autoridades da Igrexa non viviron con confusión nin angustia o derrubamento da visión do mundo que se vińa aceptando ata daquela. $\mathrm{O}$ único que lles interesaba era a infalibilidade das Escrituras, que crían, erroneamente, ameazada polo sistema copernicano. 
Non se pode pasar por alto á lixeira que había moito máis en xogo. Tanto o cardeal Bellarmine como o papa Paulo V (o antigo cardeal Camillo Borghese) foran membros do Santo Oficio cando Giordano Bruno foi condenado á fogueira en 1600. Malia Bruno non ser astrónomo, servírase do copernicanismo como plataforma desde a que lanzar a súa nova cosmoloxía, segundo a cal as estrelas eran soles rodeados por planetas habitados, e o universo unha manifestación necesaria da infinidade de Deus e, en consecuencia, infindo. O resultado foi unha forma radical de panteísmo que derrubaba os principios básicos da cristiandade. Bruno foi executado en Roma no ano 1600 e resulta improbable que, só dezaseis anos despois, o papa Paulo V e o cardeal Bellarmine xa esquecesen os ecos do seu copernicanismo. O 27 de febreiro de 1615 Giovanni Ciampoli, amigo de Galileo, sondou sobre esta cuestión o cardeal Maffeo Barberini —o posterior papa Urbano VIII-, quen indicou que lle gustaría que se procedese «con maior precaución para non ir máis aló dos argumentos esgrimidos por Ptolomeo e Copérnico» nin "traspasar os límites da física e a matemática». O futuro papa advertiu, así mesmo, do perigo que suporía ampliar o copernicanismo con xuízos errados, pois, como Ciampoli lle explicou a Galileo,

A vosa opinión sobre o xogo de luces e sombras percibido nas zonas iluminadas e escuras da Lúa establece certa analoxía entre o globo lunar e a Terra; un vén, amplía esta cuestión e di que pońedes habitantes humanos na Lúa; outro dá en cuestionar como eses van poder ser descendentes de Adán, ou como ían poder saír da arca de Noé, e moitas outras extravagancias que vós nunca imaxinarades.

Nós chegamos a ver o noso planeta Terra como un máis de entre un amplo número de astros que orbitan arredor do seu propio sol, e xa resulta habitual facer suposicións sobre a existencia de vida noutros planetas; mais este non era o caso no século Xvir. Cando Benedetto Castelli, o máis íntimo colaborador de Galileo, sacou a colación o movemento da Terra no transcurso dunha conversación co cardeal Francesco Barberini, sobrińo do papa Urbano VIII, recibiu a resposta de que, se de verdade a Terra se movía, «habería que a considerar planeta, o cal, segundo parece, entra en gran contradición cos postulados da teoloxía». A isto Castelli replicou que Galileo pretendía demostrar que a Terra non era un planeta, e o cardeal retrucou que certamente debería facelo. 


\section{TIÑA RAZÓN A IGREXA NO REFERIDO Á CIENCIA?}

En tempos de Galileo o copernicanismo era unha conxectura pendente de confirmación. Se este astrónomo non fose tan dogmático, podería evitar un enfrontamento coa Igrexa e, como conclúe Brandmüller,

[p]olo tanto, velaquí un feito tan grotesco como que a Igrexa, á que tan a miúdo se acusa de se trabucar neste caso, tiña razón, e precisamente nun terreo que non era o seu $-\mathrm{o}$ da ciencia natural—, cando lle solicitou a Galileo que tratase o sistema copernicano como mera hipótese.

Con todo, Brandmüller esaxera: os cregos que, de acordo coa metodoloxía da época, sostiñan que os modelos astronómicos constituían simples construtos hipotéticos tiñan dereito a lle recomendaren a Galileo que se referise ao copernicanismo como conxectura, mais podían esixirllo? Ao lle imporen a Galileo o deber de falar hipoteticamente ou gardar silencio, eses cregos actuaban como teólogos, non como científicos. Cando o papa Urbano VIII declarou que os camiños do Señor son inescrutables que e El puido deseñar o mundo dun modo que escapa por completo á nosa aprehensión, baseaba este argumento na omnipotencia de Deus; o cal implicaba, sen dar apenas lugar a confusión, que cuestionar tal aserto equivalía a negar a Súa omnipotencia. Naquela época non había quen se decatase de que estaba a nacer unha nova ciencia e ninguén imaxinaba que ía resultar ser extremadamente poderosa. A postura de Bellarmine e do papa Urbano VIII era razoable, mais en sentido limitado: o cardeal e o papa eran homes do seu tempo, non heraldos do futuro. Véndoo en retrospectiva, sabemos que a ruta que conduciu ata a ciencia moderna se abriu ao longo do carreiro que seguía Galileo, e non da estrada convencional que algúns se encargaban de sinalizar.

\section{ESTÁN SUBDETERMINADAS AS TEORÍAS?}

Por veces sorprende que o argumento do papa Urbano VIII sobre a omnipotencia de Deus teña ecos en disquisicións contemporáneas da filosofía da ciencia e pode considerarse unha versión teolóxica da tese referida á subdeterminación das 
teorías. Como explica Larry Laudan nunha entrada da Routledge Encyclopedia of Philosophy,

[c]o termo «subdeterminación» denomínase unha ampla familia de argumentos referidos ás relacións que existen entre a teoría e a evidencia, todos os cales comparten a conclusión de que a evidencia se ve, en maior ou menor medida, impotente á hora de nos orientar nas escollas entre teorías ou hipóteses contrarias. Baixo un aspecto ou outro, a subdeterminación probablemente sexa a idea más rotunda e persuasiva das que alimentan as diversas formas de escepticismo e relativismo epistemolóxico do século xx.

A subdeterminación ten tras de si unha longa historia. Na antigüidade e na Idade Media, cando o home se apercibiu de que se pode dar conta dos mesmos datos usando teorías diferentes, xerouse un concepto «instrumentalista» das explicacións científicas, perspectiva segundo a cal os sistemas astronómicos teñen como obxectivo "gardar as aparencias», concretamente fornecendo instrumentos matemáticos con que determinar a posición e o tamaño ou velocidade que semellan ter os corpos celestiais. Deste xeito, unha boa teoría astronómica pode servir para predicir eclipses, mais non debería tomarse como unha descrición fidedigna do modo en que os planetas se moven na realidade. Para coñecer a verdadeira natureza do mundo facía falta outra clase de ciencia: unha ciencia demostrativa, como pretendía ser a filosofía aristotélica, coa cal se investigasen as causas reais dos feitos observados. Esta dicotomía de achegamentos á cosmoloxía tivo importantes consecuencias institucionais, xa que dun profesor de astronomía se esperaba que ensinase a "gardar as aparencias", non o que as ocasionaba, pois xa se encargaban os profesores de filosofía natural de estudar o que había detrás dos fenómenos ou máis aló deles. Galileo en Padua non ensinaba filosofía, senón matemáticas, e había lidar con profesores daquela disciplina que non tiñan nin idea de que as matemáticas podían aprenderlles algo sobre o mundo real. Esta división de tarefas tamén tiña implicacións económicas: un profesor de filosofía podía cobrar o séxtuplo do soldo dun colega que ensinase matemáticas. De aí o moito que lle insistiu Galileo ao gran duque, cando foi chamado de novo a Florencia en 1610, para que o nomeasen non só matemático, senón tamén filósofo. 


\section{GALILEO E O CATOLICISMO NA ACTUALIDADE}

O papa Xoán Paulo II tiña moito interese en propiciar un diálogo entre ciencia e relixión e coidaba que non se podía comezar a conversar honradamente sen antes recoñecer as achegas de Galileo. No transcurso dunha alocución dirixida á Academia Pontificia das Ciencias en 1979, manifestou:

Permítanme, señores, que chame a súa atención sobre algunhas cuestións que me parecen relevantes para entender o caso Galileo na súa correcta perspectiva. As coincidencias que amosaba entre relixión e ciencia eran máis numerosas e, sobre todo, máis importantes que o malentendido que desembocou nun conflito amargo e doloroso.

O papa mencionou tres puntos de coincidencia. $\mathrm{O}$ primeiro foi que Galileo estaba convencido de que a ciencia e a fe non poden discrepar e, referíndose á carta que Galileo lle enviou a Benedetto Castelli o 21 de decembro de 1613, o papa declarou que o Segundo Concilio Vaticano non expresara o contrario. O segundo punto foi que Galileo cría que Deus ilumina aqueles que tratan de comprender a Súa creación; a humildade e unha mente aberta constitúen, segundo subliñou o papa, as condicións necesarias para que teña lugar un intercambio frutífero entre científicos e crentes. O terceiro punto de coincidencia estaba en que Galileo recoñecera que na Biblia existen diferentes estilos literarios. E o papa concluíu:

As diversas coincidencias que citei non resolven por si mesmas todos os problemas que presenta o caso Galileo, mais si contribúen a fixar un punto de partida que propicie unha solución digna, unha mentalidade que conduza a solucionar leal e honradamente as vellas oposicións.

Poida que a teoloxía católica contemporánea se puxese ao nivel da esexese galilea, mais aínda así o lector quererá ter unha idea de que clase de cristián era Galileo. Non podemos penetrar os seus pensamentos máis íntimos, pero el sentía, verdadeiramente, que formaba parte da Igrexa. No século XvII, o matemático e filósofo do gran duque da Toscana tińa que ser católico romano, mesmo se a súa adhesión era puramente formal, mais Galileo non afirmaba o seu compromi- 
so coa boca pequena. Por exemplo, sabemos que consideraba importante facer peregrinacións e votos; non sería un apaixonado viaxeiro, e, con todo, en 1618 fixo a viaxe de Florencia a Loreto (uns douscentos quilómetros) co fin de visitar a chamada Casa da Nosa Señora, moi popular na súa época. Dez anos despois pensaba volver, mais disuadiuno a súa mala saúde.

O que nos chama a atención é que Galileo cría que Deus o elixira a el para que fixese todos aqueles descubrimentos astronómicos e que lle concedera a el, e só a el, o privilexio de facer as descubertas telescópicas. O 30 de xaneiro de 1610 escribiulle ao secretario de Estado toscano: «Estoulle infinitamente agradecido a Deus por que tivese a ben concederme ser a única persoa que fixo as primeiras observacións de cousas admirables desde sempre ignoradas». No Sidereus nuncius que apareceu en marzo de 1610, Galileo engadiu que «o Facedor das Estrelas [lle dixera] claramente que lles puxese aos satélites de Xúpiter o nome do gran duque». Varios anos despois, nos seus comentarios a un libro do xesuíta Orazio Grassi, Galileo foi aínda máis lonxe: «Que lle vas facer — dille ao seu rival— se se me concedeu a min, e a ninguén máis, facer todos os descubrimentos celestiais». Esa crenza na singularidade do seu destino que albergaba Galileo non garda ningunha relación particular coa persoa de Cristo, nome que nunca achamos nos seus escritos. Mais, xaora, o compromiso relixioso dun ser humano non constitúe unha calidade observable e non resulta posible inspeccionar a cara máis fonda da fe de Galileo. 



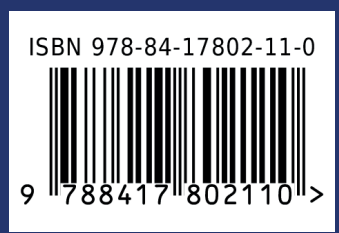

Parte dos problemas e das insuficiencias das primeiras teorías do nacionalismo, a etnicidade e o multiculturalismo derivábanse dunha concepción das comunidades culturais como grupos prepolíticos, resultado obxectivo dos «feitos empíricos» demográficos e étnicos diferenciais. Así e todo, a filosofía, os estudos históricos e culturais así como as ciencias sociais máis recentes cuestionaron esta perspectiva en canto debedora de asuncións claramente insostibles. Entre estas últimas, a visión das culturas, os grupos étnicos e as nacións como totalidades orgánicas, integradas e homoxéneas, ignorando ou poñendo en segundo plano a diversidade interna, a pluralidade de interpretacións e proxectos concorrentes, así como o conflito entre eles. Como se fosen entidades definitivamente cristalizadas na historia, como conxuntos dados de antemán e esencialmente alleos a calquera eventual proceso de evolución, mudanza ou reformulación.

De maneira moi diferente, da man dunha óptica interdisciplinar e construtivista de varia índole, insistiuse na natureza non de obxectos, senón de procesos participativos complexos, continxentes das nacións, grupos étnicos e culturas, na súa apertura e indeterminación. As contribucións presentadas en Cultura, sentido e política, libro que recolle boa parte das achegas da segunda xeira do seminario $\mathrm{O}(\mathrm{s})$ Sentido(s) da(s) Cultura(s), desenvolto no Consello da Cultura Galega durante os últimos anos, exploran da man de recoñecidos e recoñecidas especialistas diversas dimensións desde esta innovadora e moi plural perspectiva: xénero, nación, emigración, refuxiados, sustentabilidade, emocións, arte, museos, danza, paisaxe, populismo, relixión etc.

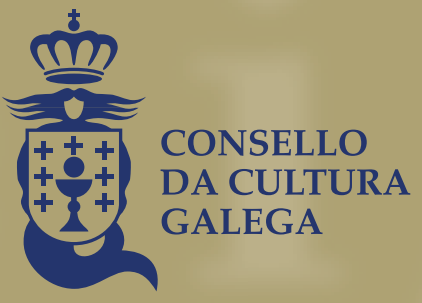

